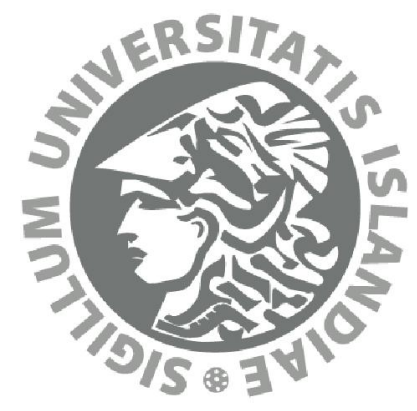

\title{
Áhrif gæðastjórnunar á mannvirkjagerð
}

Anna Hulda Ólafsdóttir

Iōnað̃arverkfræðði- vélaverkfræð̄i og

tölvunarfræað̄ideild

Háskóli Íslands 



\title{
Áhrif gæðastjórnunar á mannvirkjagerð
}

\author{
Anna Hulda Ólafsdóttir
}

60 eininga ritgerð sem er hluti af Magister Scientiarum gráðu í iðnaðarverkfræði

\author{
Leiðbeinandi \\ dr. Helgi Pór Ingason \\ Meðleiðbeinandi \\ dr. Páll Jensson \\ Prófdómari / Fulltrúi deildar \\ dr. Gunnar Stefánsson
}

Iðnaðarverkfræði-, vélaverkfræði- og tölvunarfræðideild

Verkfræði- og náttúruvísindasvið

Háskóli Íslands

Reykjavík, febrúar 2011 Háskóli Î́slands

Reykjavík, ágústmánuður 2011 



\begin{abstract}
Áhrif gæðastjórnunar á mannvirkjagerð
60 eininga ritgerð sem er hluti af Magister Scientiarum gráðu í iðnaðarverkfræði

Höfundarréttur (C) 2011 Anna Hulda Ólafsdóttir

Öll réttindi áskilin
\end{abstract}

Iðnaðarverkfræði- vélaverkfræði- og tölvunarfræðideild

Verkfræði- og náttúruvísindasvið

Háskóli Íslands

VRII Harðarhaga 2-6

107 Reykjavík

Sími: 5254000

Skráningarupplýsingar:

Anna Hulda Ólafsdóttir, 2011, Áhrif gœðastjórnunar á mannvirkjagerð, meistararitgerð, Iðnaðarverkfræði- vélaverkfræði og tölvunarfræðideild, Háskóli Îslands, 490 bls.

Prentun: Háskólaprent

Reykjavík, ágústmánuður 2011 



\section{Útdráttur}

Markmið verkefnisins er að skoða áhrif gæðastjórnunar á mannvirkjagerð. Sérstök áhersla er lögð á að skoða hvernig áhrif gæðastjórnunar eru á verkkaupa og pá sérstaklega hvort marktækur munur sé á ánægju verkkaupa með framkvæmd verka hjá verktökum sem starfa eftir gæðastjórnunarkerfi miðað við verktaka sem starfa ekki eftir gæðastjórnunarkerfi. Einnig er kannað hvort marktækur munur sé á vinnubrögðum verktaka sem kveðast vinna eftir gæðastjórnunarkerfi miðað við pá sem starfa ekki eftir slíku og að lokum er staða gæðastjórnunar í mannvirkjagerð á Íslandi könnuð.

Leitast var við að svara pessum spurningum með pví að hanna og leggja spurningalista fyrir verkkaupa og verktaka. Spurningalisti var lagður símleiðis fyrir verkkaupa og voru peir beðnir um að hafa pann verktaka í huga sem kom mest að framkvæmdinni. Spurningalisti var svo lagður fyrir verktaka og svör verkkaupa tengd við svör viðkomandi verktaka. Pannig var fylgni mæld milli ánægju verkkaupa með framkvæmd verks hjá verktaka við pætti úr könnun verktaka, eins og hvort hann starfar eftir gæðastjórnunarkerfi eða ekki. Gögn kannananna voru einnig greind sér í lagi og niðurstöður túlkaðar frá peim auk pess sem fyrri rannsóknir voru skoðaðar og auka innsýn nýtt sem skýrsluhöfundur fékk með viðtölum við fagaðila og á ráðstefnu og fundi tengdu málefninu.

Helstu niðurstöður eru að marktækur munur og sterk fylgni er milli ánægju verkkaupa með framkvæmd verks sem verktaki vann og hvort verktaki starfar eftir gæðastjórnunarkerfi eða ekki. Einnig sýna niðurstöður að peir verktakar sem kveðast starfa eftir gæðastjórnunarkerfi starfa eftir mun markvissari og skilvirkari vinnubrögðum en peir sem starfa ekki eftir slíku kerfi, en marktæk fylgni mældist milli margra pátta tengdum verklagi verktaka og hvort peir starfa eftir gæðastjórnunarkerfi eða ekki. Аð lokum leiðir rannsóknin í ljós að staða gæðastjórnunar í mannvirkjagerð á Íslandi er sérstaklega slök meðal smárra verktakafyrirtækja og telur skýrsluhöfundur að brýn pörf sé fyrir aðgengilegt og notendavænt gæðastjórnunarkerfi fyrir slík fyrirtæki. Staðan er allt önnur meðal stærstu verktakafyrirtækjanna en pekking og verklag innan peirra er töluvert betra. 


\section{Abstract}

The objective of this thesis is to examine the effect of quality management in the construction industry in Iceland. Particular emphasis is placed on examining how quality management affects the contractee and notably whether discernable differences exist in contractee satisfaction with regard to project execution depending on whether the project involved is completed by contractors that work in accordance with a quality management system as opposed to contractors that do not. Moreover, to examine whether there is a discernable difference in the working methods of those contractors who claim to work in accordance with a quality management system compared to those who do not. Finally, the status of quality management in the construction industry in Iceland is examined.

In an effort to answer these questions a questionnaire was designed and circulated among contractees and contractors. A questionnaire was placed by telephone before contractees wherein they were asked to refer to the principal contractor involved in the project concerned. A questionnaire was then placed before the contractor and the answers from the contractee compared to the answers from the contractor(s) involved. Thus correlation was gauged between the contracture's satisfaction with the contractor's completion of a project and certain aspects related to the examination of the contractor such as whether or not he conducted his operations in accordance with a quality management system. Other findings of the surveys were also analyzed separately and conclusion deducted there from, in addition to which previously conducted studies were examined and additional insight utilized which the author obtained through interviews with professionals at a conference and a meeting relating to the subject matter.

The main conclusions were that there is a significant difference and a strong correlation between contractee satisfaction with a project's execution depending on whether or not the contractor conducts his operations in accordance with a quality management system. The findings also show that those contractors who claim to conduct their operations in accordance with a quality management system employ much better aimed and effective working methods compared to those contractors who do not but discernable differences could be gauged between many aspects of the working methods employed by individual contractors and whether or not they conducted their operations in accordance with a quality management system. Finally the findings show that the status of quality management in the construction industry in Iceland is particularly poor within the smaller construction companies. The situation is completely different with regard to large construction companies, where the knowledge and the working methods appear to be of a considerably higher standard. 
Dessi ritgerð er tileinkuð móður minni, Guðrúnu Pórsdóttir, sem var vön að hvetja mig áfram íöllu sem ég tók mér fyrir hendur og sýndi pað og sannaði að allt er hogt ef viljinn er fyrir hendi. Án hennar vaeri ég ekki par sem ég er núna. 



\section{Formáli}

Pessi ritgerð er 60 eininga meistararitgerð í Iðnaðarverkfræði, við Háskóla Íslands. Ritgerðin var skrifuð undir handleiðslu dr. Helga Pórs Ingasonar, dósents við IVT deild verkfræði- og náttúruvísindasviðs Háskóla Íslands og dr. Páls Jenssonar, prófessors við verkfræði- og náttúruvísindasvið Háskóla Íslands. 



\section{Efnisyfirlit}

Áhrif gæðastjórnunar ........................................................................................................

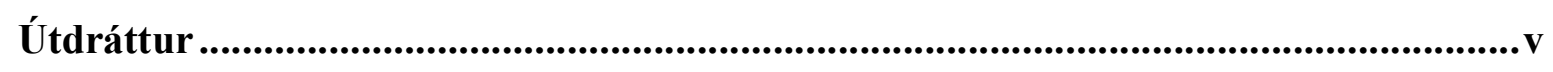

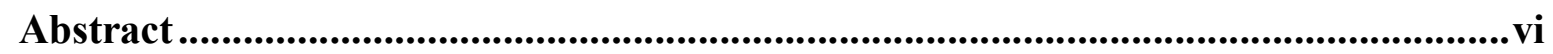

Formáli .......................................................................................................................................ix

Efnisyfirlit ...................................................................................................................................

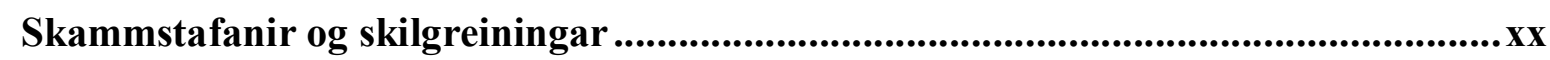

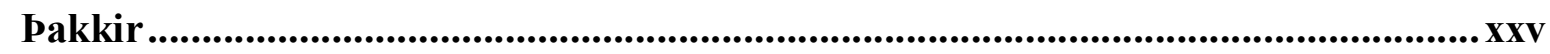

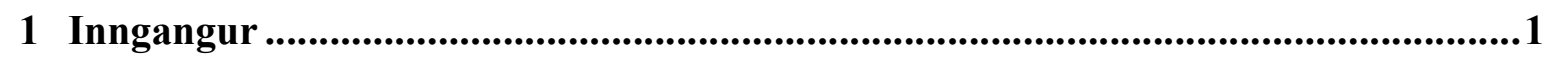

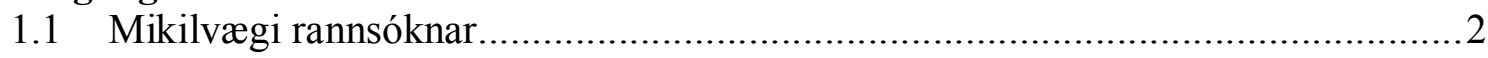

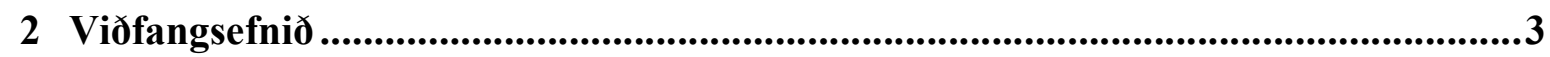

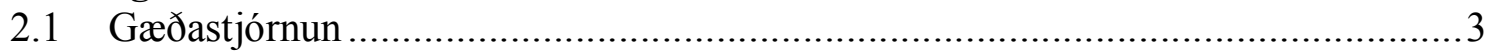

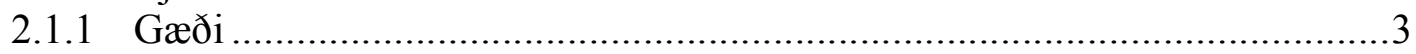

2.1.2 Hvað er gæðastjórnun ? ...........................................................................5

2.1.3 bróun gæðastjórnunar og altæk gæðastjórnun (AGS, e. Total quality management, TQM) ………………………………........................

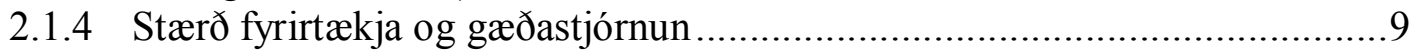

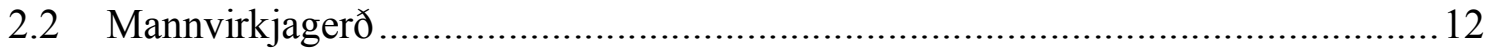

2.2.1 Sérkenni mannvirkjagerðar og gæðastjórnun ...........................................13

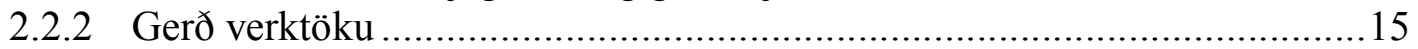

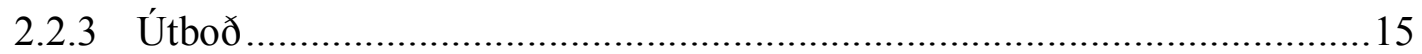

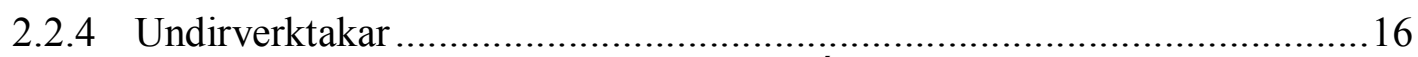

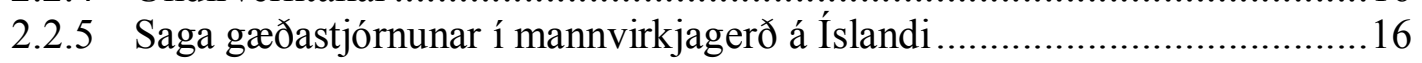

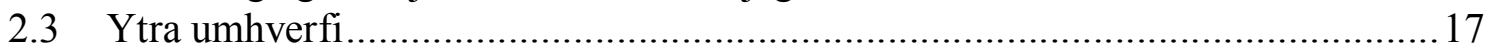

2.3.1 Áhrif af hruni íslenska efnahagslífsins á byggingaiðnaðinn ...........................17

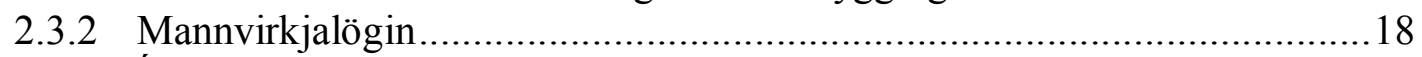

2.3.3 ÍST-30, Almennir útboðs- og samningsskilmálar um
verkframkvæmdir.............................................................................20

2.3.4 ISO ……

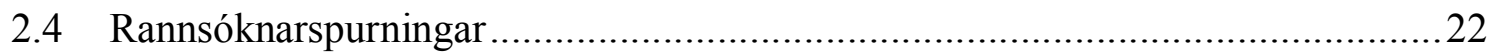

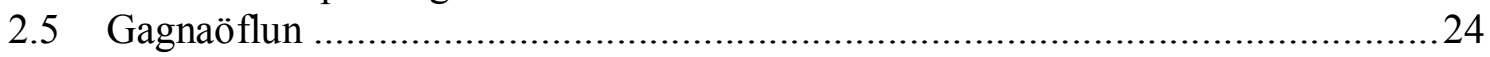

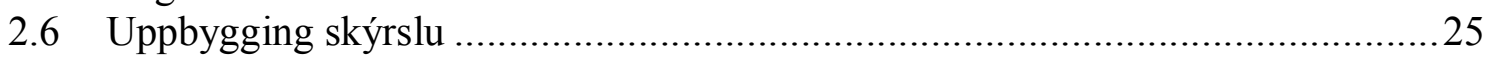

3 Fræðileg umfjöllun - Fyrri rannsóknir ...............................................................26

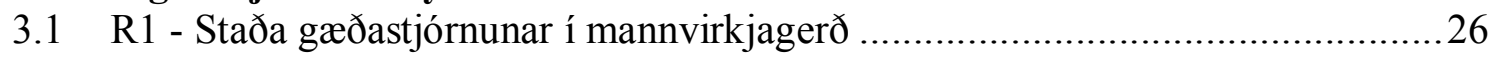

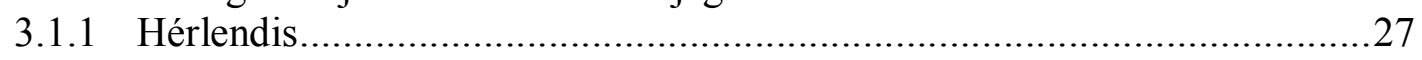

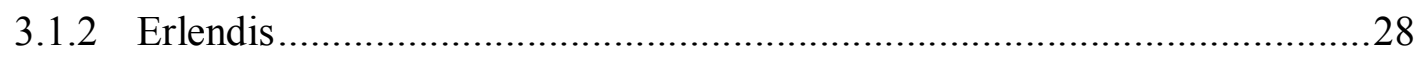

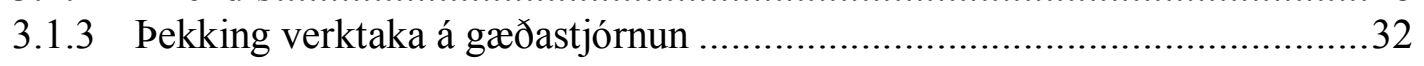




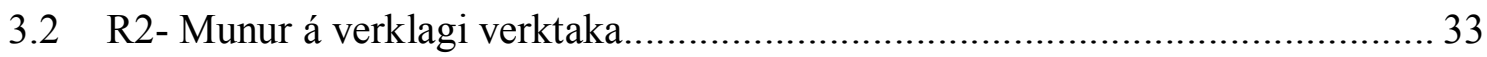

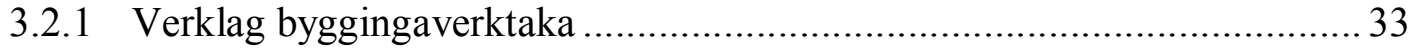

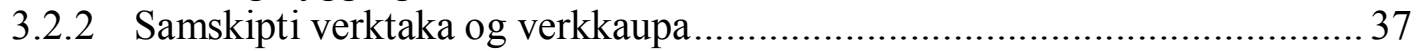

3.2.3 Viðhorf verktaka til gæðastjórnunar ..................................................... 38

3.2.4 Kröfur til verktaka um skipulag og markvissa stjórnun............................ 38

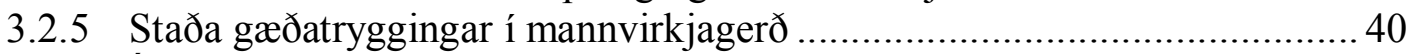

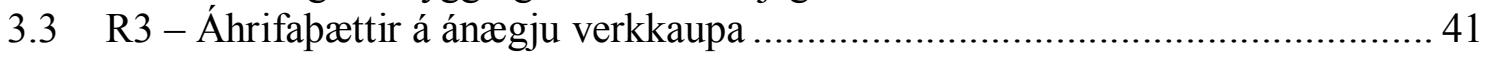

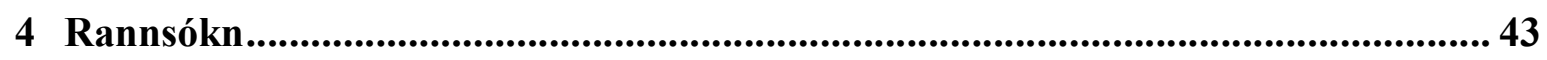

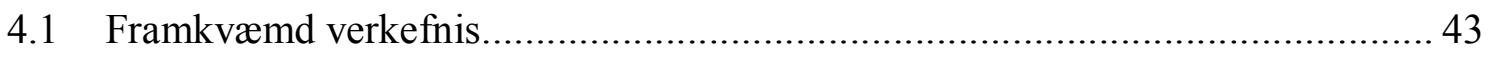

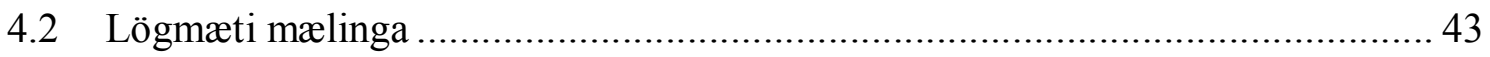

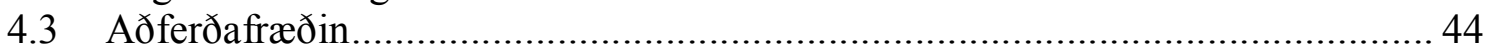

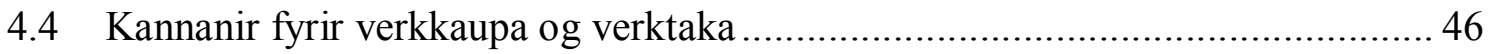

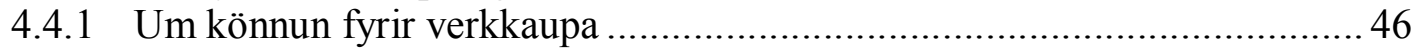

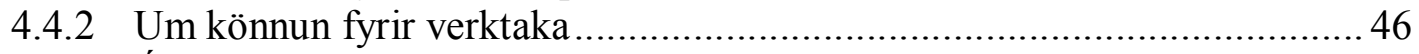

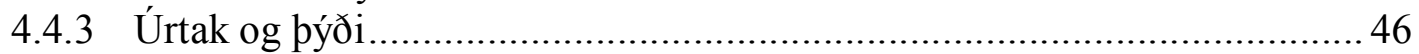

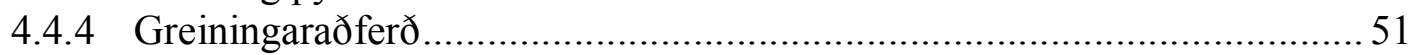

4.5 Greining gagna úr könnun verkkaupa ..................................................... 55

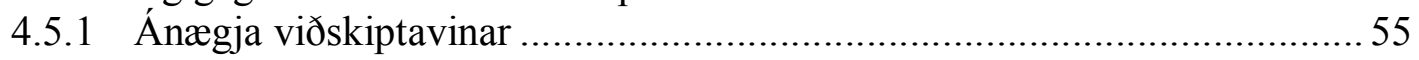

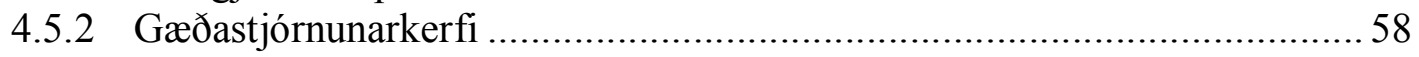

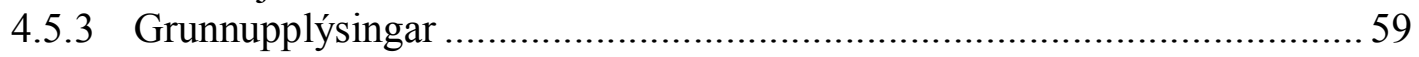

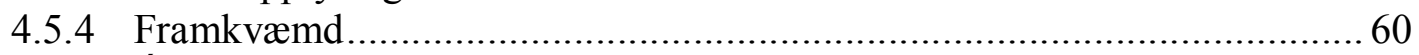

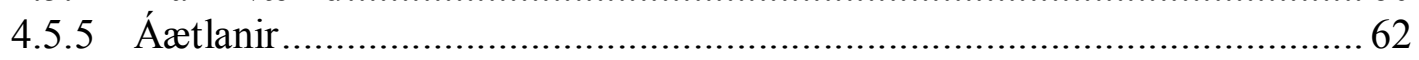

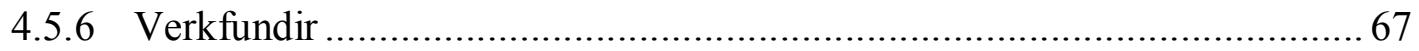

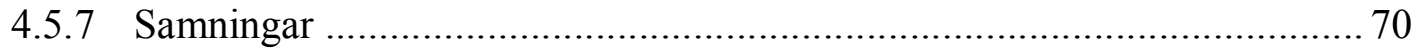

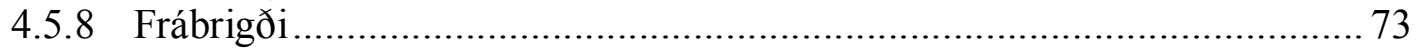

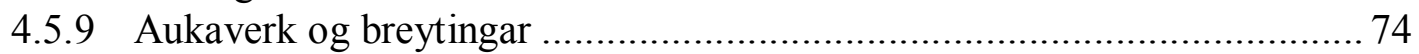

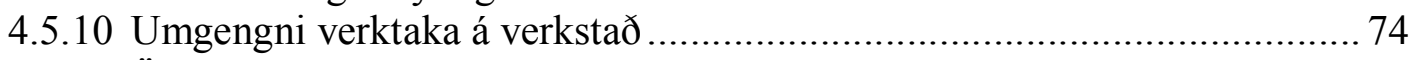

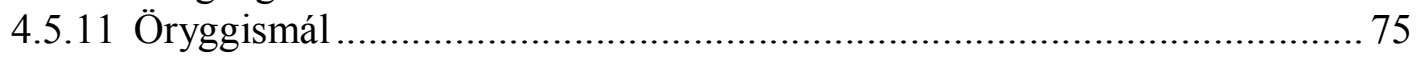

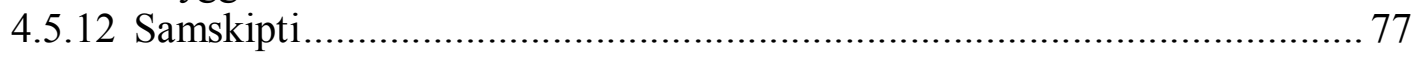

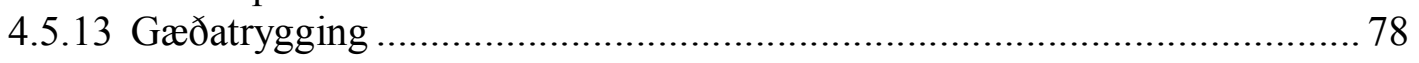

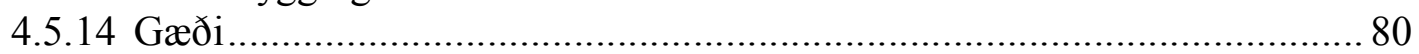

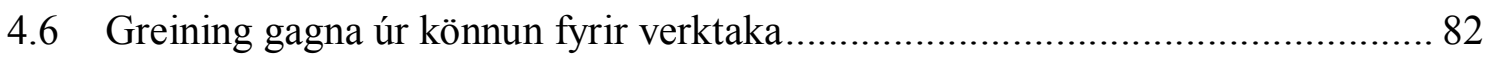

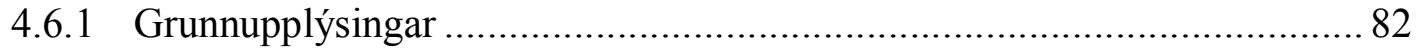

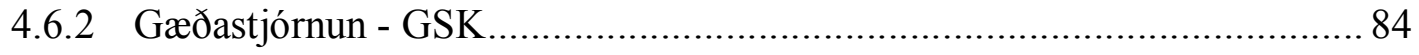

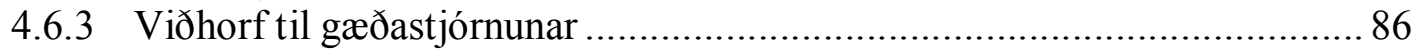

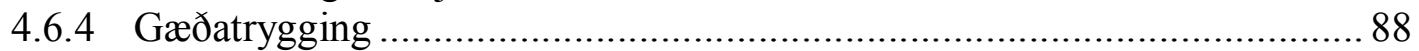

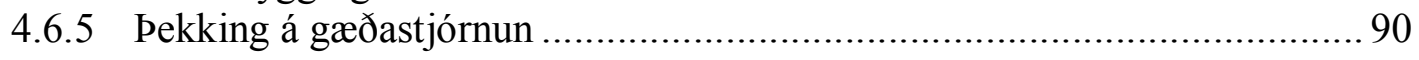

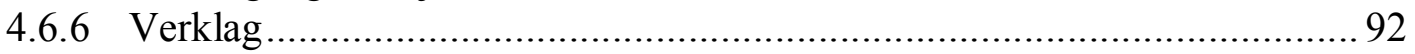

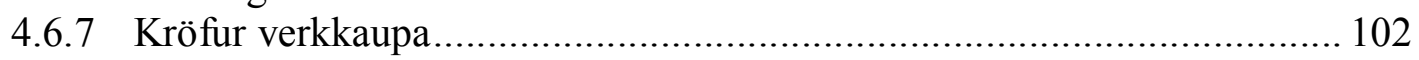

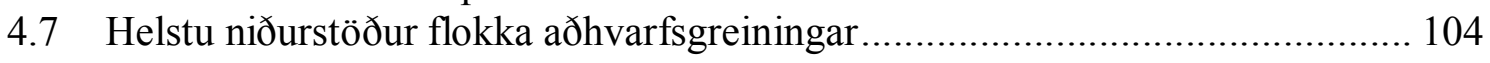

5 Niðurstöður og umræða...................................................................................... 106

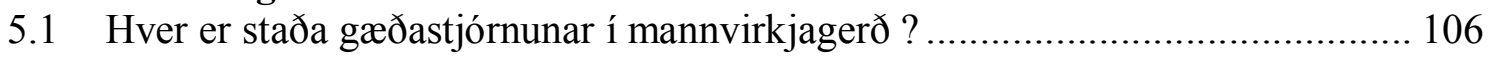

5.1.1 Hver er pekking verktaka á gæðastjórnun? ........................................ 107

5.2 Í hverju felst munurinn á verktökum, sem starfa eftir gæðastjórnunarkerfi, og verktökum sem starfa ekki eftir gæðastjórnunarkerfi ?.............................. 108

5.2.1 Eru fyrirtæki sem starfa eftir gæðastjórnunarkerfi með ánægðari viðskiptavini en fyrirtæki sem starfa ekki eftir pví ? 
5.2.2 Er munur á verklagi íslenskra byggingaverktaka með tilliti til pess hvort peir starfa eftir gæðastjórnunarkerfi eða ekki ?

5.2.3 Er munur á samskiptum milli verktaka og verkkaupa með tilliti til pess hvort verktaki starfar eftir gæðastjórnunarkerfi eða ekki?

5.2.4 Er munur á viðhorfi verktaka til gæðastjórnunar eftir pví hvort verktaki starfar eftir gæðastjórnunarkerfi eða ekki ?....

5.2.5 Er munur á kröfum til verktaka, um skipulag og markvissa stjórnun, milli verktaka sem starfa eftir gæðastjórnunarkerfi og peirra sem gera pað ekki?

5.2.6 Er munur á stöðu gæðatryggingar í mannvirkjagerð meðal verktaka sem starfa eftir gæðastjórnunarkerfi og peirra sem gera pað ekki ?

5.3 Hvaða pættir hafa mest áhrif á ánægju verkkaupa ?

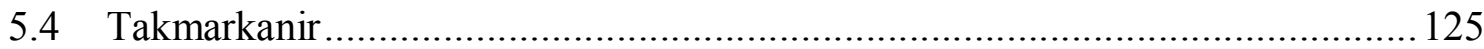

6 Lokaorð og frekari rannsóknir ................................................................126

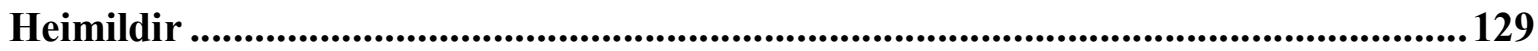

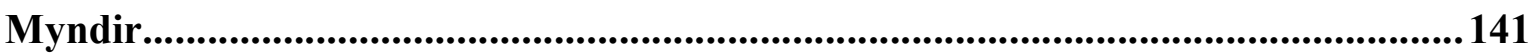

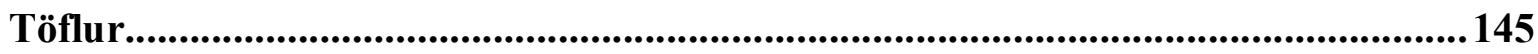

Viðauki A - Könnun ætluð verkkaupum.........................................................164

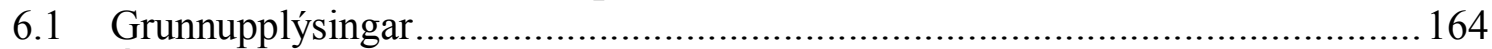

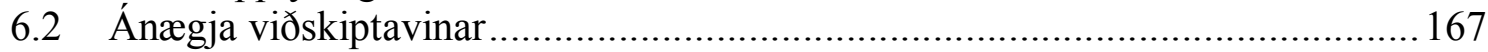

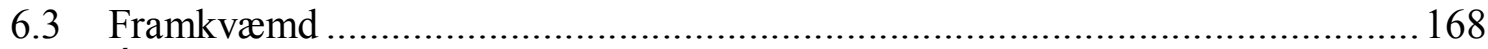

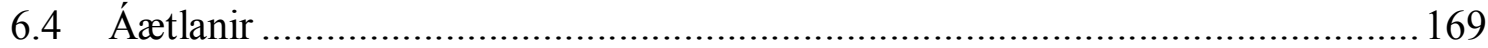

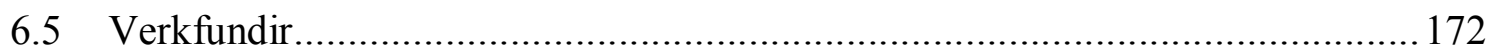

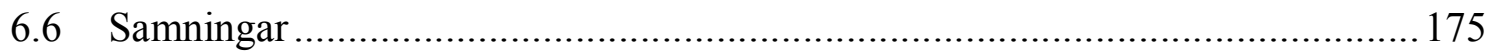

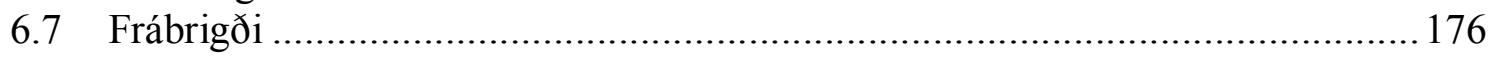

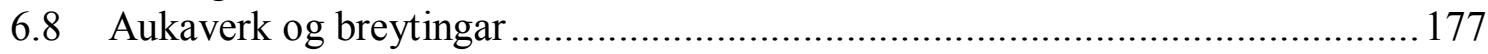

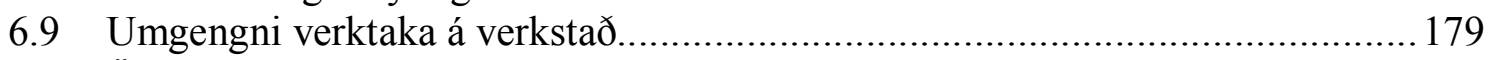

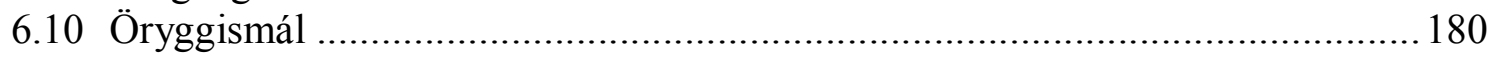

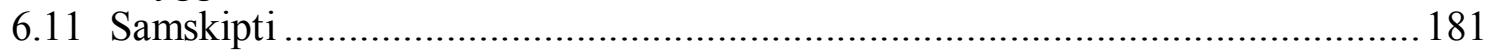

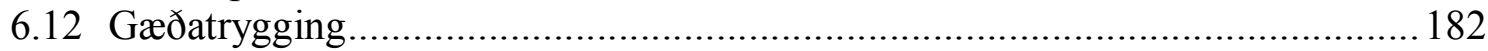

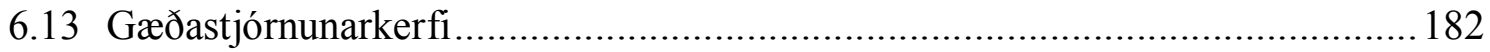

6.14 Gæði 182

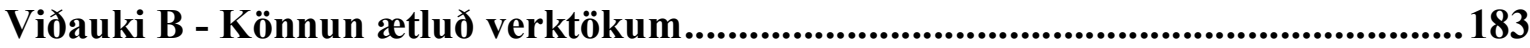

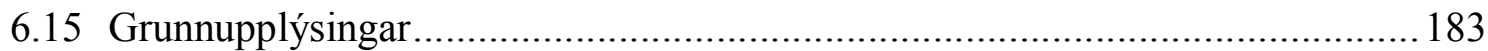

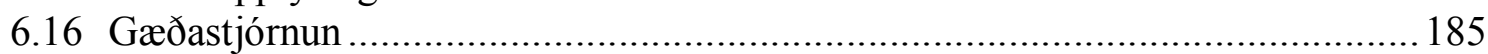

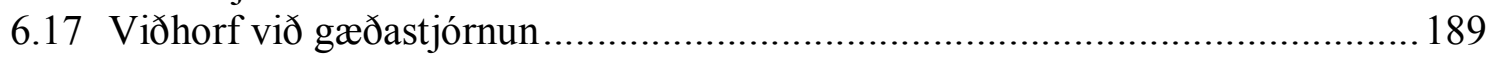

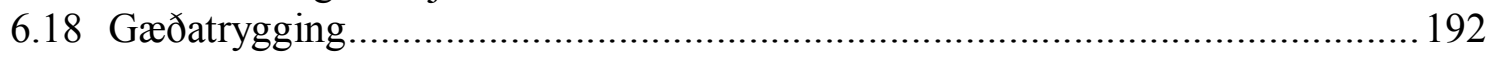

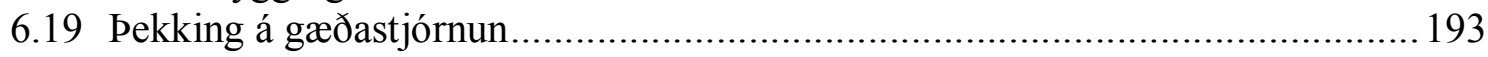

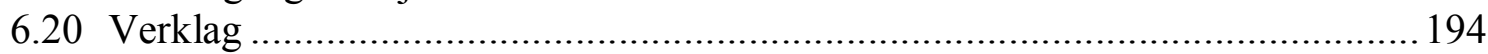

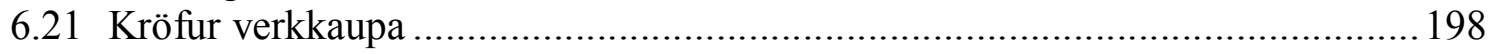

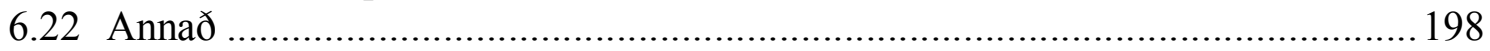

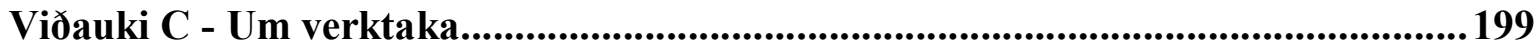


1. Er vitað um tengsl verktaka og verkkaupa ? ................................................ 199

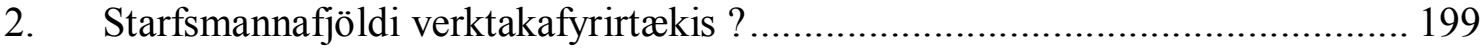

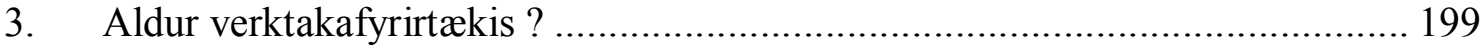

4. $\quad$ Er verktaki að vinna eftir gæðastjórnunarkerfi svo vitað sé til ?...................... 199

5. Á hverju byggir gæðastjórnunarkerfið samkvæmt gögnum? ............................ 199

6. Er gæðastjórnunarkerfið vottað svo vitað sé til? ......................................... 200

7. Hvernig vottun hefur fyrirtækið hlotið fyrir gæðastjórnunarkerfið svo vitað

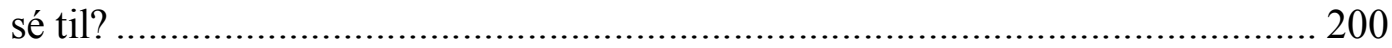

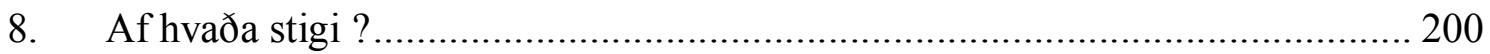

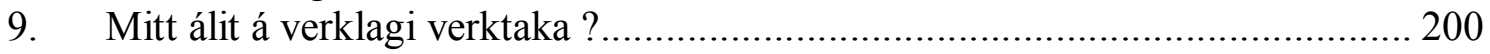

Viðauki D - Breytuheiti......................................................................................... 201

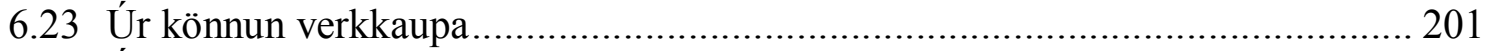

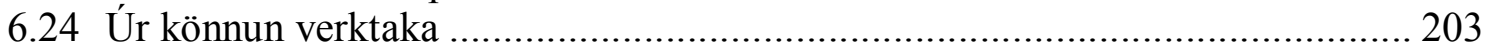

Viðauki E - Tíonitöflur úr könnun verkkaupa .................................................. 207

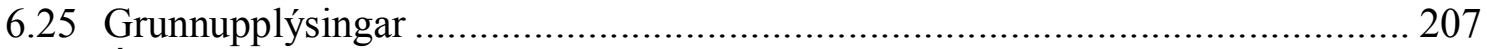

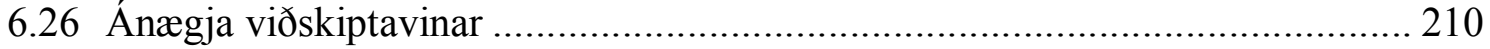

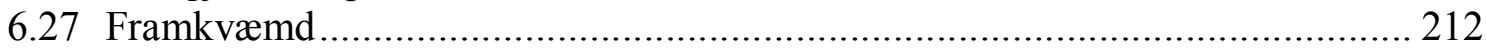

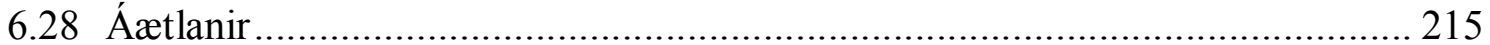

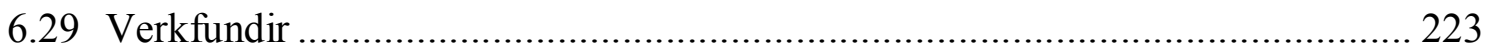

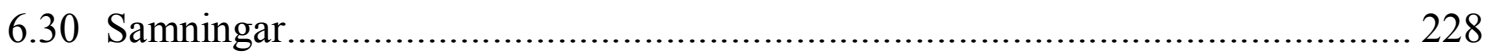

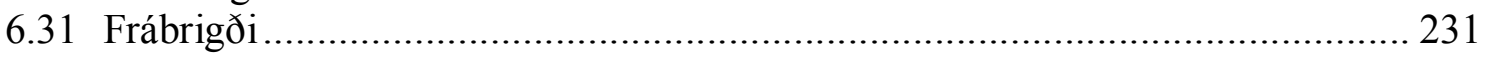

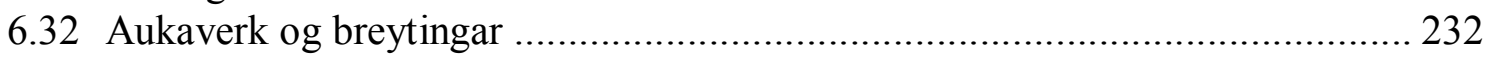

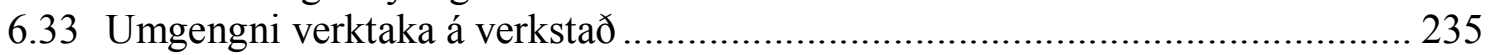

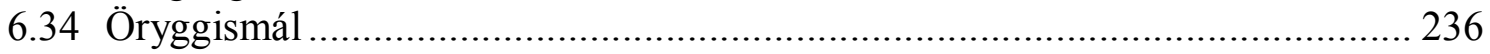

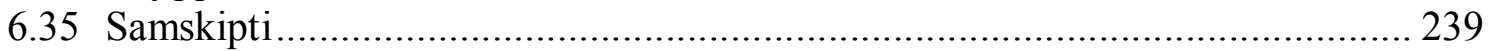

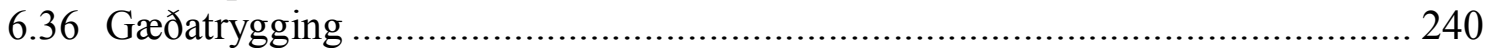

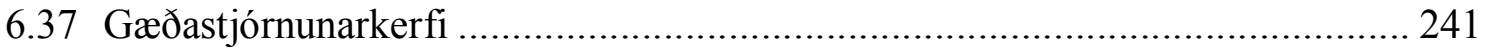

6.38 Gæði 242

Viðauka F - Tengslatöflur og fylgni milli breyta hjá verkkaupum ......................... 245

6.39 Fylgni við ánægju verkkaupa með umræddan verktaka .................................. 245

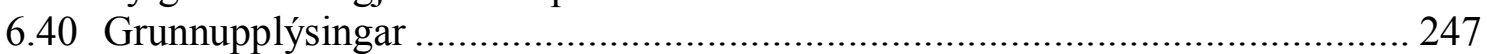

6.40.1 Tvívítt fylgnifylki: framkvæmdaár, ánægja_umræddan ........................ 247

6.40.2 Tvívítt fylgnifylki: kyn_verkkaupa, aldur, fyrir_einst,

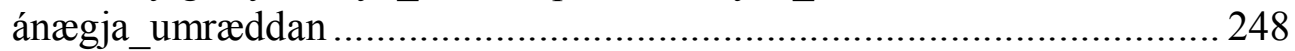

6.40.3 Fylgni: kyn_verkkaupa * ánægja_umræddan .................................... 249

6.40 .4 Fylgni: fyrir_einst * ánægja_umræddan .......................................... 250

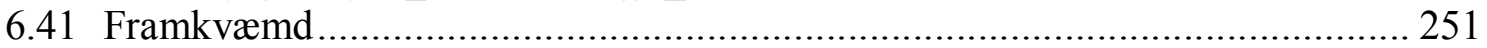

6.41.1 Fylgni: ánægja_bygg * ánægja_umræddan * fyrir_einst....................... 251

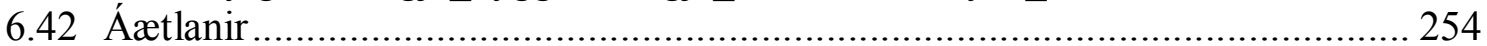

6.42.1 Tvívítt fylgnifylki: ánægja_umræddan, ánægja_tíma, skrifleg_tíma,

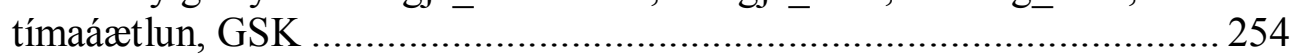

6.42.2 Fylgni: skrifleg_tíma * ánægja_umræddan * fyrir_einst....................... 255

6.42.3 Fylgni: tímaáætlun * ánægja_umræddan * fyrir_einst .......................... 257

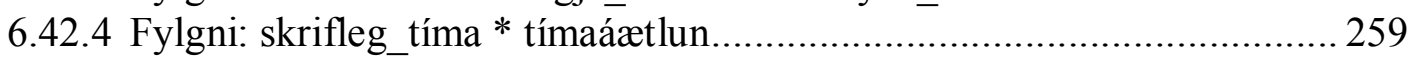

6.42.5 Tvívítt fylgnifylki: ánægja_umræddan, ánægja_greiðslu, skrifleg_greiðslu, greiðsluáætlun, GSK ............................................. 260

6.42.6 Fylgni: skrifleg_greiðslu * ánægja_umræddan * fyrir_einst ................... 260 
6.42.7 Fylgni: greiðsluáætlun * ánægja_umræddan * fyrir_einst ......................262

6.42.8 Fylgni: skrifleg_greiðslu * greiðsluáætlun ........................................265

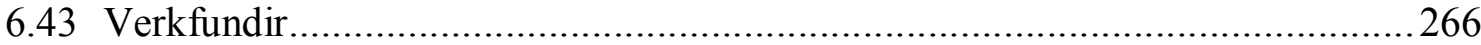

6.43.1 Tvífylgnifylki: ánægja_umræddan, verkfundir, verkfundir_verkkaupi, verkfundir_fundargerð, verkfundir_fleiri, verkfundir_staða, GSK ..........266

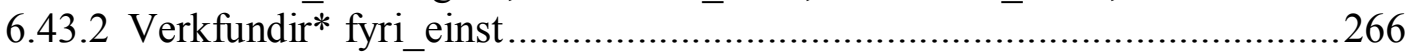

6.43.3 Fylgni: verkfundir * ánægja_umræddan * fyrir_einst...........................268

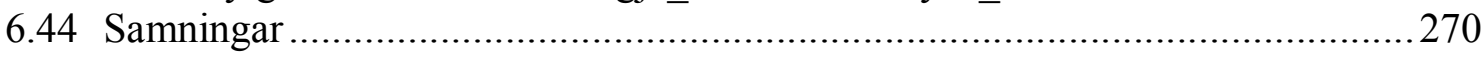

6.44.1 Tvífylgnifylki: ánægja_umræddan, GSK, samningur_ræddur, samningur_sundurliðaður, samningur_ósætti....................................2270

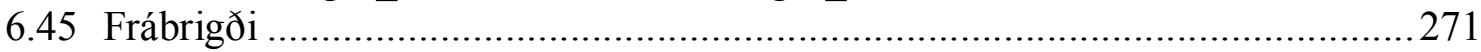

6.45.1 Tvífylgnifylki: ánægja_umræddan, frábrigði, frábrigði_tilkynnt, GSK ....271

6.45.2 Fylgni: frábrigði * ánægja umræddan ...............................................2271

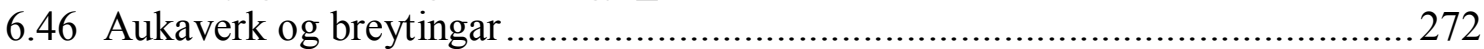

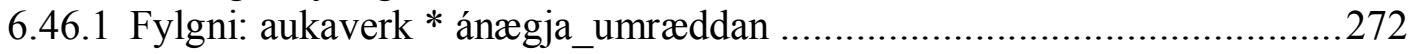

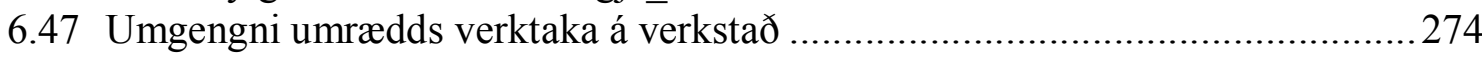

6.47.1 Fylgni: umgengni * ánægja_umræddan ..........................................2274

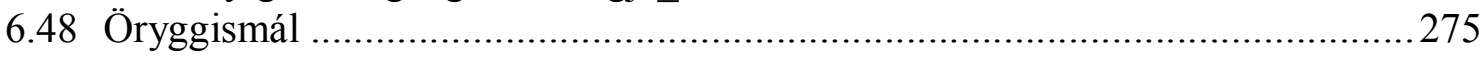

6.48.1 Tvífylgnifylki: ánægja_umræddan, GSK öryggismál_rædd, öryggismál_verktaka, ánægja_öryggismál ......................................2275

6.48.2 Fylgni: öryggismál_rædd * ánægja_umræddan * fyrir_einst..................2276

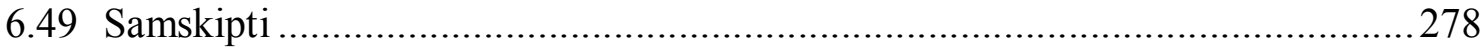

6.49.1 Tvívítt fylgnifylki: ánægja_umræddan, ánægja_samskipti, pjónustulund, samskipti_rædd .........................................................278

6.49.2 Fylgni: ánægja_samskipti * ánægja_umræddan * fyrir_einst .................2278

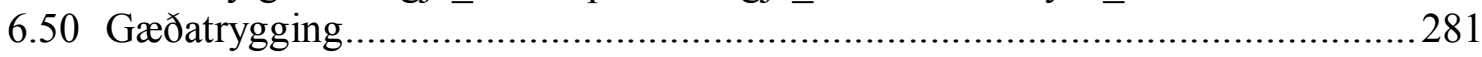

6.50.1 Fylgni: gæðatrygging * ánægja_umræddan * fyrir_einst.......................228

6.50.2 Fylgni: gæðatrygging * ánægja_umræddan * fyrir_einst.......................2283

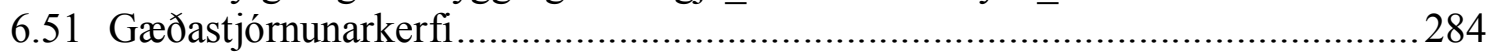

6.51.1 Tvífylgnifylki: GSK, ánægja_umræddan, ánægja_tíma, ánægju_greiðslu, ánægja_öryggismál, ánægja_samskipti,

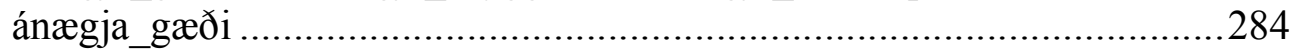

6.51.2 Fylgni: fyrir_einst, ánægja_umræddan, GSK ..................................228

6.51.3 Fylgni: skrifleg_tíma * GSK .......................................................28

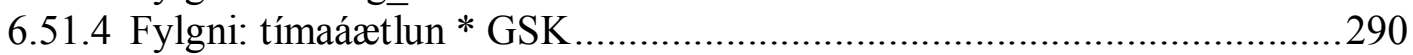

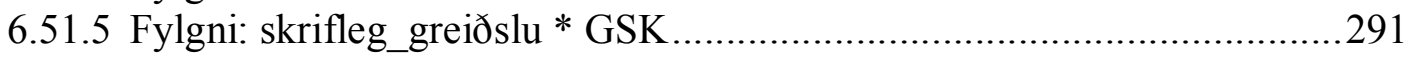

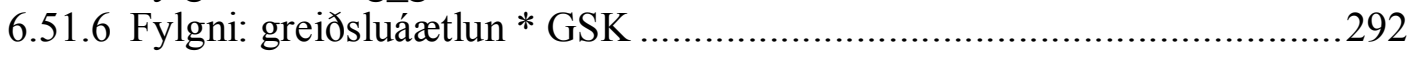

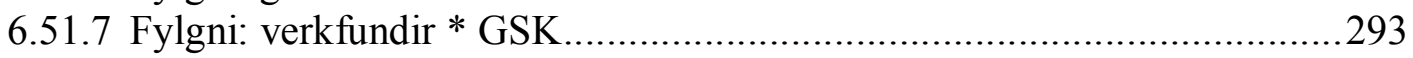

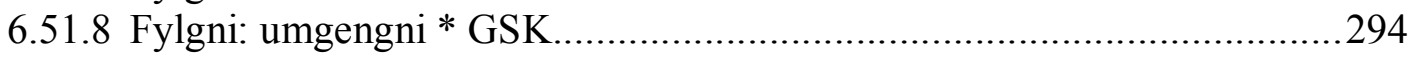

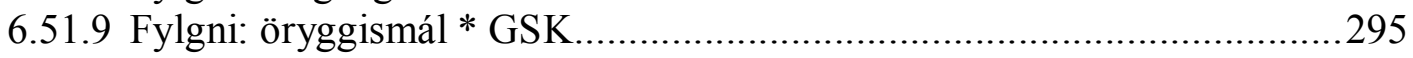

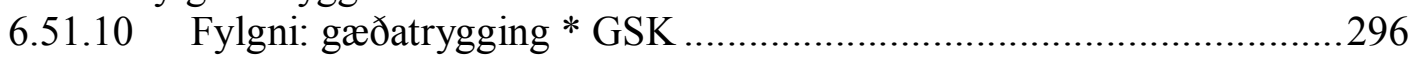

6.51.11 Tvífylgnifylki: GSK, ánægja_umræddan, gæðatrygging_verktaki, gæðatrygging_ósk, gæðatrygging_undirverktaki ...................................297

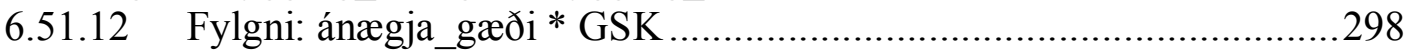

6.51.13 Tvífylgnifylki: GSK, ávinningur, ávinningur/kostnaður, rekstrarafkoma, samkeppnishæfi, frábrigði_gsk, mannafli, trú_gsk.........299

6.51.14 Tvífylgnifylki: GSK, ánægja_umræddan, almennt, ÍST30, ISO9001, útboðsgögn. 
6.51.15 Tvífylgnifylki: GSK, ánægja_umræddan, merking, geymsla, varðveislutími, förgun

6.51.16 Tvífylgnifylki: GSK, ánægja_umræddan, starfslýsingar_skriflegar, starfslýsingar_kynnt, verkáætlun_skrifleg, verktöf_skrifleg, greiðsluáætlun_skrifleg......

6.51.17 Tvífylgnifylki: GSK, ánægja_umræddan, verkfundir_reglubundnir, fundargerð, verkdagbók

6.51.18 Tvívítt fylgnifylki: GSK, ánægja_umræddan, frábrigði_tilkynnt, aukaverk_skráð, hættumat, gæðaeftirlit_utanaðkomandi, gæðastýringaráætlun

Viðauki G - Athugasemdir um könnun fyrir verkkaupa .................................... 306

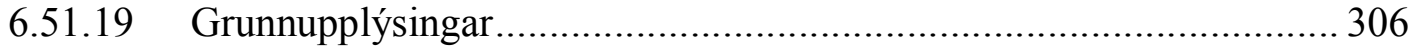

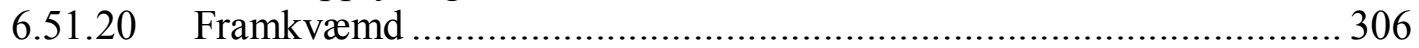

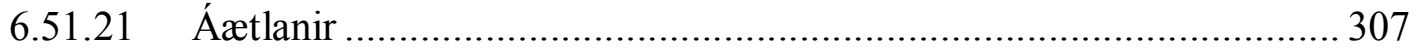

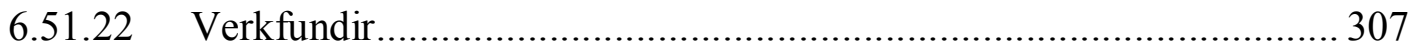

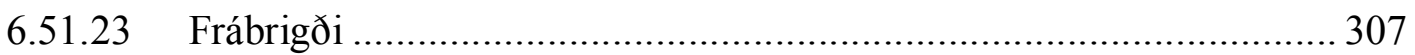

Viðauki H - Tíonitöflur úr könnun verktaka ...................................................... 308

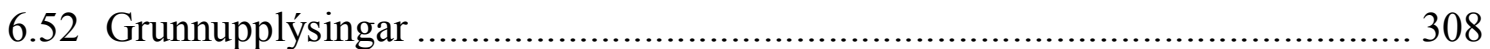

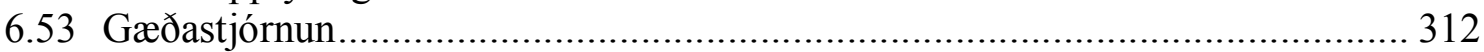

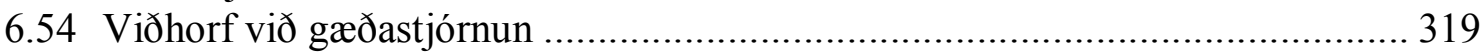

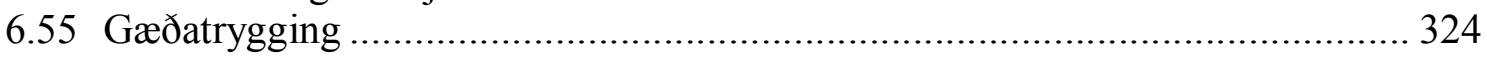

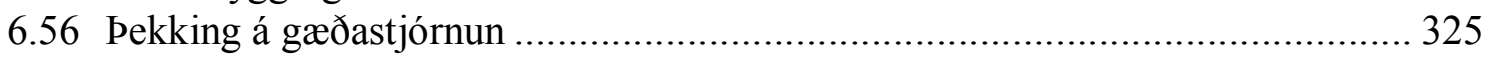

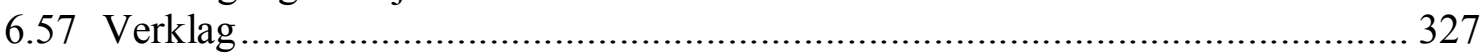

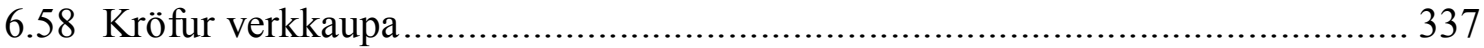

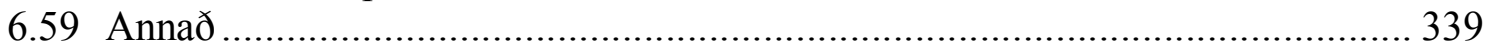

Viðauki I - Tengslatöflur og fylgni milli breyta hjá verktökum............................. 341

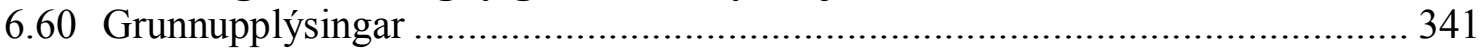

6.60.1 Tvívítt fylgnifylki: ánægja_umræddan, stærð, aldur_fyrirt .................... 341

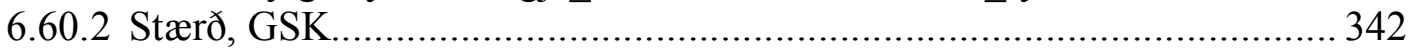

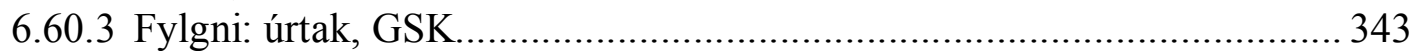

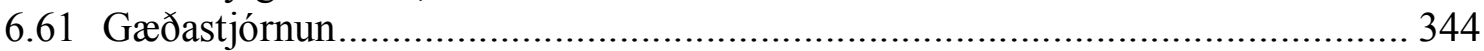

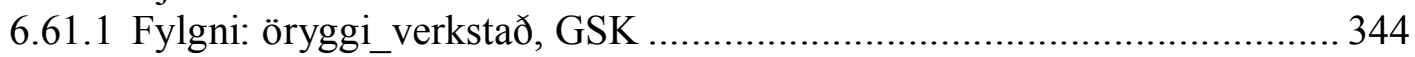

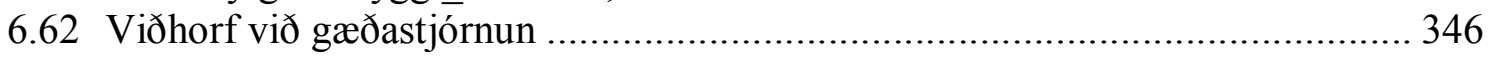

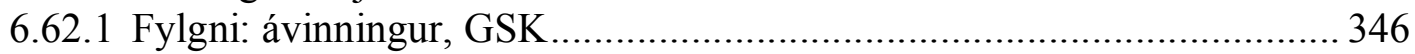

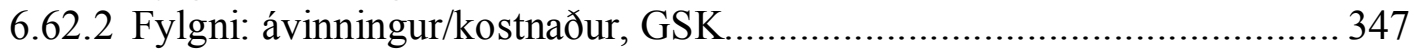

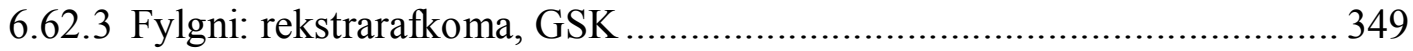

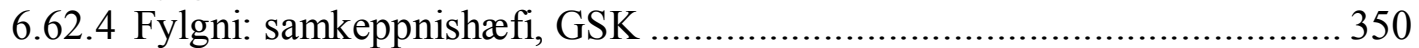

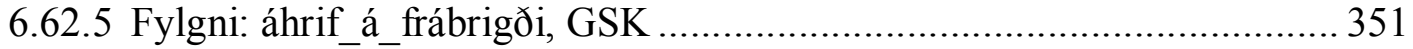

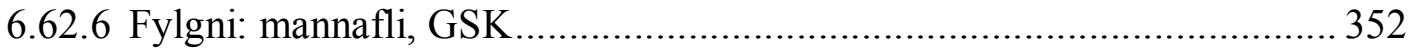

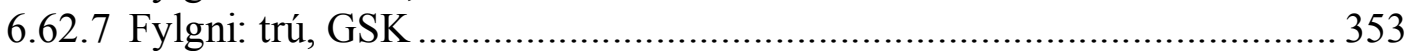

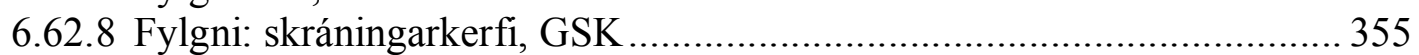

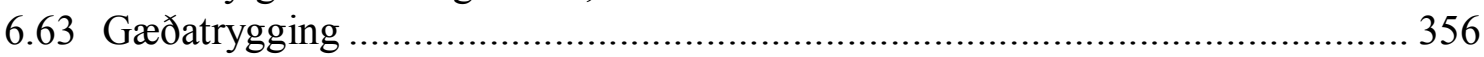

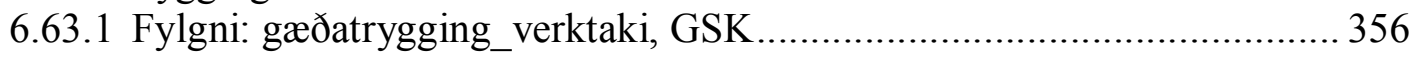

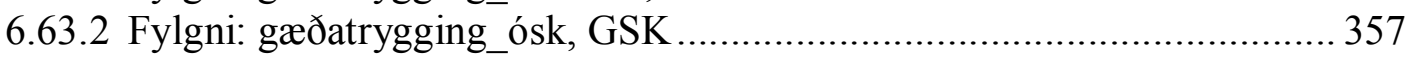

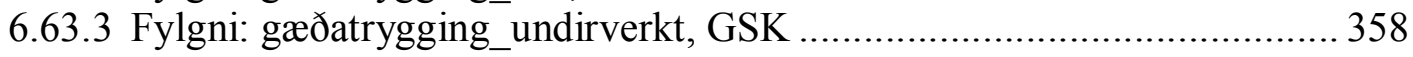

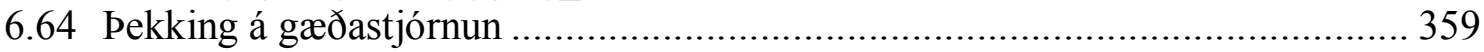

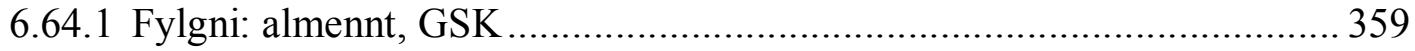




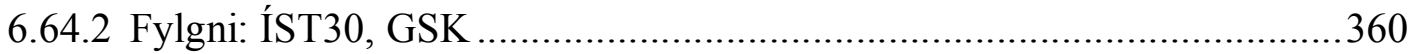

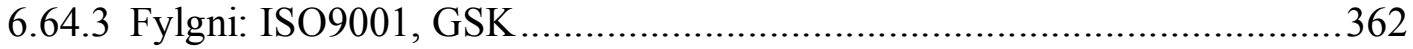

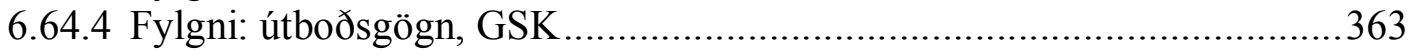

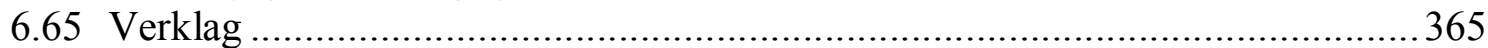

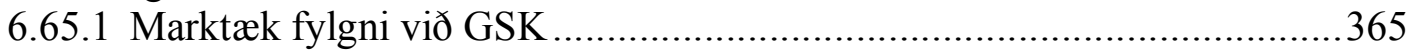

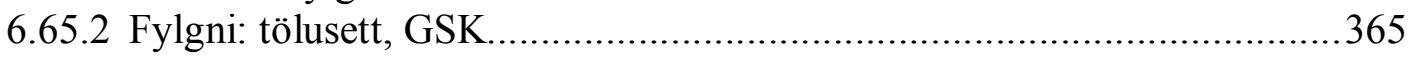

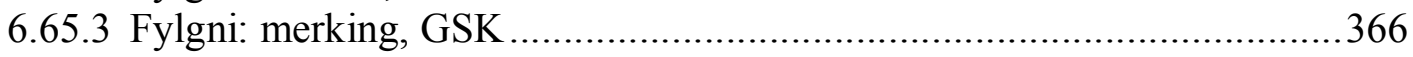

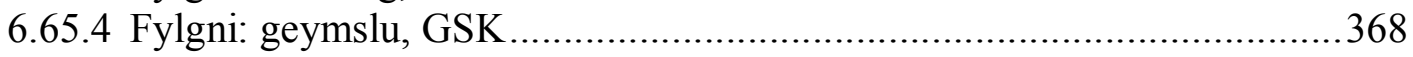

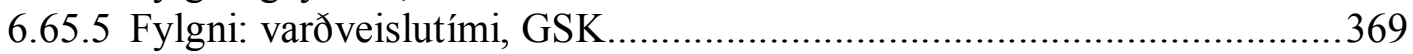

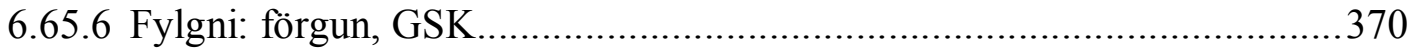

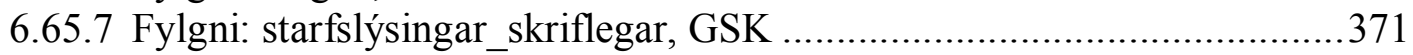

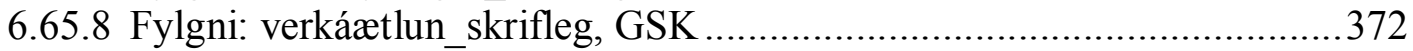

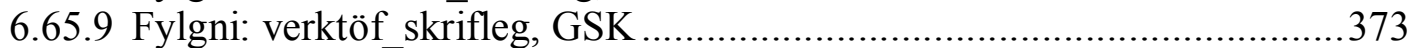

6.65.10 Fylgni: greiðsluáætlun_skrifleg, GSK .............................................374

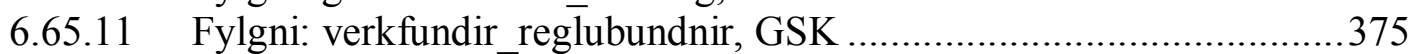

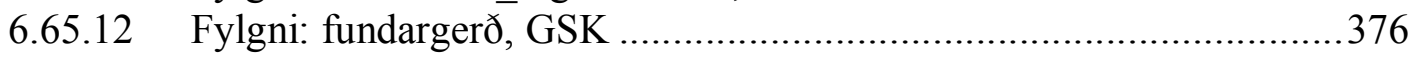

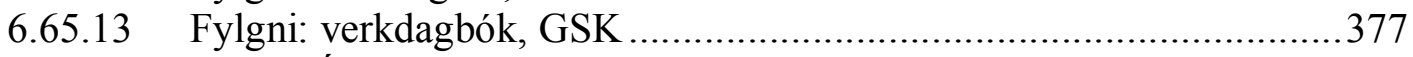

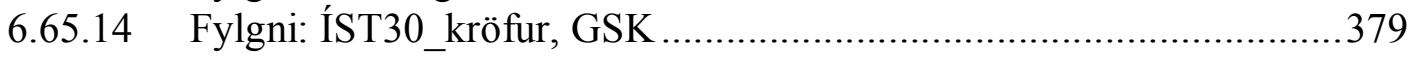

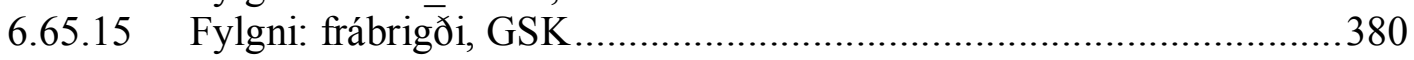

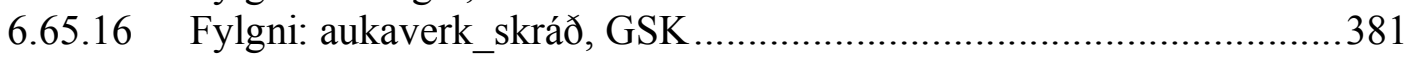

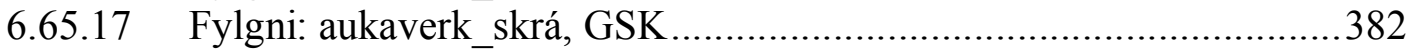

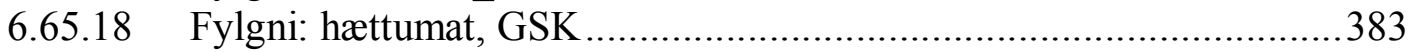

6.65.19 Fylgni: gæðaeftirlit_utanaðkomandi, GSK .....................................384

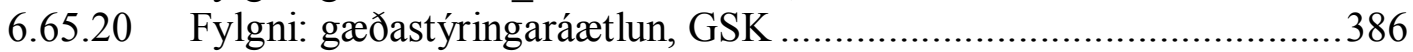

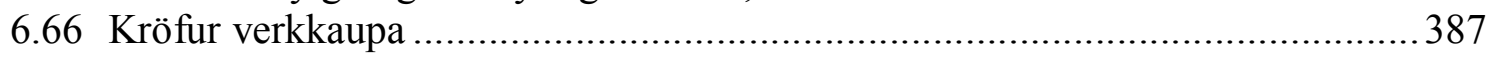

Viðauki J - Athugasemdir um könnun fyrir verktaka...............................................388

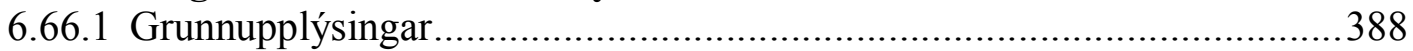

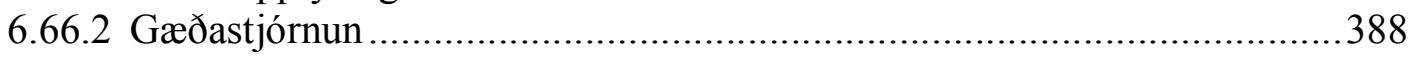

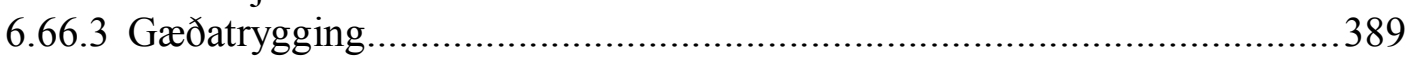

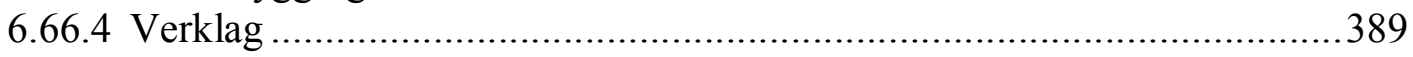

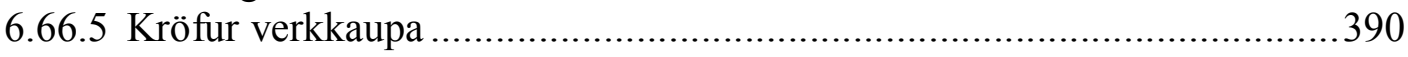

Viðauki K - Flokkunar aðhvarfsgreining (e. Categorical Regression -

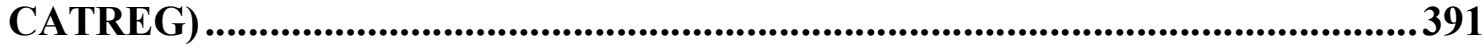

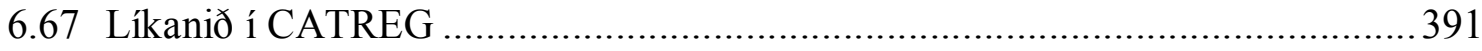

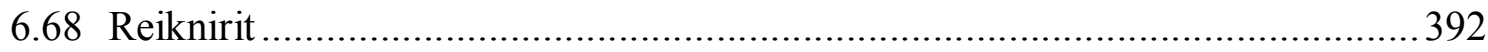

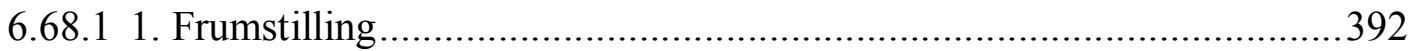

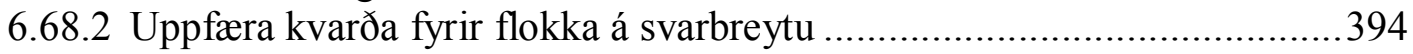

6.68.3 Uppfæra kvarða fyrir flokka og vægi aðhvarfsgreiningarstuðla................394

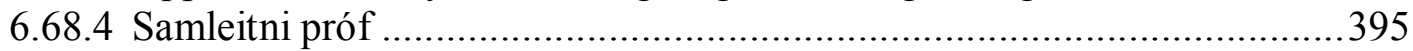

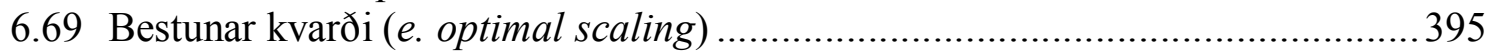

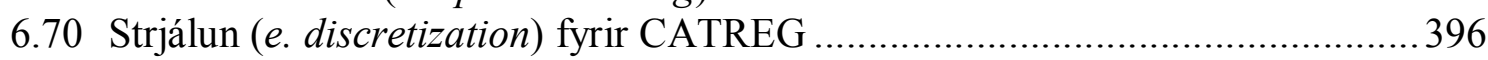

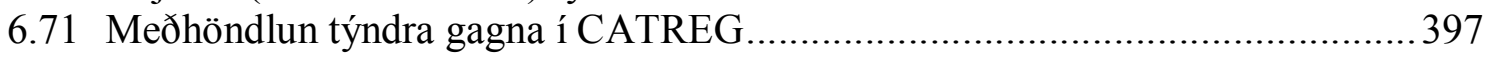

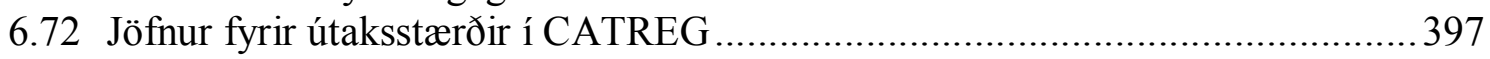

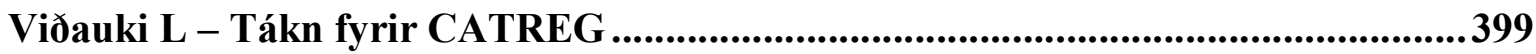

Viðauki L - Tákn fyrir CATREG ................................................................................399 
Viðauki M - Hvernig besta flokka aðhvarfsgreiningar líkan er valið...................... 401

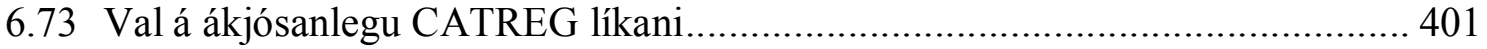

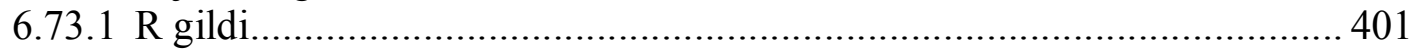

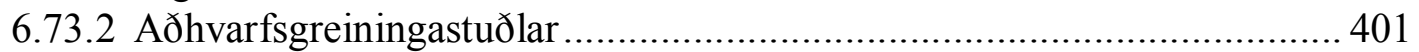

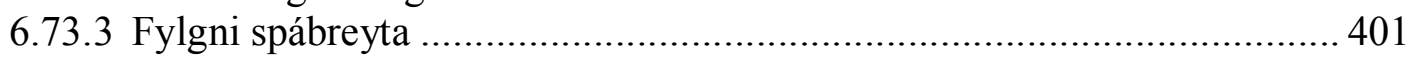

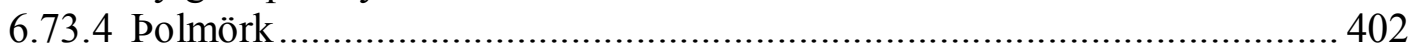

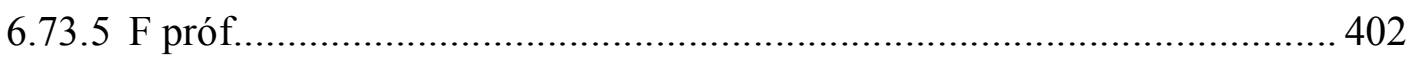

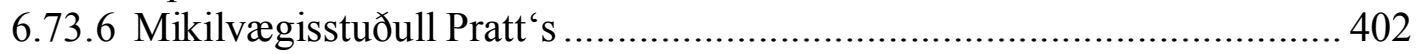

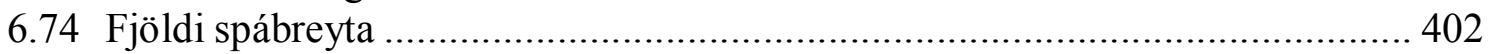

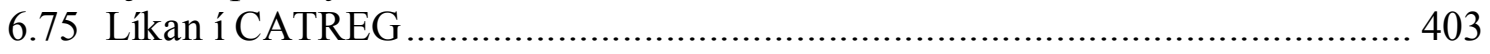

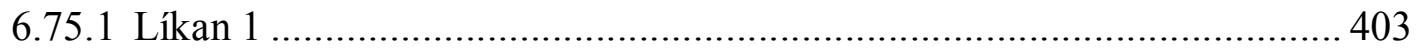

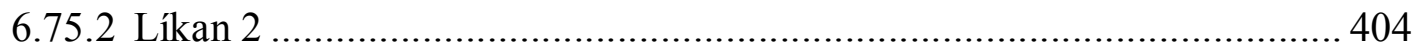

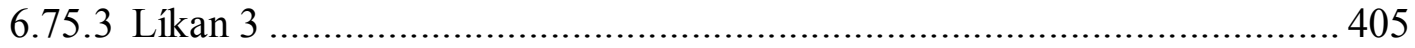

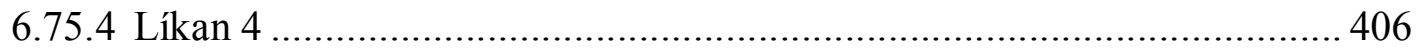

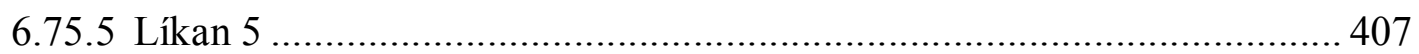

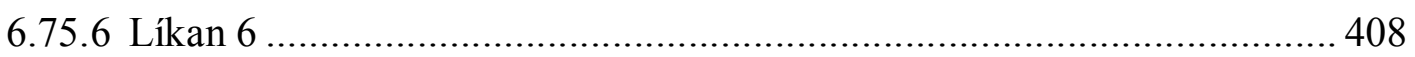

Viðauki N-Ályktunartölfrææði og marktektarpróf .................................................. 412

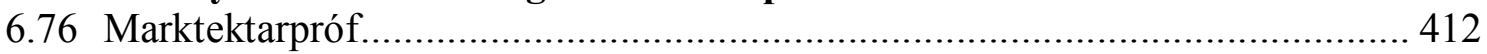

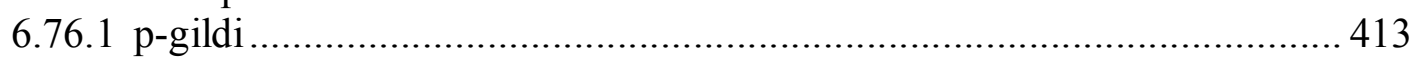

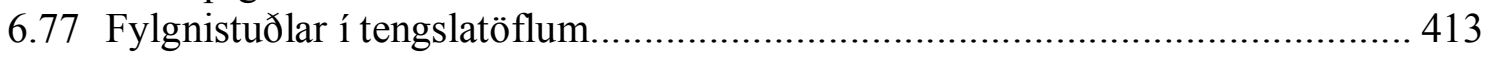

Viðauki O - Svör við opnum spurningum................................................................. 415

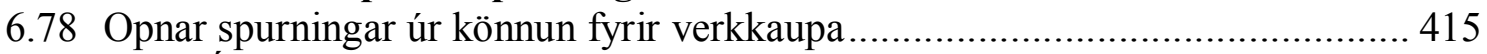

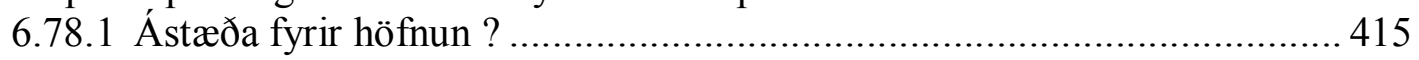

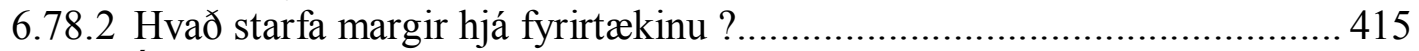

6.78.3 Í hvers konar starfsemi er fyrirtækið ?.............................................. 416

6.78.4 Í hvaða tilgangi var farið út í verkframkvæmdir ?................................ 418

6.78.5 Starfsgrein verktaka sem hafour er í huga? ...................................... 421

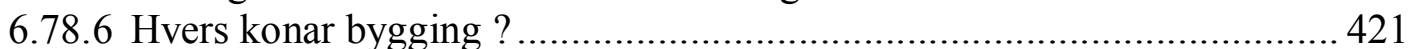

6.78.7 Hvaða menntun hefur pú ? ............................................................ 424

6.78.8 Hvaða páttur stóð upp úr sem pú varst mest ósátt/ur við ? .................... 424

6.78.9 Er verkið farið fram úr eða fór verkið fram úr tímaáætlun hjá

umræddum verktaka - hvaða pátt telur pú að hafi haft mestu áhrif? ....... 427

6.78.10 Var greiðsluáætlunin endurskoðuð og uppfærð reglulega ?............... 429

6.78.11 Er verkið farið fram úr eða fór verkið fram úr greiðsluáætlun hjá

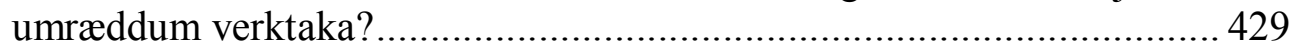

6.78.12 Hafðir pú umsjónarmann sem sá um að umræddur verktaki framfylgdi ákvæðum samningsins ? ................................................... 430

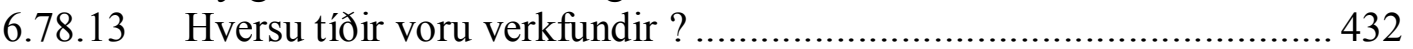

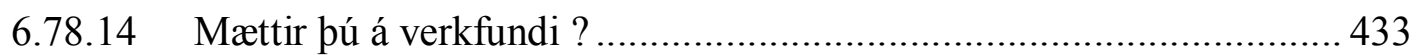

6.78.15 Var rituð fundargerð á verkfundum ?........................................... 433

6.78.16 Hvernig var pér tilkynnt um frábrigði ? ......................................... 435

6.78.17 Нvað var pað sem pér pótti miður fara varðandi umgengni verktaka ef eitthvað var?

6.78.18 Komu upp einhver vandamál í samskiptum pínum við verktaka? Hver pá ? .................................................................................... 436

6.78.19 Eru einhver atriði sem pér finnst hafa vantað upp á gæði ? Hvað pá ? 437 
6.78.20 Að lokum eitthvað sem pú vilt koma á framfæri ?............................439

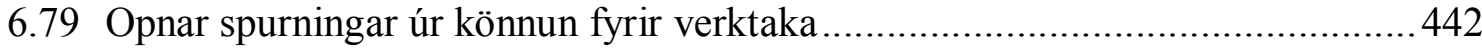

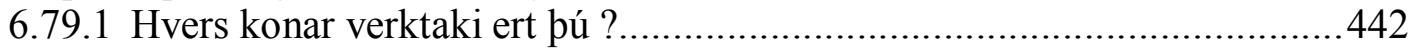

6.79.2 Í hvaða sveitarfélagi/um starfar fyrirtækið sem pú starfar hjá ?...............442

6.79.3 Hvaða menntun hefur bú ?.......................................................................44 44

6.79.4 Hver er staða pín innan fyrirtækisins ?................................................44 44

6.79.5 Hvernig vottun hefur fyrirtækið hlotið ? ...........................................445

6.79.6 Veitið pið verkkaupa upplýsingar um gæðastjórnunarkerfið sem pið notið í verkbyrjun - Í hvaða tilfellum ?.................................................445

6.79.7 Viðhafið pið sérstakar öryggisráðstafanir á verkstað - Hvaða öryggisráðstafanir viðhafið pið ?

6.79.8 Ef pið sýnið verkkaupa fram á gæðatryggingu hvað kemur pá fram í henni ?

6.79.9 Leggið pið fram skriflega verkáætlun fyrir hvert verk - Í hvaða tilfellum ?....

6.79.10 Sendið pið verkkaupa skriflega rökstudda tilkynningu um verktöf pegar svo ber undir - Í hvaða tilfellum?

6.79.11 Gerið pið skriflega greiðsluáætlun við verkkaupa fyrir hvert verk Í hvaða tilfellum?

6.79.12 Er venja að gert sé samkomulag um reglubundna verkfundi með verkkaupa - Í hvaða tilfellum?

6.79.13 Er venja að rituð sé fundargerð á verkfundum - Í hvaða tilfellum?.....449

6.79.14 Haldið pið verkdagbók - Hvað kemur fram í henni ?

6.79.15 Er venja að pað sé tekið fram í samningum að pað beri að fara eftir kröfum samskiptastaðalsins IST 30 - Í hvaða tilfellum ?

6.79.16 Eru óskir verkkaupa um aukaverk og breytingar skráðar - Í hvaða tilfellum?

6.79.17 Ef óskir um aukaverk og breytingar eru skráðar, kemur pá fram í skráningu áhrif á verðlagningu heildarverks og framvindu - Í hvaða tilfellum?.

6.79.18 Hversu oft skilið pið skrá yfir hugsanlegar kröfur um greiðslur vegna aukaverka og breytinga til verkkaupa - Hversu oft?

6.79.19 Gerið pið hættumat og/eða áhættugreiningu á verkstað ?

6.79.20 Eitthvað að lokum sem pú vilt koma á framfæri ?

Viðauki P - Hönnun spurningalista fyrir verkkaupa og verktaka 455

Viðauki Q - Tilgátupróf 


\section{Skammstafanir og skilgreiningar}

Aðalverk. Par sem verktakinn sér um alla framkvæmd en ekki hönnun.

Aðalverktaki. Verktaki er nefndur aðalverktaki ef hann fær aðra verktaka, einn eða fleiri, að framkvæma hluta verks sem hann hefur tekið að sér. Aðalverktaki er ábyrgur fyrir framkvæmdum sem undirverktakar vinna. Verkkaupa er bó heimilt að hafna undirverktaka ef hann telst vanhæfur að mati verkkaupa (ÍST EN ISO 9000:2000, 2000). Sá sem er aðalverktaki sér pví um að semja og ber ábyrgð á heildarverki en felur sérhæfoum verktökum og efnissölum einstaka pætti samkvæmt sérstökum samningum.

Alverk. Pegar verktakinn sér um hönnun og alla framkvæmd.

Almennt útboð. Útboð auglýst og ótilgreindum fjölda er gefinn kostur á að gera tilboð (ÍST EN ISO 9000:2000, 2000).

Alútboð. Útboð pegar tilboða er leitað í bæði hönnun og framkvæmd verks samkvæmt forsögn (ÍST EN ISO 9000:2000, 2000).

Alverktaki. Verktaki sem tekur að sér að bæði hanna og framkvæma verk samkvæmt alútboði (ÍST EN ISO 9000:2000, 2000).

Altæk gæðastjórnun (e. Total Quality Management, TQM). Stjórnunarstefna fyrirtækis sem snýst um gæði og byggist á pátttöku allra starfsmanna. Hún miðar að pví að ná langtíma árangri með pví að stuðla að ánægju viðskiptavina og hag allra starfsmanna fyrirtækisins og samfélagsins (Steinunn Huld Atladóttir og Ómar Imsland, 2003).

Aukaverk. Verkkaupa er heimilt að krefjast breytinga á umfangi verksins innan eðlilegra marka. Honum er heimilt að gera sérstakar kröfur um breytingar á efnisvali, hönnun, framkvæmd verksins og um aukaverk. Allar kröfur um breytingar á verki skulu vera skriflegar (ÍST EN ISO 9000:2000, 2000).

Byggingarstjóri. Einstaklingur eða lögaðili sem ber ábyrgð á skipulagi, framkvæmd eða eftirliti með verki, og starfar í págu verkkaupa.

CATREG. Aðhvarfsgreining fyrir flokka-breytur.

Fagverk. Pegar samið er beint við verktaka í hverjum verkpætti.

Flokka-breyta. Breyta par sem svarmöguleikar eru fyrirfram ákveðnir flokkar, en ekki sérstök tala byggð á mælingum eða svar á samfelldum skala. Ein gerð af flokkabreytu eru spurningar par sem svarmöguleikarnir eru valdir með Likert skala (mjög ánægð/ur, frekar ánægð/ur, hvorki ánægð/ur né óánægð/ur, frekar óánægð/ur, mjög óánægð/ur) en með slíkum skala er ekki hægt að segja að bil sé jafnt á milli svarmöguleika (Watters, 2008). 
Fjármagnsstreymi. Er pá átt við flæði greiðslna sem verkkaupi parf að láta af hendi yfir verktímann (sjá bls.215).

Formlegir verkfundir. Pá er átt við skipulagða fundi par sem farið er yfir fyrir fram ákveðin málefni (sjá bls. 223).

Frábrigði. Varanlegur galli eða auka útgjöld. Til dæmis að kröfum viðskiptavinar er ekki mætt, að vandamálið er með vöru eða pjónustu eða að gæðastjórnunarkerfið er á einhvern hátt ófullnægjandi eða einhverjar aðrar aðstæður par sem eitthvað er ekki í samræmi við kröfur eða væntingar (Staðlarád Íslands, 2003, bls. 31).

Framleiðslu í taka tío (e. Just in time, JIT). Safn innbyrðis tengdra verkferla sem útfærðir eru til að ná miklum framleiðsluafköstum með lágmarks birgðum (hráefnum, vörum í vinnslu og fullunnum vörum).

Gilt hlutfall. Hlutfall svara við tiltekinni spurningu miðað við heildarfjölda svara við sömu spurningu.

Gæði (e. Quality). Баð sem viðskiptavinurinn vill. Verkefnastjórnunarfélag Íslands skilgreinir gæði á eftirfarandi hátt: „Рað að hvaða marki safn tiltekinna eðlislægra eiginleika uppfyllir kröfur“" (ÍST EN ISO 9000:2000, 2000).

Gæðahandbók. Gæðahandbók er notuð til daglegra starfa og er hún í samræmi við stjórnunar- og framleiðsluferla. Mikilvægt er að starfsmennirnir eigi auðvelt með að skilja pað sem skrifað er og að gátlistar séu auðveldir í notkun og að kerfið í heild sinni sé einfalt í notkun. Gæðahandbók á að vera skrifuð á einföldu máli, einföld í uppbyggingu og eins stutt og kostur er. Leitast skal við að láta gátlista og eftirlitsblöð vera eins einföld til útfyllingar og hægt er. Par að auki skal byggja bókina upp í samræmi við stjórnunar-, vinnu- og framleiðsluferla í fyrirtækinu. Gæðahandbók á að innihalda umfang gæðastjórnunarkerfisins, verklagsreglur eða tilvísanir í pær og lýsingu á samverkan ferla í gæðastjórnunarkerfinu (ISO 9001 fyrir lítil fyrirtæki - Leiðsögn, 2003).

Gæðastefna (e. Quality Plan ). Æðstu stjórnendur purfa að tryggja að gæðastefnan hæfi tilgangi fyrirtækisins, feli í sér skuldbindingu um að fara að kröfum og bæta stöðugt virkni gæðastjórnunarkerfisins, skapi umgerð til pess að koma með og rýna gæðamarkmið, sé kynnt og hún skilin innan fyrirtækisins og að lokum að hún sé rýnd með tilliti til pess hvort hún eigi áfram við (ISO 9001 fyrir lítil fyrirtæki - Leiðsögn, 2003).

Gæðastjórnun (e. Control, $Q \boldsymbol{C}$ ). Samhæfð starfsemi til að stýra og stjórna fyrirtæki með tilliti til gæða. Stýring og stjórn á pví er varðar gæði felur venjulega í sér að setja fram gæðastefnu og gæðamarkmið og að koma upp skipulagningu gæða, gæðastýringu, gæðatryggingu og gæðaumbótum (ÍST EN ISO 9000:2000, 2000).

Gæðatrygging (e. Quality Assurance, $Q A$ ). Staðlaráo Íslands skilgreinir gæðatryggingu á eftirfarandi hátt „Sá hluti af gæðastjórnun, er beinist að pví að uppfylla gæðakröfur“ (ÍST EN ISO 9000:2000, 2000). Í pessari ritgerð mun orðið gæðatrygging vera notað yfir pað pegar verktaki hefur sett fram skriflega hvernig hann hyggst framkvæma verkið pannig að sett gæðamarkmið náist. 
Hlutfall. Hlutfall svara við tiltekinni spurningu miðað við heildarfjölda pátttakenda í könnuninni.

Jafnbilakvarði. Gefur upplýsingar um röð einstaklinga. Á milli peirra eru alltaf jöfn bil (Amalía Björnsdóttir, 2004).

Jafnbilabreyta. Breyta mæld á jafnbilamælikvarða.

Lítið fyrirtæki. Lítil fyrirtæki eru skilgreind út frá starfsmannafjölda en ekki síður út frá hugmyndafræðinni sem fylgt er við rekstur fyrirtækisins. Litlu fyrirtæki er venjulega stjórnað af mjög fámennum hópi fólks. Fyrirtæki í einstaklingseign, eign tveggja eða priggja meðeiganda, fjölskyldufyrirtæki og fyrirtæki með premur eða fjórum stjórnendum eru dæmigerð fyrirtæki sem talað er um sem „lítil fyrirtæki“" hér á eftir (ISO 9001 fyrir lítil fyrirtæki - Leiðsögn, 2003).

Markverk. Pegar verkkaupi og verktaki skrifa undir svo nefndan marksamning par sem báðir aðilar hafa komið saman um verð sem mannvirkið á að kosta. Með slíkum samning hefur verktakinn einnig hagsmuni af pví að verkið klárist á réttum tíma og undir kostnaðaráætlun. Ef verkinu lýkur undir kostnaðar-áætlun fær verktakinn greiddan hluta af sparnaðinum, en ef verkið fer fram úr áætlun fær verktakinn aðeins hluta af mismuninum greiddan.

Nafnkvarði. Setur einstaklinga í ákveðna flokka. Slíkur kvarði felur aðeins í sér upplýsingar um hvaða flokki viðkomandi tilheyrir eða að hann hafi eiginleika sem eru eigindlega ólíkir hinum flokkunum (Amalía Björnsdóttir, 2004).

Nafnabreyta. Breyta með nafnkvarða.

Óformlegir verkfundir. Pá er átt við fundi sem var ekki endilega boðað til með fyrirvara og ekki farið yfir skipulagða eða fyrir fram ákveðna fundardagskrá (sjá bls.223).

Raðkvarði. Geymir upplýsingar um röð einstaklinga, en pað er samt ekki endilega jafnlangt á milli gilda á breytunni. Dæmi um raðkvarða er svarkvarði með mismunandi gildum. Raðkvarði er mikið notaður í könnunum í pessari rannsókn par sem svörin eru t.d. mjög sammála, frekar sammála, hlutlaus, frekar ósammála og mjög ósammála. Gera má ráð fyrir að sá sem er mjög sammála sé jákvæðari en sá sem er frekar sammála, en sá sé aftur á móti meira sammála en sá sem merkir við hlutlaust. Á hinn bóginn er með öllu óljóst hvort jafnmikill skoðanamunur er á milli pessara priggja einstaklinga (Amalía Björnsdóttir, 2004).

Raðbreyta. Breyta með raðkvarða.

Umræddir verktakar. Pegar talað er um umrædda verktaka er átt við pá verktaka sem verkkaupar sem voru pátttakendur í könnun fyrir verkkaupa höfơ í huga við svörun spurninganna. Hluti af pessum umræddu verktökum tók pátt í sérstakri könnun ætlaðri verktökum.

Umsjónarmaður. „Umsjónarmaður verkkaupa er sérstakur fulltrúi verkkaupans og hefur hann yfirumsjón með eftirliti og með pví að verktakinn standi við gerða samninga. Hann 
getur pví einn gefið út og veitt móttöku fyrir hönd verkkaupans yfirlýsingum varðandi verkið og metið gilt eða hafnað efni og vinnu. Hann getur mætt fyrir hönd verkkaupans við úttekt á verkinu og samið um öll minniháttar viðbótarverk. Að öðru leyti getur hann komið fram fyrir hönd verkkaupa gagnvart verktaka um allt sem varðar framkvæmd verksins“ (BSTR, 2003, bls. 17.5.1).

Verkdagbók. Dagbók um hvert verk. Í hana skal skrá verkefni hvers dags, mannafla skv. starfsgreinum, tæki, veðurfar og annað sem pýðingu hefur fyrir framgang verksins (ÍST 30:2003, Almennir útboðs- og samningsskilmálar um verkframkvæmdir, 2003).

Verkefnastjórnun. Aðferðafræði sem felur í sér undirbúning, skipulagningu, áætlanagerð, vöktun og eftirlit á öllum páttum verkefnis. Aðferðafræðin er hvetjandi fyrir pátttakendur til að ná markmiðum verkefnis innan sampykktrar áætlunar um tíma kostnað og frammistöðu eða árangur verkefnis (Steinunn Huld Atladóttir og Ómar Imsland, 2003).

Verklagsregla. Inniheldur tilvitnun í stefnu (ef við á), tilgang og umfang (hvers vegna og hve víðtæk) ábyrgðar á framgangi og gæðum verksins (hver), framkvæmd (hvað - prep fyrir brep) og tilvísanir í skjöl og skrár.

Vottun. Formleg viðurkenning annarra á gæðastjórnunarkerfi fyrirtækisins. Í sumum löndum eru vottuð gæðastjórnunarkerfi kölluð „skráð“ gæðastjórnunarkerfi og hugtakið „skráning“ notað í stað vottunar (ISO 9001 fyrir lítil fyrirtæki - Leiðsögn, 2003).

Öryggisbil. Skekkjan sem úrtakið ber frá býðinu. P.e. ef öryggisbilið er 5 og $50 \%$ pátttakenda í rannsókn svara á ákveðinn hátt má gera ráð fyrir að milli 45 og 55\% pýðis myndu svara á sama hátt.

Öryggisstig. Segir til um með hversu mikilli vissu er hægt að áætla að svör pýðis myndu falla innan tiltekins öryggisbils. 95\% öryggisbil gefur pví 95\% vissu að svör pýðis myndu í 45-55\% tilfella vera á sama hátt og í býðinu í dæminu hér að ofan. 



\section{Pakkir}

Skrif pessarar skýrslu hefur verið löng og spennandi ferð. Ófyrirséðar hindranir töfðu framgang verkefnisins en mér til mikils happs gat ég unnið hana undir handleiðslu fróðra og hæfileikaríkra manna sem gátu leiðbeint mér.

Sérstakar pakkir vil ég færa leiðbeinendum verkefnisins, Helga Pór Ingasyni og Páli Jenssyni fyrir góða leiðsögn.

Einnig vil ég færa Ferdinand Hansen pakkir, en hann hefur reynst mér einstaklega vel bæði til aðstoðar við gagnasöfnun og til handleiðslu. Ásamt pví sem ég pakka Samtökum iðnaðarins fyrir fjárhagslegan stuðning.

Einnig pakka ég sérstaklega öllum peim sem tóku pátt í könnunum og viðtölum í rannsókninni ásamt peim byggingafulltrúum sem lögðu fram vinnu við að afla gagna fyrir rannsóknina. Án peirra hjálpar hefơi rannsóknin ekki verið gerleg.

Ég pakka Ólafi Hauki Árnasyni og Björgu Hilmarsdóttur fyrir góða yfirferð með tilliti til íslensks málfars og Gunnari Finnson með tilliti til ensks málfars.

Ég pakka Unni Guðnadóttur og Eyjólfi Bjarnasyni fyrir yfirferð á spurningalistum og að lokum pakka ég öllu pví góða fólki sem aðstoðaði mig á einhvern hátt bæði beint og óbeint. 



\section{Inngangur}

Á fáeinum árum hafa verið miklar sveiflur í mannvirkjagerð á Íslandi. Aðstæður í efnahagslífinu hafa breyst mikið að undanförnu og sjaldan hefur ríkt jafn mikil óvissa og ójafnvægi í pjóðarbússkapnum. Alpjóðlega fjármálakreppan sem hófst sumarið 2008 hefur reynst dýpri og víðtækari en gert var ráð fyrir. Misserin fyrir upphaf hennar einkenndust af spennu á byggingamarkaði og sjaldan eða aldrei hefur eins mikið verið byggt á eins stuttum tíma. Með auknum hraða við byggingaframkvæmdir heyrðust efasemdaraddir sem álitu gallatíðni í mannvirkjagerð vaxa samhliða auknum byggingahraða. Ekki liggja pó fyrir neinar rannsóknir sem staðfesta pað. Til að tryggja fyrirmyndar mannvirkjagerð parf vinnubrögð og skiptir par gæðastjórnun miklu máli að mati skýrsluhöfundar. Setja parf skýrar reglur til að tryggja öryggi og heilnæmi mannvirkja, að gerðar séu kröfur um hæfni og öguð vinnubrögð peirra sem að mannvirkjagerðinni koma og síðast en ekki síst að markvisst og faglegt byggingareftirlit fari fram. Markmið verkefnisins er að rannsaka áhrif gæðastjórnunar í mannvirkjagerð á Íslandi. Spurningar, sem leitast er eftir að svara, eru eftirfarandi:

- Hver er staða gæðastjórnunar í mannvirkjagerð á Íslandi ?

- Í hverju felst munurinn á verktökum, sem starfa eftir gæðastjórnunarkerfi, og peim sem starfa ekki eftir gæðastjórnunarkerfi ?

- Hvaða pættir hafa mest áhrif á ánægju verkkaupa ?

Leitast er við að fá svör við pessum spurningum með eigindlegum og megindlegum rannsóknaraðferðum. Til eigindlegra aðferða telst gerð spurningalistanna sem voru lagðir fyrir verkkaupa og verktaka með pað að markmiði að rannsaka verklag verktaka með tilliti til ánægju verkkaupa og hvort verktaki starfar eftir gæðastjórnunarkerfi eða ekki. Til megindlegra aðferða telst gagnaúrvinnsla úr niðurstöðum kannanna fyrir bæði verkkaupa og verktaka. Eigindlegum aðferðum var einnig beitt við pað að rannsaka stöðu pekkingar sem var könnuð með viðtölum, lestri greina og umræðum á fundum tengdum málefninu.

Mannvirkjagerð er mikilvæg uppspretta atvinnu og verðmætasköpunar fyrir íslensku pjóðina. Vonast er eftir pví að niðurstöður rannsóknarinnar geti hjálpað íslenskum verktakafyrirtækjum til að sjá ávinning af notkun gæðastjórnunar í starfsemi sinni. 


\subsection{Mikilvægi rannsóknar}

Að mati skýrsluhöfundar er mikil vöntun á rannsóknum á sambærilegu efni hér á landi en undirrituð fann einungis eina rannsókn sem tekur á sambærilegu efni hérlendis og er pað rannsókn Guðjónu Bjarkar Sigurðardóttur, sem ber nafnið Goeðastjórnun verktaka $i$ mannvirkjagerð á Íslandi, og var unnin við Háskólann á Bifröst. Rannsóknin er pví mikilvæg til að bæta pekkingu á pessu efni.

Fyrrnefnd rannsókn Guðjónu, sem er leitandi rannsókn ${ }^{1}$, gefur til kynna að gæðastjórnun hafi ekki náð að festa rætur á meðal verktaka á Íslandi vegna pess að pekking peirra á gæðastjórnun er ekki nægjanlega góð og skuldbinding stjórnenda skortir (Guðjóna Björk Sigurðardóttir, 2008). Athyglisvert er pví að kanna hvernig verkkauparnir upplifa verklag verktaka og hvort pað samræmist pví verklagi sem verktakarnir telja sig vera að vinna eftir. Skýrsluhöfundur telur að ef hægt væri að sýna betur fram á gagnsemi gæðastjórnunarkerfis í byggingafyrirtækjum væru stjórnendur viljugri til að innleiða slík kerfi. Eins og er pá hefur ekki verið hægt að sýna beint fram á allan pann ávinning sem hlýst af notkun slíks kerfis í mannvirkjagerð en talað hefur verið um að spara mætti 3-4 milljarða króna árlega í íslenskum byggingaiðnaði ef unnt væri að sneiða alfarið hjá mistökum í undirbúnings- og hönnunarferlinu en talið er raunhæft að skera mætti pennan kostnað niður um meira en helming með bættum vinnubrögðum (Óskar Valdimarsson, 2006). Par sem engar rannsóknir hafa verið gerðar hér á landi sem sýna tölfræðilega fram á ávinning af einhverju tagi vegna innleiðingar gæðastjórnunar í byggingaiðnaðinum telur skýrsluhöfundur að framlag rannsóknarinnar sé afar gagnleg viðbót við pá pekkingu sem nú er til. Vonir standa til að með henni sé hægt að sýna betur fram á pann ávinning sem hlýst af gæðastjórnun í pessari atvinnugrein.

\footnotetext{
${ }^{1}$ Aðferðafræði sem byggist á litlum úrtökum og hentar vel pegar lítið er vitað um viðfangsefnið og er markmiðið að veita innsýn í og skilning á viðfangsefninu
} 


\section{Viðfangsefnið}

Meginviðfangsefni pessa verkefnis snýst um að rannsaka áhrif gæðastjórnunar í mannvirkjagerð á Íslandi.

Í fyrsta áfanga er verklag verktaka kannað út frá sjónarmiðum verkkaupa og gerð er úttekt á pví hvaða pættir hafa mesta fylgni við ánægju verkkaupa. Í öðrum áfanga er sjónum beint að fjölmennri stétt iðnaðarmanna. Gerð er úttekt á stöðu gæðastjórnunar í pessu umhverfi, gæðatryggingu, samskiptum verkkaupa og verktaka og viðhorfi og bekkingu verktaka á gæðastjórnun.

\subsection{Gæðastjórnun}

\subsubsection{Gæði}

Vandasamt getur verið að skilgreina hugtök og mæla gæði en engu að síður er nauðsynlegt að sett séu fram áhersluatriði um helstu pætti sem mikilvægir eru og einkenna vönduð verk. Skilgreining á gæðum skiptir pví miklu máli innan gæðastjórnunar en ekki er síður mikilvægt að allir innan fyrirtækisins skilji og geri sér ljósa skilgreininguna en pað stuðlar að sameiginlegu tungumáli innan fyrirtækisins, óhád bakgrunni starfsmanna. (Eyjólfur Bjarnason, 2004)

Í bók Oaklands og Marosszeks, sem ber heitið Total Quality in the Construction Supply Chain, telja peir að eitt helsta vandamál byggingaiðnaðarins sé óljós skilgreining á gæðum innan hans. Núverandi skilgreiningar á hugtakinu eru taldar eiga betur við vörur í framleiðsluiðnaði. Vandamálið felst fyrst og fremst í flókinni keðju aðila sem kemur að hverri framkvæmd fyrir sig, en til að ná fram réttum gæðum parf samvinna milli allra aðila að vera mjög gott. (John Oakland \& Marton Marosszek, 2006)

Í rannsókn Peter Hoonakkers frá árinu 2006, sem ber heitið Quality management in construction industry, vann hann úr gögnum tveggja spurningakannanna fyrir verktaka og viðtölum við fagaðila í Bandaríkjunum. Hann komst meðal annars að peirri niðurstöðu skilgreining á gæðum mannvirkja meðal verktaka er afar óljós. Oftar en ekki er bara farið eftir tilfinningu verktaka en vandasamt er að skilgreina hugtakið á mælanlegan hátt. Ein augljós skilgreining felst $i ́$ ánægju viðskiptavinar en erfitt er að mæla hana á viðeigandi hátt. Ef allir verktakar myndu láta verkkaupa svara stöðluðum spurningum um ánægju með framkvæmdir væri hægt að greina gögnin og sjá hvaða pættir hafa mestu áhrif á ánægju verkkaupa. Peter bendir einnig á að ef verktakar á annað borð láta verkkaupa svara spurningum um ánægju sína með framkvæmdina pá mistekst peim yfirleitt að taka næsta skref, p.e. að greina gögnin (Hoonakker, Quality management in construction industry, 2006).

Margar skilgreiningar eru til á gæðum en ef kenningar helstu kenningasmiða gæðastjórnunar eru skoðaðar kemur í ljós að pær hafa pað allar sameiginlegt að áherslan er 
alltaf á notandann og parfir hans. Deming talaði um að gæðum ætti ávallt að vera beint að viðskiptavininum bæði í nútíð og framtíð (Wadsworth, 2002). Hann sagði að einungis væri hægt að ná stöðugleika í kröfum viðskiptavina um gæði ef pau væru skilgreind af peim. Juran skilgreindi gæði sem hæfileika til notkunar eða getu vörunnar til pess að pjóna kröfum viðskiptavinarins (e. fitness for use) og lagði hann sérstaka áherslu á jafnvægið milli einkenna vöru og gallaleysis auk pess sem hann lagði áherslu á hlut viðskiptavinarins í gæðum (Joseph M. Juran, 1979). Hann skilgreindi viðskiptavininn sem hvern pann sem er undir áhrifum vörunnar og getur hann pví verið bæði innri eða ytri viðskiptavinur. Í samhengi við mannvirkjagerð eru margir innri viðskiptavinir, t.d. er aðalverktaki innri viðskiptavinur undirverktaka, en verkkaupinn telst svo til ytri viðskiptavinar. Crosby talaði um að mikilvægast væri að kröfur væru skilgreindar á mælanlegan og umfram allt skýran hátt en til pess að hægt sé að stýra gæðum er nauðsynlegt að hægt sé að mæla pau. Gæði eru raunar ekkert nema samræming á kröfum. Segja má að Crosby hafi litið meira á gæði út frá rekstrarlegu sjónarmiði heldur en Deming og Juran (Deming, Out of the Crisis, 1986)(Crosby P. , 1979)(Juran, 1979).

Verkefnastjórnunarfélag Íslands skilgreinir gæði á eftirfarandi hátt; „,a að að hvaða marki safn tiltekinna eðlisloegra eiginleika uppfyllir kröfur viðskiptavinar" (Staðlaráð Íslands, 2000). Frá pessu sjónarhorni eru gæði „rétt“ pegar vara nær eða fer fram úr kröfum viðskiptavinarins. Við petta má bæta að gæðin eru ákvörðuð af viðskiptavininum. Eins og Grönroos orðaði pað: ,,pað sem telst til gæða er hvernig viðskiptavinurinn skynjar gæði“. Á pjónustusviðinu hefur pað verið viðurkennt að gæði, eins og viðskiptavinurinn skynjar pau, hefur tvær víddir. Önnur er tæknilega víddin eða útkoman. Hin víddin er kölluð hagnýt gæði og tengist pví hvernig viðskiptamaðurinn fær vöruna“ (Grönroos, C., 1984).

Ef tekið er mið af ofangreindum skilgreiningum geta hús A og hús B verið jöfn að gæðum prátt fyrir að hús A sé helmingi ódýrara, ef báðar byggingar sinna sínu hlutverki og veita eigendum sínum pá tilfinningu að peir hafi fengið pað sem jafngilti verðinu á verkinu (Ashford, 2003), p.e. að pví gefnu að kröfur viðskiptavinar séu uppfylltar í báđum tilfellum. Margir telja að dýr varningur eins og hús B sé gæðavara samanborið við ódýrari vöru eins og hús A. Par kemur til sögunar annað hugtak, náskylt gæðum, sem er áreiðanleiki. Gæði bygginga koma oft ekki í ljós fyrr en byggingin hefur verið lengi í notkun. Ef breytileiki í framleiðslu eininga eða uppsetningu peirra er meiri fyrir hús A en fyrir hús $\mathrm{B}$ er líklegt að byggingin parfnist meira viðhalds sem dregur úr gæðum hennar. Pannig byggist gæðaímynd ekki einungis á getu fyrirtækja til að framleiða góða vöru, heldur einnig á pví hvort geta sé til pess að öll eintök framleiðslunnar séu alltaf jöfn að gæðum (Brynhildur Bergbórsdóttir, 1998). Pví felast gæði bygginga í samningsbundnum kröfum og að pær séu uppfylltar á réttum tíma á umsömdum kostnaði. Auk pess sem að mannvirkið dugi með lágmarksviðhaldi ætlaðan notkunartíma.

Pað virðist eðlilegt að samband gæða og framleiðslukostnaðar sé pannig að ef gæði eru aukin pá aukist framleiðslukostnaður einnig. Gæðastjórnun heldur fram hinu gagnstæða og Deming rökstuddi pað á pann veg að ef gæði eru léleg pá er hluti framleiðslunnar ónýtur. Í almennri framleiðslu parf pví að henda eða endurvinna pann hluta sem er lélegur, en í samhengi við byggingaframkvæmdir er oft eina leiðin að endurvinna. Afleiðing endurvinnu er óparflega langur framkvæmdatími auk kostnaðar vegna hráefnis og vinnu. Gæði koma ekki af sjálfum sér (John Oakland \& Marton Marosszek, 2006, bls. 8). Ef gæði eru aukin, nýtist hráefni betur og kostnaður við endurvinnslu minnkar og afleiðingin er aukin framleiðni (Brynhildur Bergpórsdóttir, 1998). 


\subsubsection{Hvað er gæðastjórnun ?}

Notkun á gæðastjórnun fer stöðugt vaxandi í heiminum og er hún orðin vel bekkt og notuð innan flestra atvinnugreina (Lagrosen, 2006). Nokkuð hefur borið á mismunandi skilningi manna á hugtakinu geeðastjórnun líkt og hugtakinu geeði. Tilgangur gæðastjórnunar er fyrst og fremst að bæta samkeppnishæfni, gera vinnubrögðin agaðri og ná fram auknum hagnaði (Viðskiptablaðið, 2002).

Skýrsluhöfundur telur að vöntun sé á almennri skilgreiningu á gæðastjórnunarkerfi fyrir byggingafyrirtæki. Er pá sérstaklega átt við fyrirtæki sem hafa ekki fengið vottun en starfa engu að síður eftir gæðastjórnunarkerfi. Í pessu samhengi er brýn nauðsyn að petta sé gert miðað við stærð fyrirtækja og umfang verkefna. Samkvæmt Birni Karlssyni forstjóra Mannvirkjastofnunar er ráðlagt að skilgreining á nauðsynlegu umfangi gæðastjórnunarkerfa fyrir íslensk fyrirtæki í mannvirkjagerð verði tilbúin í lok árs 2011. Mun skilgreiningin taka tillit til stærðar fyrirtækja og verkefna (Björn Karlsson, 2011).

Eins og fram kom í kaflanum hér að framan um gceði flokkast vara með rétt gæði ef kröfur viðskiptavinar til vörunnar eru uppfylltar. Gæðastjórnun er stjórnunaraðferð til pess að ná sem bestum gæðum fyrir framleidda vöru (byggingu) eða pjónustu (hönnun) en hugmyndafræðin byggist á pví að skilgreina og koma upp fastmótuðum vinnuferlum sem eru síðan notaðir til að búa til slíkar afurðir. Hún byggist á pví að skilgreina vinnuferla í upphafi og vakta að unnið sé eftir peim og að parfir viðskiptavinarins séu uppfylltar innan gefins ramma um tíma og kostnað. Í fræðum um gæðastjórnun í

byggingaiðnaði er oft fjallað um gæðastjórnunarpríhyrninginn sem sýndur er á myndinni hér til hliðar. Dríhyrningurinn byggist á stoðunum premur sem gæðastjórnun er talinn hvíla á (Óskar Valdimarsson, 2006), en pessar stoðir byggjast á pví að

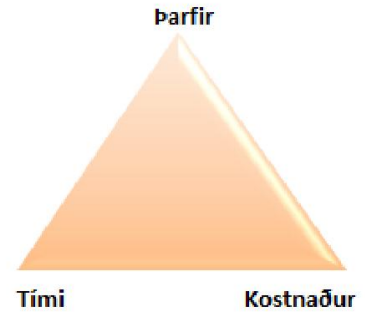

Mynd 1

Goedastjórnunarpríhyrningurinn skilgreina parfir viðskiptavina innan gefins tíma og kostnaðar (Agnes Hólm Gunnarsdóttir , Helgi Pór Ingason, 2007).

Gæðastjórnun er langtímaviðfangsefni en ekki bara skyndiplástur. Hún felur í sér að stjórnendur nái fram skilvirkari og betri stjórnun á hlutum sem peir fást við á hverjum degi. Hún á að tryggja að allar aðgerðir innan fyrirtækis verði áhrifaríkari og skilvirkari (Wilkipedia, 2011). Hún byggist á annarri hugmyndafræði og krefst annarra stjórnunaraðferða en peirra sem kalla má hefðbundnar. Mörg fyrirtæki hafa tekið upp aðferðafræði sem byggist á bónuskerfi og greiða auka-póknun peim sem skila gallalausri framleiðslu. Til pess er oftast nauðsynlegt að taka upp skoðunarkerfi til að finna gölluð eintök og skrá hvaða starfsmaður er ábyrgur fyrir mistökunum. Árangurinn reynist oftar en ekki skila sér í auknum kostnaði, versnandi starfsanda og lakari gæðum (Brynhildur Bergpórsdóttir, 1998).

Gæðastjórnunarkerfi flytur boð frá viðskiptavinum og stjórnendum til almennra starfsmanna og tryggir pannig gagnaöflun, eftirfylgni og umbætur. Pví má segja að gæðastjórnunarkerfi sé lífæð fyrirtækis (Er ráoning gæðastjóra rétta lausnin ?, 2007). Philip Crosby, sem oft hefur verið nefndur faðir gæða byltingarinnar (Winter Park Public 
Library) líkti gæðastjórnunarkerfi við blóð fyrirtækja. Hann sagði að blóðið kæmi frá gæðamenningunni en pað væri nauðsynlegt til að halda lífinu í fyrirtækjunum. Gæðamenningin væri svo sprottin frá skuldbindingu stjórnenda og stefnu en menntun, framkvæmd og gæði væru afleiðingar hennar. Баð er ekki fyrr en gæðamenning hefur fest sig í sessi innan fyrirtækis að allir fara að tala sama tungumálið en pá læur árangurinn ekki á sér standa. Баð gæti hins vegar tekið tíma að afturkalla skaða vegna rangrar pekkingar á gæðum (Crosby P. B., 1989).

Pví má segja að gæðastjórnun feli í sér að mæta sífellt skilgreindum kröfum og væntingum viðskiptavina með sem minnstum tilkostnaði með pví að virkja pað besta í hverjum einasta starfsmanni. Miðað við starf stjórnenda má bví segja að gæðastjórnun sé að marka stjórnunarstefnu (gæðastefnu) og framfylgja henni núnalegu starfi, en stefnan felst í peim viðmiðunarreglum sem stuðst er við varðandi allar ákvarðanir er snerta stjórnun núnalegum rekstri (Óskar Valdimarsson, 2006).

Að útbúa gæðakerfi og innleiða gæðastjórnun er ekki eins erfitt og margir telja. Ef hlutirnir eru á annað borð í lagi ætti gæðakerfi í raun bara að lýsa vinnubrögðum sem hafa verið viðhöfð́ í mörg ár og kjarni starfsmanna viðkomandi fyrirtækis pekkir. •að gefur augaleið að ef verklag fyrirtækis er ekki nógu gott fyrir pá vandast málið og koma parf til umbóta sem stjórnandi parf að stýra og leggja blessun sína yfir (Ferdinand Hansen, 2006). Einnig tala margir um að innleiðing gæðastjórnunarkerfis sé mjög dýr en hafa verður í huga að pað er líka dýrt að henda vörum, gera mistök, glata hráefni og tíma (Hansson, 2003). Til að innleiða og próa gæðastjórnunarkerfi parf að fylgja nokkrum skrefum samkvæmt ÍST EN ISO 9000:2008 og eru pau m.a. eftirfarandi (Staðlaráð Íslands, 2000):

a) að ákvarða parfir og væntingar viðskiptavina og annarra hagsmunaaðila,

b) að setja fram gæðastefnu og gæðamarkmið fyrir fyrirtækið,

c) að ákvarða pau ferli og pá ábyrgð sem parf til pess að ná gæðamarkmiðum,

d) að ákvarða og láta í té pær auðlindir sem pörf er á til að ná gæðamarkmiðum,

e) að koma upp aðferðum til pess að mæla virkni og hagkvæmni hvers ferils,

f) að beita pessum atriðum til að ákvarða virkni og hagkvæmni hvers ferils,

g) að finna leið til að hindra frábrigði og uppræta orsakir peirra

h) af koma upp og beita ferli fyrir stöðugar umbætur á gæðastjórnunarkerfinu

Innleiðing gæðakerfis getur á margan hátt verið flókið ferli eins og skrefin hér að ofan gefa til kynna. Engu að síður pá byggir gæðakerfið á einfaldri hugmynd. Grunnhugmyndin er pessi; Skjalfestu pað sem pú cetlar að framkvoema, gerðu pað sem pú skjalfestir. Kjarninn í öllum gæðakerfum er að skjalfesta og skrá öll nauðsynleg gögn. Einnig er afar mikilvægt að gögn séu endurskoðuð eftir pörfum og geymd með viðeigandi hætti til fyrir fram ákveðins tíma. Skjalfesting ætti í sjálfum sér ekki að vera markmið heldur virðisaukandi starfsemi en hún gerir kleift að miðla fyrirmælum og tryggja samræmi í aðgerðum samkvæmt gæðastöðlunum. Með skjalfestingu er einnig hægt að tryggja rekjanleika, veita hlutlægar sannanir og leggja mat á virkni gæðastjórnunarkerfisins. 


\subsubsection{Próun gæðastjórnunar og altæk gæðastjórnun (AGS, e. Total quality management, TQM)}

Sögu gæðastjórnunar má rekja aftur til fyrri hluta aldarinnar en pá voru Bandaríkjamenn fyrstir pjóða farnir að notast við tölfræðilega stjórnun ferla. Segja má að gæðabyltingin hafi breiðst út um heiminn, fyrst til Kyrrahafslandanna og síðar til Evrópu á árunum 1980-90. Petta má glögglega sjá á fjölda rita um efnið, en algjör sprenging varð í útgáfu efnis um gæðastjórnun á pessu árabili. Upphaf gæðastjórnunar hefur oft verið rakið til ferða Bandaríkjamannanna priggja, peirra Demings, Juran og Feigenbaum, til Japans á árunum upp úr 1950. Ekki störfuðu pessir mætu menn saman en allir unnu peir ötullega að pví að kenna Japönum nýja hugsun í stjórnun ( Brynhildur Bergpórsdóttir, 1998).

Frumkvöðlarnir eru fleiri sem skýrsluhöfundur telur að eigi skilda sérstaka athygli. beir eru Juran, Deming, Feigenbaum, Crosby og Ishikawa (Frank M. Gryna, Richard C. H. Chuna \& Joseph A. DeFeo, 2007). Hér verður farið stuttlega í framlag pessara sannkölluðu kenningasmiða fræðigreinarinnar.

J.M. Juran. Af helstu verkum má nefna Gæða príeykið og gæðastjórnun í öllu fyrirtækinu (e. Quality Trilogy og Company Wide Quality Management) (Juran, 1979).

W. Edward Deming. Af helstu verkum má nefna 14 atriði fyrir stjórnun og kenning um pekkingu (e. 14 Points for Management og System of Profound Knowledge) (Deming, The New Economics, 1993).

A.V. Feigenbaum. Af helstu verkum má nefna Gæðastjórnun sem grundvallaraðferð við stjórnun (e. Total Quality Control as a Fundamental Way to Manage Busniness) (Feigenbaum, 1991).

Philip Crosby. Af helstu verkum má nefna Gæði kosta ekkert og núll gallar (e. Quality is Free og Zeo Defects) (Crosby P. , 1979).

Kaoru Ishikawa. Af helstu verkum má nefna Sjö tæki gæðastjórnunar og gæðahringir (e. Seven Basic Tools og Quality Circles) (Ishikawa, K. \& D.J. Lu, 1985).

Kenningar pessara mætu manna hafa allar marga sameiginlega fleti en eru engu að síður frábrugðnar hver annarri að einhverju leyti (Frank M. Gryna, Richard C. H. Chuna \& Joseph A. DeFeo, 2007).

Mikið hefur verið ritað af fræðigreinum um altæka gæðastjórnun (AGS), en segja má að pað sem hefur verið kallað altæk gæðastjórnun sé nútíma gæðastjórnun. Peir sem fylgja ISO 9001 og innleiða gæðakerfi á grundvelli staðalsins hafa í raun innleitt pað sem áður var kallað altæk gæðastjórnun. аð verður pví ekki gerður greinarmunur á hugtökum gæðastjórnunar og altækrar gæðastjórnunar í pessari ritgerð en stundum er talað um að í altækri gæðastjórnun hafa gæði verið skilgreind í víðara samhengi (Kujala, 2004). Í grein eftir Magnús B. Jóhannsson, páverandi framkvæmdastjóra Íslenskrar gæðastjórnunar sf., segir hann að altæk gæðastjórnun sé lífsviðhorf jafnt sem stjórnunaraðferð og ef menn tileinki sér aðferðir hennar nái peir árangri.

Kjarninn í peim skilgreiningum á altækri gæðastjórnun sem skýrsluhöfundur hefur lesið fela í sér að hún sé stjórnun allra peirra pátta í fyrirtæki sem leiða til pess að pau atriði, sem 
viðskiptavinurinn telur mikilvæg við vöruna eða pjónustuna, verði framúrskarandi. Tekið er á frammistöðu fyrirtækjaheildar og athygli beint að mikilvægi ferla innan alls fyrirtækisins. Hefur altækri gæðastjórnun verið líkt við heilt burðarvirki með раð аð markmiði að hjálpa fyrirtækjum að ná afburða frammistöðu með sampættingu í mismunandi starfsemi par sem að markmiðið eru sífelldar umbætur ( Department of trade industry).

Pví hefur verið haldið fram að mikilvægasti pátturinn í velgengni fyrirtækis við að innleiða altæka gæðastjórnun sé geta pess til að fella inn aðferðir hennar í hversdagsvinnu (Low Sui Pheng and Jasmine Ann Teo, 2004). Altæk gæðastjórnun er aðferð til að hugsa um markmið, fyrirtæki, ferla og fólk til að tryggja að hlutirnir séu gerðir rétt í fyrsta sinn. Oakland sagði að pegar öllu er á botninn hvolft pá er altæk gæðastjórnun aðferð til að skipuleggja, flokka og skilja starfsemi sem er bundin við hvern einstakling á hverju stigi fyrir sig (Oakland, J. S. , 1995) og er pað nokkuð góð lýsing á aðferðafræðinni. Мeð innleiðingu á (altækri) gæðastjórnun er mikilvægt að stjórnendur séu viðbúnir til að breyta fyrirtækjamenningu og stjórnunaraðferðum (Quazi, H. A., and Padibjo, S. R., 1997). Menn purfa að tileinka sér fimm atriði í altækri gæðastjórnun, p.e. viðskiptavinurinn er í öndvegi, öll vinna er hluti af ferli, forvarnarstarf er gert með skipulagningu, pað er fólk sem skilar gæðum og að lokum að pað er sífellt hægt að gera betur.

Altæk gæðastjórnun er sögð hafa sprottið upp frá niðurstöðum rannsóknar á tölfræðilegri stjórnun ferla sem Walter A. Shewhart gerði hjá Bell símafyrirtækinu í Bandaríkjunum á árunum milli fyrri og seinni heimstyrjaldar. Bandaríkjamönnum tókst að ná árangri með aðstoð tölfræðilegra aðferða á árunum fyrir seinni heimstyrjöldina en fljótlega eftir heimstyrjöldina hættu peir að nota tölfræðilegar aðferðir við stjórnun fyrirtækja vegna mikillar eftirspurnar og lítillar samkeppni. Margir eru peirra skoðunar að bandarískar vörur hafi farið halloka fyrir öðrum vörum í samkeppninni vegna pessa hliðarspors (Magnús B. Jóhannesson, 1994). Síðar lýsti dr. Deming peirri skoðun sinni að líklega var pað rangur hópur manna í Bandaríkjunum sem helgaði sig gæðastjórnun. Stjórnendur fyrirtækjanna höfou ekki verið með í verkefninu. Áherslan hafði verið lögð á að kenna verkfræðingum og hönnuðum aðferðirnar. Núna er megináhersla lögð á leiðtogahlutverk stjórnenda fyrirtækja í altækri gæðastjórnun.

Gæðahreyfingin hefur pví ákveðinn vísindalegan grunn í tölfræðieftirliti. Sérstaklega er pá átt við gæðaeftirlit með framleiðsluferlum. Með gæðaeftirliti er leitast við að ná stöðugum vöru-gæðum (Kujala, 2004).

Рó að uppruna altækrar gæðastjórnunar megi rekja til Bandaríkjanna pá hafði hún gríðarleg áhrif á Japan og átti hún pátt í endurreisn japanska efnahagslífsins eftir seinni heimstyrjöldina. Japanir fengu pá til liðs við sig tvo menn sem voru í fararbroddi í gæðastjórnun í Bandaríkjunum, pá dr. Joseph M. Juran og dr. W. Edwards Deming. Eftir innreið pessara manna í japanskt efnahagslíf má segja að vörur frá Japan hafi fengið á sig gerbreyttan stimpil, en pær voru áður pekktar fyrri háa bilanatíðni og lélega vöru. Nú ráða Japanir yfir stórum hluta af heimsmarkaði á flestum sviðum og ljóst er að stjórnendur japanskra fyrirtækja hafa lagt mikla áherslu á leiðtogahlutverk og náð að tileinka sér aðferðir altækrar gæðastjórnunar með frábærum árangri (Magnús B. Jóhannesson, 1994).

Mikið af rannsóknum hefur verið gert á altækri gæðastjórnun og nytsemi hennar í byggingaiðnaðinum. Ekki verða pær tíundaðar frekar í pessum kafla en umfjöllum um 
nokkrar má sjá í kafla 3.1 á bls. 26. Segja má um pær rannsóknir, sem skýrsluhöfundur fann um málefnið, að allar eiga pær pað sameiginlegt að niðurstöður benda til pess að með innleiðingu á altækri gæðastjórnun í bygginga- og verktakafyrirtækjum megi uppskera meiri ánægju meðal viðskiptavina, meiri gæði á vöru og stærri markaðshlutdeild. Einnig hafa rannsóknir sýnt að ekki er auðvelt að innleiða altæka gæðastjórnun í byggingafyrirtæki hvort sem pau eru lítil eða stór (S.L.Tang, 2005)(John Oakland \& Marton Marosszek, 2006) en helstu ástæður eru taldar upp í kafla 2.2.1 á bls. 13.

\subsubsection{Stærð fyrirtækja og gæðastjórnun}

Рað er eins með skilgreiningu á stærð fyrirtækja og skilgreiningu á gœðum og gœðastjórnun að menn virðast ekki vera fullkomlega sammála um hvernig skilgreina eigi hugtakið. Sumir vilja notast við hugmyndafræði sem fylgt er við rekstur fyrirtækisins frekar en starfsmannafjölda, eins og gert er í ISO bókinni ISO 9001 Leiðsögn fyrir litil fyrirtceki (Staðlaráo Íslands, 2003). Samkvæmt skilgreiningu Evrópusambandsins flokkast fyrirtæki með 0-9 starfsmenn undir pað að vera smá og fyrirtæki með 99 starfsmönnum og færri flokkast undir раð аð vera lítil (Gustafsson, 2001). Ef við notum pessa skilgreiningu til pess að flokka íslensk fyrirtæki í bygginga- og mannvirkjagerð á árabilinu 1998-2005 pá falla 99,8\% peirra undir pað að vera smá (Hagstofa Íslands, 2007). Framlag smárra fyrirtækja er bví afar mikilvægt fyrir íslenska hagkerfið en pað hefur víða verið viðurkennt sem mikilvægur páttur í öðrum hagkerfum (Hansson, 2003).

Að pví slepptu hvaða skilgreining er notuð um stærð fyrirtækja er pað ljóst að stór partur af íslenskum byggingafyrirtækjum eru lítil fjölskyldufyrirtæki, mjög oft einyrkjar. Slík fyrirtæki hafa oftar en ekki önnur markmið en pau stærri og einkennist rekstur peirra síður af gróðasjónarmiðum en hjá stærri fyrirtækjum. Oft er aðal markmiðið að fullnægja fjárhagslegum pörfum, að viðskiptavinir séu ánægðir og ánægja starfsmanna í starfi (Helen Reijonen \& Raija Komppula, 2007).

Par sem að smá fyrirtæki hafa verið sein til að innleiða gæðastjórnun eru umræður um próun gæðastjórnunar í peim afar mikilvægar. Umfang gæðastjórnunarkerfis ætti alltaf að taka mið af stærð fyrirtækisins en rannsóknir hafa gefið til kynna að stefnumótun gæðastjórnunar í stórum fyrirtækjum henti ekki peim litlu. Einnig hefur sú gagnrýni komið fram að ferlar innan gæðastjórnunar séu ekki hannaðir til að taka á lykileinkennum lítilla fyrirtækja. Gæti pví verið að taka pyrfti frekar á innleiðingarferlinu hjá litlum fyrirtækjum (Hansson, 2003). Samkvæmt rannsókninni „ISO 9001:2000 in small organizations; lost oppurtunities, benefits and influencing factors" sem Poksinska, Eklund og Dahlgaard gerðu árið 2006 kom í ljós að lítil fyrirtæki skynjuðu gæðakerfið sem skráningarkerfi fremur en gæðakerfi og upplifðu pau lágmarks ávinning af kerfinu (Bozena Poksinska, Jörgen A.E. Eklund \& Jens Jörn Dahlgaard, 2006). Einnig eru til rannsóknir sem sýna fram á að litlum fyrirtækjum gangi vel að innleiða gæðastjórnunarkerfi og hún hafi gert fyrirtækjum kleift að stytta boðleiðir ( Brynhildur Bergpórsdóttir, 1998).

Samkvæmt bókinni ISO 9001 fyrir lítil fyrirtceki - Leiðsögn kemur fram að par sem gæðastjórnunarkerfi fjalla um pað hvernig fyrirtækinu er stjórnað má beita peim á allar stærðir fyrirtækja á öllum sviðum stjórnunar. Í raun má segja að gæðastjórnunarkerfi sé leiðin sem fyrirtæki beitir við að beina og stýra starfsemi sem varðar gæði í fyrirtækinu. 
Pað felur í sér stjórnskipulag fyrirtækisins ásamt skipulagningu ferla, auðlinda og skjalfestingu sem notuð er til að uppfylla gæðamarkmið, til umbóta á vöru og pjónustu og til að uppfylla kröfur viðskiptavina. Öll fyrirtæki hafa stjórnskipulag hvort sem pað hefur skilgreint gæðastjórnunarkerfi eða ekki, og á pví ætti gæðastjórnunarkerfi fyrirtækisins að byggjast (Staðlaráo Íslands, 2003, bls. 17).

Eins og áour segir ætti umfang gæðastjórnunarkerfis ávallt að taka mið af stærð fyrirtækisins og í pví samhengi er til að mynda vert að nefna að ádur en framkvæmdastjórar í litlum og meðalstórum fyrirtækjum ráða gæðastjóra ættu peir að íhuga hvort hlutverki gæðastjóra sé ekki betur komið í peirra eigin höndum. Peir geta svo úthlutað verkefnum til peirra sem best pekkja til á hverju sviði. Hlutverk gæðastjóra er mikilvægt og ef samstarf milli gæðastjóra og framkvæmdastjóra er ekki eins og best verður á kosið er hætt við að starfsmenn fyllist vantrú á kerfinu. Ef aftur á móti framkvæmdastjórinn stýrir vinnunni sjálfur aukast líkur á að gæðastjórnunarkerfið verði samofið rekstrinum og gagnsemi pess komi í ljós ( Ferdinand Hansen, 2007). Í grein, sem birtist í tölublaðinu Omega árið 2006, eftir Aldowaisan og Youssef, komu fram tillögur um hvernig lítil fyrirtæki geta innleitt gæðastjórnunarkerfi með sem mestum ávinningi og minnstum kostnaði. Par er lagt til að dregið sé úr ráðgjafakostnaði með pví að gera hlutina sjálfur. Jafnframt er lögð meiri áherslu á pátttöku starfsmanna og að meiri tíma sé varið í pað að öðlast pekkingu og getu til að vinna með staðalinn og pjálfun í að vinna með hugtök og verkfæri gæðastjórnunar. Ekki er ráðlagt að lítil fyrirtæki sækist eftir bví að fá vottun nema pað sé fjárhagslega hagkvæmt (Youssef, 2006).

Engin ástæða er til pess að lítil fyrirtæki ættu að vera verr rekin en pau stærri og pó að stærri fyrirtæki eyði jafnan háum upphæðum í innleiðingu gæðastjórnunarkerfis hafa smærri fyrirtæki oft náð sambærilegum árangri. Par sem að boðleiðir eru styttri og færri stjórnunarprep ætti innleiðingarferlið að vera töluvert auðveldara hjá litlum fyrirtækjum ( Brynhildur Bergpórsdóttir, 1998).

Samkvæmt Chung pá hentar ISO bæði stórum og litlum fyrirtækjum, en fyrir lítil fyrirtæki, sem eru einföld í uppbyggingu, pá eru ákveðnar kröfur í staðlinum sem eru ekki nothæfar. Ef páttur í staðlinum er ekki krafa pá nægir oft einföld yfirlýsing varðandi pað í gæðahandbók til að uppfylla staðalinn og ættu vottunaraðilar að nota pennan sveigjanleika sem er byggður inn í staðalinn. (Chung, 1999). Engu að síður heyrast efasemdaraddir ${ }^{2}$ sem segja að ISO 9001 staðallinn henti síður litlum fyrirtækjum en stærri par sem verklag peirra geti verið mun einfaldara. Samkvæmt rannsókn Aldowaisan og Youssef, sem minnst var á hér að ofan, pá er skortur á nægu vinnuafli, fjármagni, tíma og hæfni helstu pættirnir sem hafa hamlað litlum fyrirtækjum við að ná ávinningi við innleiðingu á ISO gæðastjórnunarkerfi. Einnig kom fram að litlum fyrirtækjum hættir til að takmarka vinnu utanaðkomandi ráogjafa en sú leið getur lagt gæðakerfin í hættu par sem að pátttaka og pjálfun starfsmanna verður pá takmarkaðri og meiri áhersla lögð á að gæðastjórnunarkerfið sé gott á pappírum. Pannig fengu fyrirtækin vottun á kostnað gæða (Youssef, 2006).

Sænsk rannsókn frá árinu 2006 sýndi fram á að lítil fyrirtæki lögðu eins litla vinnu og mögulegt var í innleiðingaferli gæðastjórnunarkerfa og skynjuðu pau almennt gæðastjórnunarkerfi einungis sem skráningarkerfi fremur en gæðakerfi. Fyrirtækin

\footnotetext{
${ }^{2}$ Sjá t.d. svör verktaka við opnu spurningunni pegar peir voru spurðir hvort peir vildu bæta við einhverju í lokin.
} 
innleiddu kerfin ekki vegna innri hvata og fengu pau lágmarks ávinning af kerfinu. Niðurstöður rannsóknarinnar benda á að gæði og áhrif gæðastjórnunarkerfisins ákvarðast ekki af kröfum ISO heldur hvernig kerfinu er beitt og innleitt (Bozena Poksinska, Jörgen A.E. Eklund, \& Jens Jörn Dahlgaard., 2006).

Í rannsókn sem Formanco og Revelo framkvæmdu árið 1999 leituðust peir til að finna aðferð til pess að bæta efnisflæði í litlum byggingafyrirtækjum með pví að nota aðferðir gæðastjórnunar. Prjú brasilísk fyrirtæki tóku pátt í verkefninu með pví að vinna sig í gegnum nokkur stig innleiðingar á altækri gæðastjórnun. Aðferðir sem voru notaðar við innleiðinguna byggjast á einföldum og vel pekktum aðferðum gæðastjórnunar til að koma auga á vandamál og greina pau og leysa, svo sem flæðirit, hugarflug og Pareto skema. Niðurstöður verkefnisins voru pær að pað eru ýmsir erfiðleikar tengdir pví að innleiða slíkar aðferðir í lítil byggingafyrirtæki (Formoso, C. T., \& Revelo, V. H., 1999). 


\subsection{Mannvirkjagerð}

Í pessum kafla verður aðeins farið í sérkenni mannvirkjagerðar, en frekari umfjöllun um gæðastjórnun í mannvirkjagerð er í kafla 3.1 á bls. 26.

Mannvirkjagerð er mikilvæg uppspretta atvinnu og verðmætasköpunar fyrir íslensku pjóðina, fjárbinding pjóðarinnar í mannvirkjum er geysimikil og ljóst er að pegar fjallað er um mannvirkjagerð og möguleika á hagræðingu í greininni er um að ræða mikla pjóðhagslega hagsmuni (Óskar Valdimarsson, 2006). Byggingastarfsemi og mannvirkjagerð spannaði til að mynda rúmlega $12 \%$ af allri heildarveltu pjóðarinnar árið 2010 samkvæmt tölum frá Hagstofunni (Hagstofa Íslands, 2011). Par eru ekki meðtalin afleidd störf en oft hefur verið sagt að með hverju starfi í mannvirkjagerð fylgi að minnsta kosti tvö önnur í öðrum atvinnugreinum svo sem í framleiðslu, verslun og pjónustu. Pað er pví til mikils að vinna ef hægt er að ná betri nýtingu á hráefni og mannafla í greininni. Ef hægt væri að lækka kostnað vegna frábrigða gætu sparast umtalsverðar upphæðir. Endurvinna vegna frábrigða getur verið gríðarlega kostnaðarsöm og tímafrek og verður oft til pess að áætlanir riðlast. Í grein sem var birt í Journal of Performance of Constructed Facilities í desember 2009 komu fram niðurstöður rannsóknar um endurvinnu ${ }^{3}$ (e. rework) vegna frábrigða á framkvæmdum og áhrif hennar á kostnaða og tímaáætlun framkvæmda. Rannsóknin byggist á gögnum um 260 byggingar víðs vegar í Ástralíu og er notuð leiðagreining (e. path analys) til pess að búa til líkan af marktækustu og sterkustu fylgnipáttum við endurvinnu vegna frábrigða. Niðurstöður leiddu í ljós að marktæk fylgni er milli minni áherslu á gæðastjórnun og hærri kostnaðar vegna endurvinnu á frábrigðum (Peter E. D. Love, David J. Edwards, Jim Smith \& Derek H. T. Walker, 2009).

Fyrirtæki í mannvirkjagerð standa frammi fyrir ýmsum vandamálum. Til dæmis hefur aðgangur að verkefnum í mannvirkjagerð verið sveiflukenndur í áranna rás og hefur pað vafalaust reynst fyrirtækjum í iðnaðinum pungbært. Fyrirtæki sjá oft ekki verkefni nema fáar vikur fram í tímann og er líklegt að pað hafi hamlandi áhrif á uppbyggingu í greininni (Samtök iðnaðarins). Grafið hér að neðan sýnir vel hversu sveiflukennd heildarvelta iðnaðarins hefur verið undanfarin ár og sjást áhrif kreppunar sem herjað hefur undanfarin ár greinilega.

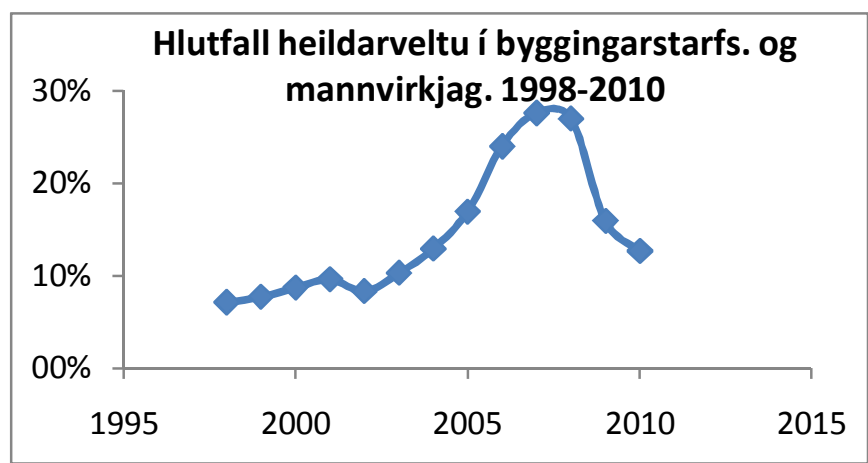

Mynd 2 Hlutfall heildarveltu í byggingastarfsemi og mannvirkjagerð 1998-2010 miðað við heildarveltu af annarri starfsemi pjóðarinnar (Hagstofa Íslands, 2011).

\footnotetext{
${ }^{3}$ Með endurvinnu er átt við hvers konar vinnu sem hefur purft að framkvæma aftur vegna pess að gæðakröfur stóðust ekki.
} 


\subsubsection{Sérkenni mannvirkjagerðar og gæðastjórnun}

Áður en krafa um innleiðingu gæðastjórnunarkerfa vaknaði hjá byggingaverktökum var iðnaðurinn vanur að eiga við vottun á vörum, og pví mætti ætla að skrefið væri ekki svo stórt sem pyrfti að taka til að heimfæra sömu aðferðir í stjórnun byggingaframkvæmda. Eins og Roy Gils orðaði pað á sínum tíma pá eru reglur og staðlar eins mikill partur af byggingaiðnaði eins og byggingarefni og verkalýðsfélög (Giles, 1997).

Mannvirkjagerð hefur ýmis sérkenni sem gera hana frábrugðna öðrum atvinnugreinum (John Oakland \& Marton Marosszek, 2006, bls. 3) og hafa pau ýtt undir pann skilning sem ríkt hefur innan hennar að gæðastjórnun sé aðeins fyrir framleiðslu- og pjónustuiðnað. petta er að sjálfsögðu ekki byggt á traustum grunni og hefur bað sýnt sig að gæðastjórnun á mjög vel við í mannvirkjagerð (Guðjóna Björk Sigurðardóttir, 2008).

Eins of fram hefur komið varð gæðastjórnun upphaflega til í framleiðsluiðnaðinum og bera núverandi gæðakerfi keim af pví, en margar rannsóknir hafa staðfest ávinning gæðastjórnunar í framleiðslu- og pjónustuiðnaði. Við skoðun heimilda um petta efni má draga saman eftirfarandi meginlínur sem telja má til peirra sérkenna mannvirkjagerðar sem eiga stærstan pátt í pví af hverju ekki hefur reynst betur en raun ber vitni að innleiða gæðastjórnun í byggingafyrirtæki.

1. Aðfangakeðjan. Yfirleitt eru margir ótengdir aðilar sem koma að hverri framkvæmd fyrir sig og gerir pað að verkum að margir koma að pví sama markmiði að ná fram gæðum á byggingarverkefninu (Abdullah, 2006), (Prof. Jozef Gašparík, PhD., Sylvia Szalayová, PhD.), (Giles, 1997). Pessari keðju af hagsmunaaðilum, sem koma að hverri framkvæmd fyrir sig, hefur verið líkt við aðfangakeðju (e. Supply Chain) par sem að keðja af viðskiptavinum og birgjum er við hverja framkvæmd. Slök vinnubrögð hjá einum aðila geta haft áhrif á pann næsta og pannig verða til keðjuverkandi vandamál sem geta haft áhrif á gæði verksins í heild. (Gopal K. Kanji, Alfred Wong, 1998), (Ruben Vrijhoef and Lauri Koskela, 1999) og (John Oakland \& Marton Marosszek, 2006). Einnig er samband aðalverktaka og undirverktaka oft skammtímasamband (John Oakland \& Marton Marosszek, 2006).

2. Verkefnauppbygging. Framkvæmdir flokkast í flestum tilfellum undir pað að vera verkefni, en með pví er átt að hvert verk er einstakt og sérstakt að einhverju leyti og pví er ekki alltaf hægt að flytja reynslu og bekkingu yfir á önnur verk. Par af leiðandi verður minna um sjálfræði varðandi endurtekningar og aukinn gróða. Par sem að verkin eru yfirleitt ólík geta skapast vandamál varðandi gæðakerfi sem pyrfti í raun að geta tekið á ólíkum kröfum og kringumstæðum verka (Gopal K. Kanji, Alfred Wong, 1998) (John Oakland \& Marton Marosszek, 2006), (Abdullah, 2006) og (Prof. Jozef Gašparík, PhD., Sylvia Szalayová, PhD.) Í rannsókn eftir Hakim og Abdullah, sem var birt 2006, leggja peir fram tillögu að lausn á pessu vandamáli. Peir benda á að vel sé hægt að innleiða gæðastjórnun á verkefnastigi en ekki bara á fyrirtækjastigi eins og pekkt er, en lítið af rannsóknum hefur verið gert með tilliti til pess. Í raun má segja að ekki sé til neitt sérstakt verkefna- miðað gæðastjórnunarkerfi (Abdullah, 2006). Pví er mikilvægt fyrir fyrirtæki, sem eru verkefnamiðuð, eins og fyrirtæki í mannvirkjagerð, að gerð sé gæðahandbók fyrir hvert verk (e. Project Quality Plan, PQP) sem inniheldur gæðakerfið sem fyrirtækið hefur innleitt ásamt viðbót fyrir hvert tiltekið verk sem sýnir fram á 
hvernig verkið skuli vera unnið til að uppfylltar séu gæðakröfur (Prof. Jozef Gašparík, PhD., Sylvia Szalayová, PhD.).

Byggingaiðnaðurinn hefur verið gagnrýndur fyrir slök gæði, háan kostnað, lélegar öryggisráðstafanir og framkvæmdahraða (Gopal K. Kanji, Alfred Wong, 1998). Oakland og Marosszek segja í bók sinni Total Quality in the Construction Supply Chain að helstu vandamál iðnaðarins séu svipuð hvar sem er í heiminum. Eftirfarandi pættir hafa oft verið skotmörk fyrir gagnrýnendur;

1. Breytingar og óskilvirkar ákvarðanir. Algengt er að breytingar á hönnun eigi sér stað meðan á framkvæmd stendur. Par af leiðandi getur verið erfitt að viðhalda réttum gæðum (Gopal K. Kanji, Alfred Wong, 1998). Раð getur verið mjög kostnaðarsamt að laga frábrigði og breytingar. Einnig er algengt að hönnun taki lengri tíma en áætlað var og upphaflegar kostnaðartölur standast sjaldan. Of stórt bil er á milli hönnunar og framkvæmda á verkstað sem gerir ákvarðanir óskilvirkar (John Oakland \& Marton Marosszek, 2006)

2. Öryggi. Tíðni slysa í byggingaframkvæmdum er há miðað við ýmsar aðrar iðngreinar til að mynda talar Oakland og Marosszek um að slysatíðni í byggingaframkvæmdum sé priðjungi hærri en við námugröft og skógrækt (John Oakland \& Marton Marosszek, 2006)

3. Áreiðanleiki. Algengt er að verktaki sé með fleiri en eitt verk í gangi en almennt er talað um að tvö af hverjum premur verkefnum séu kláruð á réttum tíma. Pað getur einnig skapað vandamál að sum verk geta tekið langan tíma, jafnvel mörg ár, en margt getur breyst í ytra og innra umhverfi á svo löngum tíma (John Oakland \& Marton Marosszek, 2006).

Önnur vandamál varðandi gæðastjórnun, sem nefnd hafa verið, eru misskilningur á ISO 9000 gæðakerfi, gæði sett í annað sæti á eftir viðskiptum, ferlar kunna að hafa virst of flóknir, vanpekking á ISO 9000 staðlinum, vinnutap verkamanna við sín hefobundnu störf á meðan innleiðingarferlið stendur yfir, vöntun á reglugerð sem skyldar verktaka að innleiða gæðakerfi, engin hvatning frá verkkaupum, erfiðleikar við að heimfæra staðalinn á iðnaðinn (Abdullah, 2006) og að lokum íhaldssemi byggingaiðnaðarins (viðnám við breytingum) en pað er algengt viðhorf meðal byggingafyrirtækja að pað sé óparfi að taka upp sérstakt gæðastjórnunarkerfi. Einnig er algengt að byggingafyrirtæki sitji álengdar og fylgist fremur með hvernig öðrum sambærilegum fyrirtækjum tekst til við að innleiða gæðastjórnunarkerfi og hugsi sér frekar að láta reyna á innleiðingu ef vel tekst til hjá fyrirtækinu sem fylgst var með. Pannig reyna flest fyrirtæki að lágmarka áhættu og hámarka hagnað (S.L.Tang, 2005) (John Oakland \& Marton Marosszek, 2006). Einnig hafa byggingafyrirtæki kvartað undan háum upphafskostnaði við innleiðingu gæðastjórnunarkerfis, en pað hefur löngum verið pekkt að upphafskostnaður, sem fylgir pví að koma sér upp réttum búnaði og pjálfun starfsmanna til að vinna eftir gæðakerfi, getur verið talsverður en hann er engu að síður lítilfjörlegur samanborið við pann kostnað sem fylgir leiðréttingu frábrigða (Giles, 1997). Að lokum hafa ýmsir fræðimenn bent á að vandamálin koma sérstaklega upp á fyrstu stigum innleiðingar á ISO 9000 (Low, S.P. and Goh, K.H, 1994) en ýmis vandamál hafa komið upp við innleiðingu gæðastjórnunar í byggingaiðnaði og má par m.a nefna skort á skuldbindingu stjórnenda, skort á samskiptum og skort á gæðamenningu (Young, 2007). 


\subsubsection{Gerð verktöku}

Flest verk í mannvirkjagerð eru með peim hætti að verkkaupi fær til sín aðila sem sjá um hönnun og framkvæmd verksins en pó er nokkur munur á bví hversu mikil ábyrgð er sett í hendur verktaka hverju sinni. Í alverki er verktakinn ábyrgur fyrir öllu en í fag-eða aðalverki koma oft upp álita- og ágreiningsmál par sem vinnubrögð undirverktaka eru oft mjög misjöfn en oft eru peir ekki með neitt gæðakerfi og getur pví verið erfitt fyrir aðalverktaka að fá pá til að uppfylla kröfur (Jónas Brjánsson, 2010). Í pessari rannsókn hafa verk verið flokkuð með eftirfarandi hætti:

1. Aðalverk. Par sem verktakinn sér um alla framkvæmd en ekki hönnun.

- Verktaki sá er nefndur aðalverktaki sem fær aðra verktaka, einn eða fleiri, til að framkvæma hluta verks sem hann hefur tekið að sér. Aðalverktaki er ábyrgur fyrir framkvæmdum sem undirverktakar vinna. Verkkaupa er pó heimilt að hafna undirverktaka ef hann telst vanhæfur að mati verkkaupa (ÍST EN ISO 9000:2000, 2000). Sá sem er aðalverktaki sér pví um að semja og ber ábyrgð á heildarverki en felur sérhæfoum verktökum og efnissölum einstaka pætti samkvæmt sérstökum samningum.

2. Alverk. Pegar verktakinn sér um hönnun og alla framkvæmd.

- Verktaki sem tekur að sér að bæði hanna og framkvæma verk samkvæmt alútboði (ÍST EN ISO 9000:2000, 2000).

3. Fagverk. Pegar verkkaupi semur beint við verktaka í hverjum verkpætti

4. Markverk. Pegar verkkaupi og verktaki skrifa undir svo nefndan marksamning, par sem báðir aðilar hafa komið sér saman um verð sem mannvirkið á að kosta. Með slíkum samningi hefur verktakinn einnig hagsmuni af pví að verkið klárist á réttum tíma og undir kostnaðaráætlun. Ef verkinu lýkur undir kostnaðar-áætlun fær verktakinn greiddan hluta af sparnaðinum, en ef verkið fer fram úr áætlun fær verktakinn aðeins hluta af mismuninum greiddan.

\subsection{3 Útboð}

Eitt af sérkennum mannvirkjagerðar eru tilboðsmarkaðurinn. Flest fyrirtæki í mannvirkjagerð vinna á opnum tilboðsmarkaði og er kostnaður verktaka við tilboðsgerð oft umtalsverður (Sveinn Hannesson, 2005). Verk eru pá boðin út og getur verkkaupi valið að taka lægsta tilboði. Vert er að benda á að til eru rannsóknir sem hafa engu að síður sýnt fram á pað að ef lægsta tilboðinu er tekið leiðir pað sjaldan til lægsta heildarkostnaðar. (Giles, 1997).

Með útboði getur verkkaupinn ákvarðað viðskiptaleg markmið sín en skortir jafnan getu til pess að ákvarða nákvæmar kröfur verksins. Hugsanlegt er að samband, sem myndast milli verkkaupa og verktaka á tilboðsmarkaði, geti haft áhrif á viðhorf verktaka gagnvart 
verkkaupa og par af leiðandi gæðastjórnun verktaka (Guðjóna Björk Sigurðardóttir, 2008). Vel unnin og sundurliðuð útboðsgögn skipta höfuðmáli og eru pau grundvöllurinn að öllu sem á eftir kemur og ættu verkkaupar ekki að spara við sig í peim efnum. Útboðsgögn eru oft með peim hætti að túlka má hluti á fleiri en einn veg (Sigríður Sigurðardóttir, 2010).

Útboð geta verið pað sem kallast almenn útboð eða alútboð. Almenn útboð eru auglýst og ótilgreindum fjölda er gefinn kostur á að gera tilboð (ÍST EN ISO 9000:2000, 2000) en með alútboði er leitað tilboða í bæði hönnun og framkvæmd verksins samkvæmt forsögn (ÍST EN ISO 9000:2000, 2000).

Nú er í próun verkefni hjá sprotafyrirtækinu Strax ehf. sem er að próa vettvang par sem verkkaupar og verksalar eru leiddir saman á netinu og allir aðilar markaðarins geta fengið allar nauðsynlegar upplýsingar og pjónustu tengda verktakaviðskiptum á einum stað. Í raun er útkoma verkefnisins rafrænn miðill sem leiðir saman verkkaupa og verksala í öruggu ferli par sem auðvelt er að nálgast viðskiptasögu og upplýsingar um verktaka eins og hvaða tryggingar og menntun peir hafa. Með pessu móti er verkkaupum auðveldað að taka upplýsta ákvörðun um val á verktaka. Ásamt pví að vera útboðs- og upplýsingavefur fyrir verkkaupa pá er vefurinn einnig hugsaður sem samfélags- og upplýsingavefur fyrir meistara, fagmenn og hönnuði (Naglinn, 2011).

\subsubsection{Undirverktakar}

Pegar verk eru unnin sem aðalverk, alverk eða markverk pá ræður verktaki til sín undirverktaka og birgja eftir pörfum og er pá komin sjálfur í hlutverk verkkaupa. Ábyrgð verktakans til undirverktakans er pví að sá hinn sami viðhafi ekki lakari vinnubrögð en hann hefur sjálfur lofað verkkaupa og pví er mikilvægt að undirverktaki fari í einu og öllu eftir samningi sem verktaki og verkkaupi hafa gert með sér (Alfred Wong \& Patrick Fung., 1997). Til pess að tryggja gæði parf ákveðið eftirlit að vera með undirverktökum og ætti verktaki ávallt að krefja undirverktaka um gæðatryggingu. Með pví getur verktaki krafist að undirverktaki vinni samkvæmt gæðakerfi sínu (Ferdinand Hansen, 2007). Eftir að verktaki hefur skrifað undir samning við verkkaupa fer í raun hluti af kröfum samnings yfir til undirverkaka og birgja (Alfred Wong \& Patrick Fung., 1997).

Samband milli verktaka og undirverktaka eru yfirleitt verkefnalegs eðlis par sem oft er um skammtímasamband er að ræða. Slíkt samband getur haft ýmis vandamál í för með sér en erfitt getur verið að fá undirverktaka til að tileinka sér gæðastjórnun (John Oakland \& Marton Marosszek, 2006).

\subsubsection{Saga gæðastjórnunar í mannvirkjagerð á Íslandi}

Á Íslandi ná umræður og vinna við gæðastjórnun í mannvirkjagerð aftur til seinni hluta 9. áratugarins. Segja má að fyrsta raunverulega átakið í pessa veru hafi hafist með framtaki fimm innlendra fyrirtækja og stofnana, p.e. Íslenskra aðalverktaka $h f$., Jarðborana $h f$., Ístaks hf., Ármannsfells hf. ásamt Rannsóknarstofnunar byggingaiðnaðarins sem hélt utan 
um hópinn. Pessi fyrirtæki tóku sig saman og fengu til landsins norskan sérfræðing, Odd Sjöholt, en Odd sá um að leiða vinnu pessara fyrirtækja við að útbúa og innleiða gæðastjórnun innan fyrirtækjanna (Eyjólfur Bjarnason, 2010).

Í kjölfar pessa framtaks jókst umræða um gæðastjórnun talsvert meðal fyrirtækja og úr varð að stofnað var Gœðaráð byggingaiðnaðarins. Gæðaráðið vann mikið frumkvöðlastarf á sviði gæðastjórnunar par sem almenn pekking á faginu var takmörkuð hérlendis á pessum tíma (Eyjólfur Bjarnason, 2010). Var pað fyrsti vettvangurinn par sem allir aðilar, sem málið varðar, koma saman og ræða vandamálin (Morgunblaðið, 1993). Gæðaráðið stóð m.a. fyrir ráđstefnum, ásamt pví að halda uppi áróðri fyrir góðri og markvissri stjórnun í mannvirkjagerð. Á svipuðum tíma, eða árið 1986 var Gæeðastjórnunarfélagið stofnað, en frá árinu 2001 hefur félagið borið nafnið Stjórnvisi. Rétt eins og Gæðaráð byggingaiðnaðarins pá vann Gæðastjórnunarfélagið mikið og gott frumkvöðlastarf og hefur síðan haldið á lofti umræðu og fræðslu um gæðastjórnun. Annað stórt átak í gæðastjórnun fór af stað 1997 pegar Samtök Iðnaðarins hófu átak í gæðastjórnun fyrir verktakafyrirtæki í mannvirkjagerð sem enn stendur yfir (Eyjólfur Bjarnason, 2010).

\subsection{Ytra umhverfi}

\subsection{1 Áhrif af hruni íslenska efnahagslífsins á byggingaiðnaðinn}

Aðstæður í efnahagslífinu hafa breyst mikið að undanförnu og sjaldan hefur ríkt jafnmikil óvissa og ójafnvægi í pjóðarbúskapnum. Alpjóðlega fjármálakreppan, sem hófst sumarið 2008, hefur reynst bæði dýpri og víðtækari en gert var ráð fyrir og liggur nú fyrir að skuldasúpa fullvalda stórvelda á borð við Bandaríkin, Bretland, Japan og ríkja meginlands Evrópu nálgist hættumörk og gæti vel til pess komið að hún dýpkaði enn á ólgusjó alpjóðahagkerfisins með kreppu á skuldabréfamörkuðum. Petta kemur fram í nýrri rannsókn Alpjóðagreiðslubankans í Basel (e. Bank for International Settlements) (Örn Arnarson, 2010). Раð hefur engum Íslendingi dulist að kreppan, sem nú stendur yfir, hefur leikið pjóðina verr en flestar aðrar pjóðir. Smæð pjóðarinnar, sjálfstæði gjaldmiðils, skuldir pjóðarbúsins og stærð fjármálakerfisins hér á landi hafa leikið pjóðina grátt.

Í ljósi ofangreindra staðhæfinga er óhætt að fullyrða að verulega hefur dregið úr arðsemi pess að byggja á síðustu misserum, enda ljóst að flest sveitarfélög eru vel í sveit sett varðandi nýbyggingar eftir mikla penslu á íbúðamarkaði á árunum fyrir hrun. Auk pess jókst byggingakostnaður gífurlega í kjölfar hruns krónunnar sökum pess hversu pungt innfluttir liðir vega í vísitölunni. Árið 2009 dróst fjárfesting í íbúðarhúsnæði saman um $58 \%$, en sá samdráttur kemur í kjölfar 22\% samdráttar árið á undan (Ingólfur Bender, 2010). Minnkandi umsvif byggingaiðnaðarins koma glögglega í ljós pegar tölur Hagstofunnar um innflutning byggingarefna eru skoðaðar. Gríðarlegur samdráttur hefur verið í innflutningi byggingarefna. Að sama skapi var mikil uppsveifla í byggingaiðnaðinum á árunum fyrir hrun og var byggingahraðinn orðinn geigvænlegur og skammtímahugsun virtist ríkjandi. Skortur var farinn að gera vart við sig á hæfu og faglegu vinnuafli og leiddi til pess að stýring gæða fluttist meira yfir á ábyrgð eftirlitsmanna og mistökin uppgötvuðust par af leiðandi of seint (Guðjóna Björk Sigurðardóttir, 2008). Á árinu 2009 dróst innflutningur á timbri saman um 40\% frá fyrra ári og um $70 \%$ á steypustyrktarjárni fyrir sama tímabil í tonnum talið. Pegar árið 2009 er borið saman við 
árið 2007 kemur í ljós að innflutningur á timbri og krossviði hefur dregist saman um 60\%, innflutningur á rúðugleri hefur dregist saman um 45\% á sama tímabili og pá dróst innflutningur á steypustyrktarjárni saman um 80\% árið 2009 borið saman við árið 2007. Pessar tölur endurspegla skýrt hversu mikið umsvif í byggingaiðnaðinum hafa dregist saman, en ljóst er að hann hefur átt sérstaklega erfitt uppdráttar í kjölfar fjármálahrunsins og peirrar kreppu sem á eftir fylgdi (Ingólfur Bender, 2010).

Fjöldinn allur af byggingafyrirtækjum hefur neyðst til að segja upp stórum hluta af starfsmönnum sínum og mörg peirra hafa purft að leggja árar í bát og lýsa yfir gjaldproti. Ekkert fyrirtæki í iðnaðinum hefur sloppið algjörlega við áhrif hrunsins og liggur fyrir að erfitt verður að endurreisa og rétta við mörg peirra byggingafyrirtækja sem átt hafa hvað erfiðast í glímunni við pessar hamfarir. Samkvæmt tölum Hagstofunnar urðu 257 byggingafyrirtæki gjaldprota árið 2009 og er pað langt um meira en pað sem verið hefur undanfarin ár. Til samanburðar urðu 150 fyrirtæki í byggingaiðnaðinum gjaldprota árið 2008 (Hagstofa Íslands, 2010), 103 árið 2007, ekki nema 82 árið 2006 og ef horft er til ársins 2005 voru pað ekki nema 61 fyrirtæki sem lýstu sig gjaldprota (Hagstofa Íslands, 2009). Frá árinu 2005 til ársins 2009 hefur pví fjöldi fyrirtækja í byggingaiðnaðinum, sem hafa purft að lýsa sig gjaldprota, rúmlega fjórfaldast.

Par sem leitast var við í rannsókn pessari að rannsaka áhrif gæðastjórnunar á mannvirkjagerð á Íslandi verður að taka tillit til pess að rannsóknin er gerð á pessum erfiða tíma fyrir pjóðarbúskapinn. Gera má ráð fyrir að niðurstöðurnar muni litast að einhverju leyti af áhrifum frá hruninu. Skýrsluhöfundur telur líklegt að hrunið sé pess valdandi að áætlanir, bæði fjárhagslegar og tímalegar, hafi farið úr skorðum. Pá er erfitt að greina hvort pær hefou staðist ef efnahagslífið ætti ekki undir petta högg að sækja.

\subsubsection{Mannvirkjalögin}

Hinn 28. desember 2010 undirritaði forseti Íslands, Ólafur Ragnar Grímsson, ný lög um mannvirki og tóku pau gildi 1. janúar 2011. Ætlun peirra er m.a. að auka á gæði mannvirkja, efla neytendavernd og gera stjórnsýslu mannvirkjamála sem skilvirkasta. Samkvæmt 5. grein laganna á ríkið að starfrækja sérstaka Mannvirkjastofnun sem hefur m.a. eftirlit með framkvæmd laganna (Alpingi, 2010). Stofnunin tók til starfa um áramótin 2010/2011 (Mannvirkjastofnun).

Með nýju lögunum er ábyrgð eiganda mannvirkis skýrari en í fyrri lögum og kemur greinilega fram að hin endanlega ábyrgð er eigandans en pað er hann sem sér um að ráða fagaðila sem sjá svo um einstaka pætti mannvirkjagerðarinnar og eru par með ábyrgir gagnvart eigandanum. Gerð er til pess krafa að eigandi mannvirkis ráði sérstakan hönnunarstjóra sem ekki má jafnframt vera hönnuður að viðkomandi mannvirki. Pað sama á við byggingarstjóra, en peir mega ekki jafnframt vera iðnmeistarar viðkomandi verkhluta. Enda í raun óeðlilegt að ætlast til pess að menn hafi eftirlit með sjálfum sér. Minni verk eru pó undanskilin pessu ákvæði.

Mikil áhersla er lögð á gæðastjórnun í nýju lögunum og til merkis um pað kemur orðið gaeðastjórnun 27 sinnum fram í peim. Gerð er krafa um að hönnuðir, byggingastjórar og iðnmeistarar starfi eftir gæðastjórnunarkerfi (Alpingi, 2010). 
Gerð er um pað krafa að hönnuðir, byggingarstjórar eða iðnmeistarar hafi virkt gæðastjórnunarkerfi en samkvæmt 17. grein laganna kemur fram að hafi hönnuðir, byggingarstjórar eða iðnmeistarar ekki hlotið vottun faggiltrar vottunarstofu á gæðastjórnunarkerfum sínum skal Mannvirkjastofnun gera úttekt á gerð og virkni pessara gæðastjórnunarkerfa. Í 24., 28. og 32. grein kemur fram hvað gæðastjórnunarkerfin purfi að minnsta kosti að fela í sér en samkvæmt 60. grein laganna kemur m.a. fram að heimilt er að gera mismunandi kröfur til gæðakerfa eftir gerð mannvirkis (Alpingi, 2010).

Samkvæmt bráðabirgðaákvæði kemur fram að fyrir 1. janúar 2015 skulu Mannvirkjastofnun og byggingafulltrúar hafa komið sér upp gæðastjórnunarkerfi. Hafi gæðastjórnunarkerfi byggingafulltrúa ekki hlotið vottun faggiltrar vottunarstofu skal Mannvirkjastofnun til 1. janúar 2018 gera úttekt á gerð og virkni gæðastjórnunarkerfanna (Alpingi, 2010).

Skýrsluhöfundi finnst lögin ekki skilgreina nægilega ítarlega hversu umfangsmikil gæðastjórnunarkerfi ofangreindra aðila purfi að vera með tilliti til stærðar fyrirtækja og sótti par af leiðandi kynningarfund um nýju Mannvirkjalögin og nýstofnaða Mannvirkjastofnun sem Samtök iðnaðarins héldu 23. febrúar 2011, til pess að leita svara við eftirfarandi spurningum;

1) Hvernig hyggst stofnunin fylgja pví eftir að allir peir aðilar sem verða nú, að starfa eftir gæðastjórnunarkerfi samkvæmt nýju lögunum geri pað í raun og veru?

2) Hvernig skilgreinir stofnunin gæðastjórnunarkerfi par sem ekki er farið fram á vottun, sér í lagi fyrir lítil fyrirtæki og einyrkja?

Framsögumenn fundarins voru Steinunn Fjóla Sigurðardóttir lögfræðingur og Hafsteinn Pálsson verkfræðingur, starfsmenn umhverfisráðuneytisins. Í umræðutíma eftir fundinn velti skýrsluhöfundur ofangreindum spurningum upp en varð fátt um svör. Dví var leitað svara hjá Birni Karlssyni forstjóra mannvirkjastofnunar. Pau svör fengust, eins og fram kemur í kafla 2.1.2 á bls. 5, að ráðlagt sé að skilgreining á nauðsynlegu umfangi gæðastjórnunarkerfa fyrir íslensk fyrirtæki í mannvirkjagerð verði tilbúin í lok árs 2011. Mun skilgreiningin taka tillit til stærðar fyrirtækja og verkefna. Áætlað er að eftirlit með pví hvort aðilar starfi eftir gæðastjórnunarkerfum hefjist 1. jan 2015 og eftirlit með virkni kerfa hefjist 1. jan 2018. Björn tók undir pað með skýrsluhöfundi að eitt af vandamálunum við skilgreiningu gæðastjórnunarkerfa í pessu samhengi væri gagnvart mjög litlum fyrirtækjum og einyrkjum. Líklega fælu kerfi fyrir slíka aðila aðallega í sér að einsleitt kerfi væri til að halda utan um skjöl til að tryggja að eftirlitsaðilar gætu skoðað skjölin án mikillar fyrirhafnar. Pví pyrfti sama kerfi að vera fyrir alla. Tilgangurinn væri bví ekki endilega að pvinga aðila til að fara eftir ákveðnu vinnulagi, heldur fremur að tryggja að farið sé með skjöl á samræmdan hátt (Björn Karlsson, 2011).

Mannvirkjalögin undirstrika enn frekar en nokkru sinni pá nauðsyn að verkkaupi vandi valið á peim aðilum sem valdir eru til verka í ljósi peirrar ábyrgðar sem nú er sett á hendur verkkaupum. Upplýsingar um menntun fagmanna og jákvæð ummæli fyrri viðskiptavina verktaka eru pví undirstaða pess að verkkaupar geti valið rétta aðila. Verkefni, eins og nú eru í uppbyggingu hjá sprotafyrirtækinu Strax ehf., og minnst var á í kafla 2.2.3 á bls. 15, eru pví mikilvæg í pessu samhengi. Par á að vera vettvangur á veraldarvefnum par sem auðvelt á að vera fyrir verkkaupa að nálgast viðskiptasögu og aðrar upplýsingar um verktaka eins og hvaða tryggingar og menntun peir hafa (Naglinn, 2011). Frá pví að 
frumvarp um lögin kom fyrst fram á sjónarsviðið hafa ýmsar athugasemdir og ábendingar um innihald peirra komið fram og pá sérstaklega í tengslum við pað að hagsmunum neytenda sé hugsanlega ekki sem best gætt með nýju lögunum vegna aukinnar ábyrgðar sem er sett á verkkaupa. Gagnrýnin hefur pá aðallega beinst að pví að verkkaupi hafi oft ekki næga pekkingu til að axla pá ábyrgð sem af honum er krafist. Magnús Sædal Svavarsson, byggingafulltrúi í Reykjavík, tekur í sama streng í viðtali við Samiðn (Magnús Sædal Svavarsson, 2007) en einnig hafa Neytendasamtökin sömu áhyggjur sem Hildigunnur Hafsteinsdóttir opinberar á síðu félagsins ( Hildigunnur Hafsteinsdóttir f.h. Neytendasamtakanna, 2008).

\subsection{3 ÍST-30, Almennir útboðs- og samningsskilmálar um verkframkvæmdir}

Mörg byggingafyrirtæki notast við ÍST-30 staðalinn og er algengt að tekið sé fram í útboðum að uppfylla purfi kröfur ÍST-30, sérstaklega í útboðum opinberra verkkaupa. Staðallinn lýsir peim skilyrðum sem markaðurinn hefur sett um góða stjórnun við verklegar framkvæmdir (Eyjólfur Bjarnason og Ferndinand Hansen hjá Samtökum Iðnaðarins, 2004). Í honum koma fram pau atriði sem talin eru nauðsynleg varðandi samskipti verkkaupa og verktaka.

Nýjasta útgáfa staðalsins er ÍST 30:2003, Almennir útboðs- og samningsskilmálar um verkframkvæmdir. Er sú útgáfa nr. 5. en hann kom fyrst út árið 1969, síðan 1979 og 1988 og síðast 1997. Vinnuhópur á vegum Byggingastaðlaráðs (BSTR) vann að endurskoðun staðalsins sem kom út 2003 (ÍST 30:2003, Almennir útboðs- og samningsskilmálar um verkframkvæmdir, 2003). Í fréttablaði Staðlaráðs Íslands, Staðlamálum, frá pví í mars 2011, kemur fram að gert sé ráð fyrir að frumvarp að nýrri útgáfu ÍST 30 verði laust til umsagnar í vor og að nýr staðall taki gildi á haustmánuðum ( Staðlaráo Íslands, 2011).

\subsubsection{ISO}

Alpjóðlegu staðlasamtökin (e. International Organization for Standardization) eru samtök staðlastofnana einstakra landa (ISO meðlima). Samtökin eru bau stærstu sinnar tegundar í heiminum. Frá 1947 og fram til dagsins núna hafa pau gefið út meira en 18.500 alpjóðlega staðla (International Standardization for Organization, 2010).

Við gerð allra alpjóðlegra staðla vinna sérstakar tækninefndir ISO. Frumvörpum að alpjóðastöðlum, sem unnin eru af tækninefndunum, er dreift til meðlima samtakanna til umsagnar. Sú regla er höfð á að alpjóðastaðall er ekki gefinn út nema að lágmarki 75\% peirra meðlima, sem greiða atkvæði, hafi sampykkt. Sérhver meðlimur á rétt á að eiga fulltrúa í peim tækninefndum sem viðkomandi hefur áhuga á. Alpjóðlegar stofnanir, svo sem ríkisstofnanir auk annarra stofnanna, taka einnig pátt í starfinu í samvinnu við ISO. Auk pess hefur ISO náið samstarf við Alpjóðaraftækniráðið (e. International Electrotechnical Commission, IEC) um alla pætti er varða stöðlun á sviði raftækni (Staðlaráð Íslands, 2003). ISO 9000 staðlaröðin var próuð til að hjálpa fyrirtækjum við innleiðingu á gæðastjórnun og til að starfrækja virk gæðakerfi. Staðlaröðin er samsett úr eftirfarandi fjórum alpjóðlegum stöðlum:

- ISO 9000 - Gæðastjórnunarkerfi - Grunnatriði og íðorðasafn

- Dar eru sett fram hugtök, meginreglur, grunnatriði og iorðasafn.

- ISO 9001 - Gæðastjórnunarkerfi - kröfur 
- Dar eru settar fram poer kröfur sem parf að uppfylla.

- ISO 9004 - Gæðastjórnunarkerfi - leiðbeiningar um bætta frammistöðu

- Dar er að finna leiðsögn um pað hvernig stuðla megi að stöðugum umbótum á heildarframmistöðu fyrirtcekis.

- ISO 19011 - Leiðbeiningar fyrir gæði og umhverfisstjórnunarkerfi

- Dar eru leiðbeiningar um úttektir á gcðastjórnunarkerfum. 


\subsection{Rannsóknarspurningar}

Spurningar rannsóknarverkefnisins eru eftirfarandi:

1. Hver er staða gaðastjórnunar í mannvirkjagerð ?

Spurningalisti er lagður fyrir verkkaupa símleiðis par sem staða gæðastjórnunar í verkum sem eru um pað bil að klárast eða er nýlokið, er könnuð óbeint. Auk pess er spurningalisti lagður símleiðis fyrir verktaka par sem staða gæðastjórnunar innan verktakafyrirtækjanna er könnuð út frá sjónarhorni verktakanna sjálfra.

\section{a. Hver er bekking verktaka á gæðastjórnun ?}

Verktakar voru spurðir hversu vel peir hefðu kynnt sér gæðastjórnun almennt, hversu vel peir hefou kynnt sér ISO 9001 og ÍST 30.

2. Í hverju felst munurinn á verktökum sem starfa eftir gaðastjórnunarkerfi og verktökum sem starfa ekki eftir gæðastjórnunarkerfi ?

Verkkaupar eru spurðir um pað hvaða verktaka peir höfðu í huga við svörun spurningalistans og var leitast eftir pví að fá sem flesta verktaka sem verkkaupar höfou haft í huga til að svara sérstakri könnun ætlaðri verktökum. Svör viðkomandi verkkaupa og umrædds verktaka voru svo tengd til frekari greiningar.

a. Eru fyrirtæki sem starfa eftir gæðastjórnunarkerfi með ánægðari viðskiptavini en fyrirtaki sem starfa ekki eftir bví ?

Ánægja verkkaupa er könnuð með tilliti til pess hvort umræddur verktaki starfi eftir gæðastjórnunarkerfi og leitast er við að kanna hvort marktækur munur sé á ánægju verkkaupa með framkvæmd verks hjá umræddum verktaka, samskipti, tímastjórnun, fjármagnsflæði og gæði, ef umræddur verktaki starfar eftir gæðastjórnunarkerfi, heldur en ef umræddur verktaki starfar ekki eftir pví. Núlltilgátan er að enginn munur sé á ánægju verkkaupa eftir bví hvort umræddur verktaki starfi eftir gæðastjórnunarkerfi byggðu á viðurkenndum gæðastjórnunarstöðlum eða ekki og með úrvinnslu gagna úr könnunum er leitast við að svara pví.

b. Er munur á verklagi íslenskra byggingaverktaka með tilliti til pess hvort beir starfa eftir gæðastjórnunarkerfi eða ekki ?

Verklag verktaka er sérstaklega kannað með tilliti til pess hvort peir vinni eftir gæðastjórnunarkerfi eða ekki. Spurt er hvort verklagi íslenskra verktaka sé ábótavant en jafnframt hvort fyrirtæki, sem starfa eftir gæðastjórnunarkerfi, noti markvissari vinnubrögð en fyrirtæki sem gera pað ekki. 
c. Er munur á samskiptum milli verktaka og verkkaupa með tilliti til pess hvort verktaki starfar eftir gaðastjórnunarkerfi eða ekki ?

Sérstaklega er leitast við að kanna hvernig samskiptum verkkaupa og verktaka er háttað. Kannað er sérstaklega hvort munur sé á samskiptum milli verkkaupa og verktaka eftir pví hvort verktakarnir starfa eftir gæðastjórnunarkerfi eða ekki.

d. Er munur á viðhorfi verktaka til gæðastjórnunar eftir pví hvort verktaki starfar eftir gæðastjórnunarkerfi eða ekki ?

Viðhorf verkataka til gæðastjórnunar er kannað með margvíslegum hætti. Kannað er hvort viðhorf verktaka til gæðastjórnunar sé jákvætt eða neikvætt. Skoðað er hvort finna megi viðhorfsmun milli verktaka sem starfa eftir gæðastjórnunarkerfi og peim sem gera pað ekki. Pá er kannað hvort finna megi viðhorfsmun eftir stærð fyrirtækja og hvert sé viðhorf einyrkja og mjög lítilla verktaka.

e. Er munur á kröfum til verktaka, um skipulag og markvissa stjórnun, milli verktaka sem starfa eftir gæðastjórnunarkerfi og peirra sem gera pað ekki ?

Kannað er hvort kröfur til verktaka um skipulag og markvissa stjórnun komi einungis frá hinu opinbera og hvort slíkar kröfur hafi breyst eftir efnahagshrunið. Sérstaklega er kannað hvort verktakar sem starfa eftir gæðastjórnunarkerfi finnist verkkaupar gera meiri/minni kröfur í sinn garð en verktakar sem starfa ekki eftir pví.

f. Er munur á stöðu gæðatryggingar í mannvirkjagerð meðal verktaka sem starfa eftir gæðastjórnunarkerfi og peirra sem gera pað ekki ?

Sérstaklega er leitast við að rannsaka stöðu gæðatryggingar í mannvirkjagerð og hvort munur sé meðal verktaka sem starfa eftir gæðastjórnunarkerfi og meðal verktaka sem gera pað ekki, með tilliti til gæðatryggingar.

3. Hvaða pættir hafa mest áhrif á ánægju verkkaupa ?

Sérstök áhersla er lögð á að greina hvaða pættir hafa áhrif á ánægju verkkaupa með framkvæmd verka. Skoðað er hvort lýsa mætti sambandi milli ánægju verkkaupa og annarra pátta með línulegu aðhvarfsgreiningarlíkani (CATREG). 


\subsection{Gagnaöflun}

Farið var yfir fyrri rannsóknir sem gerðar hafa verið í gæðastjórnun, pó einkum gæðastjórnun í mannvirkjagerð. Í framhaldi af pví var útbúinn spurningalisti fyrir verkkaupa. Við gerð spurningalistans var stuðst við gæðastjórnunarstaðalinn ISO 9001 og samskiptastaðalinn ÍST 30 auk innsæis frá verkefnastjóra gæðastjórnunar Samtaka iðnaðarins, Ferdinands Hansens, og gæðastjóra ÍAV, Eyjólfs Bjarnasonar.

Upplýsingar um verkkaupa fengust frá starfandi byggingafulltrúum sveitarfélagana. Óskað var eftir bví að fá upplýsingar um verkkaupa sem höfðu verið í framkvæmdum undanfarin 5 ár, að peim verkkaupum utanskildum sem voru sjálfir verktakar. Af augljósum ástæðum pótti pað ekki vænlegt að taka viðtal við verkkaupa sem voru á sama tíma verktakarnir í verkinu.

Farin var sú leið að notast við símaviðtöl við verkkaupana par sem hópurinn samanstóð af einstaklingum og fyrirtækjum og oftar en ekki lágu upplýsingar um netfang ekki fyrir. Einnig voru margir verkkaupar sem gátu ekki tekið pátt í könnuninni sökum pess að peir voru ekki með verktaka í vinnu sem peir gátu haft í huga pegar spurningunum var svarað. Var dregin sú ályktun að skilvirkasta leiðin til að komast að pví hvort viðkomandi gæti tekið pátt í könnuninni væri pví símtal. Ekki var raunhæft að taka viðtal við alla verkkaupa á pessum svæðum innan tímaramma verkefnisins, svo farin var sú leið að hverju sveitarfélagi var gefinn ákveðinn tímarammi fyrir viðtöl með tilliti til fjölda verkkaupa og var reynt að̃ ná sem flestum viðtölum á peim tíma.

Pegar viðtölum við verkkaupa var lokið var útbúinn spurningalisti fyrir verktaka. Leitað var eftir upplýsingum um umrædda verktaka sem verkkaupar í fyrri könnun höfou í huga pegar peir svöruðu. Til að fá fleiri svör var einnig leitað á internetinu eftir upplýsingum um fleiri verktaka sem voru með veffang og peim send könnunin í netpósti. Auk pess var notast við netfangalista frá Samtökum iðnaðarins og aðgengi að fundi á vegum Samtakanna fyrir meistarafélag iðnaðarmanna í Hafnarfirði. Svör við könnun verktaka fengust pví með prennum hætti, p.e. með símaviðtölum, netkönnun og á pappír.

Skýrsluhöfundur veit ekki til pess að gerð hafi verið sambærileg könnun og var pví ekki hægt að bera svörin saman við aðra könnun. 


\subsection{Uppbygging skýrslu}

- Fræðileg umfjöllun - Fyrri rannsóknir.

Farið er yfir fræðilega umfjöllun út frá rannsóknarspurningunum.

- Ytra umhverfi.

Farið er yfir mannvirkjalögin sem liggja nú fyrir Alpingi, helstu staðla og hugsanleg áhrif efnahagshrunsins á mannvirkjagerð.

\section{- Rannsókn.}

Farið er yfir framkvæmd verkefnis, lögmæti mælinga, aðferðafræði, kannanir fyrir verkkaupa og verktaka ásamt greiningu á gögnum úr könnunum og helstu niðurstöður flokka aðhvarfsgreiningar (e. CATREG).

- Niðurstöður og umræða

Svör við rannsóknaspurningum eru dregin saman í lokin út frá greiningu gagna úr könnunum og fræðilegri umfjöllun ásamt pví að niðurstöður og vangaveltur eru ræddar.

- Lokaorð.

Tillögur að áframhaldandi rannsóknum á pessu sviði eru lagðar fram auk ýmissa vangaveltna.

Í skýrslunni er vísað í heimildir með nafni höfundar og útgáfuári, nema sérstök ástæða pyki til að tíunda auk pess aðra pætti. Ítarlegri heimildaskrá er að finna aftast. 


\section{Fræðileg umfjöllun - Fyrri rannsóknir}

Lítið hefur borið á rannsóknum á gæðastjórnun í mannvirkjagerð á Íslandi en par ber helst að nefna rannsókn Guðjónu Sigurðardóttur frá árinu 2008, og ber heitið Gceðastjórnun verktaka í mannvirkjagerð á Íslandi. Viðfangsefnið hefur verið rannsakað víða erlendis svo sem í Asíu, Bandaríkjunum og Evrópu. Rannsóknir, sem gerðar hafa verið um gæðastjórnun í mannvirkjagerð, byggjast margar á innleiðingu gæðastjórnunar, frammistöðumælingum á fyrirtækjum sem annars vegar nota gæðastjórnun og hins vegar peirra fyrirtækja sem ekki nota gæðastjórnun, ásamt pví að vinsælt hefur verið að rannsaka aðferðir fyrirtækja í byggingaiðnaði sem hefur vegnað betur en öðrum og par með ályktað um hvaða aðferðir séu bestar (e. best practice).

Pessi kafli er byggður upp með tilliti til rannsóknaspurninganna og verður niðurstaðna annarra rannsókna og fræða getið í samhengi við pær.

\subsection{R1 - Staða gæðastjórnunar í mannvirkjagerð}

Gæðastjórnun hefur verið mikilvægur páttur í alls kyns starfsgreinum í mörg ár. Innleiðing skilvirkrar gæðastjórnunar hefur verið komið á í framleiðslu iðnaðinum og hefur sá iðnaður verið fyrirmynd fyrir annann iðnað. Undanfarna áratugi hafa byggingafyrirtæki verið gagnrýnd fyrir slaka frammistöðu og framleiðni samanborið við aðrar starfsgreinar (Gopal K. Kanji, Alfred Wong, 1998). Samhliða hafa orðið breytingar í byggingaiðnaðinum og má segja að ákveðin vakning hafi átt sér stað meðal byggingafyrirtækja sem lýsir sér í aukinni sjálfsskoðun. Iðnaðurinn hefur opnað á pað að hleypa inn hugmyndum sem geta bætt ferla og viðskiptahætti. Skilvirk gæðastjórnun hefur verið viðurkennd aðferð til pess að auðvelda frammistöðu umbætur í byggingaiðnaðinum (S.L.Tang, 2005).

Nú vita margir hvað gæðastjórnun er en vitneskjan er ekki almenn hjá fyrirtækjum í mannvirkjagerð (Eyjólfur Bjarnason, 2010). Verktakar bera pað gjarnan fyrir sig að gæðastjórnun henti ekki verktakafyrirtækjum, heldur séu pað fræði sem eiga betur við í framleiðslufyrirtækjum en fræðingar í gæðastjórnun eru almennt á peirri skoðun að svo sé ekki raunin. Crosby segir til að mynda í bókinni Quality is free. the art of making quality certain að gæðastjórnun eigi heima í öllum atvinnugreinum (Crosby P. , 1979). Pað er einmitt á valdi fyrirtækjanna sjálfra að setja upp sín eigin gæðakerfi með peim vinnuferlum sem best henta hverri starfsemi. Pví er mikilvægt að verkkaupar í byggingaiðnaði vakti ferlana hjá hönnuðum og verktökum par sem að vinnuferlar geta verið mjög mismunandi milli fyrirtækja og einnig innan hvers fyrirtækis og ræðst af stærð eða flækjustigi verkefna (Óskar Valdimarsson, 2006). 


\subsubsection{Hérlendis}

Fæst íslensk fyrirtæki í byggingaiðnaði hafa vottað gæðastjórnunarkerfi prátt fyrir að mörg peirra segjast starfa eftir slíku kerfi ${ }^{4}$. Рað er vissulega stefnumarkandi ákvörðun innan fyrirtækis að taka upp gæðastjórnunarkerfi. Formgerð og skjalfesting gæðastjórnunarkerfis á ekki að vera einsleit fyrir öll fyrirtæki en uppbygging og innleiðing gæðastjórnunarkerfis byggist á mismunandi pörfum, markmiðum, vörum og ferlum hvers fyrirtækis.

Eina alpjóðlega vottunarstofnunin á Íslandi eru BSI (BSI, British Standards Institution, 2007) en aðrir vottunaraðilar eru Vottun hf. (Vottun hf.) og Samtök Iðnaðarins. Samkvæmt vef Framkvæmdasýslu ríkisins eru 15 ráðgjafarstofur og verktakar á sviði mannvirkjagerðar með vottað gæðakerfi samkvæmt ISO 9001 (e. International Standardization Organization) staðlinum (Framkvæmdasýsla ríkisins) en peir aðilar sem hafa hlotið vottun hjá Samtökum iðnaðarins geta fengið ákveðið vottunarprep sem fullnægir ekki endilega öllum kröfum sem vottað gæðakerfi samkvæmt ISO 9001 parf að uppfylla.

Á Íslandi hafa Samtök iðnaðarins (SI), sem eru hagsmunasamtök sem stór hluti fyrirtækja innan mannvirkjagerðar eiga hlut að, verið í forystu í gæðamálum undanfarin ár. Samtökin leggja áherslu á að fyrirtæki taki upp hugmyndafræði gæðastjórnunar og bjóða peir félagsmönnum upp á gögn og aðstoð við að koma á gæðastjórnun í fyrirtækjum sínum auk pess sem verktakar, meistarar og byggingastjórar geta leigt aðgang að miðlægu gæðakerfi GSI (Samtök iðnaðarins. Gæðastjórnun, stjórnun og rekstur). SI bjóða upp á innleiðingu gæðastjórnunar í fjórum prepum (D, C, B og loks A) par sem að kröfur sem verktakar verða að gangast undir og starfa samkvæmt til að fá vottun aukast með hverju prepi. begar fyrirtæki hefur fengið A-vottun eiga pau mjög skammt í að fullnægja hinum alpjóðlega gæðastaðli ISO-9000:2000 (Samtök iðnaðarins. Gæðavottun SI). SI er einnig í samstarfi við Mannvirkjastofnun og helstu opinberar stofnanir landsins um innleiðingu gæðastjórnunar við verklegar framkvæmdir (Samtök iðnaðarins. Gæðastjórnun, stjórnun og rekstur), auk pess sem samtökin hafa sett á fót námskeið um gæðastjórnun í byggingaiðnaði sem fjöldi aðila úr hópi hönnuða, eftirlitsmanna verkkaupa og verktaka hafa sótt (Óskar Valdimarsson, 2006).

prátt fyrir margar tilraunir Samtaka iðnaðarins virðist sem ekki hafi tekist að kveikja áhuga verktaka á gæðastjórnun og skilningur peirra á hugtökum gæðastjórnunar er takmarkaður. Svo virðist sem stjórnendur í mannvirkjagerð eigi erfitt með að átta sig á pví að pað sem er huglægt parf líka að skilgreina og skrá í verklýsingar (SI - Fréttir og greinar - Handverk og stjórnun, 2007). Í grein sem ber nafnið Goeðastjórar hoeddir og hunsaðir eftir Ferdinand Hansen kemur fram að svo virðist sem að stjórnendur haldi að með pví að ráða inn gæðastjóra pá sé búið að tryggja pað að fyrirtækið sé farið að vinna í gæðamálum (Ferdinand Hansen, 2006). Pó virðist sem að ákveðin vakning hafi orðið á undanförnum árum í mannvirkjaiðnaði og mörg fyrirtæki hafa tekið upp gæðastjórnun, m.a. pannig að starfsmenn fyrirtækjanna fylgjast sjálfir með framleiðslunni á öllum stigum og grípa inn í á viðeigandi hátt par sem við á. Með peirri próun, sem hefur átt sér stað í gæðastjórnun innan greinarinnar, hafa mörg störf í svokölluðum eftirlitsiðnaði breyst og má par t.d. nefna störf byggingafulltrúa (Samtök iðnaðarins. Framtíðarsýn árið 2005- Stefnumótun fyrir íslenskan mannvirkjaiðnað, 2005).

\footnotetext{
${ }^{4}$ Sjá niðurstöður úr könnun meðal verktaka
} 
Eins og fram kemur í ritgerð Guðjónu Bjarkar Sigurðardóttur átta stjórnendur margra fyrirtækja í starfsgreininni sig ekki á að gæðakerfið er stjórnkerfi fyrirtækisins, líkt og taugakerfið er stjórnkerfi mannslíkamans. Einnig kemur fram að verktakar hafa í auknum mæli verið að kaupa sér pá pjónustu að láta gera fyrir sig gæðaverkmöppur vegna kröfu verkkaupa en algengt sé að mappan fari beint upp í hillu eða til verkkaupa án pess að verktaki kynni sér innihaldið (Guðjóna Björk Sigurðardóttir, 2008). Er petta í samræmi við pað sem viðmælanda skýrsluhöfundar, Sigríði Sigurðardóttur ${ }^{5}$, fannst um stöðu gæðastjórnunar í mannvirkjagerð á Íslandi. Sigríður starfar mikið í eftirliti og sagði hún að eftir að byggingafyrirtæki fóru að taka upp gæðastjórnunarkerfi (pó ekki nema að nafninu til) hefði hefðbundið framkvæmdaeftirlit próast í pað að vera gæðaeftirlit. Ábyrgðin er pá sett svolítið í hendurnar á verktakanum að sjá um úttektir, en algengt er að verkkaupar velji sér verktaka með gæðastjórnunarkerfi til að spara sér kostnað við úttektarmenn. Аð mati Sigríðar nýtist petta fyrirkomulag ekki eins og ætlast er til. Verktakar taka pessu ef til vill ekki nægilega alvarlega og eru jafnvel ekki með kunnáttu til að vera með gæðakerfi. Virðist svo vera að margir verktakar hafi keypt gæðamöppu og ekki gert annað við hana en að setja hana upp í hillu og látið par við sitja og talið sig vera með pessu búna að innleiða gæðakerfi hjá sér (Sigríður Sigurðardóttir, 2010). Er petta í samræmi við álit annars viðmælanda skýrsluhöfundar Jónasar Brjánssonar, starfsmann Eflu í eftirliti, verkefna- og framkvæmdastjórnun. Hann áréttaði að mikilvægt væri að verkkaupinn fylgdi gæðamálum eftir frá upphafi og var sammála pví að eitthvað hefơi borið á að verktakar keyptu gæðamöppu t.d. hjá SI og segðust par með starfa eftir gæðastjórnunarkerfi en hefou hugsanlega aldrei lesið gæðakerfið yfir. Hann bendir einnig á að erfitt hafi reynst að fylgja pví eftir að verktakar vinni eftir kerfi sem er ekki vottað (Jónas Brjánsson, 2010). Óskar Valdimarsson undirstrikar að nokkru leyti pessa skoðun Sigríðar og Brjáns í grein sinni Gcðastjórnun við mannvirkjagerð en par segir hann að ferðalag íslensks byggingaiðnaðar að gæðaeftirliti sé hafið pótt enn sé langt í land (sjá nánar um gæðaeftirlit á bls. 35) (Óskar Valdimarsson, 2006).

Nágrannalöndin hafa mörg hver hafið notkun á prívíðum upplýsingalíkönum (t.d. Danmörk, Finnland, Noregur og Bandaríkin) og hafa stjórnvöld jafnvel gert pað að kröfu að peir sem koma að opinberum framkvæmdum noti slíkt. Á Íslandi er unnið að priggja ára innleiðingaráætlun 2009-2011 sem nú er í mótun og tekur mið af reynslu annarra landa sem nú pegar hafa sambærilega stefnu um innleiðslu BIM (BIM Ísland, 2011). Upplýsingalíkön mannvirkja (e: Building Information Modeling, BIM) er ný aðferðafræði við hönnun mannvirkja. Með pví geta hönnuðir sett rafrænt upp prívítt líkan af mannvirkjum. Byggingarhlutar eru svo tengdir saman og upplýsingar (efni, áferð, magn og fleira) eru síðan tengdar við pá. Мeð pessu eru lögð drög að aukinni sampættingu hönnunarferlisins og samhæfingu hönnuða. Vonast er til að petta auki gæði hönnunargagna sem stuðlar svo að aukinni hagkvæmni (Framkvæmdasýsla ríkisins ).

\subsubsection{Erlendis}

Skýrsluhöfundur las talsvert af greinum um gæðastjórnun í byggingaiðnaði og er ljóst að rauði práđurinn í peim lestri var að fræðimenn voru almennt á pví að prátt fyrir sérkenni mannvirkjagerðar pá gæti gæðastjórnun bætt verklag innan iðnaðarins sem skilaði sér með

\footnotetext{
5 arkitekt og markaðsstjóri hjá verkfræðistofunni Eflu sem stóð á dögunum fyrir námskeiði hjá Endurmenntun Háskóla Íslands og bar heitið „Framkvæmdarferli mannvirkjagerða“
} 
auknum hagnaði, skilvirkni og ánægðari viðskiptavinum. Einnig voru flestir peirra skoðunar að innleiðingarferlið væri strembið og fyrirtæki í byggingaiðnaðinum vanti almennt skilning á peim ávinningi sem hægt er að ná með gæðastjórnun í greininni. Frá 1985 og til dagsins núna hafa pó nokkur forystu fyrirtæki í iðnaðinum sýnt fram á góða beitingu fræðanna innan mannvirkjagerðar (John Oakland \& Marton Marosszek, 2006).

Margir alpjóðlegir verkkaupar krefjast pess að byggingaverktakar peirra séu með ISO vottað gæðakerfi en undanfarna áratugi hafa byggingafyrirtæki verið gagnrýnd fyrir frammistöðu og framleiðni samanborið við aðrar starfsgreinar (Gopal K. Kanji, Alfred Wong, 1998). Samhliða hafa orðið breytingar í byggingaiðnaðinum og má segja að ákveðin vakning hafi átt sér stað meðal byggingafyrirtækja sem lýsir sér með aukinni sjálfsskoðun. Iðnaðurinn hefur opnað á pað að hleypa inn viðhorfum sem geta bætt ferla og viðskiptahætti. Skilvirk gæðastjórnun, sérstaklega altcek gæðastjórnun (AGS) hefur verið viðurkennd aðferð til pess að auðvelda frammistöðu umbætur í byggingaiðnaðinum (S.L.Tang, 2005). Reynsla, sem fengist hefur frá löndum eins og Bretlandi, Singapore og Hong Kong, sýndi fram á að innleiðing gæðastjórnunar reyndist ganga vel í fyrstu í byggingaiðnaðinum en eftir ákveðinn tíma varð hún pungbær öllum aðilum ef réttum aðferðum var ekki beitt (Giles, 1997) (Kam, C.W. and Tang, S.L., 1997) (Low, S.P. and Goh, K.H, 1994). Pví er afar mikilvægt að staðið sé rétt að innleiðingarferlinu.

Eins og fram kemur hér að framan hafa margar rannsóknir verið gerðar erlendis á gæðastjórnun í byggingaiðnaði. Hér að aftan verður farið yfir nokkrar af helstu rannsóknum á sviðinu.

\section{Norðurlönd}

Mikil vinna hefur verið lögð í endurskoðun vinnulags við undirbúning framkvæmda hjá flestum nágrannapjóðum okkar undanfarin ár og má pá sérstaklega nefna Dani í pví samhengi (Óskar Valdimarsson, 2006). Par hefur sérstök áhersla hefur verið lögð á að byggingaiðnaðurinn notfæri sér upplýsinga- og samskiptatækni á rafrænu formi (ICT, e. Information and Communication Technology). Með verkefninu „Det Digitale Byggeri“, sem var sett af stað af dönskum stjórnvöldum, kemur fram að frá og með 1. janúar 2007 gera stjórnvöld pá kröfu að allir ráðgjafar sem koma að hönnun opinberra bygginga í Danmörku, vinni hönnun sína í prívíðu líkani, (mannvirkjaupplýsingalíkani líkt og BIM á Íslandi). Stífar kröfur eru gerðar um uppsetningu og vinnulag og er meðal annars gert ráð fyrir sérstökum kafla um gæðatryggingu á hönnunarstiginu. Telja peir að með upptöku svo markvissra vinnubragða sem staðall peirra kveður á um muni hönnunarmistökum fækka svo um munar (Det Digitale Bygger, 2010) (Óskar Valdimarsson, 2006).

\section{Bretland}

Í Bretlandi var pað markaðurinn og viðskiptavinirnir sem voru kveikjan að pví að innleiðing ISO gæðakerfa hófst í byggingaiðnaðinum. Рað var krafa frá stórum hóp viðskiptavina að byggingaverktakar innleiddu hjá sér ISO gæðakerfi til pess að fá að taka pátt í útboðum. Í kjölfar pess sáust miklar breytingar og fjöldinn allur af byggingaverktökum innleiddu hjá sér ISO gæðakerfi og leituðu til úttektarstofa til að fá gæðakerfi sín vottuð (Giles, 1997). Undanfarin ár hafa Bretar lagt aukna áherslu á gæðastjórnun í byggingaiðnaði. Ef maður sniðgengur vandamál í upphafi verks getur hann 
verið viss um að pau verða orðin að vandamálum í lok verksins (e. If you do not take trouble at the beginning, you will most certainly be given it before the end). Svo hljóðar eitt af vígorðum Breta um að leggja aukna áherslu á gæðamál í byggingaiðnaði. Árið 2000 hratt Tony Blair, páverandi forsætisráðherra Breta, af stað miklu átaki í gæðastjórnun í byggingaiðnaði, með útgáfu á stefnumótunarritinu Better Public Buildings (The Better Public Buildings Group, Lord Falconer, 2000). Verkefnið var samstarfsverkefni margra ráðuneyta og fagfélaga en í kjölfarið hafa peir lagt mikið fé í rannsóknir á málefninu. Samkvæmt skýrslu CABE frá 2006 hafa gæði bygginga aukist eftir gæðaátak Tony's (CABE, 2006). Eitt af pví sem spratt upp úr átakinu var matslíkanið DQI (e. Design Quality Indicator) sem CIC (e. Construction Industry Council) og CABE (e. Commission for Architecture and the Built Environment) próuðu. Matslíkanið metur gæði hönnunar og framkvæmda á nýjum byggingum ( Construction Industry Council) og er einn af aðalkostum pess er að mælingin fer fram á mismunandi stigum hönnunarinnar, í stað pess að mat sé eingöngu lagt á lokaafurðina en skoðanir hafa verið uppi um að slíkt kerfi henti vel við íslenskar aðstæður (Óskar Valdimarsson, 2006).

Í rannsókn eftir Roy Giles, sem birt var í blaðinu, Training for Quality, árið 1997, og ber nafnið „ISO 9000 perspective for the construction industry in the UK“", kom fram að leið in að innleiðingu gæðastjórnunar í byggingaiðnaðinum í Bretlandi var allt annað en auðveld. Prátt fyrir að breski byggingaiðnaðurinn hafi lifað með hugmyndinni um gæðastjórnun, gæðatryggingu og vottun í mörg ár segir Gils að breski byggingaiðnaðurinn hafi ekki verið ákafur að prófa pessa nýju hugmyndafræði í stjórnun byggingaframkvæmda. Hann gengur jafnvel svo langt að segja аð раð hafi verið engu líkara en verktakar teldu að ef krafan um innleiðingu ISO 9000 væri hunsuơ nógu lengi pá myndi hún hverfa. Byggingaiðnaðurinn í Bretlandi hefur verið gagnrýndur fyrir slæleg vinnubrögð við að stýra byggingaframkvæmdum Buildings (The Better Public Buildings Group, Lord Falconer, 2000). Pörfin fyrir gæðastjórnun kemur bersýnilega fram í heilbrigðis, og öryggiskröfum í bygginga-reglugerðum, auk pess sem hún birtist í kvörtunum verkkaupa vegna frábrigða og brostinna tíma- og fjárhagsáætlana sem gefa til kynna mistúlkun verktaka á kröfum verkkaupa. Fljótlega eftir gæðavakninguna í byggingaiðnaðinum urðu til gæðakerfi (e. scheme) sem voru búin til á svipaðan hátt og ISO staðlar, p.e. af tilnefndum fulltrúum allra hagsmunaaðila, par sem kröfur ISO 9000 höfðu verið túlkaðar og heimfærðar fyrir byggingaiðnaðinn. Pessi kerfi var svo hægt að fá vottuð hjá ýmsum vottunaraðilum. Ekki var óalgengt að vottunaraðilar byðu upp á nokkrar gerðir af gæðakerfum með mismunandi miklum kröfum (liklega svipað og prepakerfið sem pekkist nú hjá Samtökum iðnaðarins). Gils bendir einnig á að prátt fyrir meiriháttar frampróun í byggingaiðnaði bendir allt til pess að gallatíðni í iðnaðinum sé sú sama og hún var fyrir 20 árum. Petta bendir til pess að allt sem iðnaðurinn hefur reynt á pessu tímabili til að bæta gæði hafi ekki tekist eins og ætlast var til. Ef iðnaðurinn vill raunverulega minnka kostnað og verða samkeppnishæfur á alpjóðarmarkaði er pörf á róttækri skoðun á pví hvernig iðnaðurinn sér, kennir og vinnur með gæði (Giles, 1997).

\footnotetext{
Bandaríkin

Í rannsókn sem Peter Hoonakker rannsóknasérfræðingur vann fyrir Háskólann í Wisconsin-Madison árið 2006 rannsakaði hann hugsanlegan ávinning af pví að innleiða gæðakerfi, ásamt pví að hann grófst fyrir um pær hindranir sem standa í vegi fyrir innleiðingu gæðakerfis hjá byggingafyrirtækjum í Bandaríkjunum. Hann notaðist við bæði megindlegar (spurningalisti) og eigindlegar (viðtöl) rannsóknaraðferðir. Niðurstöður rannsóknarinnar voru meðal annars pær að með innleiðingu gæðastjórnunar í
} 
byggingafyrirtækjum gæti pað leitt til sparnaðar, bætt gæði vöru, aukið ánægju viðskiptavina, ásamt pví að draga úr slysum á starfsmönnum. Einnig tókst Peter að sýna fram á að almennt væru byggingafyrirtæki með góðan skilning á mikilvægi forystuhæfileika, mannauðsstjórnunar og ánægju viðskiptavina en pau vantaði skilning á mikilvægi áætlunargerðar, ferlastjórnunar, greiningar mælinga og viðskiptalegra niðurstaðna. Með áætlunargerð er átt við að sett séu markmið til að auka pjónustu og pá sér í lagi langtímamarkmið sem miða að pví að bæta gæði. Мeð ferlastjórnun og greiningu gagna er átt við að gögnum um gæði vara og pjónustu sé safnað og pau greind. Með viðskiptalegum niðurstöðum er átt við að framleiðni og umbætur í meginpáttum fyrirtækisins séu skoðaðar, p.e. viðskiptavild, markaðshlutdeild, mannauðsstjórnun, frammistaða birgja og samstarfsaðila auk framleiðslugetu. Einnig sýndu niðurstöður fram á að einungis eitt af hverjum tuttugu byggingafyrirtækjum, sem hann tók viðtal við, höfðu tileinkað sér aðferðir gæðastjórnunar. Hin fyrirtækin voru meðvituð um aðferðir gæðastjórnunar en höfou hugsað sér að fylgjast með pví hvernig fyrirtækjunum, sem væru að innleiða kerfið, vegnaði áður en pau sjálf færu út í að taka upp slíkt kerfi. Flestir voru auk pess vantrúaðir á að slíkt kerfi gagnaðist nokkurn tíma byggingaiðnaðinum. Petta er bara eitt dæmi af fjölmörgum sem sýnir fram á viðnám við breytingum í byggingaiðnaðinn. Einnig undirstrikar petta nauðsyn pess að til séu dæmi um bestu frammistöðu fyrirtækja ( $e$. best practice cases). Ef byggingafyrirtæki sjá að ákveðin aðferð virkar eru pau viljugri að tileinka sér aðferðirnar, sérstaklega ef pað leiðir af sér sparnað (Hoonakker, Quality management in construction industry, 2006).

\begin{abstract}
Asía og Ástralía
Í rannsókn, sem Abdullah gerði árið 2006 í Malasíu, og ber heitið Quality management in construction, kemur fram að hluti af helstu vandamálunum við innleiðingu gæðastjórnunar sé m.a skortur á skilningi á ISO 9001 staðlinum, viðnám við breytingum og of hár kostnaður, misskilningur á ISO 9000 gæðakerfi, gæði sett í annað sæti á eftir viðskiptum, ferlar kunni að hafa virst of flóknir, vanpekking á ISO 9000 staðlinum, vinnutap verkamanna við sín hefðbundnu störf á meðan innleiðingarferlið stendur yfir, vöntun á reglugerð sem skyldar verktaka að innleiða gæðakerfi, engin hvatning frá verkkaupum og að lokum erfiðleikar við að heimfæra staðalinn fyrir iðnaðinn (Abdullah, 2006) og síðast en ekki síst eðli mannvirkjagerðar (Bhimaraya A. Metri, 2005).
\end{abstract}

Endurvinna vegna frábrigða getur verið gríðarlega kostnaðarsöm og tímafrek og verður oft til pess að áætlanir riðlast. Samkvæmt rannsókn eftir Xiao H. og Proverbs D. sem var birt í International Journal of Quality \& Reliability Management, koma færri frábrigði upp í framkvæmdum hjá japönskum verktökum heldur en hjá bandarískum eða breskum og telja skýrsluhöfundar að ástæðan felist í dýpri gæðavitund, nánara sambandi verktaka við undirverktaka og próaðra gæðastjórnunarkerfis og gæðaeftirlitsferla meðal japanskra verktaka heldur en meðal bandarískra og breskra (Xiao, Hong, Proverbs, David., 2002). Sýnt hefur verið fram á að fylgni er milli áherslu á gæðastjórnun og kostnaðar sem fer í endurvinnu vegna frábrigða. Í grein, sem var birt í Journal of Performance of Constructed Facilities í desember 2009, komu fram niðurstöður rannsóknar um endurvinnu ${ }^{6}$ (e. Rework) vegna frábrigða á framkvæmdum og áhrif hennar á kostnaðar- og tímaáætlun framkvæmda. Rannsóknin byggist á gögnum um 260 byggingar víðs vegar í Ástralíu og er notuð leiða-greining (e. path analys) til pess að búa til líkan af marktækustu og sterkustu

\footnotetext{
${ }^{6}$ Með endurvinnu er átt við hvers konar vinnu sem hefur purft að framkvæma aftur vegna pess að gæðakröfur stóðust ekki.
} 
fylgnipáttum við endurvinnu vegna frábrigða. Niðurstöður leiddu í ljós að marktæk fylgni er milli minni áherslu á gæðastjórnun og hærri kostnaðar vegna endurvinnu á frábrigðum (Peter E. D. Love, David J. Edwards, Jim Smith \& Derek H. T. Walker, 2009).

\subsubsection{Pekking verktaka á gæðastjórnun}

„Hvarvetna og i öllu er pað nútímans reynsla, að pekkingin er pað, sem sigrinum ræður. मаð er pekkingin og vísindin, sem finna upp vopnin og áhöldin til varnar og sóknar $i$ lífsbaráttunni, baráttunni fram á við og upp á við til meira ljóss, meira frelsis, meira manngildis, sem er tímans krafa." Svo hljóðar brot úr ræðu Hannesar Hafsteins ráðherra sem hann flutti í tilefni af lagningu hornsteins Safnahússins við Hverfisgötu, 23. september 1906 (Menntamálaráðuneytið, 2007). •аð er eins með mannvirkjagerð og allt annað sem maðurinn tekur sér fyrir hendur að pekking er lykillinn að framförum.

Í bók Crosbys sem ber nafnið Quality is free. the art of making quality certain, segir að vandamálið við gæðastjórnun felist í pví hvað fólk telur sig vita um gæðastjórnun fremur en hvað pað raunverulega veit (Crosby P. , 1979). Margar rannsóknir hafa sýnt fram á að pekking á gæðastjórnun meðal verktaka er ekki nægjanlega góð. Í rannsókninni Total quality management in the construction industry: A preliminary analysis, sem var gerठ af Boaden, Ruth, Dale og Barrie á meðal breskra verktaka, kom til að mynda fram að pekking breskra verktaka á gæðastjórnun væri ekki nægjanlega góð og verktakar hafi oft ruglað saman hugtökum eins og gæðastjórnun og gæðatrygging (Boaden, 1992).

Í rannsókn Guðjónu Bjarkar Sigurðardóttur, sem ber nafnið „Gœðastjórnun verktaka $i$ mannvirkjagerð á Íslandi“, sýndu niðurstöður fram á pað að gæðastjórnun hefur ekki náð að festa rætur á meðal verktaka á Íslandi vegna pess að pekking peirra á henni er ekki nægjanleg ásamt pví að skortur er á skuldbindingu stjórnenda. Vanpekkingar gætir meðal annars á hugtökum gæðastjórnunar en hennar gætir einnig meðal verkkaupa og eftirlitsmanna (Guðjóna Björk Sigurðardóttir, 2008).

Sú pekking, sem parf til að ná fram viðeigandi gæðum í mannvirkjagerð, er vissulega til staðar, en spurning er hvort réttir aðilar búi yfir henni. Roy Giles, páverandi forstjóri Aspect International Management Limited, segir í grein sinni ISO 9000 perspective for the construction industry in the UK sem birtist í tölublaðinu Training for Quality árið 1997, að öll sú pekking og reynsla, sem parf til að ná fram viðeigandi gæðum sé nú pegar til staðar í iðnaðinum (Giles, 1997). Rannsóknir hafa sýnt fram á að eitt af helstu vandamálunum við innleiðingu gæðastjórnunar er m.a skortur á skilningi á ISO 9001 staðlinum innan mannvirkjagerðar (Abdullah, 2006), pekkingu á gæðastjórnun (Young, 2007) og sér í lagi hugtökum gæðastjórnunar (Hansson, 2003). 


\subsection{R2- Munur á verklagi verktaka}

Eins og staðan er nú á Íslandi geta verktakar í raun sagt að peir starfi eftir gæðastjórnunarkerfi sem sé ekki vottað án pess að hafa nokkra hugmynd um hvað gæðastjórnunarkerfi er.

\subsubsection{Verklag byggingaverktaka}

\section{Áætlunargerð og verkdagbók}

Samkvæmt Oakland er algengt að tvö af hverjum premur verkefnum í mannvirkjagerð séu kláruo á réttum tíma (John Oakland \& Marton Marosszek, 2006, bls. 3). Líklega má rekja ástæðuna að einhverju leyti til viðhorfs verktaka til áætlunargerða en tíma- og kostnaðaráætlanir hafa lengi verið umdeildar innan mannvirkjagerðar. Verktakar hafa jafnvel verið sakaðir um marklausar áætlanir sem standist sjaldan. Ástæðurnar eru margar en stór páttur er að markmið verkkaupans er að lágmarka kostnað og ljúka par með verkinu á sem skemmstum tíma (Guðjóna Björk Sigurðardóttir, 2008). Einnig hefur helsta gagnrýni innan mannvirkjagerðar á ISO 9000 gæðastjórnunarkerfi oftar en ekki snúist um aukið skrifræði (Giles, 1997).

Í rannsókn Peters Hoonakkers, sem minnst var á í kafla 3.1.2 á bls. 28, sýna niðurstöður m.a. fram á að almennt vanti byggingafyrirtæki skilning á mikilvægi áætlunargerðar sem snúi að pví að sett séu markmið til að auka pjónustu og pá sér í lagi langtíma markmið sem miða að pví að bæta gæði (Hoonakker, Quality management in construction industry, 2006).

Ferdinand Hansen, verkefnastjóri gæðastjórnunar hjá Samtökum iðnaðarins, hefur skrifað fjöldann allan af greinum tengdum gæðastjórnun og gæðastjórnun í mannvirkjagerð. Í bókinni Hvernig gera má betur - kennslubók SI, sem Ferdinand hafơi umsjón með, er bent á að verktaki ætti alltaf að leggja fram tímasetta verkáætlun par sem hann sýndi fram á að hann réði yfir tækjum, hráefni og mannafla við hæfi fyrir hvern verkpátt. Góðri áætlunargerð fylgir að verk eru greind niður í helstu verkpætti sem er nauðsynlegt til að hægt sé að gera sér grein fyrir pví hvenær hefja skuli hvern verkpátt og hvenær honum parf að vera lokið til að verkið standist tímaáætlun (Hvernig gera má betur - kennslubók SI, 2007).

Segja má að áætlanir, sem tengjast tíma og kostnaði, séu prenns konar í mannvirkjagerð. Í fyrsta lagi er pað framkvæmdaáætlun eða verkáætlun, í öðru lagi kostnaðaráætlun og í priðja lagi tímaáætlun. Verkáætlunin snýst fyrst og fremst um að greina pá verkpætti sem eru í verkefninu og er tímaáætlunin unnin út frá henni. Verk í mannvirkjagerð eru oft bundin af afhendingardegi og pví getur orðið pörf á að pjappa verkefni saman (e. crashing the project) (Jack R. Meredith \& Samuel J. Mantel,Jr, 2009) en kostnaður af slíku getur verið verulegur (S. Keoki Sears, 2008). Kostnaðaráætlanir eiga sér stað á skipulagsstigi bæði fyrir hönnuði og verktaka. Raunin er oft sú að verktaka er gefinn takmarkaður tími til að gera pessa áætlun en pau mistök, sem gerð eru af peim sökum koma oft ekki í ljós fyrr en í lok verks (Garðar Örn Porvarðarson, 2010).

Til pess að auðvelda rekjanleika við byggingaframkvæmdir er mikilvægt að verktaki haldi verkdagbók. Samkvæmt grein 13.2.3 í ÍST 30 segir að verktaki skuli halda dagbók yfir verkið og skrá í hana verkefni hvers dags, mannafla skv. starfsgreinum, tæki, veðurfar og 
annað sem pýðingu hefur fyrir framgang verksins (ÍST 30:2003, Almennir útboðs- og samningsskilmálar um verkframkvæmdir, 2003).

\section{Samningar}

Áætla má að vönduð tilboðsgerð með ítarlegri sundurliðun dragi úr líkum á ágreiningi milli verkkaupa og verktaka og sé pví mikilvægur páttur í ánægju verkkaupa. Samkvæmt bókinni Hvernig gera má betur - kennslubók SI, kemur fram að öll samskipti milli verkkaupa og verktaka eiga að byggjast á staðlinum ÍST-30 og að við samningagerð sé nauðsynlegt að verktaki kynni verkkaupa hvernig hann hyggist standa að verki varðandi aukaverk, breytingar, frábrigði, dagbókarskýrslur o.fl. sem tilheyrir öruggri daglegri stjórnun (Hvernig gera má betur - kennslubók SI, 2007).

\section{Öryggismál}

Eftir lestur fræðigreina um byggingaframkvæmdir virðast fræðimenn yfirleitt vera peirrar skoðunar að slys í tengslum við byggingaframkvæmdir séu óparflega algeng og mörg peirra má vafalaust rekja til skipulagsleysis á byggingavinnustað.

Öryggismál eru mikilvægur hluti af gæðastjórnun og ættu pau ávallt að vera hluti af gæðastjórnunarkerfum verktaka. Samkvæmt Oakland eru byggingaframkvæmdir með hættulegri iðnaði sem menn fást við. Slysatíðni er talin vera priðjungi hærri en við námugröft og skógrækt (John Oakland \& Marton Marosszek, 2006, bls. 3).

Á grafinu hér að neðan má sjá fjölda slysa við byggingaframkvæmdir og tilkynnt voru til Vinnueftirlitsins á árunum 1998-2010. Ef myndin er borin saman við mynd á bls. 12 sem sýnir hlutfall heildarveltu í byggingastarfsemi og mannvirkjagerð á sama tímabili miðað við heildarveltu af annarri starfsemi pjóðarinnar, sést greinilega að fylgni er par á milli. Fjöldi slysa náđi hámarki í uppsveiflunni enda byggingahraðinn mikill á peim tíma.

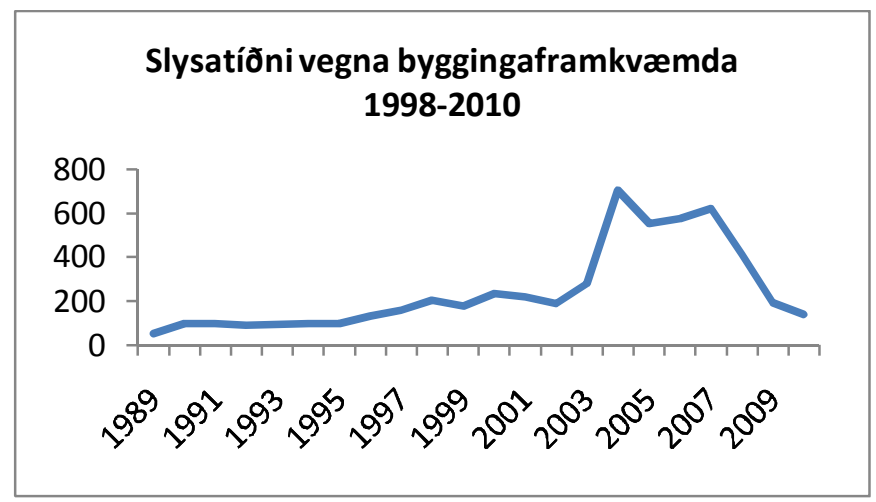

Mynd 3 Slysatiðni við byggingaframkvoemdir, mynd gerð eftir upplýsingum frá Vinnueftirlitinu (Vinnueftirlitið, 2005-2011).

Eins og kunnugt er eru byggingaframkvæmdir afar mismunandi að umfangi og pað sama getur gilt fyrir öryggis- og heilbrigðisáætlanir, en engu að síður ætti ávallt að ræða öryggismál áður en framkvæmdir hefjast. Ábyrgð verkkaupa samkvæmt lögum er talsverð pegar kemur að byggingaframkvæmdum en ekki virðist sú ábyrgð vera öllum verkkaupum kunnug, sérstaklega er pá átt við smærri verkkaupa. Árið 1997 tóku gildi hér á landi reglur um aðbúnað, hollustuhætti og öryggisráðstafanir á byggingavinnustöðum. Par er sérstaklega er fjallað um ábyrgð og skyldur par sem fleiri en einn verktaki eru að störfum 
(Vinnueftirlitið, Sigfús Sigurðsson, 2002). Samkvæmt fræðslu- og leiðbeiningarriti um öryggis- og heilbrigðisáætlun fyrir byggingavinnustaði skal gera öryggis- og heilbrigðisáætlun ef tveir eða fleiri atvinnurekendur eða verktakar eru samtals með fleiri en 10 manns í vinnu á byggingavinnusvæðinu. Einnig kemur bar fram að verkkaupa ber að sjá um að gerð sé öryggis- og heilbrigðisáætlun fyrir byggingarsvæðið (Sigfús Sigurðsson, Hörður Bergmann, Ása Guðbjörg Ásgeirsdóttir, 2002).

Í rannsókn eftir Ricardo R. Ramı, Luis Fernando C. Alarcón, Peter Knights, sem birtist í tímaritinu Journal of management in engineering í júlí 2004 undir titlinum, Benchmarking System for Evaluating Management Practices, sýna niðurstöður m.a. fram á pað að mikil fylgni var milli velgengni í öryggismálum og peirra fyrirtækja sem störfuðu með gæðastjórnunarkerfi (Ricardo R. Ramı, Luis Fernando C. Alarcón, Peter Knights, 2004)

\section{Gæðaeftirlit}

Síauknar kröfur undanfarin ár um innra eftirlit, vöktun og gæðaeftirlit verktaka með eigin verkpáttum hafa verið gerðar en gæðaeftirlit er mikilvægur hluti af gæðastjórnun fyrirtækja. Innra eftirlit getur falist í pví að halda dagbók, vakta verkáætlanir og skrá ýmsar tæknilegar staðreyndir. Innra eftirlit er líka til að staðfesta eftirfylgni með pví að fara yfir gátlista frá hönnunar- og verkpáttarýnisfundum (Ferdinand Hansen, Samtök iðnaðarins, 2007). Byggingarstjóri mannvirkis á að framkvæma innra eftirlit eiganda frá pví að byggingarleyfi er gefið út og par til lokaúttekt hefur farið fram (Alpingi, 2010).

Í grein eftir Óskar Valdimarsson, sem birtist í tímaritinu Verktækni árið 2006 og ber heitið Gceðastjórnun við mannvirkjagerð, er fjallað um nauðsyn pess að viðhafa gæðastjórnun við undirbúning, hönnun og byggingu mannvirkja á Íslandi. Par kemur fram að með upptöku gæðastjórnunar í íslenskum byggingaiðnaði mun aðferðafræðin færast yfir á pað form að vöktun verði á vinnuferlum hönnuða og verktaka frekar en með peim hætti sem viðgengist hefur í áratugi í mannvirkjagerð á Íslandi, p.e. að verkkaupar, eða fulltrúar peirra, rýna teikningar að hönnun lokinni til að sannfæra sig um ágæti hönnunarinnar, og á sama hátt eru verkkaupar með eftirlitsmenn á sínum vegum við verkframkvæmdir til að sannreyna að efnisleg gæði séu í samræmi við teikningar og verklýsingar. Myndin hér að neðan sýnir muninn á pessu greinilega. Fyrri ferillinn lýsir peirri aðferðafræði sem hefur verið viðhöfó í byggingaiðnaði á Íslandi um áratuga skeið, bæði hvað varðar hönnunarpáttinn og verkframkvæmdir en seinni ferillinn lýsir peirri aðferðafræði sem fæst með innleiðingu gæðastjórnunar í mannvirkjagerð, p.e. vöktun á vinnuferlum hönnuða og verktaka par sem verkkaupinn fer yfir í upphafi nokkuð nákvæmlega pá vinnuferla sem hönnuður eða verktakar hyggjast nota við verkefnið, en eftir pað eru vinnuferlarnir vaktaðir. Stöðug vöktun og endurskoðun fyrirtækja á vinnuferlum sínum er einmitt eitt af grundvallaratriðum í hugmyndafræði gæðastjórnunar. Samhliða pví sem gæðastjórnunarkerfi fyrirtækja styrkist minnkar pörfin fyrir hið hefðbundna gæðaeftirlit (Óskar Valdimarsson, 2006). 


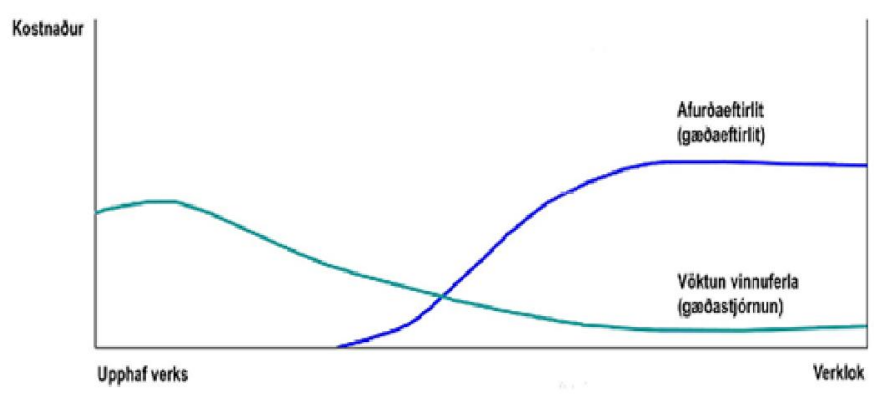

Mynd 4 Mismunur á afburðaeftirliti og úttekt á afurð í verklok (e. product checking) og vöktun vinnuferla (e. process checking) ${ }^{7}$

Раð virðist rökrétt að með vöktun vinnuferla fækki frábrigðum á framkvæmdum en endurvinna vegna frábrigða getur verið gríðarlega kostnaðarsöm og tímafrek eins og fyrr segir og verður oft til pess að áætlanir riðlast. Eins og fram hefur komið pá sýndu niðurstöður rannsóknar eftir Peter Love, David Edwards, Jim Smith og Derek Walker, sem birt var í Journal of Performance of Constructed Facilities í desember 2009, fram á að marktæk fylgni er milli minni áherslu á gæðastjórnun og hærri kostnaðar vegna endurvinnu á frábrigðum (Peter E. D. Love, David J. Edwards, Jim Smith \& Derek H. T. Walker, 2009).

\section{Innra verklag}

Flestir stjórnendur í mannvirkjagerð eru iðnlærðir og svo virðist sem að peir eigi oft erfitt með að átta sig á að pað sem er huglægt parf líka að skilgreina og skrá í verklýsingar (SI Fréttir og greinar - Handverk og stjórnun, 2007). Umhverfi skjölunar í byggingaiðnaðinum hefur frekar verið að verja galla en að eltast við gæði. Takmörkun upplýsinga í skjölun getur aftur á móti leitt af sér ósamræmi í nálgun á gæðum og felst lykilvirkni gæðastefnu í átt að framförum í skilvirkri gæðaskjölun (Giles, 1997). Samkvæmt viðmælanda skýrsluhöfundar, sem hefur mikla reynslu af byggingaiðnaðinum vantar mikið upp á skráningu hjá verktökum á Íslandi og pá sérstaklega hjá smáum verktaka fyrirtækjum (Jónas Brjánsson, 2010). Ein af grundvallaraðferðum gæðastjórnunar er einmitt að gera verkferla og stjórnun sýnileg og gera pannig starfsmönnum, sem vinna við stjórnun og rekstur, kleift að skila jafngóðu verki í samræmi við pað sem ákveðið hefur verið og krafist er (SI - Fréttir og greinar - Handverk og stjórnun, 2007).

Gagnrýni í tengslum við beitingu á ISO 9000 stöðlum hefur tilhneigingu til að beinast helst að aukinni skriffinnsku og stjórnsýslukostnaði (einkum fyrir lítil fyrirtæki) (Giles, 1997). Talsverðar kröfur eru gerðar um skjalfestingu í ISO 9001:2008. Í grein 4.2.1 kemur fram að gerðar séu kröfur um skjalfestar yfirlýsingar um gæðastefnu, gæðamarkmið, gæðahandbók, verklagsreglur auk skrár sem ákvarðar pætti sem eru nauðsynlegir til að tryggja árangursríka skipulagningu, starfrækslu og stýringu á ferlum. Krafan um gæðahandbók felur í sér að hún innihaldi umfang kerfisins, skjalfestar verklagsreglur og lýsingu á samverkan ferlanna innan gæðastjórnunarkerfisins (ÍST EN ISO 9001:2008, Gæðastjórnunarkerfi - kröfur, 2008). Pví má segja að gæðahandbók sé samansafn

\footnotetext{
${ }^{7}$ Mynd tekin úr grein eftir Óskar Valdimarsson, Gaðastjórnun við mannvirkjagerð, sem birtist í tölublaðinu Verktækni árið 2006
} 
ákvarðana sem eigendur og stjórnendur fyrirtækis hafa gert aðgengilegar fyrir starfsmenn til að fara eftir (SI - Fréttir og greinar - Handverk og stjórnun, 2007).

\subsubsection{Samskipti verktaka og verkkaupa}

Gott upplýsingaflæði og ábyrg samvinna á milli viðskiptavinar og verktaka er leið til að tryggja að kröfum viðskiptavinar sé fullnægt við verklegar framkvæmdir. Góð samskipti milli viðskiptavinar og fyrirtækis sem framleiðir vöru eru líklega hvergi mikilvægari en hjá verkkaupa og verktaka. Eins og Thomas J. "Tom" Peters, rithöfundur, fyrirlesari og stjórnunarfræðingur lét hafa eftir sér, „Samskipti eru töfralyf alls við öllu“ (e. Communication is everyone's panacea for everything) og á pað sannarlega við um byggingaiðnaðinn.

Oakland og Marton segja að góð samskipti milli verkkaupa og verktaka séu lykillinn að farsælum framkvæmdum en víða sé pottur brotinn í samskiptum innan mannvirkjagerðar. Sérstaklega tala peir um að samskipti milli fyrirtækja í aðfangakeðjunni ${ }^{8}$ séu oft og tíðum slök en til að ná fram gæðum er grundvallaratriði að allir aðilar hafi góð samskipti sín á milli (John Oakland \& Marton Marosszek, 2006).

Sigríður Sigurðardóttir, arkitekt og markaðsstjóri hjá verkfræðistofunni Eflu pekkir samskipti milli verkkaupa og verktaka vel. Spurð um hvernig henni pætti samskiptum verktaka og verkkaupa vera háttað á Íslandi um pessar mundir sagði hún pau vera misjöfn en almennt góð (Sigríður Sigurðardóttir, 2010). Annar viðmælandi skýrsluhöfundar, Jónas Brjánsson, starfsmaður Eflu í eftirliti, framkvæmda- og verkefnastjórnun, var sammála Sigríði að almennt væru samskiptin góð og menn skynjuðu að allir væru að vinna vinnuna sína. Hann hafði við petta að bæta að samskipti undirverktaka og verktaka væru aftur á móti oft ekki nógu skilvirk (Jónas Brjánsson, 2010). Rannsóknir hafa gefið til kynna að partur af helstu vandamálunum við innleiðingu gæðastjórnunar í byggingaiðnaði séu m.a skortur á samskiptum (Young, 2007).

Kröfur um góð samskipti eru mikið grundvallaratriði í gæðastjórnunarstöðlum. Í samskiptastaðlinum ÍST-30:2003, Almennir útboðs- og samningsskilmálar um verkframkvæmdir, er vel farið yfir hvernig samskiptum verkkaupa og verktaka ætti helst аð vera háttað. Margir eru peirrar skoðunar að öll samskipti milli verkkaupa og verktaka ættu að byggjast á staðlinum (Hvernig gera má betur - kennslubók SI, 2007) og tekur skýrsluhöfundur undir pá afstöðu. ISO 9001:2008 gerir einnig kröfur um góð samskipti við viðskiptavini og segir í grein 7.2.3 að fyrirtæki skuli ákvarða og innleiða virkar aðferðir til að eiga samskipti við viðskiptavini varðandi upplýsingar um vöru, fyrirspurnir, samninga, meðferð pantana/breytinga og endurgjöf frá viðskiptavinum (par á meðal kvartanir) (Staðlaráð Íslands, 2008).

Verkfundir eru miðpunktur samskipta við verklegar framkvæmdir og ætti verkkaupi ávallt að eiga kost á pví að mæta á vel skipulagða verkfundi með verktaka en áætla má að markvissir og vandaðir verkfundir séu mikilvægur páttur í ánægju viðskiptavina og farsælum framkvæmdum. Einnig er lykilatriði að rituð sé fundargerð á verkfundum en

\footnotetext{
${ }^{8}$ Sjá nánar um aðfangakeðjuna kafla 2.2.1 á bls. 62
} 
raunveruleg krafa á verktaka að halda fundargerð á verkfundum er ekki til staðar nema um alútboð sé að ræða. Í raun er pað hlutverk verkkaupa að sjá um slíkt, en í grein 17.10 í ÍST30 kemur fram að rita eigi fundargerð á verkfundum, en einnig að fulltrúi verkkaupa eigi að sjá um pað nema um alútboð sé að ræða pá á verktaki að sjá um slíkt (ÍST 30:2003, Almennir útboðs- og samningsskilmálar um verkframkvæmdir, 2003).

\subsubsection{Viðhorf verktaka til gæðastjórnunar}

Algengt viðhorf meðal byggingafyrirtækja er að pað sé óparfi að taka upp sérstakt gæðastjórnunarkerfi. Einnig er algengt að byggingafyrirtæki sitji álengdar og fylgist fremur með hvernig öðrum sambærilegum fyrirtækjum tekst að innleiða gæðastjórnunarkerfi og hugsi sér frekar að láta reyna á innleiðingu ef vel tekst til hjá fyrirtækinu sem fylgst var með. Pannig reyna flest fyrirtæki að lágmarka áhættu og hámarka hagnað (S.L.Tang, 2005) (John Oakland \& Marton Marosszek, 2006). Einn viðmælandi skýrsluhöfundar, Sigríður Sigurðardóttir, telur að viðhorfið í byggingaiðnaðinum á Íslandi sé með peim hætti að bæði verkkaupar og verktakar reyni eftir fremsta megni að gæta að sínum hagsmunum sem leiðir gjarnan til ósætta milli verktaka og verkkaupa um vafaatriði (Sigríður Sigurðardóttir, 2010).

Í rannsókn Peters Hoonakkers, sem minnst var á í kafla 3.1.2 á bls. 28, sýna niðurstöður m.a. fram á að flestir verktakar, sem tóku pátt í rannsókninni, voru vantrúaðir á að slíkt kerfi gagnaðist nokkurn tíma í byggingaiðnaðinum (Hoonakker, Quality management in construction industry, 2006).

Crosby sagði að viðhorf til gæða skiptist í fjóra flokka, frá sjónarhorni stjórnenda, frá sérfræðingum í gæðastjórnun, frá almennum starfsmönnum og frá viðskiptavinum. Hann taldi að almennt væri gjá milli skilnings stjórnenda á stöðu gæðastjórnunar og raunverulegrar pekkingar starfsmanna sem væri nauðsynlegt að brúa ( Philip B. Crosby Philip Crosby Associates III, Inc., 2000).

\subsubsection{Kröfur til verktaka um skipulag og markvissa stjórnun}

Раð er grundvallaratriði í öllum viðskiptum að kröfur og væntingar viðskiptavina séu uppfylltar til pess að fyrirtæki haldi velli. Í nútíma samfélagi eru kröfurnar sífellt að breytast og aukast svo stöðugar umbætur verða að eiga sér stað til að viðhalda gæðum vöru. Að pessu parf að huga við gerð mannvirkja par sem í flestum tilfellum er gerð sú krafa að mannvirkið standist tímans tönn. Brot úr bréfi Hallgríms Melsted, landsbókavarðar til Johannesar Magdahls Nielsens arkitekts um Safnahúsið við Hverfisgötu, dagsettu 15. nóvember 1905, lýsir pessu ágætlega en par segir; „Fyrir pví pykir mér rétt, að vér kostum hlutfallslega bó nokkru til að koma upp byggingu, er svari kröfum tímans, en eigi jafnframt alllanga framtið fyrir sér" (Menntamálaráðuneytið, 2007). Gæði eru stefnumarkandi og próunin eltir kröfurnar sem aukast sífellt. Viðskiptavinir krefjast nú meiri pjónustu, meiri gæða og tækninýjunga á styttri tíma en nokkru sinni áður. Ekki er að undra að byggingaiðnaðurinn hafi að pessu gefnu leitað lausna hjá framleiðsluiðnaðinum og heimfært og tileinkað sér aðferðir paðan eins og gæðastjórnun. Eins og fram hefur komið pá hefur innleiðing gæðastjórnunar aukist til 
muna í byggingafyrirtækjum víðs vegar um heim til að mæta betur kröfum viðskiptavina enda til mikils að vinna ef innleiðing heppnast vel (Hoonakker, Quality management in construction industry, 2006). Раð er í raun erfitt að sjá hvernig fyrirtæki geta yfir höfuð sniðgengið gæðastjórnun í pví umhverfi sem við lifum í með síauknum kröfum samtímans.

Gæðamál snúast um mannlega upplifun og samskipti og kröfur manna misjafnar. Verkkaupar líkt og verktakar eru af öllum stærðum og gerðum og er pað pekkt staðreynd að einstaklingsverkkaupar gera sjaldan ef nokkurn tíma jafnmiklar kröfur til verktaka um skipulag og markvissa stjórnun, og opinberir verkkaupar. Til að kóróna petta pá eru kröfur opinberra verktaka líka mismunandi, en Framkvæmdasýsla ríkisins leitast nú við að stuðla að gæðastjórnun við opinberar framkvæmdir með pví að samræma pær kröfur sem gerðar eru til ráðgjafa og verktaka af opinberum verkkaupum. Sjálf Framkvæmdasýsla ríkisins hefur frá árinu 2003 unnið eftir gæðastjórnunarkerfi ISO 9001 og unnið hefur verið að vottun kerfisins undanfarin ár (Framkvæmdasýsla ríkisins).

Að mati eins viðmælanda sem starfar í eftirliti, framkvæmda- og verkefnastjórnun eru oft gerðar óraunhæfar kröfur til verktaka varðandi frágang bygginga. Hann telur að stilla verði kröfum í hóf en á sama tíma sækjast eftir eðlilegri fagmennsku og frágangi (Jónas Brjánsson, 2010). Annar viðmælandi skýrsluhöfundar taldi að verkkaupar væru ekki nægjanlega kröfuharðir á að verktakar störfuðu eftir gæðakerfi (Sigríður Sigurðardóttir, 2010). Hugsanlega er hluti af ástæðunni að sumir verktakar mættu sinna pví betur að starfa eftir gæðakerfum sem peir segjast vera að vinna eftir.

Að mörgu parf að huga sem viðkemur einni byggingu. Mikilvægt er að fyrirtæki ákvarði pær kröfur sem viðskiptavinur tilgreinir en ekki er síður mikilvægt að fyrirtæki ákvarði pær kröfur sem viðskiptavinur tilgreinir ekki en eru nauðsynlegar vegna tilgreindrar eða áætlaðrar notkunar (John Oakland \& Marton Marosszek, 2006). Auk pess sem ákvarða verður kröfur til vörunnar sem leiða af lögum eða reglugerðum (Staðlaráð Íslands, 2003, bls. 87). Pegar öllu er á botninn hvolft er markmiðið alltaf að skilja og mæta kröfum viðskiptavinarins og eiga gott samstarf við hann (Giles, 1997).

Hugsanlega koma kröfur viðskiptavina hvergi betur fram en í kvörtunum. Fyrirtæki ættu pví ávallt að líta á kvartanir sem uppsprettu framfara frekar en vandamál. Vandamálin felast frekar í peim sem eru óánægðir og kvarta ekki. Í gæðastjórnun er lögð mikil áhersla á að finna væntingar viðskiptavina og mæta peim. Pau fyrirtæki sem setja upp formlegt gæðakerfi verða að hafa skilvirkt kerfi par sem kvartanir og úrvinnsla peirra er skráð (Jón Freyr Jóhannsson, 1996). Í ISO 9000 staðlaröðinni er gerður greinarmunur á kröfum til gæðastjórnunarkerfa og kröfum til vöru. Kröfur, sem gerðar eru til vöru, geta svo ýmist verið tilgreindar af viðskiptavinum eða af fyrirtækinu með hliðsjón af væntanlegum kröfum viðskiptavina eða af reglugerðum. Í grein 7.2.1 í ISO 9001:2008 kemur fram að gæðastjórnunarkerfi sé hvati fyrir fyrirtæki til pess að greina kröfur viðskiptavina og skilgreina pau ferli sem stuðla að pví að pað takist að vinna vöru sem viðskiptavinurinn telur viðunandi. Í grein 8.2.1 kemur svo fram að fyrirtækið eigi að vakta upplýsingar sem tengjast pví hvort viðhorf viðskiptavina sé að fyrirtækið hafi uppfyllt kröfur peirra (ÍST EN ISO 9001:2008, Gæðastjórnunarkerfi - kröfur, 2008). 


\subsubsection{Staða gæðatryggingar í mannvirkjagerð}

Gæðatrygging er skjal sem á að veita viðskiptavini raunverulegar upplýsingar um hve vel fyrirtækið er í stakk búið til að uppfylla kröfur um pöntun eða samning og styrkja pannig tiltrú viðskiptavinarins. Í samhengi við byggingaiðnaðinn er tilgangurinn pví fyrst og fremst fólginn í pví að verktakar sýni verkkaupa fram á að peir valdi verkefninu áður en gengið er til samninga. Einn stærsti vandinn við pað að fjárfesta í byggingu sem á eftir að byggja felst fyrst og fremst í pví að hvorki er hægt að skoða né meta hönnun og framleiðslu að fullu fyrr en að verki loknu og að óbreyttu er lítil trygging fyrir pví að hlutirnir verði eða gangi eftir í samræmi við væntingar verkkaupa. Pví er hlutverk gæðatryggingar mjög mikilvægt í byggingaiðnaðinum (Ferdinand Hansen, 2007).

Í grein 3.2.11 í ISO 9000:2000 er gæðatrygging skilgreind á eftirfarandi hátt; ,sá hluti af gœðastjórnun sem beinist að pví að veita tiltrú á að gœðakröfur muni uppfylltar" (Staðlaráð Íslands, 2000). Í raun má segja að gæðatrygging séu allar pær vinnureglur sem verktakinn ætlar að vinna eftir í verkinu til að tryggja ákveðin gæði. Verkkaupar á Íslandi eru í auknum mæli farnir að fara fram á gæðatryggingu, sérstaklega við útboð par sem opinberir verkkaupar eða fyrirtæki koma að. Eftir að gengið hefur verið frá samningum pá breytist gæðatryggingin í gæðaverkmöppu sem verktakinn vinnur eftir á verkstað og afhendir verkkaupa svo í lok verks.

Núna eru fá verktakafyrirtæki með vottað gæðakerfi eins og fram hefur komið. Pegar fyrirtæki, sem er ekki vottað, leggur fram gæðatryggingu pyrfti verkkaupinn ávallt að rýna gögnin til pess að meta hvort pau fullnægja kröfum. Í greininni „Gceðastjórnun og ÍST 30“ eftir Ferdinand Hansen segir að hann geti nánast fullyrt að verkkaupar rýna almennt ekki gæðatryggingar verktaka í útboðum en pað er bæði tímafrekt og flókið. •ar með nær gæðatrygging ekki tilgangi sínum.

Eins og áður hefur verið komið inn á pá eru margir aðilar sem koma að hverri framkvæmd. Til pess að endanlegur viðskiptavinur fái kröfur sínar uppfylltar parf sérhver aðili í ferlinu að standa sig. Pví ætti pað ekki að vera nóg að aðalverktaki sýni fram á gæðatryggingu heldur ættu allir aðilar í keðjunni að gera pað. Pegar verkkaupi ræður annan aðila til að vinna hluta af verkinu er hann sjálfur kominn í hlutverk verkkaupa og verður par af leiðandi að tryggja að sá hinn sami viðhafi ásættanleg vinnubrögð. Verktakar sem eru með undirverktaka í vinnu ættu pví ávallt að fara fram á gæðatryggingu frá undirverktaka og bera hana saman við sína eigin gæðatryggingu sem verkkaupinn var búinn að sampykkja. Hafa ber pó í huga að undirverktakar eru oft mjög lítil fyrirtæki og einyrkjar sem eru ekki mjög sterkir fjárhagslega og ekki með neina ferla eða stefnur né heldur tryggingu fyrir gæðum. Í slíkum tilfellum ætti undirverktakinn að kynna sér vandlega innihald gæðatryggingar aðalverktaka svo öllum sé ljóst hverju var búið að lofa verkkaupa auk pess sem aðalverktaki parf að gæta að eftirliti með undirverktaka (SI - Fréttir og greinar. Hver er gæðatryggingin pín, 2007). 


\subsection{R3 - Áhrifapættir á ánægju verkkaupa}

Áhersla á ánægju verkkaupa hefur aukist samhliða aukinni samkeppni á markaðinum meðal byggingafyrirtækja (Sami Kärnä , 2009). Рað er nokkuð óhætt að staðhæfa að í nánast öllum iðnaði sé ánægja viðskiptavina mikilvæg breyta og er byggingaiðnaðurinn sannarlega ekki utanskilinn í pví samhengi. Mikilvægi pess að frammistöðumat fyrirtækja sé ekki einvörðungu byggt á fjárhagslegri velgengni hefur verið kunnugt mönnum um árabil (Eccles, 1991).

Eins og fram hefur komið pá er mannvirkjagerð frábrugðin öðrum atvinnugreinum, m.a. að pví leyti að mikið af verkum koma í gegnum útboð. Рað er pví mögulegt að verktakar gefi ánægju verkkaupa ekki eins mikinn gaum og vera mætti. Aftur á móti hafa rannsóknir sýnt fram á að stór hluti viðskiptavina verktaka koma frá núverandi viðskiptavinum peirra eða verkkaupum sem hafa heyrt gott orðspor af honum. Talað er um að 80 prósent af nýrri vinnu hjá verktökum komi frá núverandi viðskiptavinum eða frá viðskiptavinum sem heyrt hafa mælt með viðkomandi verktaka (Giles, 1997). Undirstrikar ofangreind staðhæfing mikilvægi pess að halda viðskiptavinum ánægðum en skýr skilningur á væntingum viðskiptavinar um gæði er forsenda pess að vera fær um að fullnægja kröfum hans (Giles, 1997).

Í rannsókn Peters Hoonakkers, sem minnst var á í kafla 3.1.2 á bls. 28, sýna niðurstöður m.a. fram á að almennt séu byggingafyrirtæki með góðan skilning á mikilvægi ánægju viðskiptavina (Hoonakker, Quality management in construction industry, 2006). Pví ber saman við niðurstöðu rannsóknar Guðjónu, sem fyrst var fjallað um í kafla 1.1 á bls. 2, og sýnir að ríkjandi viðhorf verktaka á Íslandi sé að gera vel við verkkaupa. Niðurstöður gáfu einnig til kynna að eitthvað bæri á pví meðal verktaka að peir reyndu að klekkja á verkkaupum í útboðum par sem lægstbjóðandi fær verkið. Einnig virtist sem stærri fyrirtæki legðu mun meiri vinnu í að koma til móts við viðskiptavininn en pau minni (Guðjóna Björk Sigurðardóttir, 2008).

Stóra spurningin er hvaða páttur vegur pyngst í ánægju verkkaupa. Óánægja meðal verkkaupa hefur oftar en ekki beinst að pví að framkvæmdir hafa farið fram úr tímaog/eða kostnaðaráætlun og gæðin hafa ekki verið eins og vænst var (The Construction Task Force, 1998). Rannsóknir hafa einnig gefið til kynna að aðrir pættir hafi áhrif á heildaránægju verkkaupa með framkvæmd verka. Torbica og Stroh gerðu rannsókn sem birtist í tímaritinu Journal of Construction Engineering and Management árið 2001, par sem að peir mæla frammistöðu verktaka út frá ánægju verkkaupa. Samkvæmt Torbica og Stroh getur fyrirtæki ekki haldið velli til langs tíma nema að viðskiptavinir séu ánægðir. Rannsóknin byggði á 16 verktökum í Flórida og tæplega 300 viðskiptavinum peirra og út frá svörum verkkaupanna gerðu peir margvítt aðhvarfsgreiningarlíkan fyrir heildaránægju verkkaupa með framkvæmd verksins. Líkanið samanstóð af 3 víddum sem hver innihélt margar spurningar. Víddirnar voru pjónusta, hönnun og gæði byggingar. Allir pættir reynast marktækir, en merkilegt er að pjónustupátturinn var mikilvægastur en pað er líka sá páttur sem verkkaupar voru óánægðastir með (Zeljko M. Torbica og Robert C. Stroh, 2001). Rannsókn, sem Tony Auchterlounie \& Dr. John Hinks gerðu, og heitir The measurement of customer satisfacation in the private house building sector og fjallar um mælingar á ánægju verkkaupa, styðja niðurstöðu Tobrica og Stroh. Niðurstöður rannsóknarinnar sem byggðust á svörum 113 einstaklingsverkkaupa í norður hluta Manchester, sýndu fram á að ánægja verkkaupa með pætti tengda pjónustu verktaka höfou 
meiri áhrif á heildaránægju verkkaupa með framkvæmd verksins en ánægja verkkaupa með gæði byggingainnar (Tony Auchterlounie \& Dr. John Hinks, 2001).

Margar rannsóknir hafa sýnt fram á pað að gæðastjórnun gerir verktökum kleift að leggja meiri áherslu á parfir viðskiptavina, fá aukinn skilning á pörfum peirra, ásamt pví að bæta pjónustu við pá og samstarf við undirverktaka. Gæðastjórnun getur hjálpað til við að halda núverandi viðskiptavinum auk pess að fá nýja. Samkvæmt ÍST EN ISO 9000:2000 getur gæðastjórnun skapað umgerð um stöðugar umbætur og par með aukið líkur á ánægju viðskiptavina og ánægju annarra hagsmunaaðila (Staðlaráð Íslands, 2000). Einnig er pað liður í mælingu á frammistöðu gæðastjórnunarkerfis að fyrirtækið vakti upplýsingar um hvort viðhorf viðskiptavina sé að fyrirtækið hafi uppfyllt kröfur peirra (Staðlaráð Islands, 2000). 


\section{Rannsókn}

\subsection{Framkvæmd verkefnis}

Verkbyrjun er 13. janúar 2010 og lýkur verkefninu með kynningu á niðurstöðum í ágúst 2011. Pví er skipt niður í verkpætti sem endurspegla meginútlínur og áherslur verkefnisins. Helstu verkpættirnir eru: rannsókn á fræðilegum bakgrunni, hönnun spurningalista fyrir verkkaupa, símafundir með verkkaupum, hönnun spurningalista fyrir verktaka, símafundir með verktökum ásamt netkönnun og fundir með verktökum, viðtöl við fagaðila og að lokum úrvinnsla og kynning niðurstaðna. Мeð sundurliðun verks eru aðalpættirnir brotnir niður í smærri einingar og hún er forsenda pess að hægt sé að hafa eftirlit með framkvæmd verkefnisins.

\subsection{Lögmæti mælinga}

Áður en rannsóknin var framkvæmd var unnið að pví að búa til gildan (e. validity) mælikvarða fyrir pá pætti sem leitast var eftir að mæla. Ekki ber pó mönnum alltaf saman um pað hvernig best sé að mæla fræðileg hugtök sem ekki er hægt að mæla beint. Gott dæmi um slíkt eru gáfnapróf sem mæla IQ (Sarah Boslaugh \& Paul Andrew Watters, 2008). Fræðimenn á sviði gæðastjórnunar voru fengnir til að gefa sitt álit á frumgerð af spurningalistunum og aðferðafræði rannsóknarinnar ${ }^{9}$ Áhrif gæðastjórnunar eru einmitt pess eðlis að erfitt er að mæla pau. Ætla má að áhrifanna gæti í stjórnunarháttum fyrirtækja á pann veg að stjórnun verði skilvirkari og vinnubrögð markvissari og skjalfestari. Einnig er gert ráð fyrir að skilvirkari vinnubrögð skili sér beint með aukinni ánægju viðskiptavina og betri rekstrarafkomu fyrirtækja. Vandinn við að mæla áhrifin felast fyrst og fremst í flækjustiginu. Erfitt er að segja til um pað nákvæmlega hvaða pættir eru bein afleiðing af gæðastjórnunarkerfinu og hvað má skýra með öðrum páttum. Á Íslandi eru sárafá byggingafyrirtæki sem starfa eftir vottuðu gæðastjórnunarkerfi sem gerir pað að verkum að ómögulegt er að nota pann hóp sem samanburðarhóp við önnur fyrirtæki. bví verður að notast við pau fyrirtæki sem að eigin sögn starfa eftir gæðastjórnunarkerfi sem samanburðarhóp við pau fyrirtæki sem ekki starfa eftir gæðastjórnunarkerfi.

Í beinu samhengi við mælingu á áhrifum gæðastjórnunar er mikilvægt að gæði séu mæld en gæði eru huglægt hugtak sem einnig er erfitt að mæla. Pví verður ánægja viðskiptavina notuð sem mælistika fyrir pað að tilteknum gæðum hafi verið náð.

\footnotetext{
${ }^{9}$ Sjá viðauka um hönnun spurningalista bls. 388
} 


\subsection{Aðferðafræðin}

Ómögulegt er að mæla nákvæmlega hver áhrif gæðastjórnunar eru á mannvirkjagerð. Gert er ráo fyrir að áhrifin felist bæði í betri afkomu fyrirtækja, skilvirkari vinnuferlum og ánægju viðskiptavina svo fátt eitt sé nefnt. Í grein eftir Bassioni, Price og Hassan, sem ber heitið Performance Measurement in Construction sem birtist í Journal of management in engineering árið 2004, er farið yfir helstu frammistöðumælikvarða og beitingu peirra á byggingafyrirtækjum í Bretlandi. Par kemur fram að skýrsluhöfundar telja að pörf sé á að próa og rannsaka leið til að frammistöðumæla fyrirtæki í byggingaiðnaðinum sem tekur á öllum peim páttum sem áður pekktir frammistöðumælikvarðar gera (H.A.Bassioni, A.D.F.Price, \& \& T.M.Hassan, 2004). Pessi rannsókn tekur ekki á öllum hliðum sem talið er að áhrif gæðastjórnunar gæti. Eins og fram hefur komið er mannvirkjagerð verkefnamiðuð. Líklegt pykir að áhrif gæðastjórnunar gæti bæði á fyrirtækja-stigi og á verkefna-stigi. Rannsóknin tekur að hluta til á peim áhrifum sem gætir á verkefna-stigi, en farin var sú leið að notast við staðgengilspætti (e. proxy measurement) eins og ánægju verkkaupa með ýmsa pætti byggingaframkvæmda (Sarah Boslaugh \& Paul Andrew Watters, 2008).

Aðferðafræði rannsóknarinnar byggist á sex páttum eins og sjá má hér að neðan.

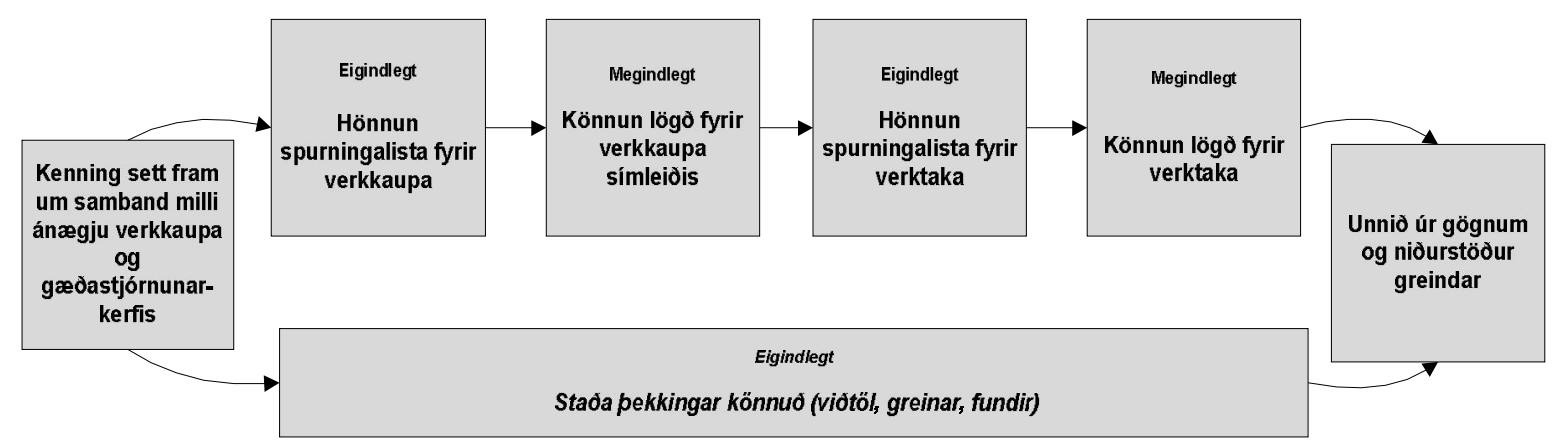

Mynd 5 Aðferðafræði rannsóknar

Í upphafi var kenning sett fram um áhrif gæðastjórnunar á mannvirkjagerð. Kenningin er að fyrirtæki sem starfa eftir gæðastjórnunarkerfi hafi ánægðari viðskiptavini og vinni samkvæmt markvissari vinnubrögðum.

Næst var spurningalisti hannaður sem ætlaður er verkkaupum. Ekki lágu fyrir sambærilegar rannsóknir til samanburðar og voru pví allar spurningarnar samdar sérstaklega, en við gerð spurningalistans var stuðst við gæðastaðalinn ISO 9001, samskiptastaðalinn ÍST 30 auk fræðigreina og rannsókna um gæðastjórnun. Ekki var gerð sérstök forprófun á spurningalistanum en honum var breytt í samræmi við ábendingar frá Ferdinand Hansen ${ }^{10}$, Eyjólfi Bjarnasyni ${ }^{11}$ og dr. Helga Pór Ingasyni. Auk pess voru nokkrar spurningar umorðaðar eftir ábendingar frá svarendum í fyrstu viku viðtala.

\footnotetext{
${ }^{10}$ verkefnastjóri gæðastjórnunar hjá Samtökum iðnaðarins

${ }^{11}$ Gæðastjóri ÍAV
} 
Pví næst var spurningalistinn lagður fyrir verkkaupa í gegnum síma og peir beðnir að hafa í huga tiltekinn verktaka við svörun spurninganna. Pegar viðtölum við verkkaupa var lokið var hafist handa við hönnun spurningalista fyrir verktaka. Eins og við gerð spurningalistans fyrir verkkaupana var stuðst við gæðastaðalinn ISO 9001, samskiptastaðalinn ÍST 30, fræðigreinar og rannsóknir tengdar gæðastjórnun og innlegg frá Ferdinand Hansen. Auk pess fór Unnur Guðnadóttir ${ }^{12}$ yfir og leiðrétti spurningalistann með tilliti til skýrleika spurninga. Næst var haft upp á peim verktökum sem verkkaupar höfơu haft í huga við svörun könnunar fyrir verkkaupa og peim boðið að taka pátt í könnuninni. Svör frá umræddum verktökum bárust ýmist gegnum internetið eða í formi símaviðtals. Til að fá fleiri svör var könnunin einnig send á slembiúrtak verktaka í gegnum internetið.

Aðferðafræði sem var beitt við hönnun spurningalistanna felur í sér 11 pætti, sjá viðauka bls. 455. Skýrsluhöfundur telur að með pví að unnið sé að öllum pessum páttum skref fyrir skref á skipulegan og markvissan hátt sé hámarksárangur tryggður og líkurnar á að mikilvæg atriði sem og smærri atriði verði útundan minnki umtalsvert. Spurningalistana má sjá í heild sinni í viðaukum annars vegar á bls. 141 og hins vegar á bls. 183.

Verkkauparnir voru spurðir út í framkvæmdina sem peir höfou staðið í á 5 ára tímabili, 2005-2010 og beðnir um að hafa pann verktaka sem peim fannst hafa unnið mest í verkinu í huga við svörun spurninganna. Könnunin skiptist í 12 pætti sem taka m.a. á ánægju verkkaupa, áætlanagerð, fyrirkomulagi verkfunda og samninga, frábrigðum, umgengni og öryggismálum verktaka, samskiptum, gæðatryggingu og gæðum og að sjálfsögðu gæðastjórnunarkerfi verktaka.

Verktakarnir sem haft var samband við voru annars vegar peir verktakar sem verkkauparnir höfơ haft í huga við svörun spurninganna, nefndir „umræddir verktakar“ í par til gerðri könnun og hins vegar slembiúrtak ${ }^{13}$ verktaka. Svör umræddra verktaka voru svo tengd sérstaklega viðkomandi verkkaupum til sérstakrar greiningar. Slembiúrtaki verktaka var sérstaklega bætt við hóp umræddra verktaka m.a. til að varpa betur ljósi á verklag verktaka og pekkingu peirra og áliti á gæðastjórnun. Könnunin skiptist í 8 flokka sem tengdust gæðastjórnunarkerfi og verklagi verktaka, viðhorfi og pekkingu á gæðastjórnun, ásamt kröfum verkkaupa í garð verktaka.

Í gegnum allt rannsóknarferlið var pekking á gæðastjórnun í mannvirkjagerð könnuð ásamt rannsóknum á sviði gæðastjórnunar. Nánar um afraksturinn má sjá í kafla um fræðilega umfjöllun og fyrri rannsóknir á bls. 26. Einnig tók undirrituð viðtöl við nokkra fagaðila, sótti ráðstefnu og fyrirlestur en afraksturinn af pví má sjá í kafla um viðtöl á bls. 104. Að lokum eru niðurstöður úr öllum páttum greindar saman og dregnar ályktanir.

\footnotetext{
12 Annars árs nemi í meistaranámi í félagssálfræði, sem hefur auk pess tekið námskeið í gerð spurningalista

${ }^{13}$ Sjá nánar um skiptingu úrtaks verktaka á bls. 76
} 


\subsection{Kannanir fyrir verkkaupa og verktaka}

\subsubsection{Um könnun fyrir verkkaupa}

Verkkaupar voru spurðir út í framkvæmdir sem peir höfðu staðið í á 5 ára tímabili, 20052010 og beðnir um að hafa pann verktaka sem peim fannst hafa unnið mest í verkinu í huga við svörun spurninganna.

Könnunin skiptist í 14 pætti sem taka m.a. á ánægju verkkaupa, áætlanagerð, fyrirkomulagi verkfunda og samninga, frábrigðum, umgengni og öryggismálum verktaka, samskiptum, gæðatryggingu og gæðum og að sjálfsögðu gæðastjórnunarkerfi verktaka.

\subsubsection{Um könnun fyrir verktaka}

Verktakarnir sem haft var samband við voru annars vegar beir verktakar sem verkkauparnir höfou haft í huga við svörun spurninganna, nefndir „umræddir verktakar“ í par til gerðri

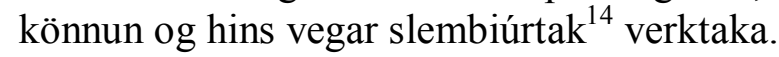

Svör umræddra verktaka voru svo tengd sérstaklega viðkomandi verkkaupum til sérstakrar greiningar.

Könnunin skiptist í 8 pætti sem tengjast m.a. gæðastjórnunarkerfi og verklagi verktaka, viðhorfi og pekkingu á gæðastjórnun, ásamt kröfum verkkaupa í garð verktaka.

\subsection{3 Úrtak og býði}

Hægt er að reikna út hversu stórt úrtak parf að vera til að hægt sé að ná tiltekinni tölfræðilegri nákvæmni. Í rannsóknarverkefnum með takmörkuðu fjármagni og mannafla er pumalputtaregla að stærð úrtaks er haft eins stórt og mögulegt er, miðað við ofangreindar skorður, líkt og gert var í pessari rannsókn. Pá er einnig hægt að nota sömu formúlu til að reikna öryggisbil út frá stærð býðis og úrtaks auk öryggisstigs.

Til að reikna út hversu stórt úrtak parf að vera til að ná tiltekinni tölfræðilegri nákvæmni til að heimfæra á pýðið parf fyrst að skilgreina öryggisbil og öryggisstig ${ }^{15}$. En öryggisbil má reikna með eftirfarandi jöfnu, út frá gefnum forsendum;

$$
\text { Stærð úrtaks }=\frac{Z^{2}(p) *(1-p)}{c^{2}}
$$

par sem Z er Z gildi (1,96 fyrir 95\% öryggisstig), p er hlutfall úrtaks sem svara á ákveðinn hátt (til að reikna stærð úrtaks sem pörf er á er $\mathrm{p}=0,5)$ og c er öryggisbil, gefið upp í tugastaf (p.e. $0,04= \pm 4$ ) (Creative research systems, 2010).

\footnotetext{
${ }^{14}$ Sjá nánar um skiptingu úrtaks verktaka á bls. 76

${ }^{15}$ Sjá kafla um skilgreiningar
} 


\section{Verkkaupar}

\section{Pýði}

Skilgreint pýði fyrir verkkaupa er eftirfarandi:

„Deir verkkaupar sem stóðu i framkvoemdum á árunum 2005-2010 á/i Akranesi, Akureyri, Hafnarfirði, Kópavogi, Reykjanesbœe eða Reykjavik og voru með verktaka i vinnu i pað minnsta $30 \%$ af framkvoemdinni og voru ekki sjálfir verktakar i framkvomdinni “.

Ofangreindar skorður gera pað að verkum að erfitt er að gera sér fyllilega grein fyrir stærð pýðis.

Til ógildra teljast peir sem unnu framkvæmdina sjálfir og/eða með aðstoð ættingja og vina, peir sem voru verkkaupar og verktakar að sömu framkvæmdinni og aðrar ástæður eins og ef viðkomandi talar ekki íslensku eða er látinn ${ }^{16}$.

Tafla 1 Pýdi fyrir verkkaupa ${ }^{17}$

\begin{tabular}{|c|c|c|c|}
\hline & Heild & Ógilt & Рýði \\
\hline Akranes & 63 & 16 & 47 \\
\hline Akureyri & 396 & 208 & 188 \\
\hline Hafnarfjörður & 341 & 144 & 197 \\
\hline Kópavogur & 169 & 81 & 88 \\
\hline Reykjanesbær & 262 & 131 & 131 \\
\hline Reykjavík $^{18}$ & 324 & 80 & 244 \\
\hline Samtals & 1555 & 660 & 895 \\
\hline
\end{tabular}

\section{Úrtak}

Til að ná fullkomnu ytra lögmæti (e. external validity) parf úrtakið að vera handahófskennt og hlutfallslega nógu stórt með tilliti til pýðisins (Sarah Boslaugh \& Paul Andrew Watters, 2008). Par sem að úrtakið fyrir könnun verkkaupa er ekki sérlega stórt og upplýsingar um verkkaupa á öllu Íslandi lágu ekki fyrir var ekki hægt að setja saman fullkomlega handahófskennt úrtak. Pví verður að varast að draga afgerandi ályktanir út frá úrtakinu fyrir allt pýðið.

Í úrtakinu voru alls 575 verkkaupar. Par af teljast 459 til brottfalls af ýmsum ástæðum, par með talið peir sem ekki náðist í vegna pess að símanúmer var ótengt, fannst ekki eða reynt hafði verið oftar en prisvar að ná í viðkomandi og að lokum peir sem vildu ekki svara.

\footnotetext{
${ }^{16}$ Að auki var áætlað að helmingur peirra sem ekki var haft samband við teldist til ógildra.

${ }^{17}$ Allar tölur í töflunni eru byggðar á gögnum sem fengust frá byggingafulltrúum sveitarfélaganna

${ }^{18}$ Samkvæmt starfsmanni byggingafulltrúa Reykjavíkur, 03.04.2010, voru 1500-2000 byggingarleyfi gefin út á tímabilinu. Tiltekin starfsmaður taldi ekki nema 324 flokkast undir gild tilfelli og fékk skýrsluhöfundur einungis upplýsingar um pau tilfelli. Við nánari skoðun flokkuðust 244 tilfelli af peim 324 sem upplýsingar lágu fyrir um, sem gild tilfelli.
} 
Nettóurtak verkkaupa ${ }^{19}$ er pví 116 og stærð pýðis er 895 . Með 95\% öryggisstig og p=0,5 fæst pví að öryggisbil er 8,49. Рað er pví hægt að segja að pau hlutföll sem fást fyrir úrtak séu í 95\% tilfella rétt fyrir pýðið með $\pm 8,49$ öryggisbil. Раð pýðir að ef $50 \%$ pátttakenda svaraði ákveðinni spurningu á tiltekinn hátt í úrtakinu má gera ráð fyrir, með 95\% vissu, að um pað bil 41,5 - 58,5\% pýðisins myndi svara á sama hátt. Til pess að fá ásættanlegra öryggisbil verður úrtakið að vera stærra. Til að mynda pyrfti 360 pátttakendur til pess að fá öryggisbil niður í 4, með 95\% öryggisstig.

\section{Svarhlutfall}

116 verkkaupar $^{20}$ tóku pátt í könnuninni símleiðis, einstaklings-verkkaupar jafnt sem fyrirtækja-verkkaupar. Pátttakendur höfou staðið í framkvæmdum á Akranesi, Akureyri, Hafnarfirði, Kópavogi, Reykjanesbæ og Reykjavík ${ }^{21}$, einhvern tíma á árunum 2005-2010.

Flestir pátttakendur komu frá höfuðborginni eða tæplega 38\%, en er pað í takt við pá staðreynd að flestar framkvæmdir áttu sér stað par á pessu tímabili. Næstflestir pátttakendur komu frá Hafnarfirði eða 25\%.

Tafla 2 Úrtak verkkaupa

\begin{tabular}{lccc}
\hline \hline & Úrtak $^{22}$ & Svartíðni & Svarhlutfall (\%) \\
\hline Akranes & 47 & 6 & 12,7 \\
Akureyri & 120 & 7 & 5,8 \\
Hafnarfjörður & 96 & 30 & 31,2 \\
Kópavogur & 30 & 17 & 56.7 \\
Reykjanesbær & 51 & 12 & 23,5 \\
Reykjavík & 231 & 44 & 19.0 \\
Samtals & $\mathbf{5 7 5}$ & $\mathbf{1 1 6}$ & $\mathbf{2 0 , 2}$ \\
\hline \hline
\end{tabular}

\section{Verktakar}

\section{•ýði}

Skilgreint pýði fyrir verktaka er eftirfarandi:

\section{„, Starfandi byggingaverktakar á Íslandi 2010 sem vinna á opnum tilboðsmörkuðum “.}

Samkvæmt tölum frá Hagstofunni um fjölda starfandi verktaka fyrir árið 2010 voru 3032 verktakar sem hægt er að flokka með pýðinu (Hagstofa Íslands, 2011). Hafa verður í huga

\footnotetext{
${ }^{19}$ Hér er stærð úrtaks miðuð við fjölda pátttakenda

${ }^{20}$ Upplýsingar um nafn pátttakenda og lóða liggja fyrir um alla sem voru í úrtakinu, bæði fyrir svarendur og pá sem ekki svöruðu, en pær fylgja ekki með sökum nafnleyndar.

${ }^{21}$ Frá byggingafulltrúa í Reykjavík fékkst einungis úrtak peirra verkkaupa sem stóđu í framkvæmdum á pessu tímabili, en ekki pykir ástæða til að draga pá ályktun að sérstaklega hafi verið valið í úrtakið með tilliti til hagsmuna eða annarra ástæðna.

${ }^{22}$ Í úrtakinu teljast peir sem svöruðu könnun, peir sem svöruðu ekki eftir meira en 3 tilraunir, peir sem vildu ekki svara og að lokum peir sem leitað var eftir númeri sem ekki fannst.
} 
að hluti fyrirtækja í mannvirkjagerð vinnur einkum við að byggja og selja fasteignir (Sveinn Hannesson, 2005). Í pessari rannsókn verður slíkum verkum ekki gerð sérstök skil. Ástæðan er sú að aðferðafræði rannsóknarinnar felst einkum í pví að kanna ánægju verkkaupa með framkvæmd verka frá upphafi til enda hjá verktökum. Pví er ekki grundvöllur fyrir pví að taka verk með í rannsóknina par sem verktaki stóð í framkvæmdum við byggingu og svo sölu á sama verki. Verktakar sem vinna ekki á opnum tilboðsmarkaði og eru einvörðungu í pví að byggja og selja svo fasteignirnar eru taldir með inn í pýði rannsóknarinnar par sem að ekki lágu fyrir nákvæmari tölur. Pví má áætla að pýðið sé minna en taflan hér að neðan gefur til kynna.

Tafla 3 Dýdi fyrir verktaka

\begin{tabular}{lccc}
\hline \hline Starfandi verktakar á Íslandi 2010 & Pýði & Úrtak & Hlutfall (\%) \\
\hline Bygging íbúðar- og atvinnuhúsnæðis & 2168 & & \\
Undirbúningsvinna á byggingarsvæði & 130 & & \\
Raflagnir & 477 & & \\
Pípulagnir, uppsetning hitunar- og loftræstikerfa & 257 & & \\
Samtals & 3032 & 297 & 9.8 \\
\hline \hline
\end{tabular}

\section{Úrtak}

Úrtakið samanstendur af 297 verktökum sem skiptast í 4 flokka. Heildarfjöldi svara er 96 sem gefur $32 \%$ svarhlutfall. Flokkarnir eru eftirfarandi:

1. Umræddir verktakar

2. Fundur

3. Póstlisti

4. Slembiúrtak

Nánar er farið í ofantalda flokka hér að neðan.

1. Umræddir verktakar. Eins og áđur hefur komið fram var leitast við að fá pá verktaka sem verkkaupar úr fyrri könnun höfơ haft í huga við svörun spurninga til að taka pátt í sérstakri könnun fyrir verktaka. Til pess að fá sem besta svörun frá pessum hópi var bæði notast við rafræna pátttöku í gegnum internetið ásamt símaviðtölum við verktaka allt eftir pví hvað hentaði pátttakendum. Framvegis verður talað um pennan hóp pátttakenda sem umrcedda verktaka.

Par sem svör verkkaupa eru tengd við svör umrceddra verktaka pegar niðurstöður fyrir pann hóp eru greindar, eru svör sumra verktaka tví- eða jafnvel prítalin í peirri greiningu. Ástæðan er sú að í einhverjum tilfellum voru verkkaupar með sama verktaka í huga. Réttast er að taka fram að pessi endurtalning á sér ekki stað pegar heildarúrtak verktaka er greint.

Verkkauparnir 116 sem tóku pátt í könnuninni sem ætluð er verkkaupum voru samtals með 88 umrcedda verktaka í huga. Er pá búið að taka tillit til pess að í einhverjum tilfellum voru verkkaupar með sömu verktakana í huga. 36 (41\%) af verktökunum umræddu reyndist ógerlegt að ná í vegna dræmra upplýsinga um viðkomandi verktaka, eða vegna pess að við- 
komandi verktaki var ekki lengur starfandi. Í úrtakinu fyrir verktaka eru pví 52 verktakar úr hópi umrceddra verktaka og af peim var 31 verktaki $^{23} \mathrm{sem}$ tók pátt í könnuninni (60\% svarhlutfall). Fyrir pær sakir að í einhverjum tilfellum reyndust verkkaupar vera með sömu verktaka í huga var hægt að tengja svörin við 46 verkkaupa $^{24}$.

2. Fundur. Spurningalisti var prentaður út og lagður fyrir verktaka á fundi sem haldinn var á vegum Samtaka Iðnaðarins, 4. febrúar 2010 fyrir meðlimi meistarafélags iðnaðarmanna í Hafnarfirði. 44 verktakar mættu á fundinn og af peim kusu 28 að svara, sem gefur tæplega 64\% svörun. Pegar notast er við hóp af fólki sem hittist af einhverri ástæðu í úrtak kallast pað hentugleika úrtak (e. convenience sample). Hafa verður í huga að mögulegt er að skekkja fylgi slíku úrtaki (Routio, 2007).

3. Póstlisti. Verktökum með skráð netföng hjá Samtökum Iðnaðarins var send könnunin á rafrænu formi. 149 verktakar voru á póstlistanum og svöruðu 33 peirra könnuninni sem gefur tæplega 23\% svarhlutfall.

4. Slembiúrtak. Til að fá aukasjónarhorn og meiri svörun var einnig notast við slembiúrtak par sem verktökum sem undirrituð fann upplýsingar um í gegnum internetið, var sendur netpóstur og óskað eftir pátttöku beirra með svörun í gegnum internetið. 16 verktökum var sendur póstur og áminning og fengust 3 svör, sem gefur tæplega 19\% svarhlutfall.

Pegar talað er um heildarúrtak er átt við alla 4 hópana hér að ofan. Samantekt á dreifingu svara í heildarúrtaki má sjá í töflunni hér að neðan:

Tafla 4 Úrtak verktaka

\begin{tabular}{lccc}
\hline & Úrtak & Svartíoni & Svarhlutfall (\%) \\
\hline Fundur & 44 & 28 & 63.6 \\
Póstlisti & 149 & 33 & 22.1 \\
Slembiúrtak & 16 & 3 & 18.8 \\
Umræddir verktakar & 52 & 32 & 61.5 \\
Samtals & $\mathbf{2 6 1}$ & $\mathbf{9 6}$ & $\mathbf{3 6 . 8}$ \\
\hline \hline
\end{tabular}

Samantekt á pví hvernig pátttakendur tóku könnunina má sjá í töflunni hér að neðan:

\footnotetext{
${ }^{23}$ Reyndar fengust 32 svör en 2 svör bárust frá sama verktaka fyrirtækinu frá mismunandi aðila innan fyrirtækisins. Líklega eru fleiri en einn sem lesa almennan póst innan pess fyrirtækis.

${ }^{24}$ Athuga að í pessum hóp er 31 viðtal en í 4 tilfellum voru 3 verkkaupar með sama verktaka í huga og í 7 tilfellum voru tveir verkkaupar með sama verktaka í huga.
} 


\begin{tabular}{lccc}
\hline \hline & Tíðni & Hlutfall (\%) & Uppsafnað hlutfall (\%) \\
\hline Fundur & 28 & 29.2 & 29.2 \\
Netið & 57 & 59.4 & 88.5 \\
Símleiðis & 11 & 11.5 & 100.0 \\
Samtals & 96 & 100.0 & \\
\hline \hline
\end{tabular}

Nettóúrtak verktaka $^{25}$ er pví 96 og stærð pýðis er 3032. Með 95\% öryggisstig og p=0,5 fæst pví að öryggisbil er 9,8. Рað er pví hægt að segja að pau hlutföll sem fást fyrir úrtak séu í 95\% tilfella rétt fyrir býðið með $\pm 9,84$ öryggisbil. Sem pýðir að ef $50 \%$ pátttakenda svaraði ákveðinni spurningu á tiltekinn hátt í úrtakinu má gera ráð fyrir, með 95\% vissu, að um pað bil 40,2 - 59,8\% pýðisins myndi svara á sama hátt. Til pess að fá prengra öryggisbil verður úrtakið að vera stærra. Til að mynda pyrfti 500 pátttakendur til pess að fá öryggisbil niður í 4, með 95\% öryggisstig.

Gera verður ráð fyrir ytri skekkju (e. external validity) par sem að úrtakið er ekki sérlega stórt (Sarah Boslaugh \& Paul Andrew Watters, 2008) og nauðsynlegar upplýsingar um alla starfandi verktaka á Íslandi lágu ekki fyrir svo ekki var hægt að setja saman fullkomlega handahófskennt úrtak. Dví verður að varast að draga afgerandi ályktanir út frá úrtakinu fyrir allt pýðið.

Nauðsynlegt er einnig að gert sé ráð fyrir innri skekkju (e. inernal validity) í ljósi pess að verktakar gætu reynt að láta sjálfan sig líta betur út pegar könnun var svarað (Sarah Boslaugh \& Paul Andrew Watters, 2008).

Í fullkomnum heimi hefði verið ráð að eyða út skekkju með pví að velja í úrtakið á pann veg að раð stæði saman af tveimur jafnstórum, handahófskenndum hópum (Sarah Boslaugh \& Paul Andrew Watters, 2008) sem væru annars vegar með verktaka sem starfa eftir gæðastjórnunarkerfi og hins vegar með verktaka sem starfa ekki eftir gæðastjórnunarkerfi.

\subsubsection{Greiningaraðferð}

Margar aðferðir hafa verið próaðar til pess að rannsaka gögn sem samanstanda af flokkabreytum $^{26}$ og raðbreytum. Sér í lagi hafa aðferðir verið próaðar til pess að heimfæra línulega aðhvarfsgreiningu yfir á slík gögn (Watters, 2008). Hér verður stuttlega farið yfir pær greiningaraðferðir sem beitt var til pess að greina gögnin.

\footnotetext{
${ }^{25}$ Hér er stærð úrtaks miðuð við fjölda pátttakenda

${ }^{26}$ Sjá skilgreiningu á flokkabreytu í kafla um skammstafanir og skilgreiningar
} 


\section{Grunnathuganir}

Við greiningu gagna í pessari rannsókn voru gerðar tíðnitöflur fyrir allar spurningar kannananna par sem fram kemur tíðni svara í hverjum svarflokk, hlutfall miðað við heildarfjölda pátttakenda og gilt hlutfall sem stendur fyrir hlutfall svara í viðkomandi flokki miðað við heildarfjölda svara sem barst við tiltekinni spurningu. Auk pess er uppsafnað hlutfall sýnt miðað við gilt hlutfall og fjöldi gilda sem flokkast undir vantar (e. missing values), en pað er mismunur á fjölda pátttakenda og svörum sem bárust við tiltekinni spurningu. Gildi er pví sagt vanta ef pátttakandi sleppir að svara viðkomandi spurningu eða ef pátttakandi var ekki spurður tiltekinnar spurningar par sem slíkt var ekki viðeigandi. Til dæmis voru pátttakendur í könnun fyrir verktaka ekki spurðir hvort gæðastjórnunarkerfi fyrirtækisins væri vottað ef peir höfou svarað að fyrirtækið starfaði ekki eftir gæðastjórnunarkerfi. Flestallir rannsakendur standa frammi fyrir pví að eitthvað af gögnum vantar. Gagnlegt getur verið að greina á milli af hverju gögn vantar. Til dæmis gæti verið gagnlegt að kóða mismunandi pau gögn sem vantar vegna pess að viðkomandi var ekki spurður tiltekinnar spurningar par sem pað var ekki viðeigandi fyrir tiltekinn pátttakanda og pau gögn sem vantar vegna pess að viðkomandi pátttakandi vildi ekki svara. Gildi sem vantar gera pað að verkum að tölfræðilegur kraftur spurningarinnar minnkar en einnig má gera ráð fyrir að skekkja komi í úrvinnslu ef mikið af gögnum vantar í ákveðna spurningu vegna pess að pátttakendur kusu að svara henni ekki (Watters, 2008). Skiptar skoðanir eru á pví hvernig rannsakendur eigi að meðhöndla gildi sem vantar. Engin sérstök meðhöndlun á slíkum gildum var gerð fyrir tíðnitöflur en nánar er farið út í sérstaka meðhöndlun í CATREG ${ }^{27}$.

Samband milli tveggja eða fleiri breyta er gefið upp í tengslatöflu (e. contingency table). Slíkar töflur eru einnig nefndar RxC töflur, par sem R stendur fyrir Row eða röð og C fyrir column eða dálk. Par er tíðni svara og hlutfall gefið í flokkum milli breyta. Auk pess eru fylgnistuðlar reiknaðir, sem gefa til kynna hversu sterk tengsl eru milli breyta og hvort pau eru marktæk.

Ýmsar aðferðir hafa verið próaðar til að mæla fylgni hjá flokkagögnum og raðbreytum. Hafa ber í huga að fylgnistuðlar segja bara til um samband á milli breyta en ekki er hægt að alhæfa um orsakasamband tveggja breyta einungis út frá fylgnistuðli. Рað er til mikið af slíkum mæli aðferðum, sumar peirra bera jafnvel meira en eitt nafn (Sarah Boslaugh \& Paul Andrew Watters, 2008). Eins og Albert Einstein lét eitt sinn hafa eftir sér; „Everything that can be counted does not necessarily count; everything that counts cannot necessarily be counted”, með öðrum orðum, "allt sem hægt er að mæla er ekki endilega pess vert að mæla, allt sem er vert að mæla er ekki endilega hægt að mæla".

Við greiningu gagna var notast við tvö sett af fylgnistuðlum. Pegar fylgni milli raðbreyta var skoðuð var ákveðið að notast við fylgnistuðla Spearman's rank order, Goodman og Kruskal's gamma, Sommer's d og ýmist Kendall's tau-b eða Kendall's tau-c eftir pví sem við átti. Fyrir nafnabreytur var notast við tengsla stuðul (e.contingency coefficient), lambda og óvissu stuðull (e. uncertanity coefficient). Nánar má lesa um fylgnistuðla og marktækni peirra í viðauka á bls. 414 .

\footnotetext{
${ }^{27}$ Gildi sem flokkast undir vantar voru meðhöndluð í flokka aðhvarfsgreiningunni CATREG
} 


\section{Tilgátupróf}

Núlltilgáta, táknuð með $\mathrm{H}_{0}$, er staðhæfing um stika pýðis sem rannsakandi telur eðlilegt að halda fram í upphafi. Gagntilgáta, táknuð með $\mathrm{H}_{1}$, staðhæfir öfugt við $\mathrm{H}_{0} . \mathrm{H}_{0}$ er bví hafnað ef gögnin benda sterklega til pess að $\mathrm{H}_{0}$ sé röng. En ef gögnin benda ekki nægjanlega sterkt til pess að $\mathrm{H}_{0}$ sé röng er henni ekki hafnað. Undirstrikað er að núlltilgáta er ávallt hrakin eða studd, en ekki sönnuð eða afsönnuð (Sarah Boslaugh \& Paul Andrew Watters, 2008).

Í upphafi rannsóknarinnar var sett fram eftirfarandi núlltilgáta sem var leitast til að hrekja eða styðja með Mann-Whitney U test;

$\mathrm{H}_{0}=$ enginn munur er á áncegju verkkaupa eftir pví hvort umrceddur verktaki starfi eftir gœðastjórnunarkerfi byggðu á viðurkenndum gœðastjórnunarstöðlum eða ekki.

Árétta ber að við tilgátupróf geta tvenns konar mistök átt sér stað í tölfræðilegri ályktun. Annars vegar höfnunarvilla og hins vegar sampykktarvilla (Sarah Boslaugh \& Paul Andrew Watters, 2008)

Höfnunarvilla (e. Type I error) er pað nefnt pegar núlltilgátan er ranglega hrakin. Líkurnar á pessu eru $\alpha$ í venjulegu tilgátuprófi par sem vikmörkin eru $\alpha$ (Sarah Boslaugh \& Paul Andrew Watters, 2008).

Sampykktarvilla (e. Type II error) er pað nefnt pegar núlltilgátan er ranglega studd. Venja er að tákna líkurnar á pessari villu með $\beta$ (Sarah Boslaugh \& Paul Andrew Watters, 2008).

Notast var við Mann-Whitney $U$ test (einnig kallað Mann-Whitney-Wilcoxon (MWW) eða Wilcoxon rank-sum test) sem er stikalaust próf notað til að sannreyna hvort tvö óhád úrtök af athugunum hafi jafnhá gildi. Prófið er eitt pekktasta sinnar tegundar (Wikipedia, 2011).

\section{Flokka aðhvarfsgreining (e. Categorical Regression - CATREG)}

Notast var við flokka aðhvarfsgreiningu til pess að búa til línulegt líkan sem skýra átti tengsl milli valdra pátta og ánægju verkkaupa. Svör verkkaupa voru tengd við svör viðkomandi verktaka og var pannig hægt að nota gögn úr báðum könnunum til að búa til líkanið.

Í aðhvarfsgreiningu er ein eða fleiri breytur notaðar til að spá fyrir um útkomu á annarri breytu. Á einfaldan hátt má skýra petta pannig að skoðuð eru línuleg tengsl á milli tveggja breyta. Petta er gert með pví að lágmarka summu fervika í öðru veldi milli háðu (e. depentent) breytunnar, einnig nefnd svarbreyta, og óháðu (e. indepentent) breytanna, einnig nefndar spábreytur (Jacqueline J. Meulman, Willem J. Heiser, SPSS Inc, 2004).

Pegar töluleg gögn eiga í hlut er margvíð aðhvarfsgreining algengasta aðferðin til að spá fyrir um háða breytu út frá setti af svarbreytum (Anita J. van der Kooij, 2003). Pegar greina á flokkunarbreytur er ekki hægt að nota hefðbundna aðhvarfsgreiningu til að greina gögnin. Hópur fólks hjá Data Theory Scaling System Group (DTSS) hefur próað aðferð sem hefur verið nefnd flokkunar aðhvarfsgreining (e. categorical regression). Aðferðin 
gengur einnig undir styttingar nafninu CATREG. Dessi aðferð hefur verið innleidd í SPSS Statistics (Jacqueline J. Meulman, Willem J. Heiser, SPSS Inc, 2004) en gögn rannsóknarinnar voru unnin í pví forriti.

CATREG er stika-laus (e. nonparametric) aðferð til að framkvæma margvíða aðhvarfsgreiningu á flokkagögnum eða blöndu af tölulegum gögnum og flokkagögnum. CATREG leyfir ólínulega umbreytingu gagna, par á meðal svarbreyta. Einnig er hægt að nota CATREG til pess að kanna tilvist ólínulegs sambands breyta (Anita J. van der Kooij, 2003).

Hægt er að aðlaga flest hefðbundin líkön til pess að greina gögn sem skiptast í flokka (e. categorical data) en slíkar aðlaganir virka yfirleitt illa ef fáar athuganir ${ }^{28}$ eru til staðar, breyturnar eru margar og/eða gildi fyrir breytur eru of mörg. Мeð pví að kvarða flokka er komist hjá ofangreindum vandamálum með bestunarkvarða (e. optimal scaling) sem er notaður í CATREG (Jacqueline J. Meulman, Willem J. Heiser, SPSS Inc, 2004).

Nánar má lesa um líkanið og reikniritið í CATREG í viðauka á bls. 391.

\footnotetext{
${ }^{28}$ Ef úrtak er lítið
} 


\subsection{Greining gagna úr könnun verkkaupa}

Hér eru kynntar helstu niðurstöður sem fengust úr könnun fyrir verkkaupa sem staðið hafa í framkvæmdum á tímabilinu 2005 til 2010 á Íslandi.

Pegar marktæk fylgni mælist milli breyta er gildi pess fylgnistuðuls sem gaf mestu fylgnina gefið upp í sviga. Gildi allra útreiknaðra fylgnistuðla má sjá í viðauka $\mathrm{F}$ á bls. 245.

Uppbygging pessa kafla er sem hér segir: Farið er í frumniðurstöður á öllum flokkum innan könnunar par sem fram kemur fylgni við ánægju verkkaupa með umræddan verktaka og við pað hvort umræddur verktaki starfaði eftir gæðastjórnunarkerfi eða ekki, samkvæmt svörum verktaka úr könnun fyrir verktaka ${ }^{29}(G S K)$. Niðurstöður úr pessari greiningu eru svo fléttaðar inn í niðurstöðukafla sem byggður er upp út frá rannsóknaspurningunum.

Sérstök athygli er vakin á pví að breytan $G S K$ stendur fyrir pví hvort verktakar vinna eftir gæðastjórnunarkerfi byggðu á viðurkenndum gæðastöðlum og er hún úr könnun verktaka en sérstök greining á könnun verktaka er í kafla 4.6.

Öll breytuheiti eru skilgreind í viðauka D á bls. 201.

\subsection{1 Ánægja viðskiptavinar}

Gæði verks felast í pví að kröfum viðskiptavinar sé fullnægt. Pví er afar mikilvægt að ánægja viðskiptavinar sé mæld til að meta pað hvort tilætluðum gæðum hafi verið náð. Verkkauparnir, sem eru í pessu tilfelli hinir eiginlegu viðskiptavinir, voru spurðir annars vegar hvort peir væru ánægðir með framkvæmd verksins í heild og hins vegar hvort peir væru ánægðir með framkvæmd verksins sem umræddur verktaki vann. Á skífuritunum hér að neðan má sjá skiptingu svara fyrir ánægju verkkaupa með framkvæmd verksins í heild og ánægju verkkaupa með framkvæmd verksins hjá umræddum verktaka.

\footnotetext{
${ }^{29}$ Svör umræddra verktaka voru pöruð sérstaklega við svör viðkomandi verktaka til að reikna út fylgni milli GSK og annarra pátta í könnun fyrir verkkaupa
} 

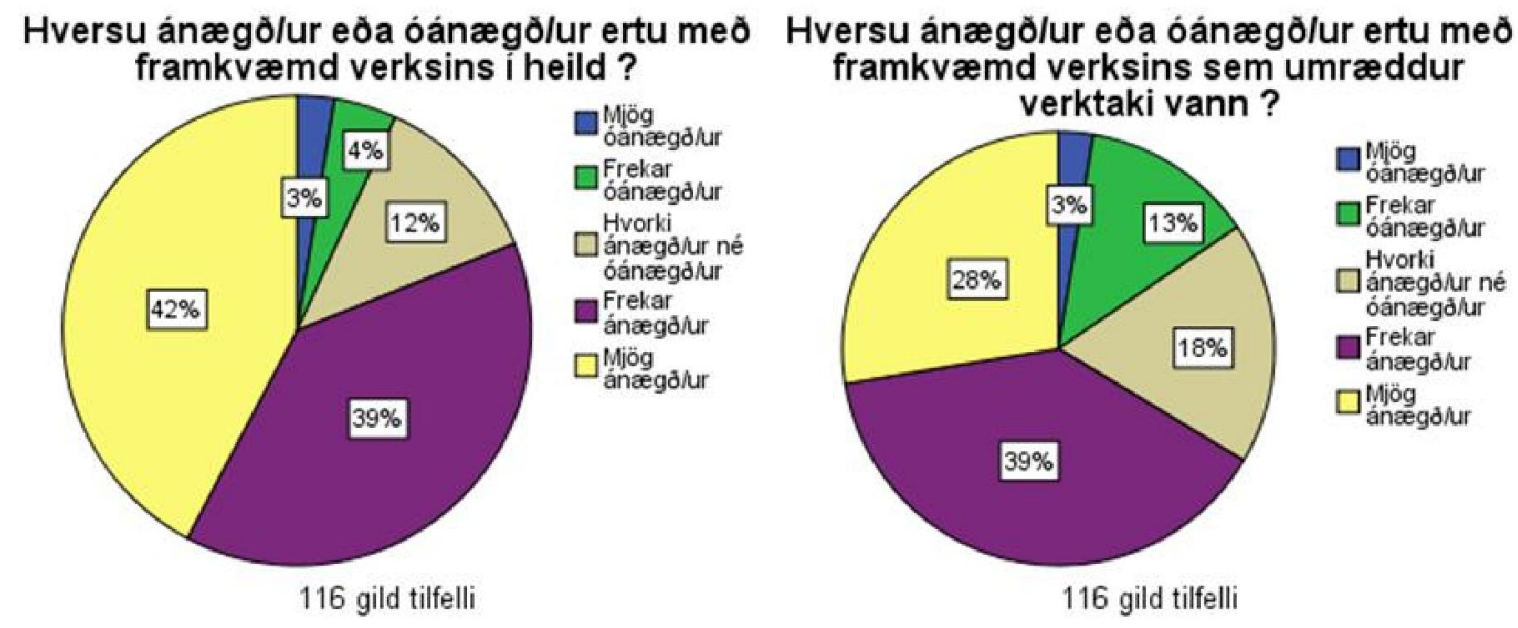

\section{Mynd 6 Svarhlutfall verkkaupa með ánoegju framkvoemdar verksins i heild og hjá umrceddum verktaka}

Hlutfall pátttakenda sem voru mjög ánægðir með framkvæmd verksins í heild er $42 \%$ en ekki nema rúmlega $27 \%$ pátttakenda voru mjög ánægðir með framkvæmd verksins sem umræddur verktaki vann. Pennan mun má skýra með pví að hjá stærstum hluta pátttakenda var um fagverk að ræða, p.e. að verkkaupi réð til sín verktaka á hverju fagsviði fyrir sig og má pví ætla að margir pættir, óháðir vinnu umrædds verktaka, geti haft áhrif á ánægju verkkaupa með framkvæmd verksins í heild.

\section{GSK}

Fylgni milli annars vegar GSK og hins vegar ánægju verkkaupa með framkvæmd hjá umræddum verktaka (Gamma 0,623) reyndist vera mjög marktæk og sterk. Ef aðilar sem vitað er til pess að séu tengdir verktaka nánum persónulegum böndum eru sigtaðir frá úrtakinu verður fylgnin enn sterkari (Gamma 0,668) og sér í lagi fyrir fyrirtækja-verkkaupa (Gamma 1,000). Meðal einstaklings-verkkaupa mælist há fylgni milli ofangreindra pátta (Gamma 0,750) en hún nær bví ekki að flokkast undir pað að vera marktæk. Hafa verður í huga að einn af páttunum sem hefur áhrif á marktækni fylgnistuðla er fjöldi svara. 


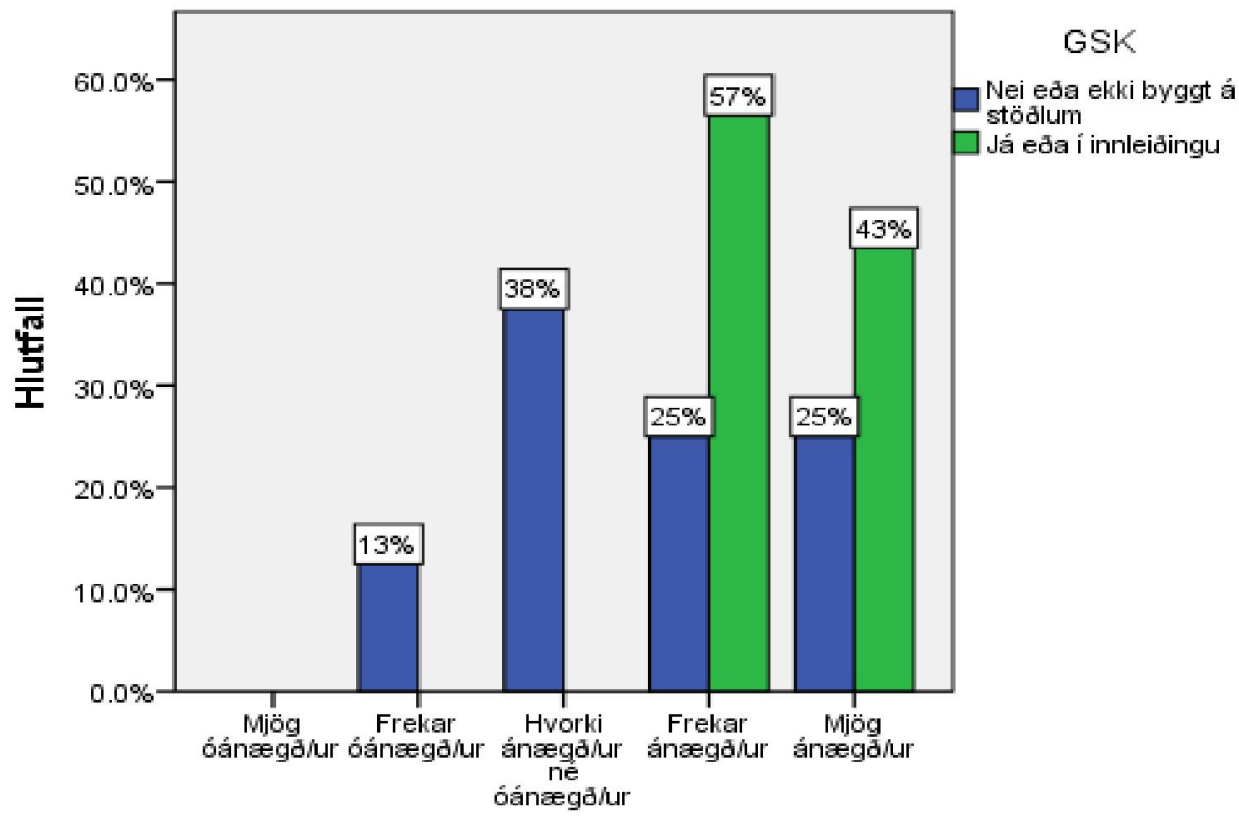

Hversu ảnægó/ur eôa óảnægô/ur ertu meô framkvæmd verksins sem umræddur verktaki vann?

47 gild tilfelli; 24 nei $\& 23$ ja

Mynd 7 Hlutfallsleg skipting GSK með tilliti til ánoegju verkkaupa með umrceddan verktaka

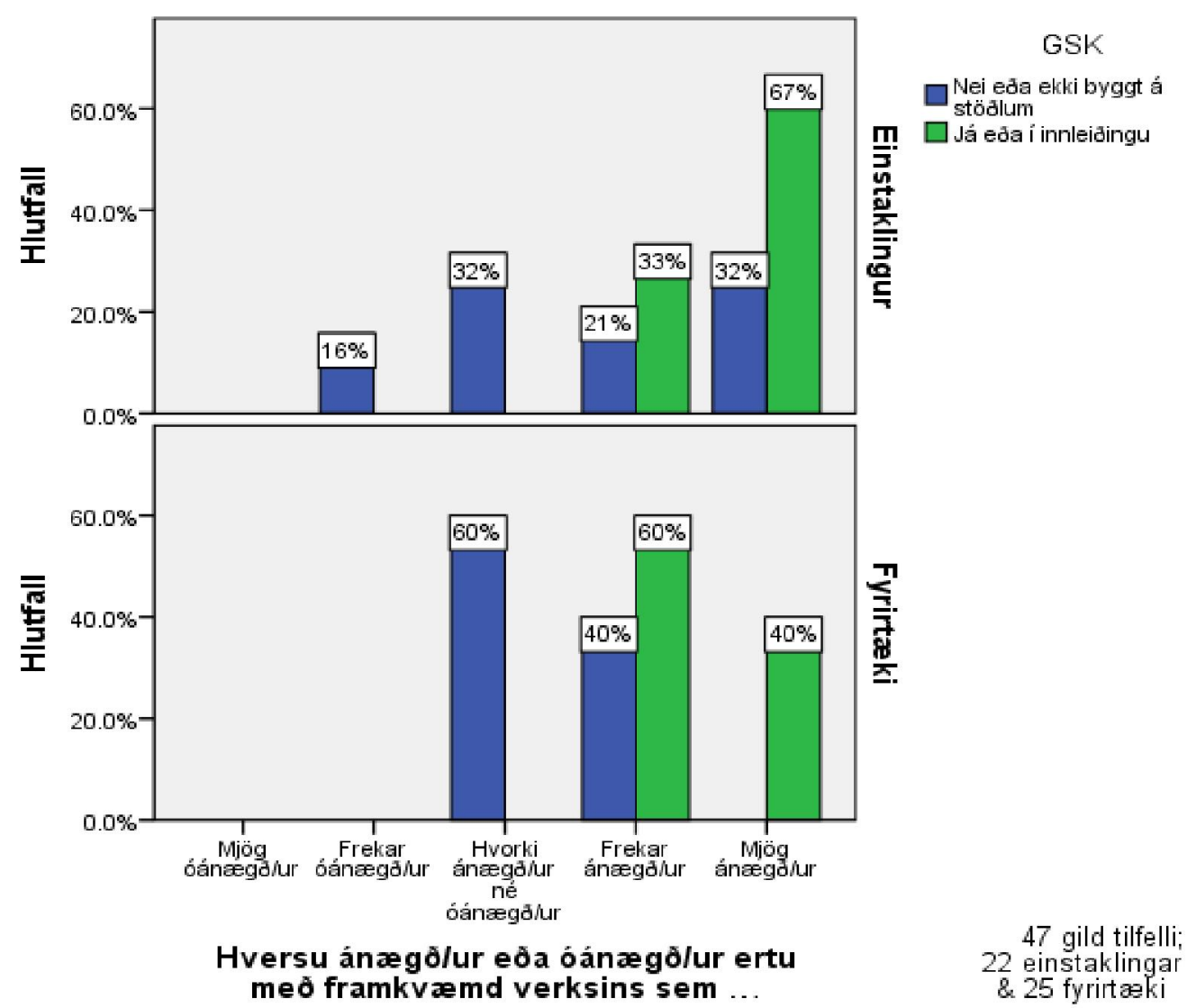

Mynd 8 Hlutfallsleg skipting á GSK með tilliti til ánogju verkkaupa með umroeddan verktaka sér í lagi fyrir einstaklings- og fyrirtcekjaverkkaupa 


\subsubsection{Gæðastjórnunarkerfi}

Pátttakendur voru spurðir að pví hvort peir hefðu vitneskju um pað hvort umræddur verktaki ynni eftir ákveðnu gæðastjórnunarkerfi og ef svo var hvort peir vissu á hverju gæðastjórnunarkerfið byggði og hvort pað hefði hlotið vottun.

Tæplega 26\% pátttakenda taldi umræddan verktaka notast við gæðastjórnunarkerfi og tæplega 33\% taldi svo ekki vera. Enginn svarenda taldi verktaka vera í innleiðingarferli en rúmlega $41 \%$ höfou ekki hugmynd um hvort umræddur verktaki ynni eftir gæðastjórnunarkerfi.

Pátttakendur svöruðu í flestum tilfellum eftir pví hvað peir töldu, en byggðu ekki endilega svar sitt á staðreyndum. Ef svör verkkaupa eru pöruð við svör umræddra verktaka í könnun fyrir verktaka mælist marktæk og sterk (Gamma 0,801) fylgni milli pess hvort verkkaupar töldu verktaka vinna eftir gæðastjórnunarkerfi og hvort verktakarnir sögðust vera að vinna eftir gæðastjórnunarkerfi eða ekki. Stólparitið hér að neðan sýnir hvernig svarhlutfall verkkaupa féll innan svarflokka hjá verktökum pegar peir voru spurðir hvort peir störfuðu eftir gæðastjórnunarkerfi í könnun fyrir verktaka.

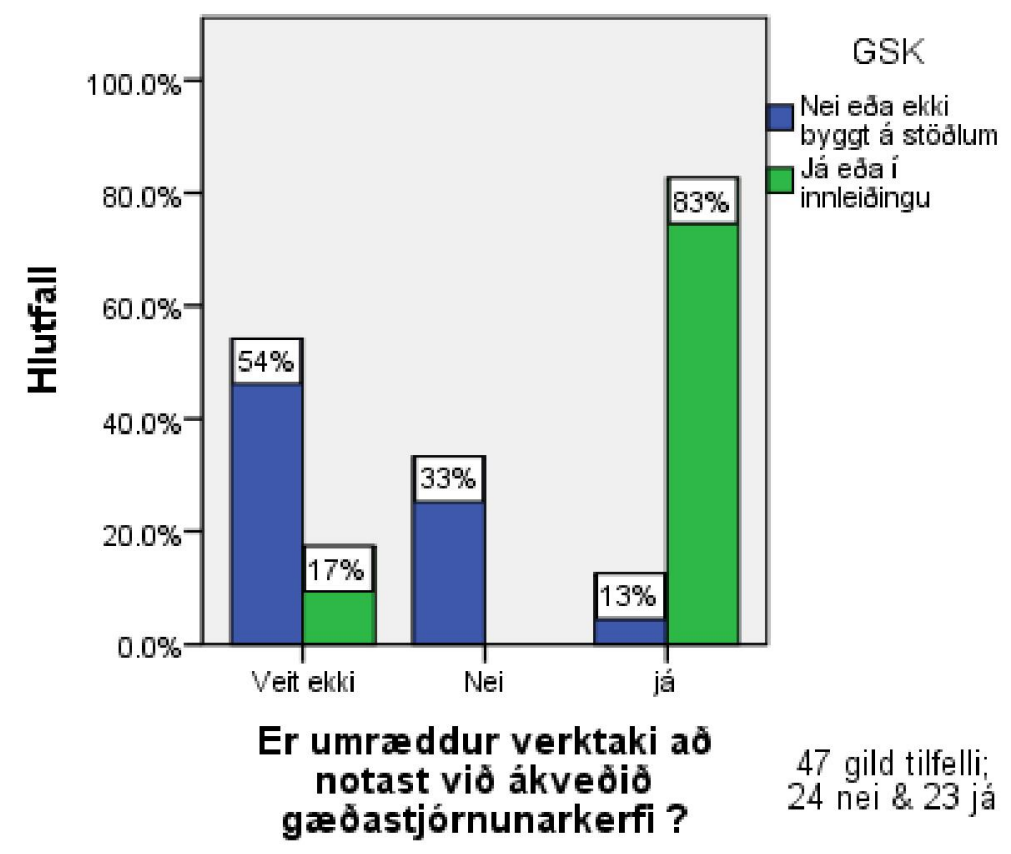

Mynd 9 Hlutfall svara verkkaupa um pað hvort peir telja að umrceddur verktaki vinni eftir gaðastjórnunarkerfi m.t.t. svara verktaka (GSK) 


\subsubsection{Grunnupplýsingar}

Tæplega 64\% pátttakenda voru einstaklingsverkkaupar, tæplega 90\% voru karlmenn og flestir, eða rúmlega 37\%, voru á aldrinum 36-45 ára, en sundurliðun á grunnupplýsingum eru á skífuritunum hér að neðan.
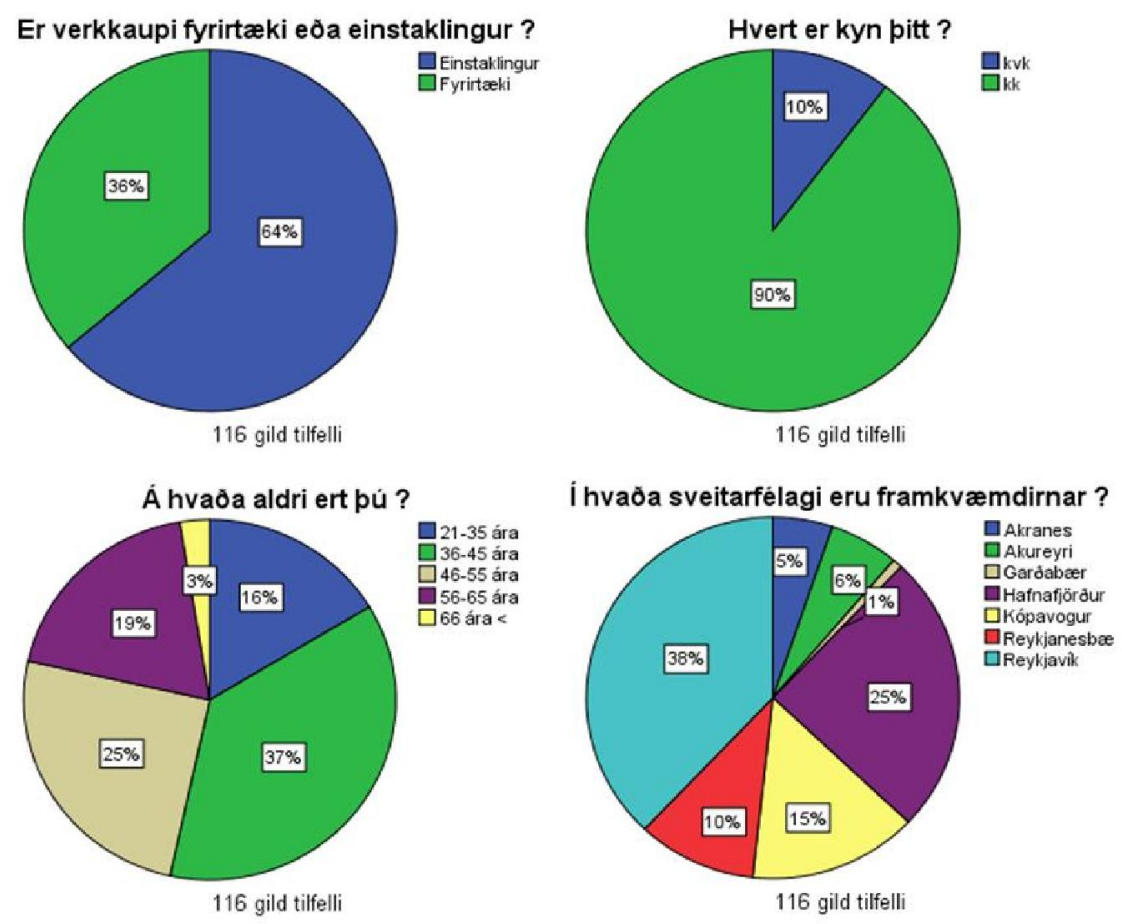

Mynd 10 Sundurliðun á grunnupplýsingum

\section{Ánægja viðskiptavinar}

Fylgni milli pess hversu ánægðir verkkaupar voru með framkvæmd verksins hjá umræddum verktaka og hvaða ár verkkaupi stóð í framkvæmdum reyndist marktæk fyrir árin 2009 (Gamma 0,633) og 2010 (Gamma 0,489), en ekki fyrir árin 2005-2008. Pessar niðurstöður gefa til kynna að verktakar vandi sig meira við að uppfylla kröfur verkkaupa eftir efnahagshrunið.

Einnig mælist marktæk fylgni milli annars vegar pess hversu ánægðir verkkaupar voru með framkvæmd verksins hjá umræddum verktaka og hins vegar kyns verkkaupa (Gamma 0,564) og aldurs (Spearman 0,282). Greina má talsvert meiri óhamingju meðal kvenkyns verkkaupa en karlkyns eins og stólparitið hér að neðan sýnir. 


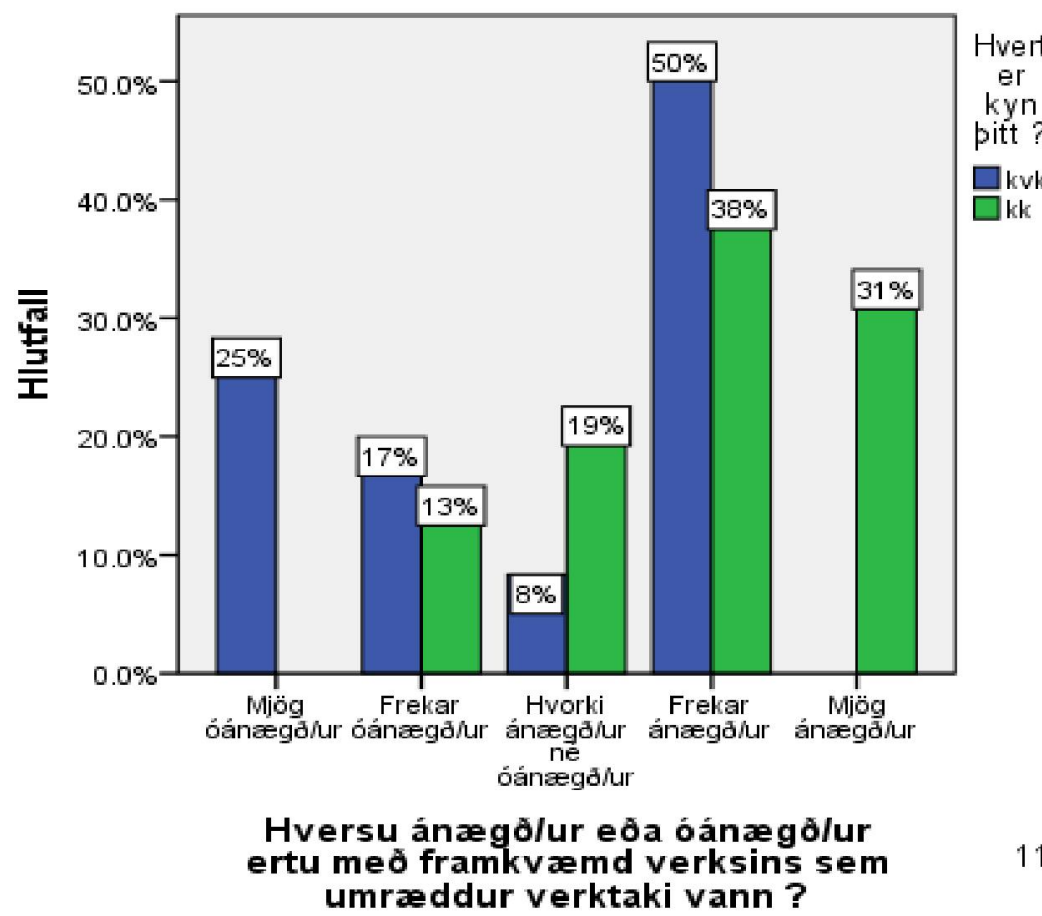

116 gild tilfelli; 12 kvk \& $104 \mathrm{kk}$

Mynd 11 Kynjahlutfall með tilliti til ánoegju verkkaupa

\subsubsection{Framkvæmd}

Pátttakendur voru spurðir að pví hvort byggingastjóri hafi séð um yfirstjórn verksins ásamt pví hvort peir hefou sjálfir verið byggingastjórar.

Í 58\% tilfella sá byggingastjórinn alfarið um yfirstjórn verksins og í rúmlega 15\% tilfella sá hann að hluta til um yfirstjórn. Eftir standa tæplega $27 \%$ tilfella par sem byggingastjórinn virðist einungis hafa verðið ,byggingastjóri““ að nafninu til. Svo virðist sem að oft hafi pað verið samkomulag milli pess sem er skráður byggingastjóri og pess sem raunverulega stjórnar verkinu að skráður byggingastjóri sé ekki með yfirstjórn verksins.

Peir pátttakendur sem voru ekki sjálfir byggingastjórar voru spurðir hvort peim pætti byggingastjóri hafa verið nægjanlega mikið til staðar. Rúmlega $21 \%$ svarenda $^{30}$ fannst byggingastjóri ekki vera nægilega mikið til staðar. Borið saman við hlutfall tilfella par sem byggingastjóri kom ekki nálægt stjórn verksins gefur pað til kynna að í mörgum tilfellum hafi pað verið samkomulagsatriði milli verkkaupa og byggingastjóra að sá síðarnefndi væri ekki meira til staðar.

Verkkaupar voru spurðir um tegund verktöku og var pá notast við skilgreiningu sem sjá má í kafla um skilgreiningar á bls. 414. Í tæplega 64\% tilfella voru framkvæmdirnar unnar sem fagverk sem gefur ákveðna hugmynd um pað að hátt hlutfall verka séu ekki mjög stórar

\footnotetext{
${ }^{30} 17$ svör eru flokkuð sem „,vantar“ en par af eru 16 pátttakendur sem ekki svöruðu vegna pess að peir voru sjálfir byggingastjórar.
} 
framkvæmdir ${ }^{31}$. Peir pátttakendur sem svöruðu pví til að verkið hafi verið unnið sem al-, aðal-, eða markverk ${ }^{32}$ voru pví næst spurðir hversu vel/illa peim pætti yfirstjórnandi verksins uppfylla skyldu sína sem milligöngumaður um samskipti við verktaka. Flestir, eða rúmlega $38 \%$, fannst yfirstjórnandi standa sig mjög vel hvað petta varðar. Rúmlega $52 \%$ svarenda voru mjög eða frekar ánægðir.

\section{Ánægja viðskiptavinar}

Fylgni milli pess hversu ánægður verkkaupi var með byggingastjóra og hversu ánægður verkkaupi var með framkvæmd verksins hjá umræddum verktaka var skoðuð með tilliti til pess hvort verkkaupi hafi verið fyrirtækjaverkkaupi eða einstaklingsverkkaupi. Fylgni reyndist marktæk fyrir einstaklingsverkkaupa (Gamma 0,482) og heildarfjölda (Gamma 0,449 ) pátttakenda, en ekki sérstaklega fyrir fyrirtækjaverkkaupa.

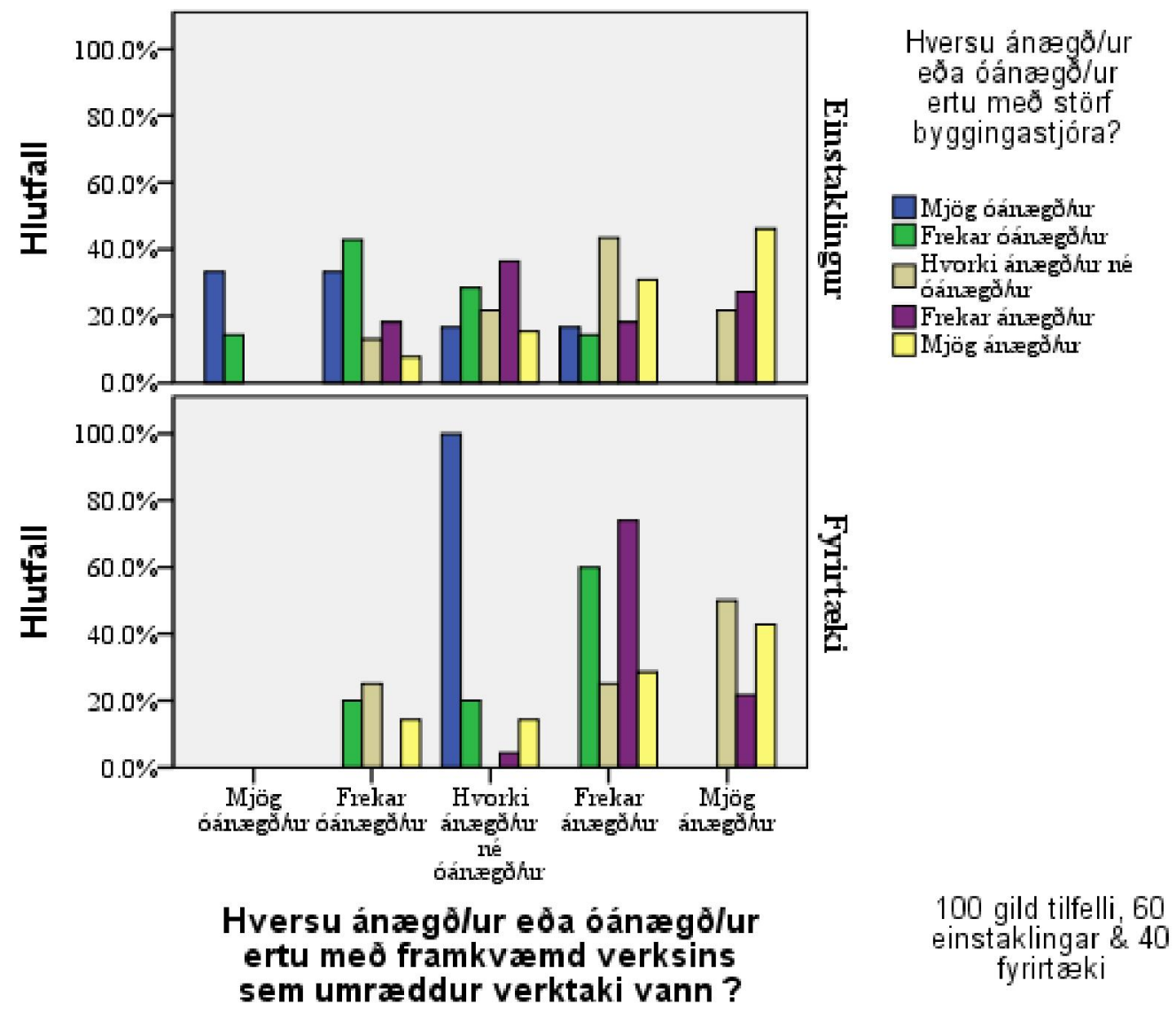

Mynd 12 Hlutfallsleg skipting á áncegju verkkaupa með byggingastjóra með tilliti til ánoegju verkkaupa með umroeddan verktaka, sér í lagi fyrir einstaklings- og fyrirtokjaverkkaupa.

\footnotetext{
${ }^{31}$ Sjá frekar kafla um athugasemdir á bls. 244

${ }^{32}$ peir pátttakendur sem sögðu verkið hafa verið unnið sem fagverk eru flokkaðir undir „vantar““
} 


\subsection{5 Áætlanir}

Gera má ráð fyrir að raunhæfar forsendur fyrir umfangi og verðlagningu framkvæmda séu stór páttur í ánægju verkkaupa. Óraunhæfar væntingar sem byggðar eru á fölskum forsendum draga pví úr gæðum framkvæmda. Spurningar varðandi tíma- og kostnaðaráætlanir voru pví lagðar fyrir pátttakendur.

Á skífuritum hér að neðan má sjá svarhlutfall við spurningum tengdum tímaáætlunum.

Lagői umræddur verktaki fram skriflega timaáætlun i upphafi verks ?
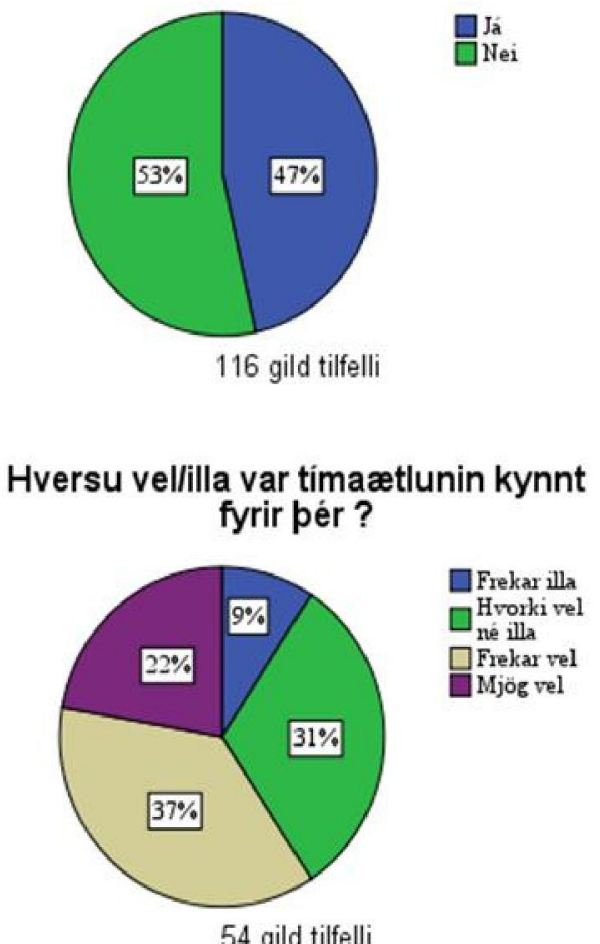

Mynd 13 Svarhlutfall á spurningum tengdum tímaácetlunum

\section{Hversu vönduôlóvönduỗ var timaảætlunin?}

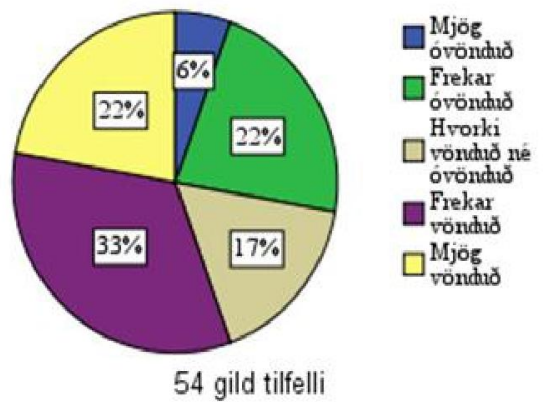

Er verkiō fariō fram úr eð̃a fór verkiō fram úr tímaáæetlun hjá umræeddum verktaka?

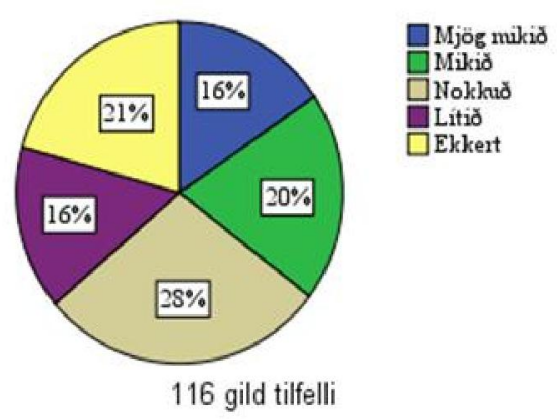

Rúmlega 46\% pátttakenda sögðu verktaka hafa lagt fram skriflega tímaáætlun, en tæplega $54 \%$ sögðu að slíkt hafi ekki verið gert. Gefa pessar niðurstöður til kynna að pað sé síður en svo regla að verktakar leggi fram skriflega tímaáætlun. Á stólparitinu hér að neðan má sjá hlutfallslega skiptingu milli einstaklings- og fyrirtækjaverkkaupa með tilliti til pess hvort lögð var fram skrifleg tímaáætlun. 


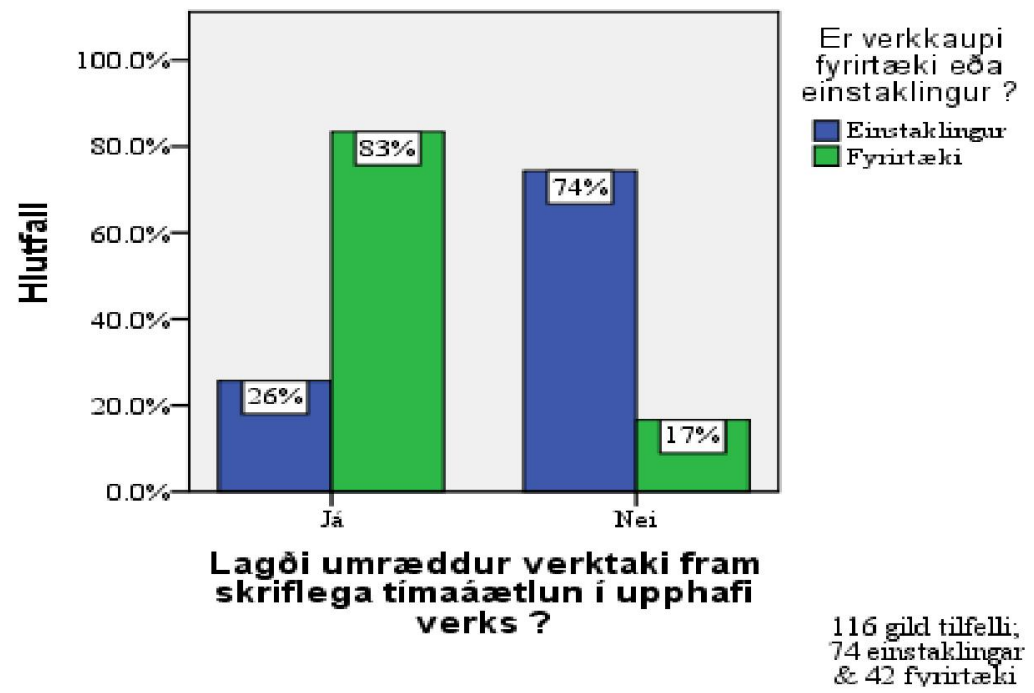

Mynd 14 Hlutfallleg skipting einstaklings- og fyrirtcekjaverkkaupa með tilliti til pess hvort lögð var fram skrifleg tímaácetlun eða ekki.

Deir verkkaupar sem sögðu verktaka hafa lagt fram skriflega tímaáætlun voru spurðir hvort hún hafi verið uppfærð og endurskoðuð reglulega. Rúmlega $43 \%$ svarenda töldu að svo hafi verið.

Allir pátttakendur voru svo spurðir hvort verkið hefði farið fram úr tímaáætlun hjá umræddum verktaka ${ }^{33}$. Niðurstöður sýna að ekki nema tæplega $21 \%$ svarenda telja að framkvæmdin sé samkvæmt tímaáætlun ${ }^{34}$, en að mati skýrsluhöfundar eru pað sláandi niðurstöður. Pó verður að taka tillit til pess að íslenskt veðurfar hefur oftar en ekki leikið byggingaverktaka grátt á Íslandi og er eðlilegt að pað tefji framkvæmdir í einhverjum tilfellum.

Á skífuritum hér að neðan má sjá svarhlutfall við spurningum tengdum tímaáætlunum.

\footnotetext{
${ }^{33}$ Verkkaupar sem höfðu einungis fengið munnlega tímaáætlun frá verktaka voru einnig spurðir

${ }^{34}$ Sjá kafla um athugasemdir á bls. 244
} 
Lagōi umræddur verktaki fram skriflega greiôslusáætlun i upphafi verks ?
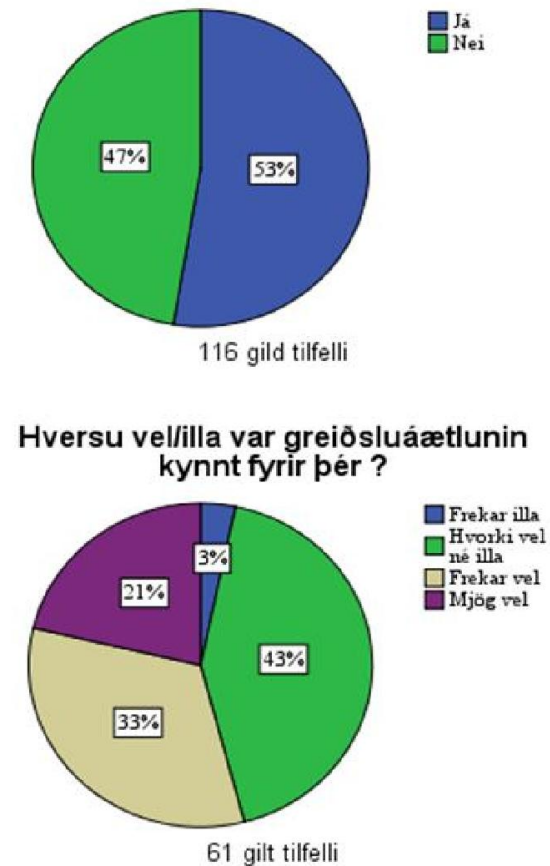

Hversu vönduơlóvönduơ var greiôsluáætlunin?

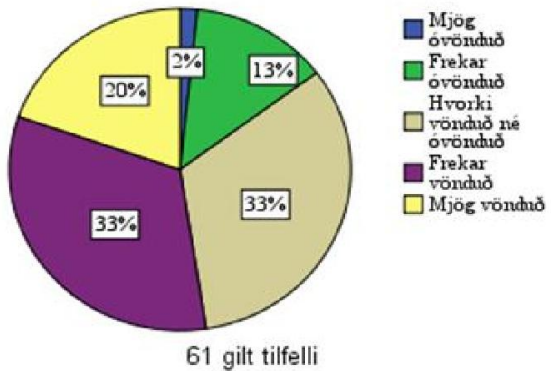

Er verkið fariơ fram ủr eða fór verkið̋ fram úr greiősluảætlun hjả umræddum verktaka?

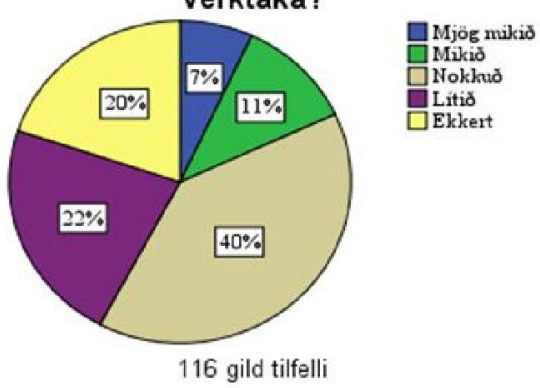

Mynd 15 Svarhlutfall á spurningum tengdum greiðsluácetlunum

Tæplega 53\% pátttakenda sögðu verktaka hafa lagt fram skriflega greiðsluáætlun, en næstum 48\% sögðu verktaka ekki hafa lagt fram skriflega greiðsluáætlun. Gefa pessar niðurstöður til kynna að pað sé síður en svo regla að verktakar leggi fram skriflega greiðsluáætlun í byrjun verks. Á stólparitinu hér að neðan má sjá hlutfallslega skiptingu milli einstaklings- og fyrirtækjaverkkaupa með tilliti til pess hvort lögð var fram skrifleg greiðsluáætlun. 


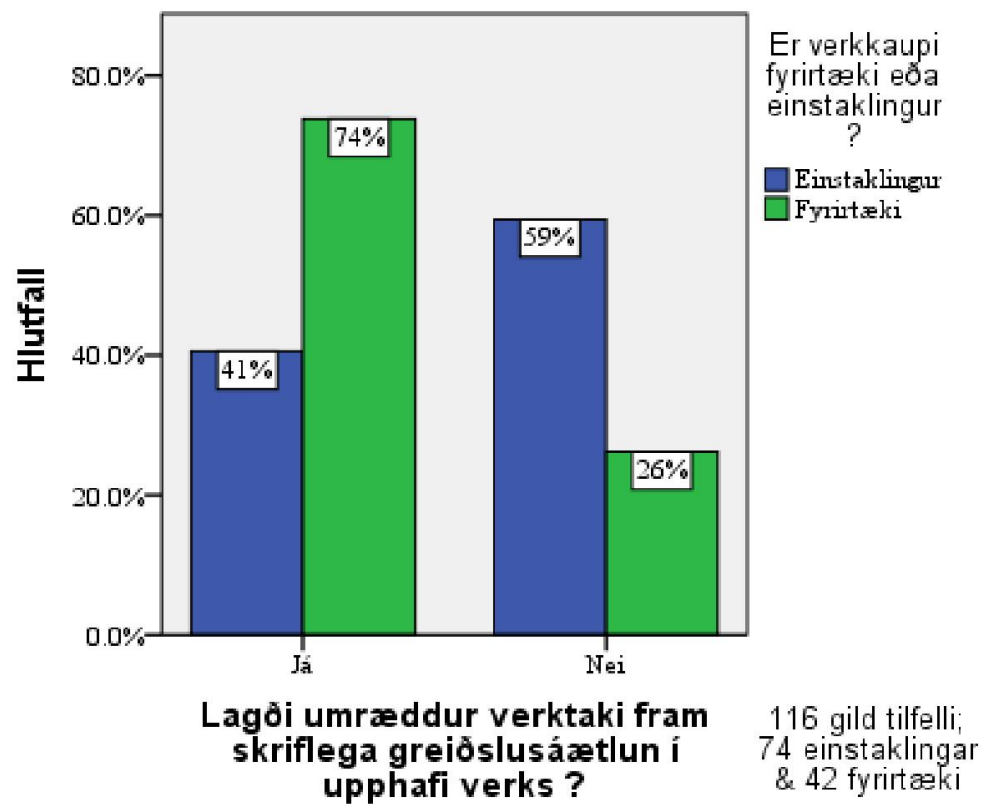

Mynd 16 Hlutfallleg skipting einstaklings- og fyrirtoekjaverkkaupa með tilliti til pess hvort lögð var fram skrifleg greiðsluácetlun eða ekki

Flestir verkkaupar, eða rúmlega 52\%, sem sögðu verktaka hafa lagt fram skriflega greiðsluáætlun töldu greiðsluáætlunina vera annað hvort mjög eða frekar vandaða.

Peir verkkaupar sem sögðu verktaka hafa lagt fram skriflega greiðsluáætlun voru spurðir hvort hún hafi verið uppfærð og endurskoðuð reglulega. Í $25 \%$ tilfella ${ }^{35}$ töldu verkkaupar að greiðsluáætlunin hafi verið endurskoðuð.

Allir $^{36}$ pátttakendur voru svo spurðir hvort verkið hefơi farið fram úr greiðsluáætlun ${ }^{37}$ hjá umræddum verktaka. Niðurstöður sýna að tæplega $20 \%$ svarenda telja að framkvæmdin sé samkvæmt greiðsluáætlun.

Hafa verður í huga að efnahagshrunið snerti margar framkvæmdir sem voru í úrtakinu og hefur pað vafalaust haft mikil áhrif á pessar niðurstöður.

\section{Ánægja viðskiptavinar}

Verkkaupar voru spurðir hversu ánægðir peir væru með tímastjórnun og fjármagnsstreymi $^{38}$ verksins sem umræddur verktaki vann. Niðurstöðurnar eru sýndar í skífuritinu hér að neðan, en pær gefa til kynna að hægt sé að gera betur við byggingaframkvæmdir

\footnotetext{
35 Stærð verks hefur vissulega áhrif á pað hvort nauðsynlegt sé að endurskoða áætlanir, en eins og fram kemur í athugasemdakafla hefði verið fróðlegt að hafa upplýsingar um slíkt.

${ }^{36}$ Verkkaupar sem höfðu einungis fengið munnlega greiðsluáætlun voru einnig spurðir

${ }^{37}$ Sjá athugasemdakafla bls. 240

${ }^{38}$ Með fjármagnsstreymi er átt við flæði greiðslna.
} 
hvað petta varðar. Athyglisvert er að verkkaupar voru almennt sáttari við fjármagnsflæði heldur en tímastjórnun prátt fyrir prengingar í efnahagslífinu undanfarið.
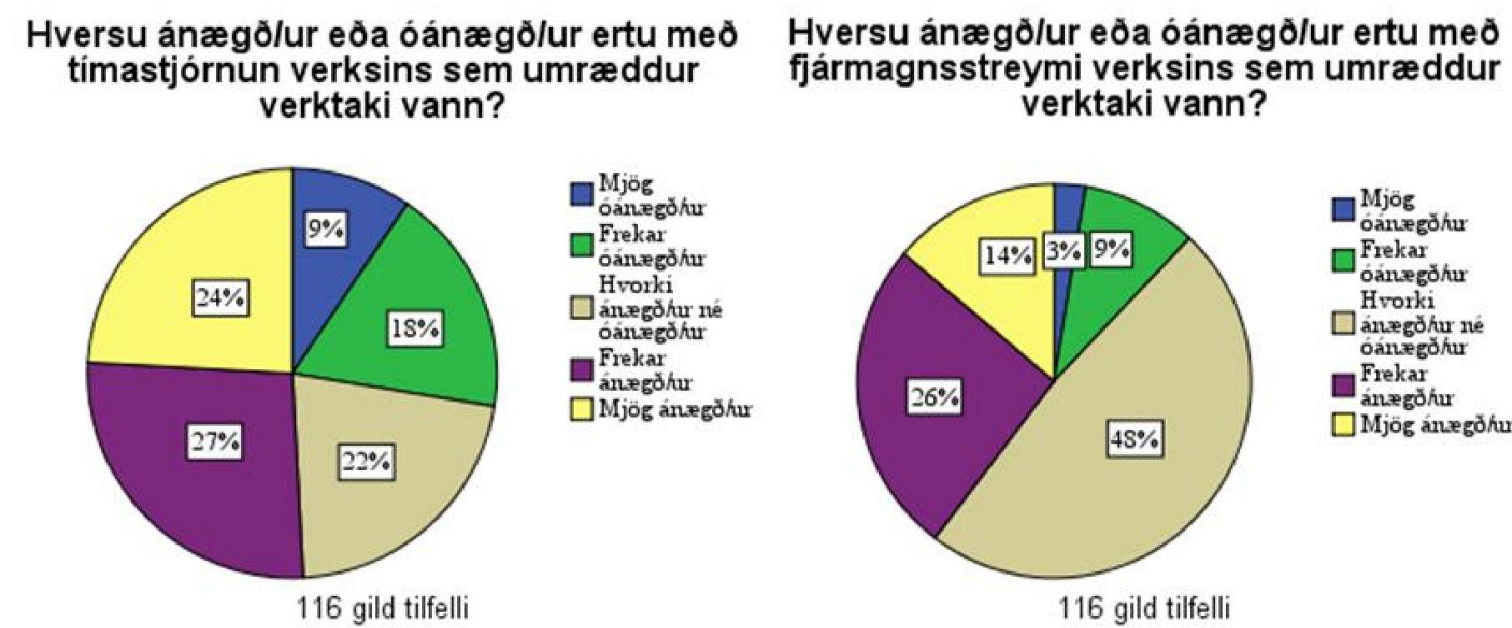

Mynd 17 Ánoegja verkkaupa með tímastjórnun og fjármagnsstreymi

Marktæk fylgni mældist á milli annars vegar hversu ánægðir verkkaupar voru með framkvæmd verksins hjá umræddum verktaka og hins vegar ánægju verkkaupa með tímastjórnun (Spearman 0,515) og hvort framkvæmdin stóðst tímaáætlun (Gamma 0,445). Einnig mældist marktæk fylgni milli pess hvort verkið hafi farið fram úr tímaáætlun og ánægju verkkaupa með tímastjórnun (Spearman 0,399). Fylgni milli pess hversu ánægður verkkaupi var með umræddan verktaka og hvort verktaki lagði fram skriflega tímaáætlun reyndist vera marktæk.

Fylgni milli pess annars vegar hversu ánægðir verkkaupar voru með framkvæmd verksins hjá umræddum verktaka og hins vegar hversu ánægðir verkkaupar voru með fjármagnsstreymi (Spearman 0,400) og hvort framkvæmdin fór fram úr greiðsluáætlun (Gamma 0,379 ) reyndist vera marktæk í báoum tilfellum. Einnig mældist mjög marktæk fylgni milli pess hvort verkið fór fram úr greiðsluáætlun og hversu ánægðir verkkaupar voru með fjármagnsstreymi (Spearman 0,460).

Fylgni milli pess hvort verkið hjá umræddum verktaka hafi farið fram úr greiðsluáætlun og hvort greiðsluætlun hafi verið skrifleg mældist marktæk en veik með Sommers'd, Kendall's tau-c og Gamma, en ekki marktæk með Spearman fylgnistuðli. Fylgni milli pess hversu ánægður verkkaupi var með umræddan verktaka og hvort verktaki lagði fram skriflega greiðsluáætlun reyndist ekki vera marktæk.

\section{GSK}

Fylgni mældist ekki marktæk milli annars vegar $G S K$ og hins vegar ánægju verkkaupa með tímastjórnun, fjármagnsstreymi og hvort framkvæmdir fóru fram úr tíma- og/eða greiðsluáætlunum. 
Fylgni milli annars vegar GSK og hins vegar hvort verktaki lagði fram skriflega tímaáætlun eða ekki (Gamma 0,840) og hvort verktaki lagði fram skriflega greiðsluáætlun eða ekki (Gamma 0,700) reyndist mjög marktæk og sterk. Hlutfallslega skiptingu svara GSK með tilliti til pess hvort lögð var fram skrifleg tímaáætlun/skrifleg greiðsluáætlun má sjá á stólparitum hér að neðan.
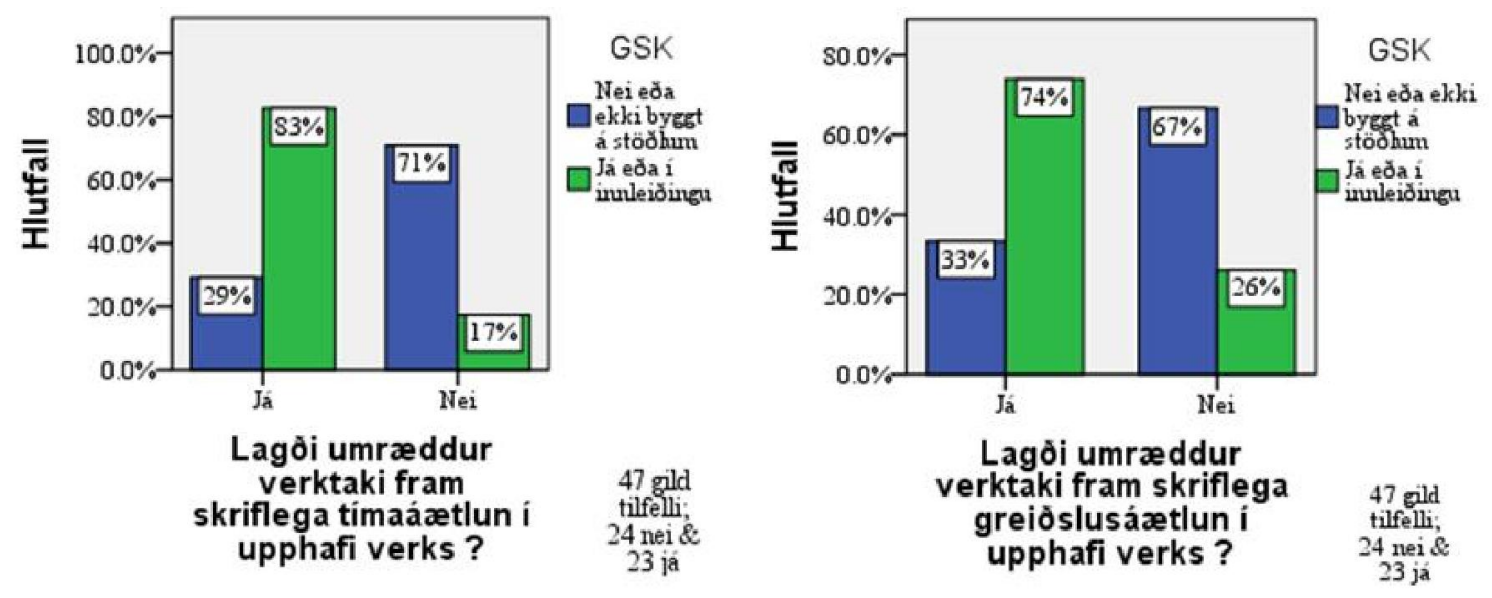

Mynd 18 Hlutfallsleg skipting GSK með tilliti til pess hvort lögð var fram skrifleg tíma og greiðsluácetlun

\subsubsection{Verkfundir}

Markvissir og reglubundnir verkfundir par sem verkkaupi og verktaki hittast og ræða framvindu framkvæmda eru vissulega mikilvægur páttur í samskiptum peirra á milli og ætla má að peir hafi áhrif á ánægju verkkaupa með framkvæmd verksins og stuðli að farsælum framkvæmdum. Ýmsar spurningar tengdar verkfundum voru pví lagðar fyrir verkkaupa.

Spurt var hvort verkkaupi hefði haft umsjónarmann ${ }^{39}$ sem sá um að framfylgja ákvæðum samningsins og ef svo var, hvaða menntun hann hefði. Rétt rúmlega $29 \%$ pátttakenda voru með sérstakan umsjónarmann. Eins og sést á stólparitinu hér að neðan, sem sýnir hlutfallslega skiptingu fyrirtækja- og einstaklingsverkkaupa með tilliti til pess hvort verkkaupi var með umsjónarmann eða ekki, var mjög fátítt að einstaklingsverkkaupar væru með umsjónarmann.

\footnotetext{
${ }^{39}$ Sjá betur skilgreiningu á umsjónarmanni á bls. 312
} 


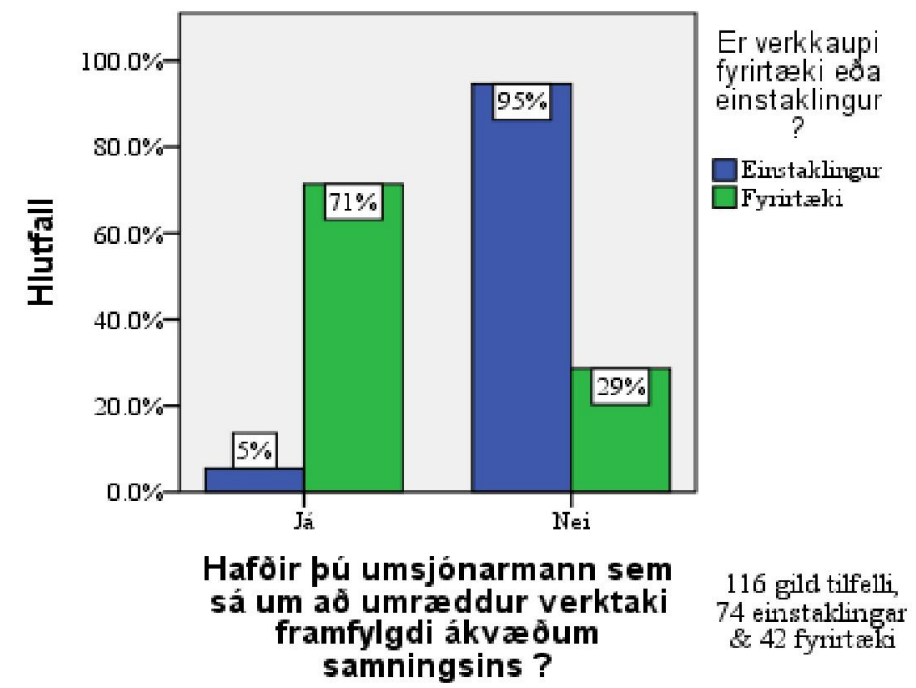

Mynd 19 Hlutfallsleg skipting fyrirtcekja- og einstaklingsverkkaupa með tilliti til pess hvort verkkaupi var með umsjónarmann.

Einnig var spurt hvort gert hafi verið samkomulag milli verkkaupa/umsjónarmanns og verktaka um reglubundna verkfundi peirra á milli. Niðurstöður sýna að rúmlega $40 \%$ svarenda sögðu að svo væri. Pátttakendur voru einnig spurðir hvort haldnir hefðu verið verkfundir ${ }^{40}$ með umræddum verktaka ${ }^{41}$ og á sama tíma voru pátttakendur beðnir um að leggja mat á pað hvort verkfundirnir hafi verið formlegir eða óformlegir. Skilgreiningu á formlegum og óformlegum verkfundum má sjá kafla um skammstafanir og skilgreiningar. Skilgreiningin býður upp á svigrúm fyrir verkkaupa til að leggja persónulegt mat á pað hvort fundirnir hafi verið nægjanlega formlegir til að geta flokkast sem slíkir. Hér að neðan má sjá hlutfallslega skiptingu fyrirtækja- og einstaklingsverkkaupa með tilliti til pess hvort haldnir voru verkfundir eða ekki, en mjög marktæk og sterk (Gamma 0,864) fylgni er par á milli.

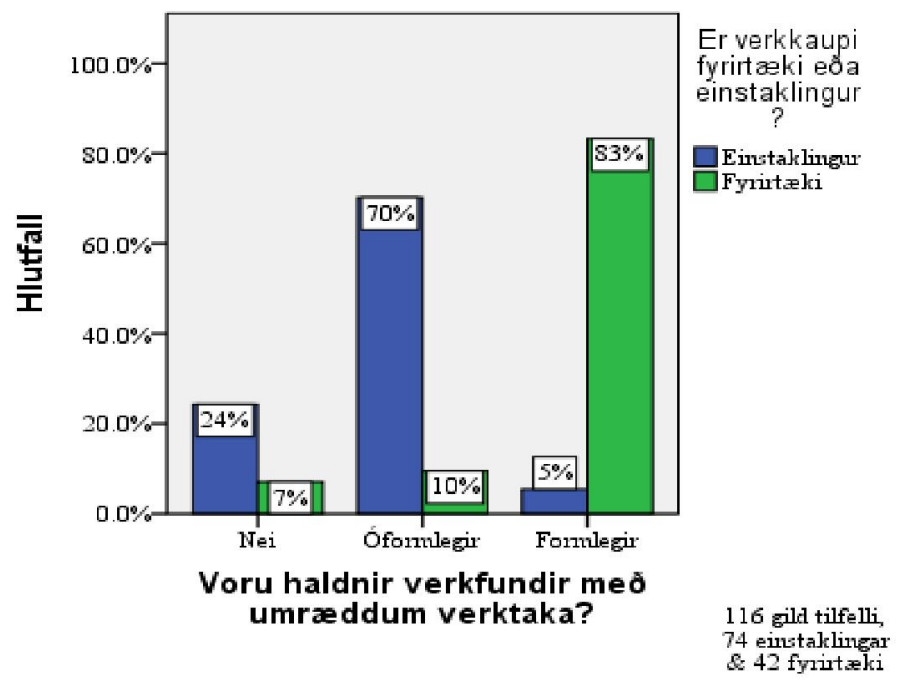

Mynd 20 Hlutfallsleg skipting fyrirtcekja- og einstaklingsverkkaupa með tilliti til pess hvort haldnir voru verkfundir með verktaka og verkkaupa.

\footnotetext{
${ }^{40}$ Hér er ekki endilega átt við reglubundna verkfundi

${ }^{41}$ Sjá betur um petta í athugasemd kafla á bls. 241
} 
Hafa ber í huga að í peim tilfellum sem verkkaupi og verktaki hittust ekki á verkfundum var í flestum tilfellum um að ræða íbúðarhúsnæði par sem verkkaupi mætti jafnvel daglega á verkstað til að fylgjast með. Баð er pví á endanum matsatriði hvort verkkaupi telji að eiginlegir verkfundir, óformlegir eða formlegir, hafi átt sér stað. Samkvæmt niðurstöðum svöruðu tæplega 34\% pátttakenda pví til að formlegir verkfundir hafi átt sér stað, rúmlega $48 \%$ töldu að ó formlegir fundir hafi átt sér stað og rúmlega $18 \%$ töldu að engir verkfundir hafi átt sér stað. Rúmlega 36\% verkkaupa sem voru ýmist með óformlega verkfundi eða ekki með verkfundi hefðu kosið að hafa verkfundina með öðrum hætti.

Einnig var kannað hvort rituð hafi verið fundargerð á verkfundunum. Tæplega 61\% svöruðu pví til að aldrei hafi verið rituð fundargerð á verkfundum.

Að lokum var spurt hvort verktaki hafi farið ítarlega yfir verklýsingar og teikningar á milli verkpátta og verkkaupi spurður hvort hann hefði viljað vera boðaður oftar á verkfundi, ef hann var á annað borð boðaður á slíka fundi. 80\% svarenda voru sáttir við fjölda verkfunda en $20 \%$ hefðu viljað hafa fleiri verkfundi. Í tæplega $28 \%$ tilfella voru verkkaupar óánægðir með yfirferð verktaka á verklýsingum og teikningum milli verkpátta.

\section{Ánægja viðskiptavinar}

Fylgni milli annars vegar hversu ánægður verkkaupi var með umræddan verktaka og hins vegar hvort haldnir hefðu verið verkfundir með fulltrúa verkkaupa og verktaka (Gamma 0,274), hversu vel verktaki hefði farið yfir stöðu mála á verkfundum (Gamma 0,329) og hvort verkkaupi hefði viljað hafa fleiri verkfundi (Gamma 0,737) reyndist í öllum tilfellum vera marktæk en ekki sérlega sterk fyrir fyrstu tvö tilfellin en sterk fyrir pað síðastnefnda. Hér að neðan má sjá stólparit sem sýnir hlutfallslega skiptingu ánægju verkkaupa með tilliti til pess hvort haldnir voru verkfundir eða ekki.

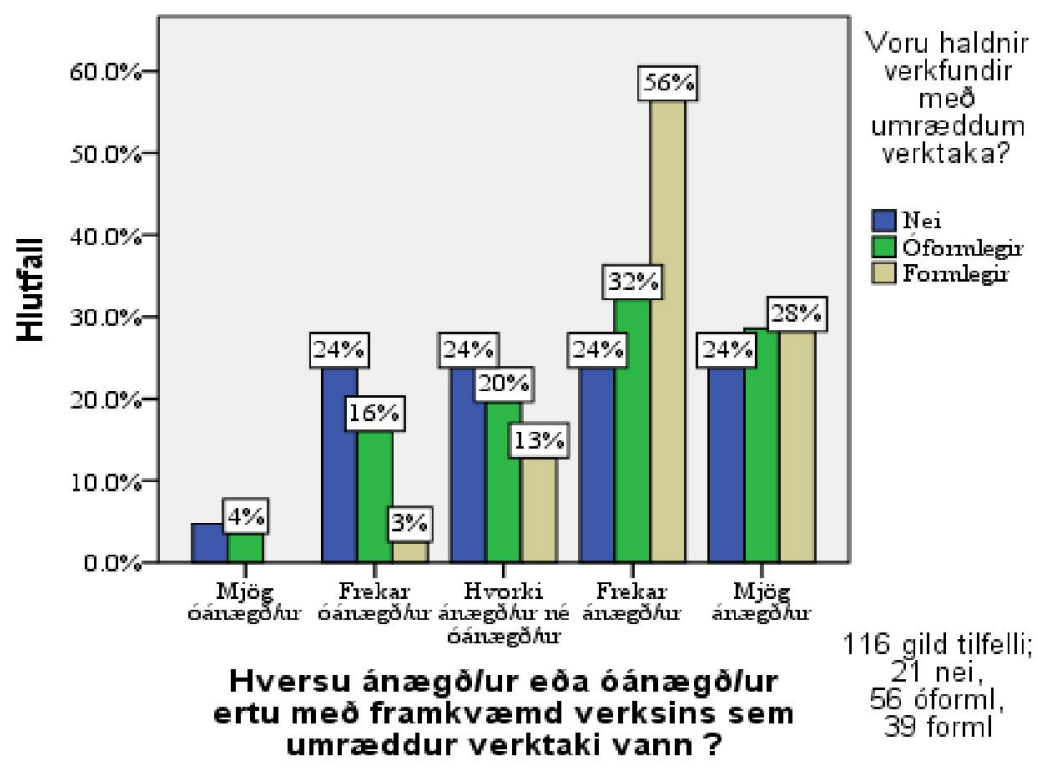

Mynd 21 Hlutfallsleg skipting fyrirkomulagi verkfunda og ánoegju verkkaupa með umrceddan verktaka. 


\section{GSK}

Fylgni milli annars vegar $G S K$ og hins vegar hvort haldnir voru verkfundir með verkkaupa (Gamma 0,778), hvort rituð var fundargerð á verkfundum (Spearman 0,441) og hversu vel verktaki fór yfir stöðu mála á verkfundum (Spearman 0,454) reyndist mjög marktæk og frekar sterk. Hér að neðan má sjá stólparit sem sýna annars vega hlutfallslega skiptingu á GSK með tilliti til pess hvort haldnir voru verkfundir eða ekki og hins vegar með tilliti til pess hvort rituð var fundargerð eða ekki.
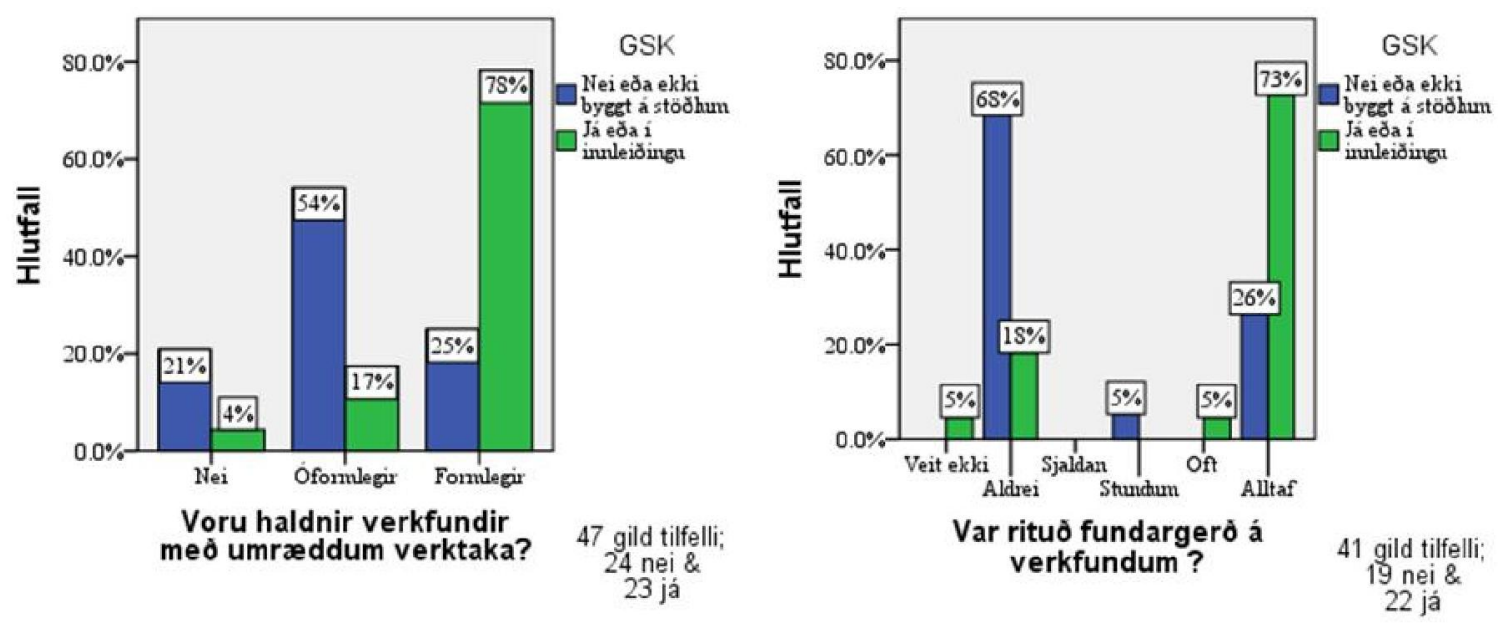

Mynd 22 Hlutfallsleg skipting GSK með tilliti til pess hvort haldnir voru verkfundir eða ekki og hvort skrifuð var fundargerð á verkfundum eða ekki

\subsubsection{Samningar}

Ef staðið er rétt að tilboðsgerð og hún vönduð með ítarlegri sundurliðun er líklegt að pað dragi úr líkum á ágreiningi milli verkkaupa og verktaka.

Á skífuritunum hér að neðan má sjá svarhlutfall við spurningum tengdum samningum. 

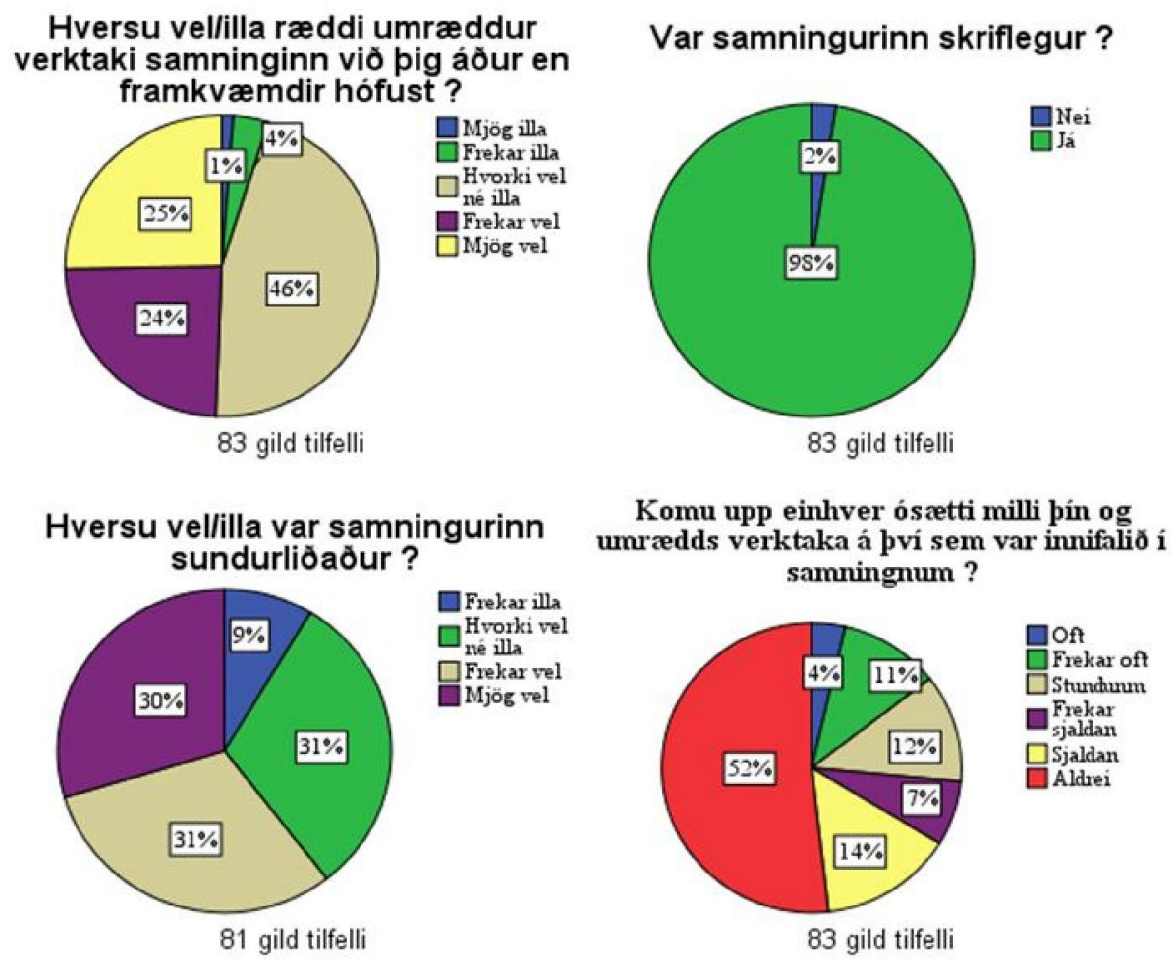

Mynd 23 Svarhlutfall á spurningum tengdum samningum.

Rúmlega 28\% verka voru unnin í reikningsvinnu og tæplega 72\% í tilboðsvinnu. Í 98\% tilfella sem verkið var í tilboðsvinnu var samningurinn skriflegur. Peir pátttakendur sem sögðu að samningur hefði verið skriflegur voru beðnir um að gefa sitt álit á pví hversu vel peim pótti samningurinn vera sundurliðaður. Að lokum var spurt hvort einhver ósætti eða misklíð hafi komið upp á milli verktaka og verkkaupa um pað hvað hefði verið innifalið í samningnum. Tæplega 52\% svarenda sögðust aldrei hafa átt í ósættum við verktaka um pað hvað var innifalið í samningum en rúmlega 48\% könnuðust við slíkt.

Hér að neðan má sjá hlutfallslega skiptingu á pví hversu vel verkkaupum fannst samningurinn vera sundurliðaður með tilliti til pess hve oft ósætti á innihaldi samnings komu upp. Fylgni milli pessa pátta reynist ekki marktæk en eins og stólparitið gefur til kynna pá er hún engu að síður til staðar í úrtakinu. 


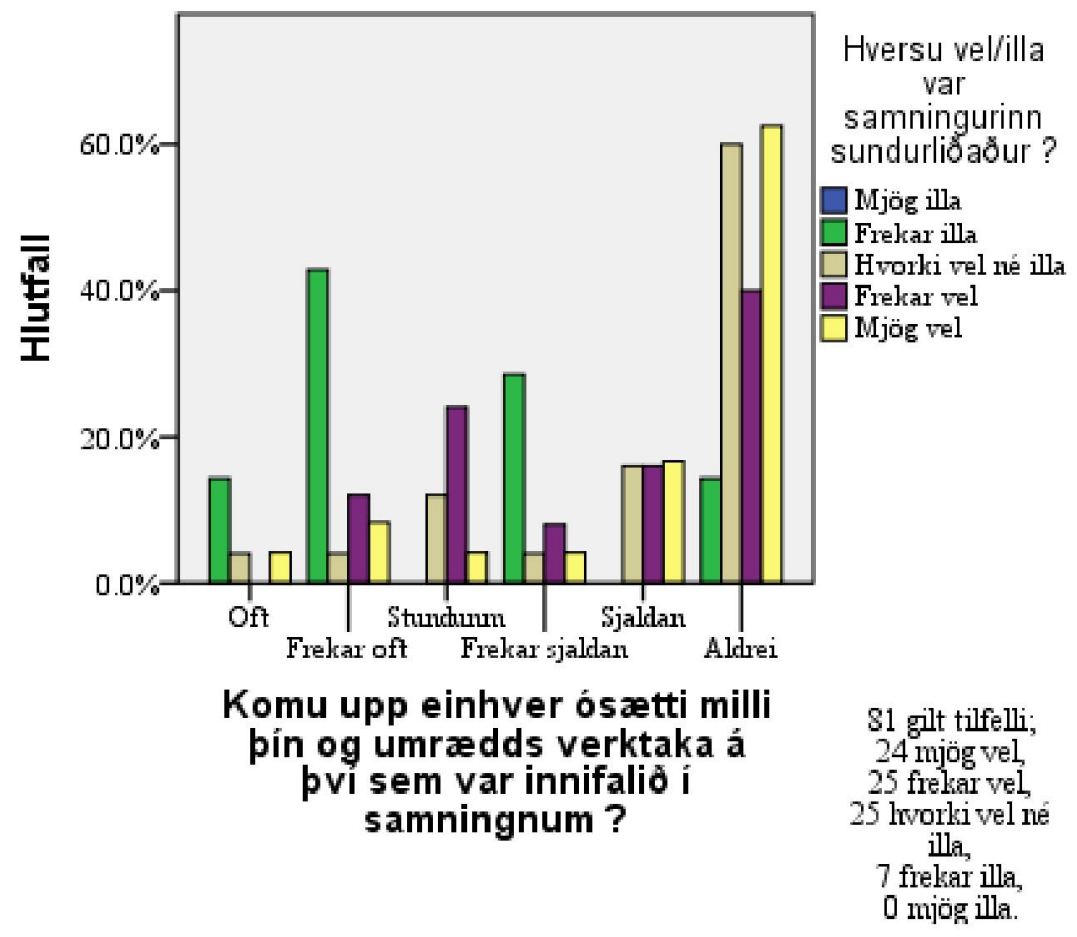

Mynd 24 Hlutfallsleg skipting á sundurliðun samnings með tilliti til fjölda óscetta um innihald samnings

\section{Ánægja viðskiptavinar}

Marktæk fylgni mælist milli pess hversu ánægðir verkkaupar voru með umræddan verktaka og hversu vel samningurinn var ræddur við verkkaupa áður en framkvæmdir hófust (Spearman 0,307).

Athyglisvert er að fylgni milli annars vegar hversu oft/eða hvort ósætti um innihald samnings hafi komið upp eða hversu vel samningurinn var sundurliðaður og hins vegar milli pess hversu ánægðir verkkaupar voru með umræddan verktaka reyndist ekki vera marktæk.

\section{GSK}

Fylgni milli annars vegar $G S K$ og hins vegar hversu vel verktaki ræddi samninginn við verkkaupa áður en framkvæmdir hófust (Spearman 0,446) og hversu vel samningurinn var sundurliðaður (Spearman 0,350) reyndist marktæk. Hér að neðan má sjá stólparit sem sýnir hlutfallslega skiptingu á $G S K$ með tilliti til pess hve vel samningur var sundurliðaður. 


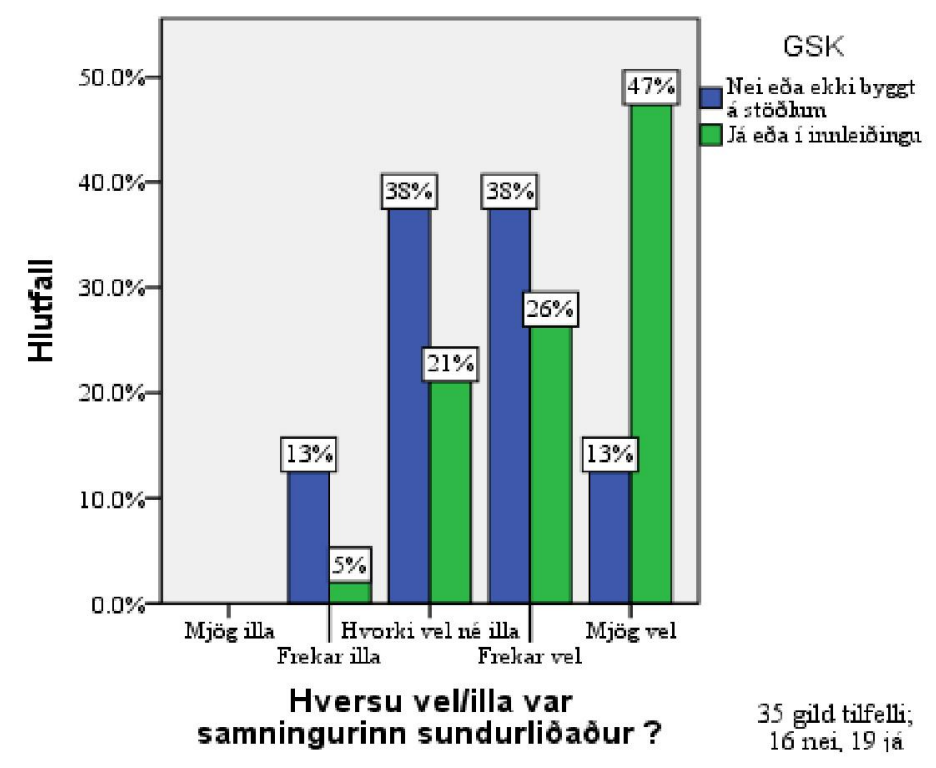

Mynd 25 Hlutfallsleg skipting á GSK með tilliti til pess hve vel samningur var sundurliðaður.

\subsubsection{Frábrigði}

Spurt var hvort einhver frábrigði ${ }^{42}$ frá verkáætlun hefðu komið upp á verktíma og ef svo var hvort verkkaupa hafi verið tilkynnt um frábrigðið munnlega eða skriflega.

Tæplega 13\% svarenda svöruðu að aldrei hefðu komið upp frábrigði á verktíma, en ástæðan fyrir svo lágu hlutfalli er líklega hversu víðtæk skilgreiningin á frábrigði er. Sundurliðun á svörum má sjá á skífuritinu hér að neðan.

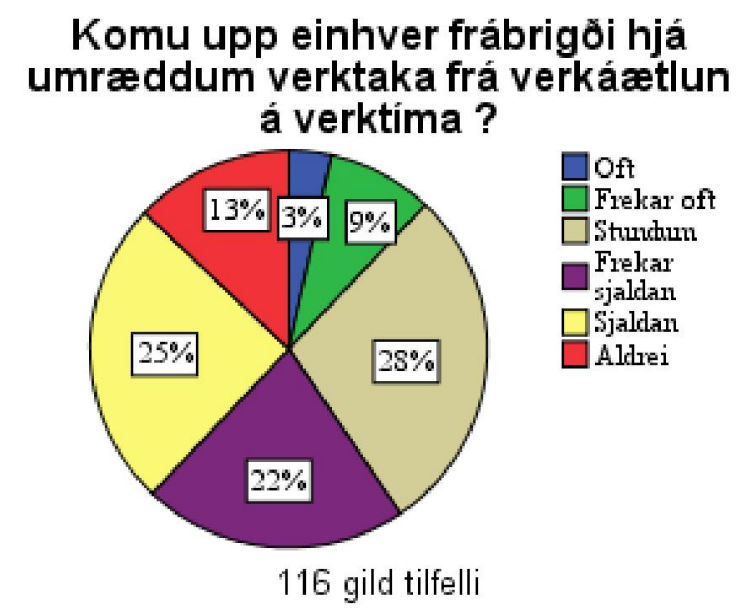

Mynd 26 Fjöldi frábrigða hjá umrceddum verktaka á verktíma

\footnotetext{
${ }^{42}$ Sjá skýringu á frábrigðum í kafla um skilgreiningar á bls. 312 auk athugasemda í athugasemdakafla bls.241
} 
Rúmlega $61 \%$ svarenda sögðu að verktaki hafi tilkynnt sér munnlega um frábrigði. Burtséð frá verklagi verktaka getur pað gefið til kynna að umrædd frábrigði hafi verið lítilsháttar.

\section{Ánægja viðskiptavinar}

Fylgni milli pess hversu ánægðir verkkaupar voru með framkvæmd verksins hjá umræddum verktaka og hversu oft frábrigði komu upp á verktíma reyndist marktæk (Gamma 0,492) en fylgni milli pess hversu ánægðir verkkaupar voru með framkvæmd verksins hjá umræddum verktaka og hvort/hvernig peim var tilkynnt um frábrigði reyndist ekki marktæk.

\section{GSK}

Fylgni milli pess annars vegar hvort verkkaupi starfaði eftir gæðastjórnunarkerfi byggðu á viðurkenndum gæðastjórnunarstöðlum og hins vegar fjölda frábrigða eða hvort/hvernig verkkaupa var tilkynnt um frábrigði reyndist ekki vera marktæk.

\subsubsection{Aukaverk og breytingar}

Spurt var hvort óskir um breytingar og aukaverk ${ }^{43}$ hafi verið skráðar ef ráðist hafði verið í slík verk og ef svo var, hvort áhrif á framvindu heildarverks og verðlagningu hafi komið par fram.

Rúmlega 35\% svarenda sögðu að gerð hafi verið aukaverk eða breyting/ar frá upphaflegu samkomulagi á framkvæmdartíma verksins. Í rúmlega $38 \%$ tilfella taldi verkkaupi að verktaki hafi ekki skráð niður óskir verkkaupa um aukaverk eða breytingar.

\section{Ánægja viðskiptavinar}

Fylgni milli pess hvort aukaverk eða breytingar hafi verið gerðar og hversu ánægður verkkaupi var með framkvæmd versins hjá umræddum verktaka reyndist ekki vera marktæk.

\subsubsection{Umgengni verktaka á verkstað}

Pátttakendur voru spurðir að pví hvernig peim hefði fundist umgengni verktaka á verkstað vera $^{44}$. Einnig var verktaki beðinn að nefna hvað honum hefði pótt miður fara varðandi umgengni verktaka á verkstað ef eitthvað var.

\footnotetext{
${ }^{43}$ Sjá skilgreiningar kafla bls. 312

${ }^{44}$ Er pá átt við umgengni bæði á meðan framkvæmdum stóð og eftir að framkvæmdum er lokið ef verkinu er lokið.
} 
Tæplega 53\% pátttakenda svöruðu að peim pætti umgengni umrædds verktaka á verkstað vera mjög eða frekar góð. Rúmlega $47 \%$ pátttakenda fannst umgengni umrædds verktaka vera í eða undir meðallagi sem gefur til kynna að umgengni verktaka sé ábótavant. Sundurliðun á svörum má sjá á skífuritinu hér að neðan.

\section{Hvernig fannst bér umgengni umrædds verktaka á verkstaõ vera?}

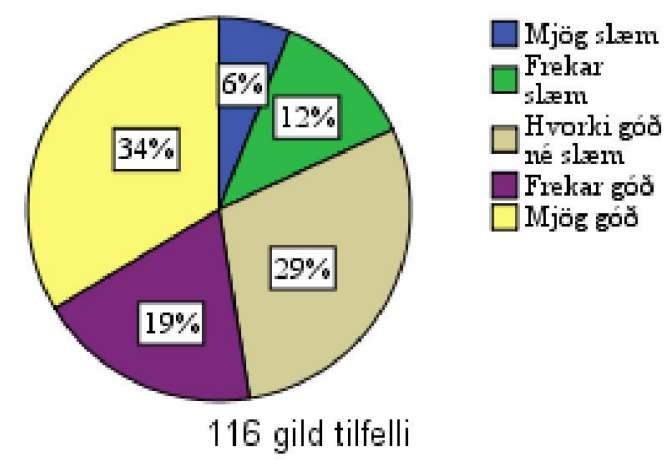

Mynd 27 Umgengni verktaka á verkstað

Að lokum var verkkaupi spurður hvort hann hefði orðið pess var að verktaki notaðist við efni sem ekki fullnægði peim kröfum sem settar höfou verið. Tæplega 95\% pátttakenda svöruðu að peir hefðu ekki orðið pess varir að notast hefði verið við efni sem ekki uppfyllti kröfur.

\section{Ánægja viðskiptavinar}

Fylgni milli pess hvernig verkkaupa fannst verktaki ganga frá eftir sig á verkstað og hversu ánægður verkkaupi var með framkvæmd verksins hjá umræddum verktaka (Gamma 0,551) reyndist vera mjög marktæk og milli pess að vera miðlungs eða frekar sterk.

\section{GSK}

Fylgni milli pess hversu vel verkkaupum fannst verktaki ganga frá eftir sig á verkstað og $G S K$ reyndist ekki vera marktæk.

\subsubsection{1 Öryggismál}

Öryggismál eru mikilvægur hluti af gæðastjórnun og ættu pau ávallt að vera hluti af gæðastjórnunarkerfum verktaka. Eins og kunnugt er eru byggingaframkvæmdir afar mismunandi að umfangi og pað sama gildir fyrir öryggis- og heilbrigðisáætlanir, en engu að síður ætti ávallt að ræða öryggismál áður en framkvæmdir hefjast.

Spurt var hvort öryggismál hefou verið rædd áður en framkvæmdir hófust og ef svo var hvort pau hafi pá sérstaklega verið sett í hendur verktaka á meðan verktíma stóð. Einnig 
var spurt hversu sáttur verkkaupi hafi verið með meðhöndlun öryggismála. Svarhlutfall á spurningum tengdum öryggismálum má sjá á skífuritum hér að neðan.
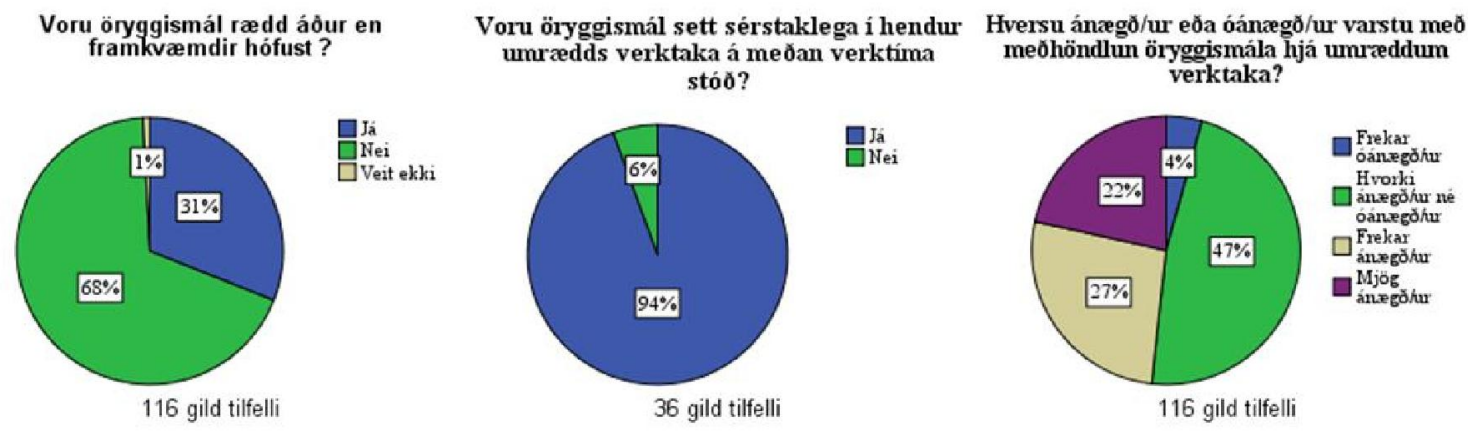

Mynd 28 Öryggismál

Rúmlega $68 \%$ pátttakenda svöruðu að öryggismál hafi ekki verið rædd áður en framkvæmdir hófust. Peir pátttakendur sem svöruðu að öryggismál hefou verið rædd áður en framkæmdir hófust svöruðu í rúmlega 94\% tilfella að öryggismál hefðu verið sett sérstaklega í hendur umrædds verktaka sem gefur tilefni til að draga í efa að verkkaupar almennt geri sér grein fyrir peirri ábyrgð sem á pá er sett með tilliti til öryggismála. Einkum og sér í lagi á petta við um einstaklinga í hópi verkkaupa.

Einungis rúmlega 4\% svarenda sögðust vera frekar óánægðir pegar pátttakendur voru spurðir hversu sáttir peir væru með meðhöndlun öryggismála hjá umræddum verktaka og enginn var mjög óánægður.

\section{Ánægja viðskiptavinar}

Fylgni milli pess hversu ánægður verkkaupi var með framkvæmd hjá umræddum verktaka og hversu ánægður verkkaupi var með meðhöndlun öryggismála hjá umræddum verktaka (Spearman 0,318) reyndist mjög marktæk og miðlungs sterk.

\section{GSK}

Marktæk og frekar sterk fylgni mældist milli annars vegar GSK og hins vegar pess hvort öryggismál voru rædd sérstaklega í verkbyrjun (Spearman 0,576) og ánægju verkkaupa með meðhöndlun öryggismála hjá verktaka (Spearman 0,393). Hér að neðan má sjá hlutfallslega skiptingu á GSK með tilliti til pess hvort öryggismál voru rædd eða ekki. 


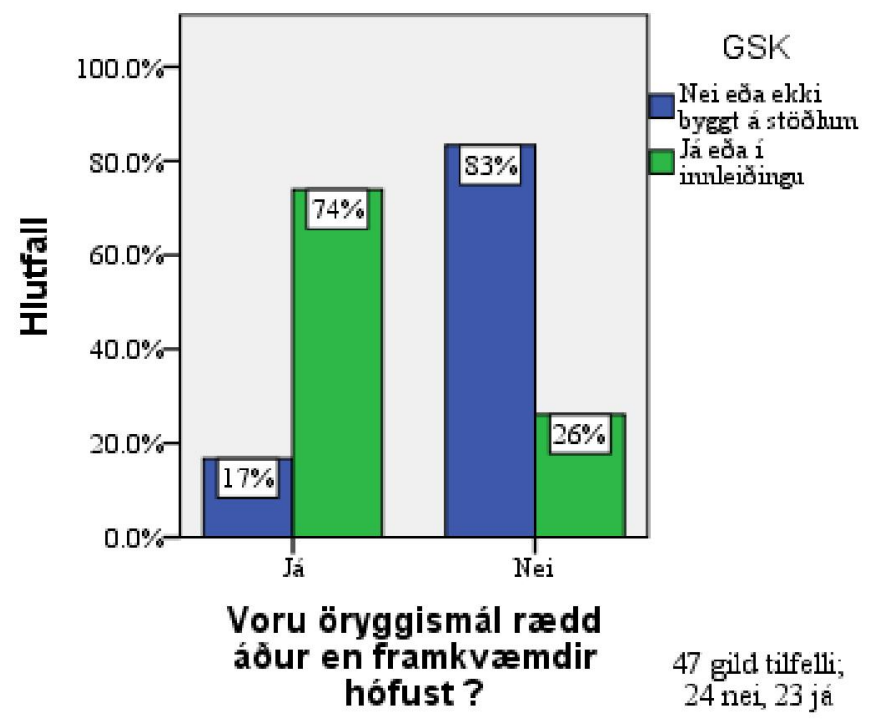

Mynd 29 Hlutfallsleg skipting á GSK með tilliti til pess hvort öryggismál voru raedd eða ekki.

\subsubsection{Samskipti}

Spurt var hvort verktaki hafi rætt við verkkaupa um væntanlegar samskiptaleiðir peirra á milli áður en samningur var gerður. Einnig var spurt hversu sáttur verkkaupi hafi verið með samskipti á milli sín og verktaka og hvort upp hafi komið einhver vandamál í samskiptum peirra á milli og hver pá. Að lokum var spurt hvað verkkaupa hafi fundist um pjónustulund verktaka. Svarhlutfall á spurningum tengdum samskiptum má sjá á skífuritum hér að neðan.
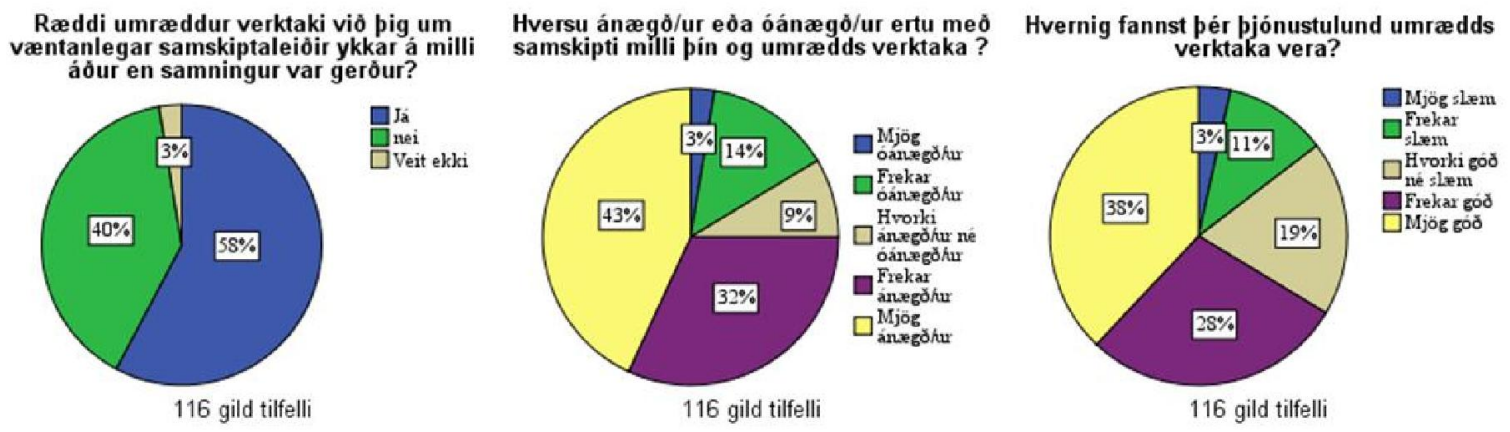

Mynd 30 Samskipti

Tæplega 58\% svarenda sögðu verktaka hafa rætt við sig áður en framkvæmdir hófust um væntanlegar samskiptaleiðir peirra á milli en skýrsluhöfundur varð pess gjarnan var að pátttakendur virtust hafa átt í erfiðleikum með að ná í verktaka yfir framkvæmdartíma. Engu að síður voru 75\% svarenda mjög eða frekar ánægðir með samskipti milli sín og umrædds verktaka.

Pátttakendur voru einnig spurðir hvernig peim hefði pótt pjónustulund umrædds verktaka vera og svöruðu rúmlega $66 \%$ að peir væru mjög eða frekar ánægðir. 


\section{Ánægja viðskiptavinar}

Fylgni milli annars vegar hversu ánægðir verkkaupar voru með umræddan verktaka og hins vegar hversu ánægðir verkkaupar voru með samskipti við verktaka (Gamma 0,579) og pjónustulund (Gamma 0,368) verktaka reyndist mjög marktæk og frekar/miðlungs sterk.

\section{GSK}

Fylgni mældist ekki marktæk milli GSK og ánægju verkkaupa með samskipti við verktaka.

\subsubsection{Gæðatrygging}

Með gæðatryggingu ${ }^{45}$ er átt við skriflegt plagg par sem verktaki setur fram allar pær vinnureglur sem hann ætlar að vinna eftir í verkinu til að tryggja ákveðin gæði.

Verkkaupar voru spurðir hvort peir hefðu farið fram á að verktaki sýndi sér skriflega hvernig hann hygðist vinna verkið til að uppfylla gæðakröfur. Niðurstöður sýna að tæplega 84\% pátttakenda sögðust ekki hafa farið fram á gæðatryggingu frá verktökum. Pessar niðurstöður gefa til kynna að kröfur verkkaupa til verktaka um skipulag og markvissa stjórnun séu ekki nægar. Ef kröfurnar eru til staðar hjá verkkaupum koma pær ekki fram nægjanlega snemma til að hægt sé að koma í veg fyrir óánægju verkkaupa vegna slakrar stjórnunar.

Einnig var spurt hvort verktaki hafi sýnt verkkaupa fram á gæðatryggingu, óháð pví hvort verkkaupi hafi farið fram á pað og gefa niðurstöður mjög svipuð hlutföll og áður. Tæplega $82 \%$ svarenda sagði að svo hefði ekki verið. Lesa má út úr pessum tölum að í einhverjum tilfellum hafi verktaki sýnt verkkaupa fram á gæðatryggingu án pess að verkkaupi hafi krafist pess.

\section{Ánægja viðskiptavinar}

Fylgni milli pess hvort umræddur verktaki hafi sýnt verkkaupa fram á gæðatryggingu í upphafi framkvæmda og hversu ánægður verkkaupi var með framkvæmdir hjá umræddum verktaka reyndist marktæk og miðlungs sterk (Gamma 0,413). Á stólparitinu hér að neðan má sjá hlutfallslega skiptingu á ánægju verkkaupa með tilliti til pess hvort verktaki lagði fram gæðatryggingu eða ekki.

\footnotetext{
${ }^{45}$ Sjá kafla um skilgreiningar bls. 312
} 


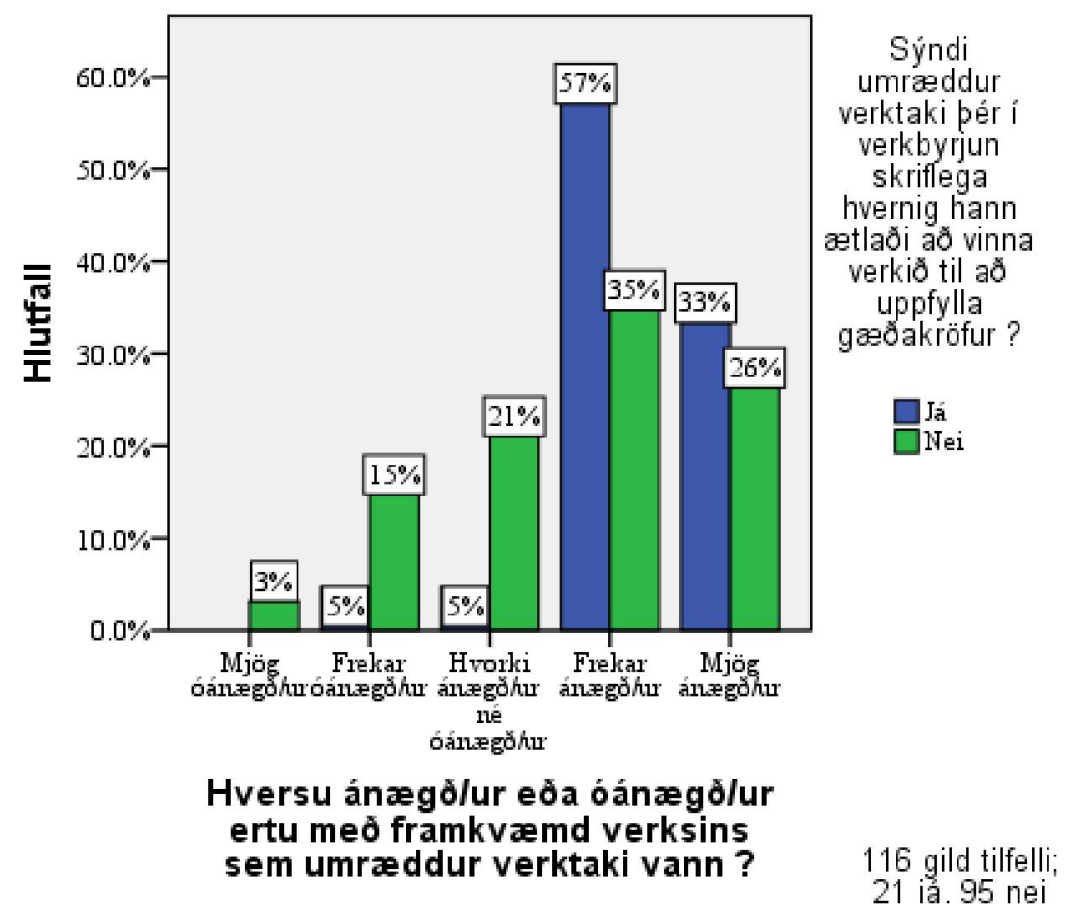

Mynd 31 Hlutfallsleg skipting á pví hvort umrceddur verktaki lagði fram gceðatryggingu með tilliti til ánoegju verkkaupa með umrceddan verktaka

\section{GSK}

Fylgni milli pess hvort verktaki hafi lagt fram gæðatryggingu í upphafi framkvæmda og hvort verktaki starfi eftir gæðastjórnunarkerfi byggðu á viðurkenndum gæðastjórnunarstöðlum reyndist vera marktæk (Gamma 0,820) og sterk. Á stólparitinu hér að neðan má sjá hlutfallslega skiptingu $G S K$ með tilliti til pess hvort verktaki lagði fram gæðatryggingu eða ekki.

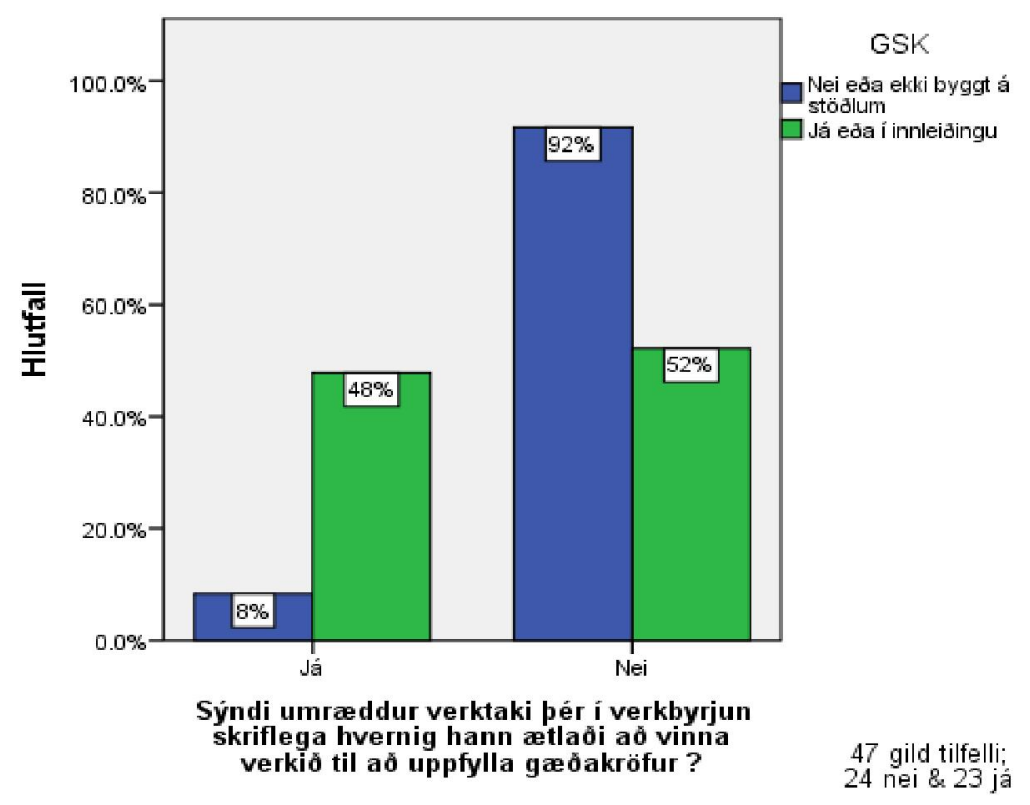

Mynd 32 Hlutfallsleg skipting á GSK með tilliti til pess hvort verktaki lagði fram gaðatryggingu eða ekki 
Fylgni milli annars vegar $G S K$, og hins vegar hversu oft verktaki telur sig leggja fram gæðatryggingu (Spearman 0,551), hversu oft verktaki telur verkkaupa óska eftir gæðatryggingu (Spearman 0,526) og hversu oft verktaki krefur undirverktaka sína um gæðatryggingu (Spearman 0,586) reyndist mjög marktæk og frekar sterk í öllum tilfellum.

\subsubsection{Gæði}

Ætla má að pegar verkkaupi gengur til samstarfs með verktaka um ákveðna framkvæmd, að gæði byggingarinnar ásamt gæðum á pjónustu og áætlunum spili inn í ánægju verkkaupa um heildarframvindu verksins. Pví voru pátttakendur spurðir um hversu sáttir peir hefðu verið með gæði verksins sem umræddur verktaki vann. Með pví er átt við gæði verklega páttarins sem verktakinn vann. Niðurstöður sýna að rúmlega $73 \%$ pátttakenda voru mjög eða frekar ánægðir en sundurliðun á svörum má sjá á skífuritinu hér að neðan.

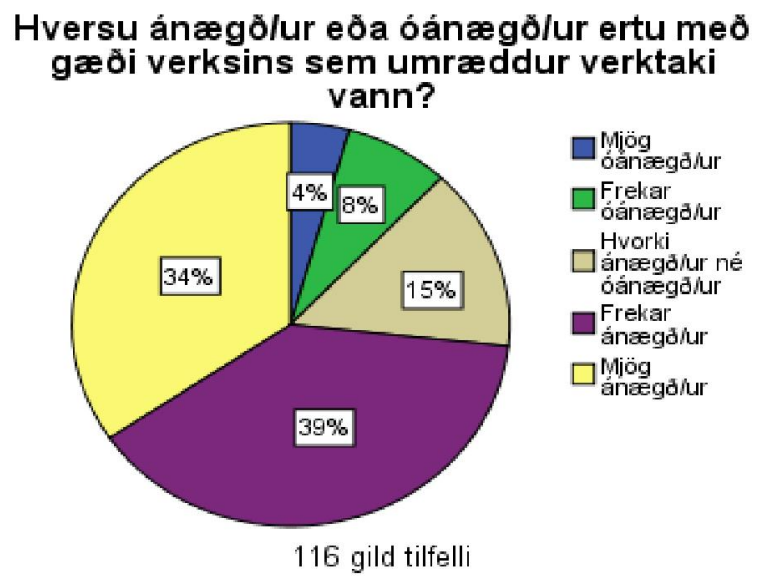

Mynd 33 Áncegja verkkaupa með goeð framkvoemda

\section{Ánægja viðskiptavinar}

Fylgni milli annars vegar ánægju verkkaupa með framkvæmd hjá umræddum verktaka og hins vegar ánægju verkkaupa með gæði verksins reyndist marktæk og sterk (Gamma $0,735)$ enda er eðlilegt að gæði framkvæmda spili stóran pátt í ánægju verkkaupa með verktaka. ๖að verður pó að hafa í huga að peir verkkaupar sem tóku pátt í könnuninni voru flestir ný búnir að standa í framkvæmdunum sem peir voru spurðir um. Eðli málsins samkvæmt koma gæði byggingaframkvæmda ekki alltaf strax í ljós.

\section{GSK}

Fylgni milli annars vegar $G S K$, og hins vegar ánægju verkkaupa með gæði verks hjá umræddum verktaka (Gamma 0,707) reyndust marktæk og sterk. Hér að neðan má sjá stólparit sem sýnir hlutfallslega skiptingu GSK með tilliti til ánægju verkkaupa með gæði framkvæmda. 


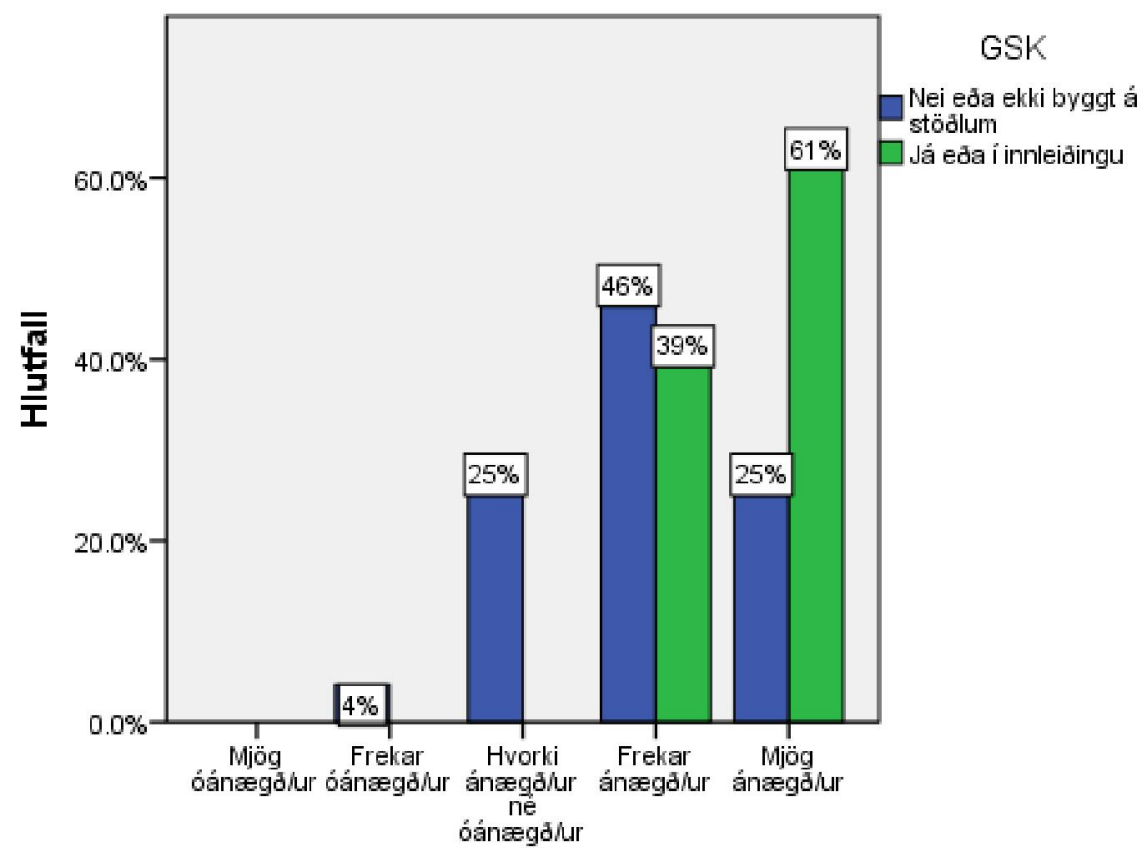

Hversu ánægō/ur eớa óánægỏ/ur ertu meô gæo̊i verksins sem umræeddur

47 gild tilfelli 24 nei \& 23 já verktaki vann?

Mynd 34 Hlutfallsleg skipting á GSK með tilliti til ánœgju verkkaupa með gœði framkvoemda 


\subsection{Greining gagna úr könnun fyrir verktaka}

Hér eru kynntar helstu niðurstöður úr könnunum fyrir verktaka sem var tekin á tímabilinu 4. febrúar til 25. febrúar 2011.

Líkt og í greiningu gagna úr könnun fyrir verkkaupa pá var mesta fylgni milli breyta sem mældust með marktæka fylgni gefin upp í sviga. Gildi allra útreiknaðra fylgnistuðla má sjá í viðauka I á bls. 341.

Uppbygging kaflans er svohljóðandi: Farið er yfir frumniðurstöður allra flokka í könnun verktaka og innan peirra er sérstaklega farið yfir fylgni við ánægju verkkaupa í könnun fyrir verkkaupa ${ }^{46}$ og GSK.

Öll breytuheiti eru skilgreind í viðauka D á bls. 201.

\subsubsection{Grunnupplýsingar}

$60 \%$ svarenda voru byggingaverktakar og $72 \%$ svarenda störfuðu hjá fyrirtækjum sem voru með minna en 10 starfsmenn. Samkvæmt skilgreiningu Evrópusambandsins flokkast fyrirtæki með 0-9 starfsmenn undir pað að vera smá og fyrirtæki með 99 starfsmönnum og færri flokkast undir pað að vera lítil (Gustafsson, 2001). Ef við notum pessa skilgreiningu til pess að flokka íslensk fyrirtæki í byggingar og mannvirkjagerð á árabilinu 1998-2005 pá falla 99,8\% peirra undir pað að vera smá (Hagstofa Íslands, 2007) en með ofangreinda viðmiðun flokkast hlutfall smárra fyrirtækja viðunandi í úrtaki. Sundurliðun á grunnupplýsingum má sjá á skífuritunum hér að neðan.
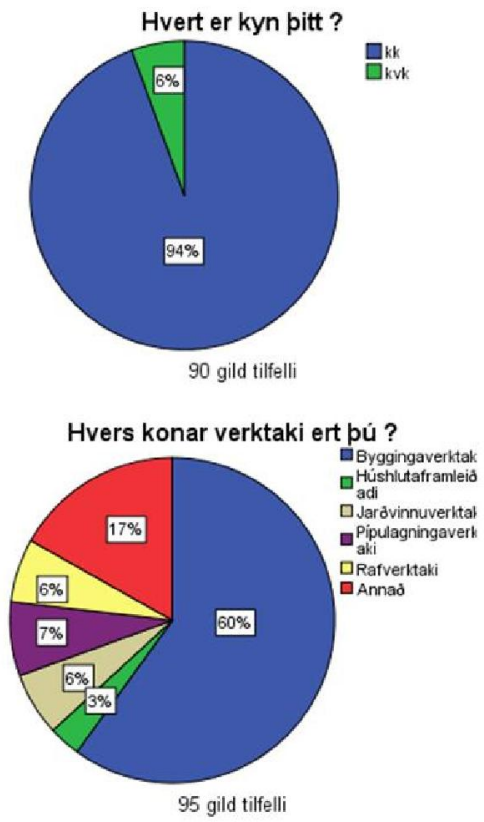

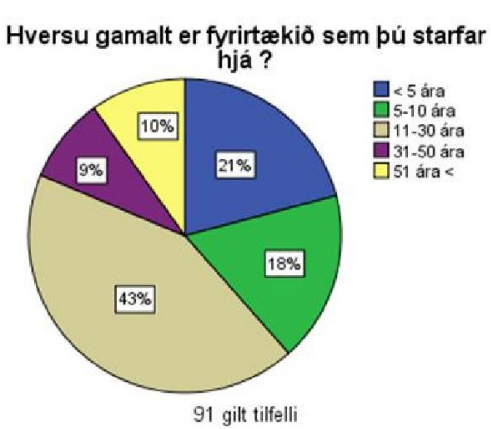

Mynd 35 Sundurliðun á grunnupplýsingum

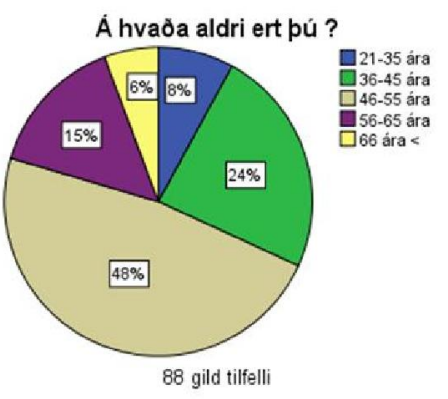

Hvaõ starfa margir hjá fyrirtækinu sem pú

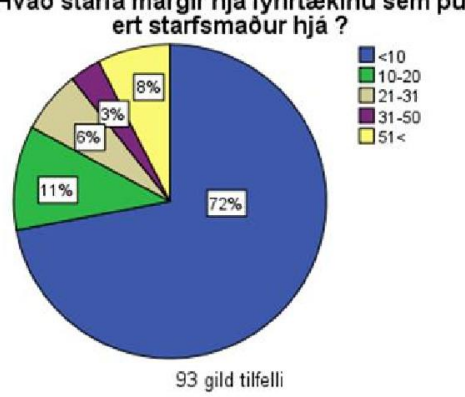

\footnotetext{
${ }^{46}$ Eins og áður pá eru svör umræddra verktaka pöruð við svör viðkomandi verkkaupa til að reikna út fylgni
} 
Tæplega 43\% fyrirtækjanna höfðu verið starfrækt í 11-30 ár. Líkt og í könnun fyrir verkkaupa voru karlmenn í miklum meirihluta og voru rúmlega 94\% pátttakenda karlmenn. Flestir voru á aldursbilinu 46-55 ára og gegndu stöðu framkvæmdastjóra.

\section{Ánægja viðskiptavinar}

Marktæk fylgni greindist milli annars vegar ánægju verkkaupa með framkvæmd verksins sem umræddur verktaki vann og hins vegar aldurs (Gamma 0,397) og stærðar (Gamma $0,623)$ verktaka fyrirtækja. Á stólparitinu hér að neðan má sjá hlutfallslega skiptingu eftir stærð fyrirtækja með tilliti til ánægju verkkaupa með framkvæmd verksins hjá umræddum verktaka.

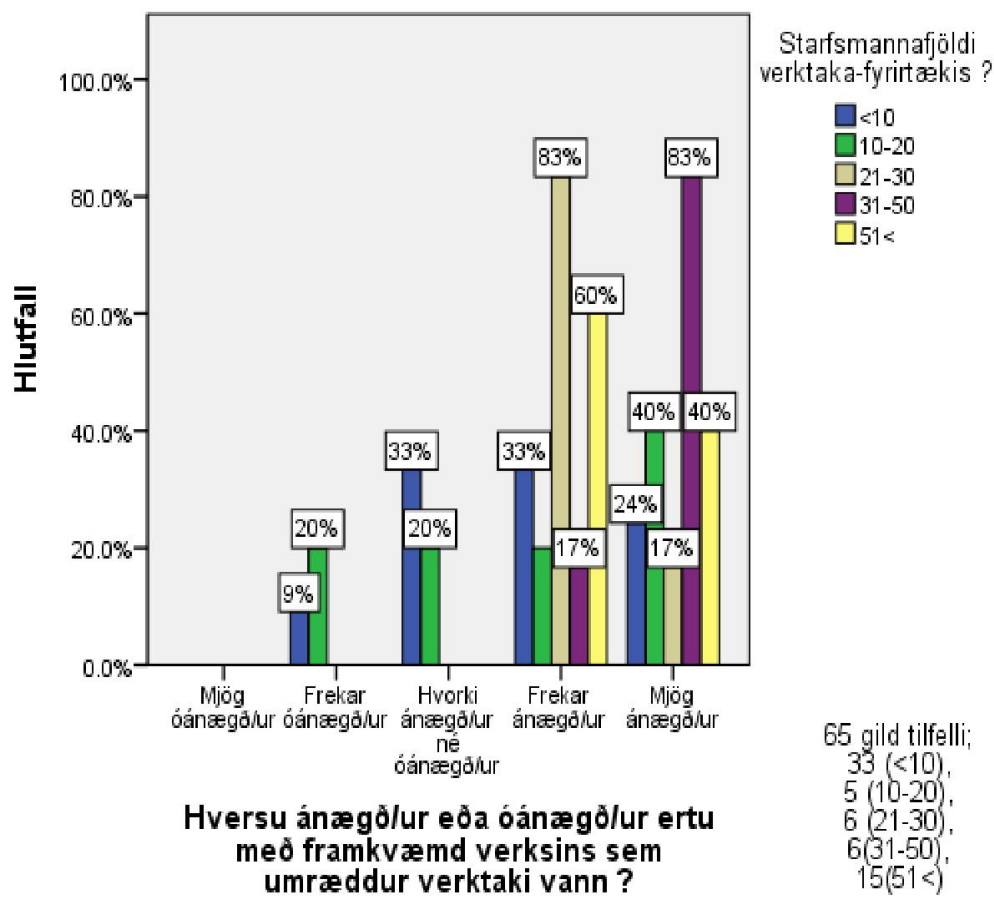

Mynd 36 Hlutfallsleg skipting eftir stoerð fyrirtoekja með tilliti til ánœegju verkkaupa ,e` framkvoemd verksins hjá umroeddum verktaka

\section{GSK}

Marktæk og sterk/miðlungs sterk fylgni greindist milli annars vegar GSK og hins vegar hversu stór (Gamma 0,870) og hversu gömul (Gamma 0,396) verktaka fyrirtækin voru. Stólparitið hér að neðan sýnir hlutfallslega skiptingu GSK með tilliti til stærð fyrirtækja, en par sést að mikill meirihluti fyrirtækja sem eru með færri en 10 starfsmenn starfa ekki eftir gæðastjórnunarkerfi en skýrsluhöfundur varð mjög var við pað í viðtölum sínum við verktaka að fámennum verktakafyrirtækjum finnst almennt vera vöntun á kerfi fyrir smærri fyrirtæki. Oft var nefnt að innleiðing gæðastjórnunarkerfis væri alltof umfangsmikil fyrir svo fámenn fyrirtæki og mikil vöntun væri á gæðastjórnunarkerfi fyrir lítil og meðalstór fyrirtæki. Talsvert af slíkum ábendingum má sjá í viðauka með opnum spurningum. 


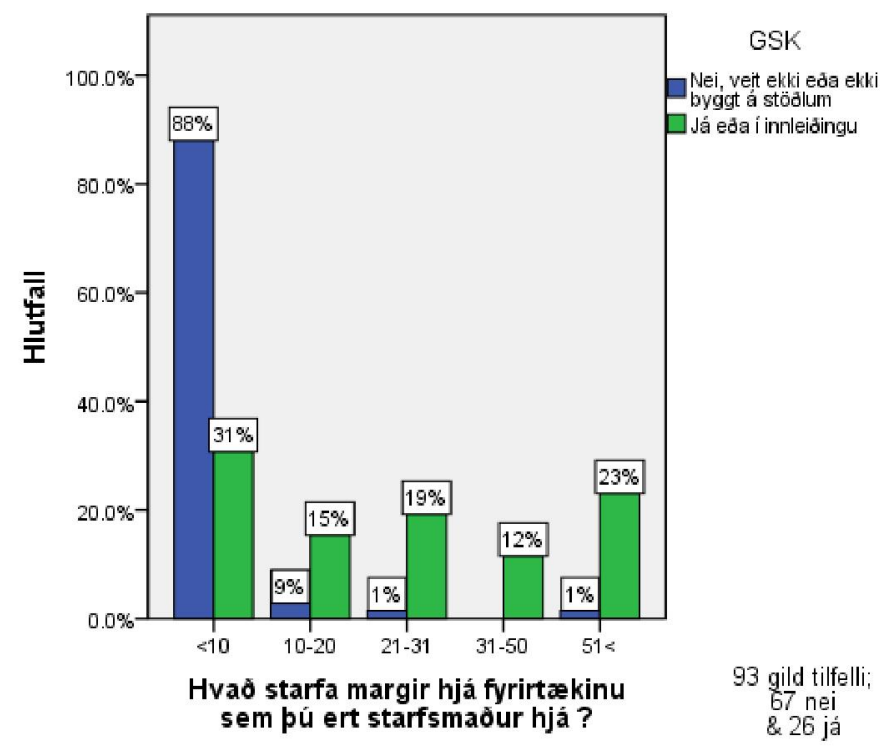

Mynd 37 Hlutfallsleg skipting á GSK með tilliti til stoerð fyrirtoekja

\subsubsection{Gæðastjórnun - GSK}

Verktakar voru spurðir hvort fyrirtæki peirra starfaði eftir gæðastjórnunarkerfi og í framhaldinu voru pau fyrirtæki sem svöruðu játandi spurð hvort gæðastjórnunarkerfið byggði á viðurkenndum gæðastaðli og hvort pað hefði hlotið vottun. Sundurliðun á svörum pátttakenda má sjá á skífuritinu hér að neðan.

Eftirfarandi sameiningar voru gerðar til að auðvelda úrvinnslu par sem að fá svör voru í sumum flokkum;

1. Pátttakendur sem höfou hlotið vottun eða voru í innleiðingu og pátttakendur sem sögðust starfa eftir gæðastjórnunarkerfi en höfou ekki hlotið vottun voru settir saman í einn flokk.

2. Pátttakendur sem sögðust starfa eftir gæðastjórnunarkerfi sem byggði engu að síður ekki á neinum viðurkenndum stöðlum, pátttakendur sem vissu ekki hvort fyrirtækið starfaði eftir gæðastjórnunarkerfi eða ekki og pátttakendur sem sögðust ekki starfa eftir gæðastjórnunarkerfi voru settir saman í einn flokk.

Breytan GSK með ofangreindum sameiningum er pví notuð við útreikninga. 


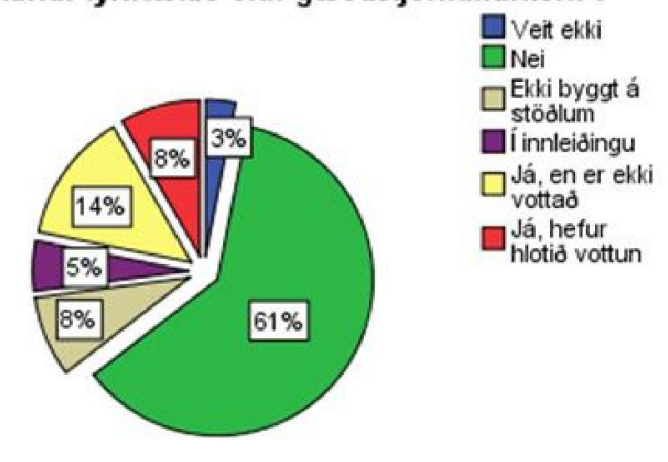

96 gild tilfelli

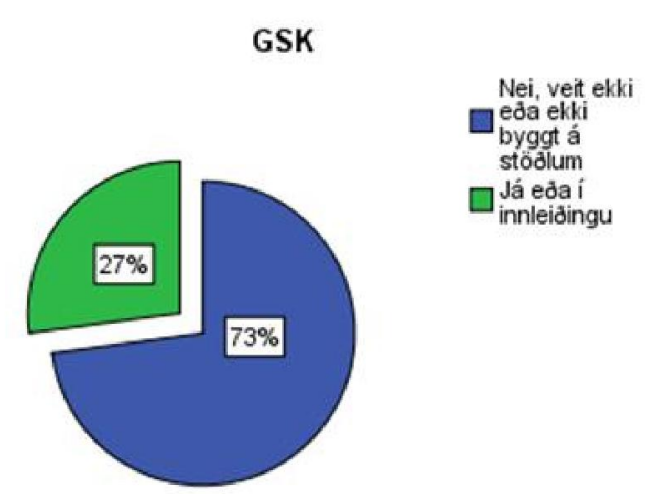

96 gild tilfelli

Mynd 38 Sundurliðun og sameining á GSK

Niðurstöður könnunarinnar sýndu að ekki nema $62 \%$ pátttakenda sem sögðust starfa eftir gæðastjórnunarkerfi sögðu að pað væri starfandi gæðastjóri innan fyrirtækisins og í öllum peim tilfellum sem gæðastjóri var starfandi innan fyrirtækisins sinnti hann annarri stöðu líka. 72\% fyrirtækja sem sögðust starfa eftir gæðastjórnunarkerfi sögðu jafnframt að ekki væri starfandi gæðaráð innan fyrirtækisins og rúmlega $20 \%$ vissu ekki til pess að til væri gæðahandbók fyrirtækisins.

Af peim fyrirtækjum sem sögðust starfa eftir gæðastjórnunarkerfi voru tæplega $65 \%$ sem staðfestu að til væri skjalfest gæðastefna og ekki nema helmingur peirra ${ }^{47}$ taldi að gæðastefnan væri mjög eða frekar vel pekkt hjá starfsmönnum fyrirtækisins. Einnig sýna niðurstöður að ekki nema tæplega 24\% fyrirtækja sem sögðust starfa eftir gæðastjórnunarkerfi sögðust jafnframt alltaf veita verkkaupa upplýsingar um gæðastjórnunarkerfið í verkbyrjun.

\section{Ánægja viðskiptavinar}

Greining á fylgni milli ánægju verkkaupa og GSK er í kafla 4.5.1 á bls. 55, en eins og fram kemur par reyndist vera mjög marktæk og sterk fylgni milli pessa pátta.

Fylgni milli ánægju verkkaupa með umræddan verktaka og pess hvort starfandi gæðastjóri var innan fyrirtækisins er ekki marktæk enda ekki nema 27 tilfelli sem flokkast undir gild tilfelli.

Engu að síður sést á stólparitinu hér að neðan að allir verkkaupar sem voru með umræddan verktaka í huga sem er með starfandi gæðastjóra voru mjög eða frekar ánægðir.

\footnotetext{
${ }^{47} 65 \%$ peirra sem sögðu að til væri skjalfest gæðastefna svöruðu hversu kunnuga peir teldu gæðastefnuna vera fyrir starfsmönnum fyrirtækisins og er átt við helming pessa hóps
} 


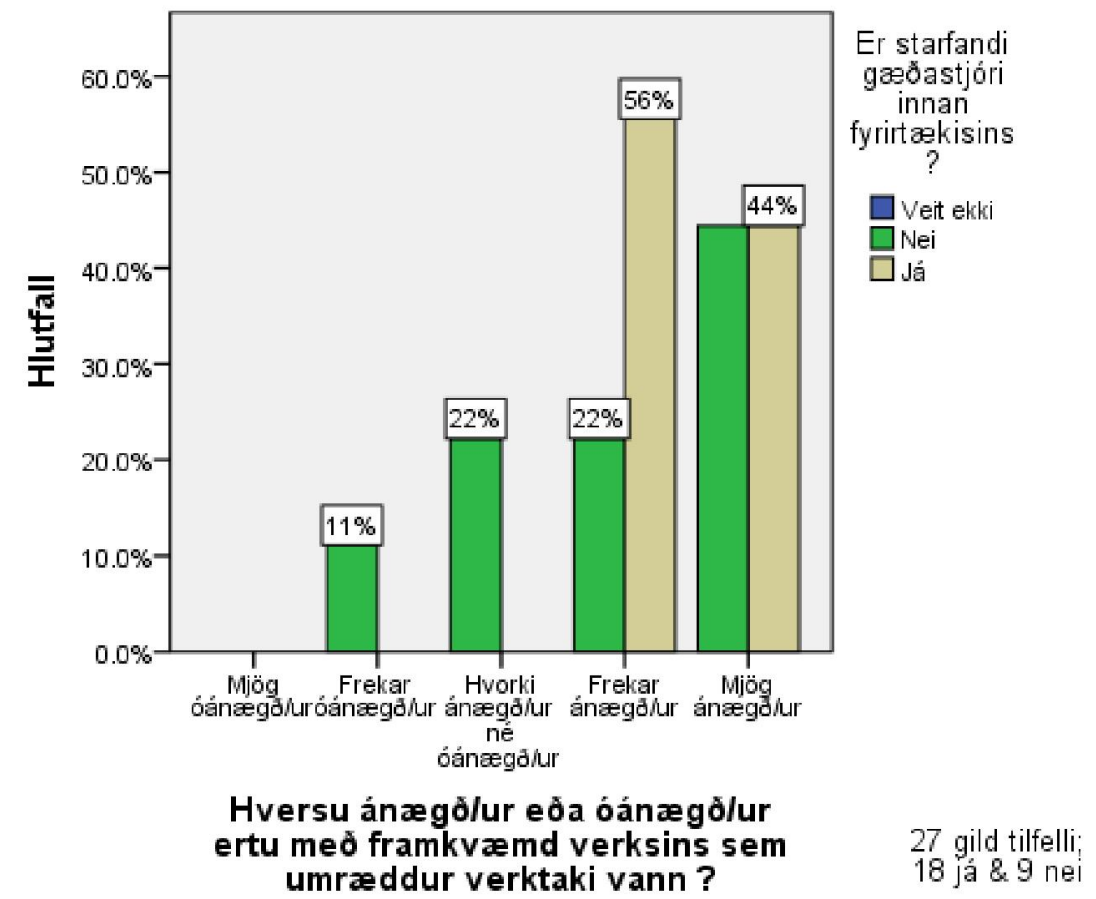

Mynd 39 Hlutfallsleg skipting á pví hvort starfandi gœðastjóri var innan fyrirtoekisins með tilliti til ánoegju verkkaupa með framkvoemd verksins

\subsubsection{Viðhorf til gæðastjórnunar}

Viðhorf verktaka til gæðastjórnunar var kannað sérstaklega. Niðurstöður gáfu til kynna að verktakar hafa almennt jákvætt viðhorf til gæðastjórnunar og telja að hún eigi við byggingaiðnaðinn en um $83 \%$ sögðust hafa mikla eða frekar mikla trú á gæðastjórnun í byggingaiðnaði. Yfir 90\% töldu að ávinningur af innleiðingu gæðastjórnunarkerfis í byggingaiðnaði væri frekar eða mjög mikill og um 75\% töldu að́ ávinningurinn væri meiri en kostnaðurinn, að rekstrarafkoman myndi batna eða batna til muna svo eitthvað sé nefnt. Sundurliðun svara má sjá á skífuritunum hér að neðan. 
Telur pú aô ávinningur náist meồ
gæeóastjórnun i byggingariônaói?

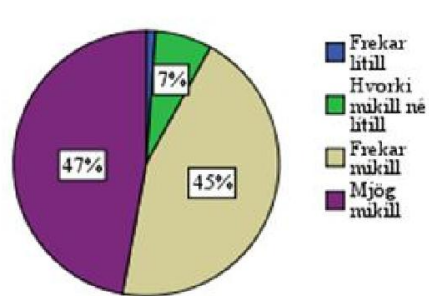

87 gild tilfelli

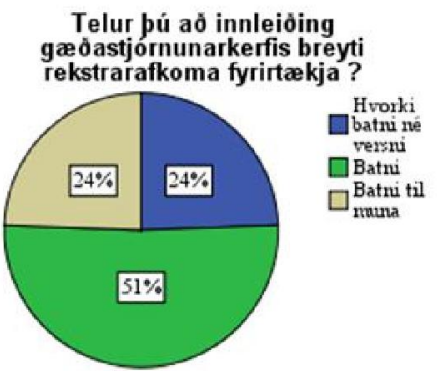

86 gild tilfelli

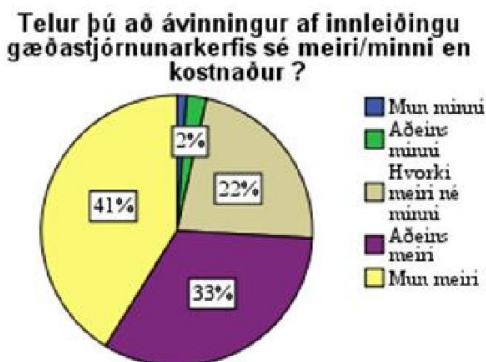

85 gild tilfelli

Telur pú aõ samkeppnishæfi fyrirtækja sé meiri/minni eftir innleióingu gaeóastjórnunarkerfis ?

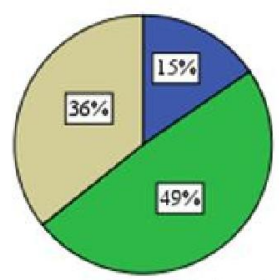

84 gild tilfelli

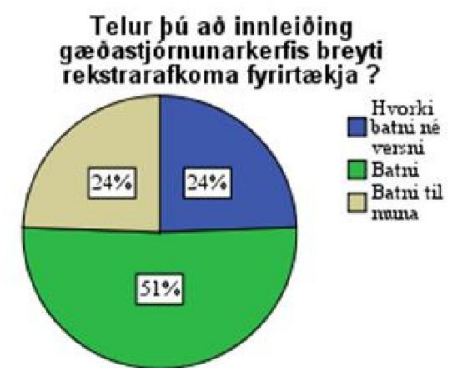

86 gild tilfelli

Telur pú aò meò innleiôingu gæôastjórnunarkerfis batni/versni nýting mannafla?

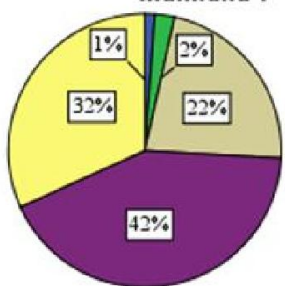

85 gild tilfelli

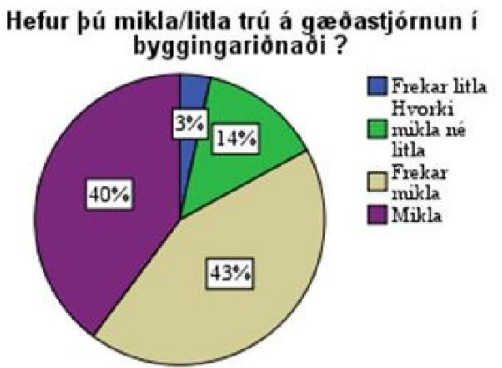

88 gild tilfelli

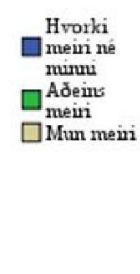

Upplifir pú gæòastjórnunarkerfi einungis sem skráningarkerfi?

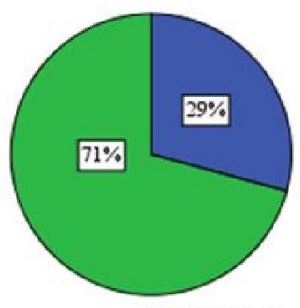

89 gild tilfelli

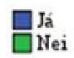

Mynd 40 Viðhorf verktaka til gœeðastjórnunar

Rúmlega 29\% sögðu að peir upplifðu gæðastjórnunarkerfi einungis sem skráningarkerfi. Fylgni milli pess hversu stór fyrirtæki voru og hvort verktaki upplifði gæðastjórnunarkerfi einungis sem skráningarkerfi reyndist ekki vera marktækt. Par sem mikill meirihluti pátttakenda starfaði hjá fyrirtækjum með fáa starfsmenn hefði fylgnin purft að vera mjög mikil til að teljast marktæk.

\section{Ánægja viðskiptavinar}

Mælingar sýna að fylgni milli ánægju verkkaupa með framkvæmdir hjá umræddum verktaka er ekki marktæk við pætti sem tengdir eru viðhorfi verktaka, að undanskildu hvort verktakar telja að innleiðing gæðastjórnunar auki/minnki samkeppnishæfi fyrirtækja (Gamma 0,495).

\section{GSK}

Niðurstöður sýna að verktakar sem hafa reynslu af gæðastjórnunarkerfi hafa mun jákvæðara viðhorf til gæðastjórnunar. Fylgni milli viðhorfs og tiltrúar verktaka á 
gæðastjórnun og GSK reyndist marktæk og jákvæð í öllum tilfellum, nema pegar spurt var hvort svarandi teldi nýtingu mannafla batna eða versna með innleiðingu gæðastjórnunarkerfis. Samantekt á marktækum fylgnistuðlum er gefin upp í töflunni hér að̃ neðan.

Tafla 6 Samantekt á marktakkri fylgni viðhorfs verktaka ${ }^{48}$ við GSK

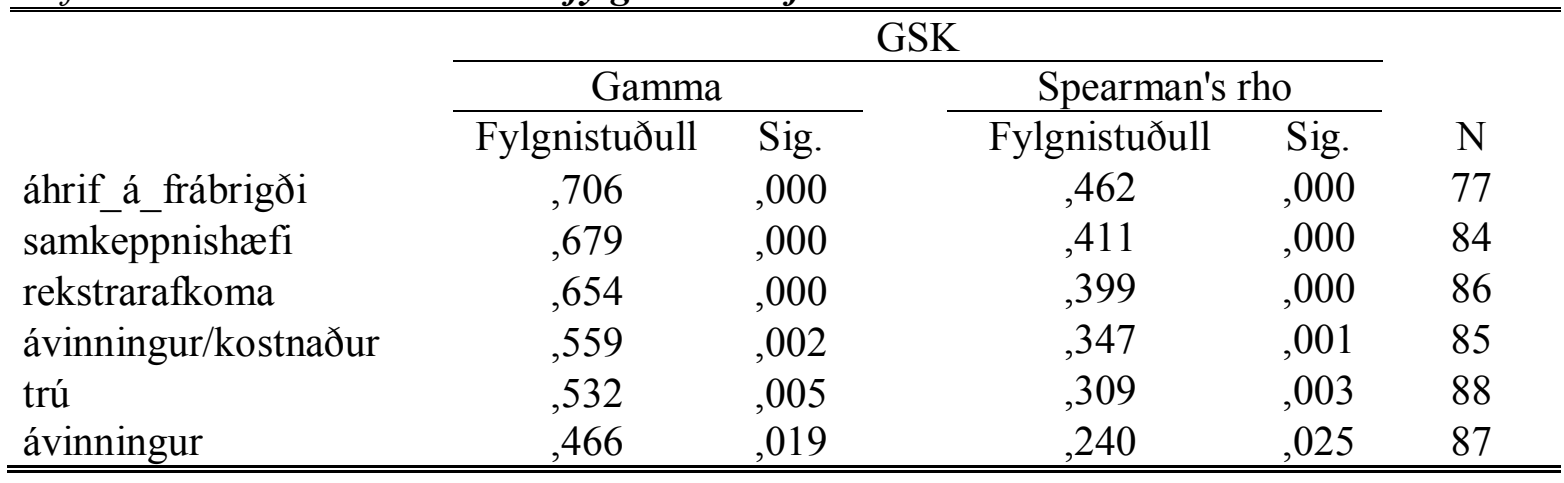

\subsubsection{Gæðatrygging}

Niðurstöður könnunarinnar sýna að staða gæðatryggingar í byggingaiðnaði á Íslandi er afar slök. Tæplega 48\% sögðust aldrei, sjaldan eða stundum sýna verkkaupa fram á gæðatryggingu ${ }^{49}$ en innan við 10\% sögðust alltaf sýna verkkaupa fram á gæðatryggingu í verkbyrjun. 89\% verktaka sögðust aldrei, sjaldan eða stundum fara fram á gæðatryggingu frá undirverktökum og ekki nema tæplega 3\% sögðust alltaf gera pað, en hlutfallslega skiptingu svara má sjá á skífuritinu hér að neðan.
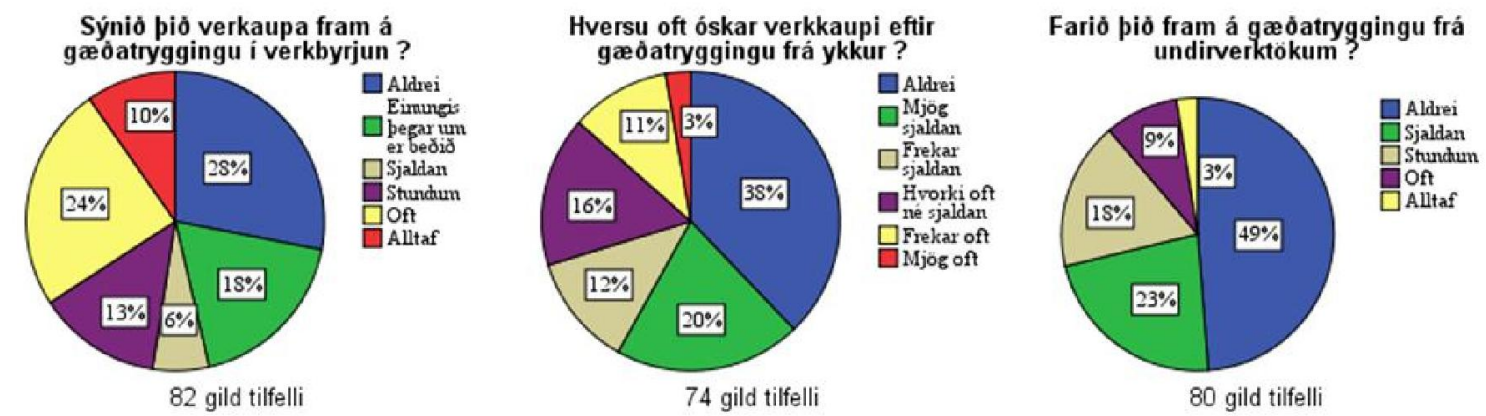

Mynd 41 Goeðatrygging

Sökin virðist pó ekki liggja öll hjá verktökunum, pví kröfur verkkaupa um að verktaki sýni fram á gæðatryggingu eru litlar. Í tæplega 14\% tilfella töldu verktakar að verkkaupar færu frekar eða mjög oft fram á gæðatryggingu.

\footnotetext{
${ }^{48}$ Athuga að breytuheiti eru öll skilgreind viðauka Error! Reference source not found. á bls. 253

${ }^{49}$ Sjá skilgreiningu á gæðatryggingu á bls. 320
} 


\section{Ánægja viðskiptavinar}

Fylgni milli annars vegar hversu ánægður verkkaupi var með framkvæmd verksins hjá umræddum verktaka og hins vegar hversu oft verktaki telur sig leggja fram gæðatryggingu reyndist ekki marktæk en marktæk fylgni var á milli pess hversu ánægður verkkaupi var með framkvæmd verksins hjá umræddum verktaka og hversu oft verktaki telur sig krefja undirverktaka um gæðatryggingu (Gamma 0,638). Stólparitið hér að neðan sýnir hlutfallslega skiptingu á pví hvort/hversu oft verktaki fer fram á gæðatryggingu frá undirverktaka með tilliti til ánægju verkkaupa með framkvæmd verksins hjá umræddum verktaka.

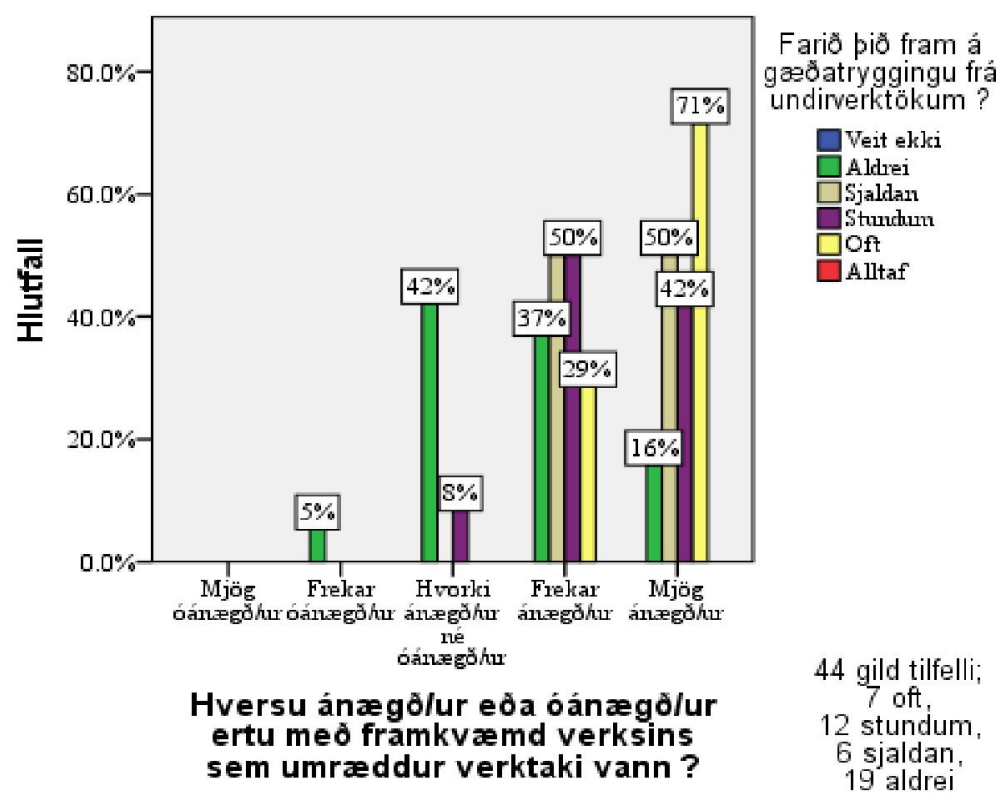

Mynd 42 Hlutfallsleg skipting á pví hvort/hversu oft verktaki fer fram á goðatryggingu frá undirverktaka með tilliti til ánoegju verkkaupa með framkvoemd verksins hjá umrceddum verktaka

Skýrsluhöfundur upplifði í gegnum viðtölin við verkkaupana að margir sögðust vera óánægðir með störf undirverktaka prátt fyrir að peir væru ánægðir með störf umrædds verktaka. Oftar en ekki virtust peir ekki telja slök vinnubrögð undirverktaka til ábyrgðar aðalverktaka. Баð ætti pví engan að undra að mjög marktæk og sterk fylgni greindist milli ánægju verkkaupa með framkvæmd verksins hjá umræddum verktaka og hvort/hversu oft verktaki krefur undirverktaka um gæðatryggingu (Gamma 0,638).

\section{GSK}

Fylgni milli annars vegar $G S K$ og hins vegar hvort/hversu oft verkkaupi sýnir verkkaupa fram á gæðatryggingu (Gamma 0,580) og hvort eða hvort/hversu oft verktaki krefur undirverkkaupa um gæðatryggingu (Gamma 0,622) reyndist vera marktæk. Á stólparitunum hér að neðan má sjá hlutfallslega skiptingu á $G S K$ með tilliti til pess hvort/hversu oft verktaki biðji undirverktaka um gæðatryggingu og hvort/hversu oft hann leggi sjálfur fram gæðatryggingu til verkkaupa. 

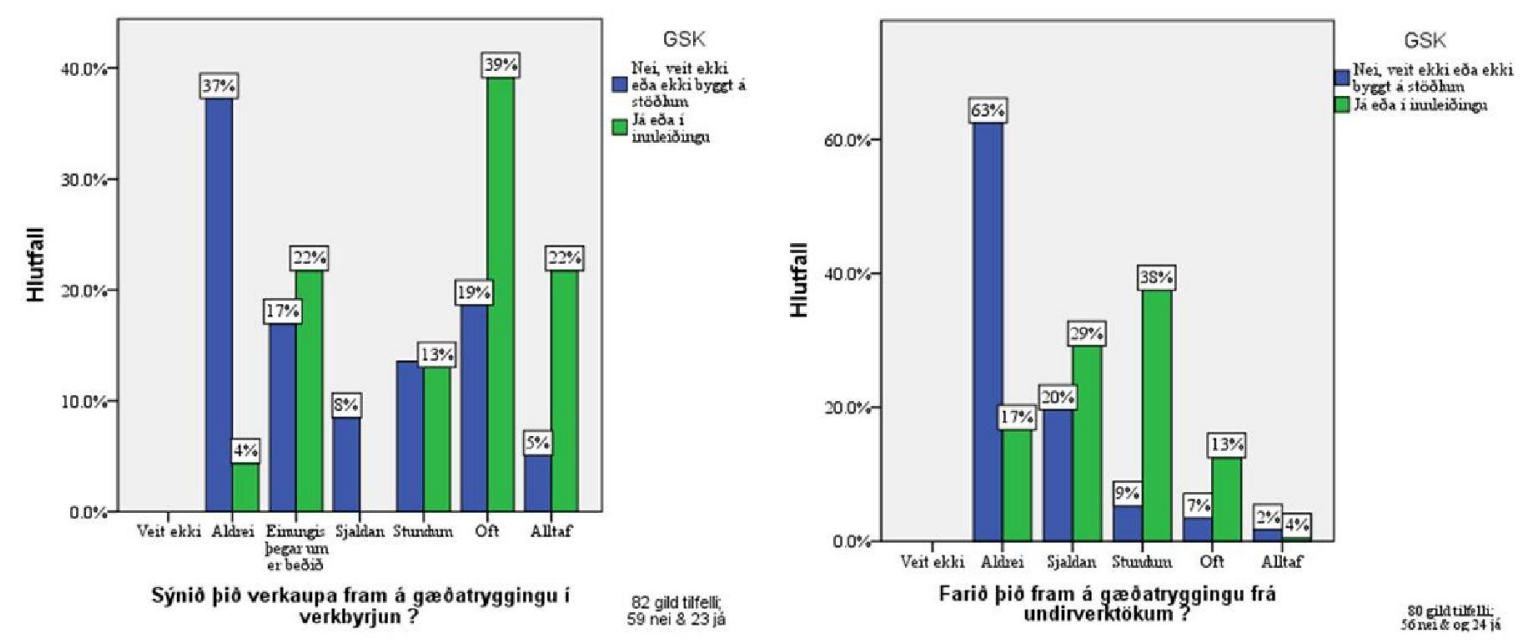

Mynd 43 Hlutfallsleg skipting á GSK með tilliti til pess hvort/hversu oft verktaki biðji undirverktaka um gæeðatryggingu og hvort/hversu oft hann leggi sjálfur fram gceðatryggingu til verkkaupa.

\subsubsection{Pekking á gæðastjórnun}

Pátttakendur voru spurðir að pví hversu mikla pekkingu peir hefðu almennt á gæðastjórnun, og sér í lagi hversu mikla pekkingu peir hefou á ÍST30 og ISO 9001. Niðurstöđurnar endurspegla pví mat verktaka á eigin pekkingu og er pví ekki ólíklegt að ákveðin hlutdrægni sé í svörunum. Tölurnar gefa til kynna að um helmingur pátttakenda hafi eitthvað kynnt sér gæðastjórnun en meðal fyrirtækja sem starfa eftir gæðastjórnunarkerfi er hlutfallið hærra.
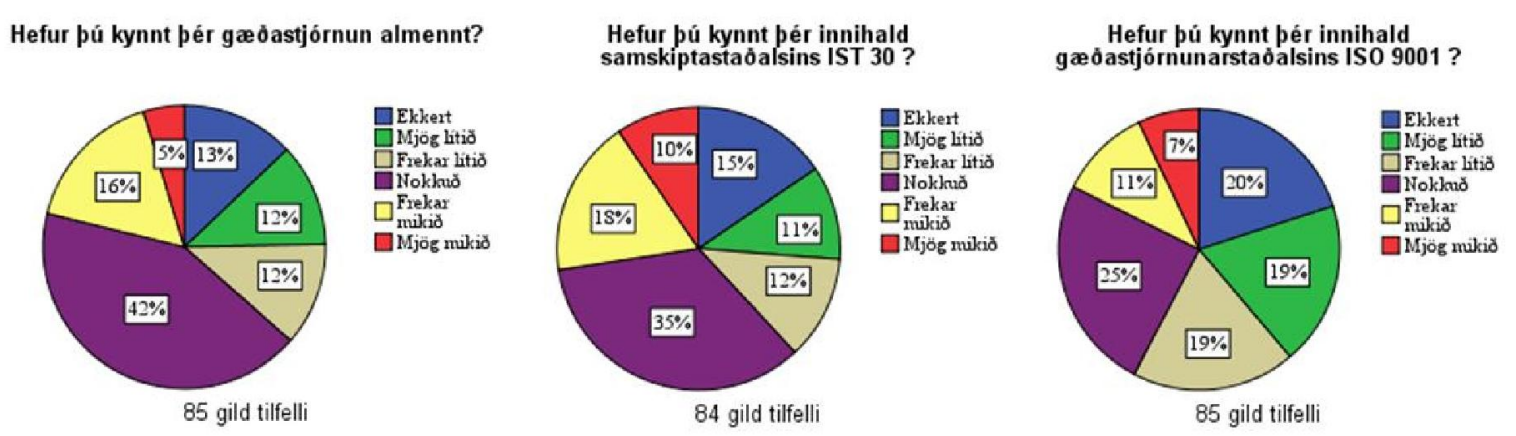

Mynd 44 Pekking verktaka á gæeðastjórnun

Pátttakendur voru einnig spurðir að pví hvort peim pætti skorta stöðluð og samræmd útboðsgögn og er pað athyglisvert að mati skýrsluhöfundar að rúmlega $61 \%$ pátttakenda fannst mjög eða frekar mikill skortur á slíkum gögnum. 


\section{Ánægja viðskiptavinar}

Fylgni milli pess hversu ánægður verkkaupi var með framkvæmd verksins hjá umræddum verktaka og almennri pekkingu verktaka á gæðastjórnun (Gamma 0,330) og pekkingu verktaka á ISO 9001 (Gamma 0,372) reyndist marktæk og miðlungs sterk. Á stólparitunum hér að neðan má sjá hlutfallslega skiptingu á almennri pekkingu verktaka á gæðastjórnun og á ISO 9001, með tilliti til ánægju verkkaupa með framkvæmd verksins hjá umræddum verktaka. Eins og sjá má voru peir verkkaupar sem voru með verktaka í huga, sem kvaðst hafa kynnt sér gæðastjórnun almennt eða ISO 9001 mjög vel, í öllum tilfellum mjög eða frekar ánægðir með framkvæmd hjá umræddum verktaka.
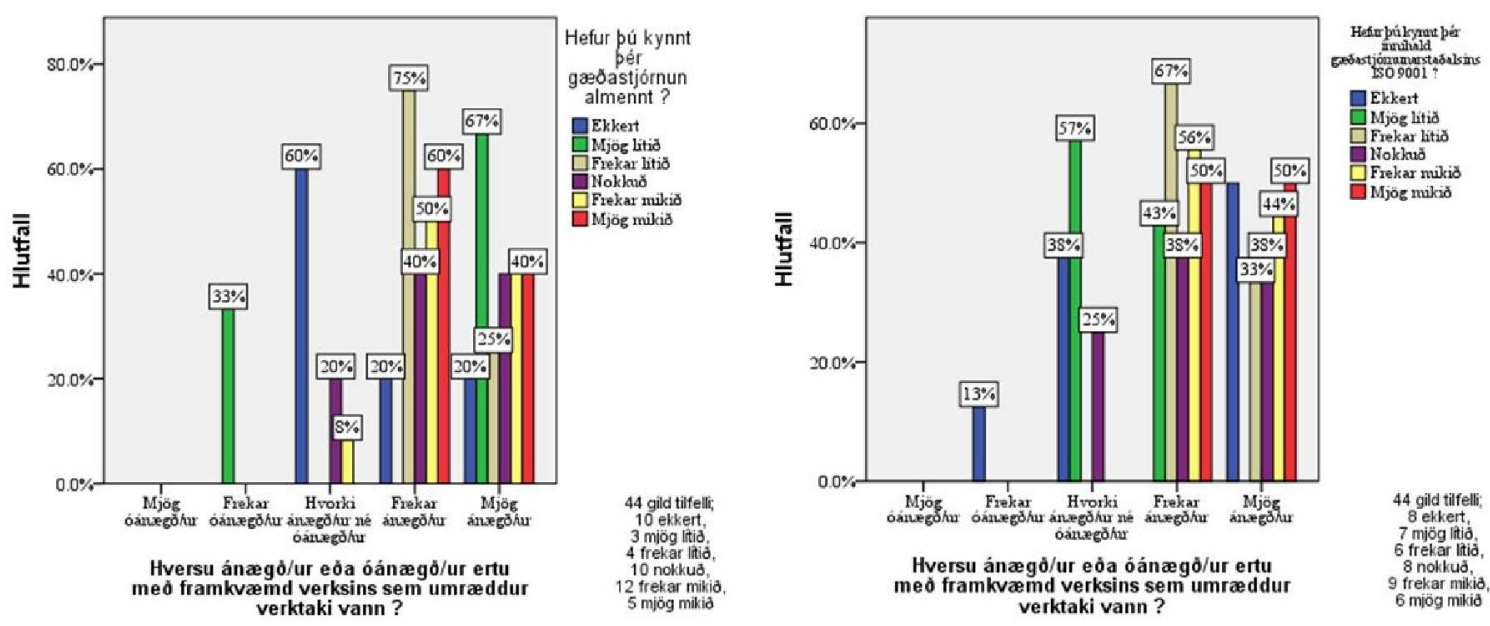

Mynd 45 Hlutfallsleg skipting á almennri pekkingu verktaka á gaðastjórnun og á ISO 9001 með tilliti til áncegju verkkaupa með framkvoemd verksins hjá umroeddum verktaka

\section{GSK}

Fylgni milli annars vegar GSK og hins vegar hver pekking verkkaupa var almennt á gæðastjórnun (Gamma 0,719), hver pekking verktaka á ÍST30 er (Gamma 0, 742) og hver pekking verktaka á ISO 9001 er (Gamma 0, 680) reyndist marktæk og mjög sterk. Stólparitið hér að neðan sýnir hlutfallslega skiptingu á GSK með tilliti til almennrar pekkingar verktaka á gæðastjórnun og pekkingar verktaka á ÍST-30 og ISO 9001. 

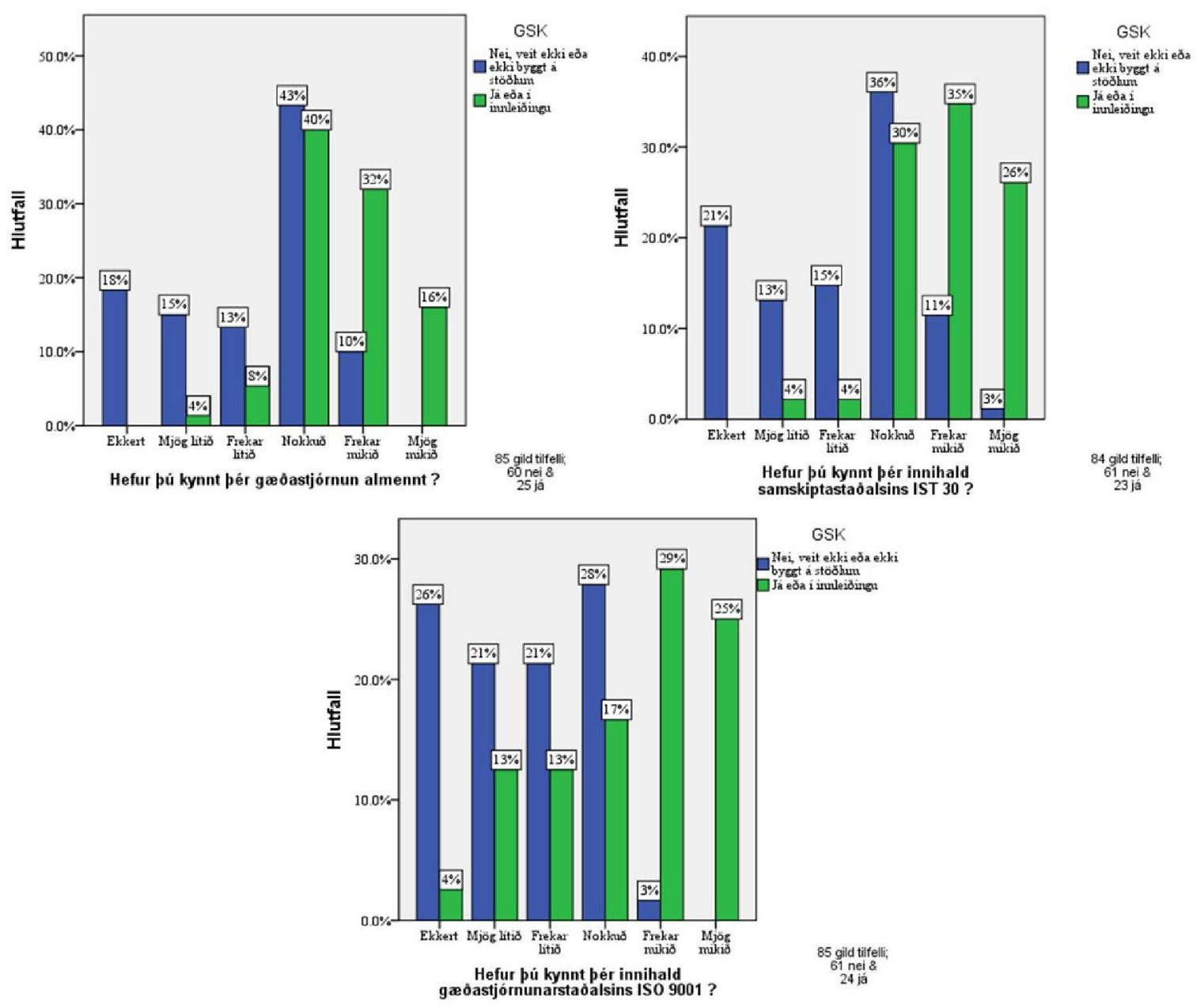

Mynd 46 Hlutfallsleg skipting á GSK með tilliti til pekkingar verktaka á gœðastjórnun

\subsubsection{Verklag}

Pátttakendur voru spurðir nokkurra spurninga varðandi skjalastjórnun og má sjá sundurgreiningu á niðurstöðum í skífuritum hér að neðan. Ekki nema rétt um helmingur svarenda sögðu að tilboð og samningar væru alltaf eða oft geymd í tölusettri röð til ákveðins tíma og rúmlega helmingur svarenda sagðist vera með ákveðið kerfi fyrir merkingu, geymslu og varðveislutíma en innan við $40 \%$ voru með sérstakt kerfi fyrir förgun skjala. 
Eru samningar og tilbod geymd i tölusettri ród til akvedins tima?

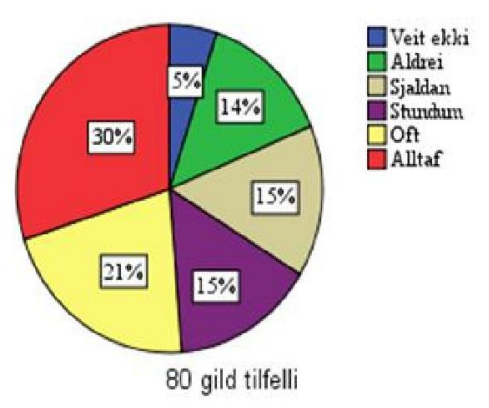

Er ákveòiò kerfi fyrir merkingu skjala?

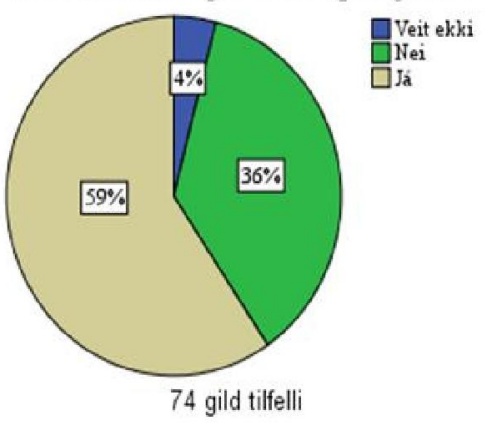

Er ákveodiỏ kerfi fyrir geymslu skjala ?

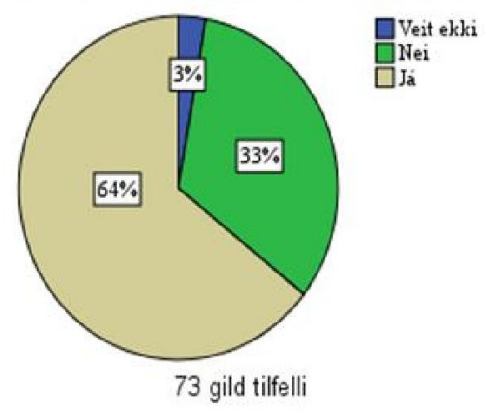

Er ákveơiò kerfi fyrir fórgun skjala?

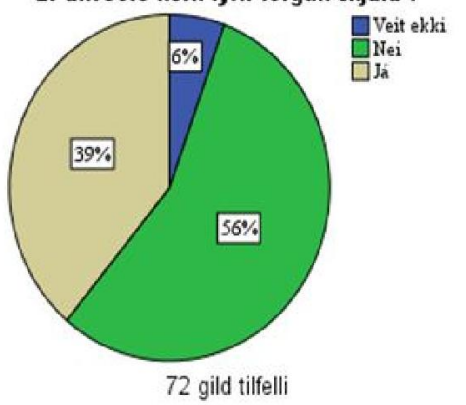

Er ákveôiô kerfi fyrir varôveislutima skjala?

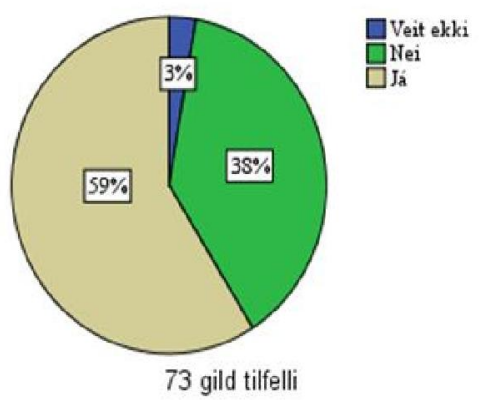

Mynd 47 Skjalastjórnun verktaka

Einnig var spurt hvort til væru starfslýsingar fyrir starfsmenn fyrirtækisins og hversu vel svarandi taldi að starfslýsingar væru kynntar starfsmönnum. Um helmingur pátttakenda svaraði að til væru engar eða fáar starfslýsingar en tæplega $20 \%$ töldu að til væru starfslýsingar fyrir alla starfsmenn. Sundurgreiningu svara má sjá á skífuritum hér að neðan.

\section{Eru til skriflegar starfslýsingar fyrir starfsmenn i fyrirtzekinu?}

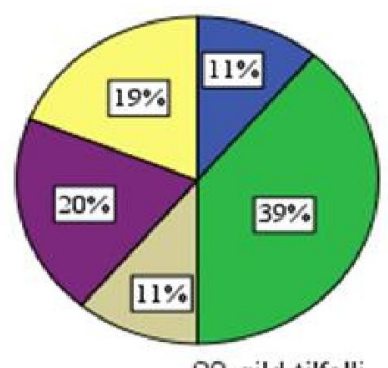

90 gild tilfelli

\section{Er innihald viôkomandi starfslýsinga kynnt fyrir starfsmönnum?}

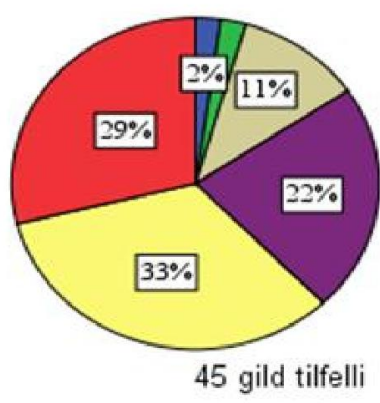

Mynd 48 Starfslýsingar

Spurt var um pað hversu oft verktakar útbyggju skriflega verk- og greiðsluáætlun og hversu oft peir útbyggju skriflega skýringu á verktöf fyrir verkkaupa. Skífuritin hér að neðan sýna sundurgreiningu svara en tæplega $28 \%$ svarenda sögðust aldrei eða sjaldan leggja fram skriflega verkáætlun. 
Leggió pió fram skriflega verkáæetlun fyrir Sendiỏ pióo verkkaupa skriflega rókstudda hvert verk?

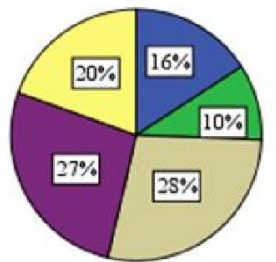

82 gild tilfelli tilkynningu um verktöf pegar svo ber undir?

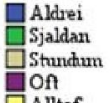

Alltaf

.

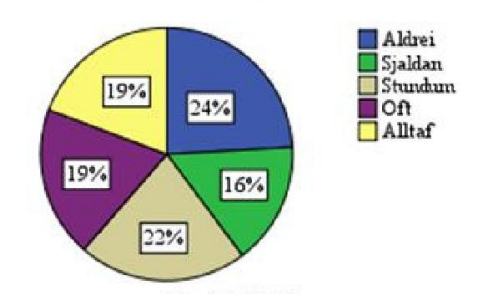

83 gild tilfelli
Gerió pióo skriflega greiósluáætlun vió verkkaupa fyrir hvert verk?

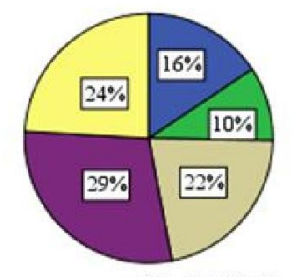

83 gild tilfelli

Mynd 49 Hlutfallsleg tiððni pess að verktaki leggi fram skriflega verkácetlun, verktöf og greiðsluácetlun

Pátttakendur voru spurðir nokkurra spurninga varðandi háttalag peirra með verkfundi. Spurt var hvort venja væri að koma á samkomulagi um reglubundna verkfundi með verkkaupa og svöruðu tæplega $19 \%$ að slíkt samkomulag væri alltaf gert og næstum $74 \%$ svöruðu að slíkt samkomulag væri gert oft eða stundum. Flestir sögðust einnig rita fundargerð á verkfundum en tæplega 32\% verkkaupa sögðust alltaf halda verkdagbók. Sundurgreiningu svara má sjá á skífuritunum hér að neðan.

Er venja aó gert sé samkomulag um
reglubundna verkfundi meó verkkaupa?

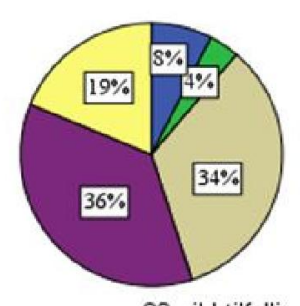

80 gild tilfelli

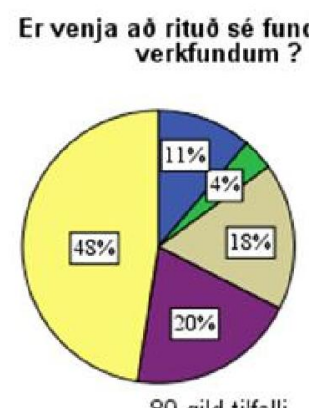

80 gild tilfelli
Haldiô pió verkdagbók?

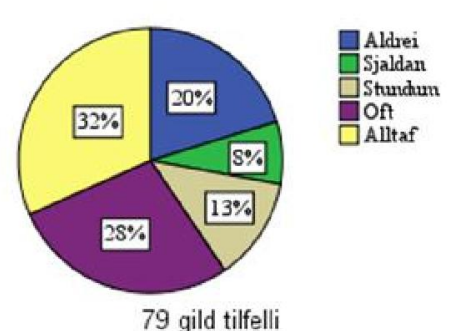

79 gild tilfelli

Mynd 50 Hlutfallsleg tiððni hvort/hversu oft verktaki kemur á samkomulagi með verkkaupa að halda reglubundna verkfundi, hvort rituð sé fundargerð á verkfundum og hvort/hversu oft verktaki heldur verkdagbók

Einnig var spurt hversu oft tekið væri fram í samningum hjá verktökum að pað bæri að fara eftir kröfum samskiptastaðalsins ÍST-30, hversu oft verktaki tilkynnti verkkaupa um frábrigði, hversu oft hann skráði aukaverk og breytingar niður og hversu oft hann skilaði verkkaupa skrá um hugsanlegar greiðslur vegna peirra. Sundurliðun á svörum má sjá á skífuritum hér að neðan. Um helmingur svarenda sagði að pað kæmi alltaf eða oft fram í samningum hjá peim að pað bæri að fara eftir kröfum samskiptastaðalsins ÍST-30 og tæplega 43\% svarenda sögðust tilkynna verkkaupa skriflega um frábrigði. 


\section{Er venja aỏ paò sé tekiô fram í samningum aó paó beri aó fara eftir kröfum} samskiptastaobalsins IST 30 ?

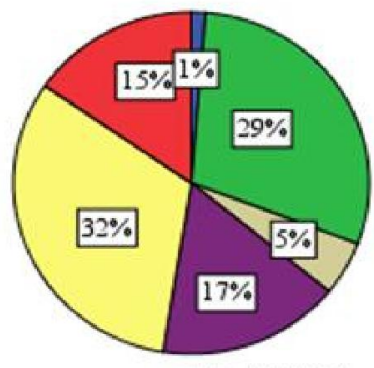

78 gild tilfelli

Hvernig er verkkaupa tilkynnt um frábrigơi ?

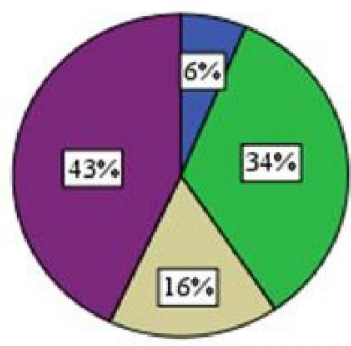

79 gild tilfelli
Hversu oft skiliò biô skrá yfir hugsanlegar kröfur um greióslur vegna aukaverka og breytinga til verkkaupa?

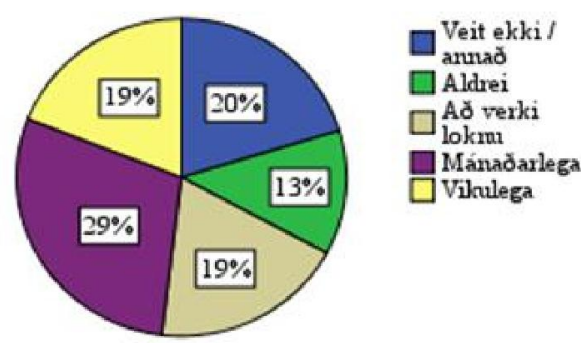

79 gild tilfelli

Eru óskir verkkaupa um aukaverk og breytingar skrádar?

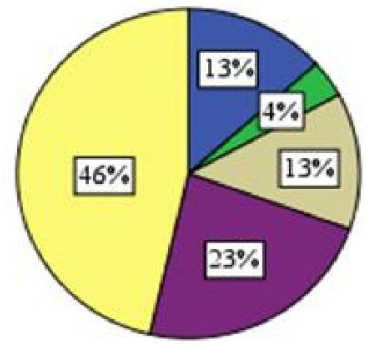

$\square$ Aldrei
$\square$ Sjaldan
$\square$ Sturudun
Ont
$\square$ Alltaf

82 gild tilfelli

Mynd 51 Aukaverk og frábrigði

Að lokum voru pátttakendur spurðir hversu oft peir útbyggju hættumat í upphafi framkvæmda og svöruðu tæplega $62 \%$ að peir gerðu pað stundum, sjaldan eða aldrei og ekki nema rúmlega $10 \%$ pátttakenda sögðust alltaf gera slíkt. Einnig var spurt hvort fyrirtækið styddist við utanaðkomandi pjónustu við gæðaeftirlit en 51\% pátttakenda sögðust aldrei styðjast við utanaðkomandi pjónustu við gæðaeftirlit eða úttektir. Prátt fyrir pað sögðust rúmlega $46 \%$ pátttakenda ekki vera með skipulagt innra eftirlit á framkvæmdum.

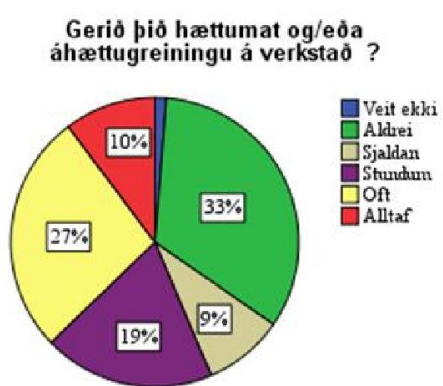

78 gild tilfelli

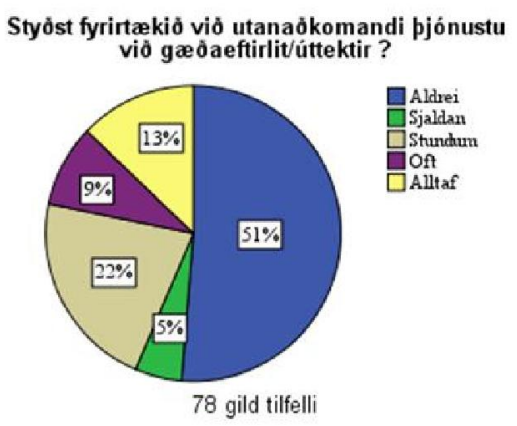

Er skipulagt innra eftirlit á framkvæmdum hjá fyrirtækinu (gæóastýringaráæatlun)?

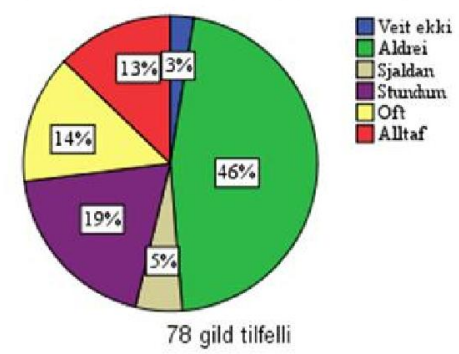

Mynd 52 Goeðaeftirlit og hoettumat 
Að lokum svöruðu tæplega $77 \%$ pátttakenda að peir viðhefðu öryggisráðstafanir oft eða alltaf $^{50}$ ádur en framkvæmdir hefjast.

\section{Ánægja viðskiptavinar}

Kannað var hvort innra verklag verktaka hefði marktæk áhrif á ánægju verkkaupa og var fylgni milli allra pátta sem tengjast verklagi verktaka mæld við ánægju verkkaupa með framkvæmd verksins hjá umræddum verktaka. Marktæk fylgni mældist við pað hvort verktaki sagðist fara eftir ákveðnu kerfi varðandi förgun skjala (Spearman 0,420) og hvort til voru skriflegar starfslýsingar fyrir starfsmenn hjá fyrirtæki verktaka (Spearman 0,349) en aðrir pættir mældust ekki með marktæka fylgni.

\section{GSK}

Einnig var kannað hvort aukið skipulag á verklagi verktaka hefði marktæka fylgni við GSK og reyndust mjög margir pættir mælast með marktæka fylgni. Yfirlit yfir pá er gefið upp í töflunni hér að neðan en á heildina litið sýna niðurstöður að verktakar sem starfa eftir gæðastjórnunarkerfi byggðu á viðurkenndum gæðastöðlum $(G S K)$ starfa eftir mun markvissari og skilvirkari vinnubrögðum en peir verkkaupar sem ekki starfa eftir gæðastjórnunarkerfi.

\footnotetext{
${ }^{50}$ Sjá kafla um athugasemdir bls.313
} 
öryggisstrúnaðarm

aukaverk_skráð

gæðastýringaráætlun

verkdagbók

verktöf_skrifleg

ÍST30_kröfur

merking

verkáætlun_skrifleg

starfslýsingar_skriflegar

tölusett

öryggisstjóri

geymslu

verkfundir_reglubundnir

fundargerð

gæðatrygging_undirverkt

gæðatrygging_verktaki

hættumat

gæðatrygging_ósk

frábrigði_tilkynnt

greiðsluáætlun_skrifleg

\begin{tabular}{|c|c|c|c|c|}
\hline \multicolumn{4}{|c|}{ GSK } & \multirow[b]{3}{*}{$\mathrm{N}$} \\
\hline \multicolumn{2}{|l|}{ Gamma } & \multicolumn{2}{|c|}{ Spearman's rho } & \\
\hline Fylgnistuðull & Sig. & Fylgnistuðull & Sig. & \\
\hline, 801 &, 000 &, 495 &, 000 & 51 \\
\hline ,791 &, 000 & ,464 &, 000 & 82 \\
\hline ,764 &, 000 & ,550 &, 000 & 78 \\
\hline, 757 & 000 & ,500 &, 000 & 79 \\
\hline ,739 &, 000 & ,520 &, 000 & 83 \\
\hline ,738 &, 000 & ,479 &, 000 & 78 \\
\hline, 717 &, 000 & ,362 &, 002 & 74 \\
\hline ,707 &, 000 & ,478 &, 000 & 82 \\
\hline ,706 &, 000 & ,505 &, 000 & 90 \\
\hline 685 &, 000 & ,464 &, 000 & 80 \\
\hline 666 &, 002 & ,406 & ,002 & 54 \\
\hline ,638 &, 003 & ,300 &, 010 & 73 \\
\hline ,633 &, 000 & ,393 &, 000 & 80 \\
\hline, 628 &, 000 & ,359 & ,001 & 80 \\
\hline 622 &, 000 & ,422 &, 000 & 80 \\
\hline ,580 &, 000 & ,390 &, 000 & 82 \\
\hline ,563 &, 000 & ,372 &, 001 & 78 \\
\hline ,534 &, 001 & ,364 &, 001 & 74 \\
\hline ,482 & 011 & ,279 & 013 & 79 \\
\hline ,356 &, 024 & 230 &, 036 & 83 \\
\hline
\end{tabular}

Innra verklag. Marktæk og sterk fylgni var milli annars vegar GSK og hins vegar hvort verktakar voru með ákveðið kerfi fyrir merkingu skjala í fyrirtækinu (Gamma 0,717), hvort verktaki var með ákveðið kerfi fyrir geymslu (Gamma 0,638) skjala, hvort skjöl voru geymd í tölusettri röð til ákveðins tíma (Gamma 0,685) og að lokum hvort til voru skriflegar starfslýsingar fyrir starfsmenn (Gamma 0,706). Stólparitin hér að neðan sýna hlutfallslega skiptingu á $G S K$ með tilliti til innra verklags verktaka.

\footnotetext{
${ }^{51}$ Skýringar á breytuheitum sem eru notuð í töfluna eru í viðauka um breytuheiti.
} 

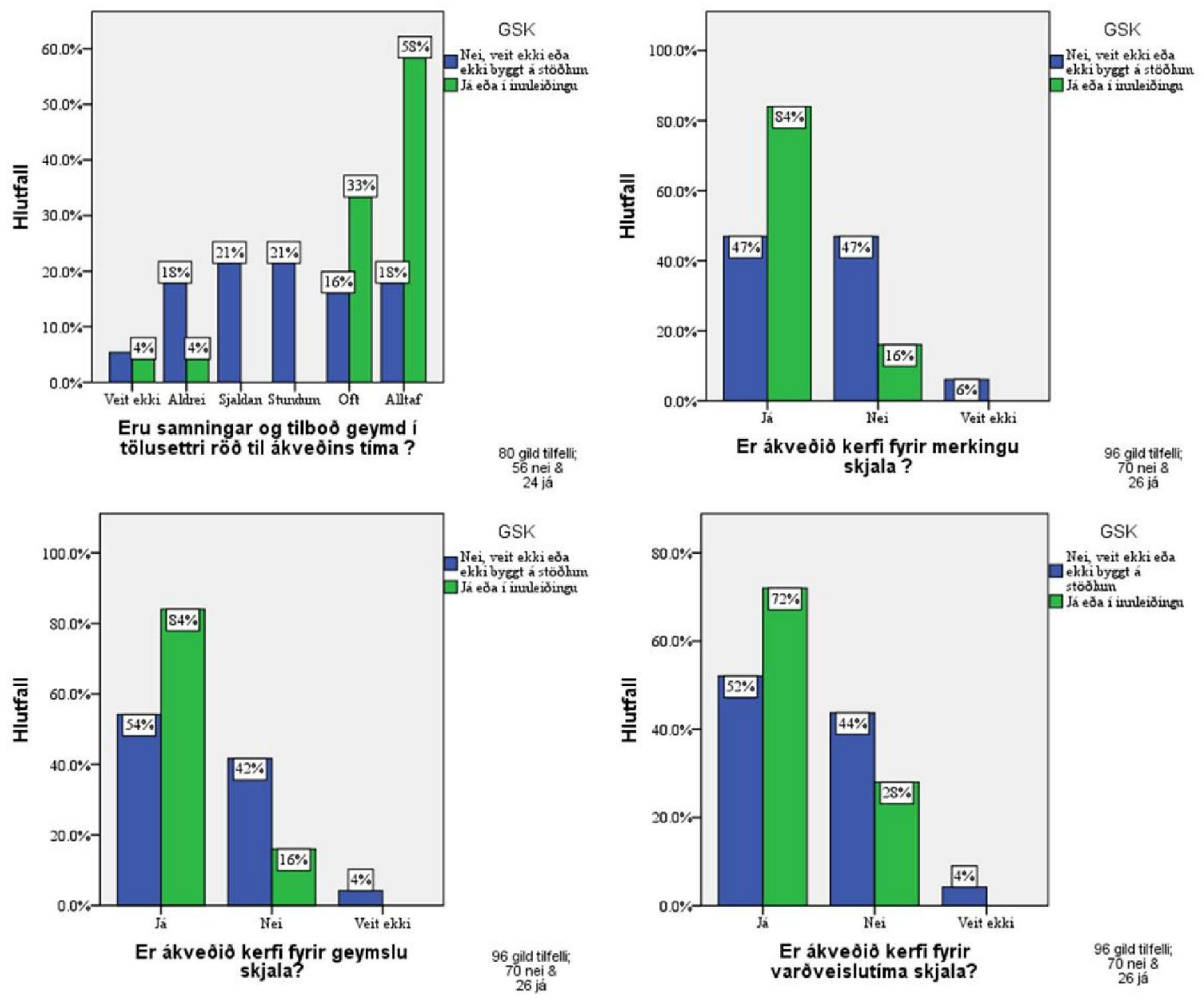

Mynd 53 Hlutfallsleg skipting á GSK með tilliti til innra verklags verktaka

Öryggismál. prír pættir sem tengjast öryggismálum verktaka mældust með marktæka fylgni við $G S K$, p.e. hvort öryggisstjóri og öryggistrúnaðarmaður starfi hjá fyrirtækinu og hvort/hversu oft verktaki gerir hættumat eða áhættugreiningu áður en framkvæmdir hefjast. Á stólparitunum hér að neðan má sjá hlutfallslega skiptingu á GSK með tilliti til ofangreindra pátta. 

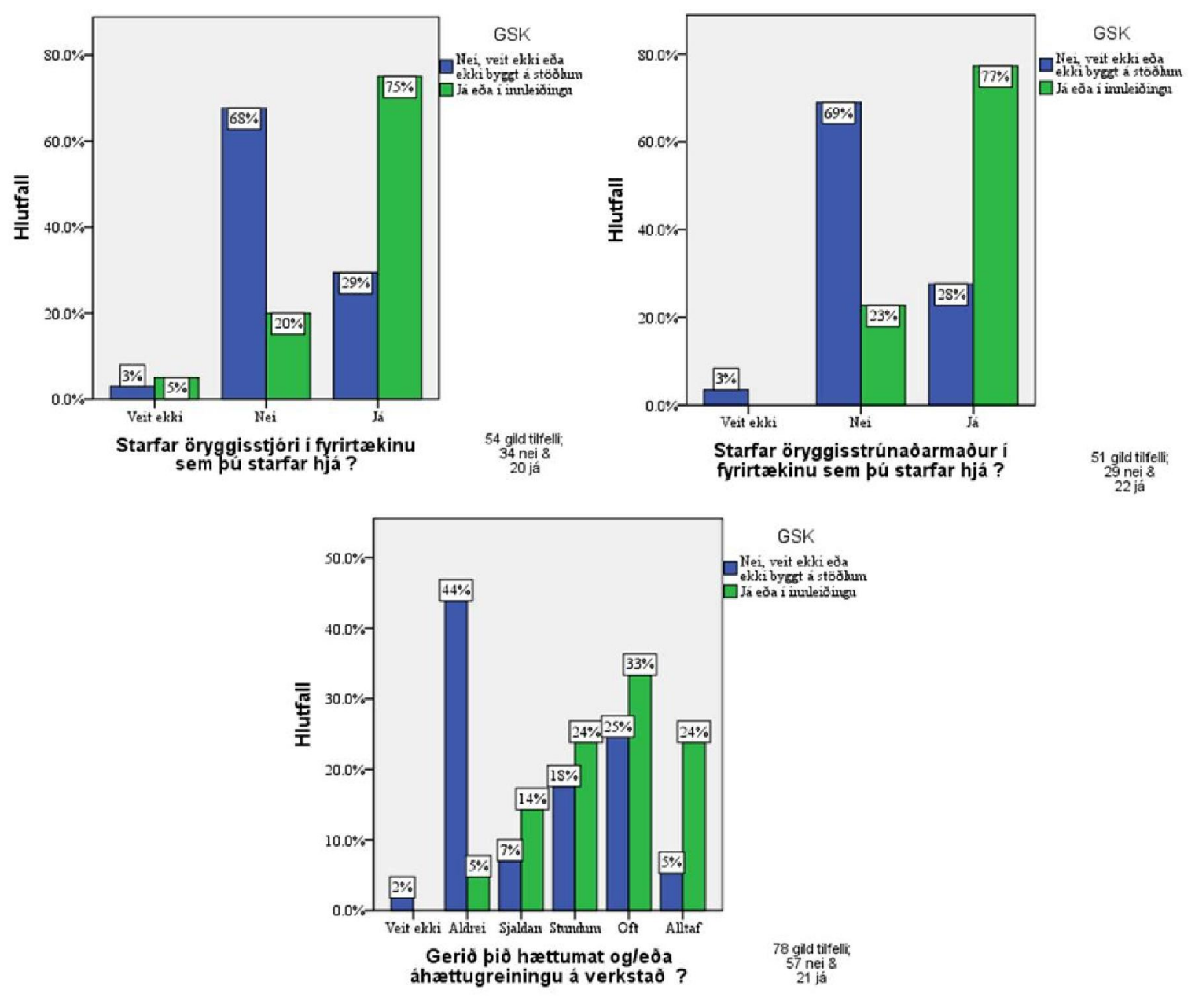

Mynd 54 Hlutfallsleg skipting á GSK með tilliti til öryggismála

Aukaverk og frábrigði. Sterk og miðlungs sterk fylgni er milli GSK og hvort/hversu oft verktaki skráir óskir verkkaupa um aukaverk og breytingar og hvernig verktaki tilkynnir verkkaupa um frábrigði. Á stólparitinu hér að neðan má sjá hlutfallslega skiptingu á GSK með tilliti til pess hvort aukaverk eru skráð og hvernig verkkaupa er tilkynnt um frábrigði. 

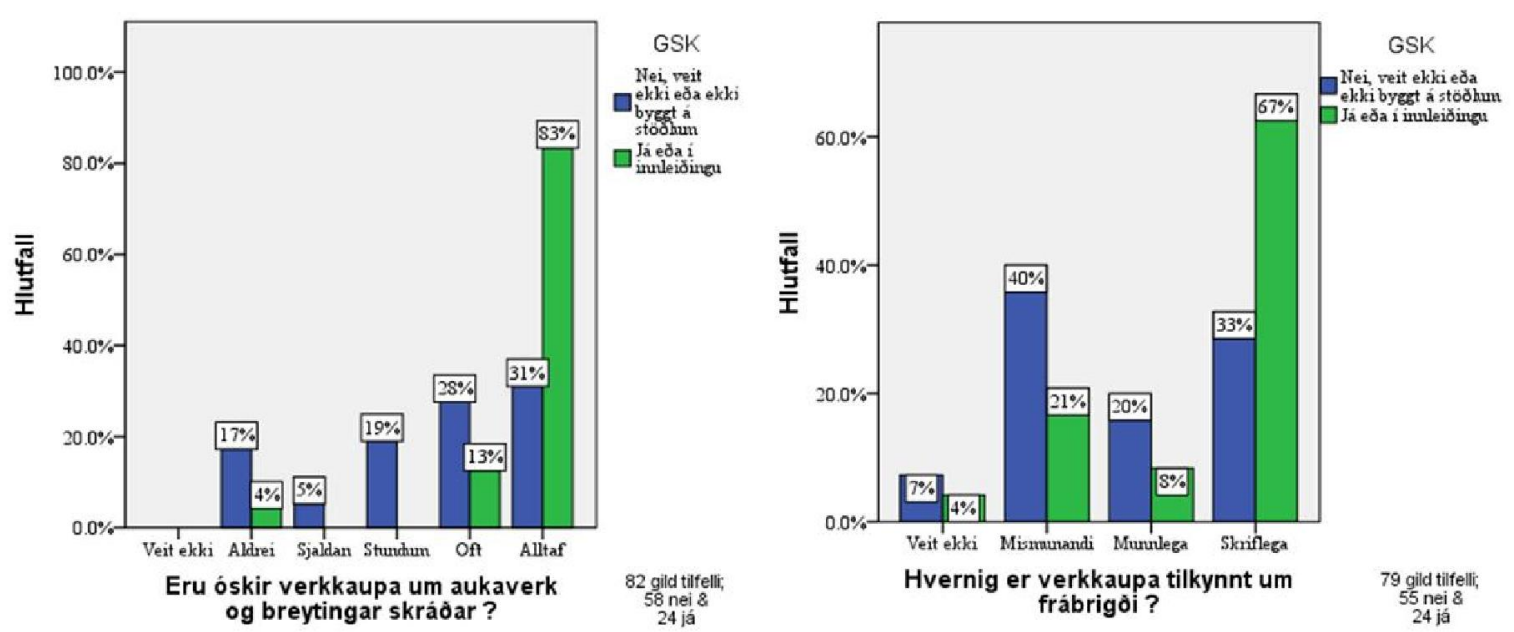

Mynd 55 Hlutfallsleg skipting á GSK með tilliti til pess hvort aukaverk eru skráð og hvernig verkkaupa er tilkynnt um frábrigði

Gæði. Sterk fylgni mældist milli GSK og hvort/hversu oft verktaki fer fram á gæðatryggingu frá undirverktökum og miðlungs sterk fylgni við bað hvort/hversu oft verktaki leggur fram gæðatryggingu. Einnig mældist sterk fylgni milli GSK og hvort/hversu oft verktaki er með innra eftirlit eða sérstaka gæðastýringaráætlun við framkvæmdir, en stólparitin hér að neðan sýna hlutfallslega skiptingu á GSK með tilliti til pess hvort/hversu oft verktaki fer fram á gæðatryggingu frá undirverktökum og útbýr gæðastýringaráætlun.
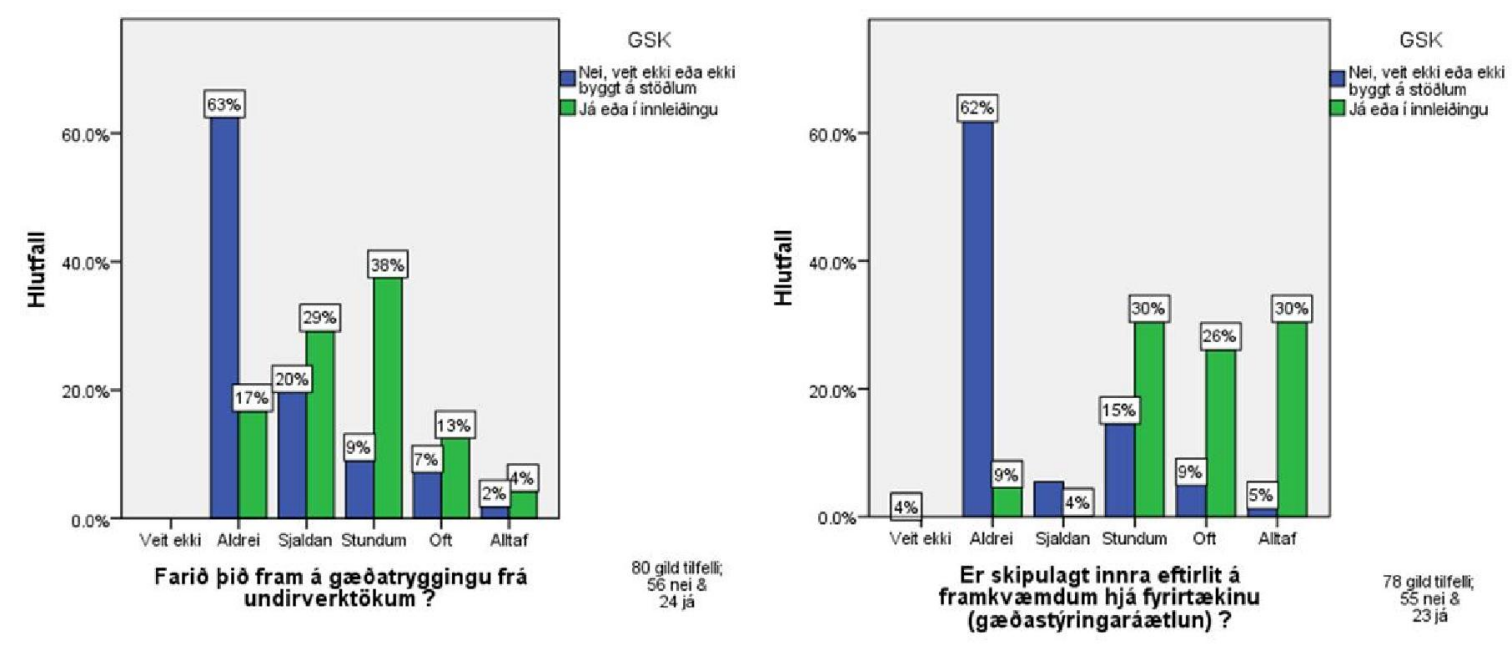

Mynd 56 Hlutfallsleg skipting á GSK með tilliti til pess hvort/hversu oft verktaki fer fram á goeðatryggingu frá undirverktaka og hvort/hversu oft hann er með sérstaka gaeðastýringarácetlun

Áætlanir. Marktæk og sterk fylgni er milli GSK annars vegar og hins vegar hvort/hversu oft verktaki leggur fram skriflega tilkynningu um verktöf ef við á, hvort/hversu oft verktaki útbýr skriflega verkáætlun og hvort/hversu oft verktaki heldur verkdagbók. En hið síðarnefnda er lykillinn að pví að geta rökstutt verktöf og sýnt fram á framvindu framkvæmda. Einnig mælist martæk en frekar veik fylgni við $G S K$ og hvort/hversu oft verktaki leggur fram skriflega greiðsluáætlun. Stólparitin hér að neðan sýna hlutfallslega 
skiptingu á GSK með tilliti til pess hvort/hversu oft verktaki leggur fram skriflegar áætlanir og hvort/hversu oft hann heldur verkdagbók.
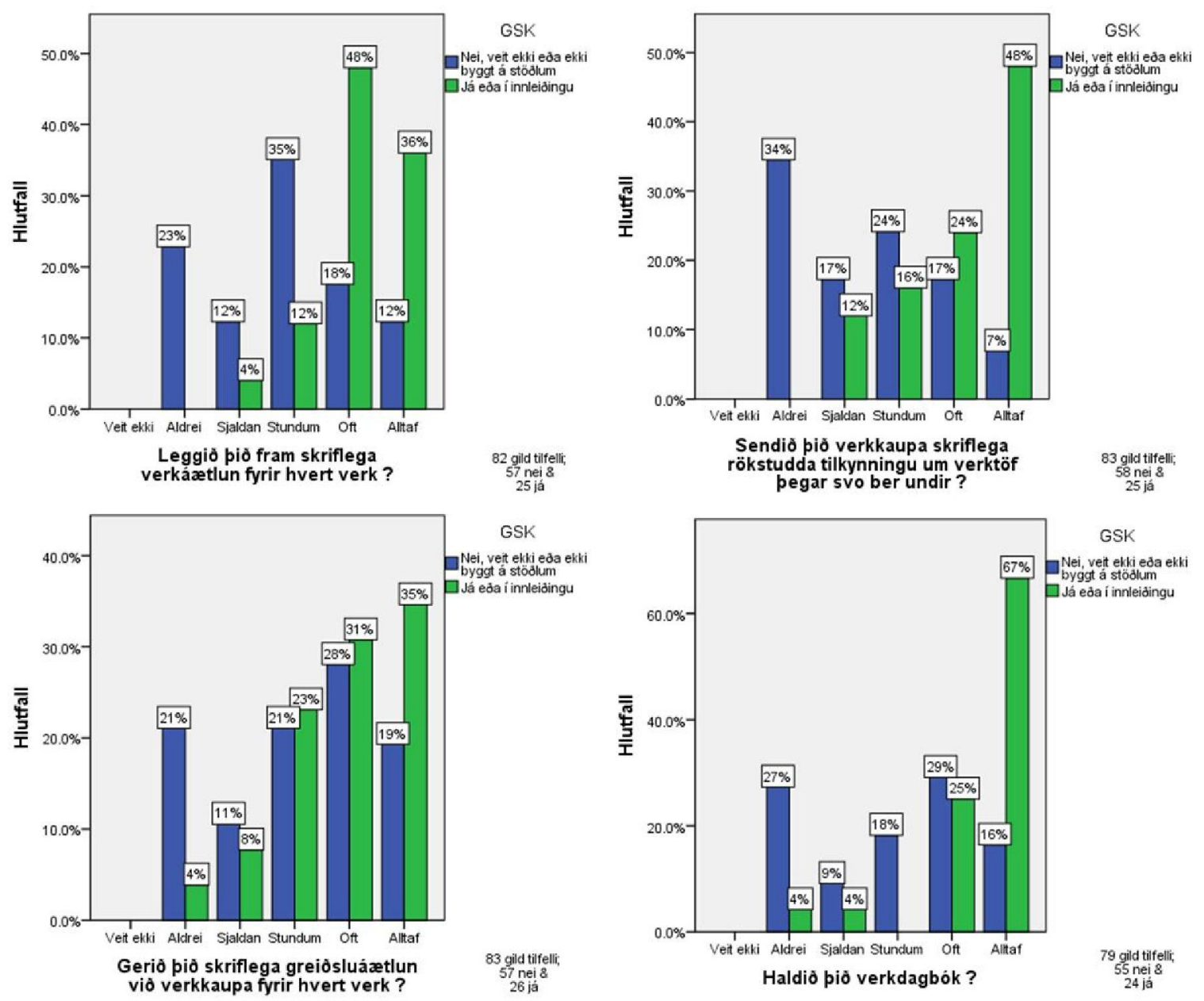

Mynd 57 Hlutfallsleg skipting GSK með tillit til skriflegra áaetlana og verkdagbókar

Verkfundir. Sterk og marktæk fylgni mælist milli annars vegar $G S K$ og hins vegar hvort/hversu oft verktaki er með reglubundna verkfundi með verktaka og hvort verktaki riti fundargerð á verkfundum. Stólparitin hér að neðan sýna hlutfallslega skiptingu á GSK með tilliti til pess hvort/hversu oft verktaki ritar fundargerð og hvort/hversu oft hann semur við verkkaupa um reglubundna verkfundi. 

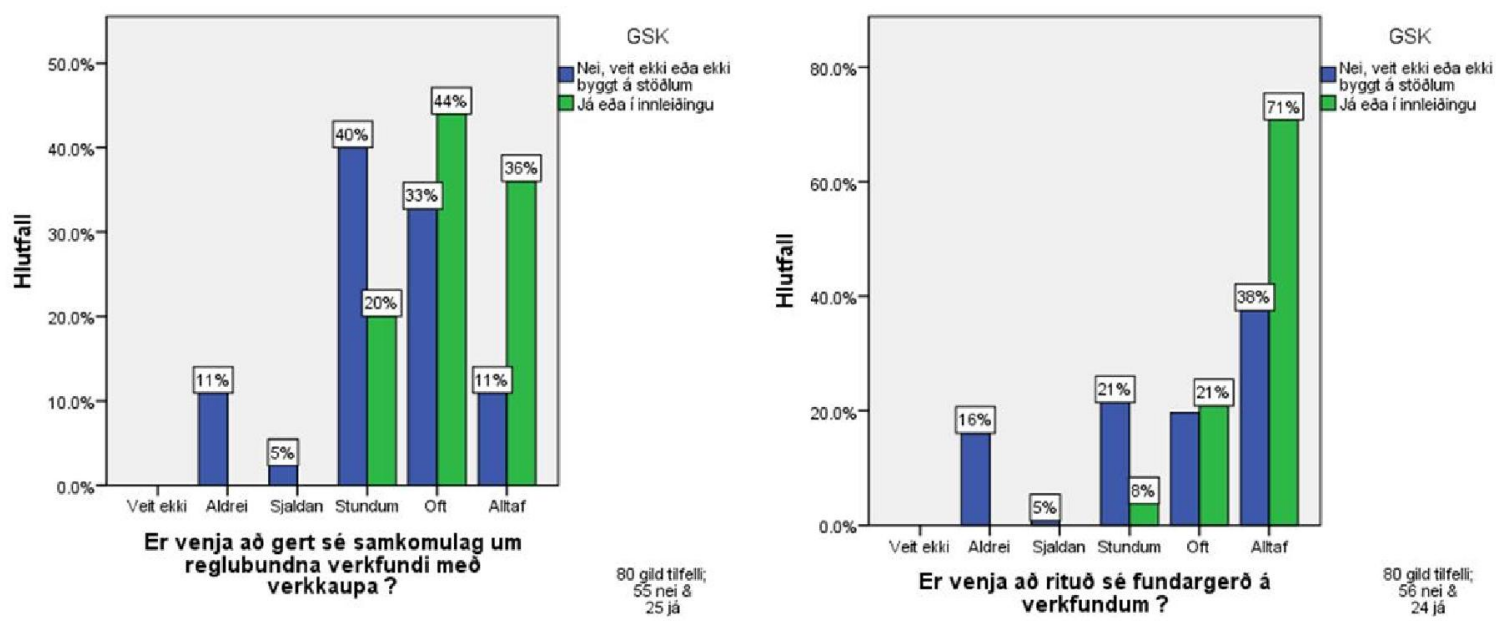

Mynd 58 Hlutfallsleg skipting á GSK með tilliti til pess hvort/hversu oft verktaki ritar fundargerð og hvort/hversu oft hann semur við verkkaupa um reglubundna verkfundi

\subsubsection{Kröfur verkkaupa}

Pátttakendur voru spurðir hvernig peim pættu kröfur verkkaupa (einstaklinga, fyrirtcekja og opinberra stofnana) um skipulag og markvissa stjórnun í garð verktaka hafa verið annars vegar fyrir efnahagshrun og hins vegar eftir efnahagshrun. Pátttakendum fannst í öllum tilfellum, p.e. fyrir einstaklinga, fyrirtæki og opinberar stofnanir, að kröfur um slíkt hefðu aukist eftir efnahagshrunið. Skífuritin hér að neðan sýna samantekt á svörum verktaka.

Almennt virðist sem verktökum finnist kröfur einstaklingsverkkaupa í garð verktaka um skipulag og markvissa stjórnun vera litlar hvort sem er fyrir eða eftir efnahagshrun, prátt fyrir að greina megi auknar kröfur eftir efnahagshrunið. Hjá opinberum stofnunum virðast kröfurnar almennt vera miklar fyrir og eftir efnahagshrun en jafnframt má greina auknar kröfur eftir efnahagshrun. 


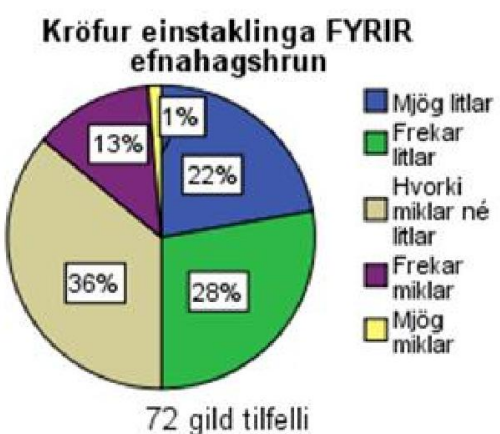

Kröfur fyrirtækja FYRIR

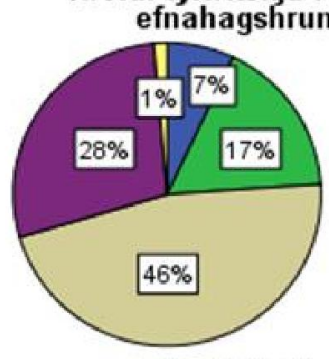

71 gilt tilfelli

Kröfur opinbera stofnana FYRIR efnahagshrun

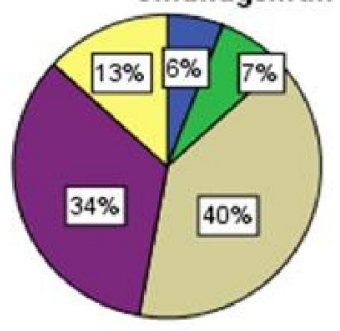

68 gild tilfelli
Kröfur einstaklinga EFTIR efnahagshrun

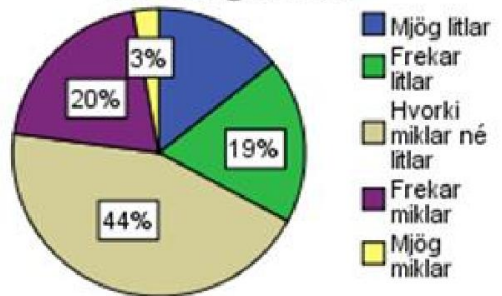

70 gild tilfelli

Kröfur fyrirtækja EFTIR efnahagshrun

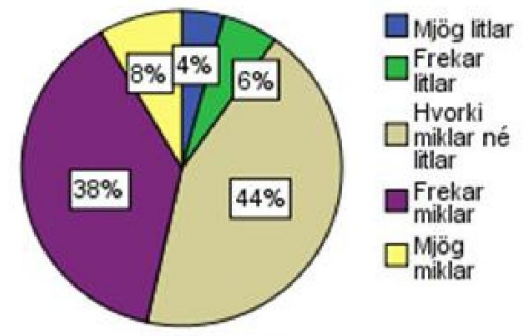

71 gilt tilfelli

Kröfur opinbera stofnana EFTIR efnahagshrun

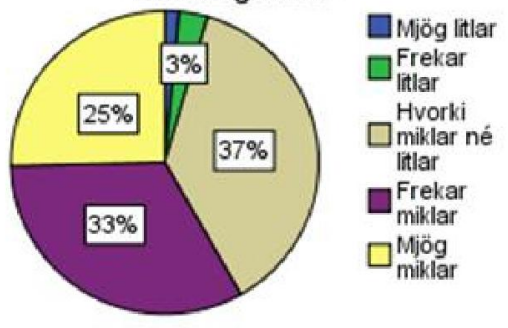

67 gild tilfelli

Mynd 59 Kröfur verkkaupa i garð verktaka um skipulag og markviss vinnubrögð fyrir og eftir efnahagshrun

Ekki greindist marktæk fylgni milli hversu miklar kröfur verktökum fannst verkkaupar hafa í sinn garð og GSK eða ánægju verkkaupa með umræddan verktaka. 


\subsection{Helstu niðurstöður flokka aðhvarfsgreiningar}

Eins og áður hefur verið komið inn á var notast við flokka aðhvarfsgreiningu (e. Categorical regression, CATREG) til pess að búa til línulegt líkan sem á að skýra tengsl milli valdra pátta og ánægju verkkaupa með framkvæmd verksins hjá umræddum verktaka. Pegar töluleg gögn eiga í hlut er margvíð aðhvarfsgreining algengasta aðferðin til að spá fyrir um háđa breytu út frá setti af svarbreytum (Anita J. van der Kooij, 2003). Nánar má lesa um aðferðina í viðauka og í kafla um greiningaraðferð.

Svör verkkaupa voru tengd við svör viðkomandi verktaka og var pannig hægt að nota gögn úr báđum könnunum til að búa til líkanið, en að sama skapi fækkaði gildum tilfellum niður í 47 par sem ekki náðist að fá alla pá verktaka sem verkkauparnir höfðu í huga við svörun í könnun fyrir verkkaupa til að taka pátt í könnun fyrir verktaka. Engar almennar reglur gilda um hve stórt úrtak parf að vera með tilliti til pess hvað hægt er að hafa margar óháðar breytur í línulegu líkani. Pumalputtaregla sem Good og Hardin settu fram (Good PI, Hardin JW, 2009) er að $N=m^{n}$, par sem $N$ er stærð úrtaks, $n$ er fjöldi óháðra breyta og $m$ er fjöldi athugana sem parf til að ná peirri nákvæmni sem sóst er eftir ef einungis ein óháð breyta væri í líkaninu. Sem dæmi má nefna að ef nægjanleg nákvæmi til að skilgreina línu $m$ séu 3 athuganir og að í úrtakinu eru 47 pátttakendur pá getur líkanið haft 3 óháðar breytur par sem $\frac{\ln (47)}{\ln (3)}=3,5$. Рað verður pví að hafa í huga að líklega er hægt að finna mun betra líkan ef til væri meira af gildum tilfellum.

Til pess að finna besta líkanið er leitast eftir pví að finna líkan sem skýrir sem mest af ferviki fyrir gögnin, p.e. með sem stærsta $\mathrm{R}$ gildið en er jafnframt með markgilda fylgnistuðla. Aðferðin sem var beitt til pess að finna slíkt líkan felst í pví að 5 pættir sem mælast með sterkustu fylgni við ánægju verkkaupa voru upphaflega notaðir sem spábreytur. Spábreytum var svo fækkað - einni í einu - á meðan pær voru ekki marktækar, með tilliti til mikilvægisstuðuls Pratt's hverju sinni. Pegar allar spábreytur voru orðnar marktækar var lokaniðurstaðan líkan sem skýrir 70,05\% af ferviki fyrir gögnin og lítur svona út:

$$
\text { ánægja } a_{u m r æ d d a n}=0,553(G S K)+0,780\left(a ́ n æ g j a_{\text {heild }}\right)
$$

Par sem skýrsluhöfundi pykir ekki sérlega upplýsandi að enda með líkan fyrir ánægju verkkaupa með umræddan verktaka par sem önnur spábreytan af tveimur er ánægja verkkaupa með framkvæmd verksins í heild, var ný nálgun við líkansmíðar tekin upp.

Sömu skref voru endurtekin og lýst var hér að ofan, nema öllum breytum sem tengdust ánægju verkkaupa með aðra pætti var sleppt. Mörg líkön voru prófuð en besta líkanið sem fannst skýrir 45,3\% af ferviki fyrir gögnin og lítur pað svona út:

$$
\text { ánægja } a_{\text {umræddan }}=0,506(G S K)+0,367\left(\text { verkfundir }_{\text {fleiri }}\right)
$$


Niðurstaðan sem líkanið gefur er að ánægja verkkaupa er undir miklum áhrifum af pví hvort verktakar starfa eftir gæðastjórnunarkerfi eða ekki. Fylgni, polmörk, marktækni, mikilvægisgildi ofl. má sjá í töflum hér að neðan:

Tafla 8 R gildi fyrir líkan 6

\begin{tabular}{clcc}
\hline \hline Margfalt $\mathrm{R}$ & $\mathrm{R}^{2}$ & Aðlagað $\mathrm{R}^{2}$ & $\mathrm{APE}$ \\
\hline .673 & .453 & .425 & .547 \\
\hline \hline Dependent Variable: ánægja umræddan & &
\end{tabular}

Predictors: ánægja heild GSK

Tafla 9 Fylgnistuðlar fyrir líkan 6

\begin{tabular}{lccccc}
\hline \hline & \multicolumn{5}{c}{ Staðlaðir stuðlar } \\
\cline { 2 - 5 } & Beta & $\begin{array}{c}\text { Bootstrap } \\
(1000) \text { mat á } \\
\text { Std. fráviki }\end{array}$ & df & F & Sig. \\
\hline GSK & .506 & .127 & 1 & 15.855 & .000 \\
verkfundir_fleiri & .367 & .154 & 1 & 5.723 & .022 \\
\hline \hline Dependent Variable: ánæegia_umreddan
\end{tabular}

Tafla 10 Fylgni og polmörk fyrir líkan 6

\begin{tabular}{lccccccc}
\hline \hline & \multicolumn{3}{c}{ Fylgni } & & \multicolumn{2}{c}{ Polmörk } \\
\cline { 2 - 3 } & $\begin{array}{c}\text { Núllta- } \\
\text { stigs }\end{array}$ & Hluta & Hlut & $\begin{array}{c}\text { Mikilvægis- } \\
\text { stuðull }\end{array}$ & $\begin{array}{c}\text { Eftir } \\
\text { umbreytingu }\end{array}$ & $\begin{array}{c}\text { Fyrir } \\
\text { umbreytingu }\end{array}$ \\
\hline GSK &, 568 &, 559 &, 498 &, 633 &, 972 &, 972 \\
verkfundir_fleiri &, 453 &, 440 &, 362 &, 367 &, 972 &, 972 \\
\hline \hline Dependent Variable: annægianumreddan & & & & &
\end{tabular}




\section{Niðurstöður og umræða}

Í upphafi voru settar fram eftirfarandi rannsóknaspurningar. Hér verða dregnar saman niðurstöður úr báðum könnunum og úr fræðakafla og pannig leitast við að gefa greina góð svör við neðangreindum spurningum. Einnig eru huglægt mat og umræða um hverja rannsóknarspurningu sett fram.

1. Hver er staða gaðastjórnunar í mannvirkjagerð ?

a. Hver er pekking verktaka á gæðastjórnun ?

2. Í hverju felst munurinn á verktökum, sem starfa eftir gæðastjórnunarkerfi, og verktökum sem starfa ekki eftir gæðastjórnunarkerfi ?

a. Eru fyrirtæki, sem starfa eftir gæðastjórnunarkerfi, með ánægðari viðskiptavini en fyrirtæki sem starfa ekki eftir gæðastjórnunarkerfi ?

b. Er verklagi íslenskra byggingaverktaka ábótavant ?

c. Hvernig er samskiptum verkkaupa og verktaka háttað í mannvirkjagerð ?

d. Hvert er viðhorf verktaka til gæðastjórnunar?

e. Kröfur til verktaka um skipulag og markvissa stjórnun?

f. Hver er staða gæðatryggingar í mannvirkjagerð ?

\section{Hvaða bættir hafa mest áhrif á ánægju verkkaupa ?}

\subsection{Hver er staða gæðastjórnunar í mannvirkjagerð?}

Niðurstöður úr könunum fyrir bæði verkkaupa og verktaka sýna að stöðu gæðastjórnunar á Íslandi er almennt ábótavant. Almenn pekking verktaka á gæðastjórnun er lítil en að sama skapi sýna niðurstöður einnig að sökin liggur ekki öll verktakamegin, heldur er pekking verkkaupa á gæðastjórnun ónóg og kröfur peirra til verktaka í mörgum tilfellum í samræmi við pað. Niðurstöður gáfu einnig til kynna að kröfur fyrirtækjaverkkaupa til verktaka um markviss vinnubrögð og stjórnun væru talsvert meiri en hjá einstaklingsverkkaupum.

Mikill munur er á stöðu gæðastjórnunar með tilliti til stærðar verktakafyrirtækja. Meðal stærstu fyrirtækjanna en pekking og verklags er töluvert betri en hjá smærri fyrirtækjunum. Telur skýrsluhöfundur að brýn pörf sé fyrir aðgengilegt og notendavænt gæðastjórnunarkerfi fyrir smá verktakafyrirtæki en ljóst er að umfang gæðastjórnunarkerfis ætti alltaf að taka mið af stærð fyrirtækis. Svör við opinni spurningu í könnun fyrir verktaka, pegar spurt var hvort peir vildu koma einhverju að að lokum, gáfu greinilega í skyn að margir fulltrúar smærri verktakafyrirtækja töldu að gæðastjórnunarkerfi hentaði síður litlum fyrirtækjum en peim stærri par sem verklag peirra gæti verið mun einfaldara. Rannsóknir hafa einnig gefið til kynna að stefnumótun gæðastjórnunar í stórum fyrirtækjum henti ekki peim litlu. Einnig hefur sú gagnrýni komið fram að líkan innan gæðastjórnunar séu ekki hönnuð til að taka á lykileinkennum lítilla fyrirtækja. Gæti pví 
verið að gefa pyrfti frekar gaum að innleiðingarferlinu hjá litlum fyrirtækjum (Hansson, 2003).

\subsubsection{Hver er pekking verktaka á gæðastjórnun?}

Í frægri bók Phil Crosby - Quality is free. the art of making quality certain - segir að vandamálið við gæðastjórnun felist í pví sem fólk telur sig vita um gæðastjórnun fremur en sem pað raunverulega veit (Crosby P. , 1979). Margar rannsóknir hafa sýnt að pekking á gæðastjórnun meðal verktaka sé ekki nægjanlega góð. Sem dæmi um pað segir í rannsókninni Total quality management in the construction industry: A preliminary analysis sem var gerð af Boaden, Ruth, Dale og Barrie á meðal breskra verktaka, að pekking breskra verktaka á gæðastjórnun sé ekki nægjanlega góð og verktakar rugli oft saman hugtökum eins og gæðastjórnun og gæðatryggingu (Boaden, 1992). Ekki pykir skýrsluhöfundi ólíklegt að sama staða sé hér á landi.

Einnig hefur verið sýnt fram á að eitt af helstu vandamálunum við innleiðingu gæðastjórnunar sé m.a skortur á skilningi á ISO 9001 staðlinum (Abdullah, 2006), pekkingu á gæðastjórnun (Young, 2007) og sér í lagi hugtökum gæðastjórnunar (Hansson, 2003)

Niðurstöður úr könnun meðal verktakanna gefa til kynna að um helmingur pátttakenda hafi eitthvað kynnt sér gæðastjórnun. Talsvert fleiri sögðust hafa kynnt sér innihald ÍST 30 en ISO 9001. Pessar niðurstöður byggjast pó einvörðungu á mati verktaka á eigin pekkingu en til að meta pekkingu peirra í raun pyrfti frekari rannsóknarvinna að eiga sér stað.

Athyglisvert er að rúmlega $61 \%$ pátttakenda fannst mjög eða frekar mikil vöntun á stöðluðum og samræmdum útboðsgögnum.

Mjög marktæk og sterk fylgni mældist milli annars vegar $G S K$ og hins vegar pekkingar verktaka á gæðastjórnun. Petta á við bæði varðandi almenna bekkingu og enn frekar pekkingu á ISO 9001 eða ÍST 30, en sterka fylgni má sjá í töflunni hér að neðan.

Tafla 11 Samantekt á marktorik fylgni pekkingar ${ }^{52}$ við GSK

\begin{tabular}{lcccccc}
\hline \hline & \multicolumn{5}{c}{ GSK } & \\
\cline { 2 - 3 } ÍST30 & Fylgnistuðull & Sig. & & Fylgnistuðull & Sig. & N \\
almennt &, 742 &, 000 & & 0,489 &, 000 & 84 \\
ISO9001 &, 719 &, 000 & & 0,462 &, 000 & 85 \\
\hline \hline
\end{tabular}

Fleiri sögðust hafa kynnt sér gæðastjórnun almennt og innihald ÍST 30 en innihald ISO 9001. Eins og áður pá byggjast pessar niðurstöður einvörðungu á mati verktaka á eigin pekkingu og gildir pví sami fyrirvari og áour.

\footnotetext{
${ }^{52}$ Skýringar á breytuheitum sem eru notuð í töfluna eru í viðauka D á bls. 253
} 


\section{2 Í hverju felst munurinn á verktökum, sem starfa eftir gæðastjórnunarkerfi, og verktökum sem starfa ekki eftir gæðastjórnunarkerfi ?}

Sérstaklega var reynt að komast til botns í pví hvort munur er á starfsháttum verktaka eftir pví hvort peir starfa eftir gæðastjórnunarkerfi byggðu á viðurkenndum stöðlum eða ekki. Eins og fram kemur í kafla 2.1.2 á bls. 5 telur skýrsluhöfundur að pað sé mikil pörf fyrir almenna skilgreiningu á gæðastjórnunarkerfi fyrir verktaka sem sækjast ekki eftir bví að fá vottun sem tekur tillit til stærðar fyrirtækja og verkefna. Eins og staðaan er nú á Íslandi geta verktakar í raun sagt að peir starfi eftir gæðastjórnunarkerfi sem sé ekki vottað án pess að hafa nokkra hugmynd um hvað gæðastjórnunarkerfi er og var skýrsluhöfundur var við pað við gerð rannsóknarinnar að verktakar segðust starfa eftir gæðastjórnunarkerfi sem peir byggðu á eigin reynslu.

Kannað var hvort verkkaupar eru almennt ánægðari með framkvæmd verka með tilliti til verklags verktaka og hvort peir standist frekar tíma- og kostnaðaráætlanir.

\subsubsection{Eru fyrirtæki sem starfa eftir gæðastjórnunarkerfi með ánægðari viðskiptavini en fyrirtæki sem starfa ekki eftir bví ?}

Eftirfarandi núlltilgáta var sett fram í upphafi; $\mathrm{H}_{0}=$ enginn munur er á ánoegju verkkaupa eftir pvi hvort umrceddur verktaki starfar eftir goðastjórnunarkerfi byggðu á viðurkenndum gœðastjórnunarstöðlum eða ekki. Notast var við stikalausa prófið, MannWhitney $U$ test, með marktektarstig 0,05 og 95\% öryggisbil, sjá nánar um pað í viðauka Q á bls. 461. Samkvæmt útreikningum með SPSS Statistics er núlltilgátunni hafnað sem pýðir að pað er marktækur munur á ánægju verkkaupa með framkvæmd verks hjá verktaka með tilliti til pess hvort hann starfar eftir gæðastjórnunarkerfi byggðu á viðurkenndum gæðastjórnunarstöðlum eða ekki.

Ef ánægja verkkaupa með framkvæmd verks hjá verktaka er könnuð með fylgnireikningum sérstaklega með tilliti til GSK sést að almennt eru verkkaupar, sem voru með í huga verktaka sem starfar eftir gæðastjórnunarkerfi, ánægðari en peir sem voru með verktaka í huga sem starfar ekki eftir gæðastjórnunarkerfi. Myndin hér að neðan sýnir petta greinilega. 


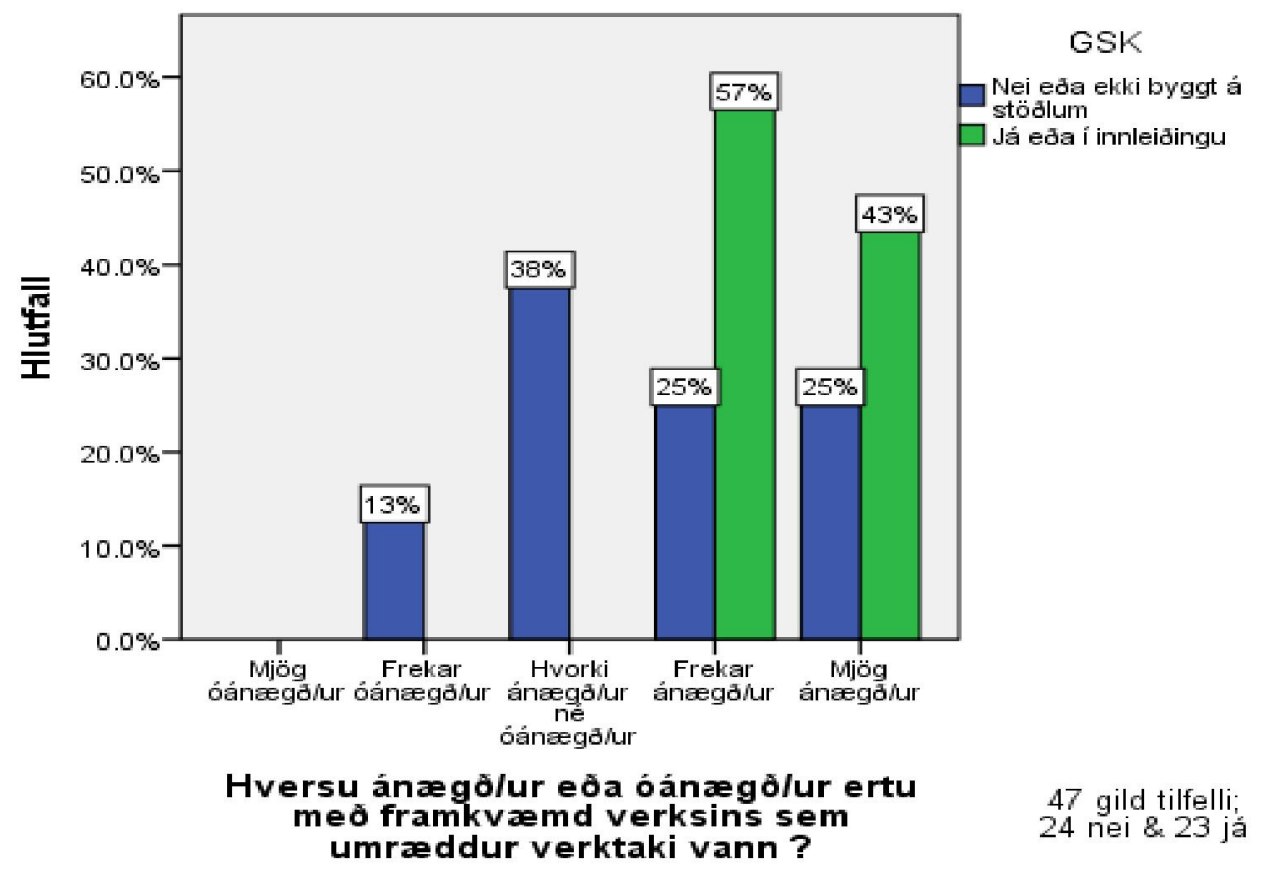

Mynd 60 Áncegja verkkaupa með framkvoemd hjá verktaka með tilliti til GSK

Fylgni milli GSK og allra breyta í könnun fyrir verkkaupa sem snéru að pví hversu ánægðir peir voru með tiltekna pætti í framkvæmd var könnuð.

Niðurstöður sýna að peir ánægjupættir sem mælast með marktæka fylgni við pað hvort verktaki starfi eftir gæðastjórnunarkerfi eða ekki eru: Áncegja verkkaupa með framkvoemd verksins hjá umrceddum verktaka, áncegja verkkaupa með öryggismál og ánogja verkkaupa með gæeði byggingar. Í töflunni hér að neðan eru pessir pættir teknir saman og styrkur fylgnistuðla sýndir.

Tafla 12 Peir ánoegjupaettir sem maeldust með marktaka fylgni við pað hvort verktaki starfaði eftir gaððastjórnunarkerfi byggðu á viðurkenndum stöðlum ${ }^{53}$

\begin{tabular}{lcccccc}
\hline \hline & \multicolumn{5}{c}{ GSK } & \\
\cline { 2 - 3 } & \multicolumn{2}{c}{ Gamma } & & \\
\cline { 2 - 3 } & Fylgnistuðull & Sig. & & Fylgnistuðull & Sig. & \\
ánægja_gæði &, 707 &, 000 & &, 446 &, 002 & 47 \\
ánægja_umræddan &, 623 &, 001 & &, 430 &, 003 & 47 \\
ánægja_öryggismál &, 580 &, 003 & &, 393 &, 006 & 47 \\
\hline \hline
\end{tabular}

Sterk fylgni mælist við pað hversu ánægðir verkkaupar eru með gæði verks sem gefur til kynna að verktakar með gæðastjórnunarkerfi vandi frekar til verka og séu hugsanlega með betra gæðaeftirlit en peir sem ekki hafa innleitt slíkt kerfi. Pessi niðurstaða kemur heim og saman við niðurstöður úr könnun verktaka par sem fylgni milli verktaka, sem starfa eftir gæðastjórnunarkerfi og hvort verktakar séu með innra eftirlit eða ákveðna gæðastýringaráætlun við framkvæmdir, reyndist mjög marktæk og sterk.

\footnotetext{
${ }^{53}$ Skýringar á breytuheitum sem eru notuð í töfluna eru í viðauka D á bls. 253
} 
Niðurstöður gefa einnig til kynna að verkkaupar séu almennt ánægðari með framkvæmd verka hjá verktökum sem starfa eftir gæðastjórnunarkerfi.

Líklegt pykir að verktökum, sem starfa eftir gæðastjórnunarkerfi, sé meira umhugað um öryggismál en peim sem starfa ekki eftir gæðastjórnunarkerfi. Niðurstöður sýna að marktækur munur er á ánægju verkkaupa með öryggismál hjá verktökum eftir pví hvort peir starfa eftir gæðastjórnunarkerfi eða ekki.

\subsubsection{Er munur á verklagi íslenskra byggingaverktaka með tilliti til pess hvort peir starfa eftir gæðastjórnunarkerfi eða ekki ?}

Niðurstöður gefa til kynna að mörg sóknarfæri leynist í bættum vinnubrögðum meðal verktaka á Íslandi. Fylgni milli pátta sem tengdust verklagi verktaka og hvort verktaki starfar eftir gæðastjórnunarkerfi byggðu á viðurkenndum gæðastöðlum (GSK), var könnuð annars vegar með tilliti til svara úr könnun fyrir verkkaupa og hins vegar með tilliti til svara úr könnun verktaka. Hér að neðan eru töflur sem sýna marktæka fylgnistuðla milli pátta sem tengjast verklagi verktaka við $G S K$, sér í lagi úr könnun fyrir verkkaupa og könnun fyrir verktaka.

Tafla 13 Peir paettir úr könnun verkkaupa, tengdir verklagi verktaka sem maeldust með marktaku fylgni við GSK $^{54}$

\begin{tabular}{lcccccc}
\hline \hline & \multicolumn{4}{c}{ GSK } & \\
\cline { 2 - 3 } & Gylgnistuðull & Sig. & & Fylgnistuðull & Sig. & N \\
\cline { 2 - 3 } öryggismál_rædd &, 868 &, 000 & &, 576 &, 000 & 47 \\
aukav_skráð_verkk &, 851 &, 000 & &, 639 &, 001 & 22 \\
skrifleg_tíma &, 840 &, 000 & &, 537 &, 000 & 47 \\
verkfundir_samkomulag &, 840 &, 000 & &, 537 &, 000 & 47 \\
gæðatrygging &, 820 &, 001 & &, 441 &, 002 & 47 \\
verkfundir &, 778 &, 000 & &, 522 &, 000 & 47 \\
skrifleg_greiðslu &, 700 &, 002 & &, 407 &, 005 & 47 \\
samningur_ræddur &, 676 &, 002 & &, 446 &, 007 & 35 \\
verkfundir_fundargerð &, 664 &, 002 & &, 441 &, 004 & 41 \\
verkfundir_staða &, 614 &, 001 & &, 454 &, 004 & 39 \\
samningur_sundurliðaður &, 513 &, 022 & &, 350 &, 039 & 35 \\
verklýsingar_milliverkpátta &, 481 &, 013 &, 340 &, 019 & 47 \\
\hline \hline
\end{tabular}

\footnotetext{
${ }^{54}$ Skýringar á breytuheitum sem eru notuð í töfluna eru í viðauka D á bls. 253
} 


\begin{tabular}{llllll} 
öryggisstrúnaðarm &, 801 &, 000 &, 495 &, 000 & 51 \\
aukaverk_skráð &, 791 &, 000 &, 464 &, 000 & 82 \\
gæðastýringaráætlun &, 764 &, 000 &, 550 &, 000 & 78 \\
verkdagbók &, 757 &, 000 &, 500 &, 000 & 79 \\
verktöf_skrifleg &, 739 &, 000 &, 520 &, 000 & 83 \\
ÍST30_kröfur &, 738 &, 000 &, 479 &, 000 & 78 \\
merking &, 717 &, 000 &, 362 &, 002 & 74 \\
verkáætlun_skrifleg &, 707 &, 000 &, 478 &, 000 & 82 \\
starfslýsingar_skriflegar &, 706 &, 000 &, 505 &, 000 & 90 \\
tölusett &, 685 &, 000 &, 464 &, 000 & 80 \\
öryggisstjóri &, 666 &, 002 &, 406 &, 002 & 54 \\
geymslu &, 638 &, 003 &, 300 &, 010 & 73 \\
verkfundir_reglubundnir &, 633 &, 000 &, 393 &, 000 & 80 \\
fundargerð &, 628 &, 000 &, 359 &, 001 & 80 \\
gæðatrygging_undirverkt &, 622 &, 000 &, 422 &, 000 & 80 \\
gæðatrygging_verktaki &, 580 &, 000 &, 390 &, 000 & 82 \\
hættumat &, 563 &, 000 &, 372 &, 001 & 78 \\
gæðatrygging_ósk &, 534 &, 001 &, 364 &, 001 & 74 \\
frábrigði_tilkynnt &, 0011 &, 279 &, 013 & 79 \\
greiðsluáætlun_skrifleg &, 352 &, 024 &, 230 &, 036 & 83 \\
\hline \hline
\end{tabular}

Í heildina á litið sýna niðurstöður að verktakar, sem starfa eftir gæðastjórnunarkerfi byggðu á viðurkenndum gæðastöðlum $(G S K)$ starfa eftir mun markvissari og skilvirkari vinnubrögðum en peir verkkaupar sem ekki starfa eftir gæðastjórnunarkerfi og eru töflurnar hér að ofan vitnisburður um pað hversu margir pættir tengdir verklagi verktaka eru með marktæka fylgni við GSK. Sérstök athygli er vakin á pví hversu há fylgni mældist meðal marktækra fylgnistuðla við GSK í könnun fyrir verkkaupa pví svör verkkaupa ættu að vera laus við alla hlutdrægni í garð verktaka.

Hér verða niðurstöður úr báðum könnunum dregnar saman í eftirfarandi flokkum, öryggismál, aukaverk og frábrigði, gœði, ácetlanir, verkfundir, samningar og innra verklag.

ÖRYGGISMÁL. Í báðum könnunum reyndust breytur tengdar öryggismálum vera með sterkustu fylgnina við GSK og styður pað enn frekar við pá kenningu að verktakar, sem starfa eftir gæðastjórnunarkerfi, hugi meira að öryggismálum en peir sem starfa ekki eftir gæðastjórnunarkerfi.

\footnotetext{
${ }^{55}$ Skýringar á breytuheitum sem eru notuð í töfluna eru í viðauka D á bls. 253
} 
Í könnun fyrir verkkaupa var sterkasta fylgnin mjög sterk milli GSK og hvort öryggismál voru rædd áður en framkvæmdin hófst. Í könnun fyrir verktaka voru prír pættir með marktæka fylgni við GSK sem tengjast öryggismálum. P.e. hvort öryggisstjóri og öryggistrúnaðarmaður starfi hjá fyrirtækinu og hvort/hversu oft verktaki geri hættumat eða áhættugreiningu áour en framkvæmdir hefjast.

Skýrsluhöfundur telur að slys í tengslum við byggingaframkvæmdir séu óparflega algeng hér á landi, en eins og fram hefur komið hefur pví verið haldið fram að byggingaframkvæmdir séu með hættulegri iðnaði (John Oakland \& Marton Marosszek, 2006). Mörg slys má vafalaust rekja til skipulagsleysis á byggingavinnustað. En öryggismál eru mikilvægur hluti af gæðastjórnun og ættu pau ávallt að vera hluti af gæðastjórnunarkerfum verktaka. Eins og kunnugt er eru byggingaframkvæmdir afar mismunandi að umfangi og pað sama getur gilt fyrir öryggis- og heilbrigðisáætlanir. Engu að síður ætti ávallt að ræða öryggismál áður en framkvæmdir hefjast.

Ábyrgð verkkaupa samkvæmt lögum er talsverð pegar kemur að byggingaframkvæmdum en ekki virðist sú ábyrgð vera öllum verkkaupum ljós, sérstaklega er pá átt við smærri verkkaupa. Árið 1997 tóku gildi hér á landi reglur um aðbúnað, hollustuhætti og öryggisráðstafanir á byggingavinnustöðum. Par er sérstaklega er fjallað um ábyrgð og skyldur par sem fleiri en einn verktaki eru að störfum (Vinnueftirlitið, Sigfús Sigurðsson, 2002).

AUKAVERRK \& FRÁBRIGĐI. Næst sterkasta fylgni tengd verklagi verktaka í báðum könnunum tengdist skráningu aukaverka. Í könnun verkkaupa var fylgni $G S K$ mjög sterk við pað hvort verktaki hafôi skráð óskir verkkaupa um aukaverk og breytingar og í könnun fyrir verktaka var sterk fylgni við pað hvort/hversu oft verktaki skráir óskir verkkaupa um aukaverk og breytingar.

Skilgreiningin á orðinu frábrigði er ögn á reiki og hugsanlega ekki í skýr í huga allra sem svöruðu könnuninni. Með frábrigði í peim skilningi, sem notast er við í pessari rannsókn, er átt við varanlegan galla eða auka útgjöld.

Í könnun verktaka var marktæk fylgni við pað hvernig verktaki sagðist tilkynna verkkaupa um frábrigði og GSK en fylgni milli pess hvernig verkkaupi sagði að sér hefði verið tilkynnt um frábrigði í könnun fyrir verkkaupa og GSK reyndist ekki vera marktæk. Ekki var heldur marktæk fylgni milli fjölda frábrigða og GSK.

GÆĐI. Pættir tengdir gæðatryggingu og innra eftirliti mældust með sterka fylgni við $G S K$ bæði úr könnun fyrir verkkaupa og úr könnun fyrir verktaka. Úr fyrrnefndri könnun mældist marktæk og mjög sterk fylgni milli pess hvort verktaki lagði fram gæðatryggingu og GSK. Úr könnun fyrir verktaka mældist sterk fylgni milli GSK og hvort/hversu oft verktaki fer fram á gæðatryggingu frá undirverktökum og miðlungs sterk fylgni við pað hvort/hversu oft verktaki leggur fram gæðatryggingu. Einnig mældist sterk fylgni milli GSK og hvort/hversu oft verktaki er með innra eftirlit eða sérstaka gæðastýringaráætlun við framkvæmdir.

Ofangreindar niðurstöður styðja pá tilgátu að verktakar, sem starfa eftir gæðastjórnunarkerfi hugsi meira um gæði framkvæmda og kröfur verkkaupa um gæði, en einn stærsti vandinn við pað að fjárfesta í byggingu, sem á eftir að byggja, felst í pví að hvorki er hægt að skoða né meta hönnun og framleiðslu að fullu fyrr en að verki loknu og 
að óbreyttu er lítil trygging fyrir pví að hlutirnir verði eða gangi eftir í samræmi við væntingar verkkaupa. Pví er afar mikilvægt að sannprófa hönnun og próun en í pví felst að gengið er úr skugga um að niðurstaðan uppfylli kröfurnar sem tilgreindar voru sem nauðsynlegar við upphaf hönnunarferilsins pegar hönnunarferli lýkur (Staðlaráo Íslands, 2003).

Síauknar kröfur eru í samfélaginu um innra eftirlit verktaka með eigin verkpáttum en tilgangur gæðatryggingar er fyrst og fremst fólginn í pví að verktakar sýni fram á að peir hafi burði til að vinna verkið áður en gengið er til samninga. Pannig er verkkaupa gert kleift að hafna peim aðilum sem ekki hafa til pess burði að vinna verkið eins og óskað er eftir.

begar verktaki ræður annan aðila til að vinna hluta af verkinu er hann sjálfur kominn í hlutverk verkkaupa og verður par af leiðandi að tryggja að sá hinn sami viðhafi viðunandi vinnubrögð. Verktakar, sem eru með undirverktaka í vinnu, ættu pví ávallt að fara fram á gæðatryggingu frá undirverktaka og bera hana saman við sína eigin gæðatryggingu sem verkkaupinn var búinn að sampykkja. Einnig ætti undirverktakinn að kynna sér vandlega innihald gæðatryggingar aðalverktaka svo öllum sé ljóst hverju var búið að lofa verkkaupa (Ferdinand Hansen, 2007).

ÁÆTLANIR. Ein helsta gagnrýni, sem verktakar hafa sætt í gegnum tíðina, snýr líklega að kostnaðar- og tímaáætlunum. Jafnvel hefur borið á pví að peir séu sakaðir um marklausar áætlanir sem standist sjaldan. Ástæðurnar eru margar en stór páttur er að markmið verkkaupans er yfirleitt að lágmarka kostnað og ljúka par með verkinu á sem skemmstum tíma (Guðjóna Björk Sigurðardóttir, 2008). Einnig eru verk í mannvirkjagerð oft bundin af afhendingardegi og pví getur orðið pörf á að pjappa verkefni saman (e. crashing the project) (Jack R. Meredith \& Samuel J. Mantel,Jr, 2009) sem getur leitt til aukins kostnaðar (S. Keoki Sears, 2008). Auk pess sem raunin er oft sú að verktaka er gefinn takmarkaður tími til að gera pessa kostnaðar áætlun og mistök sem gerð í tengslum við hana koma oft ekki í ljós fyrr en í lok verks (Garðar Örn Porvarðarson, 2010).

Niðurstöður sýna að pað heyrir frekar til undantekninga að einstaklingsverkkaupar fái afhentar skriflegar tíma- og greiðsluáætlanir í upphafi framkvæmda. Staðan er pveröfug ef einungis er horft á fyrirtækjaverkkaupa, en pað er bó alls ekki algilt að fyrirtækjaverkkaupum séu afhentar skriflegar áætlanir.

Úr könnun verkkaupa mælist marktæk og sterk fylgni milli GSK og hvort verktaki lagði fram skriflega greiðslu- og/eða skriflega tímaáætlun. Úr könnun verktaka mælist marktæk og sterk fylgni milli GSK annars vegar og hins vegar hvort/hversu oft verktaki leggur fram skriflega tilkynningu um verktöf til verkkaupa ef við á, hvort/hversu oft verktaki geri skriflega verkáætlun og hvort/hversu oft verktaki haldi verkdagbók. Hið síðarnefnda er lykillinn að pví að geta rökstutt verktöf og sýnt fram á framvindu framkvæmda. Einnig mælist marktæk en frekar veik fylgni við GSK og hvort/hversu oft verktaki leggur fram skriflega greiðsluáætlun. Samkvæmt grein 13.2.3 í ÍST 30 segir að verktaki skuli halda dagbók yfir verkið og skrá í hana verkefni hvers dags, mannafla skv. starfsgreinum, tæki, veðurfar og annað sem pýðingu hefur fyrir framgang verksins (Staðlaráð Íslands, 2003). 
Verkfundir. Ætla má að markvissir og vandaðir verkfundir séu mikilvægur páttur í ánægju viðskiptavina og farsælum framkvæmdum. Segja má að verkfundir séu miðpunktur samskipta við verklegar framkvæmdir.

Niðurstöður sýna að pættir tengdir verkfundum hafa sterka fylgni við GSK hvort sem skoðaðir eru pættir úr könnun verkkaupa eða úr könnun verktaka.

Úr könnun verkkaupa mælist sterk fylgni á milli annars vegar $G S K$ og hins vegar hvort haldnir voru verkfundir með verkkaupa, hvort gert var samkomulag um reglubundna verkfundi, hvort rituð var fundargerð á verkfundum, hversu vel verktaki fór yfir stöðu mála á verkfundum og hvort verktaki fór yfir verklýsingar og teikningar með verktaka á milli verkpátta.

Úr könnun verktaka mældist einnig sterk og marktæk fylgni milli annars vegar GSK og hins vegar hvort/hversu oft verktaki er með reglubundna verkfundi með verktaka og hvort verktaki ritar fundargerð á verkfundum. Hafa ber í huga að raunveruleg krafa á verktaka að halda fundargerð á verkfundum er ekki til staðar. Í raun er pað hlutverk verkkaupa að sjá um slíkt, en í grein 17.10 í ÍST-30 kemur fram að rita eigi fundargerð á verkfundum, en einnig að fulltrúi verkkaupa eigi að sjá um pað (Staðlaráð Íslands, 2003).

Samningar. Áætla má að vönduð tilboðsgerð með ítarlegri sundurliðun dragi úr líkum á ágreiningi milli verkkaupa og verktaka og sé pví mikilvægur páttur í ánægju verkkaupa. Samkvæmt bókinni Hvernig gera má betur - kennslubók SI, sem var gefin út af Samtökum Iðnaðarins, kemur fram að öll samskipti milli verkkaupa og verktaka eiga að byggjast á staðlinum IST-30 og að við samningagerð sé nauðsynlegt að verktaki kynni verkkaupa hvernig hann hyggst standa að verki varðandi aukaverk, breytingar, frábrigði, dagbókarskýrslur o.fl. sem tilheyrir öruggri daglegri stjórnun (Hvernig gera má betur kennslubók SI, 2007).

Marktæk og miðlungssterk fylgni greindist einnig á milli GSK og hins vegar hversu vel verktaki ræddi samninginn við verkkaupa áður en framkvæmdir hófust eða hversu vel samningurinn var sundurliðaður.

Innra verklag. Niðurstöður úr könnun verktaka gefa til kynna að innra verklag sé mun skipulagðara hjá verktökum, sem starfa eftir gæðastjórnunarkerfi, en peim sem ekki gera pað. Marktæk og mjög sterk fylgni var milli GSK og hvort verktakar voru með ákveðið kerfi fyrir merkingu skjala í fyrirtækinu. Einnig var marktæk og sterk fylgni milli GSK og hvort verktaki var með ákveðið kerfi fyrir geymslu skjala og hvort skjöl voru geymd í tölusettri röð til ákveðins tíma. 


\subsubsection{Er munur á samskiptum milli verktaka og verkkaupa með tilliti til pess hvort verktaki starfar eftir gæðastjórnunarkerfi eða ekki ?}

Í góðum og skilvirkum samskiptum verkkaupa og verktaka hlýtur að felast lykillinn að réttum gæðum í mannvirkjagerð og er pví mikilvægt að á verktímanum skapist gott upplýsingaflæði og ábyrg samvinna milli verkkaupa og verktaka. Með pví er stuðlað að pví að væntingum verkkaupa sé fullnægt með sem hagkvæmustum hætti fyrir verktakann.

Samskiptakrafa milli verkkaupa og verktaka er ólík hefobundinni samskiptakröfu milli viðskiptavinar og framleiðanda vöru, pó að sannarlega flokkist verkkaupi undir pað að vera viðskiptavinur verktaka. Börfin fyrir samskipti milli viðskiptavinar og framleiðanda vöru á lager er einfaldlega ekki sambærileg við pá samskiptapörf sem ríkir á milli verkkaupa og verktaka af peim sökum að varan er í mótun frá pví að verkkaupi kaupir vöruna og pangað til framkvæmdarferli lýkur.

Samkvæmt niðurstöðum kannana greindist ekki marktæk fylgni milli GSK og ánægju verkkaupa með samskipti. Eins og áður hefur verið komið inn á útilokar slík niðurstaða ekki að fylgni milli pessara pátta sé til staðar í raunverulega pýðinu. Erlendar rannsóknir hafa gefið til kynna að ávinningurinn af gæðastjórnun felist m.a í betri samskiptum (Young, 2007).

Pað ætti engan að undra að mjög marktæk og sterk fylgni er á milli ánægju verkkaupa með framkvæmd verksins hjá umræddum verktaka og ánægju verkkaupa með samskipti við verktaka. Par af leiðandi ætti pað að vera kappsmál verktaka að leggja rækt við samskipti sín við verkkaupa. Niðurstöður sýndu að stærstur hluti verkkaupa var frekar eða mjög ánægður með samskipti sín við verktaka, eða um 75\%. Skýrsluhöfundur telur prátt fyrir раð аð almennt megi bæta samskipti milli pessa aðila og gera pau skilvirkari. Er pá sérstaklega átt við einstaklingsverkkaupa. Hér að neðan sést hlutfall svara pegar verkkaupar voru spurðir hversu ánægðir peir voru með samskipti við verktaka.

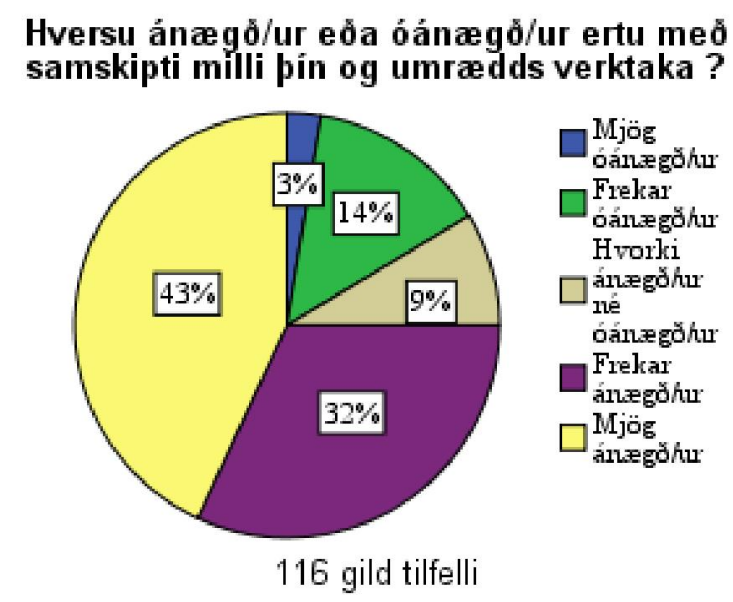

Mynd 61 Ánoegja verkkaupa með samskipti við verktaka

Skýrsluhöfundur skynjaði í viðtölum sínum við verkkaupa að samskiptum við verktaka væri oftar en ekki ábótavant, pó að 75\% peirra væru mjög eða frekar ánægðir með samskipti sín við verktaka. Til að mynda bar pað oft á góma pegar einstaklingsverkkaupar 
voru spurðir hvort haldnir hefou verið verkfundir með verktaka að svo hafði ekki verið, prátt fyrir að eftir á að hyggja hefði verkkaupi gjarnan kosið pað. Рað hafi bara ekki staðið til boða. Einnig kom nokkrum sinnum upp að verkkaupi kvartaði yfir pví að mjög erfitt hefði verið að ná í verktaka á verktíma og kröfur verkkaupa hafi potið sem vindur um eyru á verktaka. Í slíkum tilfellum er spurning hvort verktaki telji sig hafa átt samskipti við verkkaupann eða hann hafi hreinlega ekki kært sig ekki um pað. Eins og maður að nafni George Bernard Shaw orðaði eitt sinn svo lipurlega: „The single biggest problem in communication is the illusion that it has taken place". Sem pýðir á góðri íslensku; „Stcersta vandamálið i samskiptum er blekkingin að pau hafi átt sér stað“.

Deir pættir, sem tengjast samskiptahættum milli verkkaupa og verktaka og hafa marktæk áhrif á ánægju verkkaupa með samskipti sín við verktaka, eru gefnir upp í töflunni hér að neðan.

Tafla 15 Paettir sem hafa marktoka fylgni við ánaegju verkkaupa með samskipti við verktaka ${ }^{56}$

\begin{tabular}{lcccccc}
\hline \hline & \multicolumn{4}{c}{ ánægja_samskipti } & \\
\cline { 2 - 3 } & \multicolumn{2}{c}{ Gamma } & \multicolumn{2}{c}{ Spearman's rho } & \\
\cline { 2 - 3 } verkfundir_samkomulag &, 472 &, 001 & &, 296 &, 001 & 116 \\
samningur_ræddur &, 455 &, 001 & &, 360 &, 001 & 83 \\
samskipti_rædd &, 400 &, 002 & &, 273 &, 003 & 116 \\
samningur_sundurliðaður &, 310 &, 008 & &, 266 &, 016 & 81 \\
verkfundir &, 301 &, 008 & &, 227 &, 014 & 116 \\
\hline \hline
\end{tabular}

Eins gögnin sýna eru tveir pættir tengdir verkfundum með marktæka fylgni við ánægju verkkaupa með samskipti við verktaka. Annars vegar hvort samkomulagi um reglubundna verkfundi hafi verið komið á og hins vegar hvort haldnir voru verkfundir með verktaka. Sterkasta fylgnin flokkast undir pað að vera miðlungs sterk og er hún við pað hvort gert hafi verið samkomulag um reglubundna verkfundi.

Einnig greindust tveir pættir tengdir samningum marktækir við ánægju verkkaupa með samskipti við verktaka. Annars vegar hvort verktaki hafi farið yfir samninginn með verkkaupanum áður en framkvæmdir hófust og hins vegar hvort/hversu vel samningurinn var sundurliðaður. Að lokum mældist einnig marktæk og miðlungs sterk fylgni milli pess hvort samskiptaleiðir hafi verið ræddar í upphafi framkvæmda og ánægju verkkaupa með samskipti við verktaka.

Niðurstöður gefa einnig til kynna að mikill munur sé á samskiptum fyrirtækjaverkkaupa við verktaka og einstaklingsverkkaupa við verktaka. Sterk fylgni mælist á milli pess hvort verkkaupi var einstaklings- eða fyrirtækjaverkkaupi og hvort haldnir voru verkfundir með verktaka. Stólparitið hér að neðan sýnir myndræna skiptingu á pessum páttum.

\footnotetext{
${ }^{56}$ Skýringar á breytuheitum sem eru notuð í töfluna eru í viðauka D á bls. 253
} 


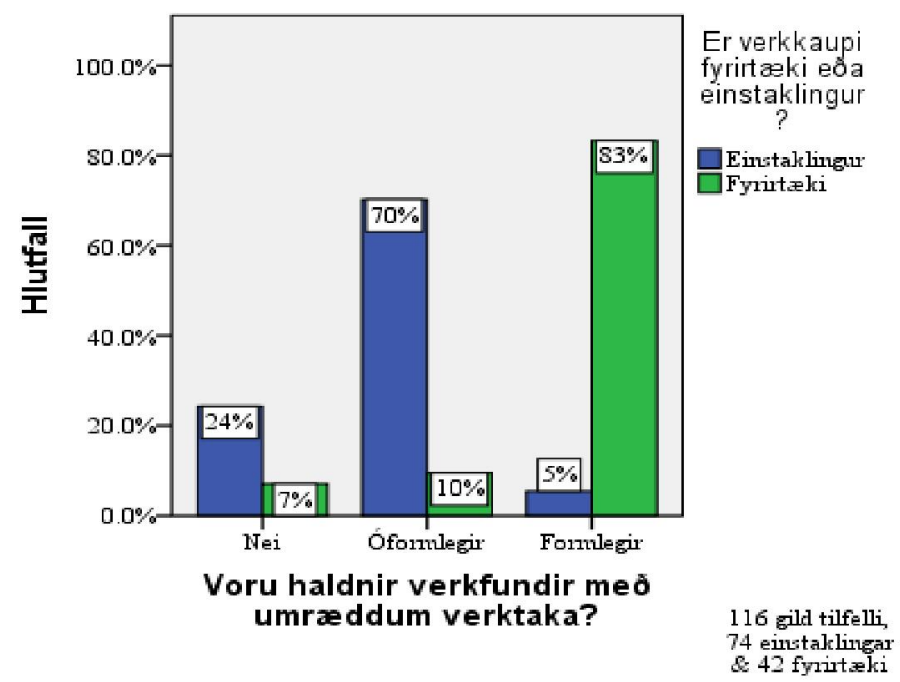

Mynd 62 Verkfundir með tilliti til gerðar verkkaupa

\subsubsection{Er munur á viðhorfi verktaka til gæðastjórnunar eftir pví hvort verktaki starfar eftir gæðastjórnunarkerfi eða ekki ?}

Rannsóknir hafa gefið til kynna að ávinningurinn af gæðastjórnun felist m.a í betri samskiptum, minni endurvinnu, tíma- og peningasparnaði, aukinni framleiðni og aukinni markaðshlutdeild (Young, 2007). Eðli gæðastjórnunar og tilgangur er einmitt að bæta samkeppnishæfi, gera vinnubrögð agaðri og ná fram auknum hagnaði (Viðskiptablaðið, 2002). Ekki vannst tími til pess að rannsaka ofangreindar staðhæfingar beint, en viðhorf verktaka til gæðastjórnunar var kannað og álit peirra á framsettum staðhæfingum.

Viðhorf verktaka til gæðastjórnunar var kannað sérstaklega og sýna niðurstöður að mikill meirihluti verktaka hefur almennt jákvætt viðhorf til gæðastjórnunar og telur að hún eigi við byggingaiðnaðinn. Til að mynda töldu yfir 90\% að ávinningur af innleiðingu gæðastjórnunarkerfis í byggingaiðnaði væri frekar eða mjög mikill og tæplega 85\% svarenda töldu einnig að samkeppnishæfi fyrirtækja myndi aukast með innleiðingu gæðastjórnunarkerfis, svo fátt eitt sé nefnt.

Ef allir peir pættir, sem verktakar voru spurðir um og snúa að viðhorfi verktaka til gæðastjórnunar, eru settir saman í einn hóp sem er kallaður viðhorf ${ }^{57}$ sést að tæplega $80 \%$ svara féllu í svarflokka 4 og 5 sem eru bestu svarflokkarnir.

\footnotetext{
57 Í flokknum viðhorf eru breyturnar trú, ávinningur, ávinningur/kostnaður, rekstrarafkoma, samkeppnishcefi, áhrif á frábrigði, mannafli. Sjá má skýringar á breytum viðauka D.
} 


\begin{tabular}{llcc}
\hline \hline & & \multicolumn{2}{c}{ Svör } \\
\cline { 3 - 4 } & & $\mathrm{N}$ & Hlutfall \\
\hline viðhorf $^{\mathrm{a}}$ & Svarflokkur 5 & 219 & $39,7 \%$ \\
& Svarflokkur 4 & 204 & $37,0 \%$ \\
& Svarflokkur 3 & 108 & $19,6 \%$ \\
& Svarflokkur 2 & 16 & $2,9 \%$ \\
& Svarflokkur 1 & 4 &, $7 \%$ \\
Samtals & & 551 & $100,0 \%$ \\
\hline \hline
\end{tabular}

a. Í flokknum viðhori eru breyturnar trú, ávinningur, ávinningur/kostnaður, rekstrarafkoma, samkeppnishaefi, áhrif_á_frábrigði, mannafli. Sjá má skýringar á breytum viðauka D.

Niðurstöður sýna að verktakar, sem hafa reynslu af gæðastjórnunarkerfi hafa mun jákvæðara viðhorf til hennar. Fylgni milli einstakra pátta, sem teknir eru inn í hópinn viðhorf og GSK reyndust marktækir í öllum tilfellum nema fyrir breytuna mannafli. Gefur pessi niðurstaða til kynna að peir verktakar sem hafa kynnt sér og prófað gæðastjórnun í sínu fyrirtæki séu jákvæðari en peir sem hafa ekki prófað að starfa eftir gæðastjórnunarkerfi. Marktækir fylgnipættir eru sýndir á stólparitinu hér að neðan.

Tafla 17 Samantekt á marktakriri fylgni viðhorfs verktaka við GSK

\begin{tabular}{lcccccc}
\hline \hline & \multicolumn{5}{c}{ GSK } \\
\cline { 2 - 3 } & Fylgnistuðull & Sig. & & Fylgnistuðull & Sig. & \\
\cline { 2 - 3 } áhrif_á_frábrigði &, 706 &, 000 & &, 462 &, 000 & 77 \\
samkeppnishæfi &, 679 &, 000 & &, 411 &, 000 & 84 \\
rekstrarafkoma &, 654 &, 000 & &, 399 &, 000 & 86 \\
ávinningur/kostnaður &, 559 &, 002 & &, 347 &, 001 & 85 \\
trú &, 532 &, 005 & &, 309 &, 003 & 88 \\
ávinningur &, 466 &, 019 & &, 240 &, 025 & 87 \\
\hline \hline
\end{tabular}

Tæplega priðjungur verktaka skilja gæðastjórnunarkerfi einungis sem skráningarkerfi. Samkvæmt rannsókninni „ISO 9001:2000 in small organizations;lost oppurtunities, benefits and influencing factors" sem Poksinska, Eklund og Dahlgaard gerðu árið 2006 kom í ljós að fyrirtækin skynjuðu gæðakerfið sem skráningarkerfi fremur en gæðakerfi og fannst pau hafa lágmarks ávinning af kerfinu (Bozena Poksinska, Jörgen A.E. Eklund \& Jens Jörn Dahlgaard, 2006). Niðurstöður sýndu engu að síður að fylgni milli pess hversu stór fyrirtæki voru og hvort verktaki upplifð̈i gæðastjórnunarkerfi einungis sem skráningarkerfi reyndist ekki vera marktækt. Hafa verður í huga að par sem mikill meirihluti pátttakenda starfaði hjá fyrirtækjum með fáa starfsmenn hefði fylgnin purft að vera mjög mikil til að teljast marktæk. 


\subsubsection{Er munur á kröfum til verktaka, um skipulag og markvissa stjórnun, milli verktaka sem starfa eftir gæðastjórnunarkerfi og peirra sem gera pað ekki ?}

Skýrsluhöfundur telur að pað sé afar mikilvægt að verktakar geri sér grein fyrir kröfum verkkaupa og samræmi vinnulag sitt samkvæmt peim. Til að mynda er líklegt að gæðatrygging hafi lítið að segja ef pekking verktaka á kröfum verkkaupa er ekki til staðar.

Niðurstöður sýna að verktökum fannst kröfur einstaklings- og fyrirtækjaverkkaupa, (hvort sem um roeðir opinberar stofnanir eða önnur fyrirtceki) hafa aukist eftir efnahagshrunið. Almennt fannst verktökum kröfur einstaklingsverkkaupa í garð verktaka um skipulag og markvissa stjórnun vera litlar en kröfur hjá opinberum stofnunum almennt vera miklar.

Ekki greindist marktæk fylgni milli hversu miklar kröfur verktökum fannst verkkaupar hafa í sinn garð og GSK.

Að mati skýrsluhöfundar eru kröfur verkkaupa til verktaka um skipulag og markvissa stjórnun ekki nægar. Sem dæmi voru ekki nema rúmlega 16\% verkkaupa sem fóru fram á gæðatryggingu frá verktaka. Hugsanlega eru kröfurnar til staðar hjá verkkaupum en menningin í byggingaiðnaðinum veitir peim ef til vill ekki svigrúm til að láta pær í ljós.

\subsubsection{Er munur á stöðu gæðatryggingar í mannvirkjagerð meðal verktaka sem starfa eftir gæðastjórnunarkerfi og peirra sem gera pað ekki ?}

Með gæðatryggingu ${ }^{58}$ er átt við skriflegt plagg par sem verktaki setur fram allar pær vinnureglur sem hann ætlar að vinna eftir í verkinu til að tryggja ákveðin gæði.

Stöðu gæðatryggingar í mannvirkjagerð á Íslandi er samkvæmt niðurstöðum beggja kannana mjög ábótavant. Niðurstöður úr könnun fyrir verkkaupa sýna að tæplega $84 \%$ verkkaupa sögðust ekki hafa farið fram á gæðatryggingu, en eins og áður segir gefur pað til kynna að almennt séu kröfur verkkaupa til verktaka um skipulag og markvissa stjórnun ekki nægar.

Niðurstöður úr könnun fyrir verktaka sýndu að almennt virtust verktakar ekki gera kröfu um gæðatryggingu til undirverktaka. Einungis 3\% verktaka sögðust alltaf fara fram á gæðatryggingu frá undirverktökum. Myndin hér að neðan sýnir hlutfallslega skiptingu á GSK með tilliti til pess hvort/hversu oft verktaki fer fram á gæðatryggingu frá undirverktökum sínum.

\footnotetext{
${ }^{58}$ Sjá kafla um skilgreiningar bls. 312
} 


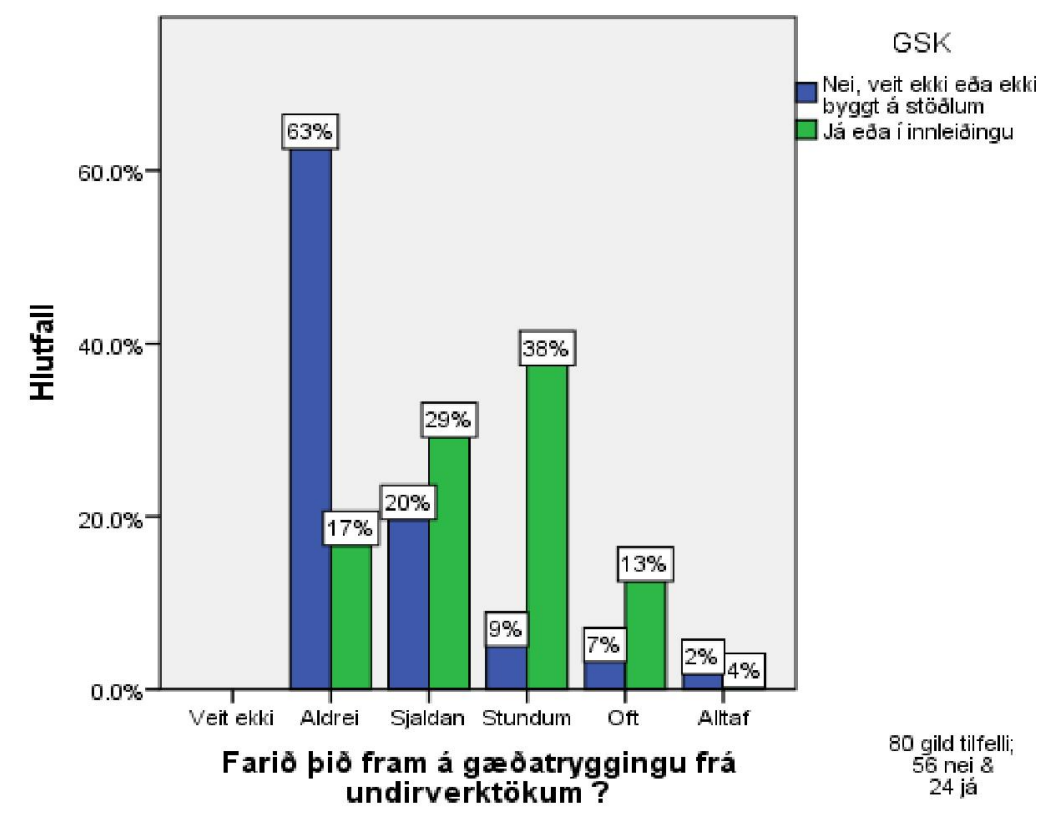

Mynd 63 Hlutfallsleg skipting á GSK með tilliti til pess hvort verktaki fer fram á gœðatryggingu frá undirverktökum

Fylgni milli annars vegar GSK og hins vegar hvort verktaki hafi lagt fram gæðatryggingu í upphafi framkvæmda samkvæmt verkkaupa reyndist marktæk og sterk. Myndin hér að neðan sýnir hlutfallslega skiptingu á GSK með tilliti til pess hvort verkkaupar fengu gæðatryggingu frá verktaka.

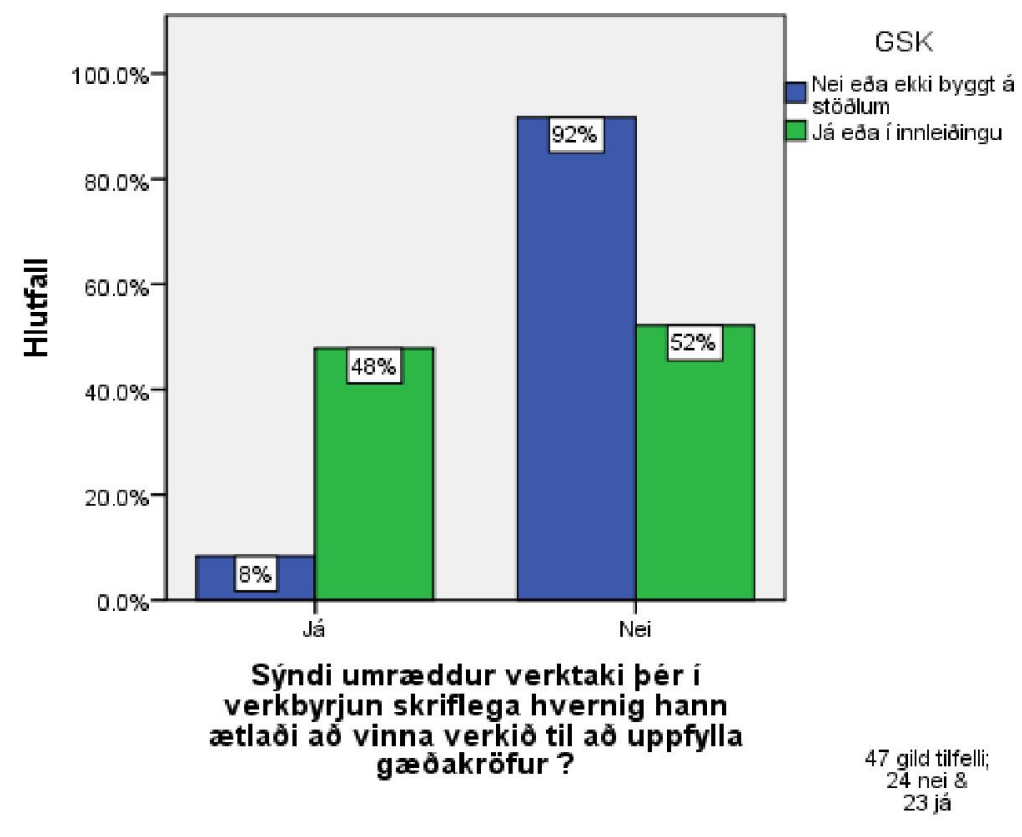

Mynd 64 Hlutfallsleg skipting á GSK með tilliti til pess hvort verktaki lét verkkaupa fá gœðatryggingu

Einnig greindist marktæk og sterk fylgni milli pess annars vegar hvort verktaki starfar eftir gæðastjórnunarkerfi byggðu á viðurkenndum gæðastjórnunarstöðlum og hins vegar hversu oft/hvort verktaki taldi sig leggja fram gæðatryggingu í upphafi framkvæmda eða hversu oft verktaki krefur undirverktaka um gæðatryggingu. 


\subsection{Hvaða pættir hafa mest áhrif á ánægju verkkaupa?}

Eðlilegt pykir að viðskiptavinurinn sé ánægður ef framkvæmdir eru eins og ætlast var til, innan gefins tíma og kostnaðar. Sérstök áhersla var lögð á að greina hvaða pættir hafa mest áhrif á ánægju verkkaupa með framkvæmd verka. Fylgni milli ánægju verkkaupa með framkvæmd verks hjá verktaka og allra annarra pátta sem spurt var um í könnun verkkaupa var skoðuð. Einnig var fylgni milli ánægju verkkaupa og allra pátta sem umrceddir verktakar voru spurðir um könnuð. Fylgnipætti má sjá í töflunum hér að neðan.

Tafla 18 Peir paettir úr könnun verkkaupa ${ }^{59}$ sem maeldust með marktaka fylgni við ánagju verkkaupa með framkvaemd verksins hjá umraeddum verktaka

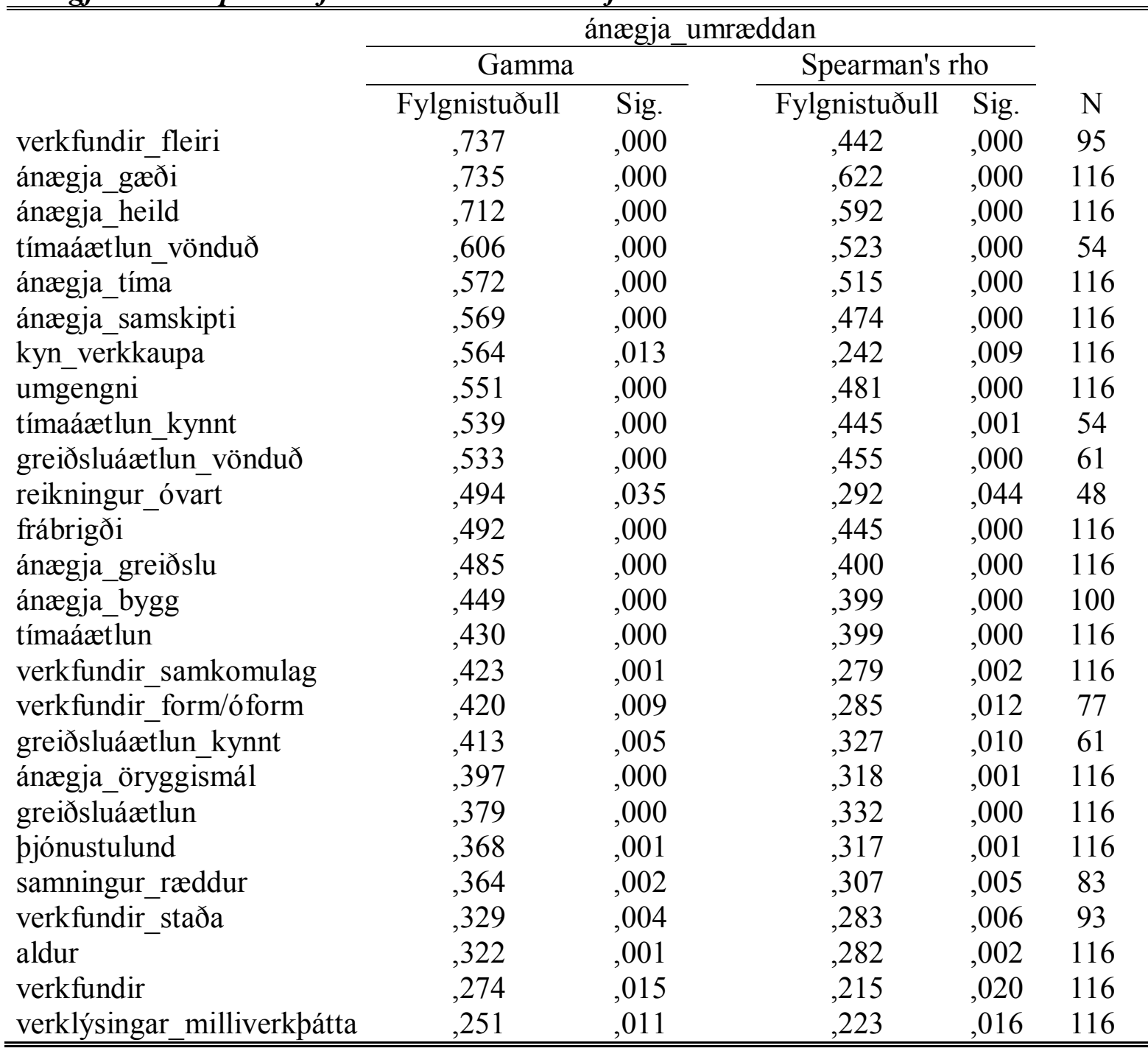

\footnotetext{
${ }^{59}$ Skýringar á breytuheitum sem eru notuð í töfluna eru í viðauka D á bls. 253
} 
Tafla 19 Deir paettir úr könnun verktaka sem maeldust með marktaka fylgni við ánoegju verkkaupa með framkvaemd verksins hjá umraeddum verktaka ${ }^{60}$

\begin{tabular}{|c|c|c|c|c|c|}
\hline & \multicolumn{4}{|c|}{ ánægja umræddan - úr könnun verktaka } & \multirow[b]{3}{*}{$\mathrm{N}$} \\
\hline & \multicolumn{2}{|c|}{ Gamma } & \multicolumn{2}{|c|}{ Spearman's rho } & \\
\hline & Fylgnistuðull & Sig. & Fylgnistuðull & Sig. & \\
\hline gæðatrygging undirverkt & ,638 &, 000 &, 504 &, 000 & 44 \\
\hline GSK & 623 & ,001 & ,430 & ,003 & 47 \\
\hline förgun & ,597 &, 002 & 420 & 007 & 40 \\
\hline samkeppnishæfi & ,495 & ,012 & 372 &, 015 & 42 \\
\hline öryggisstrúnaðarm & , 477 &, 050 & 309 &, 050 & 41 \\
\hline stærð & ,458 & ,001 & ,366 &, 003 & 65 \\
\hline starfslýsingar_skriflegar & 427 & 013 & ,349 &, 020 & 44 \\
\hline aldur fyrirt & ,397 & ,025 & 333 & 024 & 46 \\
\hline ISO9001 & 372 &, 034 & 320 &, 034 & 44 \\
\hline almennt & ,330 &, 044 & 303 & 045 & 44 \\
\hline
\end{tabular}

SAMSKIPTI. Samskipti verkkaupa og verktaka eru flókin og má skipta peim í marga hluta sem tengjast samningagerð, verkfundum, gæðatryggingu og almennum samskiptum. Níu pættir úr könnun verkkaupa, sem má tengja beint við samskipti, mælast með marktæka fylgni við ánægju verkkaupa með umræddan verktaka. Sú breyta sem mældist með hæstu fylgni var verkfundirfleiri en pá voru verkkaupar spurðir hvort peir hefðu viljað hafa fleiri verkfundi með verktaka. Aðrir pættir tengdir verkfundum, sem voru með marktæka fylgni

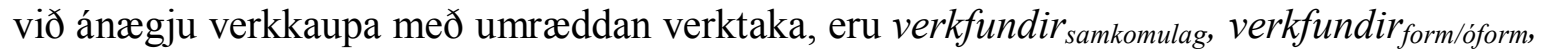
verkfundir $_{\text {staða, verkfundir og verklýsingar }}$ milliverkpátta. Pessi niðurstaða gefur tilefni til að áætla að verkkaupum sé umhugað um samskipti við verktaka og pað minnki ánægju peirra með framkvæmd verksins hjá verktaka ef ekki er séð til pess að verkfundir séu reglulega í samráði við verkkaupa.

Ánægja verkkaupa með samskipti við verktaka mældist með sterka fylgni við ánægju verkkaupa með umræddan verktaka en pað ýtir enn frekar undir mikilvægi góðra samskipta.

Einnig var marktæk fylgni við pað hversu mikla pjónustulund verkkaupa fannst verktaki hafa og hvort/hversu vel verktaki ræddi við verkkaupa um samninginn áður enn framkvæmdir hófust. Niðurstöður sýna að fylgni milli annars vegar hversu ánægðir verkkaupar voru með umræddan verktaka og hins vegar hversu oft/eða hvort ósætti um innihald samnings kom upp eða hversu vel samningurinn var sundurliðaður - er í öllum tilfellum ómarktæk. Eins og áður hefur verið komið inn á útilokar slík niðurstaða pó ekki að fylgni milli slíkra pátta sé til staðar í pýðinu

GÆĐI. Sá páttur sem mældist með næst sterkustu fylgni við ánægju verkkaupa, á eftir verkfundirfleiri, var ánægja verkkaupa með gæði verksins og par á eftir var ánægja verkkaupa með framkvæmd verksins í heild.

Til eru margar skilgreiningar á gæðum og eru mælingar á gæðum innan mannvirkjagerðar flóknar sökum eðlis iðnaðarins. Niðurstöðurnar um ánægju verkkaupa með gæði

\footnotetext{
${ }^{60}$ Skýringar á breytuheitum sem eru notuð í töfluna eru í viðauka D á bls. 253
} 
framkvæmdar endurspegla pví persónulegt mat verkkaupa á pví hvað peir telja að felist í hugtakinu gœeði. Taka verður tillit til pess að flestir af peim verkkaupum, sem tóku pátt í rannsókninni höfou nýlega staðið í framkvæmdum, en gæði mannvirkja koma oft ekki fram fyrr en löngu eftir að framkvæmd lýkur.

Einnig mælist marktæk fylgni við fjölda frábrigða á framkvæmd en líkt og fyrir hugtakið gæði pá er talið líklegt að verkkaupar leggi ekki allir sama skilning í hugtakið frábrigði, jafnvel pó að skýrsluhöfundur hafi lagt áherslu á að skýra hugtakið fyrir pátttakendum. Hér er átt við varanlegan galla eða aukaútgjöld fyrir verkkaupa. Мeð varanlegum galla er auðvitað átt við að gæði séu ekki samkvæmt kröfu verkkaupa. Út frá pessari skilgreiningu ætti engan að undra að sterk fylgni sé milli ánægju verkkaupa og fjölda frábrigða en pað er engu að síður athyglisvert að pessi páttur er ekki ofar í röðinni.

GÆĐATRYGGING. Fjórða sterkasta marktæka fylgnin mælist milli ánægju verkkaupa og hversu oft verktakar sögðust krefja undirverktaka sína um gæðatryggingu. Sú niðurstaða er sérstaklega merkileg fyrir pær sakir að hér er verið að tala um fylgni milli kannana. P.e. fylgni milli pess sem verkkaupar svöruðu í könnun fyrir verkkaupa er pöruð við svör viðkomandi umræddra verktaka í könnun fyrir verktaka. Par sem slíkar tengingar voru ekki mjög margar verður niðurstaða sem sýnir fram á svo sterka og marktæka fylgni að teljast merkileg.

GÆĐASTJÓRNUNARKERFI. Fimmta sterkasta fylgnin við ánægju verkkaupa með framkvæmdir hjá umræddum verktaka var hvort umræddur verktaki starfaði eftir gæðastjórnunarkerfi byggðu á viðurkenndum gæðastöðlum (GSK). Petta telst einnig merkileg niðurstaða, en hér er einnig átt við fylgni milli kannana og parf pví fylgnin að vera mjög afgerandi til að flokkast bæði marktæk og sterk par sem slík svör eru ekki pað mörg. Рað er pví óhætt að draga pá ályktun að peim verktökum sem starfa eftir gæðastjórnunarkerfi, sé meira umhugað um að uppfylla væntingar verkkaupa og að kröfum viðskiptavina peirra sé oftar fullnægt en verktaka sem starfa ekki eftir gæðastjórnunarkerfi.

ÁÆTLANIR. Gera má ráð fyrir að raunhæfar forsendur fyrir umfangi og verðlagningu framkvæmda séu stór páttur í ánægju verkkaupa. Óraunhæfar væntingar, sem byggðar eru á fölskum forsendum, draga pví úr gæðum framkvæmda. Samkvæmt niðurstöðum er greinilegt að páttur tímastjórnunar leikur veigamikið hlutverk í heildaránægju verkkaupa með framkvæmd verks hjá umræddum verktaka. Fjórir pættir sem tengjast tímastjórnun,

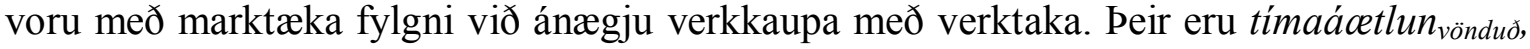
áncegja $a_{\text {tima }}$, tímaácetlun $n_{k y n t}$ og tímaácetlun p.e. hversu vönduð tímaáætlunin var að mati verkkaupa, hversu ánægður verkkaupi var með tímastjórnun, hversu vel tímaáætlunin var kynnt fyrir verkkaupa og hvort verkið fór fram úr tímaáætlun.

Athyglisvert er að fjárhagshliðin mældist ekki sem jafn mikilvægur páttur og tímahliðin, en hugsanlegt er að páttur efnahagshrunsins komi par við sögu. Mögulega sýndu verkkaupar meiri skilning á auknum fjárútlátum vegna aðstæðna í pjóðfélaginu. Engu að síður mælist marktæk fylgni milli ánægju verkkaupa með framkvæmd verks hjá verktaka og

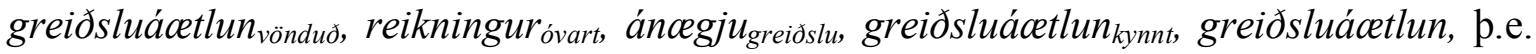
hversu vönduð greiðsluáætlunin var, hvort einhver reikningur kom á óvart, ánægju verkkaupa með fjármagnsflæði, hversu vel greiðsluáætlunin var kynnt verkkaupa og hvort framkvæmdin var komin fram úr greiðsluáætlun. 
UMGENGNI. Ellefta sterkasta fylgnin mældist við ánægju verkkaupa með umgengni verktaka. Skýrsluhöfundur greindi margoft á samtölum sínum við verkkaupana að peim pótti almennur sóðaskapur og slæm umgengni oft einkenna vinnustaði verktaka. Í einu tilfelli sagðist verkkaupi hafa gert sér ferð á vinnustað að lokum hvers vinnudags á meðan framkvæmdir stóðu yfir til pess að ganga frá eftir verktaka.

ÖRYGGI. Breytur, sem tengjast öryggismálum í könnun fyrir verkkaupa og í könnun fyrir verktaka, reyndust marktækar við ánægju verkkaupa með framkvæmd verks hjá umræddum verktaka. Annars vegar mældist veik fylgni milli ánægju verkkaupa með öryggismál við ánægju verkkaupa með framkvæmd verksins hjá umræddum verktaka. Auk pess er miðlungs sterk fylgni milli ánægju verkkaupa með framkvæmd verksins hjá umræddum verktaka og hvort öryggistrúnaðarmaður var starfandi hjá verktaka.

VIĐHORF, PEKKING OG VERKLAG. Einn páttur, sem tengist viðhorfi verktaka í garð gæðastjórnunar, hvort verktaki telji samkeppnishoefi fyrirtcekja aukast/minnka með innleiðingu gæeðastjórnunarkerfis, reyndist marktækur við ánægju verkkaupa með framkvæmd verks hjá verktaka. Einnig mældist marktæk fylgni milli pekkingar verktaka á ISO 9001 og pekkingar verktaka almennt á gæðastjórnun og ánægju verkkaupa með framkvæmd verksins hjá verktaka. Að lokum er nefnt að tveir pættir beintengdir verklagi verktaka mælast með marktæka fylgni við ánægju verkkaupa með verktaka, p.e. hvort verktaki sé með ákveðið kerfi við förgun skjala og hvort til séu skriflegar starfslýsingar fyrir starfsmenn.

Pessar niðurstöður gefa tilefni til að halda að viðhorf og pekking verktaka á skipulögðum og öguðum vinnubrögðum og síðast en ekki síst verklag verktaka hafi áhrif á ánægju verkkaupa.

GRUNNPÆTTIR. Að lokum eru nefndir nokkrir grunnpættir sem mældust með marktæka fylgni við ánægju verkkaupa með framkvæmd verks hjá verktaka. Par ber fyrst að nefna kyn verkkaupa en kvenkyns verkkaupar voru almennt talsvert svartsýnni í svörum en karlkyns verkkaupar. Einnig hafði aldur verkkaupa, aldur verktakafyrirtækis, stærð verktakafyrirtækis og ánægja verkkaupa með byggingastjóra marktæka fylgni við ánægju verkaupa með framkvæmd verks hjá verktaka.

CATREG. Að lokum var sérstaklega athugað hvort hægt væri að nota gögnin til pess að lýsa sambandi milli ánægju verkkaupa og annarra pátta með línulegu aðhvarfsgreiningarlíkani.

Рað líkan sem skýrsluhöfundur taldi vera best skýrir 45,3\% af ferviki fyrir gögnin og lítur pað svona út:

$$
\text { ánægja } a_{u m r æ d d a n}=0,506(G S K)+0,367\left(\text { verkfundir }_{\text {fleiri }}\right)
$$

Niðurstaðan sem líkanið gefur er að ánægja verkkaupa er undir miklum áhrifum af pví hvort verktakar starfa eftir gæðastjórnunarkerfi eða ekki. 


\subsection{Takmarkanir}

Prátt fyrir að rannsóknin hafi leitt í ljós pýðingarmiklar niðurstöður pá er mikilvægt að greina takmarkanir hennar og benda á önnur pörf verkefni í tengslum við málefnið. Hér verður nokkrum af helstu takmörkunum rannsóknarinnar lýst.

Hönnun spurningalista. Gögn eru talin áreiðanleg ef pau gefa rétta mynd af tilteknu ástandi, p.e. ef pau eru talin vera í samræmi við tiltekinn veruleika. Hafa verður hugfast að réttmæti spurninga hefur ekki verið staðfest með fleiri könnunum en pað krefst fleiri rannsókna til að kanna réttmæti listanna. Varðandi réttmæti mælitækja og úrvinnsluaðferða parf að huga að tveimur aðalatriðum: er mælitækið réttmætt í pví pýði sem pað var próað í (e. internal valdity) og er pað réttmætt í öðrum pýðum (e. external validity) (María Heimisdóttir, 2003). Sjá nánar um petta í kafla 4.2 á bls. 43. Athugasemdir varðandi atriði í könnunum er að finna í viðaukum á meðfylgjandi geisladisk.

Tölfræðilegur kraftur. Með stærra úrtaki hefði verið hægt að ná fram meiri tölfræðilegum krafti sem myndi styrkja ályktanir sem dregnar eru út frá úrtakinu yfir á pýðið. Sjá nánar um úrtak og pýði á bls. 4.4 .3 á bls. 46.

Úrvinnsla gagna. Ýmislegt getur dregið úr áreiðanleika rafrænna gagna og pví einsetti skýrsluhöfundur sér að gæta fyllsta öryggis með meðhöndlun gagna úr spurningakönnunum. Gögnin voru fyrst skráð inn í vefviðmótið Question Pro og tíðnitöflur prentaðar fyrir allar spurningar. Dví næst voru gögnin flutt yfir í tölfræðiforritið SPSS Statistics og flestum breytum gefin töluleg gildi til að auðvelda úrvinnslu. Pá voru tíðnitöflur bornar saman við upprunalegu töflurnar til að gæta pess að skráning hafi verið rétt unnin og geymd.

Túlkun á gögnum. Áhersla var lögð á að reyna að oftúlka engar niðurstöður. Reynt var eftir fremsta megni að ná fram lykilatriðum sem snúa að ánægju verkkaupa með framkvæmd verks hjá verktaka auk fræðirýni rannsókna. Gagnaöflunin var blönduð af innlendum og erlendum gögnum en töluvert meira er til af erlendum ritum um viðfangsefnið. Рað er ávallt pannig að úrvinnsla gagna krefst pess að sá sem greinir gögnin velji pað sem hann telur skipta máli og hafni öðru. Pessu getur alltaf fylgt ákveðin skekkja eða bjögun. Líklegt er að væntingar rannsakanda móti að einhverju leyti skilning hans á gögnunum og geta pannig haft áhrif á lokaniðurstöðu. 


\section{Lokaorð og frekari rannsóknir}

Markmið rannsóknarinnar, er að rannsaka áhrif gæðastjórnunar í mannvirkjagerð á Íslandi frá sjónarhorni verkkaupa. Svör fengust við öllum rannsóknarspurningunum og talsverð reynsla og pekking á viðfangsefninu hefur áunnist. Helstu niðurstöður eru að staða gæðastjórnunar í mannvirkjagerð og pekking verktaka á fræðigreininni er ábótavant og pá sérstaklega hjá litlum fyrirtækjum. Um verklag verktaka má segja að verktakar sem starfa eftir gæðastjórnunarkerfi hafi talsvert skilvirkari og skipulagðari vinnubrögð. Аð lokum mælist jákvæð og marktæk fylgni milli ánægju verkkaupa með framkvæmd verksins og hvort verktaki starfi eftir gæðastjórnunarkerfi eða ekki. Hugsanlega má einnig heimfæra niðurstöður rannsóknarinnar á aðrar litlar pjóðir eða iðnaða með sambærileg sérkenni og mannvirkjagerð eins og skipasmíði.

Í peim miklu efnahagsprengingum, sem nú herja pjóðina í er pörfin fyrir hagræðingu í rekstri fyrirtækja enn meiri en áður. Fátt er svo með öllu illt að ekki boði nokkuð gott, en sagt hefur verið að í kreppum opnist ný tækifæri og tími gefst fyrir sjálfsskoðun og endurmat. Pví ætti umhverfið sem nú er að vera kjörið tækifæri fyrir byggingaiðnaðinn að fara í algjöra naflaskoðun og auka við pekkingu sína í gæðastjórnun.

Krafa samfélagsins í garð verktaka um vönduð vinnubrögð og skilvirkari stjórnun er vaxandi og með nýjum mannvirkjalögum er áhersla lögð á að aðilar innan mannvirkjagerðar starfi eftir gæðastjórnunarkerfi. •að er von skýrsluhöfundar að innleiðing og eftirlit muni ganga sem best, en eins og fram hefur komið hafa rannsóknir sýnt að mikilvægt er að haldið sé rétt á spöðunum við innleiðingu gæðastjórnunarkerfis í verktakafyrirtækjum.

Skýrsluhöfundur kannaði ýmsar leiðir til að mæla áhrif gæðastjórnunar á mannvirkjagerð en viðfangsefnið er flókið og umfangsmikið. Í kjölfarið á pessari rannsókn eru settar fram eftirfarandi uppástungur um frekari rannsóknir á viðfangsefninu.

Í fyrsta lagi er lagt til að rannsóknin verði framkvæmd aftur með tilliti til athugasemda um kannanirnar sem eru í viðaukum $\mathrm{G}$ og J á bls. 306 og 388. Tvær rannsóknir sem komast að sömu niðurstöðu eru vafalaust traustari en ein. Til að fá betri mynd af heildaráhrifum pyrfti fjöldann allan af rannsóknum sem bæði staðfestu niðurstöður pessarar rannsóknar og könnuðu viðfangsefnið út frá öðru sjónarhorni. Í pessu samhengi gæti rannsókn, sem tæki á áhrifum gæðastjórnunar af hagræðingu í rekstri fyrirtækja í mannvirkjagerð, verið afar gagnleg.

Skýrsluhöfundur telur einnig að hönnun kviks kerfislíkans um viðfangsefnið væri gagnlegt, en með pví væri hægt að fá betri heildarmynd af áhrifapáttum sem gæðastjórnun hefur á mannvirkjagerð. Pannig væri hugsanlega hægt að beina stjórnendum fyrirtækja frá skammtímalausnum sem gjarnan leiða til langtímakostnaðar eins og líklegt er að niðurskurður í gæðastjórnun sé.

Afar nytsamlegt væri einnig að kanna bekkingu verktaka á gæðastjórnun til hlítar en rannsókn pessi gefur takmarkaða mynd af henni par sem að verktakar voru sjálfir spurðir hversu vel peir hefðu kynnt sér gæðastjórnun og einstaka staðla. Pví gefa niðurstöður 
einvörðungu mat verktaka á eigin pekkingu. Skýrsluhöfundur telur að slíkt innlegg væri afar mikilvægt, sérstaklega í ljósi pess hve margar erlendar rannsóknir hafa gefið til kynna að almennt skorti pekkingu meðal verktaka. Nánar má lesa um pað í fræðilegri umfjöllun, bls. 32 og niðurstöðukafla bls. 106.

Að lokum er bent á að í ljósi peirra breytinga, sem mannvirkjalögin hafa í för með sér fyrir fyrirtæki í mannvirkjagerð, pá væri afar gagnlegt ef rannsakað væri hvernig best væri að hátta gæðastjórnunarkerfum fyrir mjög lítil og smá verktakafyrirtæki. 



\section{Heimildir}

Brynhildur Bergpórsdóttir. (1998). Gceðastjórnun, eðli hennar og tilgangur. Iðntæknistofnun Íslands. Reykjavík: BÍ, LBH, RALA.

Construction Industry Council. (án dags.). DQI (Design Quality Indicator). Sótt 20. 07 2011 frá http://www.dqi.org.uk/website/default.aspa

Department of trade industry. (án dags.). Businessballs (e.d). Sótt 15. 062011 frá The Evolution of http://www.businessballs.com/dtiresources/quality_management_history.pdf

quality:

Ferdinand Hansen. (2007). Er ráoning gæðastjóra rétta lausnin ? Fréttablað Samtaka Iðnaðarins, , 11 (13), 9.

H.A.Bassioni, S.M.ASCE; A.D.F.Price; \& T.M.Hassan, M.ASCE. (04 2004). Performance Measurementin Construction. Journal of management in engineering .

Hildigunnur Hafsteinsdóttir f.h. Neytendasamtakanna. (10. 04 2008). Efni: Umsögn um frumvarp til laga um mannvirki. Sótt 25. 072011 frá Neytendasamtökin: http://ns.is/ns/frettir/?cat_id=6413\&ew_0_a_id=304108

Philip B. Crosby - Philip Crosby Associates III, Inc. (2000). Winter Park Public Library. Sótt 11. 072011 frá The views of quality : http://www.wppl.org/wphistory/PhilipCrosby/TheViewsOfQuality2000.pdf

Staðlaráð Íslands. (2011). Kynning á tillögum vinnuhóps um endurskoðun ÍST 30. Fréttablað Staðlaráð Íslands. Staðlamál , 15 (1), 8.

Abdullah, A. H. (2006). Quality management in construction. Malaysia: Universiti Teknologi Malaysia, Skudai, 81310 Johor Bahru Johor.

Agnes Hólm Gunnarsdóttir , Helgi Pór Ingason. (2007). Afburðaárangur: bók um stjórnunaraðferðir sem grundvallast á goeðastjórnun og rannsóknir á fyrirtcekjum sem . Reykjavík: Háskólaútgáfan.

Alfred Wong \& Patrick Fung. (1997). TQM in the construction industry in Hong Kong; a supply chain management perspective. Hong Kong Institute of Buisiness Studies. Hong Kong: Lingnam College.

Alpingi. (04. 02 2010). Alpingi. Sótt 04. 022010 frá Mannvirki (heildarlög): http://www.althingi.is/dba-bin/ferill.pl?ltg=135\&mnr=375

Alpingi. (28. 12 2010). Lög um mannvirki. Sótt 20. 072011 frá Stjórnartíðindi: http://www.stjornartidindi.is/Advert.aspx?ID=8a6e018b-acbe-4294-8ea0-784aa30ab5c9 
Alvin C. Burns and Ronald F. Bush. (2009). Marketing Research: Global Edition, 6/E. Reykjavík: Pearson Higher Education.

Amalía Björnsdóttir. (24. 08 2004). Tölfrceðivefur Amalíu Björnsdóttur. Sótt 19. 052011 frá Breytur: http://mennta.hi.is/vefir/tolfraedi/textar/breytur.htm

Anita J. van der Kooij, J. J. (2003). Local minima in categorical multiple regression. Leiden, Holland: Computational Statistics \& Data Analysis.

Ashford, J. L. (2003). The management of quality in construction. London: Taylor \& Francis e-Library.

Bhimaraya A. Metri. (2005). TQM critical success factors for construction firms . Management: Journal of Contemporary Management Issues , 10 (2), 61-72 .

BIM Ísland. (21. 07 2011). BIM Ísland. Sótt 21. 072011 frá BIM-Wiki: http://www.bim.is/BIMWiki.aspx

Björn Karlsson, F. m. (18. 07 2011). Gæðastjórnun í mannvirkjagerð á Íslandi í dag. (A. H. Ólafsdóttir, Spyrill)

Boaden, R. D. (1992). Total quality management in the construction industry: A preliminary analysis. International Journal of Technology Management. , 7 (4,5), 244-254.

Boris Blumberg, Donald R. Cooper and Pamela S. Schindler. (2008). Business Research methods (Second European útg.). Berkshire: McGraw- Hill Education.

Bozena Poksinska, Jörgen A.E. Eklund \& Jens Jörn Dahlgaard. (2006). ISO9001:2000 in small organisations Lost opportunities, benefitsand influencing factors Bozena. Poksinska International Journal of Quality \& Reliability Management , 23 (5), 490-512.

Bozena Poksinska, Jörgen A.E. Eklund, \& Jens Jörn Dahlgaard. (2006). ISO 9001:2000 in small organisations :Lost opportunities, benefits and influencing factors. The International Journal of Quality \& Reliability Management , 23 (5), 490-512.

Brynhildur Bergpórsdóttir. (1998). Gæðatjórnun, eðli hennar og tilgangur. Ráðunautafundur. Reykjavík: Iðntæknistofnun Íslands.

BSI, British Standards Institution. (2007). BSI á Íslandi. Sótt 12. 042011 frá http://www.bsiaislandi.is/

BSTR, V. á. (2003). ÍST 30:2003 Almennir útboðs og samningsskilmálar (5. útg.). Reykjavík: Staðlaráo Íslands.

CABE. (2006). Hm Government Better public building. HM Government. London: Commission for Architecture and the Built Environment and the Department for Culture, Media and Sport.

Chini, A. R. ( APRIL 2003). ISO 9000 and the U.S. Construction Industry. Journal of management in engineering (C) ASCE , 69-77. 
Chung, H. (1999). Understanding quality assurance in construction. A practical guide to ISO 9000 for contractors. London: E\&FN Spon.

Creative research systems. (2010). Creative research systems - your complete survey software solution since 1982. Sótt 06. 062011 frá Sample Size formular for our sample size calculator: http://www.surveysystem.com/sample-size-formula.htm

Crosby, P. B. (1989). How goes the quality revolution ? Winter Park, Fl. 32790: Philip Crosby Associates II, Inc PCA Inc, P.o.Box 2369, .

Crosby, P. (1979). Quality is free. the art of making quality certain. New York: New American Library.

Deal, L. G. (2008). Reframing Organizations. Artistry, Choice and Leadership. (4, Ritstj.) San Francisco: Jossey-Bass. A Wiley Imprint.

Deming, W. (1986). Out of the Crisis. Cambridge: Mass.: Massachusettes Institute of Technology.

Deming, W. (1993). The New Economics. Cambridge: Mass.: Massachusettes Institute of Technology.

Det Digitale Bygger. (2010). Digital Construction A Danish government initiative - english introduction. Sótt 21. 072011 frá Det Digitale Byggeri: implementerings: netværket: http://www.detdigitalebyggeri.dk/sites/default/files/attachments/Digital_Construction_Intr o.pdf

Eccles, R. (1991). The performance measurement manifesto. Harvard Business Rev , 31137 .

Egan, S. J. (1998). Rethinking Construction: The Report of the Construction Task Force. United Kingdom: Her London: Majesty's Stationery Ofc. .

Eyjólfur Bjarnason. (2004). Framkvoemdir og vinnuvernd. Reykjavík: Iðnú .

Eyjólfur Bjarnason. (2010). Íslenskir Aðalverktakar hf. og innleiðing ISO 9001 vottunar. ...upp í vindinn. Blað umhverfis- og byggingarverkfrceðinema 2010 (29), 45-48.

Eyjólfur Bjarnason og Ferndinand Hansen hjá Samtökum Iðnaðarins. (23. 04 2004). Samtök Iðnaðarins. Sótt 04.022010 frá IST-30 á rafrænu formi: http://www.si.is/starfsgreinahopar/malmidnadur/frettir-af-malmidnadi/nr/1528

Feigenbaum, A. V. (1991). Total Quality Control . USA: McGraw-Hill.

Ferdinand Hansen. (22. 11 2006). Samtök Iðnaðarins - Gœðastjórar hœeddir og hunsaðir ! Sótt 2011. 505 frá http://www.si.is/malaflokkar/gaedastjornun-ogrekstur/gaedafrettir/nr/2732

Ferdinand Hansen. (14. 08 2007). Samtök Iðnaðarins. Sótt frá Hver er gæðatryggingin pín!: http://www.si.is/malaflokkar/gaedastjornun-og-rekstur/gaedafrettir/nr/3023 
Ferdinand Hansen. (10. 07 2007). SI - Fréttir og greinar - Handverk og stjórnun. Sótt 19. 072011 frá http://www.si.is/starfsgreinahopar/mannvirkjagerd/frettir-afmannvirkjagerd/2007/07

Ferdinand Hansen. (22. 11 2006). SI - Fréttir og greinar. Gcððastjórar hœeddir og hunsaðir. Sótt 23. 62011 frá http://www.si.is/malaflokkar/gaedastjornun-ogrekstur/gaedafrettir/nr/2732

Ferdinand Hansen. (14. 8 2007). SI - Fréttir og greinar. Hver er geeðatryggingin pín. Sótt 29. 62011 frá http://www.si.is/malaflokkar/gaedastjornun-og-rekstur/gaedafrettir/nr/3023

Ferdinand Hansen, Samtök iðnaðarins. (2007). Hvernig gera má betur - kennslubók SI. Prenttækni.

Formoso, C. T., \& Revelo, V. H. (1999). Improving the materials supply system in smallsized building firms. Automation in construction , 8 (6), 663-670.

Framkvæmdasýsla ríkisins . (án dags.). BIM upplýsingalikön mannvirkja. Sótt 21. 072011 frá Framkvæmdasýsla ríkisins : http://www.fsr.is/Pages/139

Framkvæmdasýsla ríkisins. (án dags.). Framkvoemdasýsla ríkisins. Sótt 15.. 22011 frá Samstarf og próun - Gæðastjórnun: http://www.fsr.is/Pages/184

Framkvæmdasýsla ríkisins. (án dags.). Framkvoemdasýsla ríkisins. Sótt 15. 022011 frá Vottaðar ráðgjafastofur og verktakar: http://www.fsr.is/Pages/187

Frank M. Gryna, Richard C. H. Chuna \& Joseph A. DeFeo. (2007). Juran's Quality Planning and Analysis - For enterprise quality (5 útg.). Mc Graw Hill.

Garðar Örn Porvarðarson. (2010). Verkefnastjórnun i byggingariðnaði. Bifröst: Háskólinn á Bifröst.

Giles, R. (1997). ISO 9000 perspective for the construction industry in the UK. Training for Quality, Volume 5 (4), 178-181.

Good PI, Hardin JW. (2009). Common Errors in Statistics (And How to Avoid Them). (3, Ritstj.) New Jersey: Wiley.

Gopal K. Kanji, Alfred Wong. (1998). Quality culture in the construction industry. Total Quality Management, 9, Iss (4-5), 133-140.

Grönroos, C. (1984). A Service Quality Model and Its Marketing Implications. European Journal of Marketing , 18, 36-45.

Guðjóna Björk Sigurðardóttir. (2008). Gæðastjórnun verktaka i mannvirkjagerð á Íslandi. Háskólinn á Bifröst.

Gustafsson, R. ,. (2001). Experiences from implementing ISO 9000 in small enterprises - a study of Swedish organisations.),. The TQM Magazine , 13 (4), 232-246. 
H.A.Bassioni, S., A.D.F.Price, \& \& T.M.Hassan, M. (04 2004). Performance Measurementin Construction. Journal of management in engineering .

Hagstofa Íslands. (04. 07 2007). Hagstofa Íslands. Sótt 23. 062011 frá Fjöldi launagreiðenda eftir starfsmannafjölda, landsvæðum og atvinnugreinum 1998-2005: http://www.hagstofa.is/?PageID=638\&src=/temp/Dialog/varval.asp?ma=FYR01102\%26ti $=\mathrm{Fj} \% \mathrm{~F} 6 \mathrm{ldi}+$ launagrei $\% \mathrm{~F} 0$ enda + eftir + starfsmannafj $\% \mathrm{~F} 61 \mathrm{da} \% 2 \mathrm{C}+$ landsv $\% \mathrm{E} 6 \% \mathrm{~F} 0 \mathrm{um}+\mathrm{og}+\mathrm{a}$ tvinnugreinum $+1998 \% 2 \mathrm{D} 2005+\% 26$ path $=. . /$ Database/fyrirtaeki/fjoldi/\%26lang=3\%26unit $\mathrm{s}=\mathrm{Fj} \% \mathrm{~F} 61 \mathrm{di}$

Hagstofa Íslands. (20. 02 2009). Hagstofa Íslands. Sótt 09. 042010 frá Fyrirtæki og velta, Gjaldprot fyrirtækja eftir mánuðum og bálkum atvinnugreina (ÍSAT95) 2005-2007: http://hagstofan.is/?PageID=638\&src=/temp/Dialog/varval.asp?ma=FYR03002\%26ti=Gjal $\mathrm{d} \% \mathrm{FErot}+$ fyrirt $\%$ E6kja + eftir $+\mathrm{m} \% \mathrm{E} 1 \mathrm{nu} \% \mathrm{~F} 0 \mathrm{um}+\mathrm{og}+\mathrm{b} \% \mathrm{E} 1 \mathrm{kum}+$ atvinnugreina $+\% 28 \% \mathrm{CD}$ SAT95\%29+2005\%2D2007\%26path=../Database/fyrirtaeki/gjaldthrot/\%26lang=3\%26unit $\mathrm{s}=\mathrm{Fj} \% \mathrm{~F} 61 \mathrm{di}$

Hagstofa Íslands. (30. 03 2010). Hagstofa Íslands. Sótt 09. 042010 frá Fyrirtæki og velta, Gjaldprot fyrirtækja eftir mánuðum og bálkum atvinnugreina 2008-2010: http://hagstofan.is/?PageID=638\&src=/temp/Dialog/varval.asp?ma=FYR03001\%26ti=Gjal $\mathrm{d} \% \mathrm{FErot}+$ fyrirt\%E6kja + eftir $+\mathrm{m} \% \mathrm{E} 1 \mathrm{nu} \% \mathrm{~F} 0 \mathrm{um}+\mathrm{og}+\mathrm{b} \% \mathrm{E} 1 \mathrm{kum}+$ atvinnugreina $+2008 \% 2 \mathrm{D}$ $2010 \% 26$ path $=. . /$ Database/fyrirtaeki/gjaldthrot/\%26lang $=3 \% 26$ units $=F j \% F 61 d i$

Hagstofa Íslands. (28. 01 2011). Hagstofa Íslands. Sótt 07. 042011 frá Talnaefni »" Fyrirtæki og velta http://hagstofan.is/?PageID=638\&src=/temp/Dialog/varval.asp?ma=FYR01001\%26ti=Fj\% F6ldi+fyrirt\%E6kja+og $+\mathrm{f} \%$ E9laga+eftir+atvinnugreinum $+2008 \% 2 \mathrm{D} 2010 \% 26 \mathrm{path}=. . / \mathrm{Data}$ base/fyrirtaeki/fjoldi/\%26lang=3\%26units $=$ Fj\%F6ldi

Hagstofa Íslands. (19. 05 2011). Hagstofa Íslands. Sótt 11. 072011 frá Talnaefni » Fyrirtæki og velta http://hagstofan.is/?PageID=640\&src=/temp/Dialog/varval.asp?ma=FYR04101\%26ti=Heil darvelta + eftir + atvinnugreinum + og $+\mathrm{t} \%$ EDmabilum $+2010 \% 2 \mathrm{D} 2011 \% 26 \mathrm{path}=. . /$ Database $/ \mathrm{f}$ yrirtaeki/veltutolur $/ \% 26$ lang $=3 \% 26$ units $=$ Millj $\% F 3$ nir $\% 20 \mathrm{kr} \% \mathrm{~F} 3 \mathrm{na}$

Hansson, J. (2003). Total Quality Management - Aspects of Implementation and performance Investigations with a Focus on Small Organisation. Department of Business Administration and Social Science Division. Lulea university og technology.

Helen Reijonen \& Raija Komppula. (2007). Perception of success and its effect on small firm performance. Journal of Small Business and Enterprise Development , 14 (4), 689701. .

Hoonakker, P. (2006). Quality management in construction industry. University of Wisconsin-Madison. Madison: Center for Quality and Productivity Improvement (CQPI).

Hoonakker, P. (2006). Quality management in construction industry. University of Wisconsin-Madison. Madison: Center for Quality and Productivity Improvement (CQPI).

IBM SPSS Statistics 19.0 Inc. (2010). Discretization (CATREG algorithms). 
Ingólfur Bender. (19. mars 2010). Morgunkorn. Morgunkorn Íslandsbanka, 1.

International Standardization for Organization. (2010). International Standards for Business, Government and Society. Sótt 19. 042010 frá ISO members: http://www.iso.org/iso/about/iso_members.htm

Ishikawa, K. \& D.J. Lu. (1985). What is Total Quality Control: The Japanese Way. Englewood Cliffs: N.J.: Prentice-Hall.

ISO, International Organization for Standardization. (án dags.). The ISO story. Sótt 25. 07 2011 frá ISO, International Organization for Standardization: http://www.iso.org/iso/about/the_iso_story/iso_story_foreword.htm

ÍST EN ISO 9001:2008 - Gœðastjórnunarkerfi - Kröfur (4 útg.). (2008). Reykjavík: Staðlaráð Íslands.

Jack R. Meredith \& Samuel J. Mantel,Jr. (2009). Project Management, a Managerial Approach. . (7, Ritstj.) USA: John Wiley \& Sons, Inc.

Jacqueline J. Meulman, Willem J. Heiser, SPSS Inc. (2004). SPSS Categories 13.0. Chicago: SPSS Inc.

John Oakland \& Marton Marosszek. (2006). Total Quality in the Construction Supply Chain. Great Britain: Butterworth- Heinemann is an imprint of Elsevier.

Jón Freyr Jóhannsson. (19. 09 1996). Góð meðhöndlun kvartana er vopn í samkeppninni. Viðskiptablað .

Jónas Brjánsson, t. o. (14. 12 2010). Úttektir og gæðamál í framkvæmdum á Íslandi. (A. H. Ólafsdóttir, Spyrill)

Joseph M. Juran. (1979). Quality Control Handbook (3 útg.). McCraw-Hill.

Juran, J. (1979). Quality Control Handbook. New York: McGraw-Hill, Inc. .

Kam, C.W. and Tang, S.L. (1997). Development and implementation of quality assurance in public construction works in Singapore and Hong Kong. International Journal of Quality \& Reliability Management, 14 ( No. 9), pp 909-928.

Khelifa, D. M. Data Management \& Analysis: Intermediate PASW Topics II Workshop Beginning, Intermediate \& Advanced Applied Statistics. Department of Humanities and Social Sciences College of Arts and Sciences.

Kreitner, R. (2007). Management. (10, Ritstj.) Boston, New York: George T. Hoffman.

Kujala, J. L. (2004). Total Quality Management as a Cultural Phenomenon. The Quality Management Journal , 11 (4), 43-55.

Lagrosen, S. ,. (2006). A dive into the depths of quality management. European Business Review, 2 (18), 84. 
Low Sui Pheng and Jasmine Ann Teo. (15. Janúar 2004). Implementing Total Quality Management in Construction Firms. Journal of management in engineering@ASCE .

Low, S.P. and Goh, K.H. (1994). Construction quality assurance: problems of implementation at infancy stage in Singapore. International Journal of Quality \& Reliability Management, 11 ( No. 1), 22-37.

Magnús B. Jóhannesson. (3. 2 1994). mbl.is, greinasafn. Sótt 15. 72011 frá Hefur altæk gæðastjórnun skilað árangri ? http://www.mbl.is/mm/gagnasafn/grein.html?grein_id=123796

Magnús Sædal Svavarsson. (2007). Vantar víðtækari heimildir til að taka skussana úr umferð! - segir Magnús Sædal Svavarsson, byggingarfulltrúi í Reykjavík. Samiðn .

Manas, J. (2008). Managing the Gray Areas: Essential Insights for Leadin People, Projects and Organizations. (Premier, Ritstj.) United states of America: RMC publications, Inc.

Mandal, P., Love, P.E.D. and Gunasekaran, A. (2002). Towards a system dynamics modelling framework for quality in manufacturin. Int. J. Manufacturing Technology and Management , 4, 333-343.

Mannvirkjastofnun. (án dags.). Mannvirkjastofnun tekur til starfa. Sótt 22. 072011 frá Mannvirkjastofnun: http://www.brunamal.is/forsida/mannvirkjastofnun/

María Heimisdóttir. (2003). Réttmæti aðferða(fræði). Lceknablaðið .

Marx, D. H. (2009). Result of the 2008 Survey of the cidb Construction Industry Indicators and Comparison with the 2005 \& 2007 survey results. South Africa: Department of Quantity Surveying and Construction Management, University of the Free State .

Menntamálaráðuneytið. (2007). Menningarstefna i mannvirkjagerð - Stefna íslenskra stjórnvalda í byggingarlist. Reykjavík: Menntamálaráðuneytið.

Morgunblaðið. (16. 05 1993). mbl.is - greinasafn. Sótt 18. 072011 frá Gæðaráð byggingariðnaðarins Ábyrgð Byggingatjónasjóðs kemur eftir 5 ár: http://www.mbl.is/mm/gagnasafn/grein.html?grein_id=105342

Naglinn. (2011). Naglinn - við einföldum málið. Sótt 19. 072011 frá http://nagli.is/

Oakland, J. S. . (1995). Total quality management: Text with cases. London, U.K.: Butterworth-Heinemann.

Örn Arnarson. (08. 04 2010). mbl.is. Sótt 09. 042010 frá Djúpstæð skuldakreppa fullvalda ríkja yfirvofandi: http://mbl.is/mm/vidskipti/frettir/2010/04/08/djupstaed_skuldakreppa_fullvalda_rikja_yfir vofandi/

Óskar Valdimarsson. (2006). Gæðastjórnun við mannvirkjagerð. Verktcekni .

Óskar Valdimarsson. (2006). Gæðastjórnun við mannvirkjagerð. . Verktcekni . 
Peter E. D. Love, D. J. (2009). Divergence or Congruence? A Path Model of Rework for Building and Civil Engineering Projects. Jurnal of Performance of Cunstructed Facilities , 23 (6), 480-488.

Peter E. D. Love, David J. Edwards, Jim Smith \& Derek H. T. Walker. (nov/des 2009). Divergenceor Congruence ? A Path Model of Rework for Building and Civil Engineering Projects. Journal of performance of constructed facilities (C) ASCE, 480-488.

Pratt, J. W. (1987). Dividing the indivisible: Using simple symmetry to partition variance explained. Second International Conference in Statistics,. Finland: University of Tampere.: T. Pukkila, and S. Puntanen, eds. Tampere.

Prof. Jozef Gašparík, PhD., Sylvia Szalayová, PhD. Quality management system in construction firm. Bratislava : Slovak University of Technology in Bratislava Faculty of Civil Engineering.

Quazi, H. A., and Padibjo, S. R. (1997). A journey toward total quality management through ISO9000 certification - a Singapore experience. The TQM Magazine, 364-371.

QuestionPro Survey Software. (2010). QuestionPro. Sótt jan - apríl 2010 frá http://www.questionpro.com/

Ricardo R. Ramı, Luis Fernando C. Alarcón, Peter Knights. (júlí 2004). Benchmarking System for Evaluating Management Practices. Journal of management in engineering, $110-117$.

Routio, P. (03. 08 2007). Arteology, research of products and profession. Sótt 07.062011 frá Sampling: http://www2.uiah.fi/projects/metodi/152.htm\#nayte

Ruben Vrijhoef and Lauri Koskela. (1999). Roles of Supply Chain Management in Construction. IGLC-7 (bls. 26-28). Berkeley: University of California.

S. Keoki Sears, G. A. (2008). Construction Project Management: A Practical Guide to Field Construction Management. John Wiley \& Sons.

S.L.Tang, S. M. (2005). Construction quality management. Hong Kong, China: Condor Production Co. Ltd.

Sami Kärnä . (2009). CONCEPTS AND ATTRIBUTES OF CUSTOMER SATISFACTION IN CONSTRUCTION . Espoo: Helsinki University of Technology, Department of Structural Engineering and Building Technology .

Samtök iðnaðarins. (2005). Samtök iðnaðarins. Framtiððarsýn árið 2005- Stefnumótun fyrir islenskan mannvirkjaiðnað. $\quad$ Sótt $\quad 19 . \quad 07 \quad 2011$ frá http://www.si.is/starfsgreinahopar/mannvirkjagerd/framtidarsyn/

Samtök iðnaðarins. (án dags.). Samtök iðnaðarins. Gceðastjórnun, stjórnun og rekstur. Sótt 19. 072011 frá http://www.si.is/malaflokkar/gaedastjornun-og-rekstur/ 
Samtök Iðnaðarins. (án dags.). Samtök iðnaðarins. Gcðavottun SI. Sótt 19. 072011 frá http://www.si.is/malaflokkar/gaedastjornun-og-rekstur/gaedavottun-si/

Samtök iðnaðarins. (án dags.). Samtök Iðnaðarins. Mannvirkjagerð. Sótt 11. 072011 frá http://www.si.is/starfsgreinahopar/mannvirkjagerd/

Sarah Boslaugh \& Paul Andrew Watters. (2008). Statistics in a nutshell. 1005 Gravenstein Highway North, Sebastopol, CA95472: O'Reilly Media, Inc.

Senge, P. M. (1990). The Fifth Disipline: The art and practice of the learning organization. (1, Ritstj.) New York: Doubleday/Currency.

Sigfús Sigurðsson, Hörður Bergmann, Ása Guðbjörg Ásgeirsdóttir. (2002). Öryggis- og heilbrigðisácetlun fyrir byggingarvinnustaði Frœðslu- og leiðbeiningarit $n r .17$. Vinnueftirlitið. Reykjavík: Birtir fjölmiðlu.

Sigríður Sigurðardóttir, a. o. (1. desember 2010). Samskipti verkkaupa og verktaka á Íslandi. (A. H. Ólafsdóttir, Spyrill)

SPSS Statistics 19.0 Inc. (2010). Imputation of Missing Values (CATREG algorithms).

SPSS Statistics Inc. (2010). Categorical Regression - intercorrelations.

SPSS Statistics Inc. (2010). Objective Function (CATREG algorithms). Sótt 19. maí 2011 frá

http://127.0.0.1:50357/help/index.jsp?topic=/com.ibm.spss.statistics.help/alg_catreg_objfunc-opt_func.htm

SPSS Statistics Inc. (2010). Optimal Scaling Levels (CATREG algorithms).

Staðlaráð Íslands. (2003). ISO 9001 fyrir lítil fyrirtceki - Leiðsögn (2 útg.). (\#. Jón Skaptason, býð.) Reykjavík: Staðlaráð Íslands.

Staðlaráð Íslands. (2003). ÍST 30:2003, Almennir útboðs- og samningsskilmálar um verkframkvoemdir. Reykjavík: Staðlaráð Íslands.

Staðlaráð Íslands. (2000). ÍST EN ISO 9000:2000. Reykjavík: Staðlaráð Íslands.

Staðlaráð Íslands. (2008). ÍST EN ISO 9001:2008, Gceðastjórnunarkerfi - kröfur. Reykjavík: Staðlaráð Íslands.

StatSoft, Inc. (2011). (Electronic Version) Electronic Statistics Textbook. Sótt 31. 052011 frá Baisic statistics - Significance of Correlations: http://www.statsoft.com/textbook/basicstatistics/\#Correlationsc)

StatSoft, Inc. (2011). (Electronic Version): StatSoft Electronic Statistics Textbook. Sótt 03. 062011 frá Elementary Concepts in Statistics - Why small relations can be proven significant only in large samples: http://statsoft.com/textbook/elementary-concepts-instatistics/\# 
Steinunn Huld Atladóttir og Ómar Imsland. (2003). Verkefnastjórnun, Hugtakalykill (3 útg.). Reykjavík: Verkefnastjórnunarfélag Íslands.

Sveinn Hannesson . (15. 07 2005). Samtök Iðnaðarins. Sótt 17. 072011 frá Uppsveifla í byggingariðnaði og mannvirkjagerð: http://www.si.is/upplysingar-og-utgafa/leidari$\mathrm{si} / / \mathrm{nr} / 2166$

Sveinn Hannesson. (15. 07 2005). Samtök iðnaðarins. Sótt 17. 072011 frá Uppsveifla í byggingariðnaði og mannvirkjagerð: http://www.si.is/upplysingar-og-utgafa/leidari$\mathrm{si} / / \mathrm{nr} / 2166$

The Better Public Buildings Group, Lord Falconer. (2000). Better Public Buildings A proud legacy for the future. London: Department for Culture, Media and Sport.

The Construction Task Force. (1998). Rethinking construction . London: Department of Trade and Industry.

Tony Auchterlounie \& Dr. John Hinks. (2001). The measurement of customer satisfacation in the private house building sector. COBRA, Cutting Edge and ROOTS conferences. Glasgow: Bolton institute \& Center for advanced built environment research.

Viðskiptablaðið. (19. 12 2002). mbl.is-greinasafn. Sótt 23. 62011 frá Ný tækifæri með gæðastjórnun: http://mbl.is/mm/gagnasafn/grein.html?grein_id=705096

Viðskiptablaðið. (19. 12 2002). mbl.is-greinasafn. Sótt 23. 62011 frá Ný tækifæri með gæðastjórnun: http://mbl.is/mm/gagnasafn/grein.html?grein_id=705096

Vinnueftirlitið. ( 2005-2011 ). Vinnueftirlitið. Sótt 21. 072011 frá Upplýsingar úr slysaskrá Vinnueftirlitsins: http://slysatolfraedi.ver.is/t\%C3\%B61fr\%C3\%A6\%C3\%B0i.aspx

Vinnueftirlitið, Sigfús Sigurðsson. (2002). Öryggis- og heilbrigðisácetlun fyrir byggingarvinnustaði (2 útg.). Reykjavís: Gutenberg.

Vísindavefurinn. (21. 11 2005). Visindavefurinn. Sótt 05. 022010 frá Hvernig útskýrir maður aðferðafræði félagsvísinda?: http://visindavefur.hi.is/svar.asp?id=5420

Vottun hf. (án dags.). Vottun hf. Sótt 19. 072011 frá http://www.vottunhf.is/

Wadsworth, H. M. (2002). Modern methods for quality control and improvement. New York: Wiley .

Watters, S. B. (2008). Statistics in a nutshell. (M. Treseler, Ritstj.) 1005 Gravenstein Highway North, Sebastopol, CA95472.: O'Reily Media, Inc.

Wikipedia. (17. Apríl 2011). Wikipedia. Sótt 19. maí 2011 frá Monotonic function: http://en.wikipedia.org/wiki/Monotonic

Wikipedia. (7. Janúar 2011). Wikipedia. Sótt 20. Maí 2011 frá Discretization: http://en.wikipedia.org/wiki/Discretization 
Wikipedia. (28. 07 2011). Wikipedia. Sótt 02. 092011 frá Mann-Whitney U: http://en.wikipedia.org/wiki/Mann\%E2\%80\%93Whitney_U

Wilkipedia. (02. 07 2011). Wilkipedia. Sótt 12. 072011 frá Quality management: http://en.wikipedia.org/wiki/Quality_management

Winter Park Public Library. (án dags.). Winter Park History and Archives Collection. Sótt 23. 062011 frá Philip B. Crosby's Articles, Essays, and Writings : http://www.wppl.org/wphistory/PhilipCrosby/grant.htm

Xiao, Hong, Proverbs, David. (2002). The performance of contractors in Japan, the UK and the USA: An evaluation of construction quality. International Journal of Quality \& Reliability Management , 19 (6), 672-687.

Young, D. (3. 9 2007). Construction Industry Must Take Quality Seriously. Sótt 23. 62011 frá University of Ulster: Ulster news: http://news.ulster.ac.uk/releases/2007/3380.html

Youssef, T. A. (2006). An ISO 9001:2000-based framework for realizing quality in small businesses. Omega , 34, 231-235.

Zeljko M. Torbica og Robert C. Stroh. (2001). Customer Satisfaction in Home Buildingby. Journal of Construction Engineering and Management, , 127 (1), 82-86. 



\section{Myndir}

Mynd 1 Gæðastjórnunar-príhyrningurinn

Mynd 2 Hlutfall heildarveltu í byggingastarfsemi og mannvirkjagerð 1998-2010 miðað við heildarveltu af annarri starfsemi pjóðarinnar (Hagstofa Íslands, 2011).

Mynd 3 Slysatíðni við byggingaframkvæmdir, mynd gerð eftir upplýsingum frá Vinnueftirlitinu (Vinnueftirlitið, 2005-2011).

Mynd 4 Mismunur á afburðaeftirliti og úttekt á afurð í verklok (e. product checking) og vöktun

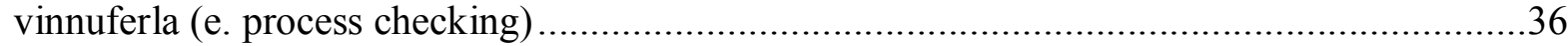

Mynd 5 Aðferðafræði rannsóknar.

Mynd 6 Svarhlutfall verkkaupa með ánægju framkvæmdar verksins í heild og hjá umræddum verktaka

Mynd 7 Hlutfallsleg skipting GSK með tilliti til ánægju verkkaupa með umræddan verktaka

Mynd 8 Hlutfallsleg skipting á GSK með tilliti til ánægju verkkaupa með umræddan verktaka sér í lagi fyrir einstaklings- og fyrirtækjaverkkaupa

Mynd 9 Hlutfall svara verkkaupa um pað hvort peir telja að umræddur verktaki vinni eftir gæðastjórnunarkerfi m.t.t. svara verktaka (GSK).....

Mynd 10 Sundurliðun á grunnupplýsingum...

Mynd 11 Kynjahlutfall með tilliti til ánægju verkkaupa.

Mynd 12 Hlutfallsleg skipting á ánægju verkkaupa með byggingastjóra með tilliti til ánægju verkkaupa með umræddan verktaka, sér í lagi fyrir einstaklings- og fyrirtækjaverkkaupa.

Mynd 13 Svarhlutfall á spurningum tengdum tímaáætlunum

Mynd 14 Hlutfallleg skipting einstaklings- og fyrirtækjaverkkaupa með tilliti til pess hvort lögð var fram skrifleg tímaáætlun eða ekki.

Mynd 15 Svarhlutfall á spurningum tengdum greiðsluáætlunum

Mynd 16 Hlutfallleg skipting einstaklings- og fyrirtækjaverkkaupa með tilliti til pess hvort lögð var fram skrifleg greiðsluáætlun eða ekki

Mynd 17 Ánægja verkkaupa með tímastjórnun og fjármagnsstreymi.

Mynd 18 Hlutfallsleg skipting GSK með tilliti til pess hvort lögð var fram skrifleg tíma og greiðsluáætlun. 
Mynd 19 Hlutfallsleg skipting fyrirtækja- og einstaklingsverkkaupa með tilliti til pess hvort verkkaupi var með umsjónarmann.

Mynd 20 Hlutfallsleg skipting fyrirtækja- og einstaklingsverkkaupa með tilliti til pess hvort haldnir voru verkfundir með verktaka og verkkaupa.

Mynd 21 Hlutfallsleg skipting fyrirkomulagi verkfunda og ánægju verkkaupa með umræddan verktaka.

Mynd 22 Hlutfallsleg skipting GSK með tilliti til pess hvort haldnir voru verkfundir eða ekki og hvort skrifuð var fundargerð á verkfundum eða ekki ......................................................... 70

Mynd 23 Svarhlutfall á spurningum tengdum samningum. .71

Mynd 24 Hlutfallsleg skipting á sundurliðun samnings með tilliti til fjölda ósætta um innihald samnings.

Mynd 25 Hlutfallsleg skipting á GSK með tilliti til pess hve vel samningur var sundurliðaður. ................73

Mynd 26 Fjöldi frábrigða hjá umræddum verktaka á verktíma.........................................................73

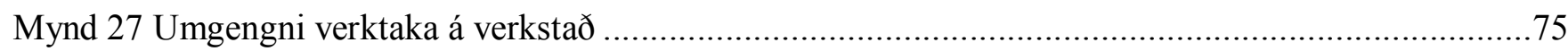

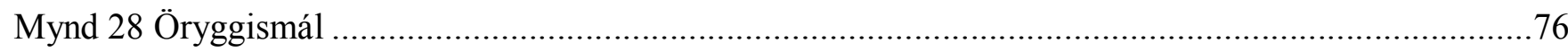

Mynd 29 Hlutfallsleg skipting á GSK með tilliti til pess hvort öryggismál voru rædd eða ekki.................77

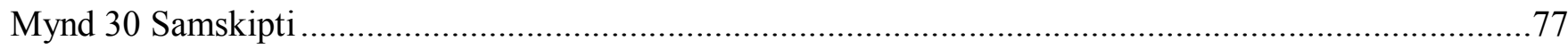

Mynd 31 Hlutfallsleg skipting á pví hvort umræddur verktaki lagði fram gæðatryggingu með tilliti til

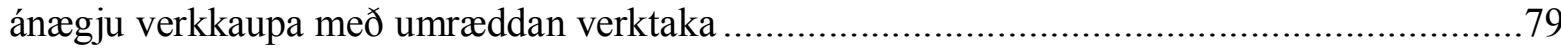

Mynd 32 Hlutfallsleg skipting á GSK með tilliti til pess hvort verktaki lagði fram gæðatryggingu eða ekki.

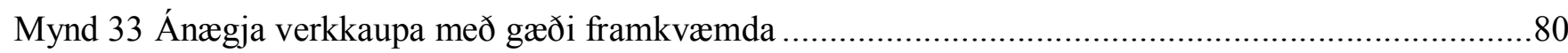

Mynd 34 Hlutfallsleg skipting á GSK með tilliti til ánægju verkkaupa með gæði framkvæmda ................81

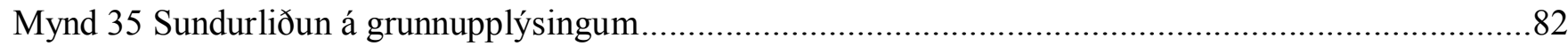

Mynd 36 Hlutfallsleg skipting eftir stærð fyrirtækja með tilliti til ánægju verkkaupa ,e‘ framkvæmd

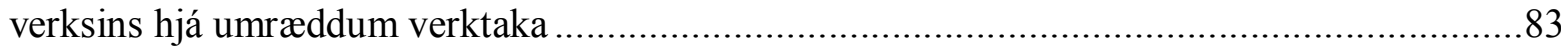

Mynd 37 Hlutfallsleg skipting á GSK með tilliti til stærð fyrirtækja ...................................................84

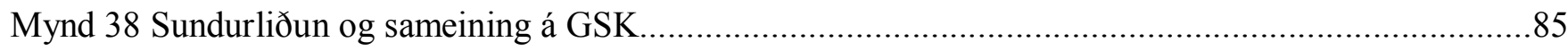

Mynd 39 Hlutfallsleg skipting á pví hvort starfandi gæðastjóri var innan fyrirtækisins með tilliti til

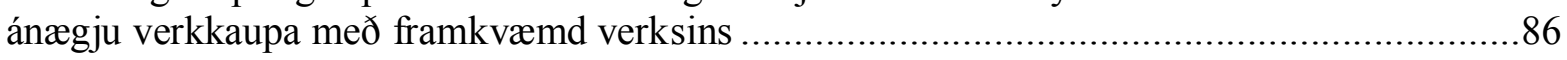

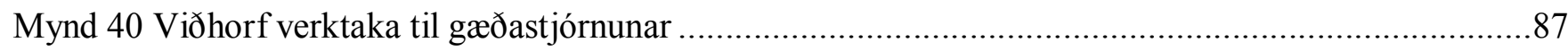

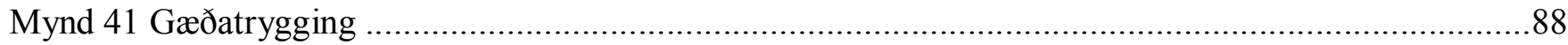


Mynd 42 Hlutfallsleg skipting á pví hvort/hversu oft verktaki fer fram á gæðatryggingu frá undirverktaka með tilliti til ánægju verkkaupa með framkvæmd verksins hjá umræddum verktaka

Mynd 43 Hlutfallsleg skipting á GSK með tilliti til pess hvort/hversu oft verktaki biðji undirverktaka um gæðatryggingu og hvort/hversu oft hann leggi sjálfur fram gæðatryggingu til verkkaupa.

Mynd 44 bekking verktaka á gæðastjórnun

Mynd 45 Hlutfallsleg skipting á almennri pekkingu verktaka á gæðastjórnun og á ISO 9001 með tilliti til ánægju verkkaupa með framkvæmd verksins hjá umræddum verktaka

Mynd 46 Hlutfallsleg skipting á GSK með tilliti til pekkingar verktaka á gæðastjórnun

Mynd 47 Skjalastjórnun verktaka

Mynd 48 Starfslýsingar

Mynd 49 Hlutfallsleg tíðni pess að verktaki leggi fram skriflega verkáætlun, verktöf og greiðsluáætlun.

Mynd 50 Hlutfallsleg tíðni hvort/hversu oft verktaki kemur á samkomulagi með verkkaupa að halda reglubundna verkfundi, hvort rituð sé fundargerð á verkfundum og hvort/hversu oft verktaki heldur verkdagbók.

Mynd 51 Aukaverk og frábrigði

Mynd 52 Gæðaeftirlit og hættumat

Mynd 53 Hlutfallsleg skipting á GSK með tilliti til innra verklags verktaka .98

Mynd 54 Hlutfallsleg skipting á GSK með tilliti til öryggismála

Mynd 55 Hlutfallsleg skipting á GSK með tilliti til pess hvort aukaverk eru skráð og hvernig verkkaupa er tilkynnt um frábrigði .

Mynd 56 Hlutfallsleg skipting á GSK með tilliti til pess hvort/hversu oft verktaki fer fram á gæðatryggingu frá undirverktaka og hvort/hversu oft hann er með sérstaka gæðastýringaráætlun

Mynd 57 Hlutfallsleg skipting GSK með tillit til skriflegra áætlana og verkdagbókar

Mynd 58 Hlutfallsleg skipting á GSK með tilliti til pess hvort/hversu oft verktaki ritar fundargerð og hvort/hversu oft hann semur við verkkaupa um reglubundna verkfundi....

Mynd 59 Kröfur verkkaupa í garð verktaka um skipulag og markviss vinnubrögð fyrir og eftir efnahagshrun.....

Mynd 60 Ánægja verkkaupa með framkvæmd hjá verktaka með tilliti til GSK

Mynd 61 Ánægja verkkaupa með samskipti við verktaka 115 
Mynd 62 Verkfundir með tilliti til gerðar verkkaupa

Mynd 63 Hlutfallsleg skipting á GSK með tilliti til pess hvort verktaki fer fram á gæðatryggingu frá undirverktökum

Mynd 64 Hlutfallsleg skipting á GSK með tilliti til pess hvort verktaki lét verkkaupa fá gæðatryggingu

Mynd 65 Kóngulóarit um hversu vel pátttakendum fannst viðkomandi orð eiga við gæðastjórnun. .323

Mynd 66 Köngulóarit af svörum við spurningunni“er farið eftir ákveðnu kerfi fyrir eftirfarandi pætti ?“

Mynd 67 Kóngulóarit af kröfum verkkaupa í garð verktaka - fyrir og eftir efnahagshrun .338

Mynd 68 Núlltilgátunni er hafnað 461

Mynd 69 Upplýsingar sem notast var við í Mann-Whitney U prófi .462 


\section{Töflur}

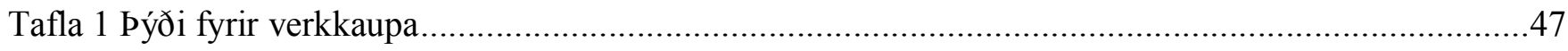

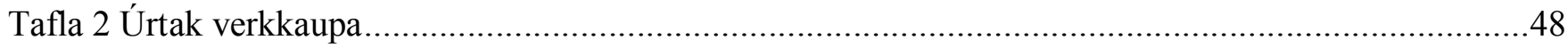

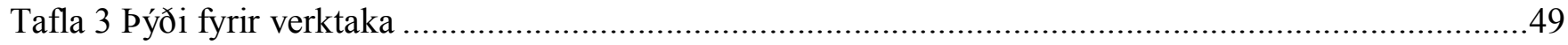

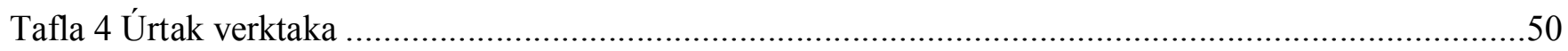

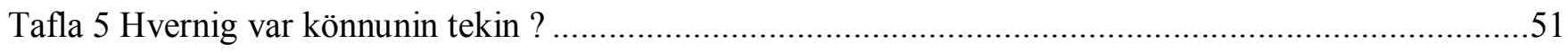

Tafla 6 Samantekt á marktækri fylgni viðhorfs verktaka við GSK ...................................................8

Tafla 7 beir pættir úr könnun verktaka tengdir verklagi verktaka sem mældust með marktæka fylgni

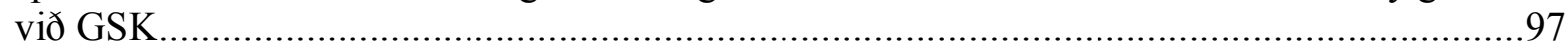

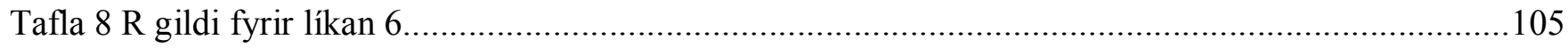

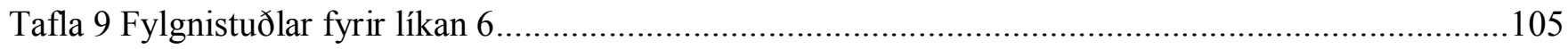

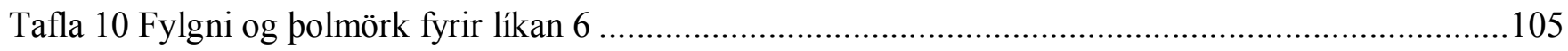

Tafla 11 Samantekt á marktærik fylgni pekkingar við GSK ........................................................107

Tafla 12 peir ánægjupættir sem mældust með marktæka fylgni við pað hvort verktaki starfaði eftir gæðastjórnunarkerfi byggðu á viðurkenndum stöðlum ...................................................109

Tafla 13 beir pættir úr könnun verkkaupa, tengdir verklagi verktaka sem mældust með marktæku

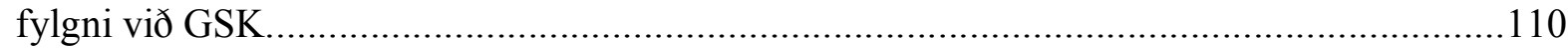

Tafla 14 beir pættir úr könnun verktaka tengdir verklagi verktaka sem mældust með marktæku fylgni

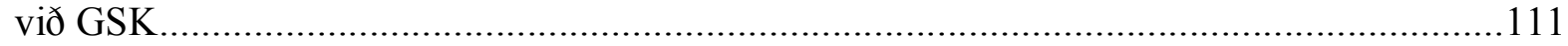

Tafla 15 Pættir sem hafa marktæka fylgni við ánægju verkkaupa með samskipti við verktaka ................116

Tafla 16 Viðhorf verktaka í garð gæðastjórnunar.......................................................................118

Tafla 17 Samantekt á marktækriri fylgni viðhorfs verktaka við GSK ................................................118

Tafla 18 beir pættir úr könnun verkkaupa sem mældust með marktæka fylgni við ánægju verkkaupa með framkvæmd verksins hjá umræddum verktaka.

Tafla 19 Peir pættir úr könnun verktaka sem mældust með marktæka fylgni við ánægju verkkaupa með framkvæmd verksins hjá umræddum verktaka ......................................................122

Tafla 20 Er verkkaupi fyrirtæki eða einstaklingur ? ......................................................................207 


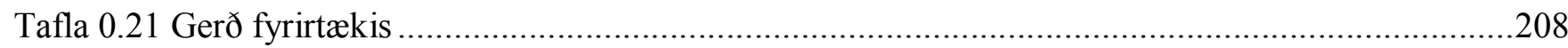

Tafla 0.22 Starfsgrein verktaka sem hafour er í huga? ...................................................................208

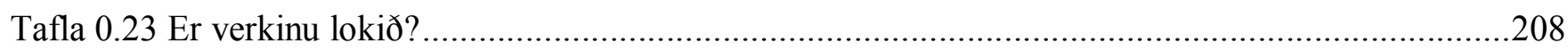

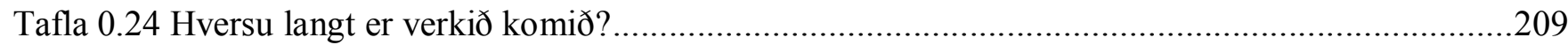

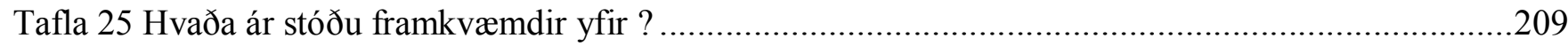

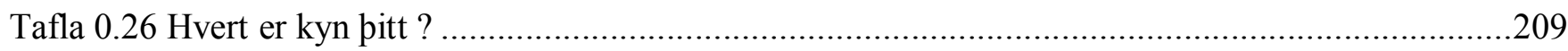

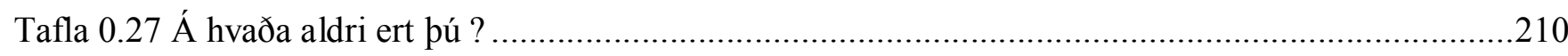

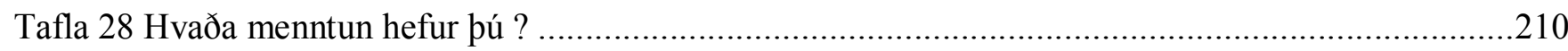

Tafla 0.29 Hversu ánægð/ur eða óánægð/ur ertu með framkvæmd verksins í heild ?..............................211

Tafla 0.30 Hversu ánægð/ur eða óánægð/ur ertu með framkvæmd verksins sem umræddur verktaki vann?

Tafla 0.31 Er pað einhver einn páttur sem stendur upp úr sem pú ert ósátt/ur við ?

Tafla 32 Dæmi um svör við spurningunni: „Hvaða páttur stóð upp úr sem pú varst mest ósátt/ur við ?“

Tafla 0.33 Sá byggingastjóri um yfirstjórn verksins ? ............................................................212

Tafla 0.34 Var svarandi sjálfur byggingastjóri ? .........................................................................212

Tafla 0.35 Finnst pér byggingastjóri hafa verið nægilega mikið til staðar ?........................................213

Tafla 0.36 Sá svarandi sjálfur um yfirstjórn verksins ? ...................................................................213

Tafla 0.37 Hversu ánægð/ur eða óánægð/ur ertu með störf byggingastjóra?..........................................214

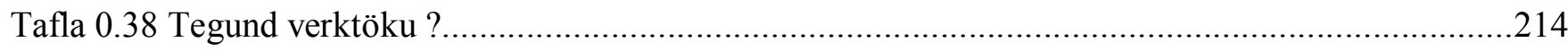

Tafla 0.39 Hversu vel/illa fannst pér yfirstjórnandi verksins uppfylla skyldu sína sem milligöngumaður um samskipti pín við verktaka?

Tafla 0.40 Hversu ánægð/ur eða óánægð/ur ertu með tímastjórnun verksins sem umræddur verktaki vann?

Tafla 0.41 Lagði umræddur verktaki fram skriflega tímaáætlun í upphafi verks ?

Tafla 42 Lagði umræddur verktaki fram skriflega tímaáætlun í upphafi verks - með tilliti til einstaklings og fyrirtækja verkkaupa

Tafla 0.43 Hversu vönduð/óvönduð var tímaáætlunin?

Tafla 0.44 Hversu vel/illa var tímaætlunin kynnt fyrir pér ?...........................................................217

Tafla 0.45 Var tímaáætlunin endurskoðuð og uppfærð reglulega ? 
Tafla 0.46 Er verkið farið fram úr eða fór verkið fram úr tímaáætlun hjá umræddum verktaka?

Tafla 0.47 Dæmi um svör við spurningunni: Hvaða ástæðu telur pú að sé á baki tafa ?

Tafla 0.48 Hversu ánægð/ur eða óánægð/ur ertu með fjármagnsstreymi verksins sem umræddur verktaki vann?

Tafla 0.49 Lagði umræddur verktaki fram skriflega greiðsluáætlun í upphafi verks ?

Tafla 50 Lagði umræddur verktaki fram skriflega greiðsluáætlun í upphafi verks - með tilliti til einstaklings- og fyrirtækja- verkkaupa

Tafla 0.51 Hversu vönduð/óvönduð var greiðsluáætlunin ?

Tafla 0.52 Hversu vel/illa var greiðsluáætlunin kynnt fyrir pér?

Tafla 0.53 Var greiðsluáætlunin endurskoðuð og uppfærð reglulega?

Tafla 0.54 Var greitt eftir framvindu verks?

Tafla 0.55 Er verkið farið fram úr eða fór verkið fram úr greiðsluáætlun hjá umræddum verktaka?

Tafla 0.56 Dæmi um svör við spurningunni: Hvaða ástæðu telur pú að sé á baki pess að greiðsluáætlun stóðst ekki ?

Tafla 0.57 Kom einhver reikningur/ar á óvart við verklok hjá umræddum verktaka?

Tafla 0.58 Hafðir pú umsjónarmann sem sá um að umræddur verktaki framfylgdi ákvæðum samningsins ?.

Tafla 0.59 Dæmi um svör við spurningunni: Hvaða menntun hefur umsjónarmaðurinn ?

Tafla 0.60 Var gert samkomulag á milli pín/umsjónarmanns og umrædds verktaka um reglubundna verkfundi?

Tafla 0.61 Voru haldnir verkfundir með umræddum verktaka?....

Tafla 0.62 Hefðir pú viljað hafa \$\{piping_text\} verkfundi með umrceddum verktaka?

Tafla 0.63 Mættir pú á verkfundi ?

Tafla 0.64 Kallaðir pú til verkfundar pegar pér fannst tilefni til ?......

Tafla 0.65 Varst pú boðuð/aður á verkfundi ?

Tafla 0.66 Var fjallað um stöðu verks miðað við tíma- og fjárhagsáætlun á verkfundunum ?......

Tafla 0.67 Var rituð fundargerð á verkfundum ?.....

Tafla 0.68 Dæmi um svör við spurningunni: Hver sá um að rita fundargerð á verkfundum ?

Tafla 0.69 Hefðir pú viljað vera boðaður oftar/sjaldnar á verkfundi með umræddum verktaka? .228 
Tafla 0.70 Hversu vel/illa fór umræddur verktaki yfir verklýsingar og teikningar á milli verkpátta með verkkaupa?

Tafla 0.71 Var verkið sem umræddur verktaki vann unnið í reikningsvinnu?.....

Tafla 0.72 Krafôist pú einhvertíma að umræddur verktaki sendi pér upplýsingar um vinnutíma og efnisnotkun á meðan framkvæmdum stóð ?

Tafla 0.73 Hversu ánægð/ur eða óánægð/ur varstu með aðgengi að slíkum upplýsingum ?

Tafla 0.74 Hversu vel/illa ræddi umræddur verktaki samninginn við pig áður en framkvæmdir hófust ?

Tafla 0.75 Var samningurinn skriflegur?

Tafla 0.76 Hversu vel/illa var samningurinn sundurliðaður? 230

Tafla 0.77 Komu upp einhver ósætti milli pín og umrædds verktaka á pví sem var innifalið í samningnum?

Tafla 0.78 Komu upp einhver frábrigði hjá umræddum verktaka frá verkáætlun á verktíma ? .231

Tafla 0.79 Hvernig var pér tilkynnt um frábrigði?

Tafla 80 Hvernig var pér tilkynnt um frábrigði - Annað ?

Tafla 0.81 Hafa verið gerð aukaverkefni eða breytingar hjá umræddum verktaka ?

Tafla 0.82 Skráði umræddur verktaki óskir um aukaverk og breytingar?

Tafla 0.83 Komu fram áhrif á verðlagningu verks og framvindu?

Tafla 0.84 Skilaði umræddur verktaki skrá yfir hugsanlegar kröfur um greiðslur vegna aukaverka og breytinga?

Tafla 0.85 Voru aukaverk unnin í reikningsvinnu ?

Tafla 0.86 Krafơist pú einhvertíma að verktaki sendi pér upplýsingar um vinnutíma og efnisnotkun vegna aukaverks á meðan framkvæmdum stóð ?

Tafla 0.87 Hversu ánægð/ur eða óánægð/ur varstu með aðgengi að slíkum upplýsingum ? .235

Tafla 0.88 Hvernig fannst pér umgengni umrædds verktaka á verkstað vera ? .235

Tafla 0.89 Varstu pess var að umræddur verktaki notaðist við efni sem fullnægði ekki kröfum sem settar voru?

Tafla 0.90 Voru öryggismál rædd áđur en framkvæmdir hófust ?

Tafla 0.91 Voru öryggismál sett sérstaklega í hendur umrædds verktaka á meðan verktíma stóð ?

Tafla 0.92 Hversu ánægð/ur eða óánægð/ur varstu með meðhöndlun öryggismála hjá umræddum verktaka? 
Tafla 93 Hvaða aðgerðir viðhafðir pú til að hafa öryggismál í lagi ef einhverjar ?

Tafla 94 Hvað pótti pér vanta upp á öryggismál hjá verktaka ?....

Tafla 0.95 Ræddi umræddur verktaki við pig um væntanlegar samskiptaleiðir ykkar á milli áður en samningur var gerður?

Tafla 0.96 Hversu ánægð/ur eða óánægð/ur ertu með samskipti milli pín og umrædds verktaka ?.... 240

Tafla 0.97 Hvernig fannst pér pjónustulund umrædds verktaka vera?

Tafla 0.98 Fórst pú fram á að umræddur verktaki sýndi pér í verkbyrjun skriflega hvernig hann ætlaði að vinna verkið til að uppfylla gæðakröfur ?

Tafla 0.99 Sýndi umræddur verktaki pér í verkbyrjun skriflega hvernig hann ætlaði að vinna verkið til að uppfylla gæðakröfur?

Tafla 0.100 Er umræddur verktaki að notast við ákveðið gæðastjórnunarkerfi ?

Tafla 0.101 Hversu ánægð/ur eða óánægð/ur ertu með gæði verksins sem umræddur verktaki vann?

Tafla 0.102 Dæmi um svör við spurningunni: Eru einhver atriði sem pér finnst hafa vantað upp á gæði ? Hvað pá ?

Tafla 0.103 Dæmi um svör við spurningunni: Að lokum eitthvað sem pú vilt koma á framfæri ?

Tafla 104 Peir pættir úr könnun verkkaupa sem mældust með marktæku fylgni við ánægju verkkaupa með framkvæmd verksins hjá umræddum verktaka.

Tafla 105 beir pættir úr könnun verktaka sem mældust með marktæku fylgni við ánægju verkkaupa með framkvæmd verksins hjá umræddum verktaka

Tafla 106 Tvívítt fylgnifylki: ánægja_umræddan, framkvæmdaár 247

Tafla 107 Tengslatafla (tîðni): framkvæmdaár*ánægja_umræddan. .248

Tafla 108 Tvívítt fylgnifylki: kyn_verkkaupa, aldur, fyrir_einst, ánægja_umræddan 248

Tafla 109 Yfirlit tilfella í greiningu milli kyn_verkkaupa og ánægja_umræddan. 249

Tafla 110 Tengslatafla (tíðni): kyn_verkkaupa * ánægja_umræddan 249

Tafla 111 Ósamhverf fylgnimæligildi: kyn_verkkaupa, ánægja_umræddan. 249

Tafla 112 Samhverf fylgnimæligildi: kyn_verkkaupa, ánægja_umræddan .249

Tafla 113 Yfirlit tilfella í greiningu milli fyrir_einst og ánægja_umræddan .250

Tafla 114 Tengslatafla (tíðni): fyrir_einst * ánægja_umræddan 250

Tafla 115 Ósamhverf fylgnimæligildi: fyrir_einst, ánægja_umræddan. .250 
Tafla 116 Samhverf fylgnimæligildi: fyrir_einst, ánægja_umræddan .250

Tafla 117 Yfirlit tilfella í greiningu milli fyrir_einst, ánægju_umrædds og ánægja_bygg. .251

Tafla 118 Tengslatafla (tîðni): ánægja_bygg *ánægja_umræddan * fyrir_einst .252

Tafla 119 Ósamhverf fylgnimæligildi: ánægja_bygg, ánægja_umræddan, fyrir_einst .253

Tafla 120 Samhverf fylgnimæligildi: ánægja_bygg, ánægja_umræddan, fyrir_einst ..... .253

Tafla 121 Tvívítt fylgnifylki: ánægja_umræddan, ánægja_tíma, skrifleg_tíma, tímaáætlun, GSK .254

Tafla 122 Yfirlit tilfella í greiningu milli fyrir_einst, ánægju_umrædds og skrifleg_tíma..... .255

Tafla 123 Tengslatafla (tíðni): skrifleg_tíma * ánægja_umræddan * fyrir_einst .255

Tafla 124 Ósamhverf fylgnimæligildi: fyrir_einst, ánægja_umrædds, skrifleg_tíma .256

Tafla 125 Samhverf fylgnimæligildi: fyrir_einst, ánægja_umrædds, skrifleg_tíma .256

Tafla 126 Yfirlit tilfella í greiningu milli fyrir_einst, ánægju_umrædds og tímaáætlun .257

Tafla 127 Tengslatafla (tîoni): tímaáætlun * ánægja_umræddan * fyrir_einst .257

Tafla 128 Ósamhverf fylgnimæligildi: tímaáætlun, ánægja_umræddan, fyrir_einst. .258

Tafla 129 Samhverf fylgnimæligildi: fyrir_einst, ánægja_umræddan, tímaáætlun .258

Tafla 130 Yfirlit tilfella í greiningu milli skrifleg_tíma og tímaáætlun .259

Tafla 131 Tengslatafla (tîðni): skrifleg_tíma * tímaáætlun. .259

Tafla 132 Ósamhverf fylgnimæligildi: skrifleg_tíma, tímaáætlun .259

Tafla 133 Samhverf fylgnimæligildi: skrifleg_tíma, tímaáætlun .259

Tafla 134 tvívítt fylgnifylki: ánægja_umræddan, ánægja_greiðslu, skrifleg_greiðslu, greiðsluáætlun, GSK.

Tafla 135 Yfirlit tilfella í greiningu milli fyrir_einst, ánægju_umrædds og skrifleg_greiðslu .260

Tafla 136 Tengslatafla (tíðni): skrifleg_greiðslu * ánægja_umræddan * fyrir_einst .261

Tafla 137 Ósamhverf fylgnimæligildi: skrifleg_greiðslu, ánægja_umræddan, fyrir_einst .261

Tafla 138 Samhverf fylgnimæligildi: fyrir_einst, ánægja_umrædds, skrifleg_greiðslu .262

Tafla 139 Yfirlit tilfella í greiningu milli fyrir_einst, ánægju_umrædds og greiðsluáætlun .262

Tafla 140 Tengslatafla (tíðni): greiðsluáætlun * ánægja_umræddan * fyrir_einst .263

Tafla 141 Ósamhverf fylgnimæligildi: greiðsluáætlun, ánægja_umræddan, fyrir_einst .264

Tafla 142 Samhverf fylgnimæligildi: fyrir_einst, ánægja_umrædds, greiðsluáætlun .264 
Tafla 143 Yfirlit tilfella í greiningu milli skrifleg_greiðslu og greiðsluáætlun.....

Tafla 144 Tengslatafla (tíðni): skrifleg_greiðslu * greiðsluáætlun

Tafla 145 Ósamhverf fylgnimæligildi: skrifleg_greiðslu, greiðsluáætlun

Tafla 146 Samhverf fylgnimæligildi: skrifleg_greiðslu, greiðsluáætlun

Tafla 147 Tvífylgnifylki: ánægja_umræddan, verkfundir, verkfundir_verkkaupi, verkfundir_fundargerð, verkfundir_fleiri, verkfundir_staða, GSK ....................................266

Tafla 148 Yfirlit tilfella í greiningu milli fyrir_einst og verkfundir .................................................267

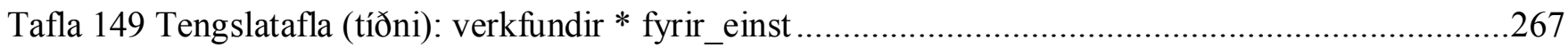

Tafla 150 Ósamhverf fylgnimæligildi: verkfundir, fyrir_einst ..........................................................267

Tafla 151 Samhverf fylgnimæligildi: verkfundir, fyrir_einst.......................................................267

Tafla 152 Yfirlit tilfella í greiningu milli fyrir_einst, ánægju_umrædds og verkfundir..........................268

Tafla 153 Tengslatafla (tíðni): verkfundir * ánægja_umræddan * fyrir_einst ......................................268

Tafla 154 Ósamhverf fylgnimæligildi: verkfundir, ánægja_umræddan, fyrir_einst ..............................269

Tafla 155 Samhverf fylgnimæligildi: fyrir_einst, ánægja_umrædds, verkfundir.................................269

Tafla 156 Tvífylgnifylki: ánægja_umræddan, GSK, samningur_ræddur, samningur_sundurliðaður,

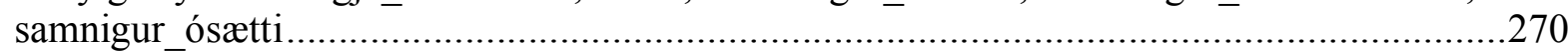

Tafla 157 Tvífylgnifylki: ánægja_umræddan, frábrigði, frábrigði_tilkynnt, GSK ...............................2271

Tafla 158 Yfirlit tilfella í greiningu milli frábrigði og ánægju_umrædds.............................................271

Tafla 159 Tengslatafla (tíðni): frábrigði * ánægja_umræddan..........................................................272

Tafla 160 Ósamhverf fylgnimæligildi: frábrigði, ánægja_umræddan ................................................22

Tafla 161 Samhverf fylgnimæligildi: frábrigði, ánægja_umræddan ..................................................22

Tafla 162 Yfirlit tilfella í greiningu milli aukaverk og ánægju_umrædds ...........................................2273

Tafla 163 Tengslatafla (tíðni): aukaverk * ánægja_umræddan .......................................................273

Tafla 164 Ósamhverf fylgnimæligildi: aukaverk, ánægja_umræddan..............................................273

Tafla 165 Samhverf fylgnimæligildi: aukaverk, ánægja_umræddan.................................................273

Tafla 166 Y firlit tilfella í greiningu milli umgengni og ánægju_umrædds..........................................274

Tafla 167 Tengslatafla (tíðni): umgengni * ánægja_umræddan.......................................................22

Tafla 168 Ósamhverf fylgnimæligildi: umgengni, ánægja_umræddan ...............................................274 
Tafla 169 Samhverf fylgnimæligildi: umgengni, ánægja_umræddan

Tafla 170 Tvívítt fylgnifylki: ánægja_umræddan, GSK, öryggismál_rædd, öryggismál_verktaka,

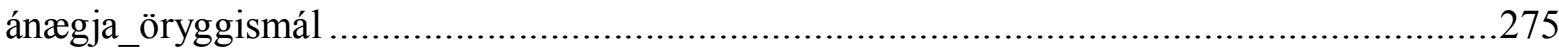

Tafla 171 Yfirlit tilfella í greiningu milli fyrir_einst, ánægju_umrædds og öryggismál_rædd .................276

Tafla 172 Tengslatafla (tíðni): öryggismál_rædd * ánægja_umræddan * fyrir_einst ............................276

Tafla 173 Ósamhverf fylgnimæligildi: öryggismál, ánægja_umræddan, fyrir_einst .............................277

Tafla 174 Samhverf fylgnimæligildi: fyrir_einst, ánægja_umrædds, öryggismál_rædd ..........................277

Tafla 175 Tvívítt fylgnifylki: ánægja_umræddan, ánægja_samskipti, pjónustulund, samskipti_rædd.......278

Tafla 176 Yfirlit tilfella í greiningu milli fyrir_einst, ánægju_umrædds og ánægja_samskipti.................278

Tafla 177 Tengslatafla (tíðni): ánægja_samskipti * ánægja_umræddan * fyrir_einst............................2279

Tafla 178 Ósamhverf fylgnimæligildi: ánægja_samskipti, ánægja_umræddan, fyrir_einst .....................280

Tafla 179 Samhverf fylgnimæligildi: fyrir_einst, ánægja_umrædds, ánægja_samskipti .........................280

Tafla 180 Yfirlit tilfella í greiningu milli fyrir_einst, ánægju_umræddan og gæðatrygging .....................281

Tafla 181 Tengslatafla (tíðni): gæðatrygging * ánægja_umræddan * fyrir_einst ..................................281

Tafla 182 Ósamhverf fylgnimæligildi: greiðsluáætlun, ánægja_umræddan, fyrir_einst ..........................282

Tafla 183 Samhverf fylgnimæligildi: fyrir_einst, ánægja_umrædds, gæðatrygging..............................282

Tafla 184 Yfirlit tilfella í greiningu milli ánægju_umræddan og gæðatrygging_undirverkt.....................283

Tafla 185 Tengslatafla (tíðni): ánægju_umræddan * gæðatrygging_undirverkt....................................283

Tafla 186 Ósamhverf fylgnimæligildi: ánægja_umræddan, gæðatrygging_undirverkt...........................283

Tafla 187 Samhverf fylgnimæligildi: ánægja_umræddan, gæðatrygging_undirverkt.............................283

Tafla 188 Tvífylgnifylki: GSK, ánægja_umræddan, ánægja_tíma, ánægja_greiðslu, ánægja_öryggismál, ánægja_samskipti, ánægja_gæði ..................................................2. 284

Tafla 189 Yfirlit tilfella í greiningu milli fyrir_einst, ánægju_umræddan og GSK ...............................285

Tafla 190 Tengslatafla (tíðni): GSK * ánægja_umræddan * fyrir_einst.............................................286

Tafla 191 Ósamhverf fylgnimæligildi: fyrir_einst, ánægja_umrædds, GSK ........................................287

Tafla 192 Samhverf fylgnimceligildi: fyrir_einst, ánægja_umræddan, GSK .........................................28

Tafla 193 Yfirlit tilfella í greiningu milli skrifleg_tíma og GSK .........................................................289

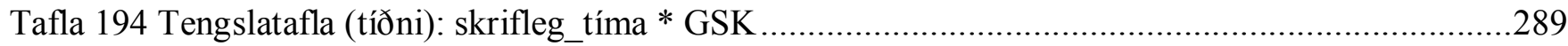


Tafla 195 Ósamhverf fylgnimæligildi: skrifleg_tíma, GSK

Tafla 196 Samhverf fylgnimæligildi: skrifleg_tíma, GSK..........................................................290

Tafla 197 Yfirlit tilfella í greiningu milli tímaáætlun og GSK......................................................290

Tafla 198 Tengslatafla (tíðni): tímaáætlun * GSK ........................................................................290

Tafla 199 Ósamhverf fylgnimæligildi: tímaáætlun, GSK ................................................................291

Tafla 200 Samhverf fylgnimæligildi: tímaáætlun, GSK .................................................................291

Tafla 201 Yfirlit tilfella í greiningu milli skrifleg_tíma og GSK .....................................................291

Tafla 202 Tengslatafla (tíðni): skrifleg_greiðslu * GSK ................................................................291

Tafla 203 Ósamhverf fylgnimæligildi: skrifleg_greiðslu,GSK ......................................................292

Tafla 204 Samhverf fylgnimæligildi: skrifleg_greiðslu,GSK ......................................................2292

Tafla 205 Yfirlit tilfella í greiningu milli greiðsluáætlun og GSK ......................................................292

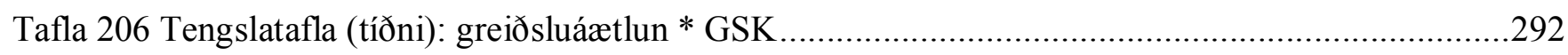

Tafla 207 Ósamhverf fylgnimæligildi: greiðsluáætlun,GSK .........................................................293

Tafla 208 Samhverf fylgnimæligildi: greiðsluáætlun, GSK .......................................................293

Tafla 209 Yfirlit tilfella í greiningu milli verkfundir og GSK ....................................................293

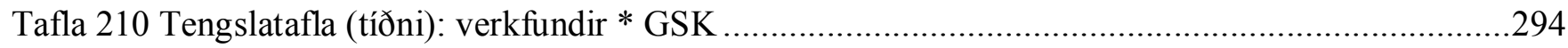

Tafla 211 Ósamhverf fylgnimæligildi: verkfundir,GSK ..............................................................294

Tafla 212 Samhverf fylgnimæligildi: verkfundir,GSK ..................................................................294

Tafla 213 Yfirlit tilfella í greiningu milli umgengni og GSK .........................................................294

Tafla 214 Tengslatafla (tíoni): umgengni * GSK .....................................................................295

Tafla 215 Ósamhverf fylgnimæligildi: umgengni, GSK .........................................................2295

Tafla 216 Samhverf fylgnimæligildi: umgengni, GSK.............................................................295

Tafla 217 Yfirlit tilfella í greiningu milli öryggismál og GSK ......................................................295

Tafla 218 Tengslatafla (tíðni): öryggismál * GSK .................................................................2296

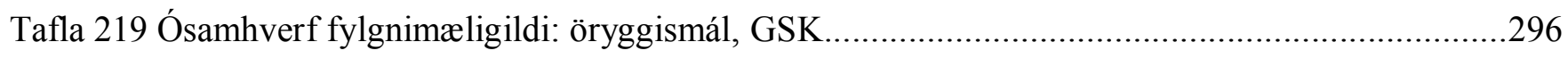

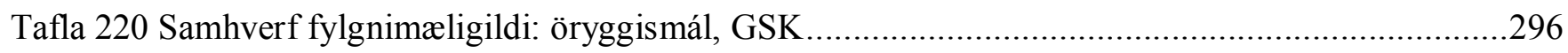

Tafla 221 Yfirlit tilfella í greiningu milli gæðatrygging og GSK .......................................................296 
Tafla 222 Tengslatafla (tíðni): gæðatrygging * GSK

Tafla 223 Ósamhverf fylgnimæligildi: gæðatrygging, GSK.

Tafla 224 Samhverf fylgnimæligildi: gæðatrygging, GSK.

Tafla 225 Tvífylgnifylki: GSK, ánægja_umræddan, gæðatrygging_verktaki, gæðatrygging_ósk, gæðatrygging_undirverktaki....

Tafla 226 Y firlit tilfella í greiningu milli ánægja_gæði og GSK

Tafla 227 Tengslatafla (tíðni): ánægja_gæði * GSK

Tafla 228 Ósamhverf fylgnimæligildi: ánægja_gæði, GSK .299

Tafla 229 Samhverf fylgnimæligildi: ánægja_gæði, GSK

Tafla 230 Tvífylgnifylki: GSK, ávinningur, ávinningur/kostnaður, rekstrarafkoma, samkeppnishæfi, frábrigði_gsk, mannafli, trú_gsk

Tafla 231 Tvifylgnifylki: GSK, áncegja_umrceddan, almennt, ÍST30, ISO9001, útboðsgögn .301

Tafla 232 Tvífylgnifylki: GSK, ánægja_umræddan, merking, geymsla, varðveislutími, förgun .302

Tafla 233 Tvífylgnifylki: GSK, ánægja_umræddan, starfslýsingar_skriflegar, starfslýsing_kynnt, verkáætlun_skrifleg, verktöf_skrifleg, greiðsluáætlun_skrifleg

Tafla 234 Tvífylgnifylki: GSK, ánægja_umræddan, verkfundir_reglubundnir, fundargerð, verkdagbók

Tafla 235 Tvívítt fylgnifylki: GSK, ánægja_umræddan, frábrigði_tilkynnt, aukaverk_skráo hættumat, gæðaeftirlit_utanaðkomandi, gæðastýringaráætlun

Tafla 0.236 Hvernig var könnunin tekin ? .308

Tafla 237 Hvers konar verktaki ert pú ? .308

Tafla 238 Hvers konar verktaki ert pú - Annað ? .309

Tafla 0.239 Hvað starfa margir hjá fyrirtækinu sem pú ert starfsmaður hjá ? .309

Tafla 0.240 Hversu gamalt er fyrirtækið sem pú starfar hjá ?. 310

Tafla 0.241 Hvert er kyn pitt?

Tafla 0.242 Á hvaða aldri ert pú ?

Tafla 243 Hvaða menntun hefur pú ?.

Tafla 244 Hvaða menntun hefur pú - Annað ?

Tafla 245 Hver er staða pín innan fyrirtækisins ?

Tafla 246 Hver er staða pín innan fyrirtækisins - Annað ?. 
Tafla 0.247 Starfar fyrirtækið eftir gæðastjórnunarkerfi ?

Tafla 0.248 Starfar fyrirtækið eftir gæðastjórnunarkerfi ? - sameinaðir flokkar.

Tafla 0.249 Var fenginn utanaðkomandi aðili við innleiðingu gæðastjórnunarkerfisins ?

Tafla 0.250 Byggir gæðastjórnunarkerfið á viðurkenndum gæðastaðli ?

Tafla 0.251 Starfar fyrirtækið eftir gæðastjórnunarkerfi byggðu á viðurkenndum stöðlum? sameinaðir flokkar....

Tafla 252 Hefur fyrirtækið hlotið vottun fyrir gæðastjórnunarkerfið ?

Tafla 253 Er starfandi gæðastjóri innan fyrirtækisins?

Tafla 254 Gegnir gæðastjórinn annarri stöðu innan fyrirtækisins líka ?

Tafla 255 Er starfandi gæðaráo hjá fyrirtækinu ?

Tafla 256 Er til gæðahandbók fyrirtækisins ?

Tafla 257 Er gæðahandbókin til á rafrænu formi ?

Tafla 258 Hefur fyrirtækið skjalfesta gæðastefnu ?

Tafla 259 Telur pú að gæðastefna fyrirtækisins séu almennt kunnug starfsmönnum fyrirtækisins ?

Tafla 260 Veitið pið verkkaupa upplýsingar um gæðastjórnunarkerfið sem pið notið í verkbyrjun ?

Tafla 261 Starfa eftirfarandi í fyrirtækinu sem pú starfar hjá ?

Tafla 262 Viðhafið pið sérstakar öryggisráðstafanir á verkstað ?

Tafla 263 Er mögulegt fyrir starfsmenn að sækja sér endurmenntun á vinnutíma ?....

Tafla 264 Telur pú að ávinningur náist með gæðastjórnun í byggingaiðnaði?

Tafla 265 Telur bú að ávinningur af innleiðingu gæðastjórnunarkerfis sé meiri/minni en kostnaður ?.

Tafla 266 Telur pú að innleiðing gæðastjórnunarkerfis breyti rekstrarafkoma fyrirtækja ?

Tafla 267 Telur pú að samkeppnishæfi fyrirtækja sé meiri/minni eftir innleiðingu gæðastjórnunarkerfis ?

Tafla 268 Telur pú að með innleiðingu gæðastjórnunarkerfis fjölgi/fækki frábrigðum í framkvæmdum?

Tafla 269 Telur pú að með innleiðingu gæðastjórnunarkerfis batni/versni nýting mannafla ?

Tafla 270 Hefur pú mikla/litla trú á gæðastjórnun í byggingaiðnaði ?......

Tafla 271 Upplifir pú gæðastjórnunarkerfi einungis sem skráningarkerfi ? 
Tafla 272 Hvernig finnst pér eftirfarandi orð eiga við gæðastjórnun ?

Tafla 273 Sýnið pið verkaupa fram á gæðatryggingu í verkbyrjun ?

Tafla 274 Hversu oft óskar verkkaupi eftir gæðatryggingu frá ykkur? .324

Tafla 275 Farið pið fram á gæðatryggingu frá undirverktökum ?

Tafla 276 Hefur pú kynnt pér gæðastjórnun almennt? 325

Tafla 277 Hefur pú kynnt pér innihald samskiptastaðalsins IST 30 ? .326

Tafla 278 Hefur pú kynnt pér innihald gæðastjórnunarstaðalsins ISO 9001 ?. .326

Tafla 279 Finnst pér vöntun á stöðluðum og samræmdum útboðsgögnum ? .327

Tafla 280 Eru samningar og tilboð geymd í tölusettri röð til ákveðins tíma ? .327

Tafla 281 Er farið eftir ákveðnu kerfi fyrir eftirfarandi pætti ?. 328

Tafla 282 Eru til skriflegar starfslýsingar fyrir starfsmenn í fyrirtækinu ?

Tafla 283 Er innihald viðkomandi starfslýsinga kynnt fyrir starfsmönnum ?

Tafla 284 Leggið pið fram skriflega verkáætlun fyrir hvert verk? .330

Tafla 285 Sendið pið verkkaupa skriflega rökstudda tilkynningu um verktöf pegar svo ber undir ? .330

Tafla 286 Gerið pið skriflega greiðsluáætlun við verkkaupa fyrir hvert verk ?....

Tafla 287 Er venja að gert sé samkomulag um reglubundna verkfundi með verkkaupa ?

Tafla 288 Er venja að rituð sé fundargerð á verkfundum ?

Tafla 289 Haldið pið verkdagbók?

Tafla 290 Er venja að pað sé tekið fram í samningum að pað beri að fara eftir kröfum samskiptastaðalsins IST 30 ?

Tafla 291 Hvernig er verkkaupa tilkynnt um frábrigði ?

Tafla 292 Eru óskir verkkaupa um aukaverk og breytingar skráðar ?

Tafla 293 Ef óskir um aukaverk og breytingar eru skráðar, kemur pá fram í skráningu áhrif á verðlagningu heildarverks og framvindu?....

Tafla 294 Hversu oft skilið pið skrá yfir hugsanlegar kröfur um greiðslur vegna aukaverka og breytinga til verkkaupa?

Tafla 295 Gerið pið hættumat og/eða áhættugreiningu á verkstað ?

Tafla 296 Styðst fyrirtækið við utanaðkomandi pjónustu við gæðaeftirlit/úttektir .336

Tafla 297 Er skipulagt innra eftirlit á framkvæmdum hjá fyrirtækinu (gæðastýringaráætlun) ? .336 
Tafla 298 Hvernig finnst pér kröfur verkkaupa um skipulag og markvissa stjórnun í garð verktaka ?

Tafla 299 Er eitthvað að lokum sem pú vilt koma á framfæri ?....

Tafla 300 Tvívítt fylgnifylki: ánægja_umræddan, stærð, aldur_fyrirt.

Tafla 301 Yfirlit tilfella í greiningu milli stærð og GSK

Tafla 302 Tengslatafla (tíðni): stærð * GSK.

Tafla 303 Ósamhverf fylgnimæligildi: stærð, GSK.

Tafla 304 Samhverf fylgnimæligildi: stærð, GSK.

Tafla 305 Y firlit tilfella í greiningu milli úrtak og GSK.

Tafla 306 Tengslatafla (tíðni): Úrtak * GSK.

Tafla 307 Ósamhverf fylgnimæligildi: Úrtak, GSK

Tafla 308 Samhverf fylgnimæligildi: Úrtak, GSK

Tafla 309 Y firlit tilfella í greiningu milli öryggi_verkstað og GSK.

Tafla 310 Tengslatafla (tíðni): öryggi_verkstað * GSK .

Tafla 311 Ósamhverf fylgnimæligildi: öryggi_verkstað, GSK

Tafla 312 Samhverf fylgnimæligildi: öryggi_verkstað, GSK.....

Tafla 313 Samantekt á marktækriri fylgni viðhorfs verktaka við GSK.

Tafla 314 Yfirlit tilfella í greiningu milli ávinningur og GSK.

Tafla 315 Tengslatafla (tíðni): ávinningur * GSK.

Tafla 316 Ósamhverf fylgnimæligildi: ávinningur, GSK

Tafla 317 Samhverf fylgnimæligildi: ávinningur, GSK

Tafla 318 Yfirlit tilfella í greiningu milli ávinningur/kostnaður og GSK

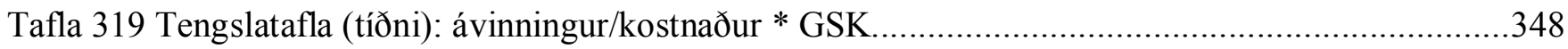

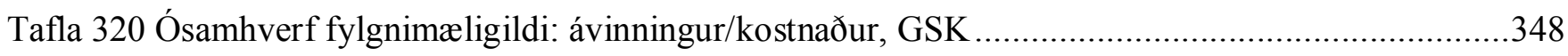

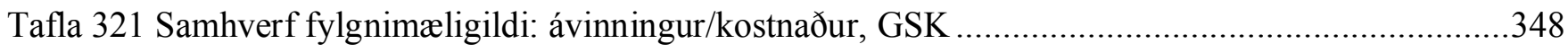

Tafla 322 Yfirlit tilfella í greiningu milli rekstrarafkoma og GSK ....................................................349

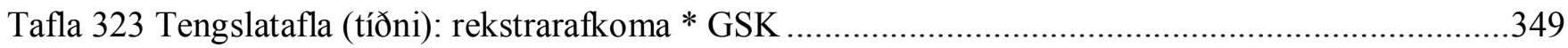

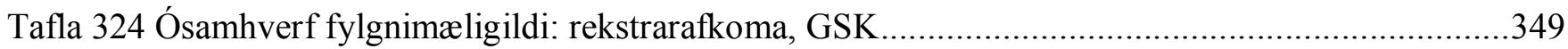




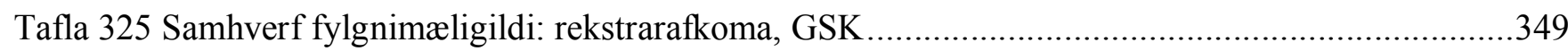

Tafla 326 Yfirlit tilfella í greiningu milli samkeppnishæfi og GSK................................................350

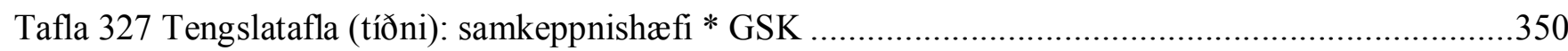

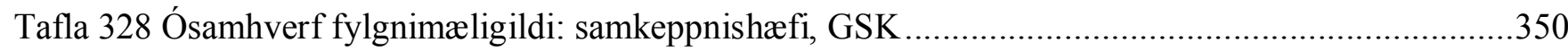

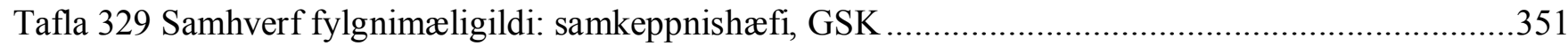

Tafla 330 Yfirlit tilfella í greiningu milli áhrif_á_frábrigði og GSK ..............................................351

Tafla 331 Tengslatafla (tíðni): áhrif_á_frábrigði, GSK ….............................................................351

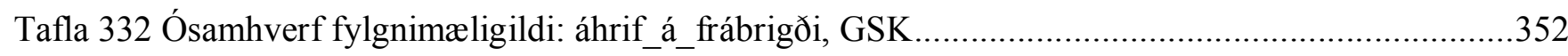

Tafla 333 Samhverf fylgnimæligildi: áhrif_á_frábrigði, GSK ........................................................352

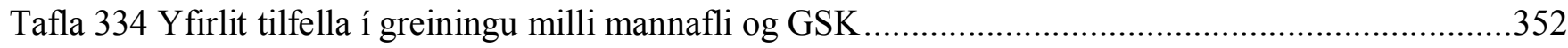

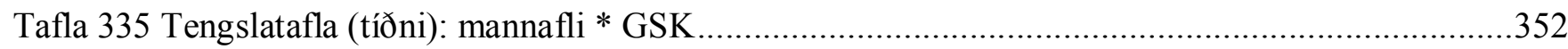

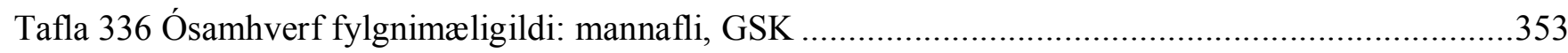

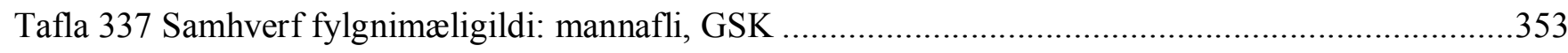

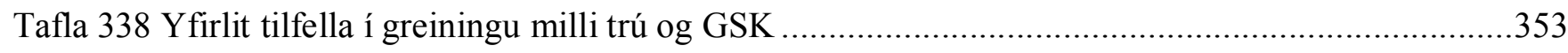

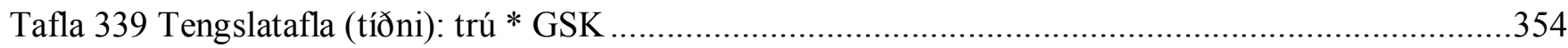

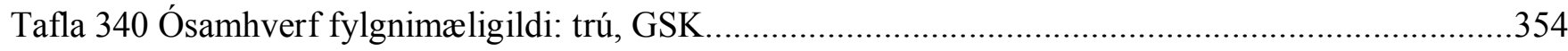

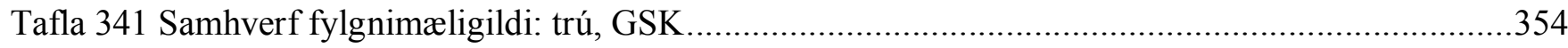

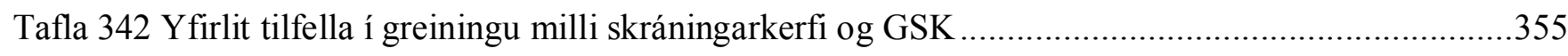

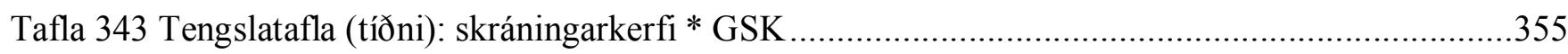

Tafla 344 Ósamhverf fylgnimæligildi: skráningarkerfi, GSK ..........................................................355

Tafla 345 Samhverf fylgnimæligildi: skráningarkerfi, GSK …........................................................355

Tafla 346 Yfirlit tilfella í greiningu milli gæðatrygging_verktaki og GSK .........................................356

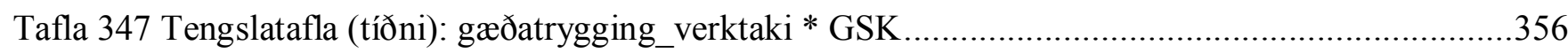

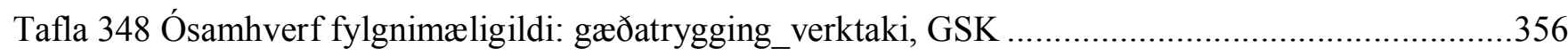

Tafla 349 Samhverf fylgnimæligildi: gæðatrygging_verktaki, GSK ..............................................357

Tafla 350 Yfirlit tilfella í greiningu milli gæðatrygging_ósk og GSK ................................................357

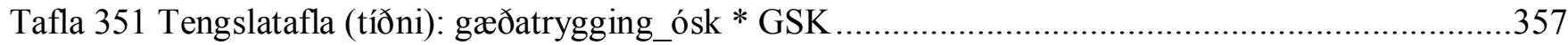


Tafla 352 Ósamhverf fylgnimæligildi: gæðatrygging_ósk, GSK.

Tafla 353 Samhverf fylgnimæligildi: gæðatrygging_ósk, GSK .358

Tafla 354 Yfirlit tilfella í greiningu milli gæðatrygging_undirverkt og GSK .358

Tafla 355 Tengslatafla (tíðni): gæðatrygging_undirverkt * GSK .358

Tafla 356 Ósamhverf fylgnimæligildi: gæðatrygging_undirverkt, GSK 359

Tafla 357 Samhverf fylgnimæligildi: gæðatrygging_undirverkt, GSK 359

Tafla 358 Samantekt á marktækri fylgni pekkingar við GSK. 359

Tafla 359 Yfirlit tilfella í greiningu milli almennt og GSK 359

Tafla 360 Tengslatafla (tíðni): almennt * GSK 360

Tafla 361 Ósamhverf fylgnimæligildi: almennt, GSK .360

Tafla 362 Samhverf fylgnimæligildi: almennt, GSK 360

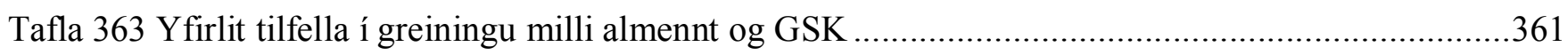

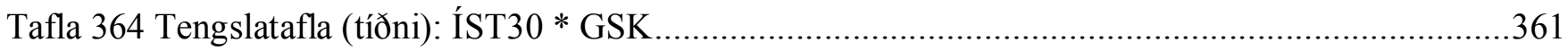

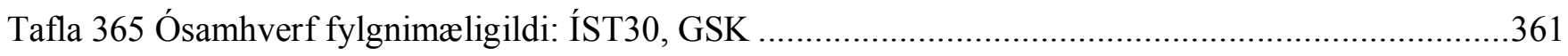

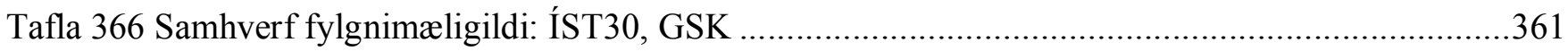

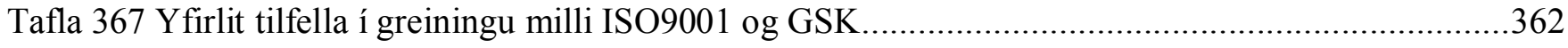

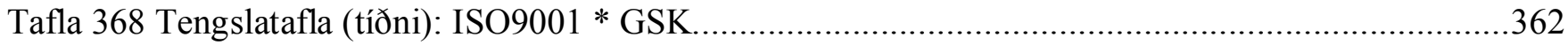

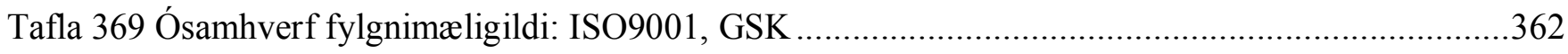

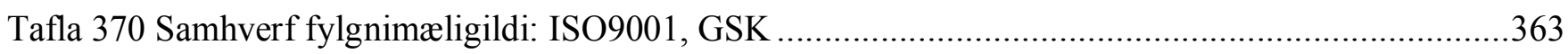

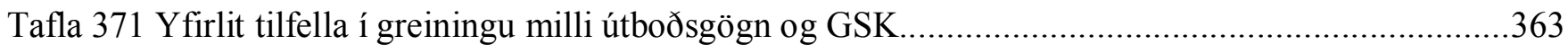

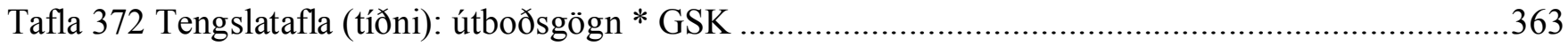

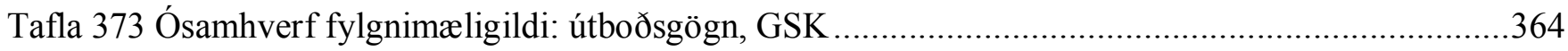

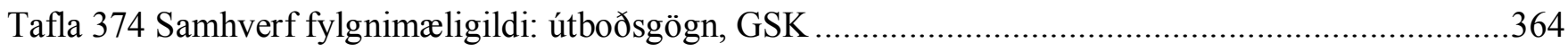

Tafla 375 peir pættir úr könnun verktaka tengdir verklagi verktaka sem mældust með marktæku

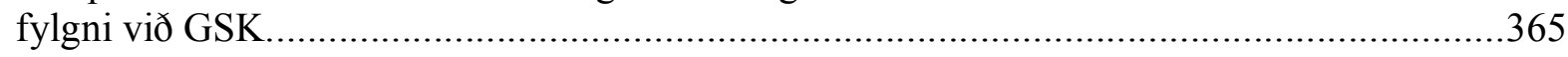

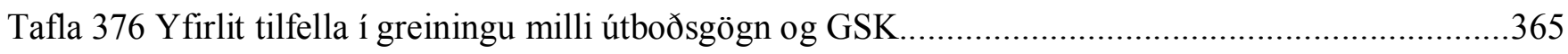

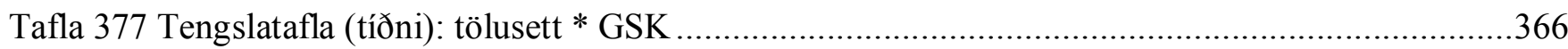




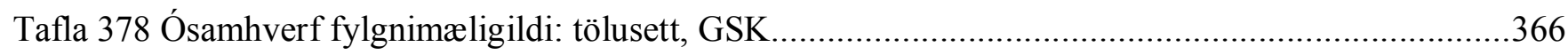

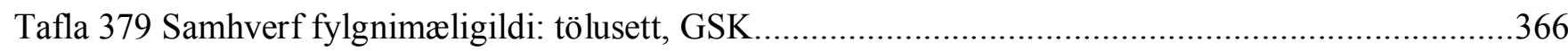

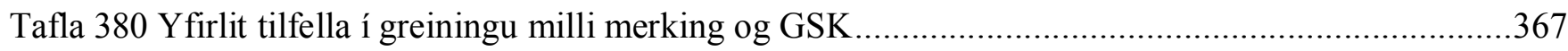

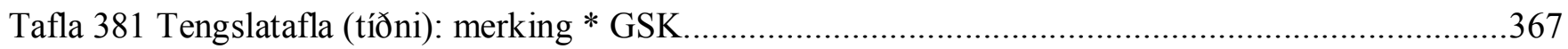

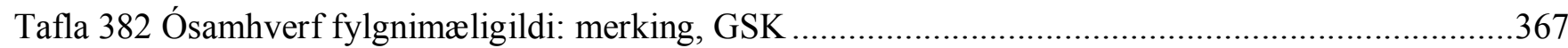

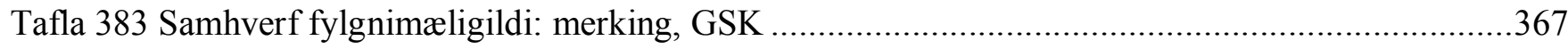

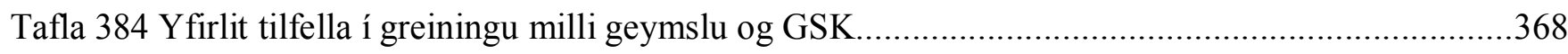

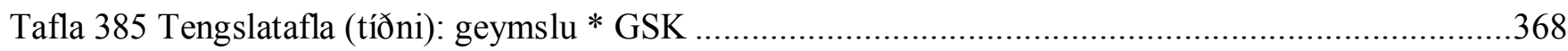

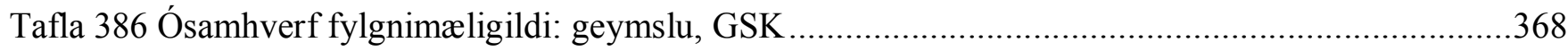

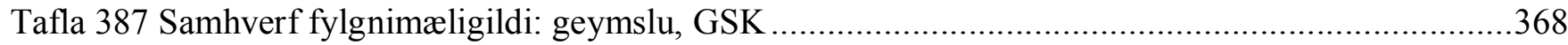

Tafla 388 Yfirlit tilfella í greiningu milli varðveislutíma og GSK.......................................................369

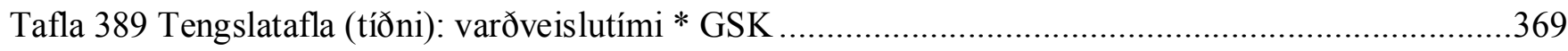

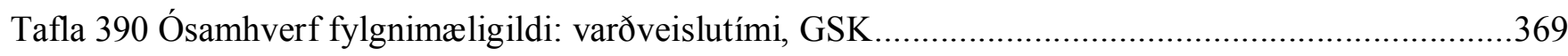

Tafla 391 Samhverf fylgnimæligildi: varðveislutími, GSK ............................................................370

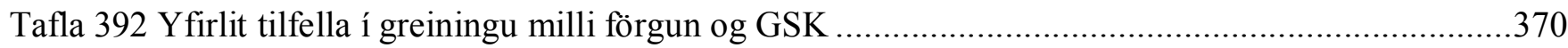

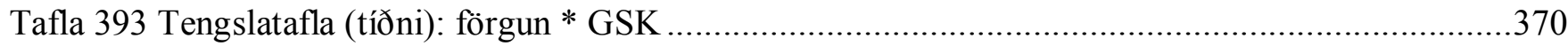

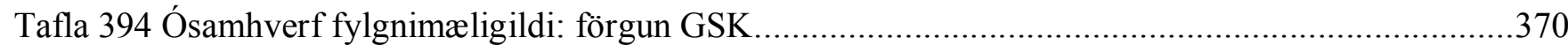

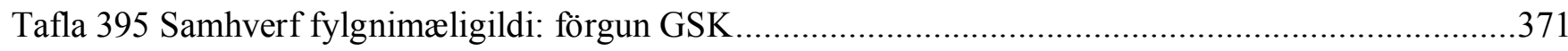

Tafla 396 Yfirlit tilfella í greiningu milli starfslýsingar_skriflegar og GSK ......................................371

Tafla 397 Tengslatafla (tíðni): starfslýsingar_skriflegar * GSK ....................................................371

Tafla 398 Ósamhverf fylgnimæligildi: starfslýsingar_skriflegar GSK...............................................372

Tafla 399 Samhverf fylgnimæligildi: starfslýsingar_skriflegar GSK .................................................372

Tafla 400 Yfirlit tilfella í greiningu milli verkáætlun_skrifleg og GSK..............................................372

Tafla 401 Tengslatafla (tíðni): verkáætlun_skrifleg * GSK .............................................................372

Tafla 402 Ósamhverf fylgnimæligildi: verkáætlun_skrifleg, GSK ....................................................373

Tafla 403 Samhverf fylgnimæligildi: verkáætlun_skrifleg, GSK .....................................................373

Tafla 404 Yfirlit tilfella í greiningu milli verktöf_skrifleg og GSK ....................................................373 
Tafla 405 Tengslatafla (tíðni): verktöf_skrifleg * GSK...

Tafla 406 Ósamhverf fylgnimæligildi: verktöf_skrifleg, GSK

Tafla 407 Samhverf fylgnimæligildi: verktöf_skrifleg, GSK

Tafla 408 Yfirlit tilfella í greiningu milli greiðsluáætlun_skrifleg og GSK.

Tafla 409 Tengslatafla (tíðni): greiðsluáætlun_skrifleg * GSK

Tafla 410 Ósamhverf fylgnimæligildi: greiðsluáætlun_skrifleg, GSK.

Tafla 411 Samhverf fylgnimæligildi: greiðsluáætlun_skrifleg, GSK.

Tafla 412 Yfirlit tilfella í greiningu milli verkfundir_reglubundnir og GSK.

Tafla 413 Tengslatafla (tíðni): verkfundir_reglubundnir * GSK . .376

Tafla 414 Ósamhverf fylgnimæligildi: verkfundir_reglubundnir, GSK .376

Tafla 415 Samhverf fylgnimæligildi: verkfundir_reglubundnir, GSK 376

Tafla 416 Y firlit tilfella í greiningu milli fundargerð og GSK. 376

Tafla 417 Tengslatafla (tíðni): fundargerð * GSK..... 377

Tafla 418 Ósamhverf fylgnimæligildi: fundargerð, GSK . 377

Tafla 419 Samhverf fylgnimæligildi: fundargerð, GSK .377

Tafla 420 Yfirlit tilfella í greiningu milli verkdagbók og GSK 378

Tafla 421 Tengslatafla (tíðni): verkdagbók * GSK 378

Tafla 422 Ósamhverf fylgnimæligildi: verkdagbók, GSK 378

Tafla 423 Samhverf fylgnimæligildi: verkdagbók, GSK 378

Tafla 424 Yfirlit tilfella í greiningu milli ÍST30_kröfur og GSK 379

Tafla 425 Tengslatafla (tíðni): ÍST30_kröfur * GSK .379

Tafla 426 Ósamhverf fylgnimæligildi: ÍST30_kröfur, GSK 379

Tafla 427 Samhverf fylgnimæligildi: ÍST30_kröfur, GSK. 379

Tafla 428 Yfirlit tilfella í greiningu milli frábrigði_tilkynnt og GSK 380

Tafla 429 Tengslatafla (tíðni): frábrigði_tilkynnt * GSK 380

Tafla 430 Ósamhverf fylgnimæligildi: frábrigði_tilkynnt, GSK 380

Tafla 431 Samhverf fylgnimæligildi: frábrigði_tilkynnt, GSK .380 
Tafla 432 Yfirlit tilfella í greiningu milli aukaverk_skráð og GSK

Tafla 433 Tengslatafla (tíðni): aukaverk_skráð * GSK

Tafla 434 Ósamhverf fylgnimæligildi: frábrigði_tilkynnt, GSK.

Tafla 435 Samhverf fylgnimæligildi: frábrigði_tilkynnt, GSK.

Tafla 436 Yfirlit tilfella í greiningu milli aukaverk_skráð og GSK

Tafla 437 Tengslatafla (tíðni): aukaverk_skrá * GSK .382

Tafla 438 Ósamhverf fylgnimæligildi: aukaverk_skrá, GSK..... .383

Tafla 439 Samhverf fylgnimæligildi: aukaverk_skrá, GSK .383

Tafla 440 Yfirlit tilfella í greiningu milli hættumat og GSK .383

Tafla 441 Tengslatafla (tíoni): hættumat * GSK .384

Tafla 442 Ósamhverf fylgnimæligildi: hættumat, GSK .384

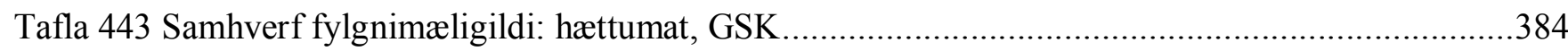

Tafla 444 Yfirlit tilfella í greiningu milli gæðaeftirlit_utanaðkomandi og GSK ...................................385

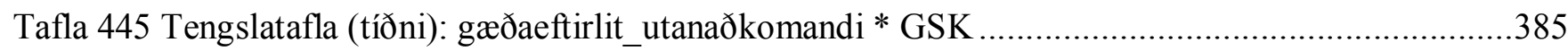

Tafla 446 Ósamhverf fylgnimæligildi: gæðaeftirlit_utanaðkomandi, GSK..........................................385

Tafla 447 Samhverf fylgnimæligildi: gæðaeftirlit_utanaðkomandi, GSK...........................................385

Tafla 448 Yfirlit tilfella í greiningu milli gæðastýringaráætlun og GSK..........................................386

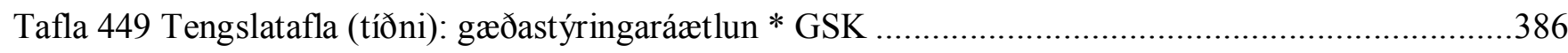

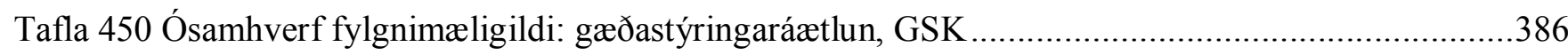

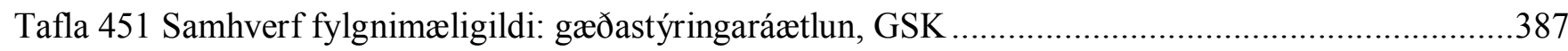

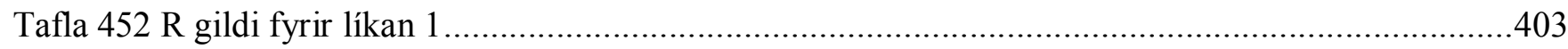

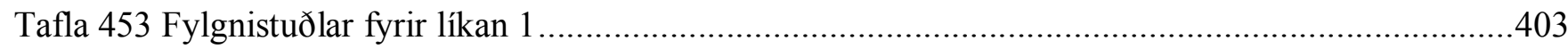

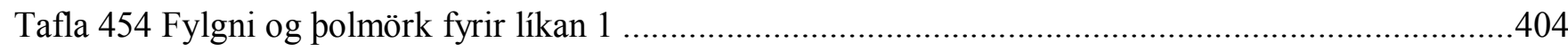

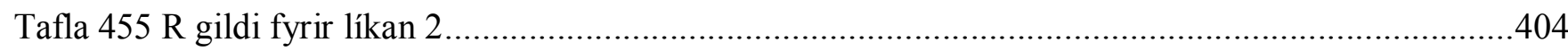

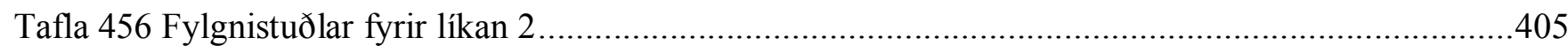

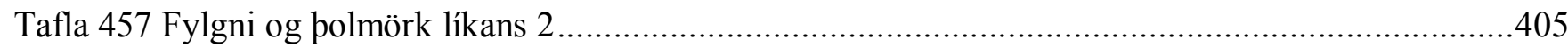

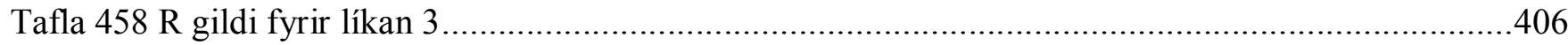




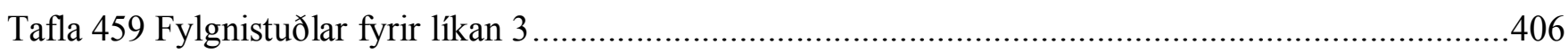

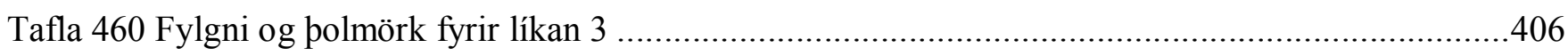

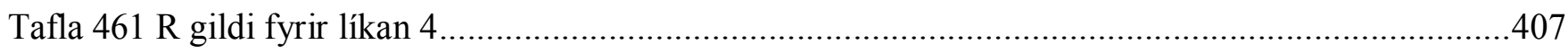

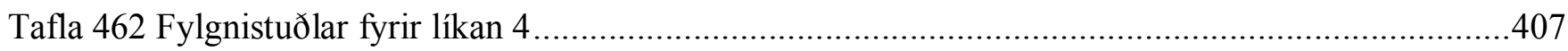

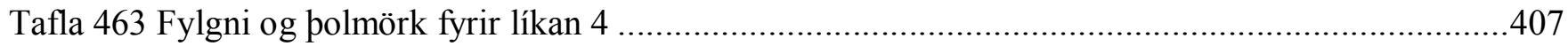

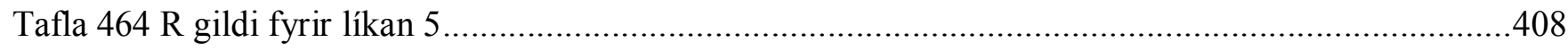

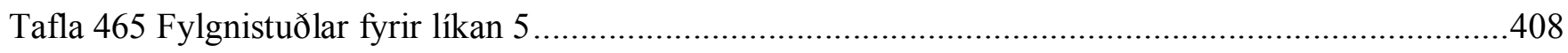

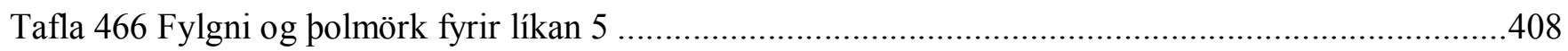

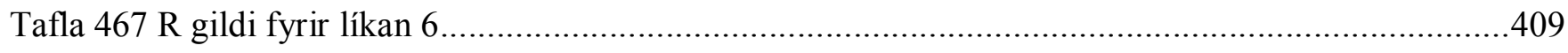

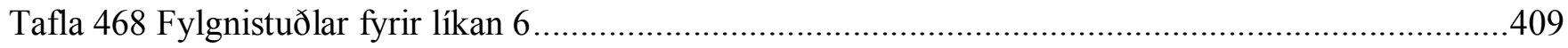

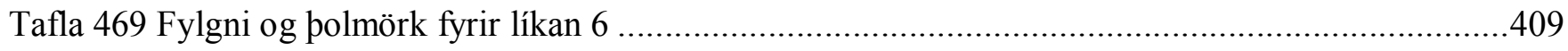

Tafla 470 Lýsandi tölfræði fyrir ánægja_umræddan ${ }^{\mathrm{c}}$ í líkani 6 ......................................................409

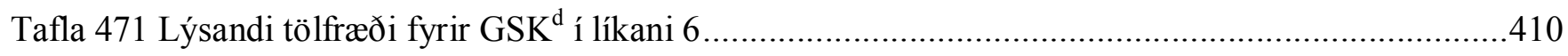

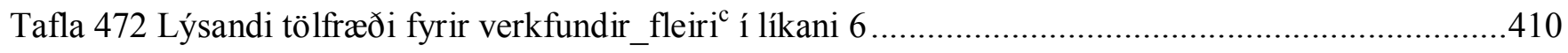

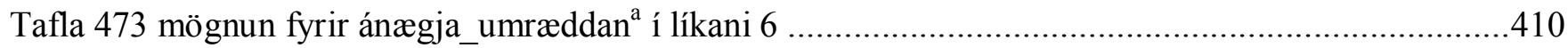

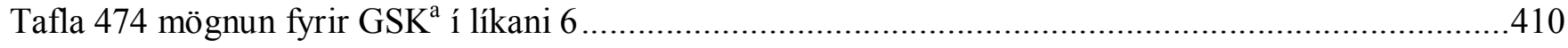

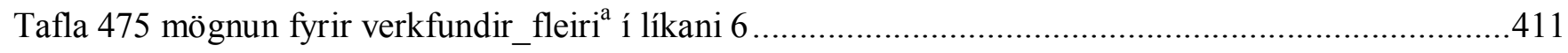




\section{Viðauki A - Könnun ætluð verkkaupum}

Ég heiti Anna Hulda og er að vinna að meistararitgerð í samstarfi við Háskóla Íslands og Samtök Iðnaðarins sem fjallar um áhrif gæðastjórnunar á mannvirkjagerð á Íslandi. pessi könnun er ætluð verkkaupum, bæði einstaklingum og fyrirtækjum, sem hafa staðið í framkvæmdum á undanförnum 5 árum.

Könnunin tekur í kringum 10 mín. Bín pátttaka í pessari könnun er algjörlega valfrjáls og getur pú hætt hvenær sem er í könnuninni. Farið verður með svör pín sem fyllstu trúnaðarupplýsingar.

Ef pú hefur einhverjar spurningar er sjálfsagt að hafa samband við mig í síma 8448904 eða með tölvupósti á anna.huldaolafsdottir@gmail.com.

Fyrirfram pakkir fyrir stuðninginn.

\subsection{Grunnupplýsingar}

1. Í hvaða sveitarfélagi eru framkvæmdirnar ?

O Akranes

O Akureyri

○ Garðabær

○ Hveragerði

O Kópavogur

○ Reykjanesbær

○ Reykjavík

2. Er verkkaupi fyrirtæki eða einstaklingur?

O Fyrirtæki

$\bigcirc$ Einstaklingur

3. Gerð fyrirtækis

○ Ríki/Borg

O Annað

4. Hvað starfa margir hjá fyrirtækinu ?

\section{5. Í hvers konar starfsemi er fyrirtækið ?}


6. Í hvaða tilgangi var farið út í verkframkvæmdir ?

7. Verktaki sem hafður er í huga pegar spurningunum er svarað:

8. Starfsgrein verktaka sem hafður er í huga?

O Byggingaverktaki

○ Pípulagarverktaki

○ Rafverktaki

○ Húshlutaframleiðandi

○ Jarðvinnuverktaki

O Annað ?

9. Hvers konar bygging ?

10. Er verkinu lokið?

O Já

○ Nei

11. Hversu langt er verkið komið?

○ 90\%-99\% lokið

○ 80\%-89\% lokið

○ 70\%-79\% lokið

○ 60\%-69\% lokið

○ 50\%-59\% lokið

○ $<50 \%$ lokið 
12. Hvaða ár stóðu framkvæmdir yfir?
○ 2005
○ 2006
○ 2007
○ 2008
○ 2009
○ 2010

13. Hvert er kyn pitt ?
○ kvk
O kk

14. Á hvaða aldri ert bú ?
$0<20$
○ 21-35
○ $36-45$
○ 46-55
O 56-65
○ $66<$

15. Hvaða menntun hefur pú ?
○ Grunnskólapróf
○ Stúdentspróf
○ Háskólapróf
○ Verkmenntun í byggingaiðnaði
○ Annað, hvað pá: 


\section{2 Ánægja viðskiptavinar}

16. Hversu ánægð/ur eða óánægð/ur ertu með framkvæm verksins í heild ?

○ Mjög ánægð/ur

○ Frekar ánægð/ur

○ Hvorki ánægð/ur né óánægð/ur

○ Frekar óánægð/ur

○ Mjög óánægð/ur

17. Hversu ánægð/ur eða óánægð/ur ertu með framkvæmd verksins sem umræddur verktaki vann?

○ Mjög ánægð/ur

○ Frekar ánægð/ur

○ Hvorki ánægð/ur né óánægð/ur

○ Frekar óánægð/ur

○ Mjög óánægð/ur

18. Er pað einhver einn páttur sem stendur upp úr sem pú ert ósátt/ur við ? ○ Já

○ Nei >>> ef svarað er "nei", skal fara næst í spurningu 20.

19. Hvaða páttur stóð upp úr sem pú varst mest ósátt/ur við ? 
20. Sá byggingastjóri um yfirstjórn verksins ?

○ Já

○ Nei

○ Að hluta

21. Var svarandi sjálfur byggingastjóri ?

○ Já > > > ef svarað er "já", skal fara næst í spurningu 25.

O Nei

22. Sá svarandi sjálfur um yfirstjórn verksins ?

○ Já

○ Nei

○ Að hluta

23. Finnst pér byggingastjóri hafa verið nægilega mikið til staðar ?

○ Já

○ Nei

24. Hversu ánægð/ur eða óánægð/ur ertu með störf byggingastjóra?

○ Mjög ánægð/ur

○ Frekar ánægð/ur

○ Hvorki ánægð/ur né óánægð/ur

○ Frekar óánægð/ur

○ Mjög óánægð/ur

\section{Tegund verktöku ?}

○ Fagverk >>> ef svarað er "fagverk", skal fara næst í spurningu 27.

O Alverk

O Aðalverk

○ Markverk

○ Veit ekki >>> ef svarað er já, skal fara næst í spurningu 27.

○ Annað >>> ef svarað er já, skal fara næst í spurningu 27.

26. Hversu vel/illa fannst pér yfirstjórnandi verksins uppfylla skyldu sína sem milligöngumaður um samskipti pín við verktaka ?

O Mjög vel

○ Frekar vel

O Hvorki vel né illa

○ Frekar illa

○ Mjög illa 


\section{4 Áætlanir}

27. Hversu ánægð/ur eða óánægð/ur ertu með tímastjórnun verksins sem umræddur verktaki vann?

○ Mjög ánægð/ur

○ Frekar ánægð/ur

○ Hvorki ánægð/ur né óánægð/ur

○ Frekar óánægð/ur

○ Mjög óánægð/ur

28. Lagði umræddur verktaki fram skriflega tímaáætlun í upphafi verks ?

○ Já

○ Nei > > > ef svarað er "nei", skal fara næst í spurningu 32.

29. Hversu vönduð/óvönduð var tímaáætlunin ?

○ Mjög vönduð

○ Frekar vönduð

○ Hvorki vönduð né óvönduð

○ Frekar óvönduð

○ Mjög óvönduð

30. Hversu vel/illa var tímaætlunin kynnt fyrir pér ?

○ Mjög vel

○ Frekar vel

O Hvorki vel né illa

○ Frekar illa

○ Mjög illa

31. Var tímaáætlunin endurskoðuð og uppfærð reglulega ?

O Já

O Nei

○ Veit ekki 


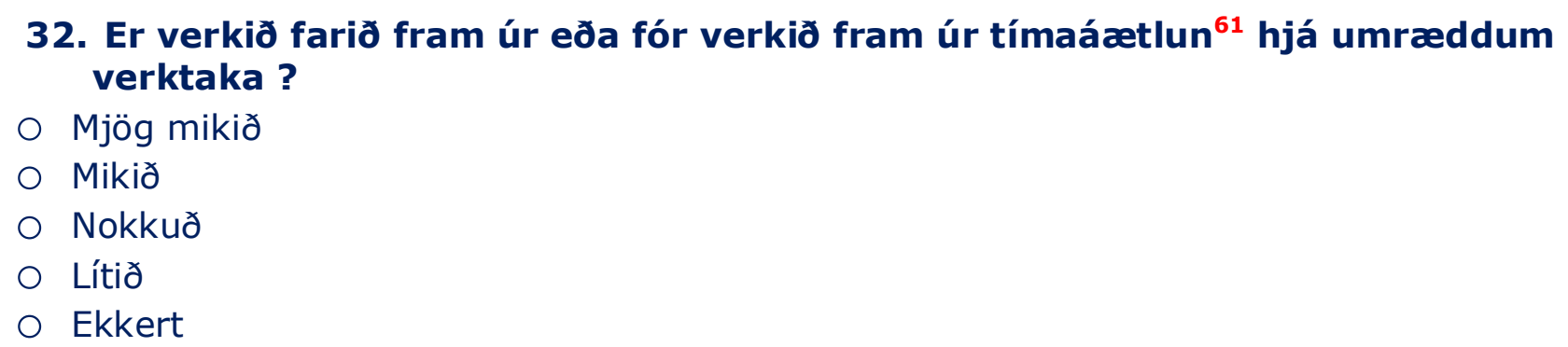

32. Er verkið farið fram úr eða fór verkið fram úr tímaáætlun ${ }^{61}$ hjá umræddum verktaka?

○ Mjög mikið

○ Mikið

○ Nokkuð

○ Lítið

O Ekkert

33. Sendi umræddur verktaki pér rökstudda tilkynningu um verktöf par sem töfin hlaust af peim atvikum sem verktaki bar fyrir sig ?

O Alltaf

O Oft

O Stundum

O Sjaldan

O Aldrei

34. Hversu ánægð/ur eða óánægð/ur ertu með fjármagnsstreymi ${ }^{62}$ verksins sem umræddur verktaki vann ?

○ Mjög ánægð/ur

○ Frekar ánægð/ur

○ Hvorki ánægð/ur né óánægð/ur

○ Frekar óánægð/ur

○ Mjög óánægð/ur

35. Lagði umræddur verktaki fram skriflega greiðsluáætlun í upphafi verks ? ○ Já

○ Nei > >> ef svarað er "nei", skal fara næst í spurningu 39.

36. Hversu vönduð/óvönduð var greiðsluáætlunin ?
○ Mjög vönduð
○ Frekar vönduð
○ Hvorki vönduð né óvönduð
○ Frekar óvönduð
○ Mjög óvönduð

\footnotetext{
${ }^{61}$ Hvort sem um ræðir skriflega eða munnlega tímaáætlun

${ }^{62}$ Með fjármagnsstreymi er átt við flæði greiðsIna til verktaka 
37. Hversu vel/illa var greiðsluáætlunin kynnt fyrir pér ?
○ Mjög vel
○ Frekar vel
O Hvorki vel né illa
○ Frekar illa
O Mjög illa

38. Var greiðsluáætlunin endurskoðuð og uppfærð reglulega ?

○ Já

O Nei

○ veit ekki

39. Var greitt eftir framvindu verks ?
○ Já
○ Nei

40. Er verkið farið fram úr eða fór verkið fram úr greiðsluáætlun ${ }^{63}$ hjá umræddum verktaka?

O Mjög mikið

○ Mikið

○ Nokkuð

○ Lítið

O Ekkert

41. Kom einhver reikningur/ar á óvart við verklok hjá umræddum verktaka? O Mjög margir

O Margir

O Nokkrir

○ Fáir

O Engin 


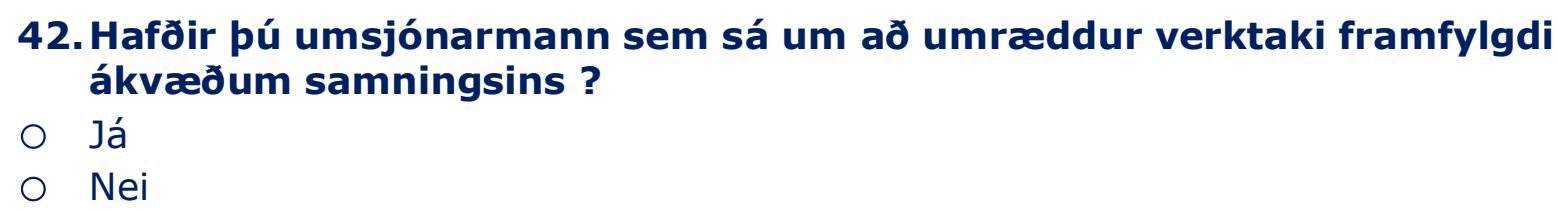
43. Var gert samkomulag á milli pín/umsjónarmanns og umrædds verktaka um reglubundna verkfundi ?
○ Já
○ Nei
○ Veit ekki

\section{Voru haldnir verkfundir með umræddum verktaka?}

○ Formlegir ${ }^{64}$ > > > ef svarað er "formlegir", skal fara næst í spurningu 46.

○ Óformlegir ${ }^{65}$ > > ef svarað er "óformlegir", skal fara næst í spurningu 46.

O Nei

45. Hefðir pú viljað hafa $\$\{\text { piping_text }\}^{66}$ verkfundi með umræddum verktaka ? ○ Já > > ef svarað er "já", skal fara næst í spurningu 53.

○ Nei >>> ef svarað er "nei", skal fara næst í spurningu 53.

\section{Hversu tíðir voru verkfundir?}

\section{Mættir bú á verkfundi ?}
O Alltaf
O Oft
O Stundum
O Sjaldan
O Aldrei

\footnotetext{
${ }^{64}$ Með formlegum verkfundum er átt við skipulagða fundi par sem farið er yfir fyrirfram ákveðin málefni.

${ }^{65}$ Með óformlegum verkfundum er átt við fundi sem var ekki endilega boðað til með fyrirvara og ekki farið yfir skipulagða fundardagskrá.

66 \$\{piping_text\} stendur fyrir "formlega" ef svarið við spurningu 44 er "óformlegir" en pað stendur fyrir "formlega eða óformlega" ef svarið við spurningu 44 er "nei" 
48. Kallaðir bú til verkfundar pegar bér fannst tilefni til ?
○ Alltaf
O Oft
O Stundum
O Sjaldan
O Aldrei

49. Varst bú boðuð/aður á verkfundi ?
O Alltaf
O Oft
O Stundum
O Sjaldan
O Aldrei

50. Var fjallað um stöðu verks miðað við tíma- og fjárhagsáætlun á verkfundunum ?

O Alltaf

O Oft

O Stundum

O Sjaldan

O Aldrei

O Veit ekki

51. Var rituð fundargerð á verkfundum ?

O Alltaf

O Oft

O Stundum

O Sjaldan

O Aldrei

O Veit ekki

52. Hefðir pú viljað vera boðaður oftar/sjaldnar á verkfundi með umræddum verktaka?

O Miklu oftar

O Oftar

O Hvorki oftar né sjaldnar

O Sjaldnar

O Miklu sjaldnar

○ Veit ekki 
53. Hversu vel/illa fór umræddur verktaki yfir verklýsingar og teikningar á milli verkpátta með verkkaupa?

○ Mjög vel

- Frekar vel

o Hvorki vel né illa

○ Frekar illa

○ Mjög illa

○ Ekkert

○ Veit ekki

54. Var verkið sem umræddur verktaki vann unnið í reikningsvinnu?

○ Já

○ Nei > > ef svarað er "nei", skal fara næst í spurningu 57.

55. Krafðist pú einhvertíma að umræddur verktaki sendi pér upplýsingar um vinnutíma og efnisnotkun á meðan framkvæmdum stóð ?

○ Já

○ Nei >>> ef svarað er "nei", skal fara næst í spurningu 61.

56. Hversu ánægð/ur eða óánægð/ur varstu við aðgengi slíkra upplýsinga ?

○ Mjög ánægð/ur

○ Frekar ánægð/ur

○ Hvorki ánægð/ur né óánægð/ur

○ Frekar óánægð/ur

○ Mjög óánægð/ur
>> > fara skal næst í spurningu 61.

>>> fara skal næst í spurningu 61.

> > fara skal næst í spurningu 61.

>> > fara skal næst í spurningu 61.

>> > fara skal næst í spurningu 61. 


\subsection{Samningar}

57. Hversu vel/illa ræddi umræddur verktaki samninginn við pig áður en framkvæmdir hófust?

O Mjög vel

○ Frekar vel

O Hvorki vel né illa

○ Frekar illa

O Mjög illa

58. Var samningurinn skriflegur?

O Já

○ Nei >>> ef svarað er "nei", skal fara næst í spurningu 60.

59. Hversu vel/illa var samningurinn sundurliðaður ?

○ Mjög vel

○ Frekar vel

O Hvorki vel né illa

○rekar illa

○ Mjög illa

60. Komu upp einhver ósætti milli bín og umrædds verktaka á bví sem var innifalid í samningnum ?

$\bigcirc$ Oft

○ Frekar oft

O Stundum

O Frekar sjaldan

○ Sjaldan

O Aldrei 


\subsection{Frábrigði ${ }^{67}$}

61. Komu upp einhver frábrigði hjá umræddum verktaka frá verkáætlun á verktíma

O Oft

O Frekar oft

O Stundum

O Frekar sjaldan

O Sjaldan

O Aldrei

62. Hvernig var bér tilkynnt um frábrigði ?

O Munnlega

O Skriflega

○ Ekki tilkynnt

O Annað:

${ }^{67}$ Ef gæði eru ekki samkvæmt kröfu viðskiptavinar í samningi, verklýsingu, teikningu eða öðrum kröfum. Varanlegur galli eða auka útgjöld. 


\subsection{Aukaverk og breytingar}

63. Hafa verið gerð aukaverkefni eða breytingar hjá umræddum verktaka ?

O Já

○ Nei >>> ef svarað er "nei", skal fara næst í spurningu 70.

64. Skráði umræddur verktaki óskir um aukaverk og breytingar ?

O Alltaf

O Oft

O Stundum

O Sjaldan

○ Aldrei >>> ef svarað er ",aldrei", skal fara næst í spurningu 66.

○ Veit ekki >>> ef svarað er "veit ekki", skal fara næst íspurningu 66.

65. Komu fram áhrif á verðlagningu verks og framvindu?

O Alltaf

O Oft

O Stundum

O Sjaldan

O Aldrei

O Veit ekki

66. Skilaði umræddur verktaki skrá yfir hugsanlegar kröfur um greiðslur vegna aukaverka og breytinga?

○ Já - Hversu títt ?:

○ Nei

○ Veit ekki

67. Voru aukaverk unnin í reikningsvinnu ?

Alltaf

O Oft

O Stundum

O Sjaldan

○ Aldrei > > ef svarað er "veit ekki", skal fara næst í spurningu 70.

○ Veit ekki >> ef svarað er "veit ekki", skal fara næst í spurningu 70. 
68. Krafðist pú einhvertíma að verktaki sendi pér upplýsingar um vinnutíma og efnisnotkun vegna aukaverks á meðan framkvæmdum stóð ?

○ Já

○ Nei $\quad$ > > ef svarað er "veit ekki", skal fara næst í spurningu 70.

○ Veit ekki >>> ef svarað er "veit ekki", skal fara næst í spurningu 70.

69. Hversu ánægð/ur eða óánægð/ur varstu með aðgengi að slíkum upplýsingum?

○ Mjög ánægð/ur

○ Frekar ánægð/ur

○ Hvorki ánægð/ur né óánægð/ur

○ Frekar óánægð/ur

○ Mjög óánægð/ur 


\subsection{Umgengni verktaka á verkstað}

70. Hvernig fannst pér umgengni umrædds verktaka á verkstað vera ?

○ Mjög góð

○ Frekar gód

○ Hvorki góð né slæm

○ Frekar slæm

○ Mjög slæm

71. Hvað var bað sem pér bótti miður fara varðandi umgengni verktaka ef eitthvað var?

72. Varstu pess var að umræddur verktaki notaðist við efni sem fullnægði ekki kröfum sem settar voru ?

O Oft

○ Frekar oft

O Stundum

O Frekar sjaldan

O Sjaldan

○ Aldrei 


\subsection{0 Öryggismál}

73. Voru öryggismál rædd áður en framkvæmdir hófust ?

○ Já

○ Nei >> ef svarað er "nei", skal fara næst í spurningu 75.

○ Veit ekki >>> ef svarað er "veit ekki", skal fara næst í spurningu 75.

74. Voru öryggismál sett sérstaklega í hendur umrædds verktaka á meðan verktíma stóð?

○ Já

O Nei

75. Hversu ánægð/ur eða óánægð/ur varstu með meðhöndlun öryggismála hjá umræddum verktaka?

○ Mjög ánægð/ur

○ Frekar ánægð/ur

○ Hvorki ánægð/ur né óánægð/ur

○ Frekar óánægð/ur

○ Mjög óánægð/ur

76. Hvað pótti pér vanta upp á öryggismál hjá verktaka ?

77. Hvaða aðgerðir viðhafðir pú til að hafa öryggismál í lagi ef einhverjar ? 


\subsection{Samskipti}

78. Ræddi umræddur verktaki við pig um væntanlegar samskiptaleiðir ykkar á milli áður en samningur var gerður?

O Já

○ nei

○ Veit ekki

79. Hversu ánægð/ur eða óánægð/ur ertu með samskipti milli pín og umrædds verktaka?

○ Mjög ánægð/ur

○ Frekar ánægð/ur

○ Hvorki ánægð/ur né óánægð/ur

○ Frekar óánægð/ur

○ Mjög óánægð/ur

80. Komu upp einhver vandamál í samskiptum pínum við verktaka ? Hver pá ?

81. Hvernig fannst pér bjónustulund umrædds verktaka vera ?

○ Mjög gód

○ Frekar gód

○ Hvorki góð né slæm

○ Frekar slæm

○ Mjög slæm 


\subsection{Gæðatrygging ${ }^{68}$}

82. Fórst bú fram á að umræddur verktaki sýndi pér í verkbyrjun skriflega hvernig hann ætlaði að vinna verkið til að uppfylla gæðakröfur ?

○ Já

○ Nei

83. Sýndi umræddur verktaki bér í verkbyrjun skriflega hvernig hann ætlaði að vinna verkið til að uppfylla gæðakröfur?

○ Já

○ Nei

\subsection{Gæðastjórnunarkerfi ${ }^{69}$}

84. Er umræddur verktaki að notast við ákveðið gæðastjórnunarkerfi ?

○ Já

○ru í innleiðingu

O Nei

○ Veit ekki

\subsection{Gæði}

85. Hversu ánægð/ur eða óánægð/ur ertu með gæði verksins sem umræddur verktaki vann?

○ Mjög ánægð/ur

○ Frekar ánægð/ur

○ Hvorki ánægð/ur né óánægð/ur

○ Frekar óánægð/ur

○ Mjög óánægð/ur

86. Eru einhver atriði sem pér finnst hafa vantað upp á gæði ? Hver bá ?

87. Að lokum eitthvað sem pú vilt koma á framfæri ? ${ }^{68}$ Skriflegt plagg um pað hvernig verktaki hyggst framkvæma verkið pannig að tilsett gæðamarkmið náist.
${ }^{69}$ Athuga að hér er verkkaupi spurður um vitneskju sína á pví hvort umræddur verktaki starfi eftir ákveðnu
gæðastjórnunarkerfi. 


\title{
Viðauki B - Könnun ætluð verktökum
}

Ég heiti Anna Hulda og er að vinna að meistararitgerð í samstarfi við Háskóla Íslands og Samtök Iðnaðarins sem fjallar um áhrif gæðastjórnunar á mannvirkjagerð á Íslandi.

Pessi könnun er ætluð verktökum

Pín pátttaka í pessari könnun er algjörlega valfrjáls og getur pú hætt hvenær sem er í könnuninni. Farið verður með svör pín sem fyllstu trúnaðarupplýsingar

Ef pú hefur einhverjar spurningar er sjálfsagt að hafa samband við mig í síma 8448904 eða með tölvupósti á anna.huldaolafsdottir@gmail.com.

\subsection{Grunnupplýsingar}

\author{
1. Hvert er kyn pitt ? \\ ○ kvk \\ O kk
}

\section{2. Á hvaða aldri ert pú ? \\ $0<20$ ára \\ ○ 21-35 ára \\ O 36-45 ára \\ ○ 46-55 ára \\ ○ 56-65 ára \\ ○ 66 ára <}
3. Hvaða menntun hefur bú ?
○ Grunnskólapróf
○ Stúdentspróf
○ Háskólapróf
○ Verkmenntun í byggingaiðnaði
○ Meistaraskólapróf
- Annad 
4. Hver er staða pín innan fyrirtækisins ?

○ Framkvæmdarstjóri

○ Verkefnastjóri

○ Gæðastjóri

○ Öryggisstjóri

○ Verkstjóri

○ Verkamaður

○ Annað

5. Starfsmannafjöldi verktakafyrirtækis ?
$0<10$
○ $10-20$
○ $21-30$
○ $31-50$
○ $51<$

6. Aldur verktakafyrirtækis ?

$0<5$ ára

O 5-10 ára

○ 11-30 ára

O 31-50 ára

○ 51 ára < 


\subsection{Gæðastjórnun ${ }^{70}$}

7. Starfar fyrirtækið eftir gæðastjórnunarkerfi ?

○ Já

○ Er í innleiðingu

○ Nei > > ef svarað er "Nei", skal fara næst í spurningu 22.

○ Veit ekki >> ef svarað er "veit ekki", skal fara næst í spurningu 22.

8. Var fenginn utanaðkomandi aðili við innleiðingu gæðakerfisins ?

O Já

○ Nei

○ Veit ekki

9. Byggir gæðastjórnunarkerfið á viðurkenndum gæðastaðli ?

○ Já

○ Nei >> ef svarað er "nei", skal fara næst í spurningu 14.

○ Veit ekki >> ef svarað er "veit ekki", skal fara næst í spurningu 14.

10. Hvaða gæðastaðli byggir fyrirtækið sitt gæðastjórnunarkerfi á ?

O ISO

O $\mathrm{SI}^{71}$

○ ÍST 30

○ Veit ekki

○ Annað :

11. Hefur fyrirtækið hlotið vottun fyrir gæðastjórnunarkerfið ?

○ Já

○ Nei >> ef svarað er "nei", skal fara næst í spurningu 14.

○ Veit ekki >> ef svarað er "veit ekki", skal fara næst í spurningu 14.

${ }^{70}$ Eftirfarandi spurningar eiga við fyrirtækið sem pú starfar hjá.

${ }^{71}$ Hér er átt við gæðastjórnunarkerfi Samtaka Iðnaðarins 
12. Hvernig vottun hefur fyrirtækið hlotið ?
$\mathrm{O}$ ISO
>>> ef svarað er "ISO", skal fara næst í spurningu 14.
O SI
O CE
>>> ef svarað er "CE", skal fara næst í spurningu 14.
○ Veit ekki
>>> ef svarað er "veit ekki", skal fara næst í spurningu 14.
○ Annað > >> ef svarað er "Annað", skal fara næst í spurningu 14.
○ A
O B
O C
O D
○ Veit ekki

13. Af hvaða stigi ?

\section{Er starfandi gæðastjóri innan fyrirtækisins?}
○ Já
○ Nei > > ef svarað er "nei", skal fara næst í spurningu 16.
○ Veit ekki >>> ef svarað er "veit ekki", skal fara næst í spurningu 16.
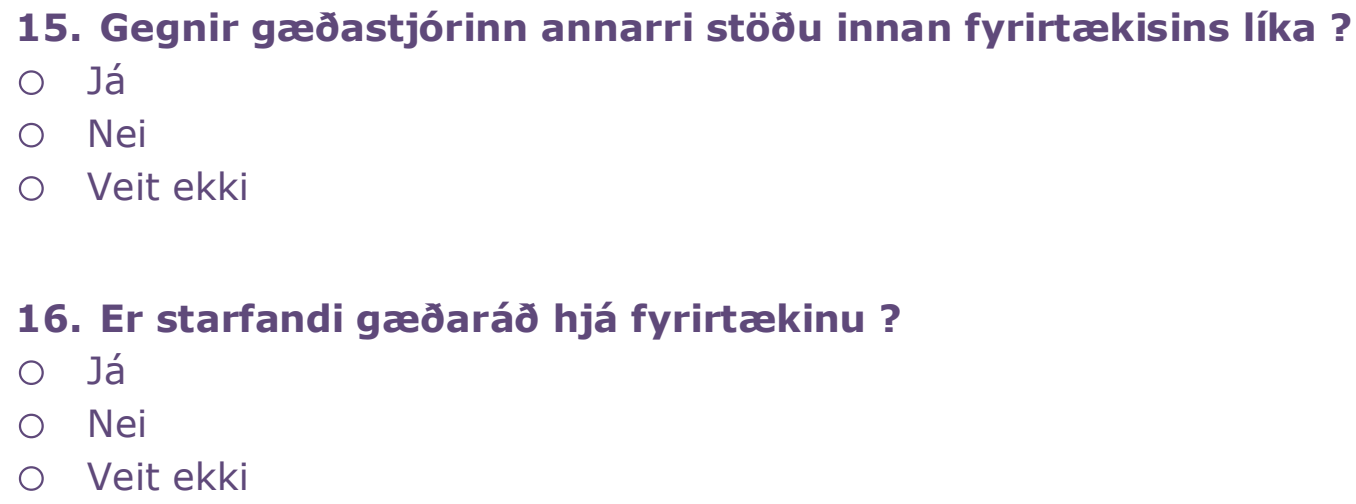

\section{Er til gæðahandbók fyrirtækisins ?}

○ Já

○ Nei $\quad$ > > ef svarað er "nei", skal fara næst í spurningu 14.

○ Veit ekki >> ef svarað er "veit ekki", skal fara næst í spurningu 14.

\section{Er gæðahandbókin til á rafrænu formi ?}
○ Já
O Nei
○ Veit ekki 
19. Hefur fyrirtækið skjalfesta gæðastefnu ?
○ Já
○ Nei $\quad$ > > > ef svarað er "nei", skal fara næst í spurningu 21.
○ Veit ekki >>> ef svarað er "veit ekki", skal fara næst í spurningu 21. 
20. Telur bú að gæðastefna fyrirtækisins séu almennt kunnug starfsmönnum fyrirtækisins?

○ Mjög kunnug

○ Frekar kunnug

○ Nokkuð kunnug

○ Lítið kunnug

○ Ekki kunnug

21. Veitið pið verkkaupa upplýsingar um gæðastjórnunarkerfið sem pið notið í verkbyrjun?

Alltaf

O Oft

O Stundum

O Sjaldan

O Aldrei

○ Veit ekki

22. Eru eftirfarandi starfandi innan fyrirtækisins?

Já Nei Veit ekki

Öryggisstjóri

Öryggistrúnaðarmaður
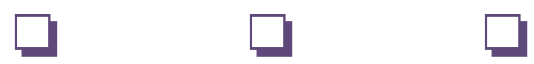

23. Viðhafið pið sérstakar öryggisráðstafanir á verkstað ?
O Alltaf
O Oft
O Stundum
O Sjaldan
O Aldrei
○ Veit ekki

24. Er mögulegt fyrir starfsmenn að sækja sér endurmenntun á vinnutíma?
○ Já
O Nei
○ Veit ekki 


\subsection{Viðhorf við gæðastjórnun}

25. Telur bú að ávinningur náist með gæðastjórnun í byggingaiðnaði?

O Mjög mikill

○ Frekar mikill

○ Hvorki mikill né lítill

○ Frekar lítill

O Mjög lítill

O Enginn

26. Telur pú að ávinningur af innleiðingu gæðastjórnunarkerfis sé meiri/minni en kostnaður?

○ Mun meiri

○ Aðeins meiri

○ Hvorki meiri né minni

○ Aðeins minni

O Mun minni

27. Telur bú að innleiðing gæðastjórnunarkerfis breyti rekstrarafkoma fyrirtækja?

O Batni til muna

O Batni

O Hvorki batni né versni

○ Versni

O Versni til muna

28. Telur bú að samkeppnishæfi fyrirtækja sé meiri/minni eftir innleiðingu gæðastjórnunarkerfis ?

○ Mun meiri

○ Aðeins meiri

O Hvorki meiri né minni

○ Aðeins minni

O Mun minni 
29. Telur pú að með innleiðingu gæðastjórnunarkerfis fjölgi/fækki frábrigðum í framkvæmdum ?

O Mun fleiri

○ Aðeins fleiri

Hvorki fleiri né færri

○ Aðeins færri

○ Mun færri

30. Telur pú að með innleiðingu gæðastjórnunarkerfis batni/versni nýting mannafla?

O Mun betri

Adeins betri

O Hvorki betri né verri

○ Aðeins verri

O Mun verri

31. Hefur pú mikla/litla trú á gæðastjórnun í byggingaiðnaði ?

○ Mikla

○ Frekar mikla

O Hvorki mikla né litla

○ Frekar litla

○ Litla

32. Upplifir bú gæðastjórnunarkerfi einungis sem skráningarkerfi ?

○ Já

○ Nei 
33. Hvernig finnst pér eftirfarandi orð eiga við gæðastjórnun ?

Mjög vel Frekar vel Hvorki velFrekar illa Mjög illa né illa

Óparfi

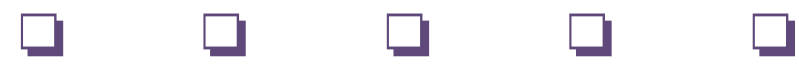

Skipulag

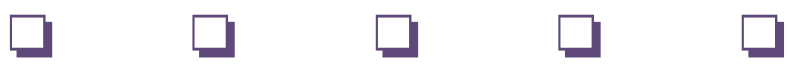

Kostnaður

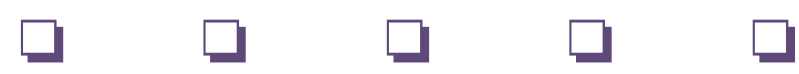

Sparnaður

Gallar

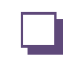

$\square$

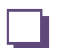

$\square$

$\square$

Gæði

Óánægja viðskiptavina

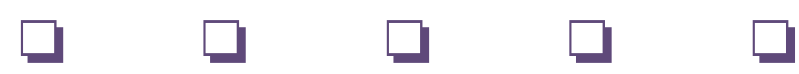

Ánægja viðskiptavina
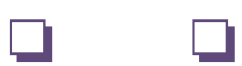

$\square$

$\square$

Tímaeyðsla

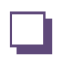

$\square$

$\square$

$\square$

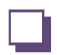

Ávinningur 


\subsection{Gæðatrygging}

34. Sýnið pið verkaupa fram á gæðatryggingu í verkbyrjun ?
○ Alltaf
O Oft
O Stundum
O Sjaldan
O Einungis pegar um er beðið
O Aldrei
○ Veit ekki

35. Hversu oft óskar verkkaupi eftir gæðatryggingu frá ykkur ?
○ Mjög oft
O Frekar oft
O Hvorki oft né sjaldan
○ Frekar sjaldan
○ Mjög sjaldan
O Aldrei
○ Veit ekki

36. Ef pið sýnið verkkaupa fram á gæðatryggingu hvað kemur pá fram í henni ?
37. Farið pið fram á gæðatryggingu frá undirverktökum ?
O Alltaf
O Oft
O Stundum
O Sjaldan
O Aldrei
O Veit ekki 


\subsection{Pekking á gæðastjórnun}

38. Hefur pú kynnt pér gæðastjórnun almennt ?
○ Mjög mikið
○ Frekar mikið
○ Nokkuð
○ Frekar lítið
○ Mjög lítið
O Ekkert

39. Hefur pú kynnt pér innihald samskiptastaðalsins IST 30 ?

○ Mjög mikið

○ Frekar mikið

○ Nokkuð

○ Frekar lítið

○ Mjög lítið

○ Ekkert

40. Hefur pú kynnt pér innihald gæðastjórnunarstaðalsins ISO 9001 ?
○ Mjög mikið
○ Frekar mikið
○ Nokkuð
○ Frekar lítið
○ Mjög lítið
○ Ekkert

41. Finnst pér vöntun á stöðluðum og samræmdum útboðsgögnum ?
O Mjög mikil
○ Frekar mikil
O Hvorki mikil né lítil
○ Frekar lítil
○ Mjög lítil
O Engin 
42. Eru samningar og tilboð geymd í tölusettri röð til ákveðins tíma ?
Alltaf
O Oft
O Stundum
O Sjaldan
O Aldrei
O Veit ekki

43. Er farið eftir ákveðnu kerfi fyrir eftirfarandi pætti ?

Já Nei Neit ekki

Merkingu skjala

Geymslu skjala

Varðveislutíma skjala

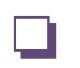

$\square$

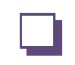

$\square$

$\square$

$\square$

Förgun skjala

44. Eru til skriflegar starfslýsingar fyrir starfsmenn í fyrirtækinu ?

O Alla starfsmenn

O Flesta starfsmenn

○ Fáa starfsmenn

Enga starfsmenn

O Veit ekki

45. Er innihald viðkomandi starfslýsinga kynnt fyrir starfsmönnum ?
○ Mjög vel
○ Frekar vel
○ Hvorki vel né illa
○ Frekar illa
○ Mjög illa
O Ekkert
O Veit ekki 
46. Leggið pið fram skriflega verkáætlun fyrir hvert verk ?
○ Alltaf
O Oft
○ Stundum
○ Sjaldan
O Aldrei
O Veit ekki

47. Sendið ріð verkkaupa skriflega rökstudda tilkynningu um verktöf pegar svo ber undir?

O Alltaf

O Oft

○ Stundum

- Sjaldan

O Aldrei

O Veit ekki

48. Gerið pið skriflega greiðsluáætlun við verkkaupa fyrir hvert verk ?

Alltaf

O Oft

O Stundum

O Sjaldan

O Aldrei

○ Veit ekki

49. Er venja að gert sé samkomulag um reglubundna verkfundi með verkkaupa ?

○ Alltaf

O Oft

O Stundum

O Sjaldan

O Aldrei

○ Veit ekki

50. Er venja að̆ rituð sé fundargerð á verkfundum ?
A Alltaf
O Oft
O Stundum
O Sjaldan
O Aldrei
O Veit ekki 
51. Haldið pið verkdagbók ?
O Alltaf
O Oft
O Stundum
O Sjaldan
O Aldrei
○ Veit ekki

52. Er venja að bað sé tekið fram í samningum að bað beri að fara eftir kröfum samskiptastaðalsins IST 30 ?

○ Alltaf

O Oft

O Stundum

O Sjaldan

O Aldrei

O Veit ekki

53. Hvernig er verkkaupa tilkynnt um frábrigði ?
O Munnlega
O Skriflega
O Mismunandi
○ Veit ekki

54. Eru óskir verkkaupa um aukaverk og breytingar skráðar ?
O Alltaf
O Oft
O Stundum
O Sjaldan
O Aldrei
○ Veit ekki

55. Ef óskir um aukaverk og breytingar eru skrádar, kemur bá fram í skráningu áhrif á verðlagningu heildarverks og framvindu ?
○ Alltaf
O Oft
○ Stundum
O Sjaldan
O Aldrei
○ Veit ekki 
56. Hversu oft skilið pið skrá yfir hugsanlegar kröfur um greiðslur vegna aukaverka og breytinga til verkkaupa?

○ Vikulega

○ Mánaðalega

○ Að verki loknu

O Aldrei

○ Veit ekki

Annað - hversu oft ?

57. Gerið pið hættumat og/eða áhættugreiningu á verkstað ?

O Alltaf

O Oft

O Stundum

O Sjaldan

O Aldrei

O Veit ekki

58. Styðst fyrirtækið við utanaðkomandi pjónustu við gæðaeftirlit/úttektir ?

Alltaf

O Oft

O Stundum

O Sjaldan

O Aldrei

○ Veit ekki

59. Er skipulagt innra eftirlit á framkvæmdum hjá fyrirtækinu (gæðastýringaráætlun) ?

○ Alltaf

O Oft

○ Stundum

O Sjaldan

O Aldrei

○ Veit ekki 
60. Hvernig finnst pér kröfur verkkaupa til verktaka um skipulag og markvissa stjórnun FYRIR EFNAHAGSHRUN hafa verið?

$\begin{array}{lllr}\text { Mjög } & \text { Frekar } & \text { Hvorki } & \text { Frekar } \\ \text { miklar } & \text { miklar } & \begin{array}{l}\text { miklarg litlar } \\ \text { litlar }\end{array} & \text { nélitlar }\end{array}$

Einstaklingar

Fyrirtæki

Opinberar stofnanir
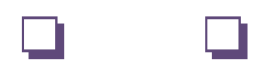

$\square$

$\square$

$\square$
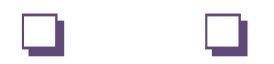

$\square$

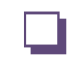

$\square$
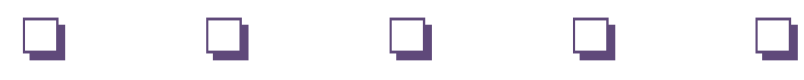

61. Hvernig finnst pér kröfur verkkaupa til verktaka um skipulag og markvissa stjórnun EFTIR EFNAHAGSHRUN hafa verið?

$\begin{array}{lllrr}\text { Mjög } & \text { Frekar } & \text { Hvorki } & \text { Frekar } \\ \text { miklar } & \text { miklar } & \begin{array}{l}\text { miklar } \\ \text { litlar }\end{array} & \text { nélitlar }\end{array}$

Einstaklingar

Fyrirtæki

Opinberar stofnanir

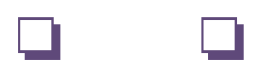

$\square$

$\square$

$\square$

$\square$

$\square$

$\square$

$\square$

$\square$

\subsection{Annad}

62. Eitthvað að lokum sem pú vilt koma á framfæri ? 


\section{Viðauki C - Um verktaka}

Aukaleg vitneskja um verktaka ${ }^{72}$

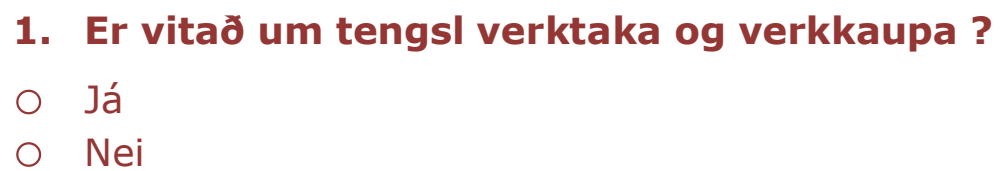

Ef ekki var tekið viðtal við verktaka var leitast við að finna svör við eftirfarandi:

\section{Starfsmannafjöldi verktakafyrirtækis ?}

$0<10$

○ $10-20$

○ $21-30$

○ $31-50$

○ $51<$

\section{Aldur verktakafyrirtækis ?}
$0<5$ ára
O 5-10 ára
○ 11-30 ára
O 31-50 ára
○ 51 ára <

4. Er verktaki að vinna eftir gæðastjórnunarkerfi svo vitað sé til ?

○ Já

○ru í innleiðingu

○ Nei $\quad$ >> ef svarað er "nei", skal fara næst í spurningu 8.

○ Óvíst $\quad>>>$ ef svarað er "óvíst", skal fara næst í spurningu 8.

5. Á hverju byggir gæðastjórnunarkerfið samkvæmt gögnum?

O ISO

O SI

O CE

Eigin kerfi

O Óvíst

O Annað

\footnotetext{
72 Leitast var við að finna svör við eftirfarandi spurningum hvort sem umræddir verktakar tóku pátt í tilætlaðri könnun.
} 199 

6. Er gæðastjórnunarkerfið vottað svo vitað sé til?
○ Já
○ Nei >>> ef svarað er "nei", skal fara næst í spurningu 9.
○ Óvíst >>> ef svarað er "óvíst", skal fara næst í spurningu 9.
7. Hvernig vottun hefur fyrirtækið hlotið fyrir gæðastjórnunarkerfið svo vitað sé til?
○ ISO >> ef svarað er "ISO", skal fara næst í spurningu 9.
O SI
O CE $\quad$ > > ef svarað er "CE", skal fara næst í spurningu 9.
○ Óvíst >>> ef svarað er "óvíst", skal fara næst í spurningu 9.
○ Annað >>> ef svarað er "annað", skal fara næst í spurningu 9.

\section{Af hvaða stigi ?}

○ A

O B

O C

O D

O Veit ekki

9. Mitt álit á verklagi verktaka ${ }^{73}$ ?

○ Gæðastjórnunarkerfi

○ Ekki gæðastjórnunarkerfi

○ Veit ekki

73 Til gaman pá lagði ég mat á pað hvort ég teldi raunhæft ef viðkomandi verktæki ynni eftir gæðastjórnunarkerfi eða ekki, ef ómögulegt var að nálgast raunverulegar upplýsingar um slíkt. 


\section{Viðauki D - Breytuheiti}

Til að spara pláss og auðvelda uppsetningu fyrir tengslatöflur og líkanútreikninga í CATREG verður notast við eftirfarandi breytuheiti fyrir ofangreint. Svarmöguleikum var gefið tölulegt gildi fyrir útreikninga og var sá kostur sem talinn er vera bestur auðkenndur með hæstu tölunni. Sem dæmi fékk valmöguleikinn mjög áncegð/ur töluna 5 en mjög óáncegð/ur fékk töluna 1. Fyrir nafnabreytur eins og fyrir_einst par sem að ekki er hægt að rökstyðja að annar svarmöguleikinn sé betri en hinn var pað tilviljun hvaða svarmöguleiki fékk hæstu töluna og hver lægstu en formerki fylgnistuðla byggjast á pví hvaða gildi svarflokkarnir fengu. Jákvæð fylgni ánægju breytu við fyrir_einst pýðir pví að fyrirtækja-verkkaupar séu líklegri til að vera ánægðari en einstaklingar par sem að svarmöguleikinn fyrirtceki fékk gildið 2 en einstaklingur fékk gildið 1.

\subsection{3 Úr könnun verkkaupa}

- $\quad$ ánægja $a_{\text {greiosslu }}=$ Hversu ánægð/ur eða óánægð/ur eru með fjármagnsstreymi verksins sem umræddur verktaki vann ? (raðbreyta)

- ánægja $a_{g æ ð i}=$ Hversu ánægð/ur eða óánægð/ur eru með gæði verksins sem umræddur verktaki vann ? (raðbreyta)

- $\quad$ ánægja $a_{u m r æ d d a n}=$ Hversu ánægð/ur eða óánægð/ur eru með framkvæmd verksins sem umræddur verktaki vann ? (raðbreyta)

- ánægjatíma $_{\text {t }}$ Hversu ánægð/ur eða óánægð/ur eru með tímastjórnun verksins sem umræddur verktaki vann? (raðbreyta)

- ánægjä̈ryggismál = Hversu ánægð/ur eða óánægð/ur varstu með meðhöndlun öryggismála hjá umræddum verktaka? (raðbreyta)

- $\quad$ aldur = aldur verkkaupa (jafnbilabreyta)

- $\quad$ aukaverk = Hafa verið gerð aukaverkefni eða breytingar hjá umræddum verktaka ? (raðbreyta)

- aukav_skráð_verkk = Skráði umræddur verktaki óskir um aukaverk og breytingar ? (raðbreyta)

- frábrigði = Komu upp einhver frábrigði hjá umræddum verktaka frá verkáætlun á verktíma ? (raðbreyta)

- $\quad$ fyrir_einst $=$ Er verkkaupi fyrirtæki eða einstaklingur ? (nafnabreyta)

- $\quad$ frábrigð $\mathrm{i}_{\text {tikynnt }}=$ Hvernig var pér tilkynnt um frábrigði ? (raðbreyta)

- greiðsluáætlun = Er verkið farið fram úr eða fór verkið fram úr greiðsluáætlun hjá umræddum verktaka ? (raðbreyta)

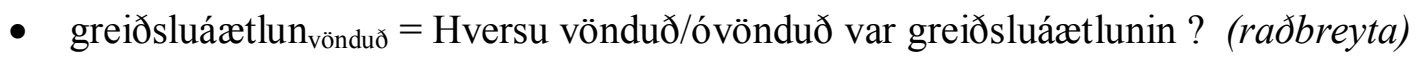

- $\quad$ greiðsluáætlun $n_{\mathrm{kynnt}}=$ Hversu vel/illa var greiðsluáætlunin kynnt fyrir bér ? (raðbreyta) 
- $\quad$ gæðatrygging = Sýndi umræddur verktaki pér í verkbyrjun skriflega hvernig hann ætlaði að vinna verkið til að uppfylla gæðakröfur ? (raðbreyta)

- $\quad \mathrm{kyn}_{\text {verkkaupa }}=$ Hvert er kyn pitt ? (raðbreyta)

- $\quad$ reikningsvinna $=$ Var verkið sem umræddur verktaki vann unnið í reikningsvinnu ? (raðbreyta)

- reikningur $_{\text {ovart }}=$ Kom einhver reikningur/ar á óvart við verklok hjá umræddum verktaka ? (raðbreyta)

- samningur $_{\text {ræddur }}=$ Hversu vel/illa ræddi umræddur verktaki samninginn við pig áður en framkvæmdir hófust? (raðbreyta)

- $\quad$ samningur $_{\text {skriflegur }}=$ Var samningurinn skriflegur ? (raðbreyta)

- $\quad$ samningur $_{\text {sundurliðaður }}=$ Hversu vel/illa var samningurinn sundurliðaður ? (raðbreyta)

- $\quad$ samningur $_{\text {osetti }}=$ Komu upp einhver ósætti milli pín og umrædds verktaka á bví sem var innifalið í samningnum ? (raðbreyta)

- $\quad$ skrifleg $_{\text {tíma }}=$ Lagði umræddur verktaki fram skriflega tímaáætlun í upphafi verks ? (raðbreyta)

- skrifleg $_{\text {greiðslu }}=$ Lagði umræddur verktaki fram skriflega greiðsluáætlun í upphafi verks ? (raðbreyta)

- $\quad$ sveitarfélag = Í hvaða sveitarfélagi eru framkvæmdirnar ? (nafnabreyta)

- tímaáætlun = Er verkið farið fram úr eða fór verkið fram úr tímaáætlun hjá umræddum verktaka ? (raðbreyta)

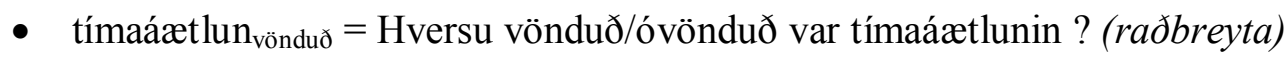

- $\quad$ tímaáætlun $n_{\mathrm{kynnt}}=$ Hversu vel/illa var tímaætlunin kynnt fyrir pér ? (raðbreyta)

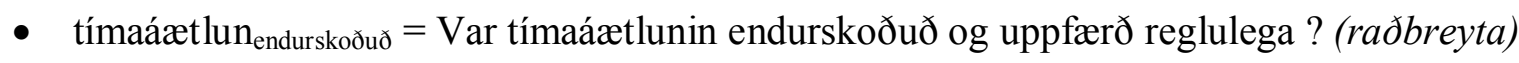

- $\quad$ tengsl = er vitað um tengsl verkkaupa og verktaka ? (raðbreyta)

- $\quad$ umgengni $=$ Hvernig fannst pér umgengni umrædds verktaka á verkstað vera ? (raðbreyta)

- umsjónarmann = Hafðir pú umsjónarmann sem sá um að umræddur verktaki framfylgdi ákvæðum samningsins? (raðbreyta)

- $\quad$ verkfundir $=$ Voru haldnir verkfundir með umræddum verktaka ? (raðbreyta)

- $\quad$ verkfundir $_{\text {fleiri }}=$ Hefðir pú viljað vera boðaður oftar/sjaldnar á verkfundi með umræddum verktaka ? (raðbreyta)

- $\quad$ verkfundir $_{\text {fundargerð }}=$ Var rituð fundargerð á verkfundum ? (raðbreyta) 
- $\quad$ verkfundir $_{\text {samkomulag }}=$ Var gert samkomulag á milli pín/umsjónarmanns og umrædds verktaka um reglubundna verkfundi ? (raðbreyta)

- $\quad$ verkfundir $_{\text {staða }}=$ Var fjallað um stöðu verks miðað við tíma- og fjárhagsáætlun á verkfundunum ? (raðbreyta)

- $\quad$ verkfundir $_{\text {verkkaupi }}=$ Mættir pú á verkfundi ? (raðbreyta)

- verkfundir $_{\text {form/óform }}=$ Hefðir pú viljað hafa $\$\{$ piping_text $\}$ verkfundi með umræddum verktaka ? (raðbreyta)

- verklýsingar milliverkpátta $=$ Hversu vel/illa fór umræddur verktaki yfir verklýsingar og teikningar á milli verkpátta með verkkaupa? (raðbreyta)

- $\quad$ jónustulund $=$ Hvernig fannst pér pjónustulund umrædds verktaka vera ? (raðbreyta)

- $\quad$ öryggismál $1_{\text {rædd }}=$ Voru öryggismál rædd áður en framkvæmdir hófust ? (raðbreyta)

- öryggismál $1_{\text {verktaka }}=$ Voru öryggismál sett sérstaklega í hendur umrædds verktaka á meðan verktíma stóð ? (raðbreyta)

\subsection{4 Úr könnun verktaka}

- ávinningur = Telur pú að ávinningur náist með gæðastjórnun í byggingaiðnaði ? (raðbreyta)

- ávinningur/kostnaður = Telur pú að ávinningur af innleiðingu gæðastjórnunarkerfis sé meiri/minni en kostnaður? (raðbreyta)

- áhrif_á_frábrigði= Telur pú að með innleiðingu gæðastjórnunarkerfis fjölgi/fækki frábrigðum í framkvæmdum? (raðbreyta)

- $\quad$ almennt = Hefur pú kynnt pér gæðastjórnun almennt ? (raðbreyta)

- aldur_fyrirt = Hversu gamalt er fyrirtækið sem pú starfar hjá ? (raðbreyta)

- $\quad$ aukaverk $_{\text {skrá }}=$ Eru óskir verkkaupa um aukaverk og breytingar skráðar ? (raðbreyta)

- $\quad$ aukaverk $_{\text {skrá }}=$ Hversu oft skilið pið skrá yfir hugsanlegar kröfur um greiðslur vegna aukaverka og breytinga til verkkaupa? (raðbreyta)

- endurmenntun = Er mögulegt fyrir starfsmenn að sækja sér endurmenntun á vinnutíma ? (raðbreyta) 
- frábrigð $\mathrm{i}_{\text {tilkynnt }}=$ Hvernig er verkkaupa tilkynnt um frábrigði ? (raðbreyta)

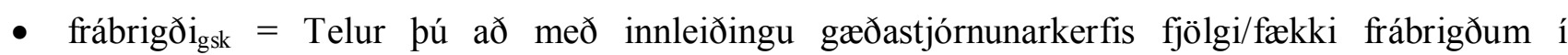
framkvæmdum ? (raðbreyta)

- $\quad$ fundargerð = Er venja að rituð sé fundargerð á verkfundum ? (raðbreyta)

- $\quad$ förgun = Er farið eftir ákveðnu kerfi fyrir förgun skjala ? (raðbreyta)

- geymsla = Er farið eftir ákveðnu kerfi fyrir geymslu skjala ? (raðbreyta)

- greiðsluáætlun $_{\text {skrifleg }}=$ Gerið pið skriflega greiðsluáætlun við verkkaupa fyrir hvert verk ? (raðbreyta)

- gæðaeftirlit $_{\text {utanaðkomandi }}=$ Styðst fyrirtækið við utanaðkomandi pjónustu við gæðaeftirlit/úttektir ? (raðbreyta)

- $\quad$ gæðastjóri = Er starfandi gæðastjóri innan fyrirtækisins ? (raðbreyta)

- gæðastýringaráætlun = Er skipulagt innra eftirlit á framkvæmdum hjá fyrirtækinu ? (raðbreyta)

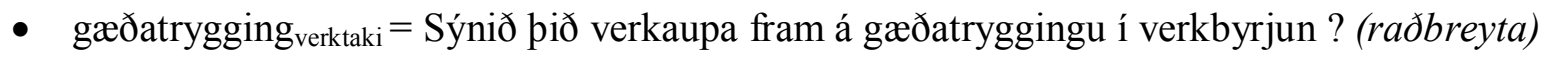

- gæðatryggingósk = Hversu oft óskar verkkaupi eftir gæðatryggingu frá ykkur ? (raðbreyta)

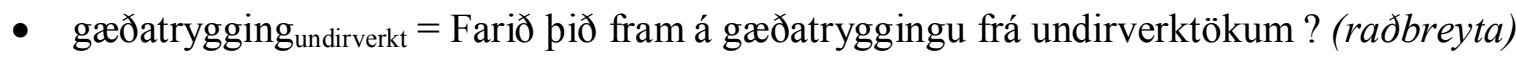

- GSK = Er viðkomandi verktaki að starfa eftir gæðastjórnunarkerfi byggðu á viðurkenndum gæðastjórnunarstaðli ${ }^{74}$ ? (raðbreyta)

- $\quad$ hættumat $=$ Gerið pið hættumat og/eða áhættugreiningu á verkstað ? (raðbreyta)

- $\quad$ ÍST30 = Hefur pú kynnt pér innihald samskiptastaðalsins ÍST 30 ? (raðbreyta)

- ÍST30_kröfur = Er venja að pað sé tekið fram í samningum að pað beri að fara eftir kröfum samskiptastaðalsins IST 30 ? (raðbreyta)

- $\quad$ ISO9001 = Hefur pú kynnt pér innihald gæðastjórnunarstaðalsins ISO 9001 ? (raðbreyta)

- kröfur_einst_EH = Hvernig finnst pér kröfur einstaklings-verkkaupa til verktaka um skipulag og markvissa stjórnun eftir efnahagshrun hafa verið ?

- kröfur_einst_FH = Hvernig finnst pér kröfur einstaklings-verkkaupa til verktaka um skipulag og markvissa stjórnun fyrir efnahagshrun hafa verið ?

\footnotetext{
${ }^{74}$ Breytan GSK var búin sérstaklega til fyrir flokka aðhvarfsgreininguna par sem svör pátttakenda sem sögðust ekki starfa eftir gæðastjórnunarkerfi og peir pátttakendur sem sögðust starfa eftir gæðastjórnunarkerfi sem ekki byggði á viðurkenndum gæðastjórnunarstaðli fengu gildið 1, en peir svör pátttakenda sem sögðust starfa eftir gæðastjórnunarkerfi sem byggir á viðurkenndum gæðastjórnunarstaðli fengu gildið 2. 
- kröfur_fyrirt_EH = Hvernig finnst pér kröfur fyrirtækja-verkkaupa til verktaka um skipulag og markvissa stjórnun eftir efnahagshrun hafa verið?

- kröfur_fyrirt_FH $=$ Hvernig finnst pér kröfur fyrirtækja-verkkaupa til verktaka um skipulag og markvissa stjórnun fyrir efnahagshrun hafa verið ?

- kröfur_opinb_EH = Hvernig finnst pér kröfur verkkaupa sem eru opinberar stofnanir til verktaka um skipulag og markvissa stjórnun eftir efnahagshrun hafa verið ?

- kröfur_opinb_FH = Hvernig finnst pér kröfur verkkaupa sem eru opinberar stofnanir til verktaka um skipulag og markvissa stjórnun fyrir efnahagshrun hafa verið ?

- mannafli $=$ Telur pú að með innleiðingu gæðastjórnunarkerfis batni/versni nýting mannafla ? (raðbreyta)

- $\quad$ merking $=$ Er farið eftir ákveðnu kerfi fyrir merkingu skjala ? (raðbreyta)

- $\quad$ rekstrarafkoma $=$ Telur pú að innleiðing gæðastjórnunarkerfis breyti rekstrarafkoma fyrirtækja ? (raðbreyta)

- samkeppnishæfi = Telur bú að samkeppnishæfi fyrirtækja sé meiri/minni eftir innleiðingu gæðastjórnunarkerfis ? (raðbreyta)

- $\quad$ samskipti $_{\text {rædd }}=$ Ræddi umræddur verktaki við pig um væntanlegar samskiptaleiðir ykkar á milli áður en samningur var gerður? (raðbreyta)

- $\quad$ skráningarkerfi = Upplifir pú gæðastjórnunarkerfi einungis sem skráningarkerfi ? (raðbreyta)

- $\quad$ starfslýsingar $_{\text {skriflegar }}=$ Eru til skriflegar starfslýsingar fyrir starfsmenn í fyrirtækinu ? (raðbreyta)

- $\quad$ starfslýsingar $_{\mathrm{kynnt}}=$ Er innihald viðkomandi starfslýsinga kynnt fyrir starfsmönnum ? (raðbreyta)

- $\quad$ stærð = Hvað starfa margir hjá fyrirtækinu sem pú ert starfsmaður hjá ? (jafnbilabreyta)

- $\quad$ trú = Hefur pú mikla/litla trú á gæðastjórnun í byggingaiðnaði ? (raðbreyta)

- $\quad$ tölusett = Eru samningar og tilboð geymd í tölusettri röð til ákveðins tíma ? (raðbreyta)

- $\quad$ Úrtak = í hvaða flokki úrtaks er pátttakandi (nafnabreyta)

- útboðsgögn = Finnst pér vöntun á stöðluðum og samræmdum útboðsgögnum ? (raðbreyta)

- $\quad$ varðveislutími = Er farið eftir ákveðnu kerfi fyrir varðveislutíma skjala ? (raðbreyta)

- $\quad$ verkáætlun $_{\text {skrifleg }}=$ Leggið pið fram skriflega verkáætlun fyrir hvert verk ? (raðbreyta)

- $\quad$ verkdagbók $=$ Haldið pið verkdagbók ? (raðbreyta) 
- $\quad$ verkfundir ${ }_{\text {reglubundnir }}=$ Er venja að gert sé samkomulag um reglubundna verkfundi með verkkaupa ? (raðbreyta)

- $\quad$ verktöf $_{\text {skrifleg }}=$ Sendið pið verkkaupa skriflega rökstudda tilkynningu um verktöf pegar svo ber undir? (raðbreyta)

- $\quad$ öryggi $i_{\text {verkstað }}=$ Viðhafið pið sérstakar öryggisráðstafanir á verkstað ? (raðbreyta)

- öryggisstjóri = Starfar öryggisstjóri í fyrirtækinu sem pú starfar hjá ? (raðbreyta)

- öryggistrúnaðarm = Starfar öryggistrúnaðarmaður í fyrirtækinu sem pú starfar hjá ? (raðbreyta)

- öryggisráðst = Viðhafið pið sérstakar öryggisráðstafanir á verkstað ? (raðbreyta) 


\section{Viðauki E - Tíðnitöflur úr könnun verkkaupa}

Könnunin fyrir verkkaupana er skipt í eftirfarandi 12 pætti:

1. Grunnupplýsingar (bls.207)

2. Ánægja viðskiptavinar (bls.210)

3. Framkvæmd (bls.212)

4. Áætlanir (bls.215)

5. Verkfundir (bls.223)

6. Samningar (bls.228)

7. Frábrigði (bls.231)

8. Aukaverk og breytingar (bls.232)

9. Umgengni umrædds verktaka á verkstað (bls.235)

10. Öryggismál (bls.236)

11. Samskipti (bls.239)

12. Gæðatrygging (bls.240)

13. Gæðastjórnunarkerfi (bls.241)

14. Gæði (bls.242)

\subsection{Grunnupplýsingar}

Tæplega 64\% pátttakenda voru einstaklingar. Ástæðan fyrir pví að ekki var hærra hlutfall fyrirtækja er einna helst sú að í fleiri tilfellum voru fyrirtækin bæði verktakar og verkkaupar og mörg fyrirtæki sem voru í framkvæmdum á pessum tíma virðast vera komin í prot og var par af leiðandi erfiðara að nálgast upplýsingar um pau en einstaklingana.

\section{Tafla 20 Er verkkaupi fyrirtaki eða einstaklingur?}

\begin{tabular}{llcccc}
\hline \hline & & Tíoni & Hlutfall (\%) & Gilt hlutfall (\%) & Uppsafnað hlutfall (\%) \\
\hline Gilt & Einstaklingur & 74 & 63.8 & 63.8 & 63.8 \\
& Fyrirtæki & 42 & 36.2 & 36.2 & 100.0 \\
& Samtals & 116 & 100.0 & 100.0 & \\
\hline \hline
\end{tabular}

Pau fyrirtæki sem tóku pátt voru svo flokkuð niður eftir pví hvort pau tilheyrðu ríki/borg eða ekki og voru rúmlega $26 \%{ }^{75}$ fyrirtækja sem tóku pátt rekin af ríki eða borg.

\footnotetext{
75 Athuga að hátt hlutfall svara flokkast undir „Vantar“, en slík gildi eru pátttakendur sem svöruðu ekki pessari spurningu. Í pessu tilfelli eru pað einungis einstaklingarnir sem svöruðu ekki. Gilt hlutfall miðast pví við svör pátttakenda miðað við heildarfjölda svara við pessari tilteknu spurningu.
} 


\begin{tabular}{llcccc}
\hline \hline & & Tíðni & Hlutfall (\%) & Gilt hlutfall (\%) & Uppsafnað hlutfall (\%) \\
\hline \multirow{2}{*}{ Gilt } & Ríki/borg & 11 & 9.5 & 26.2 & 26.2 \\
& Annað & 31 & 26.7 & 73.8 & 100.0 \\
& Samtals & 42 & 36.2 & 100.0 & \\
\multirow{2}{*}{ Vantar } & & 74 & 63.8 & & \\
Samtals & & 116 & 100.0 & & \\
\hline \hline
\end{tabular}

Í byrjun könnunarinnar voru svarendur beðnir um að hafa einn ákveðinn verktaka í huga pegar spurningunum væri svara ${ }^{76}$. Leitast var eftir pví að verktakar hefơ pann verktaka sem vann mest í verkinu í huga.

Verktakar sem verkkaupar kusu að hafa í huga voru flokkaðir niður og eins og sjá má í töflunni hér að neðan voru lang flestir verktakarnir byggingaverktakar eða tæplega $\mathbf{7 1 \%}$.

Tafla 0.22 Starfsgrein verktaka sem hafður er í huga?

\begin{tabular}{llcccc}
\hline \hline & Tíðni & Hlutfall (\%) & Gilt hlutfall (\%) & Uppsafnað hlutfall (\%) \\
\hline Gilt & Byggingaverktaki & 82 & 70.7 & 70.7 & 70.7 \\
& Pípulagningarverktaki & 4 & 3.4 & 3.4 & 74.1 \\
& Rafverktaki & 2 & 1.7 & 1.7 & 75.9 \\
Húshlutaframleiðandi & 19 & 16.4 & 16.4 & 92.2 \\
Jarðvinnuverktaki & 2 & 1.7 & 1.7 & 94.0 \\
Annað & 7 & 6.0 & 6.0 & 100.0 \\
Samtals & 116 & 100.0 & 100.0 & \\
\hline \hline
\end{tabular}

Ekki var öllum framkvæmdum lokið en um 24\% var ólokið. En eins og sjá má hér að neðan var megnið af peim verkum sem var ólokið á lokastigi.

Tafla 0.23 Er verkinu lokið?

\begin{tabular}{llcccc}
\hline \hline & & Tíoni & Hlutfall (\%) & Gilt hlutfall (\%) & Uppsafnað hlutfall (\%) \\
\hline Gilt & Já & 88 & 75.9 & 75.9 & 75.9 \\
& Nei & 28 & 24.1 & 24.1 & 100.0 \\
& Samtals & 116 & 100.0 & 100.0 & \\
\hline \hline
\end{tabular}

$25 \%$ pátttakenda ${ }^{77}$ töldu að innan við $69 \%$ væri lokið af framkvæmdinni.

\footnotetext{
${ }^{76}$ Verkkaupar voru beðnir um að tilgreina nafn verktaka svo rannsakandi gæti haft samband við umræddan verktaka til að taka pátt í sérstakri könnun fyrir verktaka. Upplýsingar um nöfn verktaka verða ekki birt.

${ }^{77}$ Athuga að hér eru mörg gildi skráð sem „vantar“ en pað eru peir pátttakendur sem ekki svöruðu spurningunni. En einungis peir pátttakendur sem töldu framkvæmdum vera lokið svöruðu ekki pessari spurningu. 208
} 


\begin{tabular}{llcccc}
\hline \hline & & Tíðni & Hlutfall (\%) & Gilt hlutfall (\%) & Uppsafnað hlutfall (\%) \\
\hline Gilt & $<50 \%$ lokið & 2 & 1.7 & 7.1 & 7.1 \\
& $50 \%-59 \%$ lokið & 4 & 3.4 & 14.3 & 21.4 \\
& $60 \%-69 \%$ lokið & 1 & .9 & 3.6 & 25.0 \\
& $80 \%-89 \%$ lokið & 5 & 4.3 & 17.9 & 42.9 \\
& $90 \%-99 \%$ lokið & 16 & 13.8 & 57.1 & 100.0 \\
& Samtals & 28 & 24.1 & 100.0 & \\
Vantar & & 88 & 75.9 & & \\
Samtals & & 116 & 100.0 & & \\
\hline \hline
\end{tabular}

Flestar framkvæmdir sem pátttakendur stóðu í voru árið 2007, eða um 40\% ${ }^{78}$.

Tafla 25 Hvaða ár stóðu framkvaemdir yfir?

\begin{tabular}{ccc}
\hline \hline & Tíoni & Hlutfall (\%) \\
\hline 2005 & 30 & $25.9 \%$ \\
2006 & 45 & $38.8 \%$ \\
2007 & 47 & $40.5 \%$ \\
2008 & 39 & $33.6 \%$ \\
2009 & 22 & $19.0 \%$ \\
2010 & 22 & $19.0 \%$ \\
\hline \hline
\end{tabular}

Pað voru afgerandi fleiri karlar sem tóku pátt, en peir voru tæplega 90\% pátttakenda ${ }^{79}$.

Tafla 0.26 Hvert er kyn pitt?

\begin{tabular}{llcccc}
\hline \hline & & Tíðni & Hlutfall (\%) & Gilt hlutfall (\%) & Uppsafnað hlutfall (\%) \\
\hline Gilt & kvk & 12 & 10.3 & 10.3 & 10.3 \\
& kk & 104 & 89.7 & 89.7 & 100.0 \\
& Samtals & 116 & 100.0 & 100.0 & \\
\hline \hline
\end{tabular}

Pátttakendum var skipt niður í 6 aldursflokka ${ }^{80}$ og voru flestir á aldursbilinu 36-45 ára, eða um 37\% pátttakenda ${ }^{81}$.

\footnotetext{
${ }^{78}$ Í mörgum tilfellum stóðu framkvæmdir yfir í meira en eitt ár og skýrir pað af hverju heildarfjöldi svara er meiri en heildarfjöldi pátttakenda við pessari spurningu. Hlutfallið sem er gefið er miðað við heildarfjölda framkvæmda/pátttakenda.

${ }^{79}$ Sjá athugasemdakafla á bls. 309

${ }^{80}$ Færa má rök fyrir pví að betra hefði verið að hafa pessa spurningu opna og skipta í flokka eftir á, en rannsakenda pótti slík nákvæmni ópörf í pessu tilfelli.

${ }^{81}$ Sjá frekar í athugasemda kafla bls. 309
} 


\begin{tabular}{llcccc}
\hline \hline & Tíðni & Hlutfall (\%) & Gilt hlutfall (\%) & Uppsafnað hlutfall (\%) \\
\hline Gilt & 21-35 ára & 19 & 16.4 & 16.4 & 16.4 \\
& 36-45 ára & 43 & 37.1 & 37.1 & 53.4 \\
& $46-55$ ára & 29 & 25.0 & 25.0 & 78.4 \\
& $56-65$ ára & 22 & 19.0 & 19.0 & 97.4 \\
66 ára $<$ & 3 & 2.6 & 2.6 & 100.0 \\
Samtals & 116 & 100.0 & 100.0 & \\
\hline \hline
\end{tabular}

Pátttakendur voru spurðir hvaða menntun peir hefou. Gefin var kostur á bví að velja meira en einn valmöguleika, en flestir gáfu einungis upp hæsta menntunarstig.

Tafla 28 Hvaða menntun hefur pú ?

\begin{tabular}{lcc}
\hline \hline & Tíðni & Hlutfall (\%) \\
\hline Grunnskólapróf & 1 & $.9 \%$ \\
Stúdentspróf & 18 & $15.5 \%$ \\
Háskólapróf & 54 & $46.6 \%$ \\
Verkmenntun í byggingaiðnaði & 40 & $34.5 \%$ \\
Annað & 3 & $2.6 \%$ \\
\hline \hline
\end{tabular}

\subsection{6 Ánægja viðskiptavinar}

Gæði verks felast í pví að kröfum viðskiptavinar séu fullnægt. Pví er afar mikilvægt að ánægja viðskiptavinar sé mæld til að meta pað hvort tilætluðum gæðum hafi verið náð. Verkkauparnir, sem eru í pessu tilfelli hinir eiginlegu viðskiptavinur voru spurðir annars vegar hvort peir væru ánægðir með framkvæmd verksins í heild og hins vegar hvort peir væru ánægðir með framkvæmd verksins sem umræddur verktaki vann.

Hlutfall pátttakenda sem voru mjög ánægðir með framkvæmd verksins í heild er $42 \%$ en ekki nema rúmlega $27 \%$ pátttakenda voru mjög ánægðir með framkvæmd verksins sem umræddur verktaki vann. Pennan mun má skýra með pví að hjá stærstum hluta pátttakenda var um fagverk að ræða, p.e. að verkkaupi réð til sín verktaka á hverju fagsviði fyrir sig og má pví ætla að margir pættir, óháðir vinnu umrædds verktaka, geti haft áhrif á ánægju verkkaupa með framkvæmd verksins í heild.

Ef hlutfall peirra verkkaupa sem svöruðu að peir væru mjög eða frekar ánægðir með framkvæmd verksins í heild er tekið saman spannar pað $81 \%$ pátttakenda og hlutfall verkkaupa sem svöruðu að peir mjög eða frekar ánægðir með framkvæmd verksins hjá umræddum verktaka spannar rúmlega 66\% pátttakenda. Pessar tölur gefa til kynna að stærstu hluti verkkaupa sé ánægður með störf verktaka á Íslandi en engu að síður eru ofangreind hlutföll ekki nógu há að mati skýrsluhöfundar.

Ef hlutfall pátttakenda sem svöruðu að peir væru hvorki ánægðir né óánægðir, frekar- og mjög óánægðir með framkvæmd verksins í heild er tekið saman spannar bað rétt um 19\% svarenda á meðan sami hópur er 210 
tæplega 34\% svarenda pegar verkkaupar eru spurðir um ánægju með framkvæmd verksins hjá umræddum verktaka. Eins og áður má skýra pennan mun að hluta til með pví að í mörgum tilfellum var um fagverk að ræða par sem margir fleiri verktakar komu við sögu í framkvæmd verksins.

\section{Tafla 0.29 Hversu áncegð/ur eða óáncegð/ur ertu með framkvaemd verksins í heild ?}

\begin{tabular}{llcccc}
\hline \hline & Tíðni & Hlutfall (\%) & Gilt hlutfall (\%) & Uppsafnað hlutfall (\%) \\
\hline Gilt & Mjög ánægð/ur & 49 & 42.2 & 42.2 & 42.2 \\
& Frekar ánægð/ur & 45 & 38.8 & 38.8 & 81.0 \\
& Hvorki ánægð/ur né & 14 & 12.1 & 12.1 & 93.1 \\
óánægð/ur & & & & \\
Frekar óánægð/ur & 5 & 4.3 & 4.3 & 100.0 \\
Mjög óánægð/ur & 3 & 2.6 & 2.6 & \\
Samtals & 116 & 100.0 & 100.0 & \\
\hline \hline
\end{tabular}

Tafla 0.30 Hversu ánaegð/ur eða óánaegð/ur ertu með framkvaemd verksins sem umraeddur verktaki vann?

\begin{tabular}{llcccc}
\hline \hline & Tíðni & Hlutfall (\%) & Gilt hlutfall (\%) & Uppsafnað hlutfall (\%) \\
\hline Gilt & Mjög ánægð/ur & 32 & 27.6 & 27.6 & 27.6 \\
& Frekar ánægð/ur & 45 & 38.8 & 38.8 & 66.4 \\
& Hvorki ánægð/ur né & 21 & 18.1 & 18.1 & 84.5 \\
& óánægð/ur & & & & \\
& Frekar óánægð/ur & 15 & 12.9 & 12.9 & 100.0 \\
Mjög óánægð/ur & 3 & 2.6 & 2.6 & \\
Samtals & 116 & 100.0 & 100.0 & \\
\hline \hline
\end{tabular}

Pátttakendur voru spurðir hvort pað væri einhver páttur sem stæði upp úr við framkvæmdina sem peir væru ósáttir við. Rúmlega 40\% svöruðu pví játandi að svo væri.

\section{Tafla 0.31 Er pað einhver einn páttur sem stendur upp úr sem pú ert ósátt/ur við ?}

\begin{tabular}{llcccc}
\hline \hline & & Tíðni & Hlutfall (\%) & Gilt hlutfall (\%) & Uppsafnað hlutfall (\%) \\
\hline Gilt & Já & 47 & 40.5 & 40.5 & 40.5 \\
& Nei & 69 & 59.5 & 59.5 & 100.0 \\
& Samtals & 116 & 100.0 & 100.0 & \\
\hline \hline
\end{tabular}

Peir sem svöruðu játandi voru í framhaldinu spurðir opinnar spurningar um pað hvaða páttur hafi staðið upp úr sem viðkomandi hafi verið mest ósátt/ur við. Svör pátttakenda við peirri spurningu er að finna á bls. 415, en hér eru nokkur dæmi um pað sem nefnt var: 
- „ósáttur við framkvoemdarhraða og gallaðar einingar"

- „dýrara en til stóð“

- „frágangur ekki nógu góður hjá verktaka“

- „kastað til höndunum“

- „lokafrágangur“"
- „, kostnaður og tími töluvert meiri“

- „undirverktakar hjá aðalverktaka“

- „tímaácetlun“

- „hönnunin“

\subsection{Framkvæmd}

Pátttakendur voru spurðir hvort byggingastjóri ${ }^{82}$ hafi séð um yfirstjórn verksins ásamt pví hvort peir hefðu sjálfir verið byggingastjórar. Ástæðan fyrir pessari spurningu var aðallega til að kanna hvort byggingastjórinn væri meira til skrauts frekar en stuðnings í sjálfri framkvæmdinni.

Í 58\% tilfella sá byggingastjórinn alfarið um yfirstjórn verksins og í rúmlega 15\% tilfella sá hann að hluta til um yfirstjórn. Eftir standatæplega $27 \%$ tilfella par sem byggingastjórinn virðist einungis hafa verðið „byggingastjóri““ að nafninu til.

\section{Tafla 0.33 Sá byggingastjóri um yfirstjórn verksins?}

\begin{tabular}{llcccc}
\hline \hline & Tíðni & Hlutfall (\%) & Gilt hlutfall (\%) & Uppsafnað hlutfall (\%) \\
\hline Gilt & Að hluta & 18 & 15.5 & 15.5 & 15.5 \\
& Já & 67 & 57.8 & 57.8 & 73.3 \\
& Nei & 31 & 26.7 & 26.7 & 100.0 \\
& Samtals & 116 & 100.0 & 100.0 & \\
\hline \hline
\end{tabular}

Tæplega 14\% verkkaupa voru sjálfir byggingastjórar. Peir verkkaupar sem voru sjálfir byggingastjórar voru ekki spurðir að næstu premur spurningum heldur voru peir næst beðnir um að svara spurningu um tegund verktöku.

Tafla 0.34 Var svarandi sjálfur byggingastjóri ?

\begin{tabular}{llcccc}
\hline \hline & & Tíðni & Hlutfall (\%) & Gilt hlutfall (\%) & Uppsafnað hlutfall (\%) \\
\hline Gilt & Já & 16 & 13.8 & 13.8 & 13.8 \\
& Nei & 100 & 86.2 & 86.2 & 100.0 \\
& Samtals & 116 & 100.0 & 100.0 & \\
\hline \hline
\end{tabular}

\footnotetext{
${ }^{82}$ Pað virtist oft vera samkomulag milli pess sem er skráður byggingastjóri og pess sem raunverulega stjórnar verkinu að skráður byggingastjóri sé ekki að stjórna.
} 
Peir pátttakendur sem voru ekki sjálfir byggingastjórar voru spurðir hvort peim pætti byggingastjóri hafa verið nægilega mikið til staðar. Petta var aðallega gert til að kanna hvort pessi páttur væri áhrifavaldur á ánægju pátttakenda. Rúmlega $21 \%$ svarenda $^{83}$ fannst byggingastjóri ekki vera nægilega mikið til staðar. Borið saman við hlutfall tilfella par sem byggingastjóri kom ekki nálægt stjórn verksins gefur pað til kynna að í mörgum tilfellum hafi pað verið samkomulagsatriði milli verkkaupa og byggingastjóra að sá síðarnefndi væri ekki meira til staðar.

Tafla 0.35 Finnst pér byggingastjóri hafa verið nagilega mikið til staðar?

\begin{tabular}{llcccc}
\hline \hline & & Tíðni & Hlutfall (\%) & Gilt hlutfall (\%) & Uppsafnað hlutfall (\%) \\
\hline Gilt & Já & 78 & 67.2 & 78.8 & 78.8 \\
& Nei & 21 & 18.1 & 21.2 & 100.0 \\
& Samtals & 99 & 85.3 & 100.0 & \\
Vantar & & 17 & 14.7 & & \\
Samtals & & 116 & 100.0 & & \\
\hline \hline
\end{tabular}

Pátttakendur voru spurðir hvort peir hefðu sjálfir verðið með yfirstjórn verksins. Rúmlega 43\% sögðu að svo væri og 22\% sögðust hafa verið með yfirstjórn að hluta.

Tafla 0.36 Sá svarandi sjálfur um yfirstjórn verksins?

\begin{tabular}{llcccc}
\hline \hline & & Tíðni & Hlutfall (\%) & Gilt hlutfall (\%) & Uppsafnað hlutfall (\%) \\
\hline Gilt & Að hluta & 26 & 22.4 & 22.4 & 22.4 \\
& Já & 51 & 44.0 & 44.0 & 66.4 \\
& Nei & 39 & 33.6 & 33.6 & 100.0 \\
& Samtals & 116 & 100.0 & 100.0 & \\
\hline \hline
\end{tabular}

Samkvæmt niðurstöðum dreifðist ánægja verkkaupa með byggingastjóra á pann veg að 46\% svöruðu í og undir meðallagi, p.e. að peir væru hvorki ánægðir né óánægðir, frekar- eða mjög óánægðir sem gefur til kynna að ýmislegt megi lagfara á pví sviði ${ }^{84}$

8317 svör eru flokkuð sem „vantar“ en par af eru 16 pátttakendur sem ekki svöruðu vegna pess að peir voru sjálfir byggingastjórar.

${ }^{84}$ Skoða athugasemda kafla á bls. 244 vegna sérstakra athugasemda fyrir pennan lið. 


\begin{tabular}{llcccc}
\hline \hline & & Tíðni & Hlutfall (\%) & Gilt hlutfall (\%) & Uppsafnað hlutfall (\%) \\
\hline Gilt & Mjög ánægð/ur & 20 & 17.2 & 20.0 & 20.0 \\
& Frekar ánægð/ur & 34 & 29.3 & 34.0 & 54.0 \\
& Hvorki ánægð/ur né & 27 & 23.3 & 27.0 & 81.0 \\
& óánægð/ur & & & & \\
& Frekar óánægð/ur & 12 & 10.3 & 12.0 & 100.0 \\
& Mjög óánægð/ur & 7 & 6.0 & 7.0 & \\
& Samtals & 100 & 86.2 & 100.0 & \\
Vantar & & 16 & 13.8 & & \\
Samtals & & 100.0 & & \\
\hline \hline
\end{tabular}

Verkkaupar voru spurðir um tegund verktöku og var pá notast við skilgreiningu sem sjá má í kafla um skilgreiningar á bls. 414. Í tæplega 64\% tilfella voru framkvæmdirnar unnar sem fagverk sem gefur ákveðna hugmynd um pað að hátt hlutfall verka séu ekki mjög stórar framkvæmdir ${ }^{85}$.

Tafla 0.38 Tegund verktöku?

\begin{tabular}{llcccc}
\hline \hline & Tíðni & Hlutfall (\%) & Gilt hlutfall (\%) & Uppsafnað hlutfall (\%) \\
\hline Gilt & Aðalverk & 23 & 19.8 & 19.8 & 19.8 \\
& Alverk & 18 & 15.5 & 15.5 & 35.3 \\
& Fagverk & 74 & 63.8 & 63.8 & 99.1 \\
& Markverk & 1 & .9 & .9 & 100.0 \\
& Samtals & 116 & 100.0 & 100.0 & \\
\hline \hline
\end{tabular}

Peir pátttakendur sem svöruðu pví til að verkið hafi verið unnið sem al-, aðal-, eða markverk ${ }^{86}$ voru pví næst spurðir hversu vel/illa peim pætti yfirstjórnandi verksins uppfylla skyldu sína sem milligöngumaður um samskipti við verktaka. Flestir, eða rúmlega 38\% fannst yfirstjórnandi standa sig mjög vel hvað petta varðar. Rúmlega 52\% svarenda voru mjög eða frekar ánægðir.

\footnotetext{
${ }^{85}$ Sjá frekar kafla um athugasemdir á bls. 244

${ }^{86}$ Peir pátttakendur sem sögðu verkið hafa verið unnið sem fagverk eru flokkaðir undir ,vantar“ 214
} 
Tafla 0.39 Hversu vel/illa fannst pér yfirstjórnandi verksins uppfylla skyldu sína sem milligöngumaður um samskipti pín við verktaka?

\begin{tabular}{llcccc}
\hline \hline & & Tíðni & Hlutfall (\%) & Gilt hlutfall (\%) & Uppsafnað hlutfall (\%) \\
\hline Gilt & Mjög vel & 16 & 13.8 & 38.1 & 38.1 \\
& Frekar vel & 6 & 5.2 & 14.3 & 52.4 \\
& Hvorki vel né illa & 13 & 11.2 & 31.0 & 83.3 \\
& Frekar illa & 3 & 2.6 & 7.1 & 90.5 \\
& Mjög illa & 4 & 3.4 & 9.5 & 100.0 \\
& Samtals & 42 & 36.2 & 100.0 & \\
Vantar & 74 & 63.8 & & \\
Samtals & 116 & 100.0 & & \\
\hline \hline
\end{tabular}

\subsection{8 Áætlanir}

Áætla má að raunhæfar forsendur fyrir umfangi og verðlagningu framkvæmda séu stór páttur í ánægju verkkaupa. Óraunhæfar væntingar sem byggðar eru á fölskum forsendum draga pví úr gæðum framkvæmda. Spurningar varðandi tíma- og kostnaðaráætlanir voru pví lagðar fyrir pátttakendur ${ }^{87}$.

Verkkaupar voru spurðir hversu ánægðir peir væru með tímastjórnun verksins sem umræddur verktaki vann. Ef niðurstöður eru teknar saman fæst að hlutfall peirra verkkaupa sem töldu sig vera mjög eða frekar ánægða með tímastjórnun verksins spannar tæplega 51\% svarenda á meðan hópur peirra sem kváðust vera frekar eða mjög óánægða spannar tæplega 28\% svarenda. Pessar niðurstöður gefa til kynna að pátt tímastjórnunar megi bæta talsvert á meðal verktaka.

Tafla 0.40 Hversu ánaegð/ur eða óáncegð/ur ertu með tímastjórnun verksins sem umraeddur verktaki vann?

\begin{tabular}{llcccc}
\hline \hline & Tíðni & Hlutfall (\%) & Gilt hlutfall (\%) & Uppsafnað hlutfall (\%) \\
\hline Gilt & Mjög ánægð/ur & 28 & 24.1 & 24.1 & 24.1 \\
& Frekar ánægð/ur & 31 & 26.7 & 26.7 & 50.9 \\
& Hvorki ánægð/ur né & 25 & 21.6 & 21.6 & 72.4 \\
& óánægð/ur & & & & \\
& Frekar óánægð/ur & 11 & 18.1 & 18.1 & 100.0 \\
Mjög óánægð/ur & 116 & 100.0 & 10.5 & \\
Samtals & &
\end{tabular}

Rúmlega 46\% pátttakenda sögðu verktaka hafa lagt fram skriflega tímaáætlun, en tæplega 54\% sögðu að slíkt hafi ekki verið gert. Gefa pessar niðurstöður til kynna að pað sé síður en svo regla að verktakar leggi fram skriflega tímaáætlun.

\footnotetext{
${ }^{87}$ Sjá tengingar við staðla í par til gerðum kafla á bls. 318
} 
Tafla 0.41 Lagði umraeddur verktaki fram skriflega tímaáatlun í upphafi verks?

\begin{tabular}{llcccc}
\hline \hline & & Tíðni & Hlutfall (\%) & Gilt hlutfall (\%) & Uppsafnað hlutfall (\%) \\
\hline Gilt & Já & 54 & 46.6 & 46.6 & 46.6 \\
& Nei & 62 & 53.4 & 53.4 & 100.0 \\
& Samtals & 116 & 100.0 & 100.0 & \\
\hline \hline
\end{tabular}

Ef verkkaupum í einstaklings- og fyrirtækja- verkkaupa sést að greinilegur munur er á háttarlagi. En tæplega $26 \%$ einstaklings-verkkaupa sagði verktaka hafa lagt fram skriflega tímaáætlun samanborið við rúmlega $83 \%$ fyrirtækja-verkkaupa.

Tafla 42 Lagði umrceddur verktaki fram skriflega tímaácetlun í upphafi verks - með tilliti til einstaklings og fyrirtakja verkkaupa

\begin{tabular}{|c|c|c|c|c|c|c|}
\hline \multicolumn{3}{|l|}{ fyrir_einst } & Tíðni & Hlutfall (\%) & Gilt hlutfall (\%) & Uppsafnað hlutfall (\%) \\
\hline \multirow[t]{3}{*}{ Einstaklingur } & Gilt & Já & 19 & 25,7 & 25,7 & 25,7 \\
\hline & & Nei & 55 & 74,3 & 74,3 & 100,0 \\
\hline & & Samtals & 74 & 100,0 & 100,0 & \\
\hline \multirow[t]{3}{*}{ Fyrirtæki } & Gilt & Já & 35 & 83,3 & 83,3 & 83,3 \\
\hline & & Nei & 7 & 16,7 & 16,7 & 100,0 \\
\hline & & Samtals & 42 & 100,0 & 100,0 & \\
\hline
\end{tabular}

Pegar peir pátttakendur sem sögðu verktaka hafa lagt fram skriflega tímaáætlun voru spurðir hversu vönduð peim hafi pótt tímaáætlunin voru tæplega $\mathbf{5 6 \%}$ sem svöruðu að tímaáæltunin hafi verið mjög eða frekar vönduð en tæplega $\mathbf{2 8 \%}$ svarenda finnst tímaáætlunin hafa verið frekar eða mjög óvönduð.

Tafla 0.43 Hversu vönduð/óvönduð var tímaácetlunin?

\begin{tabular}{llcccc}
\hline \hline \multirow{2}{*}{ Gilt } & Tíðni & Hlutfall (\%) & Gilt hlutfall (\%) & Uppsafnað hlutfall (\%) \\
& Mjög vönduð & 12 & 10.3 & 22.2 & 22.2 \\
& Frekar vönduð & 18 & 15.5 & 33.3 & 55.6 \\
& Hvorki vönduð né óvönduð & 9 & 7.8 & 16.7 & 72.2 \\
& Frekar óvönduð & 12 & 10.3 & 22.2 & 94.4 \\
& Mjög óvönduð & 3 & 2.6 & 5.6 & 100.0 \\
& Samtals & 54 & 46.6 & 100.0 & \\
Vantar & 62 & 53.4 & & \\
Samtals & & 100.0 & & \\
\hline \hline
\end{tabular}

Peir pátttakendur sem sögðu verktaka hafa lagt fram skriflega tímaáætlun ${ }^{88}$ voru spurðir hversu vel tímaáætlunin sem verktaki lagði fram hafi verið kynnt fyrir peim. Ekki nema rétt rúmlega $\mathbf{9 \%}$ svöruðu pví til að að tímaáætlunin hafi verið kynnt frekar illa fyrir sér og engum fannst hún hafa verið kynnt mjög illa fyrir sér.

\footnotetext{
${ }^{88}$ Svörin 62 sem eru flokkuð undir „vantar“ eru svör pátttakenda sem sögðu verkkaupa ekki hafa lagt fram skriflega tímaáætlun. 216
} 


\begin{tabular}{llcccc}
\hline \hline & & Tíðni & Hlutfall (\%) & Gilt hlutfall (\%) & Uppsafnað hlutfall (\%) \\
\hline Gilt & Mjög vel & 12 & 10.3 & 22.2 & 22.2 \\
& Frekar vel & 20 & 17.2 & 37.0 & 59.3 \\
& Hvorki vel né illa & 17 & 14.7 & 31.5 & 90.7 \\
& Frekar illa & 5 & 4.3 & 9.3 & 100.0 \\
& Mjög illa & 0 & 0 & 0 & 100.0 \\
& Samtals & 54 & 46.6 & 100.0 & \\
Vantar & 62 & 53.4 & & \\
Samtals & & 116 & 100.0 & & \\
\hline \hline
\end{tabular}

Sami hópur pátttakenda ${ }^{89}$ var spurður hvort tímaáætlunin hafi verið uppfærð og endurskoðuð reglulega. Athyglisvert er hve stór hluti svarenda kvaðst ekki vita hvort tímaáætlunin hafi verið uppfærð eða ekki. Líklegt er að í peim tilvikum hafi áætlunin ekki verið uppfærð.

Rúmlega 43\% svarenda töldu að tímaáætlunin hafi verið endurskoðuð og uppfærð reglulega og voru peir í kjölfarið spurðar opinnar spurningar hversu reglulega tímaáætlunin hafi verið uppfærð. 13\% peirra sagði endurskoðunina vera sjaldnar en mánaðarlega, rúmlega 65\% sagði hana vera mánaðarlega og tæplega $21 \%$ sögðu hana vera sjaldnar en mánaðarlega.

Tafla 0.45 Var tímaácetlunin endurskoðuð og uppfaerð reglulega?

\begin{tabular}{llcccc}
\hline \hline & & Tíðni & Hlutfall (\%) & Gilt hlutfall (\%) & Uppsafnað hlutfall (\%) \\
\hline Gilt & Já & 19 & 16.4 & 43.2 & 43.2 \\
& Nei & 10 & 8.6 & 22.7 & 65.9 \\
& Veit ekki & 15 & 12.9 & 34.1 & 100.0 \\
& Samtals & 44 & 37.9 & 100.0 & \\
Vantar & & 72 & 62.1 & & \\
Samtals & & 116 & 100.0 & & \\
\hline \hline
\end{tabular}

Allir pátttakendur voru svo spurðir hvort verkið hefði farið fram úr tímaáætlun hjá umræddum verktaka. Ef verktaki hafoi ekki lagt fram skriflega tímaáætlun var gert ráð fyrir að hann hafi engu að síður gert munlega tímaáætlun sem hann hafi greint verkkaupa frá. Niðurstöður sýna að ekki nema tæplega $21 \%$ svarenda telja að framkvæmdin sé samkvæmt tímaáætlun ${ }^{90}$. Rúmlega $15 \%$ svöruðu pví til að framkvæmdin væri lítillega farin fram úr tímaáætlun en meiri hluti svarenda eða tæplega $64 \%$ fannst framkvæmdin vera komin nokkuð, mikið eða mjög mikið fram úr tímaáætlun.

\footnotetext{
${ }^{89}$ Eins og áður eru pví 62 svör flokkuð undir „vantar““

${ }^{90}$ Sjá kafla um athugasemdir á bls. 244
} 


\begin{tabular}{llcccc}
\hline \hline & Tíðni & Hlutfall (\%) & Gilt hlutfall (\%) & Uppsafnað hlutfall (\%) \\
\hline Gilt & Mjög mikið & 18 & 15.5 & 15.5 & 15.5 \\
& Mikið & 23 & 19.8 & 19.8 & 35.3 \\
& Nokkuð & 33 & 28.4 & 28.4 & 63.8 \\
& Lítið & 18 & 15.5 & 15.5 & 79.3 \\
& Ekkert & 24 & 20.7 & 20.7 & 100.0 \\
& Samtals & 116 & 100.0 & 100.0 & \\
\hline \hline
\end{tabular}

Pátttakendur sem svöruðu að verkið hefði farið fram úr tímaáætlun voru spurðir hvaða ástæðu peir teldu að stæði að baki töfunum. Algengasta svarið var í tengslum við efnahagshrunið og annir hjá verktaka. Í heild sinni má sjá svör pátttakenda á bls. 427 en hér má sjá nokkur lýsandi dæmi:

Tafla 0.47 Deemi um svör við spurningunni: Hvaða ástaeðu telur bú að sé á baki tafa?

• „Hrunið. Ekki að sakast við verktakann.“

- „Allt of mikið að gera hjá verktaka

- Miklar annir hjá verktaka"

- „Flóknara en var séð fyrir í byrjun - og rangar magntölur í byrjun “

- „Lélegt utanumhald og stjórnleysi hjá verktaka
- „óviðráðanlegar aðstceður eins og frost og annað“"

- „ömurlegir verktakar“

- „vanstjórn“"

• ,allt of mikið að gera hjá öllum“

- „,margt. Illa skipulagt. Undirverktakar lélegir."

Pátttakendur voru spurðir hversu ánægðir peir væru með fjármagnsstreymi ${ }^{91}$ verksins sem umræddur verktaki vann. Flestir svöruðu pví til að peir væru hvorki ánægðir né óánægðir, eða rúmlega 48\% svarenda. Tæplega 40\% sögðust vera annað hvort eða frekar ánægðir og ekki nema rúmlega $12 \%$ voru mjög eða frekar óánægðir. Samanborið við ánægju svarenda með tímastjórnun verksins pá virðast verkkaupar vera sáttari með pennan lið, prátt fyrir prengingar í efnahagslífinu undanfarið.

\footnotetext{
${ }^{91}$ Með fjármagnsstreymi er átt við flæði greiðslna.
} 218 
Tafla 0.48 Hversu ánagd/ur eða óánaegð/ur ertu með fjármagnsstreymi verksins sem umraeddur verktaki vann?

\begin{tabular}{llcccc}
\hline \hline & Tíðni & Hlutfall (\%) & Gilt hlutfall (\%) & Uppsafnað hlutfall (\%) \\
\hline Gilt & Mjög ánægð/ur & 16 & 13.8 & 13.8 & 13.8 \\
& Frekar ánægð/ur & 30 & 25.9 & 25.9 & 39.7 \\
& Hvorki ánægð/ur né & 56 & 48.3 & 48.3 & 87.9 \\
óánægð/ur & & & & \\
Frekar óánægð/ur & 11 & 9.5 & 9.5 & 100.0 \\
Mjög óánægð/ur & 3 & 2.6 & 2.6 & \\
Total & 116 & 100.0 & 100.0 & \\
\hline \hline
\end{tabular}

Tæplega 53\% pátttakenda sögðu verktaka hafa lagt fram skriflega greiðsluáætlun, en næstum 48\% sögðu verktaka ekki hafa lagt fram skriflega greiðsluáætlun. Gefa pessar niðurstöður til kynna að pað sé síður en svo regla að verktakar leggi fram skriflega greiðsluáætlun í byrjun verks.

\section{Tafla 0.49 Lagði umraeddur verktaki fram skriflega greiðsluácetlun í upphafi verks?}

\begin{tabular}{llcccc}
\hline \hline & & Tíoni & Hlutfall (\%) & Gilt hlutfall (\%) & Uppsafnað hlutfall (\%) \\
\hline Gilt & Já & 61 & 52.6 & 52.6 & 52.6 \\
& Nei & 55 & 47.4 & 47.4 & 100.0 \\
& Samtals & 116 & 100.0 & 100.0 & \\
\hline \hline
\end{tabular}

Meðal einstaklings- verkkaupa var tæplega $41 \%$ sem sögðu verktaka hafa lagt fram skriflega greiðsluáætlun en staðan er talsvert bjartari meðal fyrirtækja-verkkaupa en tæplega $73 \%$ peirra sögðu verktaka hafa lagt fram skriflega greiðsluáætlun.

Tafla 50 Lagði umraeddur verktaki fram skriflega greiðsluácetlun í upphafi verks - með tilliti til einstaklings-og fyrirtcekja- verkkaupa

\begin{tabular}{|c|c|c|c|c|c|c|}
\hline fyrir_einst & & & Tíoni & Hlutfall (\%) & Gilt hlutfall (\%) & Uppsafnað hlutfall (\%) \\
\hline \multirow[t]{3}{*}{ Einstaklingur } & Gilt & Já & 30 & 40.5 & 40.5 & 40.5 \\
\hline & & Nei & 44 & 59.5 & 59.5 & 100.0 \\
\hline & & Samtals & 74 & 100.0 & 100.0 & \\
\hline \multirow[t]{3}{*}{ Fyrirtæki } & Gilt & Já & 31 & 73.8 & 73.8 & 73.8 \\
\hline & & Nei & 11 & 26.2 & 26.2 & 100.0 \\
\hline & & Samtals & 42 & 100.0 & 100.0 & \\
\hline
\end{tabular}

Tæplega 15\% svarenda pótti greiðsluáætlun umrædds verktaka vera mjög eða frekar óvönduð. Flestir svarendur töldu greiðsluáætlunina vera annað hvort mjög eða frekar vandaða, en sá hópur spannar rúmlega $52 \%$ svarenda. 


\begin{tabular}{llcccc}
\hline \hline \multirow{2}{*}{ Gilt } & Tíðni & Hlutfall (\%) & Gilt hlutfall (\%) & Uppsafnað hlutfall (\%) \\
& Mjög vönduð & 12 & 10.3 & 19.7 & 19.7 \\
& Frekar vönduð & 20 & 17.2 & 32.8 & 52.5 \\
& Hvorki vönduð né óvönduð & 20 & 17.2 & 32.8 & 85.2 \\
& Frekar óvönduð & 8 & 6.9 & 13.1 & 98.4 \\
& Mjög óvönduð & 1 & .9 & 1.6 & 100.0 \\
& Samtals & 61 & 52.6 & 100.0 & \\
Vantar & & 45 & 47.4 & & \\
Samtals & & 116 & 100.0 & & \\
\hline \hline
\end{tabular}

Líkt og gert var vegna tímaáætlunar voru peir pátttakendur sem sögðu verktaka hafa lagt fram skriflega greiðsluáætlun spurðir hversu vel áætlunin hafi verið kynnt fyrir peim. Ekki nema rétt rúmlega 3\% svöruðu pví til að að tímaáætlunin hafi verið kynnt frekar illa fyrir sér og engum fannst hún hafa verið kynnt mjög illa fyrir sér.

Tafla 0.52 Hversu vel/illa var greiðsluácetlunin kynnt fyrir pér?

\begin{tabular}{llcccc}
\hline \hline Gilt & & Tíðni & Hlutfall (\%) & Gilt hlutfall (\%) & Uppsafnað hlutfall (\%) \\
& Mjög vel & 13 & 11.2 & 21.3 & 21.3 \\
& Frekar vel & 20 & 17.2 & 32.8 & 54.1 \\
& Hvorki vel né illa & 26 & 22.4 & 42.6 & 96.7 \\
& Frekar illa & 2 & 1.7 & 3.3 & 100.0 \\
& Mjög illa & 0 & 0 & 0 & 100.0 \\
& Samtals & 61 & 52.6 & 100.0 & \\
Vantar & & 55 & 47.4 & & \\
Samtals & & 116 & 100.0 & & \\
\hline \hline
\end{tabular}

Sami hópur pátttakenda, p.e. sá hópur sem svarað pví til að verktaki hefơi lagt fram skriflega greiðsluáætlun, var spurður hvort greiðsluáætlunin hafi verið uppfærð og endurskoðuð reglulega. Líkt og fékkst út frá niðurstöðum um endurskoðun tímaáætlunar reyndist stór hluti svarenda ekki vita svarið við pessari spurningu. Dregin er sú ályktun að í flestum slíkum tilfellum að greiðsluáætlunin hafi ekki verið endurskoðuð eða uppfærð. Í 25\% tilfella ${ }^{92}$ töldu verkkaupar að greiðsluáætlunin hafi verið endurskoðuð.

92 Stærð verks hefur vissulega áhrif á pað hvort nauðsynlegt sé að endurskoða áætlanir, en eins og fram kemur í athugasemdakafla hefði verið fróðlegt að hafa upplýsingar um slíkt. 


\begin{tabular}{llcccc}
\hline \hline & & Tíðni & Hlutfall (\%) & Gilt hlutfall (\%) & Uppsafnað hlutfall (\%) \\
\hline Gilt & Já & 14 & 12.1 & 24.6 & 24.6 \\
& Nei & 20 & 17.2 & 35.1 & 59.6 \\
& Veit ekki & 23 & 19.8 & 40.4 & 100.0 \\
& Samtals & 57 & 49.1 & 100.0 & \\
Vantar & & 59 & 50.9 & & \\
Samtals & & 116 & 100.0 & & \\
\hline \hline
\end{tabular}

96\% svarenda sögðu að verkið hefði verið greitt eftir framvindu.

Tafla 0.54 Var greitt eftir framvindu verks?

\begin{tabular}{llcccc}
\hline \hline & & Tíðni & Hlutfall (\%) & Gilt hlutfall (\%) & Uppsafnað hlutfall (\%) \\
\hline Gilt & 9 & 7.8 & 7.8 & 7.8 \\
& & 103 & 88.8 & 88.8 & 96.6 \\
& Já & 4 & 3.4 & 3.4 & 100.0 \\
& Nei & 100.0 & 100.0 & \\
& Samtals & 116 & 10.0 & \\
\hline \hline
\end{tabular}

Allir pátttakendur voru svo spurðir hvort verkið hefði farið fram úr greiðsluáætlun ${ }^{93}$ hjá umræddum verktaka. Ef verktaki hafði ekki lagt fram skriflega greiðsluáætlun var gert ráð fyrir að hann hafi engu að síður gert munlega greiðsluáætlun sem hann hafi greint verkkaupa frá.

Niðurstöður sýna að tæplega 20\% svarenda telja að framkvæmdin sé samkvæmt greiðsluáætlun sem er allt of lágt hlutfall að mati skýrsluhöfundar. Rúmlega $22 \%$ svöruðu pví til að framkvæmdin væri lítillega farin fram úr greiðsluáætlun og spannar pví sá hluti svarenda sem svöruðu lítið eða ekkert rúmlega 42\% svarenda. 58\% svarenda fannst framkvæmdin vera komin nokkuð, mikið eða mjög mikið fram úr tímaáætlun. Að mati undirritaðar eru petta mjög sláandi tölur, en að pað verður að reiknast með inn í myndina að efnahagshrunið snerti margar framkvæmdir sem voru í úrtakinu og hefur pað vafalaust haft mikið að segja um pennan lið.

${ }^{93}$ Sjá athugasemda kafla bls. 240 


\begin{tabular}{llcccc}
\hline \hline & Tíðni & Hlutfall (\%) & Gilt hlutfall (\%) & Uppsafnað hlutfall (\%) \\
\hline Gilt & Mjög mikið & 8 & 6.9 & 6.9 & 6.9 \\
& Mikið & 13 & 11.2 & 11.2 & 18.1 \\
Nokkuð & 46 & 39.7 & 39.7 & 57.8 \\
& Lítið & 26 & 22.4 & 22.4 & 80.2 \\
Ekkert & 23 & 19.8 & 19.8 & 100.0 \\
Samtals & 116 & 100.0 & 100.0 & \\
\hline \hline
\end{tabular}

Pátttakendur sem svöruðu að verkið hefði farið fram úr greiðsluáætlun voru spurðir hvaða ástæðu peir teldu að stæði að baki. Algengasta svarið var í tengslum við efnahagshrunið. Í heild sinni má sjá svör pátttakenda á bls. 429 en hér má sjá nokkur lýsandi dæmi:

Tafla 0.56 Dcemi um svör við spurningunni: Hvaða ástceðu telur pú að sé á baki pess að greiðsluácetlun stóðst ekki?

• „Hrunið“

- ,yfirborgaðir..."

- „tafir“

- „Flóknara en í upphafi“
• ,Öll stjórnun mjög sloem “

- ,aukaverk sem voru ekki séð fyrir í byrjun og voru ekki inn i samning “

- „2007 annir hjá verktaka“

- „Magnaukning og vanstjórn“

Pátttakendur voru spurðir hvort einhver reikningur hefði komið á óvart hjá umræddum verktaka. Tæplega $21 \%$ svarenda sögðu að nokkrir, margir eða mjög margir reikningar hefðu komið á óvart við verklok. Út frá pessum niðurstöðum má draga pá ályktun að eitthvað sé um pað að verkkaupar séu ekki nægilega upplýstir um framkvæmdir. Hafa verður í huga að ekki nema 40\% pátttakenda svöruðu pessari spurningu.

Tafla 0.57 Kom einhver reikningur/ar á óvart við verklok hjá umraeddum verktaka?

\begin{tabular}{llcccc}
\hline \hline \multirow{2}{*}{ Gilt } & Tíðni & Hlutfall (\%) & Gilt hlutfall (\%) & Uppsafnað hlutfall (\%) \\
& Mjög margir & 2 & 1.7 & 4.2 & 4.2 \\
& Margir & 1 & .9 & 2.1 & 6.3 \\
& Nokkrir & 7 & 6.0 & 14.6 & 20.8 \\
& Fáir & 1 & .9 & 2.1 & 22.9 \\
& Engin & 37 & 31.9 & 77.1 & 100.0 \\
& Samtals & 48 & 41.4 & 100.0 & \\
Vantar & & 58 & 100.6 & & \\
Samtals & & 116 & & & \\
\hline \hline
\end{tabular}




\subsection{Verkfundir}

Áætla má að markvissir og vandaðir verkfundir séu mikilvægur páttur í ánægju viðskiptavina og farsælla framkvæmda.

Leitast var eftir pví að komast að pví hvaða háttarlag var milli verkkaupa og verktaka varðandi verkfundi. Ýmsar spurningar tengdar verkfundum voru lagðar fyrir verkkaupa.

Spurt var hvort verkkaupi hefði haft umsjónarmann ${ }^{94}$ sem sá um að framfylgja ákvæðum samningsins og ef svo var, hvaða menntun hann hefði.

Rétt rúmlega 29\% pátttakenda voru með sérstakan umsjónarmann sem sá um að umræddur verktaki framfylgdi ákvæðum samningsins.

Tafla 0.58 Hafðir pú umsjónarmann sem sá um að umraeddur verktaki framfylgdi ákvaeðm samningsins?

\begin{tabular}{llcccc}
\hline \hline & & Tíðni & Hlutfall (\%) & Gilt hlutfall (\%) & Uppsafnað hlutfall (\%) \\
\hline Gilt & Já & 34 & 29.3 & 29.3 & 29.3 \\
& Nei & 82 & 70.7 & 70.7 & 100.0 \\
& Samtals & 116 & 100.0 & 100.0 & \\
\hline \hline
\end{tabular}

Peir pátttakendur sem svöruðu að peir hefðu haft umsjónarmann voru spurðir hvort peir vissu hvaða menntun umsjónarmaðurinn hefðu og ef svo hvaða menntun. Svörin í heild sinni má sjá á bls. 430 en hér má sjá algeng/lýsandi svör:

Tafla 0.59 Dcemi um svör við spurningunni: Hvaða menntun hefur umsjónarmaðurinn?

- „Arkitekt“

- „Verkfrceðingur... “

- „Byggingameistari“

- „Byggingatceknifraeðingur“
- „Нӧnпиðиг“

- „Endurskoðandi. Feillinn kannski hér“

- „Húsasmíðameistari“

\footnotetext{
${ }^{94}$ Sjá betur skilgreiningu á umsjónarmanni á bls. 312
} 
Einnig var spurt hvort gert hafi verið samkomulag milli verkkaupa/umsjónarmanns og verktaka um reglubundna verkfundi peirra á milli. Niðurstöður sýna að rúmlega $40 \%$ svarenda sögðu að svo væri en tæplega $60 \%$ sögðu að svo hefði ekki verið. Hátt hlutfall peirra sem sögðu að slíkt samkomulag hafi ekki verið, byggist helst á pví hve stór hluti pátttakenda voru einstaklingar.

Tafla 0.60 Var gert samkomulag á milli pín/umsjónarmanns og umrædds verktaka um reglubundna verkfundi ?

\begin{tabular}{|c|c|c|c|c|c|}
\hline & & Tíoni & Hlutfall (\%) & Gilt hlutfall (\%) & Uppsafnað hlutfall (\%) \\
\hline \multirow[t]{3}{*}{ Gilt } & Já & 47 & 40.5 & 40.5 & 40.5 \\
\hline & $\mathrm{Nei}$ & 69 & 59.5 & 59.5 & 100.0 \\
\hline & Samtals & 116 & 100.0 & 100.0 & \\
\hline
\end{tabular}

Pátttakendur voru spurðir hvort haldnir hefðu verið verkfundir með umræddum verktaka á verktíma óháð pví hvort gert hafi verið samkomulag um reglubundna verkfundi ${ }^{95}$ og á sama tíma voru pátttakendur beðnir um að leggja mat á pað hvort verkfundirnir hafi verið formlegir eða óformlegir. Skilgreining á formlegum og óformlegum verkfundum má sjá á bls. 414. Skilgreiningin skilur eftir svigrúm fyrir verkkaupa til að leggja persónulegt mat á pað hvort fundirnir hafi verið nægjanlega formlegir til að geta flokkast sem slíkir.

Hafa ber í huga að í peim tilfellum sem verkkaupi og verktaki hittust ekki á verkfundum var í flestum tilfellum um að ræða íbúðarhúsnæði par sem verkkaupi mætti jafnvel daglega á verkstað til að fylgjast með. Раð er pví á endanum matsatriði hvort verkkaupi telji að eiginlegir verkfundir, óformlegir eða formlegir, hafi átt sér stað.

Tæplega 34\% pátttakenda svöruðu pví til að formlegir verkfundir hafi átt sér stað, rúmlega 48\% töldu að óformlegir fundir hafi átt sér stað og rúmlega 18\% töldu að engir verkfundir hafi átt sér stað.

Tafla 0.61 Voru haldnir verkfundir með umraeddum verktaka?

\begin{tabular}{llcccc}
\hline \hline & & Tíðni & Hlutfall (\%) & Gilt hlutfall (\%) & Uppsafnað hlutfall (\%) \\
\hline Gilt & Formlegir & 39 & 33.6 & 33.6 & 33.6 \\
& Óformlegir & 56 & 48.3 & 48.3 & 81.9 \\
& Nei & 21 & 18.1 & 18.1 & 100.0 \\
& Samtals & 116 & 100.0 & 100.0 & \\
\hline \hline
\end{tabular}

peir pátttakendur sem svöruðu pví til að haldnir hefðu verið óformlegir verkfundir voru jafnframt spurðir hvort peir hefou heldur kosið að hafa formlega verkfundi. Peir sem svöruðu bví til að engir verkfundir hefðu átt sér stað voru spurðir hvort peir hefðu viljað hafa formlega eða óformlega verkfundi. Rúmlega $36 \%$ hefðu kosið að hafa verkfundina með öðrum hætti.

\footnotetext{
${ }^{95}$ Sjá betur um petta í athugasemd kafla á bls. 241

224
} 


\begin{tabular}{llcccc}
\hline \hline & & Tíðni & Hlutfall (\%) & Gilt hlutfall (\%) & Uppsafnað hlutfall (\%) \\
\hline Gilt & Já & 28 & 24.1 & 36.4 & 36.4 \\
& Nei & 49 & 42.2 & 63.6 & 100.0 \\
& Samtals & 77 & 66.4 & 100.0 & \\
Vantar & & 39 & 33.6 & & \\
Samtals & & 116 & 100.0 & & \\
\hline \hline
\end{tabular}

Peir pátttakendur sem sögðu að haldnir hefðu verið verkfundir voru spurðir hversu títt peir hefðu verið yfir verktímann og má sjá svör pátttakenda við peirri spurningu á bls. 432.

Í rúmlega 8\% tilfella mættu svarendur ekki sjálfir á verkfundi en í tæplega 92\% voru svarendur alltaf með á verkfundum.

Tafla 0.63 Maettir pú á verkfundi?

\begin{tabular}{llcccc}
\hline \hline \multirow{2}{*}{ Gilt } & & Tíðni & Hlutfall (\%) & Gilt hlutfall (\%) & Uppsafnað hlutfall (\%) \\
& Alltaf & 87 & 75.0 & 91.6 & 91.6 \\
& Oft & 2 & 1.7 & 2.1 & 93.7 \\
& Stundum & 4 & 3.4 & 4.2 & 97.9 \\
& Sjaldan & 0 & 0.0 & 0.0 & 100.0 \\
& Aldrei & 2 & 1.7 & 2.1 & 100.0 \\
& Samtals & 95 & 81.9 & 100.0 & \\
Vantar & & 18.1 & & \\
Samtals & & 11 & 100.0 & & \\
\hline \hline
\end{tabular}

Spurt var hvort verkkaupi hafi einhvertíma kallað til verkfundar og hvort verkkaupi hafi verið boðaður á verkfund. Rúmlega 38\% svarenda sögðust aldrei hafa kallað til verkfundar en tæplega $62 \%$ sögðust stundum, oft eða alltaf hafa kallað til verkfunda.

\section{Tafla 0.64 Kallaðir pú til verkfundar pegar pér fannst tilefni til?}

\begin{tabular}{llcccc}
\hline \hline \multirow{6}{*}{ Gilt } & & Tíðni & Hlutfall (\%) & Gilt hlutfall (\%) & Uppsafnað hlutfall (\%) \\
& Alltaf & 23 & 19.8 & 24.5 & 24.5 \\
& Oft & 11 & 9.5 & 11.7 & 36.2 \\
& Stundum & 24 & 20.7 & 25.5 & 61.7 \\
& Aldrei & 36 & 31.0 & 38.3 & 100.0 \\
& Samtals & 94 & 81.0 & 100.0 & \\
Vantar & & 19.0 & & \\
Samtals & & 116 & 100.0 & & \\
\hline \hline
\end{tabular}

96 \$ \{piping text\} stendur fyrir „formlega“ ef svarið við spurningunni Voru haldnir verkfundir með umrceddum verktaka var „óformlegir“ en pað stendur fyrir „formlega eða óformlega““ ef svarið við sömu spurningu var „,nei““ 
Í tæplega 50\% tilfella voru svarendur alltaf boðaðir á verkfundi en í tæplega 31\% tilfellum voru svarendur aldrei boðaðir á verkfundi.

Tafla 0.65 Varst pú boðuð/aður á verkfundi?

\begin{tabular}{|c|c|c|c|c|c|}
\hline & & Tíoni & Hlutfall (\%) & Gilt hlutfall (\%) & Uppsafnað hlutfall (\%) \\
\hline \multirow[t]{5}{*}{ Gilt } & Alltaf & 47 & 40.5 & 49.5 & 49.5 \\
\hline & Stundum & 14 & 12.1 & 14.7 & 64.2 \\
\hline & Sjaldan & 5 & 4.3 & 5.3 & 69.5 \\
\hline & Aldrei & 29 & 25.0 & 30.5 & 100.0 \\
\hline & Samtals & 95 & 81.9 & 100.0 & \\
\hline \multicolumn{2}{|c|}{ Vantar } & 21 & 18.1 & & \\
\hline \multicolumn{2}{|c|}{ Samtals } & 116 & 100.0 & & \\
\hline
\end{tabular}

Einnig var spurt hversu vel hafi verið fjallað um páverandi stöðu á verkfundunum miðað við tíma- og fjárhagsáætlun. Tæplega 22\% svarenda sagði að sjaldan eða aldrei hefði verið fjallað um slíkt en tæplega $40 \%$ svaraði alltaf eða oft.

Tafla 0.66 Var fjallað um stöðu verks miðað við tíma- og fjárhagsáatlun á verkfundunum ?

\begin{tabular}{llcccc}
\hline \hline \multirow{6}{*}{ Gilt } & & Tíðni & Hlutfall (\%) & Gilt hlutfall (\%) & Uppsafnað hlutfall (\%) \\
& Alltaf & 26 & 22.4 & 28.0 & 28.0 \\
& Oft & 11 & 9.5 & 11.8 & 39.8 \\
& Stundum & 32 & 27.6 & 34.4 & 74.2 \\
& Sjaldan & 3 & 2.6 & 3.2 & 77.4 \\
& Aldrei & 17 & 14.7 & 18.3 & 95.7 \\
& Veit ekki & 4 & 3.4 & 4.3 & 100.0 \\
& Samtals & 93 & 80.2 & 100.0 & \\
Vantar & & 23 & 19.8 & & \\
Samtals & & 116 & 100.0 & & \\
\hline \hline
\end{tabular}

Einnig var kannað hvort rituð hafi verið fundargerð á verkfundunum. Tæplega 61\% svöruðu pví til að aldrei hafi verið rituð fundargerð á verkfundum. 


\begin{tabular}{|c|c|c|c|c|c|}
\hline & & Tíoni & Hlutfall (\%) & Gilt hlutfall (\%) & Uppsafnað hlutfall (\%) \\
\hline \multirow[t]{7}{*}{ Gilt } & Alltaf & 31 & 26.7 & 33.0 & 33.0 \\
\hline & Oft & 1 & .9 & 1.1 & 34.0 \\
\hline & Stundum & 2 & 1.7 & 2.1 & 36.2 \\
\hline & Sjaldan & 2 & 1.7 & 2.1 & 38.3 \\
\hline & Aldrei & 57 & 49.1 & 60.6 & 98.9 \\
\hline & Veit ekki & 1 & .9 & 1.1 & 100.0 \\
\hline & Samtals & 94 & 81.0 & 100.0 & \\
\hline \multicolumn{2}{|c|}{ Vantar } & 22 & 19.0 & & \\
\hline \multicolumn{2}{|c|}{ Samtals } & 116 & 100.0 & & \\
\hline
\end{tabular}

Ef rituð var fundargerð var spurt opinnar spurningar um pað hver hafi séð um að rita hana. Svör sem fengust má sjá í heild sinni á bls. 433 en hér má sjá nokkur lýsandi dæmi sem sýna vel að í flestum tilfellum var pað aðili frá verkkaupa sem sá um að rita fundargerðina af peim sem svöruðu.

Tafla 0.68 Demi um svör við spurningunni: Hver sá um að rita fundargerð á verkfundum?

- „eftirlitsmaður bojarins“

- „eftirlitsmenn verkkaupa“

- „Maður frá verkkaupa“

- „umsjónarmaður verkkaupa“
- „Starfsmaður verktakans framkvamdarstjóri verktakans"

- „Umsjónarmaðurinn“

- „Maður frá verkkaupa sá um að rita fundargerð“"

Að lokum var spurt hvort verktaki hafi farið ítarlega yfir verklýsingar og teikningar á milli verkpátta og verkkaupi spurður hvort hann hefði viljað vera boðaður oftar á verkfundi, ef hann var á annað borð boðaður á slíka. $80 \%$ svarenda voru sáttir við fjölda verkfunda en $20 \%$ hefou viljað hafa fleiri verkfundi ${ }^{97}$.

\footnotetext{
${ }^{97}$ Athuga einungis peir pátttakendur sem svöruðu pví að haldnir hefou verið verkfundir voru spurðir að pessari spurningu
} 


\begin{tabular}{llcccc}
\hline \hline \multirow{2}{*}{ Gilt } & Tíðni & Hlutfall (\%) & Gilt hlutfall (\%) & Uppsafnað hlutfall (\%) \\
& Miklu oftar & 4 & 3.4 & 4.2 & 4.2 \\
& Oftar & 15 & 12.9 & 15.8 & 20.0 \\
& Hvorki oftar né sjaldnar & 76 & 65.5 & 80.0 & 100.0 \\
& Sjaldnar & 0 & 0.0 & 0.0 & 100.0 \\
& Miklu sjaldnar & 0 & 0.0 & 0.0 & 100.0 \\
& Samtals & 95 & 81.9 & 100.0 & \\
Vantar & & 21 & 18.1 & & \\
Samtals & & 116 & 100.0 & & \\
\hline \hline
\end{tabular}

Í tæplega 28\% tilfella svöruðu pátttakendur pví til að peim hafi fundist verktaki hafa farið, frekar- mjög illa eða ekkert yfir verklýsingar og teikningar milli verkpátta með verkkaupa.

Tafla 0.70 Hversu vel/illa fór umraeddur verktaki yfir verklýsingar og teikningar á milli verkpátta með verkkaupa?

\begin{tabular}{llcccc}
\hline \hline & Tíðni & Hlutfall (\%) & Gilt hlutfall (\%) & Uppsafnað hlutfall (\%) \\
\hline Gilt & Mjög vel & 22 & 19.0 & 19.0 & 19.0 \\
& Frekar vel & 16 & 13.8 & 13.8 & 32.8 \\
& Hvorki vel né illa & 39 & 33.6 & 33.6 & 66.4 \\
Frekar illa & 5 & 4.3 & 4.3 & 70.7 \\
Mjög illa & 3 & 2.6 & 2.6 & 73.3 \\
Ekkert & 24 & 20.7 & 20.7 & 94.0 \\
Veit ekki & 7 & 6.0 & 6.0 & 100.0 \\
Samtals & 116 & 100.0 & 100.0 & \\
\hline \hline
\end{tabular}

\subsection{Samningar}

Áætla má að vönduð tilboðsgerð með ítarlegri sundurliðun sé mikilvægur páttur í ánægju verkkaupa. Slíkt ætti í pað minnsta að draga úr líkum á ágreiningi milli verkkaupa og verktaka.

Spurt var hvort verkið í heild hefði verið unnið í reikningsvinnu og ef svo var, hvort verkkaupi hefði pá krafist pess einhvertíma á meðan framkvæmdum stóð að verktaki sendi sér upplýsingar um vinnutíma og efnisnotkun og að sama skapi ef hann hefði gert svo hversu sáttur verkkaupi hefði verið með aðgengi að slíkum upplýsingum. Rúmlega $28 \%$ verka voru unnin í reikningsvinnu og tæplega $72 \%$ í tilboðsvinnu.

Tafla 0.71 Var verkið sem umraeddur verktaki vann unnið í reikningsvinnu?

\begin{tabular}{llcccc}
\hline \hline & & Tíoni & Hlutfall (\%) & Gilt hlutfall (\%) & Uppsafnað hlutfall (\%) \\
\hline \multirow{2}{*}{ Gilt } & Já & 33 & 28.4 & 28.4 & 28.4 \\
& Nei & 83 & 71.6 & 71.6 & 100.0 \\
& Samtals & 116 & 100.0 & 100.0 & \\
\hline \hline
\end{tabular}


Athyglisvert er að ekki nema rúmlega $21 \%$ svarenda kröfoust pess sérstaklega að verktaki sendi sér upplýsingar um efnisnotkun og upplýsingar um vinnutíma á meðan framkvæmdum stóð.

Tafla 0.72 Krafðist pú einhvertíma að umraeddur verktaki sendi pér upplýsingar um vinnutíma og efnisnotkun á meðan framkvamdum stóð?

\begin{tabular}{llcccc}
\hline \hline & & Tíðni & Hlutfall (\%) & Gilt hlutfall (\%) & Uppsafnað hlutfall (\%) \\
\hline Gilt & Já & 7 & 6.0 & 21.2 & 21.2 \\
& Nei & 26 & 22.4 & 78.8 & 100.0 \\
& Samtals & 33 & 28.4 & 100.0 & \\
Vantar & & 83 & 71.6 & & \\
Samtals & & 116 & 100.0 & & \\
\hline \hline
\end{tabular}

Peir pátttakendur sem svöruðu pví að peir hefðu krafist slíkra upplýsinga frá verktaka voru pví næst spurðir hversu sáttir peir væru við aðgengi slíkra upplýsinga, en par sem mjög fáir pátttakendur svöruðu ofangreindri spurningu játandi og enn færri svöruðu hversu sáttir peir væru með aðgengið er lítið að marka pær niðurstöður. Ef horft er fram hjá fjölda svarenda gáfu niðurstöðurnar til kynna að almennt sé aðgengi að slíkum upplýsingum gott.

Tafla 0.73 Hversu ánagd/ur eða óánagð/ur varstu með aðgengi að slíkum ${ }^{\text {98 }}$ upplýsingum ?

\begin{tabular}{llcccc}
\hline \hline & & Tíðni & Hlutfall (\%) & Gilt hlutfall (\%) & Uppsafnað hlutfall (\%) \\
\hline Gilt & Mjög ánægð/ur & 2 & 1.7 & 33.3 & 33.3 \\
& Frekar ánægð/ur & 3 & 2.6 & 50.0 & 83.3 \\
& Hvorki ánægð/ur né & 0 & 0.0 & 0.0 & 100.0 \\
& óánægð/ur & & & & 100.0 \\
& Frekar óánægð/ur & 0 & 0.0 & 0.0 & 100.0 \\
& Mjög óánægð/ur & 1 & .9 & 16.7 & \\
& Samtals & 6 & 5.2 & 100.0 & \\
Vantar & & 110 & 94.8 & & \\
Samtals & & 116 & 100.0 & & \\
\hline \hline
\end{tabular}

Ef verkið í heild var ekki unnið í reikningsvinnu var spurt hversu vel verktaki hefði rætt samninginn við verkkaupa áður en framkvæmdir hófust. Hvort samningurinn hefði verið skriflegur og ef svo, hversu vel sundurliðaður hann hefði verið ${ }^{99}$.

Tæplega 4\% svarenda fannst verktaki hafi rætt samninginn frekar eða mjög illa við pá áður en framkvæmdir hófust. Pví er dregin sú ályktun að almennt sé viðunandi hvernig verktakar gangi til verka varðandi pennan pátt.

\footnotetext{
${ }^{98}$ Hér er átt við upplýsingar um vinnutíma og efnisnotkun verktaka sem unnu í reikningsvinnu fyrir verkkaupa

${ }^{99}$ Pá er átt við hvort allir pættir hafi verið skilmerkilega tíundaðir inn í tilboðinu.
} 


\begin{tabular}{llcccc}
\hline \hline \multirow{2}{*}{ Gilt } & & Tíoni & Hlutfall (\%) & Gilt hlutfall (\%) & Uppsafnað hlutfall (\%) \\
& Mjög vel & 21 & 18.1 & 25.3 & 25.3 \\
& Frekar vel & 20 & 17.2 & 24.1 & 49.4 \\
& Hvorki vel né illa & 38 & 32.8 & 45.8 & 95.2 \\
& Frekar illa & 3 & 2.6 & 3.6 & 98.8 \\
& Mjög illa & 1 & .9 & 1.2 & 100.0 \\
& Samtals & 83 & 71.6 & 100.0 & \\
Vantar & & 33 & 28.4 & & \\
Samtals & & 116 & 100.0 & & \\
\hline \hline
\end{tabular}

Eins og áður sagði voru pátttakendur einnig spurðir hvort samningurinn hafi verið skriflegur í peim tilfellum sem verkið var unnið í tilboðsvinnu. Í lang flestum tilfellum reyndist svo vera, eða í tæplega 98\% tilfella.

Tafla 0.75 Var samningurinn skriflegur?

\begin{tabular}{llcccc}
\hline \hline \multirow{2}{*}{ Gilt } & & Tíðni & Hlutfall (\%) & Gilt hlutfall (\%) & Uppsafnað hlutfall (\%) \\
& Já & 81 & 69.8 & 97.6 & 97.6 \\
& Nei & 2 & 1.7 & 2.4 & 100.0 \\
& Samtals & 83 & 71.6 & 100.0 & \\
Vantar & & 33 & 28.4 & & \\
Samtals & & 116 & 100.0 & & \\
\hline \hline
\end{tabular}

Peir pátttakendur sem sögðust vera með skriflegan samning voru beðnir um að gefa sitt álit á pví hversu vel peim pótti samningurinn vera sundurliðaður. Í tæplega 9\% tilfella svöruðu pátttakendur að peim pætti samningurinn hafa verið frekar illa sundurliðaður en í tæplega $61 \%$ tilfella var fannst svarendum samningurinn vera frekar eða mjög vel sundurliðaður.

Tafla 0.76 Hversu vel/illa var samningurinn sundurliðaður?

\begin{tabular}{llcccc}
\hline \hline \multirow{2}{*}{ Gilt } & & Tíðni & Hlutfall (\%) & Gilt hlutfall (\%) & Uppsafnað hlutfall (\%) \\
& Mjög vel & 24 & 20.7 & 29.6 & 29.6 \\
& Frekar vel & 25 & 21.6 & 30.9 & 60.5 \\
& Hvorki vel né illa & 25 & 21.6 & 30.9 & 91.4 \\
& Frekar illa & 7 & 6.0 & 8.6 & 100.0 \\
& Mjög illa & 0 & 0.0 & 0.0 & 100.0 \\
& Samtals & 81 & 69.8 & 100.0 & \\
Vantar & & 35 & 10.2 & & \\
Samtals & & 116 & 100.0 & & \\
\hline \hline
\end{tabular}

Að lokum var spurt hvort einhver ósætti eða misklíð hafi komið upp á milli verktaka og verkkaupa um pað hvað hefði verið innifalið í samningnum.

Tæplega 52\% svarenda sögðust aldrei hafa átt í ósættum við verktaka um pað hvað var innifalið í samningum en rúmlega 48\% könnuðust við slíkt. 
Tafla 0.77 Komu upp einhver ósatti milli bín og umraedds verktaka á pví sem var innifalið i samningnum?

\begin{tabular}{llcccc}
\hline \hline Gilt & Tíðni & Hlutfall (\%) & Gilt hlutfall (\%) & Uppsafnað hlutfall (\%) \\
& Oft & 3 & 2.6 & 3.6 & 3.6 \\
& Frekar oft & 9 & 7.8 & 10.8 & 14.5 \\
& Stundum & 10 & 8.6 & 12.0 & 26.5 \\
& Frekar sjaldan & 6 & 5.2 & 7.2 & 33.7 \\
& Sjaldan & 12 & 10.3 & 14.5 & 48.2 \\
& Aldrei & 43 & 37.1 & 51.8 & 100.0 \\
& Samtals & 83 & 71.6 & 100.0 & \\
Vantar & & 28.4 & & \\
Samtals & & 116 & 100.0 & & \\
\hline \hline
\end{tabular}

\subsection{Frábrigði}

Spurt var hvort einhver frábrigði ${ }^{100}$ frá verkáætlun hefðu komið upp á verktíma og ef svo var hvort verkkaupa hafi verið tilkynnt um frábrigðið munnlega eða skriflega.

Tæplega 13\% svarenda svöruðu að aldrei hefðu komið upp frábrigði á verktíma, en ástæðan fyrir svo lágu hlutfalli er líklega hversu víðtæk skilgreiningin á frábrigði er. Rúmlega $12 \%$ svöruðu að frábrigði hjá umræddum verktaka hefðu komið oft, eða frekar oft upp. Flestir svöruðu að frábrigði hefou komið stundum upp, eða rúmlega $28 \%$ svarenda.

\section{Tafla 0.78 Komu upp einhver frábrigði hjá umraeddum verktaka frá verkácetlun á verktíma?}

\begin{tabular}{llcccc}
\hline \hline & & Tíðni & Hlutfall (\%) & Gilt hlutfall (\%) & Uppsafnað hlutfall (\%) \\
\hline Gilt & Oft & 4 & 3.4 & 3.4 & 3.4 \\
& Frekar oft & 10 & 8.6 & 8.6 & 12.1 \\
& Stundum & 33 & 28.4 & 28.4 & 40.5 \\
& Frekar sjaldan & 25 & 21.6 & 21.6 & 62.1 \\
& Sjaldan & 29 & 25.0 & 25.0 & 87.1 \\
& Aldrei & 12.9 & 12.9 & 100.0 \\
& Samtals & 116 & 100.0 & 100.0 & \\
\hline \hline
\end{tabular}

Rúmlega 61\% svarenda, sögðu að verktaki hafi tilkynnt sér munnlega um frábrigði. En burtséð frá verklagi verktaka getur pað einnig gefið til kynna að umrædd frábrigði hafi verið lítilsháttar.

\footnotetext{
${ }^{100}$ Sjá skýringu á frábrigðum í kafla um skilgreiningar á bls. 312 auk athugasemda í athugasemdakafla bls.241
} 
Tafla 0.79 Hvernig var pér tilkynnt um frábrigð ${ }^{101}$ ?

\begin{tabular}{llcccc}
\hline \hline & & Tíðni & Hlutfall (\%) & Gilt hlutfall (\%) & Uppsafnað hlutfall (\%) \\
\hline Gilt & Skriflega & 15 & 12.9 & 15.8 & 15.8 \\
& Munnlega & 58 & 50.0 & 61.1 & 76.8 \\
& Ekki tilkynnt & 18 & 15.5 & 18.9 & 95.8 \\
& Annað & 4 & 3.4 & 4.2 & 100.0 \\
& Samtals & 95 & 81.9 & 100.0 & \\
Vantar & & 18.1 & & \\
Samtals & & 116 & 100.0 & & \\
\hline \hline
\end{tabular}

peir pátttakendur sem svöruðu „,annað“ voru beðnir um að skýra hvernig peim hefði verið tilkynnt um frábrigði og fengust eftirfarandi svör frá svarendum ${ }^{102}$ :

Tafla 80 Hvernig var pér tilkynnt um frábrigði - Annað?

- „ýmist munnleg eða ekki tilkynnt“

- "allt i bland"
- "allt i bland"

- ,ýmist munnleg eða ekki tilkynnt“

\subsection{Aukaverk og breytingar}

Spurt var hvort óskir um breytingar og aukaverk ${ }^{103}$ hafi verið skráðar ef ráðist hafði verið í slík verk og ef svo hvort áhrif á framvindu heildarverks og verðlagningu hafi komið par fram.

Rúmlega 35\% svarenda sögðu að gerð hafi verið aukaverk eða breyting/ar frá upphaflegu samkomulagi á framkvæmdartíma verksins.

Tafla 0.81 Hafa verið gerð aukaverkefni eða breytingar hjá umraeddum verktaka?

\begin{tabular}{lccccc}
\hline \hline & Tíoni & Hlutfall (\%) & Gilt hlutfall (\%) & Uppsafnað hlutfall (\%) \\
\hline Gilt & 1 & .9 & .9 & .9 \\
& & 41 & 35.3 & 35.3 & 36.2 \\
& Já & 74 & 63.8 & 63.8 & 100.0 \\
& Nei & 100.0 & 100.0 & \\
& Samtals & 116 & & \\
\hline \hline
\end{tabular}

Í rúmlega 38\% tilfella taldi verkkaupi að verktaki hafi ekki skráð niður óskir verkkaupa um aukaverk eða breytingar og 40\% svarenda taldi að áhrif á verðlagningu verks og framvindu hefði aldrei komið fram á slíku plaggi. En fá svör voru við pessum spurningum.

\footnotetext{
${ }^{101}$ Sjá athugasemdakafla bls. 241

${ }^{102}$ Ekki nema rúmlega 4\% svarenda svöruðu ,annað“ og voru pví ekki nema 4 svör

${ }^{103}$ Sjá skilgreiningar kafla bls. 312

232
} 


\begin{tabular}{llcccc}
\hline \hline \multirow{6}{*}{ Gilt } & & Tíðni & Hlutfall (\%) & Gilt hlutfall (\%) & Uppsafnað hlutfall (\%) \\
& Alltaf & 15 & 12.9 & 35.7 & 35.7 \\
& Oft & 3 & 2.6 & 7.1 & 42.9 \\
& Stundum & 2 & 1.7 & 4.8 & 47.6 \\
& Sjaldan & 0 & 0.0 & 0.0 & 47.6 \\
& Aldrei & 16 & 13.8 & 38.1 & 85.7 \\
& Veit ekki & 6 & 5.2 & 14.3 & \\
& Samtals & 42 & 36.2 & 100.0 & \\
Vantar & & 74 & 63.8 & & \\
Samtals & & 116 & 100.0 & & \\
\hline \hline
\end{tabular}

Tafla 0.83 Komu fram áhrif á verðlagningu verks og framvindu?

\begin{tabular}{llrrrr}
\hline & & & & \multicolumn{2}{c}{ Uppsafnað hlutfall } \\
\hline \multirow{2}{*}{ Gilt } & Tiloni & & Hlutfall (\%) & Gilt hlutfall (\%) & (\%) \\
& Oft & 7 & 6.0 & 46.7 & 46.7 \\
& Stundum & 0 & 0.0 & 0.0 & 46.7 \\
& Sjaldan & 2 & 1.7 & 13.3 & 60.0 \\
& Aldrei & 0 & 0.0 & 0.0 & 60.0 \\
& Veit ekki & 6 & 5.2 & 40.0 & 100.0 \\
& Samtals & 0 & 0.0 & 0.0 & 100.0 \\
& & 15 & 12.9 & 100.0 & \\
Vantar & & 87.1 & & \\
Samtals & & 101 & 100.0 & &
\end{tabular}

Auk pess voru pátttakendur spurður hvort verktaki hafi skilað reglulega skrá yfir hugsanlegar kröfur um greiðslur vegna aukaverka og breytinga. Rúmlega $11 \%$ sögðu verktaka hafa skilað slíkri skrá, en rúmlega $61 \%$ sögðu verktaka ekki hafa skilað slíkri skrá. Rétt rúmlega 30\% pátttakenda gáfu svar við pessari spurningu. 
Tafla 0.84 Skilaði umraeddur verktaki skrá yfir hugsanlegar kröfur um greiðslur vegna aukaverka og breytinga?

\begin{tabular}{llcccc}
\hline \hline Gilt & & Tíðni & Hlutfall (\%) & Gilt hlutfall (\%) & Uppsafnað hlutfall (\%) \\
& Já & 4 & 3.4 & 11.1 & 11.1 \\
& Nei & 22 & 19.0 & 61.1 & 72.2 \\
& Veit ekki & 10 & 8.6 & 27.8 & 100.0 \\
& Samtals & 36 & 31.0 & 100.0 & \\
Vantar & & 80 & 69.0 & & \\
Samtals & & 116 & 100.0 & & \\
\hline \hline
\end{tabular}

Að lokum var verkkaupi spurður hvort aukaverk hafi verið unnin í reikningsvinnu og ef svo var hvort verkkaupi hafi einhvertíma krafist pess að verktaki sendi sér upplýsingar um vinnutíma og efnisnotkun vegna aukaverka á meðan framkvæmdum stóð og ef svo hversu sáttur hann hafi verið með aðgengi að slíkum upplýsingum.

Rúmlega 21\% svarenda svöruðu að aukaverk hafi aldrei verið unnin í reikningsvinnu og tæplega 5\% voru ekki vissir. bau 74\% sem eftir standa könnuðust við að aukaverk hefðu verið unnin í reikningsvinnu.

Tafla 0.85 Voru aukaverk unnin í reikningsvinnu?

\begin{tabular}{llcccc}
\hline \hline \multirow{2}{*}{ Gilt } & & Tíðni & Hlutfall (\%) & Gilt hlutfall (\%) & Uppsafnað hlutfall (\%) \\
& Alltaf & 14 & 12.1 & 33.3 & 33.3 \\
& Oft & 11 & 9.5 & 26.2 & 59.5 \\
& Stundum & 6 & 5.2 & 14.3 & 73.8 \\
& Aldrei & 9 & 7.8 & 21.4 & 95.2 \\
& Veit ekki & 2 & 1.7 & 4.8 & 100.0 \\
& Samtals & 42 & 36.2 & 100.0 & \\
Vantar & & 63.8 & & \\
Samtals & & 116 & 100.0 & & \\
\hline \hline
\end{tabular}

Peir pátttakendur sem sögðu aukaverk einhvertíma hafa verið unnin í reikningsvinnu voru spurðir hvort peir hefðu krafið verktaka um upplýsingar um vinnutíma og/eða efnisnotkun vegna aukaverksins á meðan framkvæmdinni stóð og gefa niðurstöður að rúmlega 30\% svarenda sögðust hafa farið fram á slíkar upplýsingar.

Tafla 0.86 Krafðist pú einhvertíma að verktaki sendi pér upplýsingar um vinnutíma og efnisnotkun vegna aukaverks á meðan framkvamdum stóð?

\begin{tabular}{llcccc}
\hline \hline & & Tíðni & Hlutfall (\%) & Gilt hlutfall (\%) & Uppsafnað hlutfall (\%) \\
\hline Gilt & Já & 9 & 7.8 & 29.0 & 29.0 \\
& Nei & 22 & 19.0 & 71.0 & 100.0 \\
& Samtals & 31 & 26.7 & 100.0 & \\
Vantar & & 73.3 & & \\
Samtals & & 116 & 100.0 & & \\
\hline \hline
\end{tabular}


Deir pátttakendur sem svöruðu pví að peir hefðu farið fram á upplýsingar frá verktaka um vinnutíma/efnisnotkun vegna aukaverks á meðan framkvæmdum stóð virtust almennt frekar sáttir við aðgengi að slíkum upplýsingum. En ekki pykir sérlega marktækt að túlka niðurstöður frá peirri spurningu pegar svarendur voru beðnir um að lýsa ánægju sinni um aðgengi að ofangreindum upplýsingum par sem fáir pátttakendur voru í hópi peirra sem voru beðnir um slíkt álit.

Tafla 0.87 Hversu ánagd/ur eða óánaegð/ur varstu með aðgengi að slikum upplýsingum ?

\begin{tabular}{llcccc}
\hline \hline Gilt & Tíðni & Hlutfall (\%) & Gilt hlutfall (\%) & Uppsafnað hlutfall (\%) \\
& Mjög ánægð/ur & 5 & 4.3 & 55.6 & 55.6 \\
& Frekar ánægð/ur & 1 & .9 & 11.1 & 66.7 \\
& Hvorki ánægð/ur né & 2 & 1.7 & 22.2 & 88.9 \\
& óánægð/ur & & & & \\
& Frekar óánægð/ur & 1 & .9 & 11.1 & \\
& Samtals & 9 & 7.8 & 100.0 \\
Vantar & & 107 & 92.2 & & \\
Samtals & & 116 & 100.0 & & \\
\hline \hline
\end{tabular}

\subsection{Umgengni verktaka á verkstað}

Pátttakendur voru spurðir að pví hvernig peim hafi fundist umgengni verktaka á verkstað vera ${ }^{104}$. Einnig var verktaki beðinn að nefna hvað honum hafi pótt miður fara varðandi umgengni verktaka á verkstað ef eitthvað var.

Tæplega 53\% pátttakenda svöruðu að peim pætti umgengni umrædds verktaka á verkstað vera mjög eða frekar góð. Rúmlega 47\% pátttakenda fannst umgengni umrædds verktaka vera í eða undir meðallagi sem gefur til kynna að umgengni verktaka sé ábótavant.

\section{Tafla 0.88 Hvernig fannst pér umgengni umraedds verktaka á verkstað vera?}

\begin{tabular}{llcccc}
\hline \hline & & & & Uppsafnað \\
\hline Gilt & Mjög góð & 39 & 33.6 & 33.6 & 33.6 \\
& Frekar góð & 22 & 19.0 & 19.0 & 52.6 \\
& Hvorki góð né slæm & 34 & 29.3 & 29.3 & 81.9 \\
& Frekar slæm & 14 & 12.1 & 12.1 & 94.0 \\
& Mjög slæm & 7 & 6.0 & 6.0 & 100.0 \\
Samtals & 116 & 100.0 & 100.0 & \\
\hline \hline
\end{tabular}

\footnotetext{
${ }^{104}$ Er pá átt við umgengni bæði á meðan framkvæmdum stóð og eftir að framkvæmdum er lokið ef verkinu er lokið.
} 
Að lokum var verkkaupi spurður hvort hann hefði orðið pess var að verktaki notaðist við efni sem ekki fullnægði peim kröfum sem settar höfðu verið. Tæplega 95\% pátttakenda svöruðu að peir hefðu ekki orðið pess varir að notast hefði verið við efni sem ekki uppfyllti kröfur.

Tafla 0.89 Varstu pess var að umraeddur verktaki notaðist við efni sem fullncegði ekki kröfum sem settar voru?

\begin{tabular}{llcccc}
\hline \hline & Tíoni & Hlutfall (\%) & Gilt hlutfall (\%) & Uppsafnað hlutfall (\%) \\
\hline Gilt & Oft & 0 & 0.0 & 0.0 & 0.0 \\
& Frekar oft & 0 & 0.0 & 0.0 & 0.0 \\
& Stundum & 5 & 4.3 & 4.3 & 4.3 \\
& Frekar sjaldan & 1 & .9 & .9 & 5.2 \\
Sjaldan & 0 & 0.0 & 0.0 & 5.2 \\
& Aldrei & 110 & 94.8 & 94.8 & 100.0 \\
Samtals & 116 & 100.0 & 100.0 & \\
\hline \hline
\end{tabular}

\subsection{4 Öryggismál}

Slys í tengslum við byggingaframkvæmdir eru óparflega algeng hér á landi að mati skýrsluhöfundar. Mörg peirra má vafalaust rekja til skipulagsleysis á byggingavinnustað. En öryggismál eru mikilvægur hluti af gæðastjórnun og ættu pau ávallt að vera hluti af gæðastjórnunarkerfum verktaka. Eins og kunnugt er, eru byggingaframkvæmdir afar mismunandi að umfangi og pað sama getur gilt fyrir öryggis- og heilbrigðisáætlanir, en engu að síður ætti ávallt að ræða öryggismál áður en framkvæmdir hefjast.

Ábyrgð verkkaupa samkvæmt lögum er talsverð pegar kemur að byggingaframkvæmdum en ekki virðist sú ábyrgð vera öllum verkkaupum kunnug, sérstaklega er pá átt við smærri verkkaupa. Árið 1997 tóku gildi hér á landi reglur um aðbúnað, hollustuhætti og öryggisráðstafanir á byggingavinnustöðum. Par er sérstaklega er fjallað um ábyrgð og skyldur par sem fleiri en einn verktaki er að störfum (Vinnueftirlitið, Sigfús Sigurðsson, 2002).

Spurt var hvort öryggismál hefðu verið rædd áður en framkvæmdir hófust og ef svo hvort pau hafi pá sérstaklega verið sett í hendur verktaka á meðan verktíma stóð. Einnig var spurt hversu sáttur verkkaupi hafi verið með meðhöndlun öryggismála.

Ótrúlegt en satt pá svöruðu rúmlega $68 \%$ pátttakenda að öryggismál hafi ekki verið rædd áður en framkvæmdir hófust. 


\begin{tabular}{llcccc}
\hline \hline & & Tíoni & Hlutfall (\%) & Gilt hlutfall (\%) & Uppsafnað hlutfall (\%) \\
\hline Gilt & Já & 36 & 31.0 & 31.0 & 31.0 \\
& Nei & 79 & 68.1 & 68.1 & 99.1 \\
& Veit ekki & 1 & .9 & .9 & 100.0 \\
& Samtals & 116 & 100.0 & 100.0 & \\
\hline \hline
\end{tabular}

Peir pátttakendur sem svöruðu að öryggismál hefðu verið rædd áður en framkæmdir hófust svöruðu í rúmlega 94\% tilfella að öryggismál hefðu verið sett sérstaklega í hendur umrædds verktaka sem gefur tilefni til að draga í efa að verkkaupar almennt geri sér grein fyrir peirri ábyrgð sem á pá er sett með tilliti til öryggismála. Einkum og sér í lagi einstaklingar.

Tafla 0.91 Voru öryggismál sett sérstaklega í hendur umraedds verktaka á meðan verktíma stóð ?

\begin{tabular}{llcccc}
\hline \hline & & Tíoni & Hlutfall (\%) & Gilt hlutfall (\%) & Uppsafnað hlutfall (\%) \\
\hline Gilt & Já & 34 & 29.3 & 94.4 & 94.4 \\
& Nei & 2 & 1.7 & 5.6 & 100.0 \\
& Samtals & 36 & 31.0 & 100.0 & \\
Vantar & & 80 & 69.0 & & \\
Samtals & & 116 & 100.0 & & \\
\hline \hline
\end{tabular}

Einungis rúmlega 4\% svarenda sögðust vera frekar óánægðir pegar pátttakendur voru spurðir hversu sáttir peir væru með meðhöndlun öryggismála hjá umræddum verktaka og enginn var mjög óánægður. Ef haft er í huga hlutfall peirra svarenda sem sögðu öryggismál ekki hafa verið rædd áður en framkvæmdir hófust og ánægja svarenda með meðhöndlun öryggismála má álykta að öryggismál hafi ekki mikið að segja varðandi ánægju verkkaupa.

\begin{tabular}{llcccc}
$\begin{array}{l}\text { Tafla } 0.92 \\
\text { verktaka? }\end{array}$ & Hversu áncegð/ur eða óánaegð/ur varstu með meðhöndlun öryggismála hjá umraeddum \\
\hline \hline \multicolumn{1}{c}{} & Tíðni & Hlutfall (\%) & Gilt hlutfall (\%) & Uppsafnað hlutfall (\%) \\
\hline Gilt & Mjög ánægð/ur & 25 & 21.6 & 21.6 & 21.6 \\
& Frekar ánægð/ur & 31 & 26.7 & 26.7 & 48.3 \\
& Hvorki ánægð/ur né & 55 & 47.4 & 47.4 & 95.7 \\
& óánægð/ur & & & & 100.0 \\
& Frekar óánægð/ur & 5 & 4.3 & 4.3 & 100.0 \\
& Mjög óánægð/ur & 0 & 0.0 & 0.0 & \\
& Samtals & 116 & 100.0 & 100.0 &
\end{tabular}

Ef öryggismál voru ekki sett sérstaklega í hendur verktaka var spurt hvaða aðgerðir verkkaupi hafi viðhaft til að fylgja eftir öryggiskröfum ef einhverjar voru. Einungis 9 pátttakendur svöruðu pessari spurningu og hér má sjá svör peirra: 
- „Sett er fram öryggisskrá sem allir aðilar purfa að kynna sér"

- „menn verktaka voru ekki með hjálma verkkaupi benti peim á bað“

- „Verkkaupi fylgdist sjálfur með öryggismálum “

- „Verkkaupi gerði sterkar kröfur - pað var öryggisfulltrúi frá verktaka sem sá alfarið um pann pátt"

- „Eftirlitsaðili verkkaupa sá um að hafa eftirlit með öryggismálum verktaka“
- „eftirlitsaðili verkkaupa gerði athugasemdir um pað sem honum pótti ábótavant eins og að starfsmenn varu ekki með hjálma og fór yfir öryggisácetlun með verktaka“

- „Engar... smá slys á pólverji datt“

- " tók eftir pví að peir notuðu ekki hjálma“

- „Öryggismál ekki raedd - verkkaupi taldi pau mál vera ábyrgð verktaka“"

Að lokum voru pátttakendur spurðir hvað peim hafi pótt vanta upp á öryggismál hjá verktaka. Einungis 9 pátttakendur svöruðu pessari spurningu og hér má sjá svör peirra:

\section{Tafla 94 Hvað pótti pér vanta upp á öryggismál hjá verktaka?}

- "Varðandi öryggismál: pá voru bau ekki rædd sérstaklega en peir fengu athugasemdir frá öðrum verktökum stöku sinnum um að handriði pyrftu að vera betri..."

- "ekki rædd sérstaklega - telur pað vera mál vertaka"

- “Öryggismál hjá flest öllum verktökum á Íslandi mættu vera betri ;)"
- "fá tilvik"

- "hefur fengið einhverjar ábendingar frá vinnueftirliti"

- “einhverjar ábendingar frá vinnueftirliti hafa borist"

- “járnabindingarmenn erfiðir með öryggisreglur - pólverjar hjálmlausir"

- "Öryggismál voru ekki í hávegum höfð”

- "hefðu mátt vera betri” 


\subsection{Samskipti}

Eins og maður að nafni George Bernard Shaw orðaði eitt sinn svo skemmtilega:

„The single biggest problem in communication is the illusion that it has taken place“.

Með öðrum orðum: „Stcersta vandamálið i samskiptum er blekkingin að pau hafi átt sér stað“.

Í góðum og skilvirkum samskiptum milli verkkaupa og verktaka hlýtur að felast lykillinn að góðum gæðum í mannvirkjagerð. Samskiptakrafa milli verkkaupa og verktaka er ólík hefðbundinni samskiptakröfu milli viðskiptavinar og framleiðanda vöru í flestum tilfellum, prátt fyrir að sannarlega flokkist verkkaupi undir pað að vera viðskiptavinur verktaka. Pörfin fyrir samskipti milli viðskiptavinar og framleiðanda vöru á lager, er einfaldlega ekki sambærileg og sú sem ríkir á milli verkkaupa og verktaka af peim sökum að varan er í mótun frá pví að verkkaupi kaupir vöruna og pangað til framkvæmdarferli líkur.

Spurt var hvort verktaki hafi rætt við verkkaupa um væntanlegar samskiptaleiðir peirra á milli áður en samningur var gerður. Einnig var spurt hversu sáttur verkkaupi hafi verið með samskipti á milli sín og verktaka og hvort upp hafi komið einhver vandamál í samskiptum peirra á milli og hver pá. Að lokum var spurt hvað verkkaupa hafi fundist um pjónustulund verktaka.

Tæplega 58\% svarenda sögðu verktaka hafa rætt við sig áður en framkvæmdir hófust um væntanlegar samskiptaleiðir peirra á milli. Tæplega 40\% svarenda sögðu svo ekki hafa verið. Ljóst er pó að ákveðið fyrirkomulag varðandi samskipti hefur komist á meðal verkkaupa og verktaka en pátttakendur virtust gjarnan hafa átt í erfileikum á að ná í verktaka yfir framkvæmdartíma.

Tafla 0.95 Raeddi umraeddur verktaki við pig um vantanlegar samskiptaleiðir ykkar á milli áður en samningur var gerður?

\begin{tabular}{llcccc}
\hline \hline & & Tíoni & Hlutfall (\%) & Gilt hlutfall (\%) & Uppsafnað hlutfall (\%) \\
\hline Gilt & Já & 67 & 57.8 & 57.8 & 57.8 \\
& nei & 46 & 39.7 & 39.7 & 97.4 \\
& Veit ekki & 3 & 2.6 & 2.6 & 100.0 \\
& Samtals & 116 & 100.0 & 100.0 & \\
\hline \hline
\end{tabular}

75\% svarenda voru mjög eða frekar ánægðir með samskipti milli sín og umrædds verktaka, rúmlega 16\% voru frekar eða mjög óánægðir. 


\begin{tabular}{llcccc}
\hline \hline & Tíðni & Hlutfall (\%) & Gilt hlutfall (\%) & Uppsafnað hlutfall (\%) \\
\hline Gilt & Mjög ánægð/ur & 50 & 43.1 & 43.1 & 43.1 \\
& Frekar ánægð/ur & 37 & 31.9 & 31.9 & 75.0 \\
& Hvorki ánægð/ur né & 10 & 8.6 & 8.6 & 83.6 \\
& óánægð/ur & & & & \\
& Frekar óánægð/ur & 16 & 13.8 & 13.8 & 100.0 \\
Mjög óánægð/ur & 3 & 2.6 & 2.6 & \\
Samtals & 116 & 100.0 & 100.0 & \\
\hline \hline
\end{tabular}

Pátttakendur voru einnig spurðir hvernig peim hefði pótt pjónustulund umrædds verktaka vera. Rúmlega $66 \%$ voru mjög eða frekar ánægðir á meðan tæplega 15\% voru mjög eða frekar óánægðir.

Tafla 0.97 Hvernig fannst pér pjón ustulund umraedds verktaka vera?

\begin{tabular}{llcccc}
\hline \hline & Tíðni & Hlutfall (\%) & Gilt hlutfall (\%) & Uppsafnað hlutfall (\%) \\
\hline Gilt & Mjög góð & 44 & 37.9 & 37.9 & 37.9 \\
& Frekar góð & 33 & 28.4 & 28.4 & 66.4 \\
& Hvorki góð né slæm & 22 & 19.0 & 19.0 & 85.3 \\
Frekar slæm & 13 & 11.2 & 11.2 & 96.6 \\
Mjög slæm & 4 & 3.4 & 3.4 & 100.0 \\
Samtals & 116 & 100.0 & 100.0 & \\
\hline \hline
\end{tabular}

\subsection{Gæðatrygging}

Hver er staða gæðatryggingar vegna framkvæmda á Íslandi núna ? Eru pað einungis opinberir verkkaupar og stærri fyrirtæki sem krefja verkkaupa um slíkt plagg eða hafa kröfur einstaklinga aukist á pann veg að peir séu einnig farnir að fara fram á slíkt plagg ? Er mögulegt að mæla áhrif gæðatrygging á ánægju verkkaupa?

Með gæðatryggingu ${ }^{105}$ er átt við skriflegt plagg par sem verktaki setur fram allar pær vinnureglur sem hann ætlar að vinna eftir í verkinu til að tryggja ákveðin gæði.

Spurt var hvort verkkaupi hafi farið fram á að verktaki sýndi sér skriflega hvernig hann hygðist vinna verkið til að uppfylla gæðakröfur. En með pví var verið að fiska eftir pví hvort verkkaupar krefðust gæðatryggingar af verktökum.

Niðurstöður sýna að tæplega $84 \%$ pátttakenda sögðust ekki hafa farið fram á gæðatryggingu frá verktökum sem skilur eftir rúmlega 16\% pátttakenda sem sögðust hafa farið fram á gæðatryggingu. Pessar niðurstöður gefa til kynna að kröfur verkkaupa til verktaka um skipulag og markvissa stjórnun séu ekki nægar. Ef

\footnotetext{
${ }^{105}$ Sjá kafla um skilgreiningar bls. 312 
kröfurnar eru til staðar hjá verkkaupum koma pær í pað minnsta ekki fram nægilega snemma til að hægt sé að koma í veg fyrir óánægju verkkaupa vegna slakrar stjórnunar.

Tafla 0.98 Fórst pú fram á að umraeddur verktaki sýndi pér í verkbyrjun skriflega hvernig hann aetlaði að vinna verkið til að uppfylla gaððaröfur?

\begin{tabular}{llcccc}
\hline \hline & & Tíðni & Hlutfall (\%) & Gilt hlutfall (\%) & Uppsafnað hlutfall (\%) \\
\hline Gilt & Já & 19 & 16.4 & 16.4 & 16.4 \\
& Nei & 97 & 83.6 & 83.6 & 100.0 \\
& Samtals & 116 & 100.0 & 100.0 & \\
& & &
\end{tabular}

Einnig var spurt hvort verktaki hafi sýnt verkkaupa fram á gæðatryggingu, óháð pví hvort verkkaupi hafi farið fram á pað, aðallega í peim tilgangi að sjá hvort verklag verktaka í pessum efnum væri algerlega háð kröfum verkkaupa. Niðurstöður gefa að mjög svipuð hlutföll og áður. Rúmlega $18 \%$ svarenda sagði verktaka hafa veitt sér gæðatryggingu og tæplega 82\% sagði að svo hefði ekki verið. Lesa má út úr bessum tölum að í einhverjum tilfellum hafi verktaki sýnt verkkaupa fram á gæðatryggingu án pess að verkkaupi hafi krafist pess.

Tafla 0.99 Sýndi umraeddur verktaki pér í verkbyrjun skriflega hvernig hann aetlaði að vinna verkið til að uppfylla gaðakröfur?

\begin{tabular}{llcccc}
\hline \hline & & Tíoni & Hlutfall (\%) & Gilt hlutfall (\%) & Uppsafnað hlutfall (\%) \\
\hline \multirow{2}{*}{ Gilt } & Já & 21 & 18.1 & 18.1 & 18.1 \\
& Nei & 95 & 81.9 & 81.9 & 100.0 \\
& Samtals & 116 & 100.0 & 100.0 & \\
&
\end{tabular}

\subsection{Gæðastjórnunarkerfi}

Pátttakendur voru spurðir hvort peir hefðu vitneskju um pað hvort umræddur verktaki væri að vinna eftir ákveðnu gæðastjórnunarkerfi og ef svo var hvort peir vissu á hverju gæðastjórnunarkerfið byggði og hvort pað hefði hlotið vottun.

Pátttakendur svöruðu í flestum tilfellum eftir pví hvað peir töldu, en byggðu ekki endilega svar sitt á staðreyndum.

Tæplega 26\% pátttakenda taldi umræddan verktaka vera að notast við gæðastjórnunarkerfi og tæplega 33\% taldi svo ekki vera. Enginn svarenda taldi verktaka vera í innleiðingarferli en rúmlega 41\% höfou ekki hugmynd um hvort umræddur verktaki væri að vinna eftir gæðastjórnunarkerfi. 


\begin{tabular}{llcccc}
\hline \hline & & Tíðni & Hlutfall (\%) & Gilt hlutfall (\%) & Uppsafnað hlutfall (\%) \\
\hline Gilt & já & 30 & 25.9 & 25.9 & 25.9 \\
& Nei & 38 & 32.8 & 32.8 & 58.6 \\
& Veit ekki & 48 & 41.4 & 41.4 & 100.0 \\
& Samtals & 116 & 100.0 & 100.0 & \\
\hline \hline
\end{tabular}

\subsection{Gæði}

Eins og áđur hefur komið fram pá fela gæði í sér ánægju viðskiptavinar með vöru og pjónustu. Út frá peirri skilgreiningu getur lítill hundakofi og stærðarinnar höll haft sömu gæði svo lengi sem viðskiptavinurinn er ánægður. Aætla má að pegar verkkaupi gengur í samband með verktaka um ákveðna framkvæmd, að gæði byggingainnar ásamt gæðum á pjónustu og áætlunum spili inn í ánægju verkkaupa um heildar framvindu verksins. Pví voru pátttakendur spurðir um hversu sáttir peir hefðu verið með gæði verksins sem umræddur verktaki vann. En með pví er átt við gæði verklega páttarins sem verktakinn vann.

Niðurstöður gefa að rúmlega $73 \%$ pátttakenda voru mjög eða frekar ánægðir og rúmlega 12\% voru mjög eða frekar óánægðir.

Tafla 0.101 Hversu ánagd/ur eða óánaegð/ur ertu með gaði verksins sem umraeddur verktaki vann?

\begin{tabular}{llcccc}
\hline \hline & Tíðni & Hlutfall (\%) & Gilt hlutfall (\%) & Uppsafnað hlutfall (\%) \\
\hline Gilt & Mjög ánægð/ur & 40 & 34.5 & 34.5 & 34.5 \\
& Frekar ánægð/ur & 45 & 38.8 & 38.8 & 73.3 \\
& Hvorki ánægð/ur né & 17 & 14.7 & 14.7 & 87.9 \\
óánægð/ur & & & & \\
& Frekar óánægð/ur & 9 & 7.8 & 7.8 & 95.7 \\
Mjög óánægð/ur & 5 & 4.3 & 4.3 & 100.0 \\
Samtals & 116 & 100.0 & 100.0 & \\
\hline \hline
\end{tabular}

Pátttakendur voru einnig spurðir opinnar spurningar hvort peim hafi pótt eitthvað vanta upp á gæði. Svör við peirri spurning má sjá í heild sinni á bls.437 en hér eru nokkur dæmi: 
Tafla 0.102 Dami um svör við spurningunni: Eru einhver atriði sem pér finnst hafa vantað upp á gąi ? Hvað pá?

- „Hefðu mátt vera nákvaemari“

- „Ýmislegt sem vantaði upp á. Illa steypt og margt fleira sem purfti að laga."

- „Hluti af pakinu lak“

- „Ekki alveg réttir veggir og fleira“

- „Nokkrir hlutir sem hefðu mátt vera betri ekkert alvarlegt"

- „Hann flýtti sér allt of hratt i burtu Verkkaupi purfti að ýta á verktaka til að hafa gaèin i lagi“"
- „मаð komu upp talsverð frávik en á endanum voru pau löguð og leiðrétt - en annir hjá verktaka töfðu allan framgang “

• ,Húsið heldur ;P“

- „Frágangur og vinna öll mjög slcem“

- „Húsið lekur og ýmislegt að gœðum. Gœði verks ekki góð. “

- , „Geði hefðu mátt vera aðeins betri“

- „margir paettir sem hefðu mátt vera betri. Sérstaklega er við kemur lokafrágangi “

Að lokum var pátttakendum gefinn kostur á að koma með athugasemdir ef pað var eitthvað sem peir vildu koma á framfæri. Svör við peirri spurningu má sjá í heild sinni á bls. 439 en eins og áður eru gefin upp nokkur dæmi hér til hliðsjónar. 
Tafla 0.103 Dæmi um svör við spurningunni: Að lokum eitthvað sem bú vilt koma á framfæri ?

- „Hrunið setti sannarlega svip sinn á framkvcemdirnar og ácetlanir riðluðust ögn vegna pess, svo ekki er við verktakann beint að sakast. “

- „Hefði viljað hafa formlega fundi með verktaka“"

- „Hrunið spilaði stóran pátt i pví sem illa fór"

- , ,Verkkaupi hafði mikið út á að setja hvernig fyrirkomulag byggingastjóra er háttað núna. Hann segir pað vera pannig að peir séu án undantekninga til skrauts! Hann vann verkið i góðcerinu, eða í öllu djamminu, eins og hann orðaði pað og sagði að pað hefði ekki verið til siðs að hafa eitt né neitt formlegt. Hann hefði ekki kart sig um pað og enn og siður verktakinn."

- „Hefði viljað sjá talsvert meira eftirlit að hálfu byggingarstjóra"

- „Verkkaupi taldi ekki burfa að hafa neitt formlegt eða varla skriflegt i svona litlu verki. “
- „, Verkkaupi hefði viljað fá að fylgjast miklu betur með gangi mála, hafa allt skriflegt og flott en andinn hjá verktakanum var alls ekki pannig. Hann hefði fengið annan verktaka til að taka verkið af sér en pegar hann fór með útboðsgögnin til að reyna að fá verktaka á sinum tíma 2007 vildi enginn taka við verkinu. Allt brjálað að gera hjá öllum verktökum og ekki vilji til pess að taka við jafn flóknu verki sem var með svona vel skilgreind útboðsgögn. Verktakinn sem varð fyrir valinu var siðan ekki tilbúinn til að sampykkja að nota útboðsgögnin heldur var samningurinn mjög rýr sem hann var tilbúinn að skrifa upp á. Eiginlega bara með c.a. verðtölum og c.a. tímasetningu verkloka."

- „Hefði eftir á kosið að hafa formlegri verkfundi til að styrkja stöðu sina ef eitthvað hefði farið úrskeiðis “

- „Frágangur og vinna öll mjög slaem“ 


\section{Viðauka F - Tengslatöflur og fylgni milli breyta hjá verkkaupum}

Eins og áður hefur komið fram er samband milli tveggja eða fleiri breyta er gefið upp í tengslatöflu (e. contingency table) eða RxC töflum, par sem $\mathrm{R}$ stendur fyrir Row eða röð og C fyrir column eða dálk. Par er tíðni svara gefið í flokkum milli breyta auk pess sem fylgnistuðlar eru reiknaðir. Fyrir raðbreytur var notast við eftirfarandi fylgnistuðla; Spearman's fylgnistuðull, gamma Goodmans og Kruskal's, Sommers'd, Kendall's Tau b eða Tau c eftir pví sem við á. Fyrir nafnabreytur (eða nafnabreytu og raðbreytu) var notast við tengsla stuðul (e.contingency coefficient), lambda og óvissu stuðul (e. uncertanity coefficient). En pessir stuðlar gefa til kynna hversu sterk tengsl eru milli breyta og hvort pau eru marktæk ${ }^{106}$. $^{10}$

Notast verður við breytuheiti sem eru skilgreind í par til gerðum viðauka á bls. 201 til að auðvelda uppsetningu á tengslatöflum.

Athuga að raðbreytum var gefin töluleg gildi fyrir svarflokka til að tryggja að fylgnistuðlar væru reiknaðir rétt. Sá svarflokkur sem talinn er vera bestur, eins og mjög áncegð/ur fékk hæstu töluna og sá sem talinn er vera verstur fékk lægstu töluna.

\subsection{Fylgni við ánægju verkkaupa með umræddan verktaka}

Fylgni milli ánægju verkkaupa með framkvæmd verksins hjá umræddum verktaka og allra annarra pátta sem spurt var um í könnun verkkaupa var skoðuð. Einnig var fylgni milli ánægju verkkaupa og allra pátta sem umrceddir verktakar voru spurðir um könnuð. Hér að neðan eru töflur með ofangreindum páttum annars vegar fyrir pætti sem lagðir voru fyrir verkkaupa og hins vegar eru pættir sem umrceddir verktakar voru spurðir um í könnun fyrir verktaka.

Ef rýnt er í töflurnar hér að neðan má sjá að gildunum er raðað í lækkandi röð miðað við gildi Gamma fylgnistuðuls en skýrsluhöfundur telur að Gamma lýsi fylgni gagnanna best par sem að svarflokkar breytanna eru ekki mjög margir sem leiðir af sér mikið af jafnteflum. Undir slíkum aðstæðum er almennt talið að Gamma lýsi gögnunum betur en Spearman en breyta sem er með hæstu fylgni með Gamma er ekki sama breytan og er með hæstu fylgni með Spearman.

\footnotetext{
${ }^{106}$ Sjá nánar um fylgnistuðla í kafla um greiningaraðferðir og grunnathuganir á bls. 81
} 
Tafla 104 peir paettir úr könnun verkkaupa sem maeldust með marktaeku fylgni við ánagju verkkaupa með framkvamd verksins hjá umraeddum verktaka

\begin{tabular}{|c|c|c|c|c|c|}
\hline & \multicolumn{4}{|c|}{ ánægja umræddan } & \multirow[b]{3}{*}{$\mathrm{N}$} \\
\hline & \multicolumn{2}{|c|}{ Gamma } & \multicolumn{2}{|c|}{ Spearman's rho } & \\
\hline & Fylgnistuðull & Sig. & Fylgnistuðull & Sig. & \\
\hline verkfundir_fleiri &, 737 &, 000 &, 442 & 000 & 95 \\
\hline ánægja_gæði &, 735 &, 000 & 622 & 000 & 116 \\
\hline ánægja heild &, 712 &, 000 & ,592 &, 000 & 116 \\
\hline tímaáætlun_vönduð & 606 &, 000 &, 523 & 000 & 54 \\
\hline ánægja_tíma &, 572 &, 000 &, 515 &, 000 & 116 \\
\hline ánægja_samskipti & ,569 &, 000 & ,474 &, 000 & 116 \\
\hline kyn_verkkaupa & ,564 & ,013 & 242 & 009 & 116 \\
\hline umgengni &, 551 &, 000 & ,481 &, 000 & 116 \\
\hline tímaáætlun_kynnt & ,539 &, 000 & ,445 &, 001 & 54 \\
\hline greiðsluáætlun vönduð &, 533 &, 000 & 455 & 000 & 61 \\
\hline reikningur_óvart & ,494 &, 035 & ,292 & 044 & 48 \\
\hline frábrigði ${ }^{-}$ & ,492 &, 000 & ,445 & 000 & 116 \\
\hline ánægja_greiðslu &, 485 & 000 & 400 & 000 & 116 \\
\hline ánægja_bygg & ,449 &, 000 & ,399 & 000 & 100 \\
\hline tímaáætlun & ,430 &, 000 & ,399 & 000 & 116 \\
\hline verkfundir_samkomulag & 423 & 001 & 279 & 002 & 116 \\
\hline verkfundir_form/óform &, 420 & ,009 & ,285 &, 012 & 77 \\
\hline greiðsluáætlun_kynnt & ,413 &, 005 &, 327 & 010 & 61 \\
\hline ánægja_öryggismál & ,397 &, 000 & ,318 & 001 & 116 \\
\hline greiðsluáætlun & 379 &, 000 &, 332 &, 000 & 116 \\
\hline pjónustulund & ,368 & 001 & 317 & 001 & 116 \\
\hline samningur_ræddur & ,364 &, 002 & ,307 &, 005 & 83 \\
\hline verkfundir_staða &, 329 &, 004 & 283 & 006 & 93 \\
\hline aldur $\quad-$ &, 322 & 001 & 282 &, 002 & 116 \\
\hline verkfundir & 274 & 015 & 215 & 020 & 116 \\
\hline verklýsingar_milliverkpátta & 251 &, 011 & ,223 &, 016 & 116 \\
\hline
\end{tabular}

Tafla 105 Deir paettir úr könnun verktaka sem maeldust með marktaku fylgni við ánaegju verkkaupa með framkvamd verksins hjá umraeddum verktaka

\begin{tabular}{|c|c|c|c|c|c|}
\hline \multirow[b]{4}{*}{ gæðatrygging_undirverkt } & \multicolumn{4}{|c|}{ ánægja_umræddan - úr könnun verktaka } & \multirow[b]{3}{*}{$\mathrm{N}$} \\
\hline & \multicolumn{2}{|c|}{ Gamma } & \multicolumn{2}{|c|}{ Spearman's rho } & \\
\hline & Fylgnistuðull & Sig. & Fylgnistuðull & Sig. & \\
\hline & ,638 &, 000 &, 504 &, 000 & 44 \\
\hline GSK & 623 &, 001 & 430 &, 003 & 47 \\
\hline förgun &, 597 &, 002 & 420 &, 007 & 40 \\
\hline samkeppnishæfi & ,495 &, 012 & ,372 & 015 & 42 \\
\hline öryggisstrúnaðarm & ,477 &, 050 & 309 &, 050 & 41 \\
\hline stærठ & ,458 &, 001 & 366 &, 003 & 65 \\
\hline starfslýsingar_skriflegar & ,427 &, 013 & ,349 &, 020 & 44 \\
\hline aldur_fyrirt & ,397 &, 025 & ,333 &, 024 & 46 \\
\hline ISO9001 &, 372 &, 034 & 320 & 034 & 44 \\
\hline almennt &, 330 &, 044 & ,303 &, 045 & 44 \\
\hline
\end{tabular}




\subsection{Grunnupplýsingar}

\subsubsection{Tvívítt fylgnifylki: framkvæmdaár, ánægja_umræddan}

Fylgni milli áncegja umreddan og framkvcemdaár 2009 og 2010 reyndist marktæk, en ekki fyrir árin 20052008. bessar niðurstöður gefa til kynna að verktakar vandi sig meira við að uppfylla kröfur verkkaupa eftir efnahagshrunið.

Tafla 106 Tvívítt fylgnifylki: ánaegja_umraeddan, framkvaemdaár

\begin{tabular}{|c|c|c|c|c|c|c|c|c|c|}
\hline & & & $\begin{array}{l}\text { ánægja } \\
\text { umrædd }\end{array}$ & 2005 & 2006 & 2007 & 2008 & 2009 & 2010 \\
\hline \multirow{21}{*}{$\begin{array}{l}\text { Spearm } \\
\text { an's rho }\end{array}$} & \multirow{3}{*}{$\begin{array}{l}\text { ánægja } \\
\text { umrædd }\end{array}$} & Fylgnistuðull & 1,000 & ,025 &,- 040 &,- 158 & ,039 & $.325^{* *}$ & $.242^{* *}$ \\
\hline & & Sig. (2-tailed) & 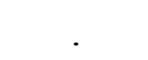 & ,791 & 667 &, 090 & ,682 &, 000 & 009 \\
\hline & & $\mathrm{N}$ & 116 & 116 & 116 & 116 & 116 & 116 & 116 \\
\hline & \multirow[t]{3}{*}{2005} & Fylgnistuðull & ,025 & 1,000 & $.419^{* *}$ & $-.367^{* *}$ & $-.379^{* *}$ & $-.286^{* *}$ & $-.286^{* *}$ \\
\hline & & Sig. (2-tailed) & ,791 & . &, 000 &, 000 &, 000 &, 002 &, 002 \\
\hline & & $\mathrm{N}$ & 116 & 116 & 116 & 116 & 116 & 116 & 116 \\
\hline & \multirow[t]{3}{*}{2006} & Fylgnistuðull &,- 040 & $.419^{* *}$ & 1,000 &,- 008 & $-.379^{* *}$ & $-.340^{* *}$ & $-.340^{* *}$ \\
\hline & & Sig. (2-tailed) & ,667 &, 000 & . & ,929 &, 000 &, 000 &, 000 \\
\hline & & $\mathrm{N}$ & 116 & 116 & 116 & 116 & 116 & 116 & 116 \\
\hline & \multirow[t]{3}{*}{2007} & Fylgnistuðull &,- 158 & $-.367^{* *}$ &,- 008 & 1,000 & $.379^{* *}$ & ,004 &,- 086 \\
\hline & & Sig. (2-tailed) &, 090 &, 000 & ,929 & . &, 000 & ,967 &, 360 \\
\hline & & $\mathrm{N}$ & 116 & 116 & 116 & 116 & 116 & 116 & 116 \\
\hline & \multirow[t]{3}{*}{2008} & Fylgnistuðull & 039 & $-.379^{* *}$ & $-.379^{* *}$ & $.379^{* *}$ & 1,000 & $.400^{* *}$ &, 121 \\
\hline & & Sig. (2-tailed) & ,682 &, 000 &, 000 &, 000 & . &, 000 & ,195 \\
\hline & & $\mathrm{N}$ & 116 & 116 & 116 & 116 & 116 & 116 & 116 \\
\hline & \multirow[t]{3}{*}{2009} & Fylgnistuðull & $.325^{* *}$ & $-.286^{* *}$ & $-.340^{* *}$ & ,004 & $.400^{* *}$ & 1,000 & $.607^{* *}$ \\
\hline & & Sig. (2-tailed) &, 000 & ,002 &, 000 & ,967 &, 000 & . &, 000 \\
\hline & & $\mathrm{N}$ & 116 & 116 & 116 & 116 & 116 & 116 & 116 \\
\hline & \multirow[t]{3}{*}{2010} & Fylgnistuðull & $.242^{* *}$ & $-.286^{* *}$ & $-.340^{* *}$ &,- 086 &, 121 & $.607^{* *}$ & 1,000 \\
\hline & & Sig. (2-tailed) &, 009 & ,002 &, 000 & ,360 & , 195 &, 000 & . \\
\hline & & $\mathrm{N}$ & 116 & 116 & 116 & 116 & 116 & 116 & 116 \\
\hline
\end{tabular}

**. Correlation is significant at the 0.01 level (2-tailed). 


\begin{tabular}{|c|c|c|c|c|c|c|c|}
\hline & & \multicolumn{5}{|c|}{ ánægja_umræddan } & \multirow[b]{2}{*}{$\underset{\mathrm{s}}{\text { Samta }}$} \\
\hline & & $\begin{array}{c}\text { Mjög } \\
\text { óánægð/ur }\end{array}$ & $\begin{array}{c}\text { Frekar } \\
\text { óánægð/ur }\end{array}$ & $\begin{array}{l}\text { Hvorki ánægð/ur } \\
\text { né óánægð/ur }\end{array}$ & $\begin{array}{c}\text { Frekar } \\
\text { ánægð/ur }\end{array}$ & $\begin{array}{c}\text { Mjög } \\
\text { ánægð/ur }\end{array}$ & \\
\hline \multirow{6}{*}{$\begin{array}{l}\text { fram- } \\
\text { kvæmdaár }^{\mathrm{a}}\end{array}$} & 2005 & 1 & 3 & 6 & 11 & 9 & 30 \\
\hline & 2006 & 2 & 4 & 10 & 18 & 11 & 45 \\
\hline & 2007 & 2 & 9 & 9 & 16 & 11 & 47 \\
\hline & 2008 & 1 & 6 & 5 & 15 & 12 & 39 \\
\hline & 2009 & 0 & 0 & 2 & 8 & 12 & 22 \\
\hline & 2010 & 0 & 0 & 1 & 13 & 8 & 22 \\
\hline Samtals & & 6 & 22 & 33 & 81 & 63 & 205 \\
\hline
\end{tabular}

Percentages and totals are based on responses.

a. Dichotomy group tabulated at value 2 .

\subsubsection{Tvívítt fylgnifylki: kyn_verkkaupa, aldur, fyrir_einst, ánægja_umræddan}

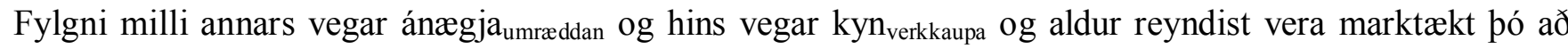
fylgnin væri ekki sérlega sterk.

Tafla 108 Tvívítt fylgnifylki: kyn_verkkaupa, aldur,fyrir_einst, ánagja_umraeddan

\begin{tabular}{|c|c|c|c|c|c|c|c|}
\hline \multirow{13}{*}{$\begin{array}{l}\text { Spearman's } \\
\text { rho }\end{array}$} & & & ánægja & umræddan & kyn_verkkaupa & aldur & fyrir_einst \\
\hline & \multirow{3}{*}{$\begin{array}{l}\text { ánægja } \\
\text { umræddan }\end{array}$} & Fylgnistuðull & & 1,000 & $.242^{* *}$ & $.282^{* *}$ &, 142 \\
\hline & & Sig. (2-tailed) & & . &, 009 &, 002 & , 129 \\
\hline & & $\mathrm{N}$ & & 116 & 116 & 116 & 116 \\
\hline & \multirow{3}{*}{$\begin{array}{l}\text { kyn } \\
\text { verkkaupa }\end{array}$} & Fylgnistuðull & & $242^{* *}$ & 1,000 & $.203^{*}$ &,- 039 \\
\hline & & Sig. (2-tailed) & & ,009 & . & ,029 & 681 \\
\hline & & $\mathrm{N}$ & & 116 & 116 & 116 & 116 \\
\hline & \multirow[t]{3}{*}{ aldur } & Fylgnistuðull & & $.282^{* *}$ & $.203^{*}$ & 1,000 & $.303^{* *}$ \\
\hline & & Sig. (2-tailed) & &, 002 & ,029 & . &, 001 \\
\hline & & $\mathrm{N}$ & & 116 & 116 & 116 & 116 \\
\hline & \multirow[t]{3}{*}{ fyrir_einst } & Fylgnistuðull & & ,142 &,- 039 & $.303^{* *}$ & 1,000 \\
\hline & & Sig. (2-tailed) & & 129 & 681 &, 001 & . \\
\hline & & $\mathrm{N}$ & & 116 & 116 & 116 & 116 \\
\hline
\end{tabular}

***. Correlation is significant at the 0.01 level (2-tailed)

*. Correlation is significant at the 0.05 level (2-tailed). 


\subsubsection{Fylgni: kyn_verkkaupa * ánægja_umræddan}

Fylgni milli áncegjamreddan (hversu áncegður verkkaupi var með framkvœemd verksins hjá umrceddum verktaka) og kyn verkkaupa var skoðuð. Athuga að breytan kyn verkkaupa var meðhöndluð sem raðbreyta par sem kvk fékk gildið 1 og kk fékk gildið 2. Öll 116 tilfellin flokkast undir gild tilfelli.

Tafla 109 Yfirlit tilfella í greiningu milli kyn_verkkaupa og ánaegja_umraeddan

\begin{tabular}{lcccccc}
\hline & \multicolumn{6}{c}{ Tilfelli } \\
\cline { 2 - 7 } & \multicolumn{2}{c}{ Gild } & \multicolumn{2}{c}{ Vantar } & \multicolumn{2}{c}{ Samtals } \\
\cline { 2 - 7 } & $\mathrm{N}$ & Hlutfall & $\mathrm{N}$ & Hlutfall & $\mathrm{N}$ & Hlutfall \\
\hline kyn_verkkaupa & 116 & $100.0 \%$ & 0 & $.0 \%$ & 116 & $100.0 \%$ \\
ánægja_umræddan & & & & & & \\
\hline \hline
\end{tabular}

Tafla 110 Tengslatafla (tíðni): kyn_verkkaupa * ánaegja_umraeddan

\begin{tabular}{|c|c|c|c|c|c|c|c|}
\hline & \multicolumn{5}{|c|}{ ánægja_umræddan } & \multirow[b]{2}{*}{ Samtals } \\
\hline & & $\begin{array}{c}\text { Mjög } \\
\text { óánægð/ur }\end{array}$ & $\begin{array}{c}\text { Frekar } \\
\text { óánægð/ur }\end{array}$ & $\begin{array}{c}\text { Hvorki } \\
\text { ánægð/ur né } \\
\text { óánægð/ur }\end{array}$ & $\begin{array}{c}\text { Frekar } \\
\text { ánægð/ur }\end{array}$ & $\begin{array}{c}\text { Mjög } \\
\text { ánægð/ur }\end{array}$ & \\
\hline \multirow[t]{2}{*}{ Kyn_verkkaupa } & kk & 0 & 13 & 20 & 39 & 32 & 104 \\
\hline & $\mathrm{kvk}$ & 3 & 2 & 1 & 6 & 0 & 12 \\
\hline Samtals & & 3 & 15 & 21 & 45 & 32 & 116 \\
\hline
\end{tabular}

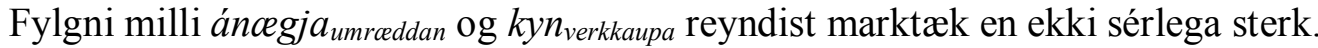

Tafla 111 Ósamhverf fylgnimaligildi: kyn_verkkaupa, ánaegja_umraeddan

\begin{tabular}{|c|c|c|c|c|c|c|}
\hline & & & Gildi & fervik ${ }^{\mathrm{a}}$ & $\mathrm{T}^{\mathrm{b}}$ & Sig. \\
\hline \multirow{3}{*}{$\begin{array}{l}\text { Raðbreyta } \\
\text { á móti } \\
\text { raðbreytu }\end{array}$} & \multirow[t]{3}{*}{ Somers' d } & Samhverft & , 179 & ,061 & 2,483 &, 013 \\
\hline & & kyn_verkkaupa svarbreyta &, 112 & 044 & 2,483 & 013 \\
\hline & & $\begin{array}{l}\text { ánægja_umræddan } \\
\text { svarbreyta }\end{array}$ & ,438 &, 141 & 2,483 & 013 \\
\hline
\end{tabular}

a. Not assuming the null hypothesis.

b. Using the asymptotic standard error assuming the null hypothesis.

Tafla 112 Samhverf fylgnimaligildi: kyn_verkkaupa, ánaegja_umraeddan

\begin{tabular}{llcccc}
\hline \hline & & Gildi & fervik $^{\mathrm{a}}$ & $\mathrm{T}^{\mathrm{b}}$ & Sig. \\
\hline Raðbreyta á & Kendall's tau-c &, 162 &, 065 & 2,483 &, 013 \\
móti raðbreytu & Gamma &, 564 &, 151 & 2,483 &, 013 \\
& $\begin{array}{l}\text { Spearman } \\
\text { fylgnistuðull }\end{array}$ &, 242 &, 083 & 2,658 & $.009^{\mathrm{c}}$ \\
N af gildum tilfellum & & & & \\
\hline \hline
\end{tabular}

a. Not assuming the null hypothesis.

b. Using the asymptotic standard error assuming the null hypothesis.

c. Based on normal approximation. 


\subsubsection{Fylgni: fyrir_einst *ánægja_umræddan}

Fylgni milli áncegja umreddan (hversu áncegður verkkaupi var með framkvoemd verksins hjá umrceddum verktaka) og fyrir_einst (hvort verkkaupi var fyrirtcekja-verkkaupi eða einstaklings-verkkaupi) var skoðuð. Öll 116 tilfellin flokkast undir gild tilfelli.

Tafla 113 Yfirlit tilfella í greiningu milli fyrir_einst og áncegja_umrceddan

\begin{tabular}{lcccccc}
\hline & \multicolumn{6}{c}{ Tilfelli } \\
\cline { 2 - 7 } & \multicolumn{2}{c}{ Gild } & \multicolumn{2}{c}{ Vantar } & \multicolumn{2}{c}{ Samtals } \\
\cline { 2 - 7 } & $\mathrm{N}$ & Hlutfall & $\mathrm{N}$ & Hlutfall & $\mathrm{N}$ & Hlutfall \\
\hline Fyrir_einst* & 116 & $100.0 \%$ & 0 & $.0 \%$ & 116 & $100.0 \%$ \\
ánægja_umræddan & & & & & & \\
\hline \hline
\end{tabular}

Tafla 114 Tengslatafla (tíðni): fyrir_einst *ánaegja_umraeddan

\begin{tabular}{|c|c|c|c|c|c|c|c|}
\hline & & \multicolumn{5}{|c|}{ ánægja_umræddan } & \multirow[b]{2}{*}{ Samtals } \\
\hline & & $\begin{array}{c}\text { Mjög } \\
\text { óánægð/ur }\end{array}$ & $\begin{array}{c}\text { Frekar } \\
\text { óánægð/ur }\end{array}$ & $\begin{array}{c}\text { Hvorki } \\
\text { ánægð/ur né } \\
\text { óánægð/ur }\end{array}$ & $\begin{array}{c}\text { Frekar } \\
\text { ánægð/ur }\end{array}$ & $\begin{array}{c}\text { Mjög } \\
\text { ánægð/ur }\end{array}$ & \\
\hline \multirow[t]{2}{*}{ fyrir_einst } & Fyrirtæki & 0 & 3 & 5 & 23 & 11 & 42 \\
\hline & Einstaklingur & 3 & 12 & 16 & 22 & 21 & 74 \\
\hline Samtals & & 3 & 15 & 21 & 45 & 32 & 116 \\
\hline
\end{tabular}

Ekki reyndist vera marktæk fylgni á milli áncegja $a_{\text {umreddan }}$ og fyrir_einst hvort sem notast var við Sommers`d eða samhverfu fylgnimælistuðlana.

Tafla 115 Ósamhverf fylgnimaligildi: fyrir_einst, ánaegja_umraeddan

\begin{tabular}{|c|c|c|c|c|c|c|}
\hline & & & Gildi & fervik $^{\mathrm{a}}$ & $\mathrm{T}^{\mathrm{b}}$ & Sig. \\
\hline \multirow{3}{*}{$\begin{array}{l}\text { Raðbreyta } \\
\text { á móti } \\
\text { raðbreytu }\end{array}$} & \multirow[t]{3}{*}{ Somers' d } & Samhverft & , 127 & ,078 & 1,621 &, 105 \\
\hline & & fyrir_einst svarbreyta & , 104 & 063 & 1,621 & 105 \\
\hline & & $\begin{array}{l}\text { ánægja_umræddan } \\
\text { svarbreyta }\end{array}$ &, 162 & 100 & 1,621 & 105 \\
\hline
\end{tabular}

a. Not assuming the null hypothesis.

b. Using the asymptotic standard error assuming the null hypothesis.

Tafla 116 Samhverf fylgnimæligildi: fyrir_einst, ánagja_umraeddan

\begin{tabular}{llcccc}
\hline \hline & Gildi & fervik $^{\mathrm{a}}$ & $\mathrm{T}^{\mathrm{b}}$ & Sig. \\
\hline Raðbreyta á & Kendall's tau-c &, 150 &, 093 & 1,621 &, 105 \\
móti raðbreytu & Gamma &, 224 &, 136 & 1,621 &, 105 \\
& Spearman fylgnistuðull &, 142 &, 087 & 1,527 & $.129^{\mathrm{c}}$ \\
N af gildum tilfellum & 116 & & & \\
\hline \hline
\end{tabular}

a. Not assuming the null hypothesis.

b. Using the asymptotic standard error assuming the null hypothesis.

c. Based on normal approximation. 


\subsection{Framkvæmd}

\subsubsection{Fylgni: ánægja_bygg * ánægja_umræddan * fyrir_einst}

Fylgni milli áncegju $u_{\text {bygg }}$ (hversu áncegður verkkaupi var með byggingastjóra) og áncegjumredds var skoðuð með tilliti til pess hvort verkkaupi hafi verið fyrirtækja-verkkaupi eða einstaklings-verkkaupi. 100 tilfelli flokkast undir gild tilfelli.

Tafla 117 Yfirlit tilfella ígreiningu millifyrir_einst, ánaegju_umraedds og ánaegja_bygg

\begin{tabular}{lccccccc}
\hline & \multicolumn{9}{c}{ Tilfelli } \\
\cline { 2 - 7 } & \multicolumn{2}{c}{ Gild } & \multicolumn{2}{c}{ Vantar } & \multicolumn{2}{c}{ Samtals } \\
\cline { 2 - 7 } & $\mathrm{N}$ & Hlutfall & $\mathrm{N}$ & Hlutfall & $\mathrm{N}$ & Hlutfall \\
\hline $\begin{array}{l}\text { Ánægja_bygg* } \\
\text { ánægja_umræddan * } \\
\text { fyrir_einst }\end{array}$ & 100 & $86.2 \%$ & 16 & $13.8 \%$ & 116 & $100.0 \%$ \\
\hline \hline
\end{tabular}




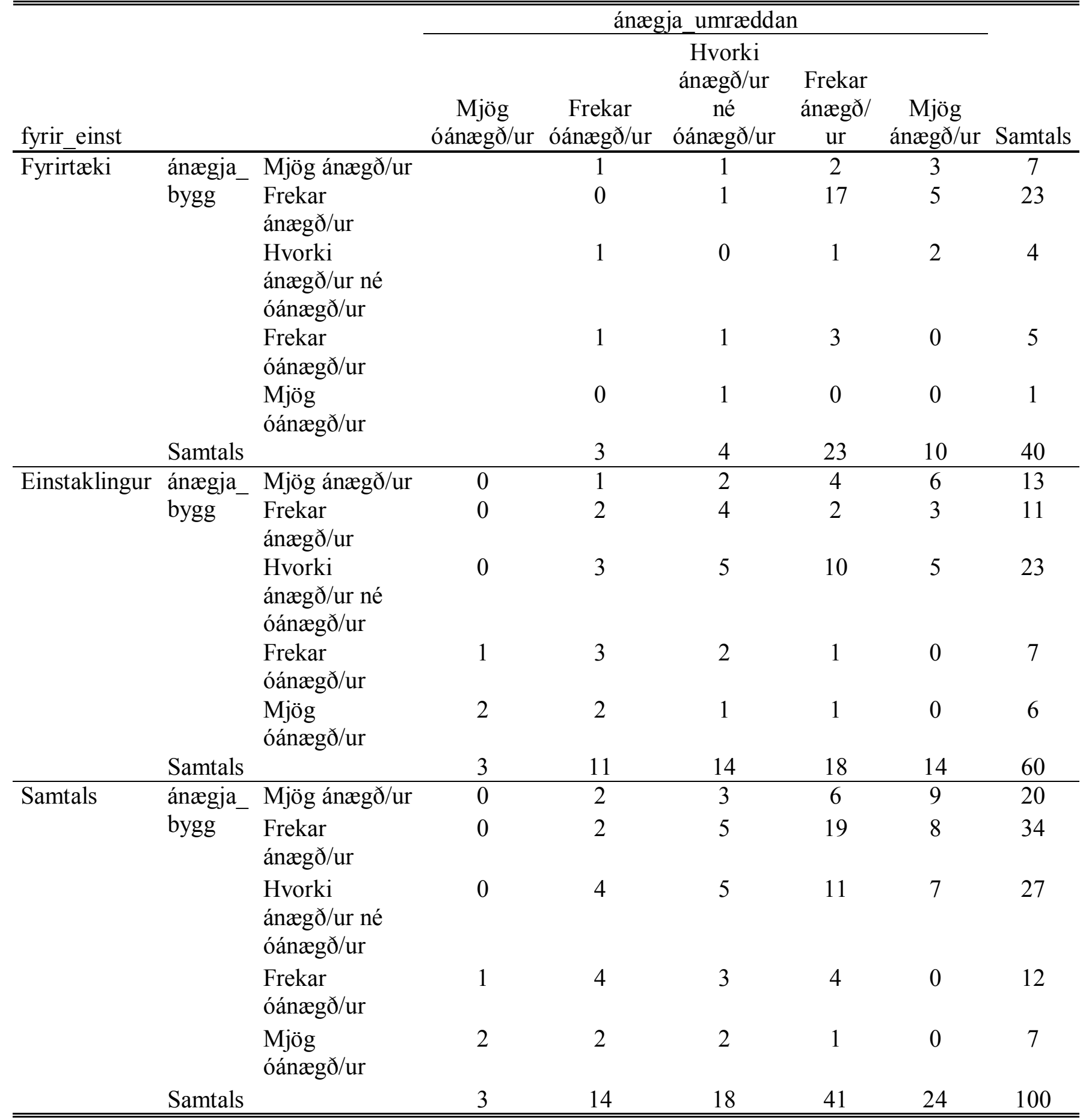

Fylgni milli áncegju $u_{\text {bygg }}$ og áncegju $u_{\text {umredds }}$ reyndist marktæk fyrir einstaklings-verkkaupa sér í lagi og heildarfjölda pátttakenda en ekki einum og sér í lagi fyrir fyrirtækja-verkkaupa. 
Tafla 119 Ósamhverf fylgnimæligildi: ánaegja_bygg,ánaegja_umraeddan,fyrir_einst

\begin{tabular}{|c|c|c|c|c|c|c|}
\hline fyrir_einst & & & Gildi & fervik $^{\mathrm{a}}$ & $\mathrm{T}^{\mathrm{b}}$ & Sig. \\
\hline \multirow[t]{3}{*}{ Fyrirtæki } & \multirow{3}{*}{$\begin{array}{l}\text { Raðbreyta Somers'd } \\
\text { á móti } \\
\text { raðbreytu }\end{array}$} & Samhverft & ,206 &, 169 & 1,194 & 232 \\
\hline & & $\begin{array}{l}\text { ánægja_bygg } \\
\text { svarbreyta }\end{array}$ & 209 & 173 & 1,194 & 232 \\
\hline & & $\begin{array}{l}\text { ánægja_umræddan } \\
\text { svarbreyta }\end{array}$ & ,202 & , 166 & 1,194 & ,232 \\
\hline \multirow[t]{3}{*}{ Einstaklingur } & \multirow{3}{*}{$\begin{array}{l}\text { Raðbreyta Somers'd } \\
\text { á móti } \\
\text { raðbreytu }\end{array}$} & Samhverft & ,376 & ,096 & 3,755 &, 000 \\
\hline & & $\begin{array}{l}\text { ánægja_bygg } \\
\text { svarbreyta }\end{array}$ & 372 & ,096 & 3,755 &, 000 \\
\hline & & $\begin{array}{l}\text { ánægja_umræddan } \\
\text { svarbreyta }\end{array}$ & ,380 & ,097 & 3,755 &, 000 \\
\hline \multirow[t]{3}{*}{ Samtals } & \multirow{3}{*}{$\begin{array}{l}\text { Raðbreyta } \\
\text { á móti } \\
\text { raðbreytu }\end{array}$} & Samhverft & ,341 & ,081 & 4,073 & ,000 \\
\hline & & $\begin{array}{l}\text { ánægja_bygg } \\
\text { svarbreyta }\end{array}$ & ,348 & 083 & 4,073 &, 000 \\
\hline & & $\begin{array}{l}\text { ánægja_umræddan } \\
\text { svarbreyta }\end{array}$ & ,334 & ,079 & 4,073 &, 000 \\
\hline
\end{tabular}

a. Not assuming the null hypothesis.

b. Using the asymptotic standard error assuming the null hypothesis.

Tafla 120 Samhverf fylgnimaligildi: ánagja_bygg, ánaegja_umraeddan,fyrir_einst

\begin{tabular}{|c|c|c|c|c|c|c|c|}
\hline fyrir_einst & & & & Gildi & fervik $^{\mathrm{a}}$ & $\mathrm{T}^{\mathrm{b}}$ & Sig. \\
\hline \multirow[t]{4}{*}{ Fyrirtæki } & Raðbreyta & \multicolumn{2}{|c|}{ Kendall's tau-b } & ,206 &, 169 & 1,194 & ,232 \\
\hline & $\begin{array}{l}\text { á móti } \\
\text { raðbreytu }\end{array}$ & Gamma & $\begin{array}{l}\text { Núllta- } \\
\text { stigs }\end{array}$ & ,294 & ,239 & 1,194 & ,232 \\
\hline & & \multicolumn{2}{|c|}{ Spearman fylgnistuðull } & 233 & ,188 & 1,478 & $.148^{\mathrm{c}}$ \\
\hline & \multicolumn{3}{|c|}{$\mathrm{N}$ af gildum tilfellum } & 40 & & & \\
\hline \multirow[t]{3}{*}{ Einstaklingur } & Raðbreyta & \multicolumn{2}{|c|}{ Kendall's tau-b } & ,376 &, 096 & 3,755 & ,000 \\
\hline & $\begin{array}{l}\text { á móti } \\
\text { raðbreytu }\end{array}$ & Gamma & $\begin{array}{l}\text { Núllta- } \\
\text { stigs }\end{array}$ & , 482 &, 117 & 3,755 &, 000 \\
\hline & $\mathrm{N}$ af gildun & \multicolumn{2}{|c|}{$\begin{array}{l}\text { Spearman fylgnistuðull } \\
\text { tilfellum }\end{array}$} & $\begin{array}{c}, 446 \\
60\end{array}$ & ,111 & 3,795 & $.000^{\mathrm{c}}$ \\
\hline \multirow[t]{5}{*}{ Samtals } & Raðbreyta & \multicolumn{2}{|c|}{ Kendall's tau-b } & ,341 & ,081 & 4,073 & 000 \\
\hline & $\begin{array}{l}\text { á móti } \\
\text { raðbreytu }\end{array}$ & \multirow[t]{2}{*}{ Gamma } & $\begin{array}{l}\text { Núllta- } \\
\text { stigs }\end{array}$ & ,449 & ,102 & 4,073 &, 000 \\
\hline & & & $\begin{array}{l}\text { Fyrsta- } \\
\text { stigs } \\
\text { hlutfylgni }\end{array}$ & ,437 & & & \\
\hline & & \multicolumn{2}{|c|}{ Spearman fylgnistuðull } & ,399 & ,092 & 4,309 & $.000^{\mathrm{c}}$ \\
\hline & $\mathrm{N}$ af gildun & tilfellum & & 100 & & & \\
\hline
\end{tabular}

a. Not assuming the null hypothesis.

b. Using the asymptotic standard error assuming the null hypothesis.

c. Based on normal approximation. 


\subsection{2 Áætlanir}

\subsubsection{Tvívítt fylgnifylki: ánægja_umræddan, ánægja_tíma, skrifleg_tíma, tímaáætlun, GSK}

Ef tvívítt fylgnifylki með Spearman's rho fyrir áncegja_umrceddan, áncegja_tíma, skrifleg_tíma, tímaácetlun, GSK er skoðað sést að marktæk fylgni er á milli annars vegar áncegja_umrceddan og hins vegar áncegja_tíma, tímaácetlun og GSK, einnig er marktæk fylgni milli GSK og skrifleg_tíma og milli tímaácetlun og ánaegja_tíma.

Tafla 121 Tvívítt fylgnifylki: ánaegja_umraeddan, ánaegja_tíma, skrifleg_tíma,tímaáaetlun, GSK

\begin{tabular}{|c|c|c|c|c|c|c|c|}
\hline & & & $\begin{array}{l}\text { ánægja } \\
\text { umrædd }\end{array}$ & $\begin{array}{c}\text { ánægja_ } \\
\text { tíma }\end{array}$ & $\begin{array}{c}\text { skrifleg } \\
\text { tíma }\end{array}$ & $\begin{array}{l}\text { tíma- } \\
\text { áætlun }\end{array}$ & GSK \\
\hline \multirow[t]{15}{*}{ Spearman's rho } & \multirow[t]{3}{*}{ ánægja_umræddan } & Fylgni-stuðull & 1,000 & $.515^{* *}$ &,- 016 & $.399^{* *}$ & $.430^{* * *}$ \\
\hline & & Sig. (2-tailed) & . &, 000 &, 863 &, 000 &, 003 \\
\hline & & $\mathrm{N}$ & 116 & 116 & 116 & 116 & 47 \\
\hline & \multirow[t]{3}{*}{ ánægja_tíma } & Fylgni-stuðull & $.515^{* *}$ & 1,000 &, 034 & $.701^{* *}$ & ,217 \\
\hline & & Sig. (2-tailed) &, 000 & . & ,714 &, 000 & ,142 \\
\hline & & $\mathrm{N}$ & 116 & 116 & 116 & 116 & 47 \\
\hline & \multirow[t]{3}{*}{ skrifleg_tíma } & Fylgni-stuðull &,- 016 & 034 & 1,000 &,- 110 & $.537^{* *}$ \\
\hline & & Sig. (2-tailed) &, 863 & ,714 & . & ,240 &, 000 \\
\hline & & $\mathrm{N}$ & 116 & 116 & 116 & 116 & 47 \\
\hline & \multirow[t]{3}{*}{ tímaáætlun } & Fylgni-stuðull & $.399^{* *}$ & $.701^{* *}$ &,- 110 & 1,000 & ,010 \\
\hline & & Sig. (2-tailed) &, 000 &, 000 & ,240 & . & ,948 \\
\hline & & $\mathrm{N}$ & 116 & 116 & 116 & 116 & 47 \\
\hline & \multirow[t]{3}{*}{ GSK } & Fylgni-stuðull & $.430^{* *}$ & 217 & $.537^{* *}$ & 010 & 1,000 \\
\hline & & Sig. (2-tailed) &, 003 & ,142 &, 000 & ,948 & . \\
\hline & & $\mathrm{N}$ & 47 & 47 & 47 & 47 & 47 \\
\hline
\end{tabular}

**. Correlation is significant at the 0.01 level (2-tailed). 


\subsubsection{Fylgni: skrifleg_tíma $*$ ánægja_umræddan $*$ fyrir_einst}

Fylgni milli skrifleg tima og áncegjumredds var skoðuð með tilliti til pess hvort verkkaupi hafi verið fyrirtækja-verkkaupi eða einstaklings-verkkaupi. Öll 116 tilfellin flokkast undir gild tilfelli.

Tafla 122 Yfirlit tilfella ígreiningu milli fyrir_einst, ánagju_umraedds og skrifleg_tíma

\begin{tabular}{lcccccc}
\hline \hline & \multicolumn{9}{c}{ Tilfelli } \\
\cline { 2 - 7 } & \multicolumn{2}{c}{ Gild } & \multicolumn{2}{c}{ Vantar } & \multicolumn{2}{c}{ Samtals } \\
\cline { 2 - 7 } & $\mathrm{N}$ & Hlutfall & $\mathrm{N}$ & Hlutfall & $\mathrm{N}$ & Hlutfall \\
\hline $\begin{array}{l}\text { skrifleg_tíma * } \\
\text { ánægja_umræddan } \\
\text { fyrir_einst }\end{array}$ & 116 & $100.0 \%$ & 0 & $.0 \%$ & 116 & $100.0 \%$ \\
\hline \hline
\end{tabular}

Tafla 123 Tengslatafla (tỉðni): skrifleg_tíma *áncegja_umraeddan *fyrir_einst

\begin{tabular}{|c|c|c|c|c|c|c|c|c|}
\hline \multirow[b]{2}{*}{ fyrir_einst } & & & \multicolumn{5}{|c|}{ ánægja_umræddan } & \multirow[b]{2}{*}{ Samtals } \\
\hline & & & $\begin{array}{c}\text { Mjög } \\
\text { óánægð/ur }\end{array}$ & $\begin{array}{c}\text { Frekar } \\
\text { óánægð/ur }\end{array}$ & $\begin{array}{l}\text { Hvorki } \\
\text { ánægð/ur } \\
\text { né } \\
\text { óánægð/ur }\end{array}$ & $\begin{array}{c}\text { Frekar } \\
\text { ánægð/ur }\end{array}$ & $\begin{array}{c}\text { Mjög } \\
\text { ánægð/ur }\end{array}$ & \\
\hline \multirow{3}{*}{ Fyrirtæki } & skrifleg tíma & Já & & 2 & 2 & 22 & 9 & 35 \\
\hline & & Nei & & 1 & 3 & 1 & 2 & 7 \\
\hline & Samtals & & & 3 & 5 & 23 & 11 & 42 \\
\hline \multirow[t]{3}{*}{ Einstaklingur } & skrifleg_tíma & Já & 1 & 5 & 6 & 4 & 3 & 19 \\
\hline & & $\mathrm{Nei}$ & 2 & 7 & 10 & 18 & 18 & 55 \\
\hline & Samtals & & 3 & 12 & 16 & 22 & 21 & 74 \\
\hline \multirow[t]{3}{*}{ Samtals } & skrifleg_tíma & Já & 1 & 7 & 8 & 26 & 12 & 54 \\
\hline & & $\mathrm{Nei}$ & 2 & 8 & 13 & 19 & 20 & 62 \\
\hline & Samtals & & 3 & 15 & 21 & 45 & 32 & 116 \\
\hline
\end{tabular}

Ósamhverfi fylgnistuðullinn Sommer's d gefur að marktæk fylgni sé á milli áncegju umredds og pess hvort umræddur verktaki hafi lagt fram skriflega tímaáætlun meðal einstaklings verkkaupa. Fylgni milli ofangreindra pátta var ekki næg til að teljast marktæk meðal fyrirtækja-verkkaupa eða heildarfjölda pátttakenda. 
Tafla 124 Ósamhverffylgnimceligildi: fyrir_einst, ánægja_umrædds, skrifleg_tíma

\begin{tabular}{|c|c|c|c|c|c|c|c|}
\hline fyrir_einst & & & & Gildi & fervik $^{\mathrm{a}}$ & $\mathrm{T}^{\mathrm{b}}$ & Sig. \\
\hline \multirow[t]{3}{*}{ Fyrirtæki } & \multirow{3}{*}{$\begin{array}{l}\text { Raðbreyt } \\
\text { a á móti } \\
\text { raðbreytu }\end{array}$} & \multirow[t]{3}{*}{ Somers' d } & Samhverft & ,186 & ,171 & 1,046 & ,296 \\
\hline & & & $\begin{array}{l}\text { skrifleg_tíma } \\
\text { svarbreyta }\end{array}$ & ,135 &, 127 & 1,046 & ,296 \\
\hline & & & $\begin{array}{l}\text { ánægja_umrædd } \\
\text { an svarbreyta }\end{array}$ & ,298 & ,273 & 1,046 & ,296 \\
\hline \multirow[t]{3}{*}{ Einstaklingur } & \multirow{3}{*}{$\begin{array}{l}\text { Raðbreyt } \\
\text { a á móti } \\
\text { raðbreytu }\end{array}$} & \multirow[t]{3}{*}{ Somers' d } & Samhverft &,- 205 & ,095 & $-2,102$ & ,036 \\
\hline & & & $\begin{array}{l}\text { skrifleg_tíma } \\
\text { svarbreyta }\end{array}$ &,- 155 & ,073 & $-2,102$ & ,036 \\
\hline & & & $\begin{array}{l}\text { ánægja_umrædd } \\
\text { an svarbreyta }\end{array}$ &,- 306 & , 140 & $-2,102$ & ,036 \\
\hline \multirow[t]{3}{*}{ Samtals } & \multirow{3}{*}{$\begin{array}{l}\text { Raðbreyt } \\
\text { a á móti } \\
\text { raðbreytu }\end{array}$} & \multirow[t]{3}{*}{ Somers' d } & Samhverft &,- 015 & ,084 &,- 175 & ,861 \\
\hline & & & $\begin{array}{l}\text { skrifleg_tíma } \\
\text { svarbreyta }\end{array}$ &,- 012 & ,071 &,- 175 & ,861 \\
\hline & & & $\begin{array}{l}\text { ánægja_umrædd } \\
\text { an svarbreyta }\end{array}$ &,- 018 & , 103 &,- 175 & ,861 \\
\hline
\end{tabular}

a. Not assuming the null hypothesis.

b. Using the asymptotic standard error assuming the null hypothesis.

Samhverfu fylgnistuðlarnir gefa allir sömu niðurstöðu og Sommer‘s d. P.e. að fylgni milli áncegjumrcedds og skrifleg $_{\text {ima }}$ er marktæk fyrir einstaklings-verkkaupa en fylgni milli ofangreindra pátta mælist ekki næg til að teljast marktæk fyrir fyrirtækja-verkkaupa og fyrir heildarfjölda pátttakenda. Engu að síður er fylgni milli áncegju $u_{\text {umredds }}$ og skrifleg tima $_{\text {veik }}{ }^{107}$ fyrir einstaklings-verkkaupa.

Tafla 125 Samhverf fylgnimæligildi: fyrir_einst, ánaegja_umraedds, skrifleg_tíma

\begin{tabular}{|c|c|c|c|c|c|c|c|}
\hline fyrir_einst & & & & Gildi & fervik $^{\mathrm{a}}$ & $\mathrm{T}^{\mathrm{b}}$ & Sig. \\
\hline \multirow[t]{4}{*}{ Fyrirtæki } & Raðbreyta & \multicolumn{2}{|c|}{ Kendall's tau-c } &, 166 & ,158 & 1,046 & ,296 \\
\hline & á móti & Gamma & Núllta-stigs & 371 & 324 & 1,046 & 296 \\
\hline & raðbreytu & \multicolumn{2}{|c|}{ Spearman fylgnistuðull } & 213 & 196 & 1,378 & $.176^{\mathrm{c}}$ \\
\hline & \multicolumn{3}{|c|}{$\mathrm{N}$ af gildum tilfellum } & 42 & & & \\
\hline \multirow[t]{4}{*}{ Einstaklingur } & Raðbreyta & \multicolumn{2}{|c|}{ Kendall's tau-c } &,- 234 & ,111 & $-2,102$ & ,036 \\
\hline & á móti & Gamma & Núllta-stigs &,- 389 & 169 & $-2,102$ & 036 \\
\hline & raðbreytu & \multicolumn{2}{|c|}{ Spearman fylgnistuðull } &,- 239 &, 111 & $-2,093$ & $.040^{\mathrm{c}}$ \\
\hline & \multicolumn{3}{|c|}{$\mathrm{N}$ af gildum tilfellum } & 74 & & & \\
\hline \multirow[t]{5}{*}{ Samtals } & \multirow{3}{*}{$\begin{array}{l}\text { Raðbreyta } \\
\text { á móti } \\
\text { raðbreytu }\end{array}$} & \multicolumn{2}{|c|}{ Kendall's tau-c } &,- 018 & 102 &,- 175 & ,861 \\
\hline & & \multirow[t]{2}{*}{ Gamma } & Núllta-stigs &,- 024 & 140 &,- 175 &, 861 \\
\hline & & & Fyrsta-stigs &,- 242 & & & \\
\hline & & \multicolumn{2}{|c|}{ Spearman fylgnistuðull } &,- 016 & ,093 &,- 173 & $.863^{\mathrm{c}}$ \\
\hline & \multicolumn{3}{|c|}{$\mathrm{N}$ af gildum tilfellum } & 116 & & & \\
\hline
\end{tabular}

a. Not assuming the null hypothesis.

b. Using the asymptotic standard error assuming the null hypothesis.

c. Based on normal approximation.

\footnotetext{
${ }^{107}$ Samkvæmt pumalputta reglum um styrk fylgni. Sjá kafla um grunnathuganir á bls. 81 256
} 


\subsubsection{Fylgni: tímaáætlun * ánægja_umræddan * fyrir_einst}

Fylgni milli tímaácetlun (pess hvort verkið hjá umrceddum verktaka hafi farið fram úr tímaácetlun) og áncegju umreddan var skoðuð með tilliti til pess hvort verkkaupi hafi verið fyrirtækja-verkkaupi eða einstaklings-verkkaupi. Öll 116 tilfellin flokkast undir gild tilfelli.

Tafla 126 Yfirlit tilfella í greiningu milli fyrir_einst, ánaegju_umraedds og tímaácetlun

\begin{tabular}{lcccccc}
\hline \hline & \multicolumn{6}{c}{ Tilfelli } \\
\cline { 2 - 7 } & \multicolumn{2}{c}{ Gild } & \multicolumn{2}{c}{ Vantar } & \multicolumn{2}{c}{ Samtals } \\
\cline { 2 - 7 } & $\mathrm{N}$ & Hlutfall & $\mathrm{N}$ & Hlutfall & $\mathrm{N}$ & Hlutfall \\
\hline $\begin{array}{l}\text { tímaáætlun * } \\
\text { ánægja_umræddan * } \\
\text { fyrir_einst }\end{array}$ & 116 & $100.0 \%$ & 0 & $.0 \%$ & 116 & $100.0 \%$ \\
\hline \hline
\end{tabular}

Í tengslatöflunni má greina munstur að verkkaupar eru óánægðari með umrædda verktaka sem stóðust ekki tímaáætlun.

Tafla 127 Tengslatafla (tíðni): tímaácetlun * ánaegja_umraeddan * fyrir_einst

\begin{tabular}{|c|c|c|c|c|c|c|c|c|}
\hline \multirow[b]{2}{*}{ fyrir_einst } & & & \multicolumn{5}{|c|}{ ánægja_umræddan } & \multirow[b]{2}{*}{ Samtals } \\
\hline & & & $\begin{array}{c}\text { Mjög } \\
\text { óánægð/ur }\end{array}$ & $\begin{array}{c}\text { Frekar } \\
\text { óánægð/ur }\end{array}$ & $\begin{array}{c}\text { Hvorki } \\
\text { ánægð/ur } \\
\text { né } \\
\text { óánægð/ur }\end{array}$ & $\begin{array}{c}\text { Frekar } \\
\text { ánægð/ur }\end{array}$ & $\begin{array}{c}\text { Mjög } \\
\text { ánægð/ur }\end{array}$ & \\
\hline \multirow[t]{6}{*}{ Fyrirtæki } & tímaáætlun & Ekkert & & 0 & 1 & 5 & 7 & 13 \\
\hline & & Lítið & & 1 & 1 & 0 & 0 & 2 \\
\hline & & Nokkuð & & 0 & 0 & 7 & 3 & 10 \\
\hline & & Mikið & & 1 & 3 & 6 & 1 & 11 \\
\hline & & $\begin{array}{l}\text { Mjög } \\
\text { mikið }\end{array}$ & & 1 & 0 & 5 & 0 & 6 \\
\hline & Samtals & & & 3 & 5 & 23 & 11 & 42 \\
\hline \multirow[t]{6}{*}{ Einstaklingur } & tímaáætlun & Ekkert & 0 & 1 & 3 & 3 & 4 & 11 \\
\hline & & Lítið & 0 & 0 & 3 & 6 & 7 & 16 \\
\hline & & Nokkuð & 0 & 3 & 4 & 7 & 9 & 23 \\
\hline & & Mikið & 1 & 5 & 2 & 3 & 1 & 12 \\
\hline & & $\begin{array}{l}\text { Mjög } \\
\text { mikið }\end{array}$ & 2 & 3 & 4 & 3 & 0 & 12 \\
\hline & Samtals & & 3 & 12 & 16 & 22 & 21 & 74 \\
\hline \multirow[t]{6}{*}{ Samtals } & tímaáætlun & Ekkert & 0 & 1 & 4 & 8 & 11 & 24 \\
\hline & & Lítið & 0 & 1 & 4 & 6 & 7 & 18 \\
\hline & & Nokkuð & 0 & 3 & 4 & 14 & 12 & 33 \\
\hline & & Mikið & 1 & 6 & 5 & 9 & 2 & 23 \\
\hline & & $\begin{array}{l}\text { Mjög } \\
\text { mikið }\end{array}$ & 2 & 4 & 4 & 8 & 0 & 18 \\
\hline & Samtals & & 3 & 15 & 21 & 45 & 32 & 116 \\
\hline
\end{tabular}


Pað kemur ekki á óvart að marktæk fylgni finnst á milli áncegju umredds og tímaácetlun með Sommers‘d. Í öllum tilfellum, p.e. fyrir heildarfjölda svara og sér í lagi meðal fyrirtækja-verkkaupa og einstaklingsverkkaupa fæst að fylgni milli ofangreindra pátta sé marktæk. Fylgnin er milli pess að vera frekar veik og miðlungs sterk.

Tafla 128 Ósamhverffylgnimaeligildi: tímaácetlun, ánaegja_umraeddan,fyrir_einst

\begin{tabular}{|c|c|c|c|c|c|c|}
\hline fyrir_einst & & & Gildi & fervik $^{a}$ & $\mathrm{~T}^{\mathrm{b}}$ & Sig. \\
\hline \multirow[t]{3}{*}{ Fyrirtæki } & Raðbreyta Somers'd & Samhverft & ,326 &, 114 & 2,825 &, 005 \\
\hline & á móti & tímaáætlun svarbreyta &, 365 & 125 & 2,825 & 005 \\
\hline & raðbreytu & $\begin{array}{l}\text { ánægja_umræddan } \\
\text { svarbreyta }\end{array}$ & ,295 & 108 & 2,825 &, 005 \\
\hline \multirow[t]{3}{*}{ Einstaklingur } & Raðbreyta Somers'd & Samhverft & ,347 & ,080 & 4,275 &, 000 \\
\hline & á móti & tímaáætlun svarbreyta &, 353 & 080 & 4,275 &, 000 \\
\hline & raðbreytu & $\begin{array}{l}\text { ánægja_umræddan } \\
\text { svarbreyta }\end{array}$ &, 341 & 079 & 4,275 &, 000 \\
\hline \multirow[t]{3}{*}{ Samtals } & Raðbreyta Somers'd & Samhverft &, 330 & ,065 & 4,987 &, 000 \\
\hline & á móti & tímaáætlun svarbreyta & ,345 &, 067 & 4,987 &, 000 \\
\hline & raðbreytu & $\begin{array}{l}\text { ánægja_umræddan } \\
\text { svarbreyta }\end{array}$ & ,316 & ,063 & 4,987 &, 000 \\
\hline
\end{tabular}

a. Not assuming the null hypothesis.

b. Using the asymptotic standard error assuming the null hypothesis.

Samhverfu fylgnistuðlarnir gefa allir sömu niðurstöðu og Sommer's d. Р.e. að fylgni milli áncegjumrceddan og tímaácetlun er marktæk í öllum tilfellum. Fylgnin flokkast til pess að vera miðlungs sterk.

Tafla 129 Samhverf fylgnimæligildi: fyrir einst, ánaegja umraeddan, tímaáaetlun

\begin{tabular}{|c|c|c|c|c|c|c|c|}
\hline fyrir einst & & & & Gildi & fervik $^{\mathrm{a}}$ & 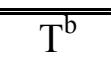 & Sig. \\
\hline \multirow[t]{4}{*}{ Fyrirtæki } & \multicolumn{3}{|c|}{ Raðbreyta á Kendall's tau-b } & ,328 &, 115 & 2,825 & ,005 \\
\hline & móti & Gamma & Núllta-stigs & ,459 &, 158 & 2,825 & 005 \\
\hline & raðbreytu & Spearma & lgnistuðull & ,386 & 130 & 2,646 & $.012^{\mathrm{c}}$ \\
\hline & \multicolumn{3}{|c|}{$\mathrm{N}$ af gildum tilfellum } & 42 & & & \\
\hline \multirow[t]{4}{*}{ Einstaklingur } & \multirow{3}{*}{$\begin{array}{l}\text { Raðbreyta á } \\
\text { móti } \\
\text { raðbreytu }\end{array}$} & \multicolumn{2}{|c|}{ Kendall's tau-b } & ,347 & ,080 & 4,275 & ,000 \\
\hline & & Gamma & Núllta-stigs & ,442 & ,098 & 4,275 & 000 \\
\hline & & Spearma & lgnistuðull & ,430 & ,094 & 4,042 & $.000^{\mathrm{c}}$ \\
\hline & \multicolumn{3}{|c|}{$\mathrm{N}$ af gildum tilfellum } & 74 & & & \\
\hline \multirow[t]{5}{*}{ Samtals } & \multirow{4}{*}{$\begin{array}{l}\text { Raðbreyta á } \\
\text { móti } \\
\text { raðbreytu }\end{array}$} & \multicolumn{2}{|c|}{ Kendall's tau-b } & ,330 & ,065 & 4,987 & ,000 \\
\hline & & \multirow[t]{2}{*}{ Gamma } & Núllta-stigs & ,430 & 082 & 4,987 &, 000 \\
\hline & & & $\begin{array}{l}\text { Fyrsta-stigs } \\
\text { hlutfylgni }\end{array}$ & ,445 & & & \\
\hline & & \multicolumn{2}{|c|}{ Spearman fylgnistuðull } & ,399 & ,077 & 4,649 & $.000^{\mathrm{c}}$ \\
\hline & \multicolumn{3}{|c|}{$\mathrm{N}$ af gildum tilfellum } & 116 & & & \\
\hline
\end{tabular}

a. Not assuming the null hypothesis.

b. Using the asymptotic standard error assuming the null hypothesis.

c. Based on normal approximation. 


\subsubsection{Fylgni: skrifleg_tíma * tímaáætlun}

Fylgni milli tímaácetlun (pess hvort verkið hjá umrceddum verktaka hafi farið fram úr tímaácetlun) og skrifleg $_{\text {tima }}$ (hvort tímaácetlun hafi verið skrifleg) var skoðuð. Öll 116 tilfellin flokkast undir gild tilfelli svo óparfi er að hafa áhyggjur af normaldreifingu vegna ályktana.

Tafla 130 Yfirlit tilfella í greiningu milli skrifleg_tíma og tímaáaetlun

\begin{tabular}{lcccccc}
\hline \hline & \multicolumn{6}{c}{ Tilfelli } \\
\cline { 2 - 8 } & $\mathrm{N}$ & Hlutfall & $\mathrm{N}$ & Hlutfall & $\mathrm{N}$ & Hlutfall \\
\cline { 2 - 8 } \\
\hline Skrifleg_tíma * tímaáætlun & 116 & $100.0 \%$ & 0 & $.0 \%$ & 116 & $100.0 \%$ \\
\hline \hline
\end{tabular}

Tafla 131 Tengslatafla (tíðni): skrifleg_tíma * tímaácetlun

\begin{tabular}{llcccccc}
\hline \hline & & \multicolumn{5}{c}{ tímaáætlun } & \\
\cline { 3 - 6 } & & Mjög & & & & \\
& mikið & Mikið & Nokkuð & Lítið & Ekkert & Samtals \\
\hline skrifleg_tíma & Já & 13 & 11 & 11 & 6 & 13 & 54 \\
& Nei & 5 & 12 & 22 & 12 & 11 & 62 \\
Samtals & 18 & 23 & 33 & 18 & 24 & 116 \\
\hline \hline
\end{tabular}

Fylgni milli tímaácetlun og skrifleg tima mælist ekki marktæk með Sommers'd né með samhverfu mæligildunum.

Tafla 132 Ósamhverf fylgnimæligildi: skrifleg_tíma, tímaáaetlun

\begin{tabular}{|c|c|c|c|c|c|}
\hline & & Gildi & " fervik $^{\mathrm{a}}$ & $\mathrm{T}^{\mathrm{b}}$ & Sig. \\
\hline \multirow{3}{*}{$\begin{array}{l}\text { Raðbreyta á Somers' d } \\
\text { móti } \\
\text { raðbreytu }\end{array}$} & Samhverft &,- 096 & ,083 & $-1,156$ & ,248 \\
\hline & $\begin{array}{l}\text { skrifleg_tíma } \\
\text { svarbreyta }\end{array}$ &,- 078 & ,068 & $-1,156$ & ,248 \\
\hline & $\begin{array}{l}\text { Tímaáætlun } \\
\text { svarbreyta }\end{array}$ &,- 124 & ,107 & $-1,156$ & ,248 \\
\hline
\end{tabular}

a. Not assuming the null hypothesis.

b. Using the asymptotic standard error assuming the null hypothesis.

Tafla 133 Samhverf fylgnimaligildi: skrifleg_tíma, tímaáaetlun

\begin{tabular}{llcccc}
\hline \hline & Gildi & fervik $^{\mathrm{a}}$ & $\mathrm{T}^{\mathrm{b}}$ & Sig. \\
\hline Raðbreyta á & Kendall's tau-c &,- 124 &, 107 & $-1,156$ &, 248 \\
móti raðbreytu & Gamma &,- 154 &, 133 & $-1,156$ &, 248 \\
& Spearman fylgnistuðull &,- 110 &, 095 & $-1,181$ & $.240^{\mathrm{c}}$ \\
N af gildum tilfellum & 116 & & & \\
\hline \hline
\end{tabular}

a. Not assuming the null hypothesis.

b. Using the asymptotic standard error assuming the null hypothesis.

c. Based on normal approximation. 


\subsubsection{Tvívítt fylgnifylki: ánægja_umræddan, ánægja_greiðslu, skrifleg_greiðslu, greiðsluáætlun, GSK}

Ef tvívítt fylgnifylki með Spearman's rho fyrir áncegja_umraeddan, áncegja_greiðslu, skrifleg_greiðslu, greiðsluácetlun, GSK er skoðað sést að marktæk fylgni er á milli annars vegar áncegja_umrceddan og hins vegar ánceja_greiðslu, greiðsluácetlun og GSK, einnig er marktæk fylgni milli GSK og skrifleg_greiðslu og milli greiðsluácetlun og áncegja_greiðslu.

Tafla 134 tvívítt fylgnifylki: ánagja_umraeddan, ánaegja_greiðslu, skrifleg_greiðslu, greiðsluáaetlun, GSK

\begin{tabular}{|c|c|c|c|c|c|c|c|}
\hline & & & $\begin{array}{l}\text { ánægja } \\
\text { umrædd }\end{array}$ & $\begin{array}{l}\text { ánægja } \\
\text { greiðslu }\end{array}$ & $\begin{array}{l}\text { skrifleg_ } \\
\text { greiðslu }\end{array}$ & $\begin{array}{l}\text { greiðslu } \\
\text {-áætlun }\end{array}$ & GSK \\
\hline \multirow{15}{*}{$\begin{array}{l}\text { Spearman's } \\
\text { rho }\end{array}$} & \multirow{3}{*}{ ánægja_umræddan } & Fylgni-stuðull & 1,000 & $.400^{* * *}$ &, 065 & $.332^{* *}$ & $.430^{* * *}$ \\
\hline & & Sig. (2-tailed) & &, 000 & ,486 &, 000 &, 003 \\
\hline & & $\mathrm{N}$ & 116 & 116 & 116 & 116 & 47 \\
\hline & \multirow[t]{3}{*}{ ánægja_greiðslu } & Fylgni-stuðull & $.400^{* *}$ & 1,000 & $.189^{*}$ & $.460^{* *}$ & ,248 \\
\hline & & Sig. (2-tailed) &, 000 & . &, 042 &, 000 & ,092 \\
\hline & & $\mathrm{N}$ & 116 & 116 & 116 & 116 & 47 \\
\hline & \multirow[t]{3}{*}{ skrifleg_greiðslu } & Fylgni-stuðull &, 065 & $.189^{*}$ & 1,000 &, 180 & $.407^{* *}$ \\
\hline & & Sig. (2-tailed) & ,486 & ,042 & . & ,053 &, 005 \\
\hline & & $\mathrm{N}$ & 116 & 116 & 116 & 116 & 47 \\
\hline & \multirow[t]{3}{*}{ greiðsluáætlun } & Fylgni-stuðull & $.332^{* *}$ & $.460^{* *}$ & 180 & 1,000 & 041 \\
\hline & & Sig. (2-tailed) &, 000 &, 000 & ,053 & . & ,786 \\
\hline & & $\mathrm{N}$ & 116 & 116 & 116 & 116 & 47 \\
\hline & \multirow[t]{3}{*}{ GSK } & Fylgni-stuðull & $.430^{* *}$ & ,248 & $.407^{* *}$ &, 041 & 1,000 \\
\hline & & Sig. (2-tailed) &, 003 & ,092 &, 005 & ,786 & . \\
\hline & & $\mathrm{N}$ & 47 & 47 & 47 & 47 & 47 \\
\hline
\end{tabular}

**. Correlation is significant at the 0.01 level (2-tailed).

*. Correlation is significant at the 0.05 level (2-tailed).

\subsubsection{Fylgni: skrifleg_greiðslu * ánægja_umræddan * fyrir_einst}

Fylgni milli skrifleg greiðslu og áncegju umredds var skoðuð með tilliti til pess hvort verkkaupi hafi verið fyrirtækja-verkkaupi eða einstaklings-verkkaupi. Öll 116 tilfellin flokkast undir gild tilfelli.

Tafla 135 Yfirlit tilfella ígreiningu milli fyrir_einst, ánaegju_umraedds og skrifleg_greiðslu

\begin{tabular}{lcccccc}
\hline & \multicolumn{6}{c}{ Tilfelli } \\
\cline { 2 - 7 } & \multicolumn{2}{c}{ Gild } & \multicolumn{2}{c}{ Vantar } & \multicolumn{2}{c}{ Samtals } \\
\cline { 2 - 7 } & $\mathrm{N}$ & Hlutfall & $\mathrm{N}$ & Hlutfall & $\mathrm{N}$ & Hlutfall \\
\hline & 116 & $100.0 \%$ & 0 & $.0 \%$ & 116 & $100.0 \%$ \\
$\begin{array}{l}\text { skrifleg_greiðslu * } \\
\begin{array}{l}\text { ánægja_umræddan } \\
\text { fyrir_einst }\end{array}\end{array}$ & & & & & & \\
\hline \hline
\end{tabular}




\begin{tabular}{|c|c|c|c|c|c|c|c|c|}
\hline \multirow[b]{2}{*}{ fyrir_einst } & & & \multicolumn{5}{|c|}{ ánægja_umræddan } & \multirow[b]{2}{*}{ Samtals } \\
\hline & & & $\begin{array}{c}\text { Mjög } \\
\text { óánægð/ur }\end{array}$ & $\begin{array}{c}\text { Frekar } \\
\text { óánægð/ur }\end{array}$ & $\begin{array}{l}\text { Hvorki } \\
\text { ánægð/ur } \\
\text { né } \\
\text { óánægð/ur }\end{array}$ & $\begin{array}{c}\text { Frekar } \\
\text { ánægð/ur }\end{array}$ & $\begin{array}{c}\text { Mjög } \\
\text { ánægð/ur }\end{array}$ & \\
\hline \multirow[t]{3}{*}{ Fyrirtæki } & skrifleg_greiðslu & Já & & 2 & 2 & 20 & 7 & 31 \\
\hline & & Nei & & 1 & 3 & 3 & 4 & 11 \\
\hline & Samtals & & & 3 & 5 & 23 & 11 & 42 \\
\hline \multirow[t]{3}{*}{ Einstaklingur } & skrifleg_greiðslu & Já & 1 & 5 & 8 & 6 & 10 & 30 \\
\hline & & Nei & 2 & 7 & 8 & 16 & 11 & 44 \\
\hline & Samtals & & 3 & 12 & 16 & 22 & 21 & 74 \\
\hline \multirow[t]{3}{*}{ Samtals } & skrifleg_greiðslu & Já & 1 & 7 & 10 & 26 & 17 & 61 \\
\hline & & $\mathrm{Nei}$ & 2 & 8 & 11 & 19 & 15 & 55 \\
\hline & Samtals & & 3 & 15 & 21 & 45 & 32 & 116 \\
\hline
\end{tabular}

Sommers‘d gefur að fylgni milli áncegju $u_{\text {umredds }}$ og skrifleg greiðslu sé ekki marktæk, hvort sem um er að ræða fyrir heildarfjölda pátttakenda, eða sér í lagi einstaklings-verkkaupa og fyrirtækja-verkkaupa.

Tafla 137 Ósamhverffylgnimaeligildi: skrifleg_greiðslu, ánagja_umraeddan,fyrir_einst

\begin{tabular}{|c|c|c|c|c|c|c|}
\hline fyrir_einst & & & Gildi & fervik $^{\mathrm{a}}$ & $\mathrm{T}^{\mathrm{b}}$ & Sig. \\
\hline \multirow[t]{3}{*}{ Fyrirtæki } & \multirow{3}{*}{$\begin{array}{l}\text { Raðbreyta Somers'd } \\
\text { á móti } \\
\text { raðbreytu }\end{array}$} & Samhverft & 039 &, 170 & ,226 & ,821 \\
\hline & & $\begin{array}{l}\text { skrifleg_greiðslu } \\
\text { svarbreyta }\end{array}$ &, 031 &, 139 & ,226 &, 821 \\
\hline & & $\begin{array}{l}\text { ánægja_umræddan } \\
\text { svarbreyta }\end{array}$ &, 050 & ,220 &, 226 & ,821 \\
\hline \multirow[t]{3}{*}{ Einstaklingur } & \multirow{3}{*}{$\begin{array}{l}\text { Raðbreyta Somers'd } \\
\text { á móti } \\
\text { raðbreytu }\end{array}$} & Samhverft & ,009 & , 105 & ,084 & ,933 \\
\hline & & $\begin{array}{l}\text { skrifleg_greiðslu } \\
\text { svarbreyta }\end{array}$ & ,007 & ,086 &, 084 & ,933 \\
\hline & & $\begin{array}{l}\text { ánægja_umræddan } \\
\text { svarbreyta }\end{array}$ & ,011 &, 135 & ,084 & ,933 \\
\hline \multirow[t]{3}{*}{ Total } & \multirow{3}{*}{$\begin{array}{l}\text { Raðbreyta } \\
\text { á móti } \\
\text { raðbreytu }\end{array}$} & Samhverft & ,059 & ,084 & ,702 & ,483 \\
\hline & & $\begin{array}{l}\text { skrifleg_greiðslu } \\
\text { svarbreyta }\end{array}$ &, 050 &, 071 &, 702 & ,483 \\
\hline & & $\begin{array}{l}\text { ánægja_umræddan } \\
\text { svarbreyta }\end{array}$ & ,072 & ,103 & ,702 & ,483 \\
\hline
\end{tabular}

a. Not assuming the null hypothesis.

b. Using the asymptotic standard error assuming the null hypothesis.

Samhverfu fylgnistuðlarnir gefa allir sömu niðurstöðu og Sommer‘s d. P.e. að fylgni milli áncegju umredds og skrifleg $g_{\text {greiðslu }}$ er ómarktæk hvort heldur sem tekið er tillit til heildarfjölda svara eða einungis fyrirtækjaverkkaupa eða einstaklings-verkkaupa. 
Tafla 138 Samhverf fylgnimaligildi: fyrir_einst, ánaegja_umraedds, skrifleg_greiðslu

\begin{tabular}{|c|c|c|c|c|c|c|c|}
\hline fyrir_einst & & & & Gildi & fervik $^{\mathrm{a}}$ & $\mathrm{T}^{\mathrm{b}}$ & Sig. \\
\hline \multirow[t]{4}{*}{ Fyrirtæki } & \multirow{3}{*}{$\begin{array}{l}\text { Raðbreyta } \\
\text { á móti } \\
\text { raðbreytu }\end{array}$} & \multicolumn{2}{|c|}{ Kendall's tau-c } &, 039 &, 170 & 226 & 821 \\
\hline & & Gamma & Núllta-stigs & 069 & 305 & 226 &, 821 \\
\hline & & Spearma & ylgnistuðull & 042 & 185 & 266 & $.792^{c}$ \\
\hline & \multicolumn{3}{|c|}{$\mathrm{N}$ af gildum tilfellum } & 42 & & & \\
\hline \multirow[t]{4}{*}{ Einstaklingur } & \multirow{3}{*}{$\begin{array}{l}\text { Raðbreyta } \\
\text { á móti } \\
\text { raðbreytu }\end{array}$} & \multicolumn{2}{|c|}{ Kendall's tau-c } & 011 & ,130 & ,084 & 933 \\
\hline & & Gamma & Núllta-stigs & 015 &, 176 & ,084 & ,933 \\
\hline & & \multirow{2}{*}{\multicolumn{2}{|c|}{$\begin{array}{l}\text { Spearman fylgnistuðull } \\
\text { tilfellum }\end{array}$}} & 010 & ,119 &, 085 & $.933^{\mathrm{c}}$ \\
\hline & $\mathrm{N}$ af gildum tilfellum & & & 74 & & & \\
\hline \multirow[t]{5}{*}{ Samtals } & \multirow{4}{*}{$\begin{array}{l}\text { Raðbreyta } \\
\text { á móti } \\
\text { raðbreytu }\end{array}$} & \multicolumn{2}{|c|}{ Kendall's tau-c } & 072 & , 103 & ,702 & 483 \\
\hline & & \multirow[t]{2}{*}{ Gamma } & Núllta-stigs & ,099 &, 141 & ,702 & ,483 \\
\hline & & & $\begin{array}{l}\text { Fyrsta-stigs } \\
\text { hlutfylgni }\end{array}$ & 025 & & & \\
\hline & & \multicolumn{2}{|c|}{ Spearman fylgnistuðull } & ,065 & ,093 & ,699 & $.486^{\mathrm{c}}$ \\
\hline & \multicolumn{3}{|c|}{$\mathrm{N}$ af gildum tilfellum } & 116 & & & \\
\hline
\end{tabular}

a. Not assuming the null hypothesis.

b. Using the asymptotic standard error assuming the null hypothesis.

c. Based on normal approximation.

\subsubsection{Fylgni: greiðsluáætlun *ánægja_umræddan * fyrir_einst}

Fylgni milli greiðsluácetlun (bess hvort verkið hjá umrceddum verktaka hafi farið fram úr greiðsluácetlun) og áncegju umreddan var skoðuð með tilliti til pess hvort verkkaupi hafi verið fyrirtækja-verkkaupi eða einstaklings-verkkaupi. Öll 116 tilfellin flokkast undir gild tilfelli.

Tafla 139 Yfirlit tilfella ígreiningu milli fyrir_einst, ánagju_umraedds og greiðsluácetlun

\begin{tabular}{lcccccc}
\hline \hline & \multicolumn{9}{c}{ Tilfelli } \\
\cline { 2 - 7 } & \multicolumn{2}{c}{ Gild } & \multicolumn{2}{c}{ Vantar } & \multicolumn{2}{c}{ Samtals } \\
\cline { 2 - 7 } & $\mathrm{N}$ & Hlutfall & $\mathrm{N}$ & Hlutfall & $\mathrm{N}$ & Hlutfall \\
\hline $\begin{array}{l}\text { greiðsluáætlun * } \\
\text { ánægja_umræddan * } \\
\text { fyrir_einst }\end{array}$ & 116 & $100.0 \%$ & 0 & $.0 \%$ & 116 & $100.0 \%$ \\
\hline \hline
\end{tabular}




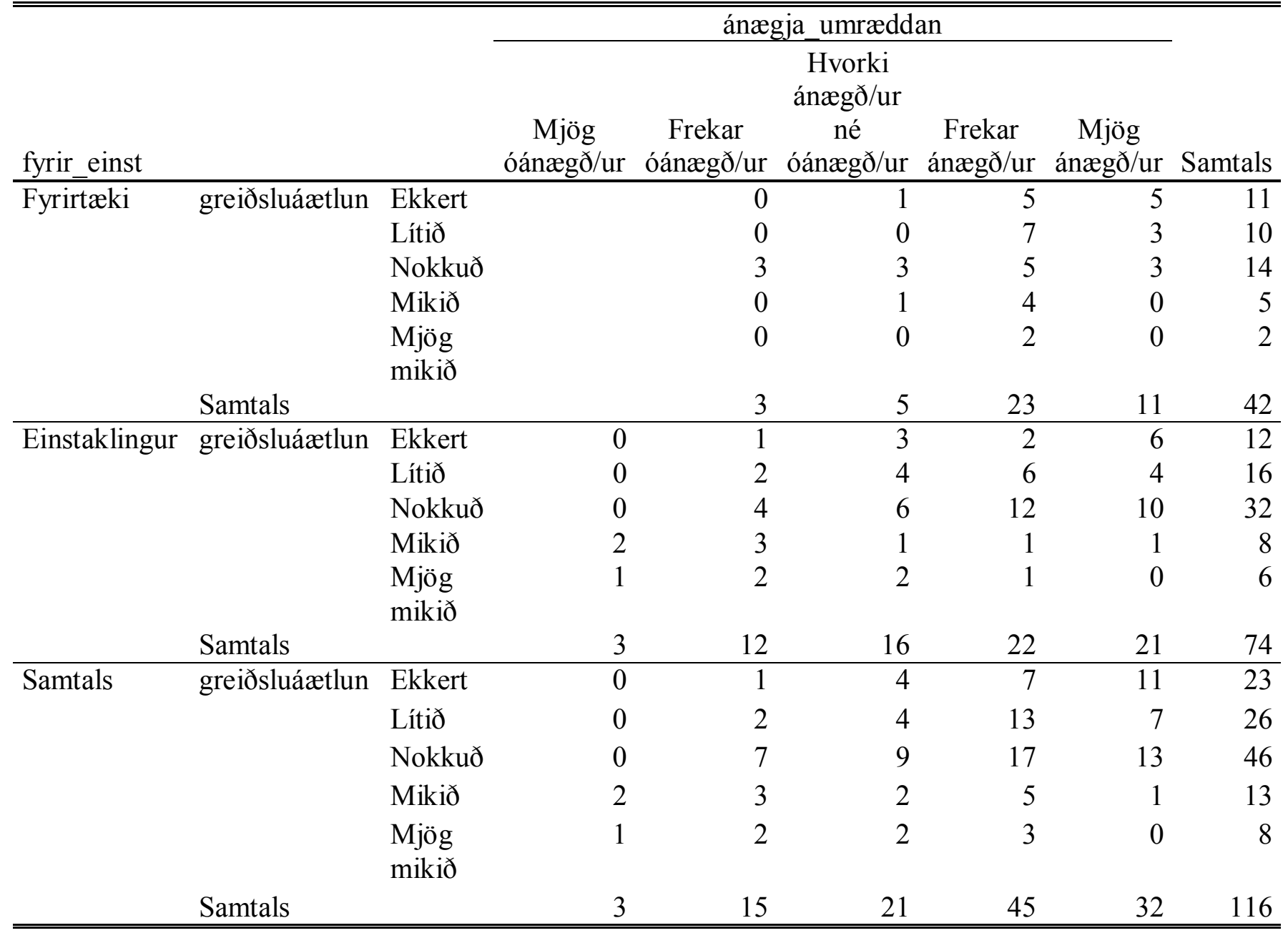

Fylgni á milli áncegju $u_{u m r e d d s}$ og greiðsluácetlun er svipuð og fylgni milli áncegjumredds og tímaácetlun með Sommers‘d. Í öllum tilfellum, p.e. fyrir heildarfjölda svara og sér í lagi meðal fyrirtækja-verkkaupa og einstaklings-verkkaupa fæst að fylgni milli ofangreindra pátta sé marktæk. Gildi fylgnistuðlanna er engu að síður ekkert rosalega hátt og er fylgnin túlkuð að hún sé milli pess að vera frekar veik og miðlungs sterk. Mesta fylgnin fæst ef greiðsluáætlun er höfô sem svarbreyta meðal fyrirtækja-verkkaupa. 
Tafla 141 Ósamhverffylgnimaeligildi: greiðsluácetlun, ánaegja_umraeddan,fyrir_einst

\begin{tabular}{|c|c|c|c|c|c|c|c|}
\hline fyrir_einst & & & & Gildi & fervik $^{\mathrm{a}}$ & $\mathrm{T}^{\mathrm{b}}$ & Sig. \\
\hline \multirow[t]{3}{*}{ Fyrirtæki } & \multirow{3}{*}{$\begin{array}{l}\text { Raðbreyta } \\
\text { á móti } \\
\text { raðbreytu }\end{array}$} & \multirow[t]{3}{*}{ Somers' d } & Samhverft & ,294 & ,098 & 2,887 &, 004 \\
\hline & & & $\begin{array}{l}\text { greiðsluáætlun } \\
\text { svarbreyta }\end{array}$ & ,326 & 107 & 2,887 &, 004 \\
\hline & & & $\begin{array}{l}\text { ánægja_umræddan } \\
\text { svarbreyta }\end{array}$ & ,267 & ,093 & 2,887 & ,004 \\
\hline \multirow[t]{3}{*}{ Einstaklingur } & \multirow{3}{*}{$\begin{array}{l}\text { Raðbreyta } \\
\text { á móti } \\
\text { raðbreytu }\end{array}$} & \multirow[t]{3}{*}{ Somers' d } & Samhverft & ,271 & ,096 & 2,751 & ,006 \\
\hline & & & $\begin{array}{l}\text { greiðsluáætlun } \\
\text { svarbreyta }\end{array}$ & ,265 & ,095 & 2,751 & ,006 \\
\hline & & & $\begin{array}{l}\text { ánægja_umræddan } \\
\text { svarbreyta }\end{array}$ & ,278 & ,098 & 2,751 & ,006 \\
\hline \multirow[t]{3}{*}{ Samtals } & \multirow{3}{*}{$\begin{array}{l}\text { Raðbreyta } \\
\text { á móti } \\
\text { raðbreytu }\end{array}$} & \multirow[t]{3}{*}{ Somers' d } & Samhverft & ,280 & ,072 & 3,806 & ,000 \\
\hline & & & $\begin{array}{l}\text { greiðsluáætlun } \\
\text { svarbreyta }\end{array}$ & ,283 &, 073 & 3,806 &, 000 \\
\hline & & & $\begin{array}{l}\text { ánægja_umræddan } \\
\text { svarbreyta }\end{array}$ & ,278 & ,071 & 3,806 & ,000 \\
\hline
\end{tabular}

a. Not assuming the null hypothesis.

b. Using the asymptotic standard error assuming the null hypothesis.

Eins og fyrir Sommers'd pá er marktæk fylgni fyrir alla flokka með samhverfu mæligildunum. Fylgnin er ekki sterk fyrir neinn flokk, en hæsta gildi fylgnistuðla er fyrir fyrirtækja-verkkaupa ólíkt pví sem var pegar fylgni milli áncegju umredds og tímaácetlun var skoðuð. En par var fylgnin hæst meðal einstaklingsverkkaupa. Í heildina er minni fylgni milli áncegjumreedds og greiðsluácetlunar en á milli áncegjumredds og tímaácetlunar.

Tafla 142 Samhverf fylgnimæligildi: fyrir einst, áncegja umraedds, greiðsluácetlun

\begin{tabular}{|c|c|c|c|c|c|c|}
\hline fyrir_einst & & & Gildi & fervik $^{\mathrm{a}}$ & 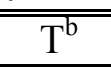 & Sig. \\
\hline \multirow[t]{4}{*}{ Fyrirtæki } & \multirow{3}{*}{$\begin{array}{l}\text { Raðbreyta á } \\
\text { móti } \\
\text { raðbreytu }\end{array}$} & Kendall's tau-b & 295 & ,099 & 2,887 &, 004 \\
\hline & & Gamma Núllta-stigs & ,431 & 137 & 2,887 & 004 \\
\hline & & Spearman fylgnistuðull & ,354 &, 115 & 2,391 & $.022^{\mathrm{c}}$ \\
\hline & \multicolumn{2}{|c|}{$\mathrm{N}$ af gildum tilfellum } & 42 & & & \\
\hline \multirow[t]{4}{*}{ Einstaklingur } & \multirow{3}{*}{$\begin{array}{l}\text { Raðbreyta á } \\
\text { móti } \\
\text { raðbreytu }\end{array}$} & Kendall's tau-b & 271 & ,096 & 2,751 & 006 \\
\hline & & Gamma Núllta- stigs & 359 &, 123 & 2,751 & ,006 \\
\hline & & Spearman fylgnistuðull & 328 &, 112 & 2,944 & $.004^{\mathrm{c}}$ \\
\hline & \multicolumn{2}{|c|}{$\mathrm{N}$ af gildum tilfellum } & 74 & & & \\
\hline \multirow[t]{5}{*}{ Samtals } & \multirow{4}{*}{$\begin{array}{l}\text { Raðbreyta á } \\
\text { móti } \\
\text { raðbreytu }\end{array}$} & Kendall's tau-b & 280 & 072 & 3,806 & ,000 \\
\hline & & Gamma Núllta- stigs & 379 & 094 & 3,806 &, 000 \\
\hline & & $\begin{array}{l}\text { Fyrsta-stigs } \\
\text { hlutfylgni }\end{array}$ & ,374 & & & \\
\hline & & Spearman fylgnistuðull & ,332 & ,084 & 3,758 & $.000^{\mathrm{c}}$ \\
\hline & \multicolumn{2}{|c|}{$\mathrm{N}$ af gildum tilfellum } & 116 & & & \\
\hline
\end{tabular}

a. Not assuming the null hypothesis.

b. Using the asymptotic standard error assuming the null hypothesis.

c. Based on normal approximation. 


\subsubsection{Fylgni: skrifleg_greiðslu * greiðsluáætlun}

Fylgni milli greiðsluácetlun (pess hvort verkið hjá umrceddum verktaka hafi farið fram úr greiðsluácetlun) og skrifleg greið̌slu (hvort greiðsluácetlun hafi verið skrifleg) var skoðuð. Öll 116 tilfellin flokkast undir gild tilfelli svo óparfi er að hafa áhyggjur af normaldreifingu vegna ályktana.

Tafla 143 Yfirlit tilfella í greiningu milli skrifleg_greiðslu og greiðsluácetlun

\begin{tabular}{lcccccc}
\hline & \multicolumn{6}{c}{ Tilfelli } \\
\cline { 2 - 7 } & \multicolumn{2}{c}{ Gild } & \multicolumn{2}{c}{ Vantar } & \multicolumn{2}{c}{ Samtals } \\
\cline { 2 - 7 } & $\mathrm{N}$ & Hlutfall & $\mathrm{N}$ & Hlutfall & $\mathrm{N}$ & Hlutfall \\
\hline $\begin{array}{l}\text { skrifleg_greiðslu } \\
\text { greiðsluáætlun }\end{array}$ & 116 & $100.0 \%$ & 0 & $.0 \%$ & 116 & $100.0 \%$ \\
\hline \hline
\end{tabular}

Tafla 144 Tengslatafla (tíðni): skrifleg_greiðslu * greiðsluácetlun

\begin{tabular}{llcccccc}
\hline \hline & & \multicolumn{3}{c}{ greiðsluáætlun } & \\
\cline { 2 - 6 } & & Mjög mikið & Mikið & Nokkuð & Lítið & Ekkert & Samtals \\
\hline \multirow{2}{*}{ skrifleg_greiðslu } & Nei & 4 & 8 & 24 & 13 & 6 & 55 \\
& Já & 4 & 5 & 22 & 13 & 17 & 61 \\
Samtals & 8 & 13 & 46 & 26 & 23 & 116 \\
\hline \hline
\end{tabular}

Fylgni milli skrifleg_greiðslu og greiðsluácetlun reyndist marktæk með Sommers 'd, Kendall's tau-c og Gamma en ekki með Spearman fylgnistuðli en hún flokkast engu að síður en undir pað að vera veik.

\section{Tafla 145 Ósamhverffylgnimaeligildi: skrifleg_greiðslu, greiðsluácetlun}

\begin{tabular}{llcccc}
\hline \hline & & Gildi & fervik $^{\mathrm{a}}$ & $\mathrm{T}^{\mathrm{b}}$ & Sig. \\
\hline $\begin{array}{l}\text { Raðbreyta á } \\
\text { móti } \\
\text { raðbreytu }\end{array}$ &, 161 &, 081 & 1,999 &, 046 \\
& $\begin{array}{l}\text { Samhverft } \\
\text { skrifleg_greiðslu } \\
\text { svarbreyta } \\
\text { greiðsluáætlun svarbreyta }\end{array}$ &, 135 &, 067 & 1,999 &, 046 \\
\hline \hline
\end{tabular}

a. Not assuming the null hypothesis.

b. Using the asymptotic standard error assuming the null hypothesis.

Tafla 146 Samhverf fylgnimaeligildi: skrifleg_greiðslu, greiðsluácetlun

\begin{tabular}{llcccc}
\hline \hline & Gildi & fervik $^{\mathrm{a}}$ & $\mathrm{T}^{\mathrm{b}}$ & Sig. \\
\hline Raðbreyta á & Kendall's tau-c &, 199 &, 100 & 1,999 &, 046 \\
móti raðbreytu & Gamma &, 268 &, 131 & 1,999 &, 046 \\
& Spearman fylgnistuðull &, 180 &, 090 & 1,958 & $.053^{\mathrm{c}}$ \\
N af gildum tilfellum & 116 & & & \\
\hline \hline
\end{tabular}

a. Not assuming the null hypothesis.

b. Using the asymptotic standard error assuming the null hypothesis.

c. Based on normal approximation. 


\subsection{Verkfundir}

\subsubsection{Tvífylgnifylki: ánægja_umræddan, verkfundir, verkfundir_verkkaupi, verkfundir_fundarger $\overline{\text {, }}$ verkfundir_fleiri, verkfundir_staða, GSK}

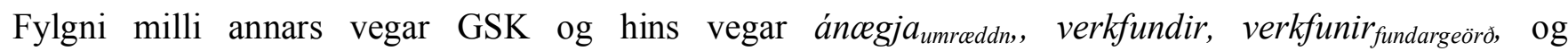
$v_{\text {verkfundir }}$ staða reyndist marktcek og i öllum tilfellum miðlungs sterk nema fyrir GSK og verkfundir en hægt er að flokka pá fylgni sem frekar sterka.

Fylgni milli annars vegar áncegja $a_{u m r e d d a n}$ og hins vegar verkfundir, verkfundir ${ }_{\text {staða }}$ og verkfundir $r_{f l e i r i}$ reyndist marktæk en ekki sérlega sterk fyrir fyrstu tvö tilfellin en miðlungs sterk fyrir pað síðast nefnda. Athuga að fylgni milli annars vegar áncegja $a_{\text {umreddan }}$ og hins vegar verkfundir $r_{\text {verkkaupi }}$ og verkfundir fundarger $_{\text {r }}$ reyndist ekki marktæk.

Tafla 147 Tvífylgnifylki: ánaegja_umraeddan, verkfundir, verkfundir_verkkaupi, verkfundir_fundargerð, verkfundir_fleiri, verkfundir_staða, GSK

\begin{tabular}{|c|c|c|c|c|c|c|c|c|c|}
\hline & & & $\begin{array}{l}\text { ánægja } \\
\text { umrædd }\end{array}$ & $\begin{array}{l}\text { verk- } \\
\text { fundir }\end{array}$ & $\begin{array}{l}\text { verkfundi } \\
\text { verkk }\end{array}$ & $\begin{array}{l}\text { verkf_- } \\
\text { fundarg }\end{array}$ & $\begin{array}{l}\text { verkf } \\
\text { fleiri }\end{array}$ & $\begin{array}{l}\text { verkf- } \\
\text { staða }\end{array}$ & GSK \\
\hline \multirow{21}{*}{$\begin{array}{l}\text { Spearman's } \\
\text { rho }\end{array}$} & \multirow{3}{*}{$\begin{array}{l}\text { ánægja } \\
\text { umræddan }\end{array}$} & Fylgnistuðull & 1,000 & $.215^{*}$ &, 044 & ,203 & $.442^{* *}$ & $.283^{* *}$ & $.430^{* *}$ \\
\hline & & Sig. (2-tailed) & . &, 020 & ,671 &, 050 &, 000 & ,006 & ,003 \\
\hline & & $\mathrm{N}$ & 116 & 116 & 95 & 94 & 95 & 93 & 47 \\
\hline & \multirow[t]{3}{*}{ verkfundir } & Fylgnistuðull & $.215^{*}$ & 1,000 &,- 055 & $.880^{* *}$ & $.262^{*}$ & $.459^{* *}$ & $.522^{* *}$ \\
\hline & & Sig. (2-tailed) &, 020 & . & ,596 &, 000 &, 010 &, 000 &, 000 \\
\hline & & $\mathrm{N}$ & 116 & 116 & 95 & 94 & 95 & 93 & 47 \\
\hline & \multirow{3}{*}{$\begin{array}{l}\text { verkfundir_- } \\
\text { verkkaupi }\end{array}$} & Fylgnistuðull & ,044 &,- 055 & 1,000 & ,074 & ,043 & $.283^{* *}$ & ,008 \\
\hline & & Sig. (2-tailed) & 671 & ,596 & . & ,480 & ,680 &, 006 & ,960 \\
\hline & & $\mathrm{N}$ & 95 & 95 & 95 & 94 & 95 & 93 & 41 \\
\hline & \multirow{3}{*}{$\begin{array}{l}\text { verkfundir } \\
\text { fundargerð }\end{array}$} & Fylgnistuðull & 203 & $.880^{* *}$ & ,074 & 1,000 & $.235^{*}$ & $.575^{* *}$ & $.441^{* * *}$ \\
\hline & & Sig. (2-tailed) &, 050 &, 000 & , 480 & . & 022 &, 000 &, 004 \\
\hline & & $\mathrm{N}$ & 94 & 94 & 94 & 94 & 94 & 92 & 41 \\
\hline & \multirow{3}{*}{$\begin{array}{l}\text { verkfundir_ } \\
\text { fleiri }\end{array}$} & Fylgnistuðull & $.442^{* *}$ & $.262^{*}$ & ,043 & $.235^{*}$ & 1,000 & $.333^{* *}$ &, 169 \\
\hline & & Sig. (2-tailed) &, 000 &, 010 & ,680 & ,022 & . & ,001 & ,292 \\
\hline & & $\mathrm{N}$ & 95 & 95 & 95 & 94 & 95 & 93 & 41 \\
\hline & \multirow{3}{*}{$\begin{array}{l}\text { verkfundir } \\
\text { staða }\end{array}$} & Fylgnistuðull & $.283^{* *}$ & $.459^{* *}$ & $.283^{* *}$ & $.575^{* *}$ & $.333^{* *}$ & 1,000 & $.454^{* *}$ \\
\hline & & Sig. (2-tailed) & ,006 &, 000 & ,006 &, 000 &, 001 & . &, 004 \\
\hline & & $\mathrm{N}$ & 93 & 93 & 93 & 92 & 93 & 93 & 39 \\
\hline & \multirow[t]{3}{*}{ GSK } & Fylgnistuðull & $.430^{* *}$ & $.522^{* *}$ & ,008 & $.441^{* *}$ & 169 & $.454^{* *}$ & 1,000 \\
\hline & & Sig. (2-tailed) &, 003 &, 000 & ,960 &, 004 & ,292 &, 004 & . \\
\hline & & $\mathrm{N}$ & 47 & 47 & 41 & 41 & 41 & 39 & 47 \\
\hline
\end{tabular}

*. Correlation is significant at the 0.05 level (2-tailed).

**. Correlation is significant at the 0.01 level (2-tailed).

\subsubsection{Verkfundir* fyri_einst}

Fylgni milli verkfundir og fyrir_einst var skoðuð og flokkast öll 116 tilfellin flokkast undir gild tilfelli. 266 


\begin{tabular}{lccccccc}
\hline & \multicolumn{9}{c}{ Tilfelli } \\
\cline { 2 - 8 } & \multicolumn{2}{c}{ Gild } & \multicolumn{2}{c}{ Vantar } & \multicolumn{2}{c}{ Samtals } \\
\cline { 2 - 8 } & $\mathrm{N}$ & Hlutfall & $\mathrm{N}$ & Hlutfall & $\mathrm{N}$ & Hlutfall \\
\hline verkfundir * fyrir_einst & 116 & $100.0 \%$ & 0 & $.0 \%$ & 116 & $100.0 \%$ \\
\hline \hline
\end{tabular}

Tafla 149 Tengslatafla (tíðni): verkfundir * fyrir_einst

\begin{tabular}{llccc}
\hline \hline & & \multicolumn{2}{c}{ fyrir_einst } & \\
\cline { 3 - 4 } & & Einstaklingur & Fyrirtæki & Total \\
\hline \multirow{2}{*}{ verkfundir } & Nei & 18 & 3 & 21 \\
& Óformlegir & 52 & 4 & 56 \\
& Formlegir & 4 & 35 & 39 \\
Samtals & & 74 & 42 & 116 \\
\hline \hline
\end{tabular}

Mjög marktæka og sterka fylgni má greina milli verkfundir og fyrir_einst.

Tafla 150 Ósamhverffylgnimaeligildi: verkfundir,fyrir_einst

\begin{tabular}{|c|c|c|c|c|c|}
\hline & & Gildi & fervik $^{\mathrm{a}}$ & $\mathrm{T}^{\mathrm{b}}$ & Sig. \\
\hline \multirow{3}{*}{$\begin{array}{l}\text { Raðbreyta á } \\
\text { móti } \\
\text { raðbreytu }\end{array}$} & Samhverft & ,642 & ,069 & 8,593 & ,000 \\
\hline & $\begin{array}{l}\text { verkfundir } \\
\text { svarbreyta }\end{array}$ & ,752 & ,078 & 8,593 & ,000 \\
\hline & $\begin{array}{l}\text { fyrir_einst } \\
\text { svarbreyta }\end{array}$ & ,559 & ,066 & 8,593 & ,000 \\
\hline
\end{tabular}

a. Not assuming the null hypothesis.

b. Using the asymptotic standard error assuming the null hypothesis.

Tafla 151 Samhverffylgnimaeligildi: verkfundir,fyrir_einst

\begin{tabular}{llcccc}
\hline \hline & Gildi & fervik $^{\mathrm{a}}$ & $\mathrm{T}^{\mathrm{b}}$ & Sig. \\
\hline Raðbreyta á & Kendall's tau-b &, 649 &, 070 & 8,593 &, 000 \\
móti raðbreytu & Kendall's tau-c &, 695 &, 081 & 8,593 &, 000 \\
& Gamma &, 864 &, 071 & 8,593 &, 000 \\
\cline { 3 - 4 } N af gildum tilfellum &, 682 &, 073 & 9,951 & $.000^{\mathrm{c}}$ \\
\hline
\end{tabular}

\footnotetext{
a. Not assuming the null hypothesis.

b. Using the asymptotic standard error assuming the null hypothesis.

c. Based on normal approximation.
} 


\subsubsection{Fylgni: verkfundir *ánægja_umræddan * fyrir_einst}

Fylgni milli verkfundir og áncegjuumredds var skoðuð með tilliti til pess hvort verkkaupi hafi verið fyrirtækja-verkkaupi eða einstaklings-verkkaupi. Öll 116 tilfellin flokkast undir gild tilfelli.

Tafla 152 Yfirlit tilfella í greiningu milli fyrir_einst, ánagju_umraedds og verkfundir

\begin{tabular}{lccccccc}
\hline \hline & \multicolumn{9}{c}{ Tilfelli } \\
\cline { 2 - 7 } & \multicolumn{2}{c}{ Gild } & & \multicolumn{2}{c}{ Vantar } & \multicolumn{2}{c}{ Samtals } \\
\cline { 2 - 7 } & $\mathrm{N}$ & Hlutfall & $\mathrm{N}$ & Hlutfall & $\mathrm{N}$ & Hlutfall \\
\hline & 116 & $100.0 \%$ & 0 & $.0 \%$ & 116 & $100.0 \%$ \\
$\begin{array}{l}\text { verkfundir* } \\
\text { ánægja_umræddan * } \\
\text { fyrir_einst }\end{array}$ & & & & & & & \\
\hline \hline
\end{tabular}

Erfitt er að greina sérstakt munstur milli ánægjuflokka sér í lagi fyrir fyrirtækja- og einstaklings-verkkaupa par sem að fáir einstaklingar voru með formlega verkfundir og fá fyrirtæki voru með óformlega eða ekki verkfundi. En fyrir heildarfjölda svara má greina aukna ánægja hjá peim verkkaupum sem voru með verkfundi.

Tafla 153 Tengslatafla (tíðni): verkfundir * ánaegja_umraeddan * fyrir_einst

\begin{tabular}{|c|c|c|c|c|c|c|c|c|}
\hline \multirow[b]{2}{*}{ fyrir_einst } & & & \multicolumn{5}{|c|}{ ánægja_umræddan } & \multirow[b]{2}{*}{ Samtals } \\
\hline & & & $\begin{array}{c}\text { Mjög } \\
\text { óánægð/ur }\end{array}$ & $\begin{array}{c}\text { Frekar } \\
\text { óánægð/ur }\end{array}$ & $\begin{array}{c}\text { Hvorki } \\
\text { ánægð/ur } \\
\text { né } \\
\text { óánægð/ur }\end{array}$ & $\begin{array}{c}\text { Frekar } \\
\text { ánægð/ur }\end{array}$ & $\begin{array}{c}\text { Mjög } \\
\text { ánægð/ur }\end{array}$ & \\
\hline \multirow[t]{4}{*}{ Fyrirtæki } & verkfundir & Formlegir & & 1 & 3 & 22 & 9 & 35 \\
\hline & & Óformlegir & & 1 & 0 & 1 & 2 & 4 \\
\hline & & $\mathrm{Nei}$ & & 1 & 2 & 0 & 0 & 3 \\
\hline & Samtals & & & 3 & 5 & 23 & 11 & 42 \\
\hline \multirow[t]{4}{*}{ Einstaklingur } & verkfundir & Formlegir & 0 & 0 & 2 & 0 & 2 & 4 \\
\hline & & Óformlegir & 2 & 8 & 11 & 17 & 14 & 52 \\
\hline & & Nei & 1 & 4 & 3 & 5 & 5 & 18 \\
\hline & Samtals & & 3 & 12 & 16 & 22 & 21 & 74 \\
\hline \multirow[t]{4}{*}{ Samtals } & verkfundir & Formlegir & 0 & 1 & 5 & 22 & 11 & 39 \\
\hline & & Óformlegir & 2 & 9 & 11 & 18 & 16 & 56 \\
\hline & & Nei & 1 & 5 & 5 & 5 & 5 & 21 \\
\hline & Samtals & & 3 & 15 & 21 & 45 & 32 & 116 \\
\hline
\end{tabular}

Sommers'd gefur að fylgni milli áncegjumredds og verkfunda sé marktæk fyrir heildarfjölda svara en ekki sér í lagi meðal fyrirtækja-verkkaupa eða einstaklings-verkkaupa. En eins og áður segir hefði purft fleiri svör í báða flokka. Marktækni meðal heildarfjölda svara er ekki sérlega sterk, en meiri fylgni fæst ef áncegja $a_{\text {umreddan }}$ er höfð sem svarbreytan. 
Tafla 154 Ósamhverffylgnimaeligildi: verkfundir, ánaegja_umraeddan,fyrir_einst

\begin{tabular}{|c|c|c|c|c|c|c|}
\hline fyrir_einst & & & Gildi & fervik $^{\mathrm{a}}$ & $\mathrm{T}^{\mathrm{b}}$ & Sig. \\
\hline \multirow[t]{3}{*}{ Fyrirtæki } & \multirow{3}{*}{$\begin{array}{l}\text { Raðbreyta Somers'd } \\
\text { á móti } \\
\text { raðbreytu }\end{array}$} & Samhverft & ,221 & , 168 & 1,224 & ,221 \\
\hline & & verkfundir svarbreyta & , 163 & 129 & 1,224 & 221 \\
\hline & & $\begin{array}{l}\text { ánægja_umræddan } \\
\text { svarbreyta }\end{array}$ & ,342 & 258 & 1,224 & ,221 \\
\hline \multirow[t]{3}{*}{ Einstaklingur } & \multirow{3}{*}{$\begin{array}{l}\text { Raðbreyta Somers' d } \\
\text { á móti } \\
\text { raðbreytu }\end{array}$} & Samhverft & ,060 & , 104 & ,572 & ,567 \\
\hline & & verkfundir svarbreyta &, 047 & ,083 &, 572 &, 567 \\
\hline & & $\begin{array}{l}\text { ánægja_umræddan } \\
\text { svarbreyta }\end{array}$ &, 081 &, 140 & ,572 & ,567 \\
\hline \multirow[t]{3}{*}{ Samtals } & \multirow{3}{*}{$\begin{array}{l}\text { Raðbreyta Somers'd } \\
\text { á móti } \\
\text { raðbreytu }\end{array}$} & Samhverft & ,186 & ,075 & 2,443 & ,015 \\
\hline & & verkfundir svarbreyta &, 173 & ,070 & 2,443 &, 015 \\
\hline & & $\begin{array}{l}\text { ánægja_umræddan } \\
\text { svarbreyta }\end{array}$ & ,201 &, 082 & 2,443 &, 015 \\
\hline
\end{tabular}

a. Not assuming the null hypothesis.

b. Using the asymptotic standard error assuming the null hypothesis.

Samhverfu fylgnistuðlarnir gefa allir sömu niðurstöðu og Sommer's d. P.e. að fylgni milli áncegjumredds og verkfunda er bara marktæk ef tekið er tillit til heildarfjölda svara en ekki ef einungis er tekið tillit til fyrirtækja-verkkaupa eða einstaklings-verkkaupa. Styrkur fylgni er eins og hjá Sommers‘d ekki mjög mikill.

Tafla 155 Samhverf fylgnimæligildi: fyrir_einst, ánaegja_umraedds, verkfundir

\begin{tabular}{|c|c|c|c|c|c|c|c|}
\hline fyrir_einst & & & & Gildi & fervik $^{\mathrm{a}}$ & $\mathrm{T}^{\mathrm{b}}$ & Sig. \\
\hline \multirow[t]{4}{*}{ Fyrirtæki } & Raðbreyta & \multicolumn{2}{|c|}{ Kendall's tau-c } & ,150 &, 122 & 1,224 & 221 \\
\hline & $\begin{array}{l}\text { á móti } \\
\text { raðbreytu }\end{array}$ & Gamma & $\begin{array}{l}\text { Núllta- } \\
\text { stigs }\end{array}$ & ,423 & ,302 & 1,224 &, 221 \\
\hline & & \multicolumn{2}{|c|}{ Spearman fylgnistuðull } & ,267 & , 197 & 1,755 & $.087^{\mathrm{c}}$ \\
\hline & \multicolumn{3}{|c|}{$\mathrm{N}$ af gildum tilfellum } & 42 & & & \\
\hline \multirow[t]{4}{*}{ Einstaklingur } & Raðbreyta & \multicolumn{2}{|c|}{ Kendall's tau-c } & ,054 & ,094 &, 572 & ,567 \\
\hline & $\begin{array}{l}\text { á móti } \\
\text { raðbreytu }\end{array}$ & Gamma & $\begin{array}{l}\text { Núllta- } \\
\text { stigs }\end{array}$ &, 106 &, 183 &, 572 &, 567 \\
\hline & & \multicolumn{2}{|c|}{ Spearman fylgnistuðull } & 070 &, 120 &, 593 & $.555^{\mathrm{c}}$ \\
\hline & $\mathrm{N}$ af gildun & tilfellum & & 74 & & & \\
\hline \multirow[t]{5}{*}{ Samtals } & Raðbreyta & \multicolumn{2}{|c|}{ Kendall's tau-c } &, 188 & ,077 & 2,443 & 015 \\
\hline & $\begin{array}{l}\text { á móti } \\
\text { raðbreytu }\end{array}$ & \multirow[t]{2}{*}{ Gamma } & $\begin{array}{l}\text { Núllta- } \\
\text { stigs }\end{array}$ & ,274 & , 108 & 2,443 &, 015 \\
\hline & & & $\begin{array}{l}\text { Fyrsta- } \\
\text { stigs } \\
\text { hlutfylgni }\end{array}$ &, 164 & & & \\
\hline & & \multicolumn{2}{|c|}{ Spearman fylgnistuðull } & ,215 & ,087 & 2,355 & $.020^{\mathrm{c}}$ \\
\hline & \multicolumn{3}{|c|}{$\mathrm{N}$ af gildum tilfellum } & 116 & & & \\
\hline
\end{tabular}

a. Not assuming the null hypothesis.

b. Using the asymptotic standard error assuming the null hypothesis.

c. Based on normal approximation. 


\subsection{Samningar}

\subsubsection{Tvífylgnifylki: ánægja_umræddan, GSK, samningur_ræddur, samningur_sundurliðaður, samningur_ósætti}

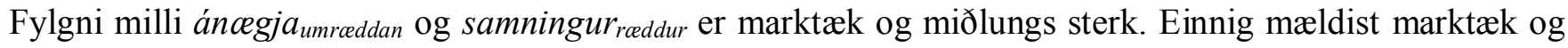

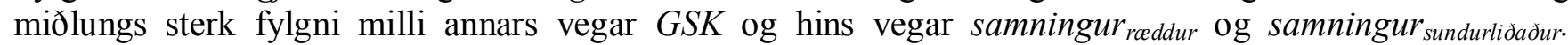
Athyglisvert er að fylgni milli annars vegar samningur óscetti og samningur sundurliðaður og hins vegar milli áncegja $a_{\text {umreddan }}$ reyndist ekki vera marktæk.

Tafla 156 Tvífylgnifylki: ánagja_umraeddan, GSK, samningur_raeddur, samningur_sundurliðaður, samnigur_óscetti

\begin{tabular}{|c|c|c|c|c|c|c|c|}
\hline & & & $\begin{array}{l}\text { ánægja } \\
\text { umræddan }\end{array}$ & GSK & $\begin{array}{l}\text { samningur } \\
\text { ræddur }\end{array}$ & $\begin{array}{l}\text { samningur } \\
\text { sundurliðað }\end{array}$ & $\begin{array}{l}\text { samningu } \\
\text { ósætti }\end{array}$ \\
\hline \multirow{15}{*}{$\begin{array}{l}\text { Spearman's } \\
\text { rho }\end{array}$} & \multirow{3}{*}{$\begin{array}{l}\text { ánægja } \\
\text { umræddan }\end{array}$} & Fylgnistuðull & 1,000 & $.430^{* *}$ & $.307^{* *}$ & ,175 &, 148 \\
\hline & & Sig. (2-tailed) & . & ,003 &, 005 & ,117 & , 183 \\
\hline & & $\mathrm{N}$ & 116 & 47 & 83 & 81 & 83 \\
\hline & \multirow[t]{3}{*}{ GSK } & Fylgnistuðull & $.430^{* *}$ & 1,000 & $.446^{* *}$ & $.350^{*}$ &,- 285 \\
\hline & & Sig. (2-tailed) &, 003 & . &, 007 & ,039 & ,097 \\
\hline & & $\mathrm{N}$ & 47 & 47 & 35 & 35 & 35 \\
\hline & \multirow{3}{*}{$\begin{array}{l}\text { samningur_ } \\
\text { ræddur }\end{array}$} & Fylgnistuðull & $.307^{* *}$ & $.446^{* *}$ & 1,000 & $.524^{* *}$ & ,092 \\
\hline & & Sig. (2-tailed) &, 005 &, 007 & . &, 000 & ,410 \\
\hline & & $\mathrm{N}$ & 83 & 35 & 83 & 81 & 83 \\
\hline & \multirow{3}{*}{$\begin{array}{l}\text { samningur } \\
\text { sundurliðaður }\end{array}$} & Fylgnistuðull &, 175 & $.350^{*}$ & $.524^{* *}$ & 1,000 &, 162 \\
\hline & & Sig. (2-tailed) &, 117 & ,039 &, 000 & . &, 147 \\
\hline & & $\mathrm{N}$ & 81 & 35 & 81 & 81 & 81 \\
\hline & \multirow{3}{*}{$\begin{array}{l}\text { samningur_ } \\
\text { ósætti }\end{array}$} & Fylgnistuðull & , 148 &,- 285 & ,092 & , 162 & 1,000 \\
\hline & & Sig. (2-tailed) & , 183 & ,097 & ,410 & , 147 & . \\
\hline & & $\mathrm{N}$ & 83 & 35 & 83 & 81 & 83 \\
\hline
\end{tabular}

**. Correlation is significant at the 0.01 level (2-tailed).

*. Correlation is significant at the 0.05 level (2-tailed). 


\subsection{Frábrigði}

\subsubsection{Tvífylgnifylki: ánægja_umræddan, frábrigði, frábrigði_tilkynnt, GSK}

Fylgni milli pess hversu ánægðir verkkaupar voru með framkvæmd verksins hjá umræddum verktaka og hversu oft frábrigði komu upp á verktíma reyndist marktækt en fylgni milli pess hversu ánægðir verkkaupar voru með framkvæmd verksins hjá umræddum verktaka og hvort/hvernig peim var tilkynnt um frábrigði reyndist ekki marktækt.

Sömuleiðis greindist ekki marktæk fylgni milli pess annars vegar hvort verkkaupi starfaði eftir gæðastjórnunarkerfi byggðu á viðurkenndum gæðastjórnunarstöðlum og hins vegar fjölda frábrigða eða hvort/hvernig verkkaupa var tilkynnt um frábrigði.

Tafla 157 Tvífylgnifylki: áncegja_umraeddan,frábrigði,frábrigði_tilkynnt, GSK

\begin{tabular}{|c|c|c|c|c|c|c|}
\hline & & & ánægja_umræddan & frábrigði & frábrigði_tilkynnt & GSK \\
\hline \multirow{12}{*}{$\begin{array}{l}\text { Spearman's } \\
\text { rho }\end{array}$} & \multirow{3}{*}{$\begin{array}{l}\text { ánægja } \\
\text { umræddan }\end{array}$} & Fylgnistuðull & 1,000 & $.445^{* *}$ &, 197 & $.430^{* *}$ \\
\hline & & Sig. (2-tailed) & . &, 000 &, 055 & ,003 \\
\hline & & $\mathrm{N}$ & 116 & 116 & 95 & 47 \\
\hline & \multirow[t]{3}{*}{ frábrigði } & Fylgnistuðull & $.445^{* *}$ & 1,000 & $.252^{*}$ &,- 210 \\
\hline & & Sig. (2-tailed) &, 000 & . &, 014 &, 158 \\
\hline & & $\mathrm{N}$ & 116 & 116 & 95 & 47 \\
\hline & \multirow{3}{*}{$\begin{array}{l}\text { frábrigði } \\
\text { tilkynnt }\end{array}$} & Fylgnistuðull & 197 & $.252^{*}$ & 1,000 & ,289 \\
\hline & & Sig. (2-tailed) & 055 & ,014 & . & 079 \\
\hline & & $\mathrm{N}$ & 95 & 95 & 95 & 38 \\
\hline & \multirow[t]{3}{*}{ GSK } & Fylgnistuðull & $.430^{* *}$ &,- 210 & ,289 & 1,000 \\
\hline & & Sig. (2-tailed) &, 003 &, 158 & 079 & . \\
\hline & & $\mathrm{N}$ & 47 & 47 & 38 & 47 \\
\hline
\end{tabular}

**. Correlation is significant at the 0.01 level (2-tailed).

*. Correlation is significant at the 0.05 level (2-tailed).

\subsubsection{Fylgni: frábrigði * ánægja_umræddan}

Fylgni milli frábrigði (hvort og hversu oft frábrigði hjá verktaka komu upp á verktíma) og áncegju umreddan var skoðuð.

Tafla 158 Yfirlit tilfella í greiningu milli frábrigði og ánagju_umraedds

\begin{tabular}{lcccccc}
\hline \hline & \multicolumn{9}{c}{ Tilfelli } \\
\cline { 2 - 7 } & \multicolumn{2}{c}{ Gild } & \multicolumn{2}{c}{ Vantar } & \multicolumn{2}{c}{ Samtals } \\
\cline { 2 - 7 } & $\mathrm{N}$ & Hlutfall & $\mathrm{N}$ & Hlutfall & $\mathrm{N}$ & Hlutfall \\
\hline $\begin{array}{l}\text { frábrigði* } \\
\text { ánægja_umræddan }\end{array}$ & 116 & $100.0 \%$ & 0 & $.0 \%$ & 116 & $100.0 \%$ \\
\hline \hline
\end{tabular}




\begin{tabular}{|c|c|c|c|c|c|c|c|}
\hline & \multicolumn{5}{|c|}{ ánægja_umræddan } & \multirow[b]{2}{*}{ Samtals } \\
\hline & & $\begin{array}{c}\text { Mjög } \\
\text { óánægð/ur }\end{array}$ & $\begin{array}{c}\text { Frekar } \\
\text { óánægð/ur }\end{array}$ & $\begin{array}{c}\text { Hvorki } \\
\text { ánægð/ur né } \\
\text { óánægð/ur }\end{array}$ & $\begin{array}{c}\text { Frekar } \\
\text { ánægð/ur }\end{array}$ & $\begin{array}{c}\text { Mjög } \\
\text { ánægð/ur }\end{array}$ & \\
\hline \multirow[t]{6}{*}{ frábrigði } & $\mathrm{Oft}$ & 3 & 0 & 1 & 0 & 0 & 4 \\
\hline & Frekar oft & 0 & 6 & 2 & 2 & 0 & 10 \\
\hline & Stundum & 0 & 6 & 6 & 12 & 9 & 33 \\
\hline & Frekar sjaldan & 0 & 3 & 5 & 13 & 4 & 25 \\
\hline & Sjaldan & 0 & 0 & 5 & 13 & 11 & 29 \\
\hline & Aldrei & 0 & 0 & 2 & 5 & 8 & 15 \\
\hline Samtals & & 3 & 15 & 21 & 45 & 32 & 116 \\
\hline
\end{tabular}

Fylgni milli frábrigði og áncegjuumredds reyndist vera mjög marktæk og rétt tæplega miðlungs sterk.

Tafla 160 Ósamhverffylgnimaeligildi: frábrigði, áncegja_umraeddan

\begin{tabular}{|c|c|c|c|c|c|c|}
\hline & & & Gildi & fervik ${ }^{\mathrm{a}}$ & $\mathrm{T}^{\mathrm{b}}$ & Sig. \\
\hline \multirow{3}{*}{$\begin{array}{l}\text { Raðbreyta } \\
\text { á móti } \\
\text { raðbreytu }\end{array}$} & \multirow[t]{3}{*}{ Somers' d } & Samhverft & ,379 & ,071 & 5,086 &, 000 \\
\hline & & frábrigði svarbreyta & ,395 & ,074 & 5,086 &, 000 \\
\hline & & $\begin{array}{l}\text { ánægja_umræddan } \\
\text { svarbreyta }\end{array}$ & ,364 & ,069 & 5,086 &, 000 \\
\hline
\end{tabular}

a. Not assuming the null hypothesis.

b. Using the asymptotic standard error assuming the null hypothesis.

Tafla 161 Samhverffylgnimaeligildi: frábrigði, ánaegja_umraeddan

\begin{tabular}{llcccc}
\hline \hline & Gildi & fervik $^{\mathrm{a}}$ & $\mathrm{T}^{\mathrm{b}}$ & Sig. \\
\hline Raðbreyta á & Kendall's tau-c &, 357 &, 070 & 5,086 &, 000 \\
móti raðbreytu & Gamma &, 492 &, 086 & 5,086 &, 000 \\
& Spearman fylgnistuðull &, 445 &, 081 & 5,303 & $.000^{\mathrm{c}}$ \\
N af gildum tilfellum & 116 & & & \\
\hline \hline
\end{tabular}

a. Not assuming the null hypothesis.

b. Using the asymptotic standard error assuming the null hypothesis.

c. Based on normal approximation.

\subsection{Aukaverk og breytingar}

\subsubsection{Fylgni: aukaverk *ánægja_umræddan}

Fylgni milli aukaverk (hvort aukaverk eða breytingar hafi verið gerðar) og áncegjumredds var skoðuð. 


\begin{tabular}{|c|c|c|c|c|c|c|}
\hline & \multicolumn{6}{|c|}{ Tilfelli } \\
\hline & \multicolumn{2}{|c|}{ Gild } & \multicolumn{2}{|c|}{ Vantar } & \multicolumn{2}{|c|}{ Samtals } \\
\hline & $\mathrm{N}$ & Hlutfall & $\mathrm{N}$ & Hlutfall & $\mathrm{N}$ & Hlutfall \\
\hline $\begin{array}{l}\text { aukaverk* } \\
\text { ánægja_umræddan }\end{array}$ & 115 & $99.1 \%$ & 1 & $.9 \%$ & 116 & $100.0 \%$ \\
\hline
\end{tabular}

Tafla 163 Tengslatafla (tíðni): aukaverk *ánaegja_umraeddan

\begin{tabular}{|c|c|c|c|c|c|c|c|}
\hline & & \multicolumn{5}{|c|}{ ánægja_umræddan } & \multirow[b]{2}{*}{ Samtals } \\
\hline & & $\begin{array}{c}\text { Mjög } \\
\text { óánægð/ur }\end{array}$ & $\begin{array}{c}\text { Frekar } \\
\text { óánægð/ur }\end{array}$ & $\begin{array}{c}\text { Hvorki } \\
\text { ánægð/ur né } \\
\text { óánægð/ur }\end{array}$ & $\begin{array}{c}\text { Frekar } \\
\text { ánægð/ur }\end{array}$ & $\begin{array}{c}\text { Mjög } \\
\text { ánægð/ur }\end{array}$ & \\
\hline \multirow[t]{2}{*}{ aukaverk } & Já & 1 & 3 & 5 & 19 & 13 & 41 \\
\hline & Nei & 2 & 12 & 15 & 26 & 19 & 74 \\
\hline Samtals & & 3 & 15 & 20 & 45 & 32 & 115 \\
\hline
\end{tabular}

Fylgni milli aukaverk og áncegjumræedds reyndist ekki vera marktæk hvort sem notast var við Sommers`d eða samhverfu fylgnimæligildin.

Tafla 164 Ósamhverffylgnimaeligildi: aukaverk, ánaegja_umraeddan

\begin{tabular}{|c|c|c|c|c|c|c|}
\hline & & & Gildi & fervik $^{\mathrm{a}}$ & $\mathrm{T}^{\mathrm{b}}$ & Sig. \\
\hline \multirow{3}{*}{$\begin{array}{l}\text { Raðbreyta } \\
\text { á móti } \\
\text { raðbreytu }\end{array}$} & \multirow[t]{3}{*}{ Somers' d } & Samhverft &,- 129 &, 080 & $-1,608$ &, 108 \\
\hline & & aukaverk svarbreyta &,- 106 &, 065 & $-1,608$ & , 108 \\
\hline & & $\begin{array}{l}\text { ánægja_umræddan } \\
\text { svarbreyta }\end{array}$ &,- 166 & , 103 & $-1,608$ & , 108 \\
\hline
\end{tabular}

a. Not assuming the null hypothesis.

b. Using the asymptotic standard error assuming the null hypothesis.

Tafla 165 Samhverffylgnimaeligildi: aukaverk, ánaegja_umraeddan

\begin{tabular}{llrrrr}
\hline \hline & \multicolumn{2}{c}{ Gildi } & fervik $^{\mathrm{a}}$ & $\mathrm{T}^{\mathrm{b}}$ & \multicolumn{1}{c}{ Sig. } \\
\hline Raðbreyta á & Kendall's tau-b &,- 132 &, 082 & $-1,608$ &, 108 \\
móti raðbreytu & Gamma &,- 231 &, 142 & $-1,608$ &, 108 \\
& Spearman fylgnistuðull &,- 144 &, 089 & $-1,551$ & $.124^{\mathrm{c}}$ \\
N af gildum tilfellum & 115 & & & \\
\hline \hline
\end{tabular}

a. Not assuming the null hypothesis.

b. Using the asymptotic standard error assuming the null hypothesis.

c. Based on normal approximation. 


\subsection{Umgengni umrædds verktaka á verkstað}

\subsubsection{Fylgni: umgengni * ánægja_umræddan}

Fylgni milli umgengni (hvernig verkkaupa fannst umgengni umrcedds verktaka á verkstað vera) og áncegju umredds var skoðuð.

Tafla 166 Yfirlit tilfella ígreiningu milli umgengni og ánagju_umraedds

\begin{tabular}{lcccccc}
\hline \hline & \multicolumn{9}{c}{ Tilfelli } \\
\cline { 2 - 7 } & \multicolumn{2}{c}{ Gild } & \multicolumn{2}{c}{ Vantar } & \multicolumn{2}{c}{ Samtals } \\
\cline { 2 - 7 } & $\mathrm{N}$ & Hlutfall & $\mathrm{N}$ & Hlutfall & $\mathrm{N}$ & Hlutfall \\
\hline $\begin{array}{l}\text { umgengni* } \\
\text { ánægja_umræddan }\end{array}$ & 116 & $100.0 \%$ & 0 & $.0 \%$ & 116 & $100.0 \%$ \\
\hline \hline
\end{tabular}

Engin augljós tengsl milli áncegju umredds og öryggismál er að sjá í tengslatöflu.

Tafla 167 Tengslatafla (tíðni): umgengni *áncegja_umraeddan

\begin{tabular}{llcccccc}
\hline \hline & \multicolumn{6}{c}{ ánægja_umræddan } \\
\cline { 3 - 7 } & & $\begin{array}{c}\text { Mjög } \\
\text { óánægð/ur }\end{array}$ & $\begin{array}{c}\text { Frekar } \\
\text { óánægð/ur }\end{array}$ & $\begin{array}{c}\text { ánægð/ur né } \\
\text { óánægð/ur }\end{array}$ & $\begin{array}{c}\text { Frekar } \\
\text { ánægð/ur }\end{array}$ & $\begin{array}{c}\text { Mjög } \\
\text { ánægð/ur }\end{array}$ & Samtals \\
\hline umgengni & Mjög slæm & 2 & 3 & 1 & 1 & 0 & 7 \\
& Frekar slæm & 1 & 5 & 3 & 4 & 1 & 14 \\
& Hvorki góð & 0 & 5 & 8 & 14 & 7 & 34 \\
& né slæm & & & & & & \\
& Frekar góð & 0 & 0 & 5 & 12 & 5 & 22 \\
Samtals & Mjög góð & 0 & 2 & 4 & 14 & 19 & 39 \\
\hline \hline
\end{tabular}

Fylgni milli umgengni og áncegju umrcedds reyndist vera mjög marktæk og milli pess að vera miðlungs og frekar sterk hvort sem notast var við Sommers'd eða samhverfu fylgnimæligildin.

Tafla 168 Ósamhverffylgnimaeligildi: umgengni, ánaegja_umrceddan

\begin{tabular}{|c|c|c|c|c|c|c|}
\hline & & & Gildi & fervik $^{\mathrm{a}}$ & $\mathrm{T}^{\mathrm{b}}$ & Sig. \\
\hline \multirow{3}{*}{$\begin{array}{l}\text { Raðbreyta } \\
\text { á móti } \\
\text { raðbreytu }\end{array}$} & \multirow[t]{3}{*}{ Somers' d } & Samhverft & ,418 & ,070 & 5,692 &, 000 \\
\hline & & umgengni svarbreyta & ,425 & ,071 & 5,692 &, 000 \\
\hline & & $\begin{array}{l}\text { ánægja_umræddan } \\
\text { svarbreyta }\end{array}$ & ,411 & ,070 & 5,692 &, 000 \\
\hline
\end{tabular}

a. Not assuming the null hypothesis.

b. Using the asymptotic standard error assuming the null hypothesis. 


\begin{tabular}{llcccc}
\hline \hline & Gildi & fervik $^{\mathrm{a}}$ & $\mathrm{T}^{\mathrm{b}}$ & Sig. \\
\hline Raðbreyta á & Kendall's tau-b &, 418 &, 070 & 5,692 &, 000 \\
móti raðbreytu & Gamma &, 551 &, 085 & 5,692 &, 000 \\
& Spearman fylgnistuðull &, 481 &, 079 & 5,856 & $.000^{\mathrm{c}}$ \\
N af gildum tilfellum & 116 & & & \\
\hline \hline
\end{tabular}

a. Not assuming the null hypothesis.

b. Using the asymptotic standard error assuming the null hypothesis.

c. Based on normal approximation.

\subsection{8 Öryggismál}

\subsubsection{Tvífylgnifylki: ánægja_umræddan, GSK öryggismál_rædd, öryggismál_verktaka, ánægja_öryggismál}

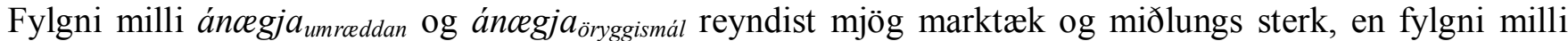

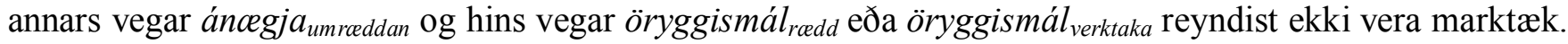
Einnig reyndist vera marktæk og frekar sterk fylgni milli annars vegar GSK og öryggismál ${ }_{\text {redd.og hins }}$ vegar áncegja öryggismál.

Tafla 170 Tvívítt fylgnifylki: ánagja_umraeddan, GSK, öryggismál_raedd, öryggismál_verktaka, ánaegja_öryggismál

\begin{tabular}{|c|c|c|c|c|c|c|c|}
\hline & & & $\begin{array}{l}\text { ánægja- } \\
\text { umræddan }\end{array}$ & GSK & $\begin{array}{l}\text { öryggism } \\
\text { ál_rædd }\end{array}$ & $\begin{array}{c}\text { öryggismál } \\
\text { verktaka }\end{array}$ & $\begin{array}{l}\text { ánægja_- } \\
\text { öryggismál }\end{array}$ \\
\hline \multirow{15}{*}{$\begin{array}{l}\text { Spearman's } \\
\text { rho }\end{array}$} & \multirow{3}{*}{$\begin{array}{l}\text { ánægja } \\
\text { umræddan }\end{array}$} & Fylgnistuðull & 1,000 & $.430^{* *}$ &, 153 & ,300 & $.318^{* *}$ \\
\hline & & Sig. (2-tailed) & . & ,003 & , 101 & ,076 & ,001 \\
\hline & & $\mathrm{N}$ & 116 & 47 & 116 & 36 & 116 \\
\hline & \multirow[t]{3}{*}{ GSK } & Fylgnistuðull & $.430^{* * *}$ & 1,000 & $.576^{* *}$ & . & $.393^{* *}$ \\
\hline & & Sig. (2-tailed) &, 003 & . &, 000 & . &, 006 \\
\hline & & $\mathrm{N}$ & 47 & 47 & 47 & 21 & 47 \\
\hline & \multirow{3}{*}{$\begin{array}{l}\text { öryggismál_ } \\
\text { rædd }\end{array}$} & Fylgnistuðull & , 153 & $.576^{* *}$ & 1,000 & & $.347^{* *}$ \\
\hline & & Sig. (2-tailed) & ,101 &, 000 & . & . &, 000 \\
\hline & & $\mathrm{N}$ & 116 & 47 & 116 & 36 & 116 \\
\hline & \multirow{3}{*}{$\begin{array}{l}\text { öryggismál_ } \\
\text { verktaka }\end{array}$} & Fylgnistuðull &, 300 & . & . & 1,000 &,- 025 \\
\hline & & Sig. (2-tailed) & ,076 & . & . & $\cdot$ & ,886 \\
\hline & & $\mathrm{N}$ & 36 & 21 & 36 & 36 & 36 \\
\hline & \multirow{3}{*}{$\begin{array}{l}\text { ánægja_- } \\
\text { öryggismál }\end{array}$} & Fylgnistuðull & $.318^{* *}$ & $.393^{* *}$ & $.347^{* *}$ &,- 025 & 1,000 \\
\hline & & Sig. (2-tailed) &, 001 &, 006 &, 000 & ,886 & . \\
\hline & & $\mathrm{N}$ & 116 & 47 & 116 & 36 & 116 \\
\hline
\end{tabular}

**. Correlation is significant at the 0.01 level (2-tailed). 


\subsubsection{Fylgni: öryggismál_rædd * ánægja_umræddan * fyrir_einst}

Fylgni milli öryggismál $l_{\text {redd }}$ (pess hvort öryggismál hafi verið raedd áður en framkvcemdir hófust) og áncegju $u_{\text {umredds }}$ var skoðuð með tilliti til pess hvort verkkaupi hafi verið fyrirtækja-verkkaupi eða einstaklings-verkkaupi. Öll 116 tilfellin flokkast undir gild tilfelli.

Tafla 171 Yfirlit tilfella í greiningu milli fyrir_einst, ánagju_umraedds og öryggismál_raedd

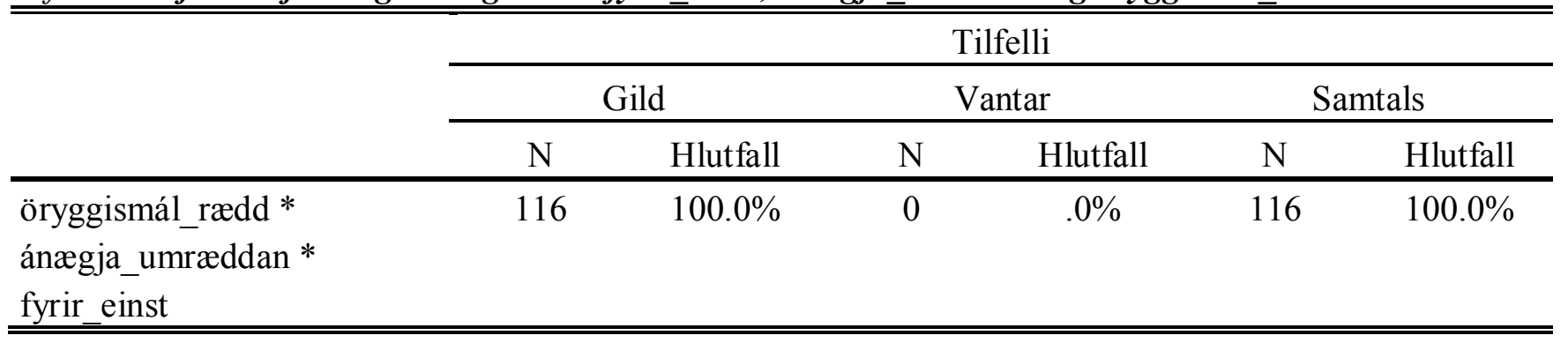

Engin augljós tengsl milli áncegju umredds og öryggismál_raedd er að sjá í tengslatöflu.

Tafla 172 Tengslatafla (tíðni): öryggismál_raedd * ánaegja_umraeddan * fyrir_einst

\begin{tabular}{|c|c|c|c|c|c|c|c|c|}
\hline \multirow[b]{2}{*}{ fyrir_einst } & & & \multicolumn{5}{|c|}{ ánægja_umræddan } & \multirow[b]{2}{*}{ Samtals } \\
\hline & & & $\begin{array}{c}\text { Mjög } \\
\text { óánægð/ur }\end{array}$ & $\begin{array}{c}\text { Frekar } \\
\text { óánægð/ur }\end{array}$ & $\begin{array}{l}\text { Hvorki } \\
\text { ánægð/ur } \\
\text { né } \\
\text { óánægð/ur }\end{array}$ & $\begin{array}{c}\text { Frekar } \\
\text { ánægð/ur }\end{array}$ & $\begin{array}{c}\text { Mjög } \\
\text { ánægð/ur }\end{array}$ & \\
\hline \multirow[t]{4}{*}{ Fyrirtæki } & öryggismál & Já & & 1 & 1 & 16 & 9 & 27 \\
\hline & _rædd & Nei & & 2 & 4 & 6 & 2 & 14 \\
\hline & & Veit ekki & & 0 & 0 & 1 & 0 & 1 \\
\hline & Samtals & & & 3 & 5 & 23 & 11 & 42 \\
\hline \multirow{3}{*}{$\begin{array}{l}\text { Einstak- } \\
\text { lingur }\end{array}$} & öryggismál & Já & 0 & 2 & 4 & 0 & 3 & 9 \\
\hline & _rædd & $\mathrm{Nei}$ & 3 & 10 & 12 & 22 & 18 & 65 \\
\hline & Samtals & & 3 & 12 & 16 & 22 & 21 & 74 \\
\hline \multirow[t]{4}{*}{ Samtals } & öryggismál & Já & 0 & 3 & 5 & 16 & 12 & 36 \\
\hline & _rædd & Nei & 3 & 12 & 16 & 28 & 20 & 79 \\
\hline & & Veit ekki & 0 & 0 & 0 & 1 & 0 & 1 \\
\hline & Samtals & & 3 & 15 & 21 & 45 & 32 & 116 \\
\hline
\end{tabular}

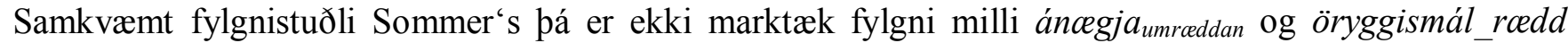
meðal einstaklings-verkkaupa sér í lagi eða heildarfjölda pátttakenda. En fylgni milli ofangreindra pátta reynist marktæk meðal fyrirtækja-verkkaupa og hæsta gildi fylgnistuðuls er pegar áncegja $a_{\text {umreddan }}$ er svarbreytan. 
Tafla 173 Ósamhverffylgnimaeligildi: öryggismál, ánoegja_umraeddan,fyrir_einst

\begin{tabular}{|c|c|c|c|c|c|c|}
\hline fyrir_einst & & & Gildi & fervik $^{\mathrm{a}}$ & $\mathrm{T}^{\mathrm{b}}$ & Sig. \\
\hline \multirow[t]{3}{*}{ Fyrirtæki } & \multirow{3}{*}{$\begin{array}{l}\text { Raðbreyta Somers'd } \\
\text { á móti } \\
\text { raðbreytu }\end{array}$} & Samhverft &, 327 &, 124 & 2,516 &, 012 \\
\hline & & $\begin{array}{l}\text { öryggismál_rædd } \\
\text { svarbrevta }\end{array}$ & 291 & 109 & 2,516 &, 012 \\
\hline & & $\begin{array}{l}\text { ánægja_umræddan } \\
\text { svarbreyta }\end{array}$ & ,375 & , 148 & 2,516 & ,012 \\
\hline \multirow[t]{3}{*}{ Einstaklingur } & \multirow{3}{*}{$\begin{array}{l}\text { Raðbreyta Somers'd } \\
\text { á móti } \\
\text { raðbreytu }\end{array}$} & Samhverft &,- 049 & ,094 &,- 519 & ,604 \\
\hline & & $\begin{array}{l}\text { öryggismál_rædd } \\
\text { svarbreyta }\end{array}$ &,- 031 &, 061 &,- 519 & ,604 \\
\hline & & $\begin{array}{l}\text { ánægja_umræddan } \\
\text { svarbreyta }\end{array}$ &,- 111 & ,212 &,- 519 & ,604 \\
\hline \multirow[t]{3}{*}{ Samtals } & \multirow{3}{*}{$\begin{array}{l}\text { Raðbreyta } \\
\text { á móti } \\
\text { raðbreytu }\end{array}$} & Samhverft & , 135 & ,076 & 1,773 & ,076 \\
\hline & & $\begin{array}{l}\text { öryggismál_rædd } \\
\text { svarbreyta }\end{array}$ & 109 &, 061 & 1,773 & ,076 \\
\hline & & $\begin{array}{l}\text { ánægja_umræddan } \\
\text { svarbreyta }\end{array}$ & , 179 & 100 & 1,773 & ,076 \\
\hline
\end{tabular}

a. Not assuming the null hypothesis.

b. Using the asymptotic standard error assuming the null hypothesis.

Samhverfu fylgnistuðlarnir gefa sömu niðurstöðu og Sommers‘d, p.e. að pað mælist ekki marktæk fylgni

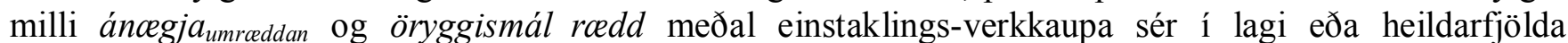
pátttakenda. En fylgni milli ofangreindra pátta reynist marktæk meðal fyrirtækja-verkkaupa en fylgnin er frekar veik.

Tafla 174 Samhverf fylgnimæligildi: fyrir einst, ánaegja umraedds, öryggismál raedd

\begin{tabular}{|c|c|c|c|c|c|c|c|}
\hline fyrir_einst & & & & Gildi & fervik $^{\mathrm{a}}$ & $\mathrm{T}^{\mathrm{b}}$ & Sig. \\
\hline \multirow[t]{4}{*}{ Fyrirtæki } & \multirow{3}{*}{$\begin{array}{l}\text { Raðbreyta } \\
\text { á móti } \\
\text { raðbreytu }\end{array}$} & \multicolumn{2}{|c|}{ Kendall's tau-c } & 267 &, 106 & 2,516 & 012 \\
\hline & & Gamma & Núllta -stigs & ,567 & 195 & 2,516 & 012 \\
\hline & & Spearma & ylgnistuðull & 357 &, 135 & 2,416 & $.020^{\mathrm{c}}$ \\
\hline & \multicolumn{3}{|c|}{$\mathrm{N}$ af gildum tilfellum } & 42 & & & \\
\hline \multirow[t]{4}{*}{ Einstaklingur } & \multirow{3}{*}{$\begin{array}{l}\text { Raðbreyta } \\
\text { á móti } \\
\text { raðbreytu }\end{array}$} & \multicolumn{2}{|c|}{ Kendall's tau-c } &,- 047 & ,092 &,- 519 & ,604 \\
\hline & & Gamma & Núllta -stigs &,- 140 & 265 &,- 519 & 604 \\
\hline & & \multicolumn{2}{|c|}{ Spearman fylgnistuðull } &,- 065 &, 124 &,- 553 & $.582^{\mathrm{c}}$ \\
\hline & \multicolumn{3}{|c|}{$\mathrm{N}$ af gildum tilfellum } & 74 & & & \\
\hline \multirow[t]{5}{*}{ Samtals } & \multirow{4}{*}{$\begin{array}{l}\text { Raðbreyta } \\
\text { á móti } \\
\text { raðbreytu }\end{array}$} & \multicolumn{2}{|c|}{ Kendall's tau-c } & ,118 & ,067 & 1,773 & ,076 \\
\hline & & \multirow[t]{2}{*}{ Gamma } & Núllta -stigs & 251 & , 139 & 1,773 & 076 \\
\hline & & & $\begin{array}{l}\text { Fyrsta-stigs } \\
\text { hlutfylgni }\end{array}$ &, 124 & & & \\
\hline & & \multicolumn{2}{|c|}{ Spearman fylgnistuðull } &, 153 & ,086 & 1,654 & $.101^{\mathrm{c}}$ \\
\hline & \multicolumn{3}{|c|}{$\mathrm{N}$ af gildum tilfellum } & 116 & & & \\
\hline
\end{tabular}

a. Not assuming the null hypothesis.

b. Using the asymptotic standard error assuming the null hypothesis.

c. Based on normal approximation. 


\subsection{Samskipti}

\subsubsection{Tvívítt fylgnifylki: ánægja_umræddan, ánægja_samskipti, pjónustulund, samskipti_ræedd}

Fylgni milli annars vegar áncegjamreddan og hins vegar áncegjasamskipti og pjónustulund reyndust mjög marktæk og miðlungs sterk.

Einnig reyndist fylgni milli samskipti $i_{r æ e d d}$ og pjónustulund vera marktæk en engu að síður veik fylgni en

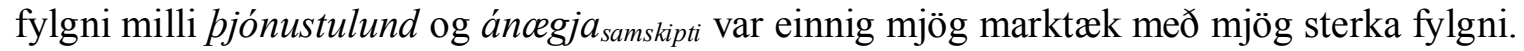

Tafla 175 Tvívítt fylgnifylki: ánægja_umræddan, ánægja_samskipti, pjónustulund, samskipti_ræedd

\begin{tabular}{lllcccc}
\hline \hline & & $\begin{array}{c}\text { ánægja_ } \\
\text { umrædda }\end{array}$ & $\begin{array}{c}\text { ánægja_ } \\
\text { samskipti }\end{array}$ & $\begin{array}{c}\text { bjónustu- } \\
\text { lund }\end{array}$ & $\begin{array}{c}\text { samskipti_ } \\
\text { rædd }\end{array}$ \\
\hline \multirow{2}{*}{$\begin{array}{l}\text { Spearman's } \\
\text { rho }\end{array}$} & ánægja & Fylgnistuðull & 1,000 & $.474^{* *}$ & $.317^{* * *}$ &, 154 \\
& umræddan & Sig. (2-tailed) &. &, 000 &, 001 &, 098 \\
& $\mathrm{~N}$ & 116 & 116 & 116 & 116 \\
\cline { 2 - 7 } & ánægja_- & Fylgnistuðull & $.474^{* *}$ & 1,000 & $.718^{* *}$ & $.273^{* *}$ \\
& samskipti & Sig. (2-tailed) &, 000 &. &, 000 &, 003 \\
& $\mathrm{~N}$ & 116 & 116 & 116 & 116 \\
\cline { 2 - 7 } & pjónustu-lund & Fylgnistuðull & $.317^{* *}$ & $.718^{* *}$ & 1,000 & $.199^{*}$ \\
& & Sig. (2-tailed) &, 001 &, 000 &. &, 032 \\
& $\mathrm{~N}$ & 116 & 116 & 116 & 116 \\
\cline { 2 - 7 } & samskipti_rædd & Fylgnistuðull &, 154 & $.273^{* *}$ & $.199^{*}$ & 1,000 \\
& & Sig. (2-tailed) &, 098 &, 003 &, 032 &. \\
& $\mathrm{~N}$ & 116 & 116 & 116 & 116 \\
\hline \hline
\end{tabular}

**. Correlation is significant at the 0.01 level (2-tailed)

*. Correlation is significant at the 0.05 level (2-tailed).

\subsubsection{Fylgni: ánægja_samskipti *ánægja_umræddan * fyrir_einst}

Fylgni milli áncegju $u_{\text {samskipti }}($ hversu áncegður verkkaupi var með samskipti sín við verktaka) og áncegju umredds var skoðuð með tilliti til pess hvort verkkaupi hafi verið fyrirtækja-verkkaupi eða einstaklings-verkkaupi. Öll 116 tilfellin flokkast undir gild tilfelli.

Tafla 176 Yfirlit tilfella í greiningu milli fyrir_einst, ánaegju_umraedds og ánaegja_samskipti

\begin{tabular}{|c|c|c|c|c|c|c|}
\hline & \multicolumn{6}{|c|}{ Tilfelli } \\
\hline & \multicolumn{2}{|c|}{ Gild } & \multicolumn{2}{|c|}{ Vantar } & \multicolumn{2}{|c|}{ Samtals } \\
\hline & $\mathrm{N}$ & Hlutfall & $\mathrm{N}$ & Hlutfall & $\mathrm{N}$ & Hlutfall \\
\hline $\begin{array}{l}\text { Ánægja_samskipti * } \\
\text { ánægja_umræddan * } \\
\text { fyrir_einst }\end{array}$ & 116 & $100.0 \%$ & 0 & $.0 \%$ & 116 & $100.0 \%$ \\
\hline
\end{tabular}




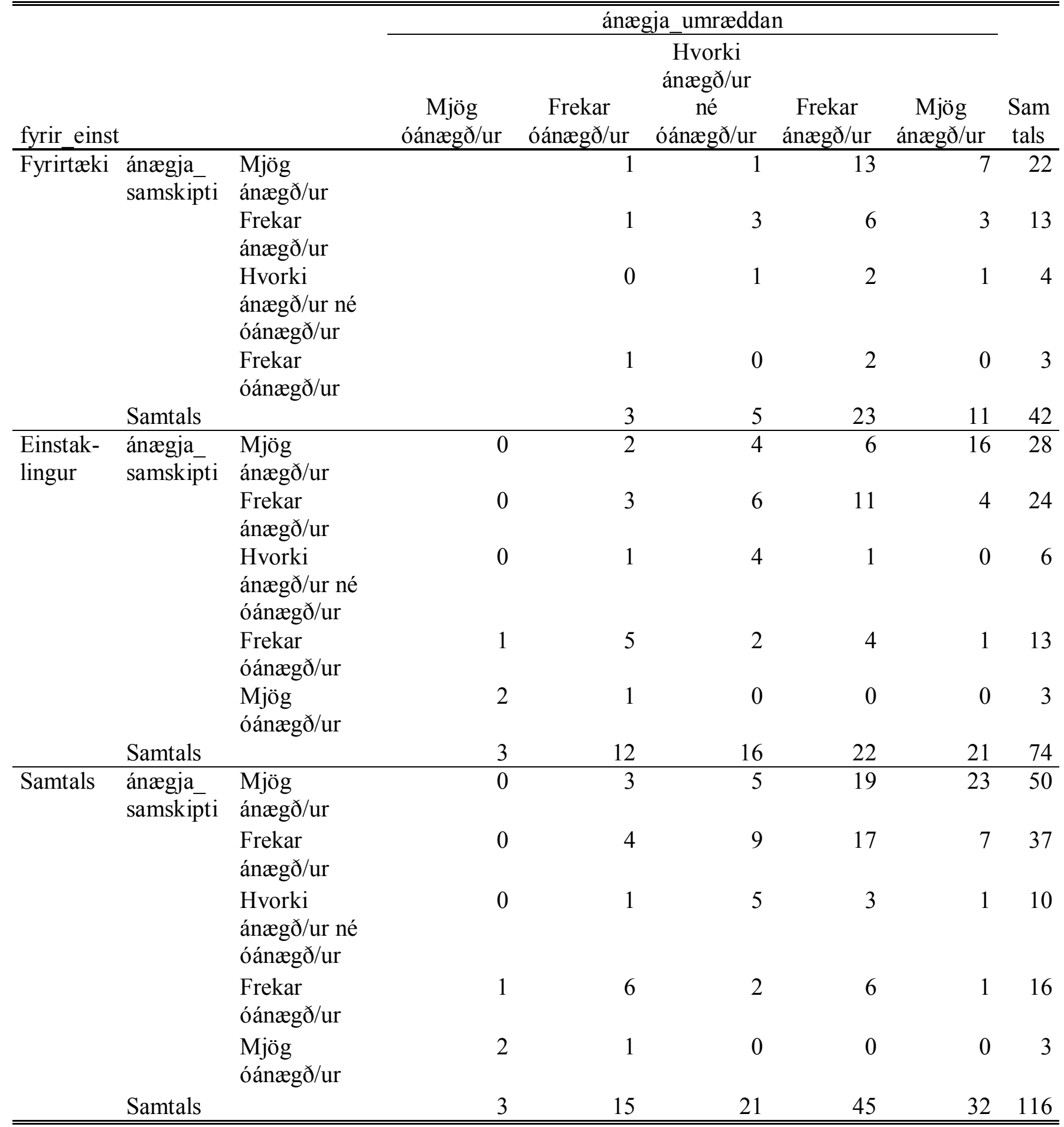

Fylgni milli áncegju $u_{\text {samskipti }}$ og áncegju $u_{u m r e d d s}$ reynist marktæk meðal einstaklings-verkkaupa og heildarfjölda verkkaupa en ekki sér í lagi fyrir fyrirtækja-verkkaupa. 
Tafla 178 Ósamhverffylgnimaeligildi: ánaegja_samskipti, ánaegja_umraeddan,fyrir_einst

\begin{tabular}{|c|c|c|c|c|c|c|}
\hline fyrir_einst & & & Gildi & fervik $^{\mathrm{a}}$ & $\mathrm{T}^{\mathrm{b}}$ & Sig. \\
\hline \multirow{3}{*}{ Fyrirtæki } & Raðbreyta Somers'd & Samhverft & ,218 &, 127 & 1,676 & ,094 \\
\hline & $\begin{array}{l}\text { á móti } \\
\text { raðbrevtu }\end{array}$ & $\begin{array}{l}\text { ánægja_samskipti } \\
\text { svarbrevta }\end{array}$ & ,219 & 127 & 1,676 & ,094 \\
\hline & & $\begin{array}{l}\text { ánægja_umræddan } \\
\text { svarbreyta }\end{array}$ & ,217 & , 129 & 1,676 & ,094 \\
\hline \multirow[t]{3}{*}{ Einstaklingur } & Raðbreyta Somers'd & Samhverft & ,488 & ,087 & 5,430 &, 000 \\
\hline & $\begin{array}{l}\text { á móti } \\
\text { raðbreytu }\end{array}$ & $\begin{array}{l}\text { ánægja_samskipti } \\
\text { svarbreyta }\end{array}$ & ,474 & ,085 & 5,430 & ,000 \\
\hline & & $\begin{array}{l}\text { ánægja_umræddan } \\
\text { svarbreyta }\end{array}$ &, 503 & ,089 & 5,430 &, 000 \\
\hline \multirow[t]{3}{*}{ Samtals } & Raðbreyta Somers' d & Samhverft & ,419 & ,071 & 5,617 &, 000 \\
\hline & $\begin{array}{l}\text { á móti } \\
\text { raðbreytu }\end{array}$ & $\begin{array}{l}\text { ánægja_samskipti } \\
\text { svarbreyta }\end{array}$ & ,408 &, 070 & 5,617 &, 000 \\
\hline & & $\begin{array}{l}\text { ánægja_umræddan } \\
\text { svarbreyta }\end{array}$ & ,430 & ,074 & 5,617 &, 000 \\
\hline
\end{tabular}

a. Not assuming the null hypothesis.

b. Using the asymptotic standard error assuming the null hypothesis.

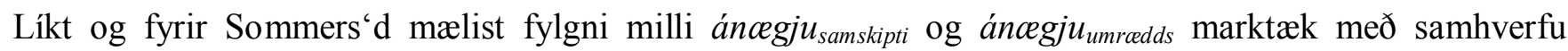
mæligildunum, meðal einstaklings-verkkaupa og heildarfjölda verkkaupa en ekki sér í lagi fyrir fyrirtækjaverkkaupa. Samkvæmt pumalputtareglu flokkast ofangreind fylgni til pess að vera miðlungs-sterk ${ }^{108}$ (Sarah Boslaugh \& Paul Andrew Watters, 2008) meðal einstaklinga en meðal heildarfjölda svara pá munar örlitlu að fylgnin geti talist svo sterk.

Tafla 179 Samhverf fylgnimæligildi: fyrir_einst, áncegja_umraedds, áncegja_samskipti

\begin{tabular}{|c|c|c|c|c|c|c|c|}
\hline fyrir_einst & & & & Gildi & fervik $^{\mathrm{a}}$ & $\mathrm{T}^{\mathrm{b}}$ & Sig. \\
\hline \multirow[t]{4}{*}{ Fyrirtæki } & \multirow{3}{*}{$\begin{array}{l}\text { Raðbreyta } \\
\text { á móti } \\
\text { raðbreytu }\end{array}$} & \multicolumn{2}{|c|}{ Kendall's tau-b } & 218 &, 127 & 1,676 &, 094 \\
\hline & & Gamma & Núllta-stigs & 343 & 194 & 1,676 & ,094 \\
\hline & & Spearma & ylgnistuðull & 245 & 142 & 1,597 & $.118^{\mathrm{c}}$ \\
\hline & \multicolumn{3}{|c|}{$\mathrm{N}$ af gildum tilfellum } & 42 & & & \\
\hline \multirow[t]{4}{*}{ Einstaklingur } & \multirow{3}{*}{$\begin{array}{l}\text { Raðbreyta } \\
\text { á móti } \\
\text { raðbreytu }\end{array}$} & \multicolumn{2}{|c|}{ Kendall's tau-b } & 489 & ,087 & 5,430 &, 000 \\
\hline & & Gamma & Núllta-stigs & 627 & 099 & 5,430 & 000 \\
\hline & & \multicolumn{2}{|c|}{ Spearman fylgnistuðull } &, 551 & ,094 & 5,605 & $.000^{\mathrm{c}}$ \\
\hline & \multicolumn{3}{|c|}{$\mathrm{N}$ af gildum tilfellum } & 74 & & & \\
\hline \multirow[t]{5}{*}{ Samtals } & \multirow{4}{*}{$\begin{array}{l}\text { Raðbreyta } \\
\text { á móti } \\
\text { raðbreytu }\end{array}$} & \multicolumn{2}{|c|}{ Kendall's tau-b } & ,419 & ,071 & 5,617 &, 000 \\
\hline & & \multirow[t]{2}{*}{ Gamma } & Núllta-stigs &, 569 & ,087 & 5,617 & 000 \\
\hline & & & $\begin{array}{l}\text { Fyrsta-stigs } \\
\text { hlutfylgni }\end{array}$ &, 576 & & & \\
\hline & & \multicolumn{2}{|c|}{ Spearman fylgnistuðull } & ,474 & ,078 & 5,743 & $.000^{\mathrm{c}}$ \\
\hline & \multicolumn{3}{|c|}{$\mathrm{N}$ af gildum tilfellum } & 116 & & & \\
\hline
\end{tabular}

a. Not assuming the null hypothesis.

b. Using the asymptotic standard error assuming the null hypothesis.

c. Based on normal approximation.

\footnotetext{
${ }^{108}$ Sjá viðauka um ályktunartölfræði og marktektarpróf á bls. 282

280
} 


\subsection{Gæðatrygging}

\subsubsection{Fylgni: gæðatrygging * ánægja_umræddan * fyrir_einst}

Fylgni milli gaðatrygging (bess hvort umraddur verktaki hafi sýnt verkkaupa fram á gaðatryggingu $i$ upphafi framkvoemda) og áncegju umreddan var skoðuð með tilliti til pess hvort verkkaupi hafi verið fyrirtækja-verkkaupi eða einstaklings-verkkaupi. Öll 116 tilfellin flokkast undir gild tilfelli.

Tafla 180 Yfirlit tilfella í greiningu milli fyrir_einst, ánaegju_umrceddan og gaeðatrygging

\begin{tabular}{lcccccc}
\hline \hline & \multicolumn{6}{c}{ Tilfelli } \\
\cline { 2 - 7 } & \multicolumn{2}{c}{ Gild } & \multicolumn{2}{c}{ Vantar } & \multicolumn{2}{c}{ Samtals } \\
\cline { 2 - 7 } & $\mathrm{N}$ & Hlutfall & $\mathrm{N}$ & Hlutfall & $\mathrm{N}$ & Hlutfall \\
\hline $\begin{array}{l}\text { gæðatrygging * } \\
\begin{array}{l}\text { ánægja_umræddan * } \\
\text { fyrir_einst }\end{array}\end{array}$ & 116 & $100.0 \%$ & 0 & $.0 \%$ & 116 & $100.0 \%$ \\
\hline \hline
\end{tabular}

Tafla 181 Tengslatafla (tỉðni): gaeðatrygging *ánaegja_umraeddan *fyrir_einst

\begin{tabular}{|c|c|c|c|c|c|c|c|c|}
\hline \multirow[b]{2}{*}{ fyrir_einst } & & & \multicolumn{5}{|c|}{ ánægja_umræddan } & \multirow[b]{2}{*}{ Samtals } \\
\hline & & & $\begin{array}{c}\text { Mjög } \\
\text { óánægð/ur }\end{array}$ & $\begin{array}{c}\text { Frekar } \\
\text { óánægð/ur }\end{array}$ & $\begin{array}{c}\text { Hvorki } \\
\text { ánægð/ur } \\
\text { né } \\
\text { óánægð/ur }\end{array}$ & $\begin{array}{c}\text { Frekar } \\
\text { ánægð/ur }\end{array}$ & $\begin{array}{c}\text { Mjög } \\
\text { ánægð/ur }\end{array}$ & \\
\hline \multirow[t]{3}{*}{ Fyrirtæki } & gæðatrygging & Já & & 1 & 1 & 12 & 5 & 19 \\
\hline & & $\mathrm{Nei}$ & & 2 & 4 & 11 & 6 & 23 \\
\hline & Samtals & & & 3 & 5 & 23 & 11 & 42 \\
\hline \multirow[t]{3}{*}{ Einstaklingur } & gæðatrygging & Já & 0 & 0 & 0 & 0 & 2 & 2 \\
\hline & & Nei & 3 & 12 & 16 & 22 & 19 & 72 \\
\hline & Samtals & & 3 & 12 & 16 & 22 & 21 & 74 \\
\hline \multirow[t]{3}{*}{ Samtals } & gæðatrygging & Já & 0 & 1 & 1 & 12 & 7 & 21 \\
\hline & & $\mathrm{Nei}$ & 3 & 14 & 20 & 33 & 25 & 95 \\
\hline & Samtals & & 3 & 15 & 21 & 45 & 32 & 116 \\
\hline
\end{tabular}

Sommers'd gefur að marktækur munur sé fyrir heildarfjölda svara milli áncegju umredds og gaeðatrygging. Fylgni milli pessa pátta mælist ekki marktæk ef fyrirtækja-verkkaupar eða einstaklings-verkkaupar eru skoðaðir sér í lagi. Fylgnin er ekki sterk en hæsta marktæka gildi á Sommer's d fæst pegar áncegjumredds er höfô sem svarbreyta. 
Tafla 182 Ósamhverffylgnimaeligildi: greiðsluácetlun, ánaegja_umraeddan,fyrir_einst

\begin{tabular}{|c|c|c|c|c|c|c|}
\hline fyrir_einst & & & Gildi & fervik $^{\mathrm{a}}$ & $\mathrm{T}^{\mathrm{b}}$ & Sig. \\
\hline \multirow[t]{3}{*}{ Fyrirtæki } & \multirow{3}{*}{$\begin{array}{l}\text { Raðbreyta Somers' d } \\
\text { á móti } \\
\text { raðbreytu }\end{array}$} & Samhverft &, 100 &, 142 & ,705 & 481 \\
\hline & & $\begin{array}{l}\text { gæðatrygging } \\
\text { svarbreyta }\end{array}$ & ,091 & 128 &, 705 & , 481 \\
\hline & & $\begin{array}{l}\text { ánægja_umræddan } \\
\text { svarbreyta }\end{array}$ &, 112 & 159 & ,705 & , 481 \\
\hline \multirow[t]{3}{*}{ Einstaklingur } & \multirow{3}{*}{$\begin{array}{l}\text { Raðbreyta Somers' d } \\
\text { á móti } \\
\text { raðbreytu }\end{array}$} & Samhverft & ,096 & 033 & 1,467 & 142 \\
\hline & & $\begin{array}{l}\text { gæðatrygging } \\
\text { svarbreyta }\end{array}$ &, 051 & 035 & 1,467 & 142 \\
\hline & & $\begin{array}{l}\text { ánægja_umræddan } \\
\text { svarbreyta }\end{array}$ & ,736 &, 052 & 1,467 & , 142 \\
\hline \multirow[t]{3}{*}{ Samtals } & \multirow{3}{*}{$\begin{array}{l}\text { Raðbreyta } \\
\text { á móti } \\
\text { raðbreytu }\end{array}$} & Samhverft & , 151 & ,064 & 2,246 &, 025 \\
\hline & & $\begin{array}{l}\text { gæðatrygging } \\
\text { svarbreyta }\end{array}$ &, 106 & 047 & 2,246 &, 025 \\
\hline & & $\begin{array}{l}\text { ánægja_umræddan } \\
\text { svarbreyta }\end{array}$ & ,260 & 109 & 2,246 &, 025 \\
\hline
\end{tabular}

a. Not assuming the null hypothesis.

b. Using the asymptotic standard error assuming the null hypothesis.

Eins og fyrir Sommers'd pá er einungis marktæk fylgni fyrir áncegju umredds og gceðatryggingar fyrir heildarfjölda svara með samhverfu mæligildunum. Fylgnin flokkast einnig undir pað að vera veik.

Tafla 183 Samhverf fylgnimæligildi: fyrir_einst, ánaegja_umraedds, gaeðatrygging

\begin{tabular}{|c|c|c|c|c|c|c|c|}
\hline fyrir_einst & & & & Gildi & fervik ${ }^{\mathrm{a}}$ & $\mathrm{T}^{\mathrm{b}}$ & Sig. \\
\hline \multirow[t]{4}{*}{ Fyrirtæki } & Raðbreyta & \multicolumn{2}{|c|}{ Kendall's tau-c } & 111 & , 158 & ,705 & ,481 \\
\hline & $\begin{array}{l}\text { á móti } \\
\text { raðbreytu }\end{array}$ & Gamma & $\begin{array}{l}\text { Núllta- } \\
\text { stigs }\end{array}$ &, 182 & 256 & ,705 & ,481 \\
\hline & & \multicolumn{2}{|c|}{ Spearman fylgnistuðull } &, 107 &, 151 & ,681 & $.500^{\mathrm{c}}$ \\
\hline & \multicolumn{3}{|c|}{$\mathrm{N}$ af gildum tilfellum } & 42 & & & \\
\hline \multirow[t]{4}{*}{ Einstaklingur } & Raðbreyta & \multicolumn{2}{|c|}{ Kendall's tau-c } & 077 & 053 & 1,467 & , 142 \\
\hline & $\begin{array}{l}\text { á móti } \\
\text { raðbreytu }\end{array}$ & Gamma & $\begin{array}{l}\text { Núllta- } \\
\text { stigs }\end{array}$ & 1,000 & 000 & 1,467 & 142 \\
\hline & & \multicolumn{2}{|c|}{ Spearman fylgnistuðull } & 214 & 074 & 1,856 & $.068^{\mathrm{c}}$ \\
\hline & \multicolumn{3}{|c|}{$\mathrm{N}$ af gildum tilfellum } & 74 & & & \\
\hline \multirow[t]{5}{*}{ Samtals } & \multirow{4}{*}{$\begin{array}{l}\text { Raðbreyta } \\
\text { á móti } \\
\text { raðbreytu }\end{array}$} & \multicolumn{2}{|c|}{ Kendall's tau-c } &, 154 & ,069 & 2,246 & ,025 \\
\hline & & \multirow[t]{2}{*}{ Gamma } & $\begin{array}{l}\text { Núllta- } \\
\text { stigs }\end{array}$ & 373 & 153 & 2,246 & 025 \\
\hline & & & $\begin{array}{l}\text { Fyrsta- } \\
\text { stigs } \\
\text { hlutfylgni }\end{array}$ & ,413 & & & \\
\hline & & \multicolumn{2}{|c|}{ Spearman fylgnistuðull } & , 181 & 077 & 1,968 & $.051^{\mathrm{c}}$ \\
\hline & \multicolumn{3}{|c|}{$\mathrm{N}$ af gildum tilfellum } & 116 & & & \\
\hline
\end{tabular}

a. Not assuming the null hypothesis.

b. Using the asymptotic standard error assuming the null hypothesis.

c. Based on normal approximation. 


\subsubsection{Fylgni: gæðatrygging * ánægja_umræddan * fyrir_einst}

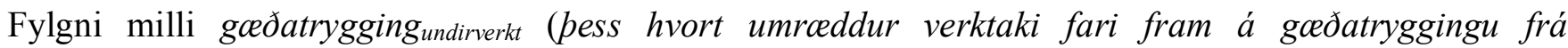
undirverktökum) og áncegjumreddan var skoðuð. 44 tilfelli flokkast undir gild tilfelli.

Tafla 184 Yfirlit tilfella í greiningu milli ánaegju_umraeddan og gaeðatrygging_undirverkt

\begin{tabular}{lccccccc}
\hline & \multicolumn{6}{c}{ Tilfelli } \\
\cline { 2 - 7 } & \multicolumn{2}{c}{ Gild } & \multicolumn{2}{c}{ Vantar } & \multicolumn{2}{c}{ Samtals } \\
\cline { 2 - 7 } & $\mathrm{N}$ & Hlutfall & $\mathrm{N}$ & Hlutfall & $\mathrm{N}$ & Hlutfall \\
\hline $\begin{array}{l}\text { ánægja_umræddan } * \\
\text { gæðatrygging_undirverkt }\end{array}$ & 44 & $37.9 \%$ & 72 & $62.1 \%$ & 116 & $100.0 \%$ \\
\hline \hline
\end{tabular}

Tafla 185 Tengslatafla (tỉðni): ánaegju_umraeddan *gaðatrygging_undirverkt

\begin{tabular}{llccccc}
\hline \hline & \multicolumn{3}{c}{ gæðatrygging_undirverkt } & \\
\cline { 3 - 6 } & & Aldrei & Sjaldan & Stundum & Oft & Samtals \\
\hline ánægja & Frekar óánægð/ur & 1 & 0 & 0 & 0 & 1 \\
umræddan & Hvorki ánægð/ur né óánægð/ur & 8 & 0 & 1 & 0 & 9 \\
& Frekar ánægð/ur & 7 & 3 & 6 & 2 & 18 \\
& Mjög ánægð/ur & 3 & 3 & 5 & 5 & 16 \\
Samtals & 19 & 6 & 12 & 7 & 44 \\
\hline \hline
\end{tabular}

Mjög marktæk og sterk fylgni greindist milli ánægju verktaka með framkvæmd verksins hjá umræddum verktaka og hvort verktaki krefur undirverktaka um gæðatryggingu hvort sem notast var við Sommers' $d$ eða samhverfu fylgnimæligildin.

Tafla 186 Ósamhverffylgnimaeligildi: áncegja_umraeddan, gaeðatrygging_undirverkt

\begin{tabular}{|c|c|c|c|c|c|}
\hline & & Gildi & fervik $^{\mathrm{a}}$ & $\overline{T^{b}}$ & Sig. \\
\hline \multirow{3}{*}{$\begin{array}{l}\text { Raðbreyta } \\
\text { á móti } \\
\text { raðbreytu }\end{array}$} & Samhverft & ,446 &, 105 & 4,122 &, 000 \\
\hline & ánægja_umræddan svarbreyta & ,434 &, 108 & 4,122 &, 000 \\
\hline & $\begin{array}{l}\text { gæðatrygging_undirverkt } \\
\text { svarbreyta }\end{array}$ & ,458 &, 105 & 4,122 &, 000 \\
\hline
\end{tabular}

a. Not assuming the null hypothesis.

b. Using the asymptotic standard error assuming the null hypothesis.

\section{Tafla 187 Samhverf fylgnimaeligildi: ánaegja_umraeddan, gaeðatrygging_undirverkt}

\begin{tabular}{llcccc}
\hline \hline & & Gildi & fervik $^{\mathrm{a}}$ & $\mathrm{T}^{\mathrm{b}}$ & Sig. \\
\hline Raðbreyta á móti & Kendall's tau-b &, 446 &, 105 & 4,122 &, 000 \\
raðbreytu & Kendall's tau-c &, 402 &, 098 & 4,122 &, 000 \\
& Gamma &, 638 &, 134 & 4,122 &, 000 \\
& Spearman fylgnistuðull &, 504 &, 116 & 3,779 & $.000^{\mathrm{c}}$ \\
& & 44 & & \\
\hline \hline
\end{tabular}

a. Not assuming the null hypothesis.

b. Using the asymptotic standard error assuming the null hypothesis.

c. Based on normal approximation. 


\subsection{Gæðastjórnunarkerfi}

\subsubsection{Tvífylgnifylki: GSK, ánægja_umræddan, ánægja_tíma, ánægju_greiðslu, ánægja_öryggismál, ánægja_samskipti, ánægja_gæði}

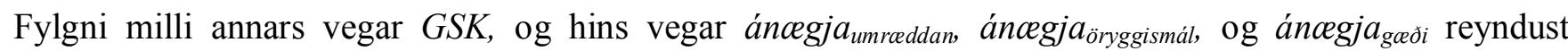
marktæk og milli pess að vera miðlungs og frekar sterk en fylgni mældist ekki marktæk milli annars vegar

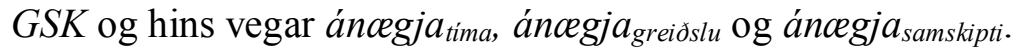

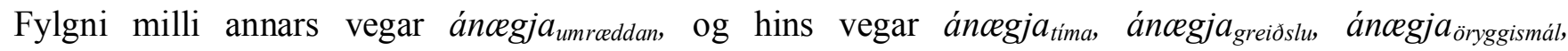

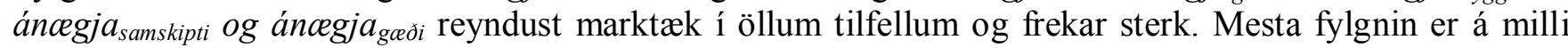
áncegja $a_{\text {gæèi }}$ og áncegja $a_{\text {umreddan. }}$

Tafla 188 Tvífylgnifylki: GSK, ánaegja_umraeddan,ánagja_tíma, ánaegja_greiðslu,ánaegja_öryggismál, ánaegja_samskipti, ánaegja_gaedi

\begin{tabular}{|c|c|c|c|c|c|c|c|c|c|}
\hline & & & GSK & $\begin{array}{l}\text { ánægja } \\
\text { umræda }\end{array}$ & $\begin{array}{c}\text { ánægja } \\
\text { tíma }\end{array}$ & $\begin{array}{l}\text { ánægja } \\
\text { greiðslu }\end{array}$ & $\begin{array}{l}\text { ánægja_- } \\
\text { öryggismál }\end{array}$ & $\begin{array}{l}\text { ánægja } \\
\text { samskipt }\end{array}$ & $\begin{array}{r}\text { ánægja } \\
\text { gæði }\end{array}$ \\
\hline \multirow{21}{*}{$\begin{array}{l}\text { Spear } \\
\text { man's } \\
\text { rho }\end{array}$} & \multirow[t]{3}{*}{ GSK } & Fylgnistuðull & 1,000 & $.430^{* *}$ & ,217 & ,248 & $.393^{* *}$ &, 097 & $.446^{* *}$ \\
\hline & & Sig. (2-tailed) & . &, 003 & 142 & ,092 & ,006 &, 518 &, 002 \\
\hline & & $\mathrm{N}$ & 47 & 47 & 47 & 47 & 47 & 47 & 47 \\
\hline & \multirow{3}{*}{$\begin{array}{l}\text { ánægja } \\
\text { umrædd } \\
\text { an }\end{array}$} & Fylgnistuðull & $.430^{* *}$ & 1,000 & $.515^{* *}$ & $.400^{* * *}$ & $.318^{* *}$ & $.474^{* *}$ & $.622^{* *}$ \\
\hline & & Sig. (2-tailed) &, 003 & . &, 000 &, 000 &, 001 &, 000 &, 000 \\
\hline & & $\mathrm{N}$ & 47 & 116 & 116 & 116 & 116 & 116 & 116 \\
\hline & \multirow{3}{*}{$\begin{array}{l}\text { ánægja_ } \\
\text { tíma }\end{array}$} & Fylgnistuðull & 217 & $.515^{* *}$ & 1,000 & $.616^{* *}$ & $.218^{*}$ & $.541^{* *}$ & $.425^{* *}$ \\
\hline & & Sig. (2-tailed) & 142 &, 000 & &, 000 & ,019 &, 000 &, 000 \\
\hline & & $\mathrm{N}$ & 47 & 116 & 116 & 116 & 116 & 116 & 116 \\
\hline & \multirow{3}{*}{$\begin{array}{l}\text { ánægja_- } \\
\text { greiðslu }\end{array}$} & Fylgnistuðull & ,248 & $.400^{* *}$ & $.616^{* *}$ & 1,000 & $.267^{* *}$ & $.408^{* *}$ & $.409^{* *}$ \\
\hline & & Sig. (2-tailed) & ,092 &, 000 &, 000 & . &, 004 &, 000 &, 000 \\
\hline & & $\mathrm{N}$ & 47 & 116 & 116 & 116 & 116 & 116 & 116 \\
\hline & \multirow{3}{*}{$\begin{array}{l}\text { ánægja_- } \\
\text { öryggis } \\
\text { mál }\end{array}$} & Fylgnistuðull & $.393^{* *}$ & $.318^{* *}$ & $.218^{*}$ & $.267^{* *}$ & 1,000 & $.297^{* *}$ & $.237^{*}$ \\
\hline & & Sig. (2-tailed) &, 006 &, 001 & 019 &, 004 & . &, 001 & 010 \\
\hline & & $\mathrm{N}$ & 47 & 116 & 116 & 116 & 116 & 116 & 116 \\
\hline & \multirow{3}{*}{$\begin{array}{l}\text { ánægja } \\
\text { samskip } \\
\text { ti }\end{array}$} & Fylgnistuðull & ,097 & $.474^{* *}$ & $.541^{* *}$ & $.408^{* *}$ & $.297^{* *}$ & 1,000 & $.564^{* *}$ \\
\hline & & Sig. (2-tailed) & ,518 &, 000 &, 000 &, 000 &, 001 & . &, 000 \\
\hline & & $\mathrm{N}$ & 47 & 116 & 116 & 116 & 116 & 116 & 116 \\
\hline & \multirow{3}{*}{$\begin{array}{l}\text { ánægja_ } \\
\text { gæði }\end{array}$} & Fylgnistuðull & $.446^{* *}$ & $.622^{* *}$ & $.425^{* *}$ & $.409^{* *}$ & $.237^{*}$ & $.564^{* *}$ & 1,000 \\
\hline & & Sig. (2-tailed) &, 002 &, 000 &, 000 &, 000 & 010 &, 000 & . \\
\hline & & $\mathrm{N}$ & 47 & 116 & 116 & 116 & 116 & 116 & 116 \\
\hline
\end{tabular}

**. Correlation is significant at the 0.01 level (2-tailed).

*. Correlation is significant at the 0.05 level (2-tailed). 


\subsubsection{Fylgni: fyrir_einst, ánægja_umræddan, GSK}

Fylgni milli ánægju umræddan og $G S K$ var skoðuð með tilliti til pess hvort verkkaupi hafi verið fyrirtækjaverkkaupi eða einstaklings-verkkaupi.

Einungis 47 tilfelli flokkast undir gild tilfelli par sem að pað voru ekki fleiri í hópi umraeddra verktaka sem tóku pátt í könnun fyrir verktaka. Ef tilfelli par sem vitað er til pess að verkkaupi og verktaki eru hagsmunalega eða persónulega tengdir eru sogtuð frá flokkast 45 tilfelli til gildra tilfella.

Tafla 189 Yfirlit tilfella í greiningu milli fyrir_einst, ánaegju_umraeddan og GSK

\begin{tabular}{|c|c|c|c|c|c|c|}
\hline & \multicolumn{6}{|c|}{ Tilfelli } \\
\hline & \multicolumn{2}{|c|}{ Gild } & \multicolumn{2}{|c|}{ Vantar } & \multicolumn{2}{|c|}{ Samtals } \\
\hline & $\mathrm{N}$ & Hlutfall & $\mathrm{N}$ & Hlutfall & $\mathrm{N}$ & Hlutfall \\
\hline $\begin{array}{l}\text { ánægja_umræddan * GSK * } \\
\text { fyrir_einst }\end{array}$ & 47 & $40.5 \%$ & 69 & $59.5 \%$ & 116 & $100.0 \%$ \\
\hline $\begin{array}{l}\text { Tengdir aðilar sigtaðir frá: } \\
\text { ánægja_umræddan * GSK * } \\
\text { fyrir_einst }\end{array}$ & 45 & $42,5 \%$ & 61 & $57,5 \%$ & 106 & $100,0 \%$ \\
\hline
\end{tabular}

Ef tíðnitafla er skoðuð virðast bæði fyrirtæki og einstaklingar sem voru með umrædda verktaka í huga sem kváðust starfa eftir gæðastjórnunarkerfi eða vera í innleiðingarferlinu vera ánægðari en peir verkkaupar sem voru með umræddan verktaka í huga sem kvaðst ekki starfa eftir gæðastjórnunarkerfi (eða sagðist starfa eftir gæðastjórnunarkerfi sem byggði ekki á viðurkenndum gæðastjórnunarstaðli). 


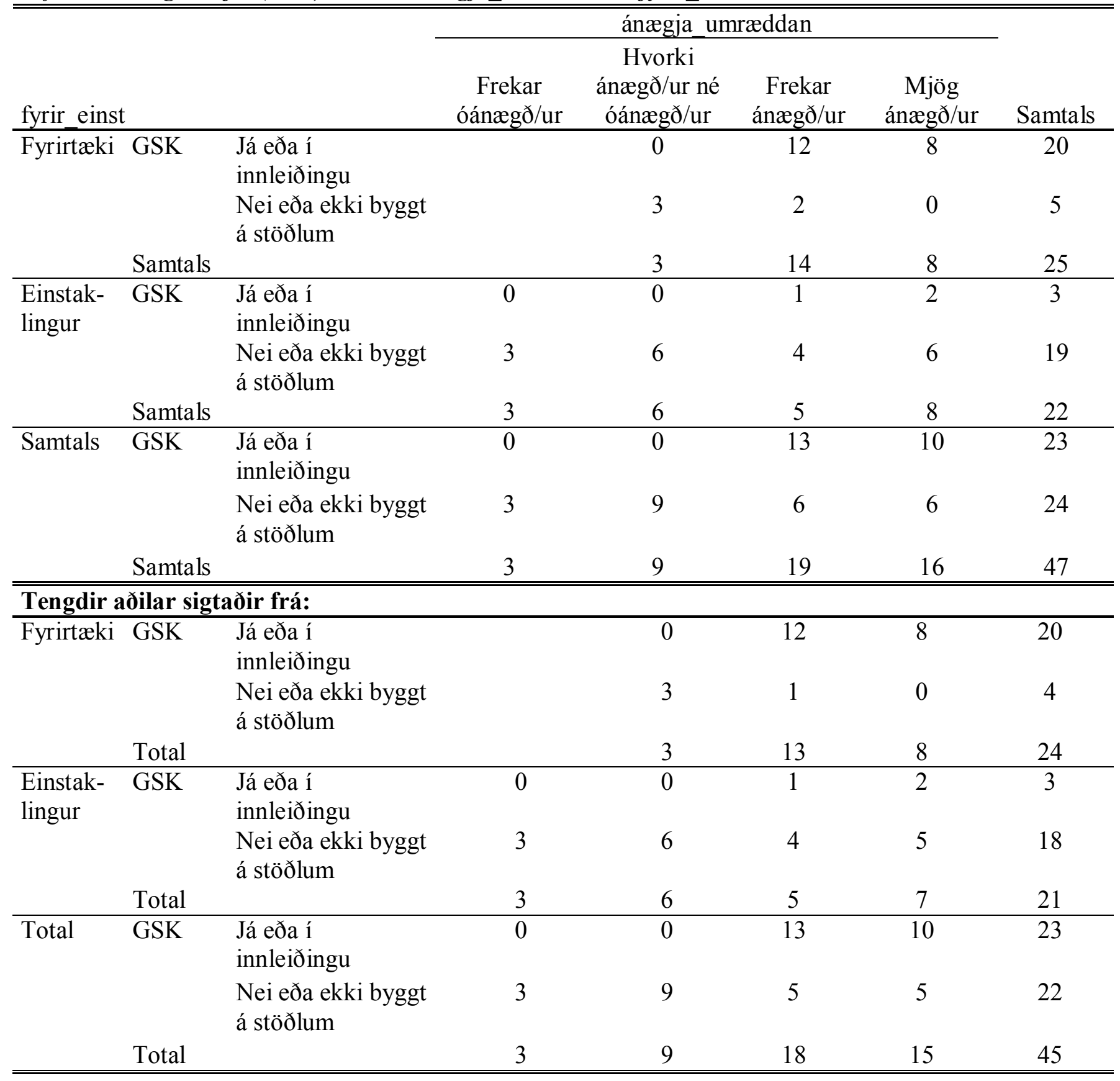

Ósamhverfi fylgnistuðullinn Sommer's d gefur að marktæk fylgni sé á milli ánægju verkkaupa með umræddan verktaka og pess hvort umræddur verktaki starfi eftir gæðastjórnunarkerfi ef horft er á heildarfjölda svara og ef horft er á fyrirtækja verkkaupa. Fylgnin mældist ekki næg meðal einstaklings verkkaupa til að geta talist marktæk, en skýrsluhöfundur telur líklegt að mæla megi marktæka fylgni með fleiri pátttakendum. Mesta marktæknin mældist fyrir heildarfjölda svara (bceði einstaklings-verkkaupa og fyrirtcekja-verkkaupa saman) en hæstu fylgnistuðlar voru hjá fyrirtækja verkkaupum og pá sér í lagi ef breytan áncegja umreddan er meðhöndluð sem svarbreyta og GSK sem spábreyta. Fylgni er hærri ef tilfellum með tengdum verkkaupum og verktökum eru sigtuð frá. 
Tafla 191 Ósamhverffylgnimaeligildi: fyrir_einst, ánægja_umrædds, GSK

\begin{tabular}{|c|c|c|c|c|c|c|c|}
\hline fyrir_einst & & & & Gildi & fervik $^{\mathrm{a}}$ & $\mathrm{T}^{\mathrm{b}}$ & Sig. \\
\hline \multirow[t]{3}{*}{ Fyrirtæki } & \multirow{3}{*}{\multicolumn{2}{|c|}{$\begin{array}{l}\text { Raðbreyta } \\
\text { á móti } \\
\text { raðbreytu }\end{array}$}} & Samhverft & 547 &, 103 & 2,849 & ,004 \\
\hline & & & GSK svarbreyta & ,427 &, 117 & 2,849 &, 004 \\
\hline & & & $\begin{array}{l}\text { ánægja_umræddan } \\
\text { svarbreyta }\end{array}$ & ,760 &, 139 & 2,849 &, 004 \\
\hline \multirow[t]{3}{*}{ Einstaklingur } & \multirow{3}{*}{\multicolumn{2}{|c|}{$\begin{array}{l}\text { Raðbreyta } \\
\text { á móti } \\
\text { raðbreytu }\end{array}$}} & Samhverft & ,250 &, 111 & 1,682 & ,092 \\
\hline & & & GSK svarbreyta & 166 & ,099 & 1,682 & ,092 \\
\hline & & & $\begin{array}{l}\text { ánægja_umræddan } \\
\text { svarbreyta }\end{array}$ & ,509 & , 196 & 1,682 & ,092 \\
\hline \multirow[t]{3}{*}{ Samtals } & \multirow{3}{*}{\multicolumn{2}{|c|}{$\begin{array}{l}\text { Raðbreyta } \\
\text { á móti } \\
\text { raðbreytu }\end{array}$}} & Samhverft & ,396 &, 114 & 3,329 & ,001 \\
\hline & & & GSK svarbreyta & ,344 & ,096 & 3,329 & ,001 \\
\hline & & & $\begin{array}{l}\text { ánægja_umræddan } \\
\text { svarbreyta }\end{array}$ & ,467 &, 140 & 3,329 &, 001 \\
\hline \multicolumn{8}{|c|}{ Tengdir aðilar sigtaðir frá: } \\
\hline \multirow[t]{3}{*}{ Fyrirtæki } & \multirow{3}{*}{\multicolumn{2}{|c|}{$\begin{array}{l}\text { Raðbreyta Somers' d } \\
\text { á móti } \\
\text { raðbreytu }\end{array}$}} & Samhverft &, 551 & ,109 & 2,518 & ,012 \\
\hline & & & GSK svarbreyta & ,407 & ,132 & 2,518 & 012 \\
\hline & & & $\begin{array}{l}\text { ánægja_umræddan } \\
\text { svarbreyta }\end{array}$ &, 850 & ,133 & 2,518 & ,012 \\
\hline \multirow[t]{3}{*}{ Einstaklingur } & \multirow{3}{*}{\multicolumn{2}{|c|}{$\begin{array}{l}\text { Raðbreyta } \\
\text { á móti } \\
\text { raðbreytu }\end{array}$}} & Samhverft & 279 &, 114 & 1,778 & ,075 \\
\hline & & & GSK svarbreyta &, 186 & , 105 & 1,778 & ,075 \\
\hline & & & $\begin{array}{l}\text { ánægja_umræddan } \\
\text { svarbreyta }\end{array}$ &, 556 & ,191 & 1,778 &, 075 \\
\hline \multirow[t]{3}{*}{ Samtals } & \multirow{3}{*}{\multicolumn{2}{|c|}{$\begin{array}{l}\text { Raðbreyta } \\
\text { á móti } \\
\text { raðbreytu }\end{array}$}} & Samhverft & ,435 & ,115 & 3,632 & ,000 \\
\hline & & & GSK svarbreyta & ,377 & ,095 & 3,632 & ,000 \\
\hline & & & $\begin{array}{l}\text { ánægja_umræddan } \\
\text { svarbreyta }\end{array}$ &, 516 & ,142 & 3,632 &, 000 \\
\hline
\end{tabular}

a. Not assuming the null hypothesis.

b. Using the asymptotic standard error assuming the null hypothesis.

Samhverfu fylgnistuðlarnir gefa allir sömu niðurstöðu og Sommer‘s d. P.e. að fylgni milli áncegju umredds og $G S K$ er marktæk fyrir heildarfjölda svara og sér í lagi fyrir fyrirtækja verkkaupa en ekki meðal einstaklings verkkaupa. Ef almennum reglum um kraft tengsla eru skoðuð ${ }^{109}$ er hægt að tala um að tengsl milli áncegju umredds og GSK séu miðlungs sterk fyrir fyrirtækja-verkkaupa og heildarfjölda ${ }^{110}$ svara. Fylgnin er sterkari ef tengdir aðilar eru sigtaðir frá.

\footnotetext{
${ }^{109}$ Sjá kafla um grunnathuganir á bls. 81

${ }^{110}$ Spearman fylgnistuðull er námundað úr 0,473 í 0,5
} 
Tafla 192 Samhverffylgnimaeligildi: fyrir_einst, ánægja_umræddan, GSK

\begin{tabular}{|c|c|c|c|c|c|c|}
\hline fyrir_einst & & & Gildi & fervik ${ }^{\mathrm{a}}$ & $\mathrm{T}^{\mathrm{b}}$ & Sig. \\
\hline \multirow[t]{4}{*}{ Fyrirtæki } & Raðbreyta & Kendall's tau-c & ,486 & ,171 & 2,849 &, 004 \\
\hline & $\begin{array}{l}\text { á móti } \\
\text { Raðbrevta }\end{array}$ & $\begin{array}{ll}\text { Gamma } & \begin{array}{l}\text { Núllta- } \\
\text { stigs }\end{array}\end{array}$ & 1,000 & 000 & 2,849 &, 004 \\
\hline & & Spearman fylgnistuðull & ,592 &, 120 & 3,527 & $.002^{\mathrm{c}}$ \\
\hline & $\mathrm{N}$ af gildun & tilfellum & 25 & & & \\
\hline \multirow[t]{4}{*}{ Einstaklingur } & Raðbreyta & Kendall's tau-c & 240 & , 142 & 1,682 & ,092 \\
\hline & $\begin{array}{l}\text { á móti } \\
\text { Raðbreyta }\end{array}$ & $\begin{array}{ll}\text { Gamma } & \begin{array}{l}\text { Núllta- } \\
\text { stigs }\end{array}\end{array}$ & ,707 & 259 & 1,682 & ,092 \\
\hline & & Spearman fylgnistuðull & ,316 & ,141 & 1,488 & $.152^{\mathrm{c}}$ \\
\hline & $\mathrm{N}$ af gildun & tilfellum & 22 & & & \\
\hline \multirow[t]{5}{*}{ Samtals } & Raðbreyta & Kendall's tau-c & ,467 & ,140 & 3,329 & ,001 \\
\hline & $\begin{array}{l}\text { á móti } \\
\text { Raðbreyta }\end{array}$ & $\begin{array}{ll}\text { Gamma } & \begin{array}{l}\text { Núllta- } \\
\text { stigs }\end{array}\end{array}$ & 623 &, 162 & 3,329 & 001 \\
\hline & & $\begin{array}{l}\text { Fyrsta } \\
\text { stigs } \\
\text { hlutfylgni }\end{array}$ & ,897 & & & \\
\hline & & Spearman fylgnistuðull & ,430 & , 126 & 3,192 & $.003^{\mathrm{c}}$ \\
\hline & $\mathrm{N}$ af gildun & tilfellum & 47 & & & \\
\hline \multicolumn{7}{|c|}{ Tengdir aðilar sigtaðir frá: } \\
\hline \multirow[t]{4}{*}{ Fyrirtæki } & Raðbreyta á & Kendall's tau-c & ,472 & , 188 & 2,518 & 012 \\
\hline & móti & Gamma Núllta-stigs & 1,000 & 000 & 2,518 & 012 \\
\hline & Raðbreyta & Spearman fylgnistuðull & 613 &, 129 & 3,636 & $.001^{\mathrm{c}}$ \\
\hline & $\mathrm{N}$ af gildum & ilfellum & 24 & & & \\
\hline \multirow[t]{4}{*}{ Einstaklingur } & Raðbreyta á & Kendall's tau-c & 272 & ,153 & 1,778 &, 075 \\
\hline & móti & Gamma Núllta-stigs &, 750 & 230 & 1,778 & 075 \\
\hline & Raðbreyta & Spearman fylgnistuðull & 350 & 143 & 1,631 & $.119^{\mathrm{c}}$ \\
\hline & $\mathrm{N}$ af gildum & ilfellum & 21 & & & \\
\hline \multirow[t]{5}{*}{ Samtals } & Raðbreyta á & Kendall's tau-c & ,516 & ,142 & 3,632 & 0 \\
\hline & móti & Gamma Núllta-stigs & 668 &, 155 & 3,632 & 0 \\
\hline & Raðbreyta & $\begin{array}{l}\text { Fyrsta-stigs } \\
\text { hlutfylgni }\end{array}$ & 907 & & & \\
\hline & & Spearman fylgnistuðull & ,473 & ,127 & 3,522 & $.001^{\mathrm{c}}$ \\
\hline & $\mathrm{N}$ af gildum & ilfellum & 45 & & & \\
\hline
\end{tabular}

a. Not assuming the null hypothesis.

b. Using the asymptotic standard error assuming the null hypothesis.

c. Based on normal approximation. 


\subsubsection{Fylgni: skrifleg_tíma * GSK}

Fylgni milli skrifleg_tíma (pess hvort var lögð fram skrifleg tímaácetlun) og GSK var skoðuð.

47 tilfelli flokkast undir gild tilfelli par sem ekki fleiri umrceddir verktakar tóku pátt í könnun fyrir verktaka.

Tafla 193 Yfirlit tilfella í greiningu milli skrifleg_tíma og GSK

\begin{tabular}{lccccccc}
\hline & \multicolumn{9}{c}{ Tilfelli } \\
\cline { 2 - 8 } & \multicolumn{3}{c}{ Gild } & \multicolumn{2}{c}{ Vantar } & \multicolumn{2}{c}{ Samtals } \\
\cline { 2 - 8 } & $\mathrm{N}$ & Hlutfall & $\mathrm{N}$ & $\mathrm{N}$ & Hlutfall & $\mathrm{N}$ \\
\hline skrifleg_tíma * GSK & 47 & $40.5 \%$ & 69 & $59.5 \%$ & 116 & $100.0 \%$ \\
\hline \hline
\end{tabular}

Tafla 194 Tengslatafla (tíðni): skrifleg_tíma * GSK

\begin{tabular}{llccc}
\hline \hline & & \multicolumn{2}{c}{ GSK } & \\
\cline { 3 - 4 } & & Nei eða ekki byggt á stöðlum & Já eða í innleiðingu & Samtals \\
\hline \multirow{2}{*}{ skrifleg_tíma } & Nei & 17 & 4 & 21 \\
& Já & 7 & 19 & 26 \\
Samtals & 24 & 23 & 47 \\
\hline \hline
\end{tabular}

Fylgni milli skrifleg_tima og GSK reyndist mjög marktæk bæði fyrir Sommers‘d og samhverfu fylgnimæligildin. Fylgnin flokkast til pess að vera sterk.

Tafla 195 Ósamhverf fylgnimæligildi: skrifleg_tíma, GSK

\begin{tabular}{|c|c|c|c|c|c|}
\hline & & Gildi & fervik $^{\mathrm{a}}$ & 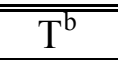 & Sig. \\
\hline \multirow{3}{*}{$\begin{array}{l}\text { Raðbreyta á Somers' d } \\
\text { móti } \\
\text { raðbreytu }\end{array}$} & Samhverft & 537 & , 122 & 4,383 &, 000 \\
\hline & $\begin{array}{l}\text { skrifleg_tíma } \\
\text { svarbreyta }\end{array}$ & ,534 & , 122 & 4,383 & ,000 \\
\hline & GSK svarbreyta &, 540 &, 122 & 4,383 &, 000 \\
\hline
\end{tabular}

a. Not assuming the null hypothesis.

b. Using the asymptotic standard error assuming the null hypothesis. 
Tafla 196 Samhverf fylgnimaligildi: skrifleg_tíma, GSK

\begin{tabular}{llcccc}
\hline \hline & & Gildi & fervik $^{\mathrm{a}}$ & $\mathrm{T}^{\mathrm{b}}$ & Sig. \\
\hline Raðbreyta á & Kendall's tau-c &, 534 &, 122 & 4,383 &, 000 \\
móti raðbreytu & Gamma &, 840 &, 104 & 4,383 &, 000 \\
& Spearman fylgnistuðull &, 537 &, 122 & 4,274 & $.000^{\mathrm{c}}$ \\
N af gildum tilfellum & 47 & & & \\
\hline \hline
\end{tabular}

a. Not assuming the null hypothesis.

b. Using the asymptotic standard error assuming the null hypothesis.

c. Based on normal approximation.

\subsubsection{Fylgni: tímaáæetlun * GSK}

Fylgni milli tímaácetlun (pess hvort verkið hjá umrceddum verktaka hafi farið fram úr tímaácetlun) og GSK var skoðuð.

47 tilfelli flokkast undir gild tilfelli par sem ekki fleiri umraeddir verktakar tóku pátt í könnun fyrir verktaka.

Tafla 197 Yfirlit tilfella í greiningu milli tímaácetlun og GSK

\begin{tabular}{lccccccc}
\hline \hline & \multicolumn{9}{c}{ Tilfelli } \\
\cline { 2 - 8 } & \multicolumn{3}{c}{ Gild } & \multicolumn{2}{c}{ Vantar } & \multicolumn{2}{c}{ Samtals } \\
\cline { 2 - 8 } & $\mathrm{N}$ & Hlutfall & $\mathrm{N}$ & $\mathrm{N}$ & Hlutfall & $\mathrm{N}$ \\
\hline tímaáætlun * GSK & 47 & $40.5 \%$ & 69 & $59.5 \%$ & 116 & $100.0 \%$ \\
\hline \hline
\end{tabular}

Tafla 198 Tengslatafla (tíðni): tímaácetlun * GSK

\begin{tabular}{llccc}
\hline \hline & & \multicolumn{2}{c}{ GSK } & \\
\cline { 3 - 4 } & & $\begin{array}{c}\text { Nei eða ekki byggt á } \\
\text { stöðlum }\end{array}$ & Já eða í innleiðingu & Samtals \\
\hline Tímaáætlun & Ekkert & 5 & 8 & 13 \\
& Lítið & 6 & 1 & 7 \\
& Nokkuð & 7 & 8 & 15 \\
& Mikið & 4 & 3 & 7 \\
& Mjög mikið & 2 & 3 & 5 \\
Samtals & 24 & 23 & 47 \\
\hline \hline
\end{tabular}

Fylgni milli tímaácetlun, GSK reyndist ekki marktæk hvort sem Somers‘d eða samhverfu fylgnimæligildin eru skoðuð. 
Tafla 199 Ósamhverf fylgnimæligildi: tímaáaetlun, GSK

\begin{tabular}{|c|c|c|c|c|c|}
\hline & & Gildi & fervik $^{\mathrm{a}}$ & $\mathrm{T}^{\mathrm{b}}$ & Sig. \\
\hline \multirow{3}{*}{$\begin{array}{l}\text { Raðbreyta á } \\
\text { móti } \\
\text { raðbreytu }\end{array}$} & Samhverft &, 009 &, 131 & ,066 & ,948 \\
\hline & $\begin{array}{l}\text { tímaáætlun } \\
\text { svarbreyta }\end{array}$ & ,011 & , 166 & ,066 & ,948 \\
\hline & GSK svarbreyta & ,007 & , 108 & ,066 & ,948 \\
\hline
\end{tabular}

a. Not assuming the null hypothesis.

b. Using the asymptotic standard error assuming the null hypothesis.

\section{Tafla 200 Samhverf fylgnimæligildi: tímaáaetlun, GSK}

\begin{tabular}{llcccc}
\hline \hline & Gildi & fervik $^{\mathrm{a}}$ & $\mathrm{T}^{\mathrm{b}}$ & Sig. \\
\hline Raðbreyta á & Kendall's tau-c &, 011 &, 166 &, 066 &, 948 \\
móti raðbreytu & Gamma &, 014 &, 212 &, 066 &, 948 \\
& Spearman fylgnistuðull &, 010 &, 148 &, 065 & $.948^{\mathrm{c}}$ \\
N af gildum tilfellum & 47 & & & \\
\hline \hline
\end{tabular}

a. Not assuming the null hypothesis.

b. Using the asymptotic standard error assuming the null hypothesis.

c. Based on normal approximation.

\subsubsection{Fylgni: skrifleg_greiðslu * GSK}

Fylgni milli skrifleg_greiðslu (pess hvort lögðvar fram skrifleg greiðsluácetlun) og GSK var skoðuð.

47 tilfelli flokkast undir gild tilfelli par sem ekki fleiri umrceddir verktakar tóku pátt í könnun fyrir verktaka.

Tafla 201 Yfirlit tilfella í greiningu milli skrifleg_tíma og GSK

\begin{tabular}{lccccccc}
\hline \hline & \multicolumn{7}{c}{ Tilfelli } \\
\cline { 2 - 7 } & \multicolumn{3}{c}{ Gild } & \multicolumn{2}{c}{ Vantar } & \multicolumn{2}{c}{ Samtals } \\
\cline { 2 - 7 } & $\mathrm{N}$ & Hlutfall & $\mathrm{N}$ & $\mathrm{N}$ & Hlutfall & $\mathrm{N}$ \\
\hline skrifleg_tíma * GSK & 47 & $40.5 \%$ & 69 & $59.5 \%$ & 116 & $100.0 \%$ \\
\hline \hline
\end{tabular}

Tafla 202 Tengslatafla (tïðni): skrifleg_greiðslu * GSK

\begin{tabular}{llccc}
\hline & & \multicolumn{2}{c}{ GSK } & \\
\cline { 3 - 5 } & & Nei eða ekki byggt á stöðlum & Já eða í innleiðingu & Samtals \\
\hline skrifleg_greiðslu & Nei & 16 & 6 & 22 \\
& Já & 8 & 17 & 25 \\
Samtals & 24 & 23 & 47 \\
\hline \hline
\end{tabular}

Fylgni milli skrifleg_greiðslu og GSK reyndist marktæk og sterk. 
Tafla 203 Ósamhverf fylgnimæligildi: skrifleg_greiðslu,GSK

\begin{tabular}{|c|c|c|c|c|c|}
\hline & & Gildi & fervik $^{\mathrm{a}}$ & 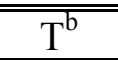 & Sig. \\
\hline \multirow{3}{*}{$\begin{array}{l}\text { Raðbreyta á Somers' d } \\
\text { móti } \\
\text { raðbreytu }\end{array}$} & Samhverft &, 407 &, 133 & 3,055 &, 002 \\
\hline & $\begin{array}{l}\text { skrifleg_greiðslu } \\
\text { svarbreyta }\end{array}$ & ,406 & , 133 & 3,055 &, 002 \\
\hline & GSK svarbreyta & 407 &, 133 & 3,055 &, 002 \\
\hline
\end{tabular}

a. Not assuming the null hypothesis.

b. Using the asymptotic standard error assuming the null hypothesis.

Tafla 204 Samhverf fylgnimaligildi: skrifleg_greiðslu,GSK

\begin{tabular}{llcccc}
\hline \hline & & Gildi & fervik $^{\mathrm{a}}$ & $\mathrm{T}^{\mathrm{b}}$ & Sig. \\
\hline Raðbreyta á & Kendall's tau-c &, 406 &, 133 & 3,055 &, 002 \\
móti raðbreytu & Gamma &, 700 &, 164 & 3,055 &, 002 \\
& Spearman fylgnistuðull &, 407 &, 133 & 2,985 & $.005^{\mathrm{c}}$ \\
N af gildum tilfellum & 47 & & & \\
\hline \hline
\end{tabular}

a. Not assuming the null hypothesis.

b. Using the asymptotic standard error assuming the null hypothesis.

c. Based on normal approximation.

\subsubsection{Fylgni: greiðsluáætlun * GSK}

Fylgni milli greiðsluácetlun (bess hvort verkið hjá umrceddum verktaka hafi farið fram úr greiðsluácetlun) og GSK var skoðuð. 47 tilfelli flokkast undir gild tilfelli par sem ekki fleiri umrceddir verktakar tóku pátt í könnun fyrir verktaka.

Tafla 205 Yfirlit tilfella í greiningu milli greiðsluácetlun og GSK

\begin{tabular}{lccccccc}
\hline \hline & \multicolumn{9}{c}{ Tilfelli } \\
\cline { 2 - 8 } & \multicolumn{3}{c}{ Gild } & \multicolumn{2}{c}{ Vantar } & \multicolumn{2}{c}{ Samtals } \\
\cline { 2 - 8 } & $\mathrm{N}$ & Hlutfall & $\mathrm{N}$ & $\mathrm{N}$ & Hlutfall & $\mathrm{N}$ \\
\hline greiðsluáætlun * GSK & 47 & $40.5 \%$ & 69 & $59.5 \%$ & 116 & $100.0 \%$ \\
\hline \hline
\end{tabular}

Tafla 206 Tengslatafla (tíðni): greiðsluácetlun * GSK

\begin{tabular}{llccc}
\hline \hline & & \multicolumn{2}{c}{ GSK } & \\
\cline { 3 - 4 } & & $\begin{array}{c}\text { Nei eða ekki } \\
\text { byggt á stöðlum }\end{array}$ & Já eða í innleiðingu & Samtals \\
\hline greiðsluáætlun & Ekkert & 4 & 6 & 10 \\
& Lítið & 6 & 6 & 12 \\
& Nokkuð & 11 & 5 & 16 \\
& Mikið & 1 & 4 & 5 \\
& Mjög mikið & 2 & 2 & 4 \\
Samtals & 24 & 23 & 47 \\
\hline \hline
\end{tabular}


Fylgni milli greiðsluácetlun, GSK reyndist ekki marktæk hvort sem Somers`d eða samhverfu fylgnimæligildin eru skoðuð.

Tafla 207 Ósamhverf fylgnimæligildi: greiðsluácetlun,GSK

\begin{tabular}{|c|c|c|c|c|c|}
\hline & & Gildi & fervik $^{\mathrm{a}}$ & $\mathrm{T}^{\mathrm{b}}$ & Sig. \\
\hline \multirow{3}{*}{$\begin{array}{l}\text { Raðbreyta á Somers' d } \\
\text { móti } \\
\text { raðbreytu }\end{array}$} & Samhverft & ,036 &, 132 & ,273 & ,785 \\
\hline & svarbreyta & 045 & 166 & 273 & ,785 \\
\hline & GSK svarbreyta & 030 &, 110 & ,273 & ,785 \\
\hline
\end{tabular}

a. Not assuming the null hypothesis.

b. Using the asymptotic standard error assuming the null hypothesis.

\section{Tafla 208 Samhverf fylgnimaligildi: greiðsluácetlun,GSK}

\begin{tabular}{llcccc}
\hline \hline & & Gildi & fervik $^{\text {a }}$ & $\mathrm{T}^{\mathrm{b}}$ & Sig. \\
\hline Raðbreyta á & Kendall's tau-c &, 045 &, 166 &, 273 &, 785 \\
móti raðbreytu & Gamma &, 058 &, 214 &, 273 &, 785 \\
& $\begin{array}{l}\text { Spearman } \\
\text { fylgnistuðull }\end{array}$ &, 041 &, 149 &, 273 & $.786^{\mathrm{c}}$ \\
\begin{tabular}{l} 
N af gildum tilfellum \\
\hline \hline
\end{tabular} & 47 & & & \\
\hline
\end{tabular}

a. Not assuming the null hypothesis.

b. Using the asymptotic standard error assuming the null hypothesis.

c. Based on normal approximation.

\subsubsection{Fylgni: verkfundir * GSK}

Fylgni milli verkfundir (bess hvort haldnir hefðu verið verkfundir) og GSK var skoðuð. 47 tilfelli flokkast undir gild tilfelli par sem ekki fleiri umrceddir verktakar tóku pátt í könnun fyrir verktaka.

\section{Tafla 209 Yfirlit tilfella í greiningu milli verkfundir og GSK}

\begin{tabular}{lccccccc}
\hline \hline & \multicolumn{7}{c}{ Tilfelli } \\
\cline { 2 - 8 } & \multicolumn{2}{c}{ Gild } & \multicolumn{2}{c}{ Vantar } & \multicolumn{2}{c}{ Samtals } \\
\cline { 2 - 8 } & $\mathrm{N}$ & Hlutfall & $\mathrm{N}$ & $\mathrm{N}$ & Hlutfall & $\mathrm{N}$ \\
\hline verkfundir * GSK & 47 & $40.5 \%$ & 69 & $59.5 \%$ & 116 & $100.0 \%$ \\
\hline \hline
\end{tabular}




\begin{tabular}{llccc}
\hline \hline & & \multicolumn{2}{c}{ GSK } & \\
\cline { 3 - 4 } & & $\begin{array}{c}\text { Nei eða ekki } \\
\text { byggt á stöðlum }\end{array}$ & Já eða í innleiðingu & Samtals \\
\hline verkfundir & Nei & 5 & 1 & 6 \\
& Óformlegir & 13 & 4 & 17 \\
Samtals & Formlegir & 6 & 18 & 24 \\
\hline \hline
\end{tabular}

Fylgni milli verkfundir og GSK reyndist mjög marktæk hvort sem Sommers`d er skoðað eða samhverfu mælikvarðarnir. Fylgnin er frekar sterk.

Tafla 211 Ósamhverf fylgnimæligildi: verkfundir, GSK

\begin{tabular}{|c|c|c|c|c|c|}
\hline & & Gildi & fervik $^{a}$ & $\mathrm{~T}^{\mathrm{b}}$ & Sig. \\
\hline \multirow{3}{*}{$\begin{array}{l}\text { Raðbreyta á } \\
\text { móti } \\
\text { raðbreytu }\end{array}$} & Samhverft & ,499 &, 115 & 4,339 &, 000 \\
\hline & $\begin{array}{l}\text { verkfundir } \\
\text { svarbreyta }\end{array}$ &, 545 & , 126 & 4,339 & ,000 \\
\hline & GSK svarbreyta & ,460 & 107 & 4,339 &, 000 \\
\hline
\end{tabular}

a. Not assuming the null hypothesis.

b. Using the asymptotic standard error assuming the null hypothesis.

Tafla 212 Samhverf fylgnimæligildi: verkfundir, GSK

\begin{tabular}{llcccc}
\hline \hline & Gildi & fervik $^{\mathrm{a}}$ & $\mathrm{T}^{\mathrm{b}}$ & Sig. \\
\hline Raðbreyta á & Kendall's tau-c &, 545 &, 126 & 4,339 &, 000 \\
móti raðbreytu & Gamma &, 778 &, 128 & 4,339 &, 000 \\
& Spearman fylgnistuðull &, 522 &, 120 & 4,107 & $.000^{\mathrm{c}}$ \\
N af gildum tilfellum & 47 & & & \\
\hline \hline
\end{tabular}

a. Not assuming the null hypothesis.

b. Using the asymptotic standard error assuming the null hypothesis.

c. Based on normal approximation.

\subsubsection{Fylgni: umgengni $*$ GSK}

Fylgni milli umgengni (hvernig verkkaupa fannst umrceddur verktaki ganga um verkstað) og GSK var skoðuð. 47 tilfelli flokkast undir gild tilfelli par sem ekki fleiri umrceddir verktakar tóku pátt í könnun fyrir verktaka.

Tafla 213 Yfirlit tilfella í greiningu milli umgengni og GSK

\begin{tabular}{lccccccc}
\hline \hline & \multicolumn{9}{c}{ Tilfelli } \\
\cline { 2 - 8 } & \multicolumn{3}{c}{ Gild } & \multicolumn{2}{c}{ Vantar } & \multicolumn{2}{c}{ Samtals } \\
\cline { 2 - 8 } & $\mathrm{N}$ & Hlutfall & $\mathrm{N}$ & $\mathrm{N}$ & Hlutfall & $\mathrm{N}$ \\
\hline umgengi * GSK & 47 & $40.5 \%$ & 69 & $59.5 \%$ & 116 & $100.0 \%$ \\
\hline \hline
\end{tabular}




\section{GSK}

Nei eða ekki byggt á stöðlum Já eða í innleiðingu

\begin{tabular}{llccc}
\hline umgengni & Mjög slæm & 1 & 0 & 1 \\
& Frekar slæm & 2 & 0 & 2 \\
& Hvorki góð né slæm & 6 & 11 & 17 \\
& Frekar góð & 5 & 6 & 11 \\
& Mjög góð & 10 & 6 & 16 \\
Samtals & & 24 & 23 & 47 \\
\hline \hline
\end{tabular}

Fylgni milli umgengni og GSK reyndist ekki vera marktæk hvort heldur sem Sommers`d eða samhverfu fylgnimæligildin voru skoðuð.

\section{Tafla 215 Ósamhverffylgnimceligildi: umgengni, GSK}

\begin{tabular}{|c|c|c|c|c|c|}
\hline & & Gildi & fervik $^{\mathrm{a}}$ & $\mathrm{T}^{\mathrm{b}}$ & Sig. \\
\hline \multirow{3}{*}{$\begin{array}{ll}\text { Raðbreyta á } & \text { Somers' d } \\
\text { móti } & \\
\text { raðbreytu } & \end{array}$} & Samhverft &,- 082 &, 136 &,- 604 &, 546 \\
\hline & umgengni svarbreyta &,- 098 & , 162 &,- 604 &, 546 \\
\hline & GSK svarbreyta &,- 070 & 117 &,- 604 &, 546 \\
\hline
\end{tabular}

a. Not assuming the null hypothesis.

b. Using the asymptotic standard error assuming the null hypothesis.

\section{Tafla 216 Samhverf fylgnimaeligildi: umgengni, GSK}

\begin{tabular}{llcccc}
\hline \hline & Gildi & fervik $^{\mathrm{a}}$ & $\mathrm{T}^{\mathrm{b}}$ & Sig. \\
\hline Raðbreyta á & Kendall's tau-c &,- 098 &, 162 &,- 604 &, 546 \\
móti raðbreytu & Gamma &,- 136 &, 224 &,- 604 &, 546 \\
& Spearman fylgnistuðull &,- 089 &, 148 &,- 601 & $.551^{\mathrm{c}}$ \\
N af gildum tilfellum & 47 & & & \\
\hline \hline
\end{tabular}

a. Not assuming the null hypothesis.

b. Using the asymptotic standard error assuming the null hypothesis.

c. Based on normal approximation.

\subsubsection{Fylgni: öryggismál * GSK}

Fylgni milli öryggismál (hvort öryggismál hafi verið raedd áður en framkvoemdin hófst) og GSK var skoðuð. 47 tilfelli flokkast undir gild tilfelli par sem ekki fleiri umrceddir verktakar tóku pátt í könnun fyrir verktaka.

Tafla 217 Yfirlit tilfella í greiningu milli öryggismál og GSK

\begin{tabular}{lccccccc}
\hline \hline & \multicolumn{6}{c}{ Tilfelli } \\
\cline { 2 - 8 } & \multicolumn{2}{c}{ Gild } & \multicolumn{2}{c}{ Vantar } & \multicolumn{2}{c}{ Samtals } \\
\cline { 2 - 8 } & $\mathrm{N}$ & Hlutfall & $\mathrm{N}$ & $\mathrm{N}$ & Hlutfall & $\mathrm{N}$ \\
\hline öryggismál * GSK & 47 & $40.5 \%$ & 69 & $59.5 \%$ & 116 & $100.0 \%$ \\
\hline \hline
\end{tabular}




\begin{tabular}{llccc}
\hline \hline & & \multicolumn{2}{c}{ GSK } & \\
\cline { 3 - 4 } & & $\begin{array}{c}\text { Nei eða ekki byggt } \\
\text { á stöðlum }\end{array}$ & Já eða í innleiðingu & Samtals \\
\hline öryggismál & Nei & 20 & 6 & 26 \\
& Já & 4 & 17 & 21 \\
Samtals & 24 & 23 & 47 \\
\hline \hline
\end{tabular}

Fylgni milli öryggismál og GSK reyndist mjög marktæk og miðlungs sterk hvort sem notast var við Sommers'd eða samhverfu mæligildin.

Tafla 219 Ósamhverf fylgnimæligildi: öryggismál, GSK

\begin{tabular}{|c|c|c|c|c|c|}
\hline & & Gildi & fervik $^{a}$ & $\mathrm{~T}^{\mathrm{b}}$ & Sig. \\
\hline \multirow{3}{*}{$\begin{array}{l}\text { Raðbreyta á } \\
\text { móti } \\
\text { raðbreytu }\end{array}$} & Samhverft &, 576 &, 119 & 4,807 &, 000 \\
\hline & $\begin{array}{l}\text { öryggismál } \\
\text { svarbreyta }\end{array}$ & ,572 & , 119 & 4,807 &, 000 \\
\hline & GSK svarbreyta & ,579 & ,119 & 4,807 &, 000 \\
\hline
\end{tabular}

a. Not assuming the null hypothesis.

b. Using the asymptotic standard error assuming the null hypothesis.

Tafla 220 Samhverf fylgnimaligildi: öryggismál, GSK

\begin{tabular}{llcccc}
\hline \hline & Gildi & fervik $^{\mathrm{a}}$ & $\mathrm{T}^{\mathrm{b}}$ & Sig. \\
\hline Raðbreyta á & Kendall's tau-b &, 576 &, 119 & 4,807 &, 000 \\
móti raðbreytu & Gamma &, 868 &, 089 & 4,807 &, 000 \\
& Spearman fylgnistuðull &, 576 &, 119 & 4,722 & $.000^{\mathrm{c}}$ \\
N af gildum tilfellum & 47 & & & \\
\hline \hline
\end{tabular}

a. Not assuming the null hypothesis.

b. Using the asymptotic standard error assuming the null hypothesis.

c. Based on normal approximation.

\subsubsection{Fylgni: gæðatrygging * GSK}

Fylgni milli gœðatrygging (bess hvort verktaki hafi lagt fram gaðatryggingu i byrjun framkvœmda) og GSK var skoðuð. 47 tilfelli flokkast undir gild tilfelli par sem ekki fleiri umrceddir verktakar tóku pátt í könnun fyrir verktaka.

Tafla 221 Yfirlit tilfella í greiningu milli gaeðatrygging og GSK

\begin{tabular}{lccccccc}
\hline \hline & \multicolumn{9}{c}{ Tilfelli } \\
\cline { 2 - 8 } & \multicolumn{2}{c}{ Gild } & \multicolumn{2}{c}{ Vantar } & \multicolumn{2}{c}{ Samtals } \\
\cline { 2 - 8 } & $\mathrm{N}$ & Hlutfall & $\mathrm{N}$ & $\mathrm{N}$ & Hlutfall & $\mathrm{N}$ \\
\hline gæðatrygging * GSK & 47 & $40.5 \%$ & 69 & $59.5 \%$ & 116 & $100.0 \%$ \\
\hline \hline
\end{tabular}




\begin{tabular}{llccc}
\hline \hline & & \multicolumn{2}{c}{ GSK } & \\
\cline { 3 - 4 } & & $\begin{array}{c}\text { Nei eða ekki byggt } \\
\text { á stöðlum }\end{array}$ & Já eða í innleiðingu & Samtals \\
\hline gæðatrygging & Nei & 22 & 12 & 34 \\
& Já & 2 & 11 & 13 \\
Samtals & 24 & 23 & 47 \\
\hline \hline
\end{tabular}

Fylgni milli gæeðatrygging og GSK reyndist marktæk hvort sem Sommers`d er skoðað eða samhverfu mælikvarðarnir. Fylgnin er frekar sterk

Tafla 223 Ósamhverf fylgnimæligildi: gaðatrygging, GSK

\begin{tabular}{|c|c|c|c|c|c|}
\hline & & Gildi & fervik $^{\mathrm{a}}$ & $\mathrm{T}^{\mathrm{b}}$ & Sig. \\
\hline \multirow{3}{*}{$\begin{array}{l}\text { Raðbreyta á } \\
\text { móti } \\
\text { raðbreytu }\end{array}$} & Samhverft & ,439 &, 120 & 3,333 &, 001 \\
\hline & $\begin{array}{l}\text { gæðatrygging } \\
\text { svarbreyta }\end{array}$ & ,395 & ,118 & 3,333 &, 001 \\
\hline & GSK svarbreyta & ,493 & ,129 & 3,333 & ,001 \\
\hline
\end{tabular}

a. Not assuming the null hypothesis.

b. Using the asymptotic standard error assuming the null hypothesis.

Tafla 224 Samhverf fylgnimæligildi: gaðatrygging, GSK

\begin{tabular}{llcccc}
\hline \hline & Gildi & fervik $^{\mathrm{a}}$ & $\mathrm{T}^{\mathrm{b}}$ & Sig. \\
\hline Raðbreyta á & Kendall's tau-b &, 441 &, 120 & 3,333 &, 001 \\
móti raðbreytu & Gamma &, 820 &, 139 & 3,333 &, 001 \\
& Spearman fylgnistuðull &, 441 &, 120 & 3,299 & $.002^{\mathrm{c}}$ \\
N af gildum tilfellum & 47 & & & \\
\hline \hline
\end{tabular}

a. Not assuming the null hypothesis.

b. Using the asymptotic standard error assuming the null hypothesis.

c. Based on normal approximation.

\subsubsection{Tvífylgnifylki: GSK, ánægja_umræddan, gæðatrygging_verktaki, gæðatrygging_ósk, gæðatrygging_undirverktaki}

Fylgni milli annars vegar GSK, og hins vegar gæðatrygging_verktaki, gœðatrygging_ósk og gœðatrygging_undirverktaki reyndist mjög marktæk og frekar sterk í öllum tilfellum.

Fylgni milli annars vegar ánœegja_umrceddan og hins vegar gœððatrygging_verktaki og gœeðatrygging_ósk reyndist ekki marktæk en marktæk fylgni var á milli ánœegja_umrceddan og gaeðatrygging_undirverktaki. 
Tafla 225 Tvífylgnifylki: GSK, áncegja_umrceddan, gaððatrygging_verktaki, gaeðatrygging_ósk, gaeðatrygging_undirverktaki

\begin{tabular}{|c|c|c|c|c|c|c|c|}
\hline & & & GSK & $\begin{array}{l}\text { ánægja } \\
\text { umrædda }\end{array}$ & $\begin{array}{l}\text { gæðatryggin } \\
\text { g_verktaki }\end{array}$ & $\begin{array}{c}\text { gæðatrygging } \\
\text { ósk }\end{array}$ & $\begin{array}{r}\text { gæðatrygging } \\
\text { undirverkt }\end{array}$ \\
\hline \multirow{15}{*}{$\begin{array}{l}\text { Spear } \\
\text { man's } \\
\text { rho }\end{array}$} & \multirow[t]{3}{*}{ GSK } & Fylgnistuðull & 1,000 & $.430^{* *}$ & $.551^{* *}$ & $.526^{* *}$ & $.586^{* *}$ \\
\hline & & Sig. (2-tailed) & . &, 003 & ,000 &, 001 & 000 \\
\hline & & $\mathrm{N}$ & 47 & 47 & 44 & 36 & 44 \\
\hline & \multirow{3}{*}{$\begin{array}{l}\text { ánægja } \\
\text { umræddan }\end{array}$} & Fylgnistuðull & $.430^{* *}$ & 1,000 & 254 & 240 & $.504^{* *}$ \\
\hline & & Sig. (2-tailed) &, 003 & . & ,097 & , 159 &, 000 \\
\hline & & $\mathrm{N}$ & 47 & 116 & 44 & 36 & 44 \\
\hline & \multirow{3}{*}{$\begin{array}{l}\text { gæðatrygging } \\
\text { _verktaki }\end{array}$} & Fylgnistuðull & $.551^{* *}$ & ,254 & 1,000 & $.884^{* *}$ & $.574^{* *}$ \\
\hline & & Sig. (2-tailed) &, 000 & ,097 & . &, 000 &, 000 \\
\hline & & $\mathrm{N}$ & 44 & 44 & 44 & 36 & 44 \\
\hline & \multirow{3}{*}{$\begin{array}{l}\text { gæðatrygging } \\
\text { _ósk }\end{array}$} & Fylgnistuðull & $.526^{* *}$ & 240 & $.884^{* *}$ & 1,000 & $.579^{* *}$ \\
\hline & & Sig. (2-tailed) &, 001 & , 159 &, 000 & . &, 000 \\
\hline & & $\mathrm{N}$ & 36 & 36 & 36 & 36 & 36 \\
\hline & \multirow{3}{*}{$\begin{array}{l}\text { gæðatrygging } \\
\text { _undirverkt }\end{array}$} & Fylgnistuðull & $.586^{* *}$ & $.504^{* *}$ & $.574^{* *}$ & $.579^{* *}$ & 1,000 \\
\hline & & Sig. (2-tailed) &, 000 &, 000 &, 000 &, 000 & . \\
\hline & & $\mathrm{N}$ & 44 & 44 & 44 & 36 & 44 \\
\hline
\end{tabular}

***. Correlation is significant at the 0.01 level (2-tailed).

\subsubsection{Fylgni: ánægja_gæði * GSK}

Fylgni milli ánœegja gøði (hversu ánœegður verkkaupi var með gœði verksins) og GSK var skoðuð. 47 tilfelli flokkast undir gild tilfelli par sem ekki fleiri umrceddir verktakar tóku pátt í könnun fyrir verktaka.

Tafla 226 Yfirlit tilfella í greiningu milli ánaegja_gaedi og GSK

\begin{tabular}{lcccccc}
\hline \hline & \multicolumn{6}{c}{ Tilfelli } \\
\cline { 2 - 7 } & \multicolumn{2}{c}{ Gild } & \multicolumn{2}{c}{ Vantar } & \multicolumn{2}{c}{ Samtals } \\
\cline { 2 - 8 } & $\mathrm{N}$ & Hlutfall & $\mathrm{N}$ & $\mathrm{N}$ & Hlutfall & $\mathrm{N}$ \\
\hline ánægja_gæði * GSK & 47 & $40.5 \%$ & 69 & $59.5 \%$ & 116 & $100.0 \%$ \\
\hline \hline
\end{tabular}

Tafla 227 Tengslatafla (tíðni): ánaegja_gaeði * GSK

\begin{tabular}{llccc}
\hline \hline & & \multicolumn{2}{c}{ GSK } & \\
\cline { 3 - 4 } & & $\begin{array}{c}\text { Nei eða ekki } \\
\text { byggt á stöðlum }\end{array}$ & Já eða í innleiðingu & Samtals \\
\hline ánægja_gæði & Frekar óánægð/ur & 1 & 0 & 1 \\
& Hvorki ánægð/ur né óánægð/ur & 6 & 0 & 6 \\
& Frekar ánægð/ur & 11 & 9 & 20 \\
& Mjög ánægð/ur & 6 & 14 & 20 \\
Samtals & & 24 & 23 & 47 \\
\hline \hline
\end{tabular}


Fylgni milli áncegja $a_{g œ ð i}$ og GSK reyndist mjög marktæk og rétt tæplega miðlungs sterk hvort sem notast var við Sommers'd eða samhverfu mæligildin.

Tafla 228 Ósamhverf fylgnimæligildi: ánagja_gaeði, GSK

\begin{tabular}{|c|c|c|c|c|c|}
\hline & & Gildi & fervik $^{\mathrm{a}}$ & $\mathrm{T}^{\mathrm{b}}$ & Sig. \\
\hline \multirow{3}{*}{$\begin{array}{l}\text { Raðbreyta á } \\
\text { móti } \\
\text { raðbreytu }\end{array}$} & Samhverft & ,422 &, 110 & 3,657 & , 000 \\
\hline & $\begin{array}{l}\text { ánægja_gæði } \\
\text { svarbreyta }\end{array}$ & ,473 & , 129 & 3,657 & , 000 \\
\hline & GSK svarbreyta &, 380 & ,096 & 3,657 &, 000 \\
\hline
\end{tabular}

a. Not assuming the null hypothesis.

b. Using the asymptotic standard error assuming the null hypothesis.

Tafla 229 Samhverf fylgnimæligildi: ánaegja_gaðdi, GSK

\begin{tabular}{llcccc}
\hline \hline & Gildi & fervik $^{\mathrm{a}}$ & $\mathrm{T}^{\mathrm{b}}$ & Sig. \\
\hline Raðbreyta á & Kendall's tau-c &, 473 &, 129 & 3,657 &, 000 \\
móti raðbreytu & Gamma &, 707 &, 146 & 3,657 &, 000 \\
& Spearman fylgnistuðull &, 446 &, 119 & 3,340 & $.002^{\mathrm{c}}$ \\
N af gildum tilfellum & 47 & & & \\
\hline \hline
\end{tabular}

a. Not assuming the null hypothesis.

b. Using the asymptotic standard error assuming the null hypothesis.

c. Based on normal approximation.

\subsubsection{Tvífylgnifylki: GSK, ávinningur, ávinningur/kostnaður, rekstrarafkoma, samkeppnishæfi, frábrigði_gsk, mannafli, trú_gsk}

Fylgni milli GSK annars vegar og ávinningur, ávinningur/kostnaður, rekstrarafkoma, samkeppnishoefi, frábrigði_gsk, trú_gsk reyndist marktæk. Í öllum tilfellum nema fyrsta var fylgnin mjög marktæk og frekar eða mjög sterk.

Fylgni milli GSK og mannafli reyndist ekki marktæk. 
Tafla 230 Tvífylgnifylki: GSK, ávinningur, ávinningur/kostnaður, rekstrarafkoma, samkeppnishaefi, frábrigði_gsk, mannafli, trú_gsk

\begin{tabular}{|c|c|c|c|c|c|c|c|c|c|c|}
\hline & & & GSK & $\begin{array}{c}\text { ávinni } \\
\text { ngur }\end{array}$ & $\begin{array}{l}\text { ávinn/ } \\
\text { kostn }\end{array}$ & $\begin{array}{l}\text { rekstra } \\
\text { rafkom }\end{array}$ & $\begin{array}{l}\text { sam- } \\
\text { keppni }\end{array}$ & $\begin{array}{c}\text { frábrigði } \\
\text { gsk }\end{array}$ & $\begin{array}{c}\text { mann- } \\
\text { afli }\end{array}$ & trú_gs \\
\hline \multirow{24}{*}{$\begin{array}{l}\text { Spear } \\
\text { man's } \\
\text { rho }\end{array}$} & \multirow[t]{3}{*}{$\overline{G S K}$} & Fylgnistuðull & 1,000 & $.379^{*}$ & $.531^{* * *}$ & $.681^{* *}$ & $.854^{* *}$ & $.848^{* *}$ & ,204 & $.673^{* *}$ \\
\hline & & Sig. (2-tailed) & . & 011 & 000 &, 000 &, 000 &, 000 & ,206 &, 000 \\
\hline & & $\mathrm{N}$ & 47 & 44 & 44 & 43 & 42 & 39 & 40 & 44 \\
\hline & \multirow{3}{*}{$\begin{array}{l}\text { ávinning } \\
\text { ur }\end{array}$} & Fylgnistuðull & $.379^{*}$ & 1,000 & $.649^{* *}$ & $.657^{* *}$ & $.570^{* *}$ & $.459^{* *}$ & $.490^{* *}$ & $.472^{* *}$ \\
\hline & & Sig. (2-tailed) & ,011 & . &, 000 &, 000 &, 000 &, 003 &, 001 &, 001 \\
\hline & & $\mathrm{N}$ & 44 & 44 & 44 & 43 & 42 & 39 & 40 & 44 \\
\hline & \multirow{3}{*}{$\begin{array}{l}\text { ávinning } \\
\text { ur/kostna } \\
\text { our }\end{array}$} & Fylgnistuðull & $.531^{* *}$ & $.649^{* *}$ & 1,000 & $.738^{* *}$ & $.577^{* *}$ & $.580^{* *}$ & $.548^{* *}$ & $.669^{* *}$ \\
\hline & & Sig. (2-tailed) &, 000 &, 000 & . &, 000 &, 000 &, 000 &, 000 &, 000 \\
\hline & & $\mathrm{N}$ & 44 & 44 & 44 & 43 & 42 & 39 & 40 & 44 \\
\hline & \multirow{3}{*}{$\begin{array}{l}\text { rekstrara } \\
\text { fkoma }\end{array}$} & Fylgnistuðull & $.681^{* *}$ & $.657^{* *}$ & $.738^{* *}$ & 1,000 & $.739^{* *}$ & $.691^{* *}$ & $.492^{* *}$ & $.731^{* *}$ \\
\hline & & Sig. (2-tailed) &, 000 &, 000 &, 000 & . &, 000 &, 000 &, 001 &, 000 \\
\hline & & $\mathrm{N}$ & 43 & 43 & 43 & 43 & 41 & 38 & 39 & 43 \\
\hline & \multirow{3}{*}{$\begin{array}{l}\text { samkepp } \\
\text { nishæfi }\end{array}$} & Fylgnistuðull & $.854^{* *}$ & $.570^{* *}$ & $.577^{* *}$ & $.739^{* *}$ & 1,000 & $.828^{* *}$ & $.392^{*}$ & $.508^{* *}$ \\
\hline & & Sig. (2-tailed) &, 000 &, 000 &, 000 & ,000 & . & ,000 &, 015 & ,001 \\
\hline & & $\mathrm{N}$ & 42 & 42 & 42 & 41 & 42 & 37 & 38 & 42 \\
\hline & \multirow{3}{*}{$\begin{array}{l}\text { frábrigði } \\
\text { gsk }\end{array}$} & Fylgnistuðull & $.848^{* *}$ & $.459^{* *}$ & $.580^{* *}$ & $.691^{* *}$ & $.828^{* *}$ & 1,000 & , 171 & $.646^{* *}$ \\
\hline & & Sig. (2-tailed) &, 000 & ,003 & ,000 & ,000 & ,000 & . & ,325 &, 000 \\
\hline & & $\mathrm{N}$ & 39 & 39 & 39 & 38 & 37 & 39 & 35 & 39 \\
\hline & \multirow[t]{3}{*}{ mannafli } & Fylgnistuðull & 204 & $.490^{* *}$ & $.548^{* *}$ & $.492^{* *}$ & $.392^{*}$ &, 171 & 1,000 & ,305 \\
\hline & & Sig. (2-tailed) & 206 &, 001 &, 000 &, 001 & 015 &, 325 & . &, 055 \\
\hline & & $\mathrm{N}$ & 40 & 40 & 40 & 39 & 38 & 35 & 40 & 40 \\
\hline & \multirow[t]{3}{*}{ trú_gsk } & Fylgnistuðull & $.673^{* *}$ & $.472^{* *}$ & $.669^{* *}$ & $.731^{* * *}$ & $.508^{* *}$ & $.646^{* *}$ & ,305 & 1,000 \\
\hline & & Sig. (2-tailed) &, 000 &, 001 &, 000 &, 000 &, 001 &, 000 &, 055 & . \\
\hline & & $\mathrm{N}$ & 44 & 44 & 44 & 43 & 42 & 39 & 40 & 44 \\
\hline
\end{tabular}

*. Correlation is significant at the 0.05 level (2-tailed).

**. Correlation is significant at the 0.01 level (2-tailed).

\subsubsection{Tvífylgnifylki: GSK, ánægja_umræddan, almennt, ÍST30, ISO9001, útboðsgögn}

Fylgni milli GSK annars vegar og almennt, ÍST30, ISO9001 reyndist marktæk og mjög sterk.

Fylgni milli annars vegar áncegja_umrceddan og hins vegar almennt og ISO9001 reyndist marktæk og miðlungs sterk. 


\begin{tabular}{|c|c|c|c|c|c|c|c|c|}
\hline & & & GSK & $\begin{array}{l}\text { ánægja } \\
\text { umræda }\end{array}$ & almennt & ÍST30 & ISO9001 & útboðsgögn \\
\hline \multirow{18}{*}{$\begin{array}{l}\text { Spearman's } \\
\text { rho }\end{array}$} & \multirow[t]{3}{*}{ GSK } & Fylgnistuðull & 1,000 & $.430^{* *}$ & $.724^{* * 7}$ & $.716^{* *}$ & $.753^{* \pi}$ &,- 118 \\
\hline & & Sig. (2-tailed) & . &, 003 & ,000 & ,000 & ,000 & ,488 \\
\hline & & $\mathrm{N}$ & 47 & 47 & 44 & 44 & 44 & 37 \\
\hline & \multirow{3}{*}{$\begin{array}{l}\text { ánægja } \\
\text { umræd } \\
\text { n }\end{array}$} & Fylgnistuðull & $.430^{* *}$ & 1,000 & $.303^{*}$ & , 137 & $.320^{*}$ &,- 191 \\
\hline & & Sig. (2-tailed) &, 003 & . &, 045 & 374 &, 034 & ,258 \\
\hline & & $\mathrm{N}$ & 47 & 116 & 44 & 44 & 44 & 37 \\
\hline & \multirow[t]{3}{*}{ almennt } & Fylgnistuðull & $.724^{* *}$ & $.303^{*}$ & 1,000 & $.800^{* *}$ & $.911^{* *}$ &,- 103 \\
\hline & & Sig. (2-tailed) &, 000 &, 045 & . &, 000 &, 000 &, 545 \\
\hline & & $\mathrm{N}$ & 44 & 44 & 44 & 44 & 44 & 37 \\
\hline & \multirow[t]{3}{*}{ ÍST30 } & Fylgnistuðull & $.716^{* *}$ & , 137 & $.800^{* *}$ & 1,000 & $.840^{* *}$ &, 115 \\
\hline & & Sig. (2-tailed) &, 000 & ,374 &, 000 & . &, 000 & ,497 \\
\hline & & $\mathrm{N}$ & 44 & 44 & 44 & 44 & 44 & 37 \\
\hline & \multirow[t]{3}{*}{ ISO9001 } & Fylgnistuðull & $.753^{* *}$ & $.320^{*}$ & $.911^{* *}$ & $.840^{* *}$ & 1,000 &,- 045 \\
\hline & & Sig. (2-tailed) &, 000 &, 034 &, 000 & ,000 & . & ,790 \\
\hline & & $\mathrm{N}$ & 44 & 44 & 44 & 44 & 44 & 37 \\
\hline & \multirow{3}{*}{$\begin{array}{l}\text { útboðs- } \\
\text { gögn }\end{array}$} & Fylgnistuðull &,- 118 &,- 191 &,- 103 &, 115 &,- 045 & 1,000 \\
\hline & & Sig. (2-tailed) & ,488 & ,258 &, 545 & ,497 & ,790 & . \\
\hline & & $\mathrm{N}$ & 37 & 37 & 37 & 37 & 37 & 37 \\
\hline
\end{tabular}

**. Correlation is significant at the 0.01 level (2-tailed).

*. Correlation is significant at the 0.05 level (2-tailed).

\subsubsection{Tvífylgnifylki: GSK, ánægja_umræddan, merking, geymsla, varơveislutími, förgun}

Fylgni milli annars vegar GSK og hins vegar merking, geymsla og förgun reyndist marktæk og miðlungs sterk.

Fylgni milli áncegja_umraeddan og förgun reyndist marktæk og miðlungs sterk en marktæk fylgni greindist ekki milli áncegja_umraedd og merking, geymsla og varðveislutimi. 


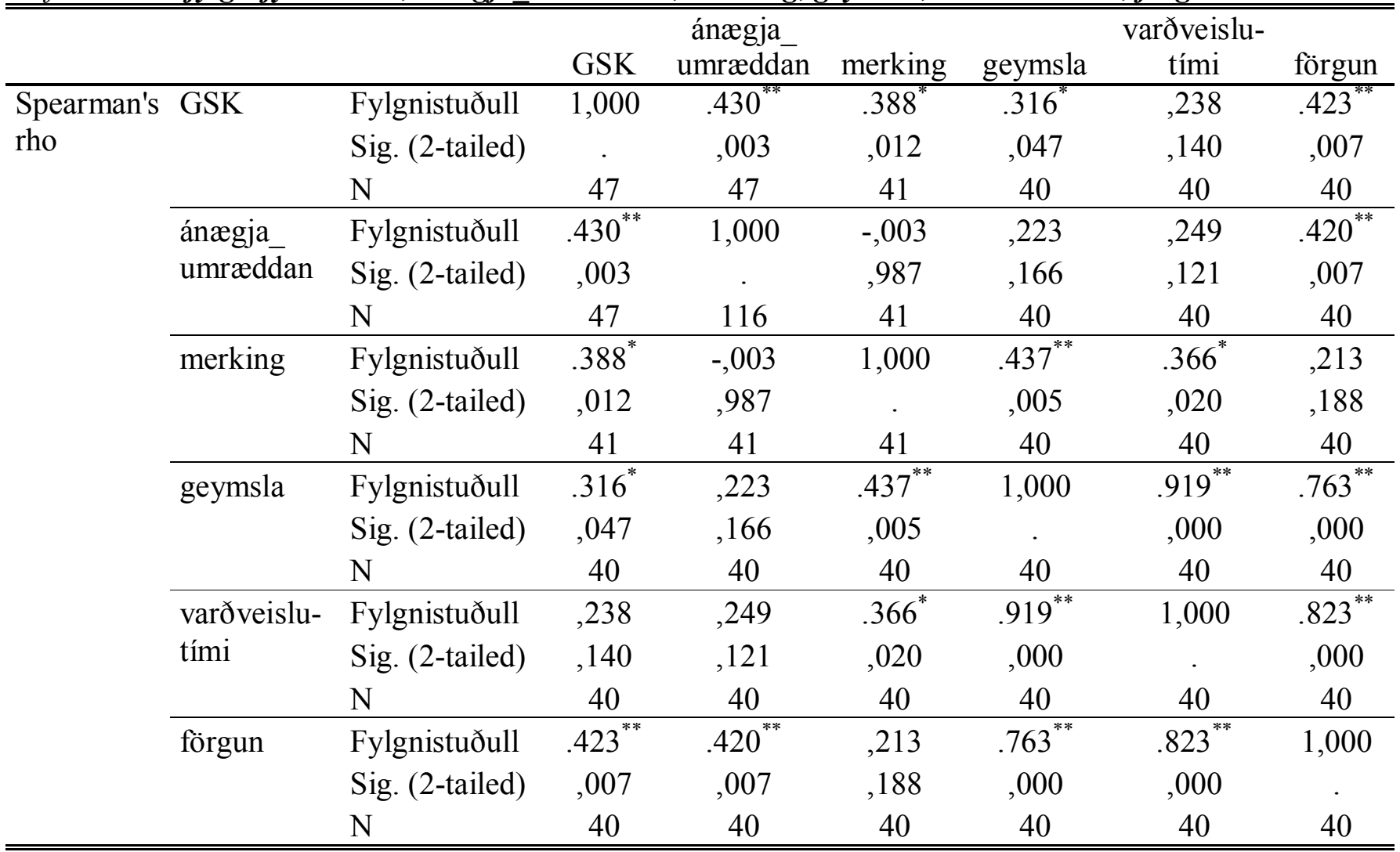

**. Correlation is significant at the 0.01 level (2-tailed)

*. Correlation is significant at the 0.05 level (2-tailed).

\subsubsection{Tvífylgnifylki: GSK, ánægja_umræddan, starfslýsingar_skriflegar, starfslýsingar_kynnt, verkáætlun_skrifleg, verktöf_skrifleg, greiðsluáætlun_skrifleg}

Fylgni milli annars vegar GSK og hins vegar starfslýsingar_skrifleg, verkácetlun_skrifleg, verktöf_skrifleg, greiðsluácetlun_skrifleg reyndist marktæk.

Fylgni milli áncegja_umrceddan og starfslýsingar_skrifleg reyndist marktæk og miðlungs sterk. 
Tafla 233 Tvífylgnifylki: GSK, ánaegja_umraeddan, starfslýsingar_skriflegar, starfslýsing_kynnt, verkácetlun_skrifleg, verktöf_skrifleg, greiðsluácetlun_skrifleg

\begin{tabular}{|c|c|c|c|c|c|c|c|c|c|}
\hline & & & GSK & $\begin{array}{l}\text { ánægja } \\
\text { umrædd }\end{array}$ & $\begin{array}{l}\text { starfslýsin } \\
\text { gar_skrif }\end{array}$ & $\begin{array}{c}\text { starfslýsing } \\
\text { ar_kynnt }\end{array}$ & $\begin{array}{l}\text { verkáætl } \\
\text { un_skrif }\end{array}$ & $\begin{array}{l}\text { verktöf_- } \\
\text { skrifleg }\end{array}$ & $\begin{array}{c}\begin{array}{c}\text { greiðslu } \\
\text { skrif }\end{array} \\
\end{array}$ \\
\hline \multirow{21}{*}{$\begin{array}{l}\text { Spear } \\
\text { man's } \\
\text { rho }\end{array}$} & \multirow[t]{3}{*}{ GSK } & Fylgnistuðull & 1,000 & $.430^{* *}$ & $.810^{* *}$ &,- 048 & $.557^{* *}$ & $.768^{* *}$ & $.391^{* *}$ \\
\hline & & Sig. (2-tailed) & & ,003 &, 000 & ,807 &, 000 &, 000 & ,010 \\
\hline & & $\mathrm{N}$ & 47 & 47 & 44 & 28 & 43 & 43 & 43 \\
\hline & \multirow{3}{*}{$\begin{array}{l}\text { ánægja } \\
\text { umræd } \\
\text { an }\end{array}$} & Fylgnistuðull & $.430^{* *}$ & 1,000 & $.349^{*}$ &,- 116 & ,028 & ,234 &, 032 \\
\hline & & Sig. (2-tailed) &, 003 & . &, 020 & ,557 & ,858 &, 130 &, 841 \\
\hline & & $\mathrm{N}$ & 47 & 116 & 44 & 28 & 43 & 43 & 43 \\
\hline & \multirow{3}{*}{$\begin{array}{l}\text { starfslýsi } \\
\text { ngar_skr } \\
\text { iflegar }\end{array}$} & Fylgnistuðull & $.810^{* *}$ & $.349^{*}$ & 1,000 & $.639^{* *}$ & $.502^{* *}$ & $.674^{* *}$ & $.488^{* *}$ \\
\hline & & Sig. (2-tailed) &, 000 &, 020 & . &, 000 &, 001 &, 000 &, 001 \\
\hline & & $\mathrm{N}$ & 44 & 44 & 44 & 28 & 43 & 43 & 43 \\
\hline & \multirow{3}{*}{$\begin{array}{l}\text { starfslýsi } \\
\text { ngar_ky } \\
\text { nnt }\end{array}$} & Fylgnistuðull &,- 048 &,- 116 & $.639^{* *}$ & 1,000 & ,231 & 148 & $.444^{*}$ \\
\hline & & Sig. (2-tailed) & ,807 &, 557 &, 000 & . & ,237 & ,453 &, 018 \\
\hline & & $\mathrm{N}$ & 28 & 28 & 28 & 28 & 28 & 28 & 28 \\
\hline & \multirow{3}{*}{$\begin{array}{l}\text { verkáætl } \\
\text { un_skrifl } \\
\text { eg }\end{array}$} & Fylgnistuðull & $.557^{* *}$ & ,028 & $.502^{* *}$ & ,231 & 1,000 & $.776^{* *}$ & $.645^{* *}$ \\
\hline & & Sig. (2-tailed) &, 000 & ,858 &, 001 & ,237 & . &, 000 &, 000 \\
\hline & & $\mathrm{N}$ & 43 & 43 & 43 & 28 & 43 & 43 & 43 \\
\hline & \multirow{3}{*}{$\begin{array}{l}\text { verktöf } \\
\text { skrifleg }\end{array}$} & Fylgnistuðull & $.768^{* *}$ & 234 & $.674^{* *}$ & , 148 & $.776^{* *}$ & 1,000 & $.605^{* *}$ \\
\hline & & Sig. (2-tailed) &, 000 & ,130 &, 000 & ,453 &, 000 & . &, 000 \\
\hline & & $\mathrm{N}$ & 43 & 43 & 43 & 28 & 43 & 43 & 43 \\
\hline & \multirow{3}{*}{$\begin{array}{l}\text { greyðslu } \\
\text { áætlun_s } \\
\text { krifleg }\end{array}$} & Fylgnistuðull & $.391^{* *}$ & ,032 & $.488^{* *}$ & $.444^{*}$ & $.645^{* *}$ & $.605^{* *}$ & 1,000 \\
\hline & & Sig. (2-tailed) & ,010 & 841 &, 001 & ,018 &, 000 &, 000 & \\
\hline & & $\mathrm{N}$ & 43 & 43 & 43 & 28 & 43 & 43 & 43 \\
\hline
\end{tabular}

**. Correlation is significant at the 0.01 level (2-tailed).

*. Correlation is significant at the 0.05 level (2-tailed).

\subsubsection{Tvífylgnifylki: GSK, ánægja_umræddan, verkfundir_reglubundnir, fundargerð, verkdagbók}

Fylgni milli annars vegar GSK og hins vegar verkfundir_reglubundnir, fundargerð, verkdagbók reyndist marktæk.

Fylgni milli annars vegar áncegja_umræeddan og hins vegar verkfundir_reglubundnir, fundargerð, verkdagbók reyndist ekki vera marktæk. 


\begin{tabular}{|c|c|c|c|c|c|c|c|}
\hline & & & GSK & $\begin{array}{l}\text { ánægja_- } \\
\text { umræddan }\end{array}$ & $\begin{array}{l}\text { verkfundir } \\
\text { reglubundnir }\end{array}$ & $\begin{array}{l}\text { fundar- } \\
\text { gerd }\end{array}$ & $\begin{array}{l}\text { verkdag- } \\
\text { bók }\end{array}$ \\
\hline \multirow{15}{*}{$\begin{array}{l}\text { Spearman's } \\
\text { rho }\end{array}$} & \multirow[t]{3}{*}{ GSK } & Fylgnistuðull & $\overline{1,000}$ & $.430^{* * \pi}$ & $.511^{* * 4}$ & $.372^{*}$ & $.627^{* *}$ \\
\hline & & Sig. (2-tailed) & . &, 003 &, 000 &, 014 &, 000 \\
\hline & & $\mathrm{N}$ & 47 & 47 & 43 & 43 & 43 \\
\hline & \multirow[t]{3}{*}{ ánægja_umræddan } & Fylgnistuðull & $.430^{* *}$ & 1,000 &,- 023 & ,072 & ,030 \\
\hline & & Sig. (2-tailed) &, 003 & . & ,883 & ,648 & ,849 \\
\hline & & $\mathrm{N}$ & 47 & 116 & 43 & 43 & 43 \\
\hline & \multirow{3}{*}{$\begin{array}{l}\text { verkfundir_reglub } \\
\text { undnir }\end{array}$} & Fylgnistuðull & $.511^{* *}$ &,- 023 & 1,000 & $.596^{* *}$ & $.707^{* *}$ \\
\hline & & Sig. (2-tailed) &, 000 & ,883 & . &, 000 &, 000 \\
\hline & & $\mathrm{N}$ & 43 & 43 & 43 & 43 & 43 \\
\hline & \multirow[t]{3}{*}{ fundargerð } & Fylgnistuðull & $.372^{*}$ & ,072 & $.596^{* *}$ & 1,000 & $.636^{* *}$ \\
\hline & & Sig. (2-tailed) &, 014 & ,648 &, 000 & . &, 000 \\
\hline & & $\mathrm{N}$ & 43 & 43 & 43 & 43 & 43 \\
\hline & \multirow[t]{3}{*}{ verkdagbók } & Fylgnistuðull & $.627^{* *}$ & 030 & $.707^{* *}$ & $.636^{* *}$ & 1,000 \\
\hline & & Sig. (2-tailed) &, 000 & 849 &, 000 &, 000 & . \\
\hline & & $\mathrm{N}$ & 43 & 43 & 43 & 43 & 43 \\
\hline
\end{tabular}

**. Correlation is significant at the 0.01 level (2-tailed).

* Correlation is significant at the 0.05 level (2-tailed).

\subsubsection{Tvívítt fylgnifylki: GSK, ánægja_umræddan, frábrigði_tilkynnt, aukaverk_skráð, hættumat, gæðaeftirlit_utanaðkomandi, gæðastýringaráætlun}

Fylgni milli annars vegar GSK og hins vegar frábrigði tilkynnt og hoettumat reyndist marktæk.

Fylgni milli annars vegar GSK og hins vegar gæeaeftirlit_utanaðkomandi og gæeðastýringarácetlun reyndist ekki marktæk. 
Tafla 235 Tvívítt fylgnifylki: GSK, ánaegja_umraeddan, frábrigði_tilkynnt, aukaverk_skrád haettumat, gaeðaeftirlit_utanaðkomandi, gaðastýringarácetlun

\begin{tabular}{|c|c|c|c|c|c|c|c|c|c|}
\hline & & & GSK & $\begin{array}{l}\text { ánægja } \\
\text { umrædd }\end{array}$ & $\begin{array}{c}\text { frábrigði } \\
\text { tilkynnt }\end{array}$ & $\begin{array}{l}\text { aukaver } \\
\text { k_skráð }\end{array}$ & $\begin{array}{c}\text { hættu- } \\
\text { mat }\end{array}$ & $\begin{array}{l}\text { gæðaeftirl } \\
\text { it_utanað }\end{array}$ & $\begin{array}{l}\text { gæðastýr } \\
\text { ingaráætl }\end{array}$ \\
\hline \multirow{21}{*}{$\begin{array}{l}\text { Spear } \\
\text { man's } \\
\text { rho }\end{array}$} & \multirow[t]{3}{*}{ GSK } & Fylgnistuðull & 1,000 & $.430^{* *}$ & $.518^{* *}$ &, 137 & $.496^{*}$ &,- 424 &, 361 \\
\hline & & Sig. (2-tailed) & . & ,003 &, 000 &, 577 &, 036 & ,063 &, 118 \\
\hline & & $\mathrm{N}$ & 47 & 47 & 43 & 19 & 18 & 20 & 20 \\
\hline & \multirow{3}{*}{$\begin{array}{l}\text { ánægja_u } \\
\text { mræddan }\end{array}$} & Fylgnistuðull & $.430^{* *}$ & 1,000 &,- 002 &,- 083 & 139 &,- 112 &, 026 \\
\hline & & Sig. (2-tailed) &, 003 & 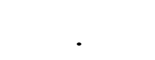 & ,992 & ,598 & ,385 & ,470 &, 870 \\
\hline & & $\mathrm{N}$ & 47 & 116 & 43 & 43 & 41 & 44 & 43 \\
\hline & \multirow{3}{*}{$\begin{array}{l}\text { frábrigði_ } \\
\text { tilkynnt }\end{array}$} & Fylgnistuðull & $.518^{* *}$ &,- 002 & 1,000 &,- 229 & ,024 & , 178 &,- 097 \\
\hline & & Sig. (2-tailed) &, 000 & ,992 & . & ,395 & ,934 & ,494 &, 710 \\
\hline & & $\mathrm{N}$ & 43 & 43 & 43 & 16 & 15 & 17 & 17 \\
\hline & \multirow{3}{*}{$\begin{array}{l}\text { aukaverk } \\
\text { _skrád }\end{array}$} & Fylgnistuðull & , 137 &,- 083 &,- 229 & 1,000 & $.533^{* *}$ & $-.327^{*}$ & $.614^{* *}$ \\
\hline & & Sig. (2-tailed) & ,577 & ,598 & ,395 & $\cdot$ &, 000 &, 033 &, 000 \\
\hline & & $\mathrm{N}$ & 19 & 43 & 16 & 43 & 41 & 43 & 42 \\
\hline & \multirow[t]{3}{*}{ hættumat } & Fylgnistuðull & $.496^{*}$ & , 139 & ,024 & $.533^{* *}$ & 1,000 & $-.420^{* *}$ & $.826^{* *}$ \\
\hline & & Sig. (2-tailed) &, 036 &, 385 & ,934 &, 000 & . & ,006 &, 000 \\
\hline & & $\mathrm{N}$ & 18 & 41 & 15 & 41 & 41 & 41 & 40 \\
\hline & \multirow{3}{*}{$\begin{array}{l}\text { gæðaeftirl } \\
\text { it_utanað } \\
\text { komandi }\end{array}$} & Fylgnistuðull &,- 424 &,- 112 & , 178 & $-.327^{*}$ & $-.420^{* *}$ & 1,000 &,- 272 \\
\hline & & Sig. (2-tailed) &, 063 & ,470 & ,494 &, 033 & ,006 & . &, 078 \\
\hline & & $\mathrm{N}$ & 20 & 44 & 17 & 43 & 41 & 44 & 43 \\
\hline & \multirow{3}{*}{$\begin{array}{l}\text { gæðastýri } \\
\text { ngaráætlu } \\
\text { n }\end{array}$} & Fylgnistuðull & ,361 & ,026 &,- 097 & $.614^{* *}$ & $.826^{* *}$ &,- 272 & 1,000 \\
\hline & & Sig. (2-tailed) & ,118 & ,870 &, 710 &, 000 &, 000 &, 078 & . \\
\hline & & $\mathrm{N}$ & 20 & 43 & 17 & 42 & 40 & 43 & 43 \\
\hline
\end{tabular}

\footnotetext{
**. Correlation is significant at the 0.01 level (2-tailed).
}

*. Correlation is significant at the 0.05 level (2-tailed). 


\section{Viðauki G - Athugasemdir um könnun fyrir verkkaupa}

- Hugsanlega hefði verið betra að einskorða rannsóknina bara við verkkaupa sem voru fyrirtæki, eða við verkkaupa sem voru einstaklingar. Kröfur milli pessa hópa eru mjög misjafnar samkvæmt niðurstöðum. Beitt var peirri aðferð að skilja pessa hópa í sundur að einhverju leyti við greiningu á niðurstöðum.

- Ekki var spurt sérstaklega um pað hvort náin tengsl væru milli verktaka og verkkaupa en slíkt var skráð ef verkkaupi minntist á að svo væri. Betra hefði verið að spyrja alla pátttakendur hvort peir væru sérstaklega tengdir umræddum verktaka og pá hvernig slíkum tengslum væri háttað.

- Spurningakannanir fyrir verkkaupa og verktaka gengu ekki undir eiginlega forprófun aðra en að sérfræðingar lásu pær yfir.

\subsubsection{Grunnupplýsingar}

- Gagnlegt hefði verið að spyrja um stærð verks og geta par með lagt betur mat á pað hversu stór verk purfi að vera til að verktakar beiti gæðastjórnun við framkvæmd verksins. Í 63\% tilfella voru framkvæmdirnar unnar sem fagverk ${ }^{111}$ sem gefur ákveðna hugmynd um pað að hátt hlutfall verka séu ekki mjög stórar framkvæmdir. Ekki var spurt sérstaklega um stærð eða umfang verksins en betra hefði verið að flokka verk niður eftir stærð og jafnvel raða í úrtak út frá stærð verka. Undirrituð var ekki með nægilega haldbær gögn til að ráðast út í slíka framkvæmd en hugsanlega væri hægt að búa pannig um málin ef rannsókn pessi væri endurtekin.

- Í nokkrum tilfellum par sem karl, sem einstaklingur, svaraði könnuninni var tekið fram að kona viðkomandi hafi séð um einhverja hlið framkvæmdarinnar. Í öllum tilfellum reyndist sú hlið tengjast utanumhaldi fjárhaghliðar.

- Færa má rök fyrir pví að nákvæmara hefoi verið að spyrja pátttakendur opinnar spurningar um aldur og skipta svo upp í flokka eftir á. Undirritaðri fannst slík nákvæmni á pessu stigi ekki vera nauðsynleg.

\subsubsection{Framkvæmd}

- Gagnlegt hefði verið að hafa spurning um pað hvort byggingastjórinn ${ }^{112}$ væri óháður verktaka, háður verktaka eða verkkaupinn sjálfur. Með nýjum mannvirkjalögum hefur verið gerð sú krafa að byggingastjóri geti ekki einnig gegnt starfi iðnmeistara og eða hönnuðar að sömu framkvæmd, pó að hægt sé að fá undanpágu frá pessu ákvæði við minni framkvæmdir. Undirrituð var vör við pað í

\footnotetext{
${ }^{111}$ Greining gagna um gerð verka er að finna á bls. 151

${ }^{112}$ Greining ganga um byggingastjóra er að finna á bls. 151 306
} 
pó nokkrum tilfellum að verkkaupi hafi verið óánægður með pað fyrirkomulag á framkvæmdinni að byggingastjórinn sem á að sjá um innra eftirlit eiganda, hafi einnig verið iðnmeistarinn. Með pví situr sami einstaklingur báðum megins við borðið.

\subsubsection{1 Áætlanir}

- Bátttakendur voru spurðir hvort framkvæmd væri farin fram úr tíma- og kostnaðaráætlunum og voru svarmöguleikarnir eftirfarandi; mjög mikið, mikið, nokkuð, lítið og ekkert. En par sem ekki var sérstaklega spurt hversu stór umrædd framkvæmd var, var ekki spurt nákvæmlega hversu mikið í tíma og peningum áætlanir væru farnar fram úr sér. Með pessu var svarendum gefin kostur á pví að leggja mat sitt á pað hversu mikið peir teldu að áætlanir væru komnar fram úr sér. Pessari aðferð var beitt í ljósi pess að gæði felast í ánægju viðskiptavinar og að mati rannsakenda gefur álit verkkaupa á pví hversu mikið honum pyki framkvæmdin vera komin fram úr áætlunum jafn skíra eða skírari mynd af stöðunni. Engu að síður er bent á að ef rannsóknin verður framkvæmd aftur er vert að skoða hvort betra væri að spyrja hversu mikið í tölum framkvæmdin væri farin fram í fjárhagsáætlun og hversu mikið í dögum/vikum/mánuðum framkvæmdin væri farin fram úr tímaáætlun og beita svo vegnu mati við greiningu (e. wight estimation) miðað við stærð framkvæmda. Pá byrfti auk pess að bæta við spurningu um pað hversu stór framkvæmdin hefði verið til að taka inn í vegna matið. Athyglisvert gæti verið að spyrja pátttakendur með báðum kvörðum.

\subsubsection{Verkfundir}

- Pátttakendur voru spurðir hvort haldnir hefðu verið verkfundir með umræddum verktaka og svarmöguleikarnir voru, „formlegir“, „óformlegir“ og „nei“. Hugsanlega hefði verið betra að skipta pessari spurningu upp í tvær spurningar par sem annars vegar hefði verið spurt hvort haldnir hefðu verið verkfundir með umræddum verktaka, með svarmöguleikunum ,já“ og ,nei“ og hins vegar par sem pátttakendur sem svöruðu ofangreindu með ,já“ væru spurðir hvort um „formlega“ eða „óformlega“ fundi væri að ræða. Par sem pátttakendur í pessari könnun svöruðu allir í gegnum símaviðtal var tekin sú ákvörðun að slá pessum spurningum saman í eina.

\subsubsection{Frábrigði}

- Auðveldara hefði verið að gera sér grein fyrir gerð frábrigða bæði fyrir pátttakendur og rannsakenda ef frábrigðum hefði verið skipt upp í flokka. Sem dæmi hefði mátt skipta frábrigðum upp í eftirfarandi 3 flokka, frábrigði sem tengjast gæðum, tíma og kostnaði. En auðvitað tengjast pessir flokkar allir og var pví farin sú leið að notast við skilgreininguna eins og hún er gefin upp á bls. 414

- Pátttakendur voru spurðir hvernig peim hafi verið tilkynnt um frábrigði ef pau á annað borð áttu sér stað á verktíma hjá umræddum verktaka. Svarmöguleikarnir voru „munnlega“, „skriflega“, „ekki tilkynnt“ og ,annað“. Ekki nema 4\% pátttakenda svöruðu „annað“ en peir pátttakendur sem völdu pann möguleika áttu kost á pví að skýra hvernig peim hafi verið tilkynnt um frábrigði með opinni spurningu. Hugsanlega hefði verið betra að skipta spurningunni í tvær spurningar. Spyrja fyrst: „,var pér tilkynnt um frábrigði“ og ef svo var spyrja pá opinnar spurningar „hvernig var pér tilkynnt um frábrigði“". 


\section{Viðauki H - Tíðnitöflur úr könnun verktaka}

Niðurstöður sem eru hér kynntar eru úr könnun fyrir verktaka sem tekin var í febrúar 2010. Pátttakendur svöruðu ýmist í gegnum internetið, á blaði eða í gegnum símaviðtal.

Hlutföllin skiptust pannig að rúmlega $28 \%$ pátttakenda tóku könnunina á sérstökum fundi og notuðust pá við blað og blýant, rúmlega $11 \%$ pátttakenda svöruðu könnuninni í gegnum símaviðtal og rúmlega $60 \%$ tóku hana í gegnum internetið.

Tafla 0.236 Hvernig var könnunin tekin?

\begin{tabular}{llcccc}
\hline \hline & & Tíðni & Hlutfall (\%) & Gilt hlutfall (\%) & Uppsafnað hlutfall (\%) \\
\hline Gilt & Viðtal & 11 & 11.5 & 11.5 & 11.5 \\
& Netið & 57 & 59.4 & 59.4 & 70.8 \\
& Fundur & 28 & 29.2 & 29.2 & 100.0 \\
& Samtals & 96 & 100.0 & 100.0 & \\
\hline \hline
\end{tabular}

Könnunin skiptist í eftirfarandi 8 flokka og verða niðurstöður kynntar úr hverjum flokki fyrir sig; grunnupplýsingar, gœðastjórnun, viðhorf við gœðastjórnun, gæðatrygging, pekking á gœеðastjórnun, verklag kröfur verkkaupa, annað.

\subsection{Grunnupplýsingar}

$60 \%$ svarenda voru byggingaverktakar en allar aðrar verktakagerðir ${ }^{13}$ voru undir $8 \%$. Tæplega $17 \%$ svarenda sögðu annað

Tafla 237 Hvers konar verktaki ert pú ?

\begin{tabular}{llcccc}
\hline \hline \multirow{6}{*}{ Gilt } & & Tíðni & Hlutfall (\%) & Gilt hlutfall (\%) & Uppsafnað hlutfall (\%) \\
& Byggingaverktaki & 57 & 59.4 & 60.0 & 60.0 \\
& Húshlutaframleiðandi & 3 & 3.1 & 3.2 & 63.2 \\
& Jarðvinnuverktaki & 6 & 6.3 & 6.3 & 69.5 \\
& Pípulagningaverktaki & 7 & 7.3 & 7.4 & 76.8 \\
& Rafverktaki & 6 & 6.3 & 6.3 & 83.2 \\
& Annað & 16 & 16.7 & 16.8 & 100.0 \\
& Samtals & 95 & 99.0 & 100.0 & \\
Vantar & & 1 & 1.0 & & \\
\hline \hline
\end{tabular}

Deir verktakar sem sögðu ,annað“ pegar spurt var um hvers konar verktaki viðkomandi væri, var eftirfarandi nefnt:

\footnotetext{
${ }^{113}$ Sjá nánar um spurningu í athugasemdakafla bls. 313 308
} 
Tafla 238 Hvers konar verktaki ert pú - Annad?

- Allt að ofan nema húsgagnafr.

- bygginga og jarðvinnu

- Byggingar og jarðvinnuverktaki

- Dúkari

- Framleiðsla malbiks og bikbindiefna auk útlagnar malbiks

- Framleiðandi

- Húshluta og almenn trésmíðapjón.
- Pjónustuaðili i Gluggaviðgerðum

- Múrverktaki

- Málun

- Málari

- Málaraverktaki

- Málaraverkt.

- Járnabindingar

$72 \%$ svarenda störfuðu hjá fyrirtækjum sem voru með minna en 10 starfsmenn ${ }^{114}$.

Tafla 0.239 Hvað starfa margir hjá fyrirtakinu sem pú ert starfsmaður hjá ?

\begin{tabular}{llcccc}
\hline \hline \multirow{2}{*}{ Gilt } & & Tíðni & Hlutfall (\%) & Gilt hlutfall (\%) & Uppsafnað hlutfall (\%) \\
& $<10$ & 67 & 69.8 & 72.0 & 72.0 \\
& $10-20$ & 10 & 10.4 & 10.8 & 82.8 \\
& $21-31$ & 6 & 6.3 & 6.5 & 89.2 \\
& $31-50$ & 3 & 3.1 & 3.2 & 92.5 \\
& $51<$ & 7 & 7.3 & 7.5 & 100.0 \\
& Samtals & 93 & 96.9 & 100.0 & \\
Vantar & & 3 & 3.1 & & \\
Samtals & & 96 & 100.0 & & \\
\hline \hline
\end{tabular}

Flestir pátttakendur störfuðu hjá fyrirtæki sem var á aldursbilinu ${ }^{115}$. 11-30 ára, eða tæplega 43\%.

${ }^{114}$ Sjá nánar um spurning í athugasemdakafla bls. 313

${ }^{115}$ Sjá nánar um spurning í athugasemdakafla bls. 313 


\begin{tabular}{llcccc}
\hline \hline \multirow{2}{*}{ Gilt } & Tíðni & Hlutfall (\%) & Gilt hlutfall (\%) & Uppsafnað hlutfall (\%) \\
& < 5 ára & 19 & 19.8 & 20.9 & 20.9 \\
& 5-10 ára & 16 & 16.7 & 17.6 & 38.5 \\
& $11-30$ ára & 39 & 40.6 & 42.9 & 81.3 \\
& $31-50$ ára & 8 & 8.3 & 8.8 & 90.1 \\
& 51 ára $<$ & 9 & 9.4 & 9.9 & 100.0 \\
& Samtals & 91 & 94.8 & 100.0 & \\
Vantar & 5 & 5.2 & & \\
Samtals & 96 & 100.0 & & \\
\hline \hline
\end{tabular}

Pátttakendur voru einnig spurðir í hvaða sveitarfélagi fyrirtækið starfi hjá ${ }^{116}$. Svör við peirri spurningu má sjá á bls. 442 .

Rúmlega 94\% pátttakenda voru karlmenn og flestir voru á aldursbilinu ${ }^{117} 46-55$ ára, eða tæplega 48\%.

Tafla 0.241 Hvert er kyn pitt?

\begin{tabular}{llcccc}
\hline \hline & & Tíoni & Hlutfall (\%) & Gilt hlutfall (\%) & Uppsafnað hlutfall (\%) \\
\hline Gilt & $\mathrm{kk}$ & 85 & 88.5 & 94.4 & 94.4 \\
& $\mathrm{kvk}$ & 5 & 5.2 & 5.6 & 100.0 \\
& Samtals & 90 & 93.8 & 100.0 & \\
Vantar & & 6 & 6.3 & & \\
Samtals & & 96 & 100.0 & & \\
\hline \hline
\end{tabular}

Tafla 0.242 Á hvaða aldri ert pú ?

\begin{tabular}{llcccc}
\hline \hline & Tíðni & Hlutfall (\%) & Gilt hlutfall (\%) & Uppsafnað hlutfall (\%) \\
\hline Gilt & $<20$ ára & 0 & 0.0 & 0.0 & 0.0 \\
& 21-35 ára & 7 & 7.3 & 8.0 & 8.0 \\
& 36-45 ára & 21 & 21.9 & 23.9 & 31.8 \\
& 46-55 ára & 42 & 43.8 & 47.7 & 79.5 \\
& 56-65 ára & 13 & 13.5 & 14.8 & 94.3 \\
& 66 ára $<$ & 5 & 5.2 & 5.7 & 100.0 \\
& Samtals & 88 & 91.7 & 100.0 & \\
Vantar & & 8 & 100.3 & & \\
Samtals & & 96 &
\end{tabular}

Pátttakendur voru spurðir um pað hvaða menntun peir hefðu, en mögulegt var að velja meira en einn valmöguleika. Ljóst er að ekki hafa allir hakað við öll menntunarstig sem peir höfou par sem að ekki nema

\footnotetext{
${ }^{116}$ Sjá nánar um spurning í athugasemdakafla bls. 313

${ }^{117}$ Sjá nánar um spurning í athugasemdakafla bls. 313 310
} 
$16 \%$ hökuðu við grunnskólapróf. En gera má ráð fyrir að allir pátttakendur hafi haft slíkt próf. En $4 \mathbf{4 2 \%}$ pátttakenda eru með meistarapróf og $\mathbf{1 9 \%}$ með verkmenntun í byggingaiðnaði, auk pess sem $\mathbf{1 0 \%}$ er með háskólapróf.

\section{Tafla 243 Hvaða menntun hefur pú?}

\begin{tabular}{lcc}
\hline \hline & Tíðni & Hlutfall (\%) \\
\hline Grunnskólapróf & 24 & $25.0 \%$ \\
Stúdentspróf & 12 & $12.5 \%$ \\
Háskólapróf & 20 & $20.8 \%$ \\
Verkmenntun í byggingaiðnaði & 30 & $31.3 \%$ \\
Meistaraskólapróf & 54 & $56.3 \%$ \\
Annað & 9 & $9.4 \%$ \\
\hline \hline
\end{tabular}

Peir pátttakendur sem svöruðu að peir hefðu aðra menntun en gefin var kostur á í svarmöguleikum, svöruðu eftirfarandi:

\section{Tafla 244 Hvaða menntun hefur pú - Annað?}

- „Byggingaiðnfræeðingur“

- ,Diploma i Goeðastjórnun. “

- „Húsgagnasmíði“

- „iðnnám“
- „Sérmenntun í stálgrindarhúsum“

- „Starfsnám viðurk. bókari“

- „Vélstjóra“

• „ýmis námskeið“

Pátttakendur voru spurðir hvaða stöðu ${ }^{118}$ peir gegndu innan fyrirtækisins og sýna niðurstöður að rúmlega $\mathbf{6 0 \%}$ gegndu stöðu framkvæmdastjóra.

Tafla 245 Hver er staða bín innan fyrirtakisins?

\begin{tabular}{lcc}
\hline \hline & Tíðni & Hlutfall (\%) \\
\hline Framkvæmdarstjóri & 68 & $70.8 \%$ \\
Verkefnastjóri & 12 & $12.5 \%$ \\
Gæðastjóri & 11 & $11.5 \%$ \\
Öryggisstjóri & 8 & $8.3 \%$ \\
Verkstjóri & 8 & $8.3 \%$ \\
Verkamaður & 5 & $5.2 \%$ \\
Annað & 10 & $10.4 \%$ \\
\hline \hline
\end{tabular}

\footnotetext{
${ }^{118}$ Sjá nánar um spurning í athugasemdakafla bls. $\underline{177}$
} 
Peir pátttakendur sem svöruðu að peir gegndu annarri stöðu en gefin var kostur á í svarmöguleikum, svöruðu eftirfarandi:

Tafla 246 Hver er staða bín innan fyrirtakisins - Annað ?

\begin{tabular}{|c|c|}
\hline $\begin{array}{l}\text { - bókari } \\
\text { - Bókari } \\
\text { - eigandi } \\
\text { - vélamadur }\end{array}$ & $\begin{array}{l}\text { - } \quad \text { Fjármál } \\
\text { - } \quad \text { smiður } \\
\text { - Smiður } \\
\text { - Stjórnarformaður }\end{array}$ \\
\hline
\end{tabular}

\subsection{Gæðastjórnun}

Rúmlega 30\% pátttakenda sögðust starfa eftir gæðastjórnunarkerfi ásamt rúmlega 6\% sem sögðust vera í innleiðingu, rúmlega 60\% sögðust ekki starfa eftir gæðastjórnunarkerfi og 3\% voru ekki vissir.

\section{Tafla 0.247 Starfar fyrirtcekið eftir gaððastjórnunarkerfi ?}

\begin{tabular}{llcccc}
\hline \hline & & Tíðni & Hlutfall (\%) & Gilt hlutfall (\%) & Uppsafnað hlutfall (\%) \\
\hline Gilt & Já & 29 & 30.2 & 30.2 & 30.2 \\
& Í innleiðingu & 6 & 6.3 & 6.3 & 36.5 \\
& Nei & 58 & 60.4 & 60.4 & 96.9 \\
& Veit ekki & 3 & 3.1 & 3.1 & 100.0 \\
& Samtals & 96 & 100.0 & 100.0 & \\
\hline \hline
\end{tabular}

Í ljósi pess hve fáir svarenda voru í innleiðingarferlinu verður peim sem skeytt saman við flokk peirra sem svöruðu játandi og peir sem ekki voru vissir er skeytt saman við hóp peirra sem svöruðu neitandi. En ef starfmaður veit ekki að fyrirtækið starfar eftir gæðastjórnunarkerfi er kerfið varla virkt. Með pessari sameiningu fæst að tæplega 37\% starfa eftir gæðastjórnunarkerfi eða eru í innleiðingu og tæplega $65 \%$ starfa ekki eftir gæðastjórnunarkerfi eða vita ekki hvort svo sé.

Tafla 0.248 Starfar fyrirtakið eftir gaðastjórnunarkerfi ? - sameinaðir flokkar

\begin{tabular}{llcccc}
\hline \hline & Tíðni & Hlutfall (\%) & Gilt hlutfall (\%) & Uppsafnað hlutfall (\%) \\
\hline \multirow{2}{*}{ Gilt } & Já eða í innleiðingu & 35 & 36.5 & 36.5 & 36.5 \\
& Nei eða veit ekki & 61 & 63.5 & 63.5 & 100.0 \\
& Samtals & 96 & 100.0 & 100.0 & \\
\hline \hline
\end{tabular}

Í rúmlega 47\% tilfella var ekki fengin utanaðkomandi aðili við innleiðingu gæðastjórnunarkerfisins. 


\begin{tabular}{llcccc}
\hline \hline \multirow{2}{*}{ Gilt } & & Tíðni & Hlutfall (\%) & Gilt hlutfall (\%) & Uppsafnað hlutfall (\%) \\
& Já & 16 & 16.7 & 47.1 & 47.1 \\
& Nei & 18 & 18.8 & 52.9 & 100.0 \\
& Veit ekki & 0 & 0.0 & 0.0 & 100.0 \\
& Samtals & 34 & 35.4 & 100.0 & \\
Vantar & & 62 & 64.6 & & \\
Samtals & & 96 & 100.0 & & \\
\hline \hline
\end{tabular}

Í tæplega 24\% tilfella sem pátttakendur sögðust starfa eftir gæðastjórnunarkerfi svöruðu peir jafnframt að kerfið byggði ekki á viðurkenndum gæðastaðli.

Tafla 0.250 Byggir gaeðastjórnunarkerfið á viðurkenndum gaeðastaðli ?

\begin{tabular}{llcccc}
\hline \hline Gilt & & Tíðni & Hlutfall (\%) & Gilt hlutfall (\%) & Uppsafnað hlutfall (\%) \\
& Já & 26 & 27.1 & 76.5 & 76.5 \\
& Nei & 8 & 8.3 & 23.5 & 100.0 \\
& Samtals & 34 & 35.4 & 100.0 & \\
Vantar & & 62 & 64.6 & & \\
Samtals & & 100.0 & & \\
\hline \hline
\end{tabular}

Dregin er sú ályktun að peir pátttakendur sem sögðust starfa eftir gæðastjórnunarkerfi sem byggir ekki á viðurkenndum gæðastjórnunarstaðli starfi ekki eftir gæðastjórnunarkerfi að mati skýrsluhöfundar.

Tafla 0.251 Starfar fyrirtakið eftir gaððastjórnunarkerfi byggðи á viðurkenndum stöðlum? - sameinaðir flokkar

\begin{tabular}{llcccc}
\hline \hline & Tíðni & Hlutfall (\%) & Gilt hlutfall (\%) & Uppsafnað hlutfall (\%) \\
\hline Gilt & Já eða í innleiðingu & 26 & 27.1 & 27.1 & 27.1 \\
& Nei, veit ekki eða ekki & 70 & 72.9 & 72.9 & 100.0 \\
& $\begin{array}{l}\text { byggt á stöðlum } \\
\text { Samtals }\end{array}$ & 96 & 100.0 & 100.0 & \\
&
\end{tabular}

Peir pátttakendur sem sögðu fyrirtækið sitt starfa eftir gæðastjórnunarkerfi byggðu á viðurkenndum gæðastaðli sögðu í flestum tilfellum að kerfið byggði á ISO ${ }^{119}$ eða kerfi Samtaka Iðnaðarins en hlutfall ${ }^{120}$ svara var tæplega $15 \%$ og $14 \%$ hver um sig.

\footnotetext{
${ }^{119}$ Sjá nánar um spurning í athugasemdakafla bls. 311
} 


\begin{tabular}{lcc}
\hline \hline & Tíðni & Hlutfall (\%) \\
\hline ISO & 14 & $14.6 \%$ \\
SI (frá Samtökum Iðnaðarins) & 13 & $13.5 \%$ \\
ÍST 30 & 4 & $4.2 \%$ \\
Veit ekki & 0 & $0.0 \%$ \\
Annað & 0 & $0.0 \%$ \\
\hline \hline
\end{tabular}

Af peim fyrirtækjum sem sögðust starfa eftir gæðastjórnunarkerfi voru tæplega $31 \%$ sem hlotið hafa vottun, en af heildarfjölda pátttakenda er pað ekki nema rúmlega $8 \%$.

Tafla 252 Hefur fyrirtakið hlotið vottun fyrir gaeðastjórnunarkerfið?

\begin{tabular}{llcccc}
\hline \hline Gilt & & Tíðni & Hlutfall (\%) & Gilt hlutfall (\%) & Uppsafnað hlutfall (\%) \\
& Já & 8 & 8.3 & 30.8 & 30.8 \\
& Nei & 17 & 17.7 & 65.4 & 96.2 \\
& Veit ekki & 1 & 1.0 & 3.8 & 100.0 \\
& Samtals & 26 & 27.1 & 100.0 & \\
Vantar & & 70 & 72.9 & & \\
Samtals & & 96 & 100.0 & & \\
\hline \hline
\end{tabular}

Pau fyrirtæki sem hlotið höfðu vottun voru einnig spurð hvernig vottun ${ }^{121}$ pau hefou hlotið. Niðurstöður má sjá hér að neðan ${ }^{122}$.

\begin{tabular}{lcc}
\hline \hline & Tíðni & Hlutfall (\%) \\
\hline ISO & 4 & $4.2 \%$ \\
SI (frá Samtökum Iðnaðarins) & 4 & $4.2 \%$ \\
CE & 1 & $1.0 \%$ \\
Veit ekki & 0 & $0.0 \%$ \\
Annað & 0 & $0.0 \%$ \\
\hline \hline
\end{tabular}

Tæplega 62\% pátttakenda sem sögðust starfa eftir gæðastjórnunarkerfi svöruðu pví jafnframt að pað væri starfandi gæðastjóri innan fyrirtækisins.

\footnotetext{
${ }^{120}$ Athuga að við pessari spurningu mátti merkja við fleiri en einn valmöguleika og pví var bara gefið upp hlutfall svara miðað við heildarfjölda pátttakenda en ekki miðað við heildarfjölda svara sem fengust við pessari spurningu.

${ }^{121}$ Sjá nánar um spurning í athugasemdakafla bls. 311

${ }^{122}$ Athuga að við pessari spurningu var boðið upp á að merkja við meira en einn svarmöguleika og er pví einungis gefið upp hlutfall svara miðað við heildarfjölda pátttakenda en ekki miðað við heildarfjölda svara við spurningunni.
} 314 


\begin{tabular}{llcccc}
\hline \hline & & Tíoni & Hlutfall (\%) & Gilt hlutfall (\%) & Uppsafnað hlutfall (\%) \\
\hline Gilt & Já & 21 & 21.9 & 61.8 & 61.8 \\
& Nei & 13 & 13.5 & 38.2 & 100.0 \\
& Veit ekki & 0 & 0.0 & 0.0 & 100.0 \\
& Samtals & 34 & 35.4 & 100.0 & \\
Vantar & & 62 & 64.6 & & \\
Samtals & & 96 & 100.0 & & \\
\hline \hline
\end{tabular}

Í öllum peim tilfellum sem gæðastjóri var starfandi innan fyrirtækisins sinnta hann annarri stöðu líka.

\section{Tafla 254 Gegnir gaeðastjórinn annarri stöðu innan fyrirtckisins líka?}

\begin{tabular}{llcccc}
\hline \hline & & Tíðni & Hlutfall (\%) & Gilt hlutfall (\%) & Uppsafnað hlutfall (\%) \\
\hline Gilt & Já & 21 & 21.9 & 100.0 & 100.0 \\
& Nei & 0 & 0.0 & 0.0 & 100.0 \\
& Veit ekki & 0 & 0.0 & 0.0 & 100.0 \\
Vantar & & 78.1 & & \\
Samtals & 96 & 100.0 & & \\
\hline \hline
\end{tabular}

Af peim fyrirtækjum sem sögðust starfa eftir gæðastjórnunarkerfi ${ }^{123}$ voru tæplega $72 \%$ sem sögðu að ekki væri starfandi gæðaráð innan fyrirtækisins.

Tafla 255 Er starfandi gaeðarád hjá fyrirtakinu?

\begin{tabular}{llcccc}
\hline \hline & & Tíðni & Hlutfall (\%) & Gilt hlutfall (\%) & Uppsafnað hlutfall (\%) \\
\hline Gilt & Já & 9 & 9.4 & 28.1 & 28.1 \\
& Nei & 23 & 24.0 & 71.9 & 100.0 \\
& Samtals & 32 & 33.3 & 100.0 & \\
Vantar & & 64 & 66.7 & & \\
Samtals & & 96 & 100.0 & & \\
\hline \hline
\end{tabular}

Af peim fyrirtækjum sem sögðust starfa eftir gæðastjórnunarkerfi voru rúmlega 79\% sem sögðu að til væri gæðahandbók fyrirtækisins.

\footnotetext{
${ }^{123}$ Taka verður tillit til pess að margir pátttakendur starfa hjá fyrirtækjum með mjög fáa starfsmenn
} 


\begin{tabular}{llcccc}
\hline \hline & & Tíðni & Hlutfall (\%) & Gilt hlutfall (\%) & Uppsafnað hlutfall (\%) \\
\hline Gilt & Já & 27 & 28.1 & 79.4 & 79.4 \\
& Nei & 6 & 6.3 & 17.6 & 97.1 \\
& Veit ekki & 1 & 1.0 & 2.9 & 100.0 \\
& Samtals & 34 & 35.4 & 100.0 & \\
Vantar & & 62 & 64.6 & & \\
Samtals & & 96 & 100.0 & & \\
\hline \hline
\end{tabular}

Pátttakendur sem sögðu að til væri gæðahandbók fyrirtækisins svöruðu í rétt rúmlega 11\% tilfella að bókin væri ekki til á rafrænu formi. Athuga að tæplega $21 \%$ pátttakenda sem sögðu að gæðahandbók væri til svöruðu pví ekki hvort hún væri til á rafrænu formi eða ekki.

Tafla 257 Er gaðahandbókin til á rafraenu formi?

\begin{tabular}{llcccc}
\hline \hline Gilt & & Tíðni & Hlutfall (\%) & Gilt hlutfall (\%) & Uppsafnað hlutfall (\%) \\
& Já & 24 & 25.0 & 88.9 & 88.9 \\
& Nei & 3 & 3.1 & 11.1 & 100.0 \\
& Veit ekki & 0 & 0.0 & 0.0 & 100. \\
& Samtals & 27 & 28.1 & 100.0 & \\
Vantar & & 69 & 71.9 & & \\
Samtals & & 96 & 100.0 & & \\
\hline \hline
\end{tabular}

Af peim fyrirtækjum sem sögðust starfa eftir gæðastjórnunarkerfi voru tæplega $65 \%$ sem staðfestu að til væri skjalfest gæðastefna pó að ekki nema helmingur peirra ${ }^{124}$ teldu að gæðastefnan væri mjög eða frekar kunnug starfsmönnum fyrirtækisins.

Tafla 258 Hefur fyrirtcekið skjalfesta gaeðastefnu?

\begin{tabular}{llcccc}
\hline \hline & & Tíðni & Hlutfall (\%) & Gilt hlutfall (\%) & Uppsafnað hlutfall (\%) \\
\hline Gilt & Já & 22 & 22.9 & 64.7 & 64.7 \\
& Nei & 12 & 12.5 & 35.3 & 100.0 \\
& Samtals & 34 & 35.4 & 100.0 & \\
Vantar & & 62 & 64.6 & & \\
Samtals & & 100.0 & & \\
\hline \hline
\end{tabular}

${ }^{124} 65 \%$ peirra sem sögðu að til væri skjalfest gæðastefna svöruðu hversu kunnuga peir teldu gæðastefnuna vera fyrir starfsmönnum fyrirtækisins og er átt við helming pessa hóps 316 


\begin{tabular}{llcccc}
\hline \hline & & Tíðni & Hlutfall (\%) & Gilt hlutfall (\%) & Uppsafnað hlutfall (\%) \\
\hline Gilt & Mjög kunnug & 5 & 5.2 & 22.7 & 22.7 \\
& Frekar kunnug & 6 & 6.3 & 27.3 & 50.0 \\
& Nokkuð kunnug & 9 & 9.4 & 40.9 & 90.9 \\
& Lítið kunnug & 2 & 2.1 & 9.1 & 100.0 \\
& Ekki kunnug & 0 & 0.0 & 0.0 & 100.0 \\
& Samtals & 22 & 22.9 & 100.0 & \\
Vantar & 74 & 77.1 & & \\
Samtals & 96 & 100.0 & & \\
\hline \hline
\end{tabular}

Tæplega 24\% fyrirtækja sem sögðust starfa eftir gæðastjórnunarkerfi sögðust jafnfram alltaf veita verkkaupa upplýsingar um gæðastjórnunarkerfið í verkbyrjun.

Tafla 260 Veitið pið verkkaupa upplýsingar um gaðastjórnunarkerfið sem pið notið í verkbyrjun?

\begin{tabular}{llcccc}
\hline \hline \multirow{2}{*}{ Gilt } & & Tíðni & Hlutfall (\%) & Gilt hlutfall (\%) & Uppsafnað hlutfall (\%) \\
& Alltaf & 8 & 8.3 & 23.5 & 23.5 \\
& Oft & 13 & 13.5 & 38.2 & 61.8 \\
& Stundum & 10 & 10.4 & 29.4 & 91.2 \\
& Sjaldan & 2 & 2.1 & 5.9 & 97.1 \\
& Aldrei & 1 & 1.0 & 2.9 & 100.0 \\
& Samtals & 34 & 35.4 & 100.0 & \\
Vantar & & 62 & 64.6 & & \\
Samtals & & 96 & 100.0 & & \\
\hline \hline
\end{tabular}

Peir pátttakendur sem svöruðu að peir veittu verkkaupum, oft, stundum eða sjaldan upplýsingar um gæðastjórnunarkerfið í verkbyrjun voru einnig spurðir í hvaða tilfellum peir veittu verkkaupum slíkar upplýsingar. Svörin má sjá á bls. 445.

Allir pátttakendur voru spurðir hvort öryggisstjóri eða öryggistrúnaðarmaður væru starfandi innan fyrirtækisins, óháð pví hvort fyrirtæki störfuðu eftir gæðastjórnunarkerfi eða ekki. En ekki nema rúmlega $56 \%$ svöruðu hvort öryggisstjóri starfaði innan fyrirtækisins og rúmlega $53 \%$ svöruðu hvort öryggistrúnaðarmaður starfaði innan fyrirtækisins. Niðurstöður gefa að rúmlega $46 \%$ svarenda sögðu að öryggisstjóri væri starfandi og rúmlega 49\% sögðu að öryggistrúnaðarmaður væri starfandi. 


\begin{tabular}{llccc}
\hline \hline & & Tíoni & Hlutfall (\%) & Gilt hlutfall (\%) \\
\hline Öryggisstjóri & Já & 25 & $26.0 \%$ & $46.3 \%$ \\
& Nei & 27 & $28.1 \%$ & $50.0 \%$ \\
\multirow{3}{*}{ Öryggistrúnaðarmaður } & Veit ekki & 2 & $2.1 \%$ & $3.7 \%$ \\
& Já & 25 & $26.0 \%$ & $49.0 \%$ \\
& Nei & 25 & $26.0 \%$ & $49.0 \%$ \\
& Veit ekki & 1 & $1.0 \%$ & $2.0 \%$ \\
\hline \hline
\end{tabular}

Allir pátttakendur voru spurðir hvort peir viðhefðu sérstakar öryggisráðstafanir á verkstað og í tæplega $77 \%$ tilfella sögðust verktakar viðhafa öryggisráðstafanir oft eða alltaf ${ }^{125}$.

Tafla 262 Viðhafið pið sérstakar öryggisráðstafanir á verkstað?

\begin{tabular}{llcccc}
\hline \hline \multirow{6}{*}{ Gilt } & & Tíðni & Hlutfall (\%) & Gilt hlutfall (\%) & Uppsafnað hlutfall (\%) \\
& Alltaf & 32 & 33.3 & 39.0 & 39.0 \\
& Oft & 31 & 32.3 & 37.8 & 76.8 \\
& Stundum & 15 & 15.6 & 18.3 & 95.1 \\
& Sjaldan & 2 & 2.1 & 2.4 & 97.6 \\
& Aldrei & 1 & 1.0 & 1.2 & 100.0 \\
& Veit ekki & 1 & 1.0 & 1.2 & \\
& Samtals & 82 & 85.4 & 100.0 & \\
Vantar & & 14 & 14.6 & & \\
\hline \hline
\end{tabular}

Peir pátttakendur sem svöruðu að peir viðhefðu öryggisráðstafanir, alltaf, oft, stundum eða sjaldan voru einnig spurðir hvaða öryggisráðsstafanir peir viðhefðu. Svör við spurningunni má sjá á bls. 445.

Rúmlega 66\% svarenda sögðu að mögulegt væri fyrir starfsmenn að sækja sér endurmenntun á vinnutíma.

\footnotetext{
${ }^{125}$ Sjá kafla um athugasemdir bls. 313

318
} 
Tafla 263 Er mögulegt fyrir starfsmenn að sakja sér endurmenntun á vinnutíma ?

\begin{tabular}{llcccc}
\hline \hline \multirow{2}{*}{ Gilt } & & Tíðni & Hlutfall (\%) & Gilt hlutfall (\%) & Uppsafnað hlutfall (\%) \\
& Já & 57 & 59.4 & 66.3 & 66.3 \\
& Nei & 26 & 27.1 & 30.2 & 96.5 \\
& Veit ekki & 3 & 3.1 & 3.5 & 100.0 \\
& Samtals & 86 & 89.6 & 100.0 & \\
Vantar & & 10 & 10.4 & & \\
Samtals & & 96 & 100.0 & & \\
\hline \hline
\end{tabular}

\subsection{Viðhorf við gæðastjórnun}

Viðhorf verktaka til gæðastjórnunar var kannað sérstaklega. Niðurstöður gáfu til kynna að verktakar hafa almennt jákvætt viðhorf til gæðastjórnunar og telja að hún eigi við byggingaiðnaðinn.

Rúmlega 92\% svarenda töldu að mjög eða frekar mikill ávinningur næðist af gæðastjórnun í byggingaiðnaði.

Tafla 264 Telur pú að ávinningur náist með gaeðastjórnun í byggingaiðnaði?

\begin{tabular}{llcccc}
\hline \hline \multirow{6}{*}{ Gilt } & & Tíoni & Hlutfall (\%) & Gilt hlutfall (\%) & Uppsafnað hlutfall (\%) \\
& Mjög mikill & 41 & 42.7 & 47.1 & 47.1 \\
& Frekar mikill & 39 & 40.6 & 44.8 & 92.0 \\
& Hvorki mikill né lítill & 6 & 6.3 & 6.9 & 98.9 \\
& Frekar lítill & 1 & 1.0 & 1.1 & 100.0 \\
& Mjög lítill & 0 & 0.0 & 0.0 & 100.0 \\
& Samtals & 87 & 90.6 & 100.0 & \\
Vantar & & 9 & 9.4 & & \\
Samtals & & 96 & 100.0 & & \\
\hline \hline
\end{tabular}

Rúmlega 74\% svarenda töldu að ávinningur af innleiðingu gæðastjórnunarkerfis sé mun eða aðeins meiri en kostnaður. 


\begin{tabular}{llcccc}
\hline & & Tíðni & Hlutfall (\%) & Gilt hlutfall (\%) & Uppsafnað hlutfall (\%) \\
\hline Gilt & Mun meiri & 35 & 36.5 & 41.2 & 41.2 \\
& Aðeins meiri & 28 & 29.2 & 32.9 & 74.1 \\
& Hvorki meiri né minni & 19 & 19.8 & 22.4 & 96.5 \\
& Aðeins minni & 2 & 2.1 & 2.4 & 98.8 \\
& Mun minni & 1 & 1.0 & 1.2 & 100.0 \\
& Samtals & 85 & 88.5 & 100.0 & \\
Vantar & & 11 & 11.5 & & \\
Samtals & & 96 & 100.0 & & \\
\hline \hline
\end{tabular}

Tæplega 76\% svarenda töldu að með innleiðingu á gæðastjórnunarkerfi myndi rekstrarafkoma fyrirtækja batna, eða batni til muna.

Tafla 266 Telur pú að innleiðing gaððastjórnunarkerfis breyti rekstrarafkoma fyrirtaekja?

\begin{tabular}{llcccc}
\hline \hline \multirow{2}{*}{ Gilt } & Tíðni & Hlutfall (\%) & Gilt hlutfall (\%) & Uppsafnað hlutfall (\%) \\
& Batni til muna & 21 & 21.9 & 24.4 & 24.4 \\
& Batni & 44 & 45.8 & 51.2 & 75.6 \\
& Hvorki batni né versni & 21 & 21.9 & 24.4 & 100.0 \\
& Versni & 0 & 0.0 & 0.0 & 100.0 \\
& Versni til muna & 0 & 0.0 & 0.0 & 100.0 \\
& Samtals & 86 & 89.6 & 100.0 & \\
Vantar & & 10 & 10.4 & & \\
Samtals & & 100.0 & & \\
\hline \hline
\end{tabular}

Tæplega $85 \%$ svarenda telja að samkeppnishæfi fyrirtækja verði meiri eða mun meiri eftir innleiðingu gæðastjórnunarkerfis. 
?

\begin{tabular}{llcccc}
\hline \hline & & Tíðni & Hlutfall (\%) & Gilt hlutfall (\%) & Uppsafnað hlutfall (\%) \\
\hline Gilt & Mun meiri & 30 & 31.3 & 35.7 & 35.7 \\
& Aðeins meiri & 41 & 42.7 & 48.8 & 84.5 \\
& Hvorki meiri né minni & 13 & 13.5 & 15.5 & 100.0 \\
& Aðeins minni & 0 & 0.0 & 0.0 & 100.0 \\
& Mun minni & 0 & 0.0 & 0.0 & 100.0 \\
& Samtals & 84 & 87.5 & 100.0 & \\
Vantar & & 12 & 12.5 & & \\
Samtals & & 100.0 & & \\
\hline \hline
\end{tabular}

Tæplega $42 \%$ svarenda töldu að frábrigði á framkvæmdum yrðu aðeins eða mun færri með innleiðingu gæðastjórnunarkerfis. Rúmlega 14\% svarenda töldu að aðeins, eða mun fleiri frábrigði kæmu upp eftir innleiðingu gæðastjórnunarkerfis. Pess ber að geta að tæplega 20\% pátttakenda svöruðu ekki spurningunni en gefur pað vísbendingu um að margir hafi ekki haft skilning á pví, hvað var átt við með orðinu „frábrigði“126. Athyglisvert er einnig hversu margir töldu að frábrigðum myndi fjölga með innleiðingu gæðastjórnunarkerfis.

Tafla 268 Telur pú að með innleiðingu gaðastjórnunarkerfis fjölgi/fakki frábrigðum í framkvaemdum ?

\begin{tabular}{llcccc}
\hline \hline \multirow{2}{*}{ Gilt } & & Tíðni & Hlutfall (\%) & Gilt hlutfall (\%) & Uppsafnað hlutfall (\%) \\
& Mun færri & 32 & 33.3 & 41.6 & 41.6 \\
& Aðeins færri & 11 & 11.5 & 14.3 & 55.8 \\
& Hvorki fleiri né færri & 23 & 24.0 & 29.9 & 85.7 \\
& Aðeins fleiri & 9 & 9.4 & 11.7 & 97.4 \\
& Mun fleiri & 2 & 2.1 & 2.6 & 100.0 \\
& Samtals & 77 & 80.2 & 100.0 & \\
Vantar & & 19 & 19.8 & & \\
Samtals & & 96 & 100.0 & & \\
\hline \hline
\end{tabular}

Rúmlega 74\% svarenda taldi að með innleiðingu gæðastjórnunarkerfis myndi nýting mannafla verða mun eða aðeins betri.

\footnotetext{
${ }^{126}$ Athuga að skilgreining á frábrigði var gefin upp.
} 
Tafla 269 Telur pú að með innleiðingu gaðastjórnunarkerfis batni/versni nýting mannafla?

\begin{tabular}{llcccc}
\hline \hline \multirow{2}{*}{ Gilt } & & Tíðni & Hlutfall (\%) & Gilt hlutfall (\%) & Uppsafnað hlutfall (\%) \\
& Mun betri & 27 & 28.1 & 31.8 & 31.8 \\
& Aðeins betri & 36 & 37.5 & 42.4 & 74.1 \\
& Hvorki betri né verri & 19 & 19.8 & 22.4 & 96.5 \\
& Aðeins verri & 2 & 2.1 & 2.4 & 98.8 \\
& Mun verri & 1 & 1.0 & 1.2 & 100.0 \\
& Samtals & 85 & 88.5 & 100.0 & \\
Vantar & & 11 & 11.5 & & \\
Samtals & & 96 & 100.0 & & \\
\hline \hline
\end{tabular}

83\% pátttakenda sögðust hafa mikla eða frekar mikla trú á gæðastjórnun í byggingaiðnaði.

Tafla 270 Hefur pú mikla/litla trú á gaðastjórnun í byggingaiðnaði ?

\begin{tabular}{llcccc}
\hline \hline Gilt & & Tíðni & Hlutfall (\%) & Gilt hlutfall (\%) & Uppsafnað hlutfall (\%) \\
& Mikla & 35 & 36.5 & 39.8 & 39.8 \\
& Frekar mikla & 38 & 39.6 & 43.2 & 83.0 \\
& Hvorki mikla né litla & 12 & 12.5 & 13.6 & 96.6 \\
& Frekar litla & 3 & 3.1 & 3.4 & 100.0 \\
& Litla & 0 & 0.0 & 0.0 & 100.0 \\
& Samtals & 88 & 91.7 & 100.0 & \\
Vantar & & 8.3 & & \\
Samtals & & 96 & 100.0 & & \\
\hline \hline
\end{tabular}

Tæplega 71\% pátttakenda sögðu að peir upplifðu gæðastjórnunarkerfi sem eitthvað meira en bara skráningarkerfi, en rúmlega $29 \%$ sögðu að upplifun peirra af gæðastjórnunarkerfi væri einungis sem skráningarkerfi.

Tafla 271 Upplifir pú gaeðastjórnunarkerfi einungis sem skráningarkerfi ?

\begin{tabular}{llcccc}
\hline \hline Gilt & & Tíðni & Hlutfall (\%) & Gilt hlutfall (\%) & Uppsafnað hlutfall (\%) \\
& Já & 26 & 27.1 & 29.2 & 29.2 \\
& Nei & 63 & 65.6 & 70.8 & 100.0 \\
& Samtals & 89 & 92.7 & 100.0 & \\
Vantar & & 7 & 7.3 & & \\
Samtals & & 96 & 100.0 & & \\
\hline \hline
\end{tabular}


Pátttakendur voru spurðir hversu vel peim pætti eftirfarandi orð eiga við gæðastjórnun. Flestum fannst ávinningur og skipulag eiga mjög eða frekar vel við, en 58 og 59 svöruðu á pann veg. Flestum fannst svo óparfi eiga mjög eða frekar illa við, eða 42 en næst flestum fannst, gallar, óáncegja viðskiptavina og tímaeyðsla eiga mjög eða frekar illa við, eða 34.

\section{Tafla $272^{127}$ Hvernig finnst pér eftirfarandi orð eiga við gaððastjórnun ?}

\begin{tabular}{lccccc}
\hline \hline & & & Hvorki vel & & \\
& Mjög illa & Frekar illa & né illa & Frekar vel & Mjög vel \\
\hline Óparfi & 26 & 16 & 13 & 5 & 2 \\
Skipulag & 0 & 2 & 7 & 23 & 36 \\
Kostnaður & 2 & 14 & 23 & 20 & 5 \\
Sparnaður & 1 & 3 & 20 & 32 & 12 \\
Gallar & 15 & 19 & 15 & 8 & 4 \\
Gæði & 0 & 1 & 10 & 22 & 30 \\
Óánægja viðskiptavina & 12 & 22 & 20 & 3 & 3 \\
Ánægja viðskiptavina & 0 & 0 & 15 & 24 & 27 \\
Tímaeyðsla & 13 & 21 & 17 & 11 & 3 \\
Ávinningur & 0 & 2 & 9 & 30 & 28 \\
\hline \hline
\end{tabular}

Ef ofangreindar niðurstöður eru settar upp í köngulóarrit má virða pær myndrænt fyrir sér.

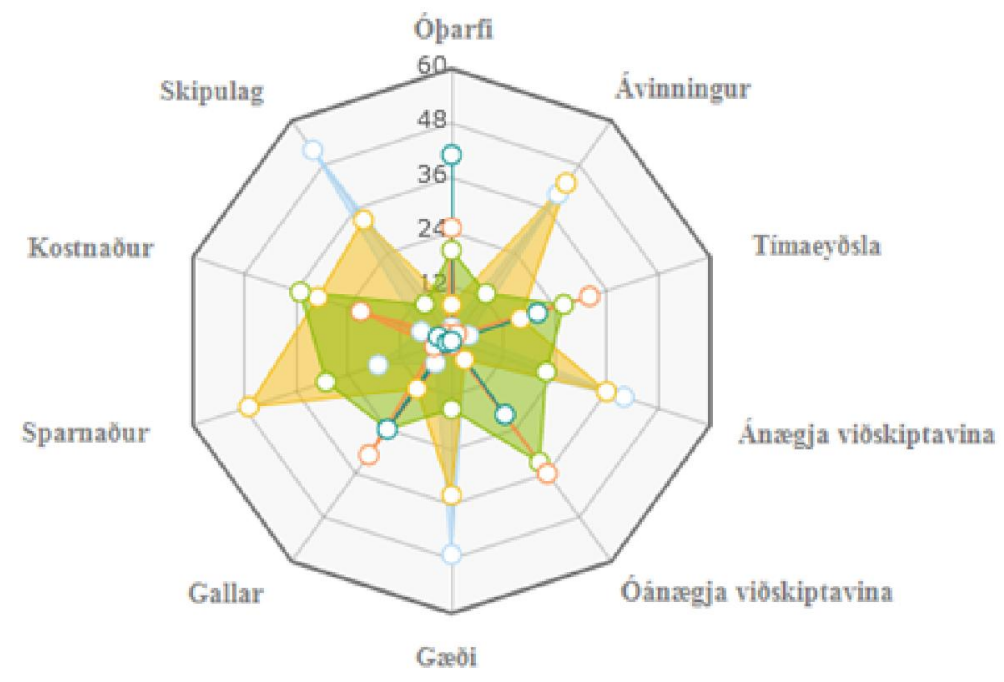

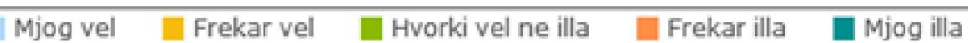

Mynd 65 Kóngulóarit um hversu vel pátttakendum fannst viðkomandi orð eiga við gaðastjórnun

${ }^{127}$ Taflan sýnir fjölda svara í hverjum flokk fyrir sig 


\subsection{Gæðatrygging}

Í tæplega 10\% tilfella sögðust pátttakendur alltaf sýna verkkaupa fram á gæðatryggingu ${ }^{128}$ í verkbyrjun og í tæplega $37 \%$ tilfella sögðust peir gera pað oft eða stundum. Rúmlega $46 \%$ sögðust einungis sýna verkkaupa fram á gæðatryggingu ef hann óskaði pess ${ }^{129}$ eða aldrei.

Tafla 273 Sýnið pið verkaupa fram á gaeðatryggingu í verkbyrjun?

\begin{tabular}{llcccc}
\hline \hline \multirow{2}{*}{ Gilt } & & Tíðni & Hlutfall (\%) & Gilt hlutfall (\%) & Uppsafnað hlutfall (\%) \\
& Alltaf & 8 & 8.3 & 9.8 & 9.8 \\
& Oft & 20 & 20.8 & 24.4 & 34.1 \\
& Stundum & 11 & 11.5 & 13.4 & 47.6 \\
& Sjaldan & 5 & 5.2 & 6.1 & 53.7 \\
& Einungis pegar um er beðið & 15 & 15.6 & 18.3 & 72.0 \\
& Aldrei & 23 & 24.0 & 28.0 & 100.0 \\
& Samtals & 82 & 85.4 & 100.0 & \\
Vantar & & 14 & 14.6 & & \\
Samtals & & 96 & 100.0 & & \\
\hline \hline
\end{tabular}

Í tæplega 38\% tilfella sögðu svarendur að verkkaupar færu aldrei fram á gæðatryggingu og í tæplega 33\% tilfella sögðu svarendur að verkkaupar færu mjög eða frekar sjaldan fram á slíkt. Í tæplega 14\% tilfella töldu svarendur að verkkaupar færu oft eða mjög oft fram á gæðatryggingu.

Tafla 274 Hversu oft óskar verkkaupi eftir gaeðatryggingu frá ykkur?

\begin{tabular}{llcccc}
\hline \hline \multirow{2}{*}{ Gilt } & & Tíoni & Hlutfall (\%) & Gilt hlutfall (\%) & Uppsafnað hlutfall (\%) \\
& Mjög oft & 2 & 2.1 & 2.7 & 2.7 \\
& Frekar oft & 8 & 8.3 & 10.8 & 13.5 \\
& Hvorki oft né sjaldan & 12 & 12.5 & 16.2 & 29.7 \\
& Frekar sjaldan & 9 & 9.4 & 12.2 & 41.9 \\
& Mjög sjaldan & 15 & 15.6 & 20.3 & 62.2 \\
& Aldrei & 28 & 29.2 & 37.8 & 100.0 \\
& Samtals & 74 & 77.1 & 100.0 & \\
Vantar & & 22 & 22.9 & & \\
Samtals & & 96 & 100.0 & & \\
\hline \hline
\end{tabular}

\footnotetext{
${ }^{128}$ Sjá skilgreiningu á gæðatryggingu á bls. 320

${ }^{129}$ Sjá athugasemdakafla bls. 316 
Pátttakendur voru spurðir hvort peir færu fram á gæðatryggingu frá undirverktökum og tæplega 49\% sögðust aldrei gera pað, 40\% sögðust gera pað stundum eða sjaldan og ekki nema tæplega 3\% gera pað alltaf.

Tafla 275 Farið pið fram á gaðatryggingu frá undirverktökum ?

\begin{tabular}{llcccc}
\hline \hline \multirow{2}{*}{ Gilt } & & Tíðni & Hlutfall (\%) & Gilt hlutfall (\%) & Uppsafnað hlutfall (\%) \\
& Alltaf & 2 & 2.1 & 2.5 & 2.5 \\
& Oft & 7 & 7.3 & 8.8 & 11.3 \\
& Stundum & 14 & 14.6 & 17.5 & 28.8 \\
& Sjaldan & 18 & 18.8 & 22.5 & 51.3 \\
& Aldrei & 39 & 40.6 & 48.8 & 100.0 \\
& Samtals & 80 & 83.3 & 100.0 & \\
Vantar & & 16 & 16.7 & & \\
Samtals & & 96 & 100.0 & & \\
\hline \hline
\end{tabular}

\subsection{Pekking á gæðastjórnun}

Pekking pátttakenda á gæðastjórnun var könnuð lítillega og gefa niðurstöður til kynna að um helmingur pátttakenda hafi eitthvað kynnt sér gæðastjórnun en meðal fyrirtækja sem starfa eftir gæðastjórnunarkerfi er hlutfallið hærra.

Pátttakendur voru spurðir hvort peir hefðu kynnt sér gæðastjórnun almennt og svöruðu tæplega 64\% að peir hefou kynnt sér gæðastjórnun mjög mikið, frekar mikið eða nokkuð en tæplega 37\% sögðust hafa kynnt sér hana frekar lítið, mjög lítið eða ekkert, en par af voru tæplega 13\% sem höfðu ekkert kynnt sér gæðastjórnun.

Tafla 276 Hefur pú kynnt pér gaeðastjórnun almennt?

\begin{tabular}{llcccc}
\hline \hline & Tíðni & Hlutfall (\%) & Gilt hlutfall (\%) & Uppsafnað hlutfall (\%) \\
\hline Gilt & Mjög mikið & 4 & 4.2 & 4.7 & 4.7 \\
& Frekar mikið & 14 & 14.6 & 16.5 & 21.2 \\
& Nokkuð & 36 & 37.5 & 42.4 & 63.5 \\
& Frekar lítið & 10 & 10.4 & 11.8 & 75.3 \\
& Mjög lítið & 10 & 10.4 & 11.8 & 87.1 \\
& Ekkert & 11 & 11.5 & 12.9 & 100.0 \\
& Samtals & 85 & 88.5 & 100.0 & \\
Vantar & & 11 & 11.5 & & \\
Samtals & & 100.0 & &
\end{tabular}


Einnig voru pátttakendur spurðir hvort peir hefðu kynnt sér samskiptastaðalinn IST 30, en tæplega $62 \%$ sögðust hafa kynnt sér staðalinn, mjög mikið, frekar mikið eða nokkuð en tæplega 16\% höfou ekkert kynnt sér staðalinn.

Tafla 277 Hefur pú kynnt pér innihald samskiptastaðalsins IST 30 ?

\begin{tabular}{llcccc}
\hline \hline \multirow{2}{*}{ Gilt } & Tíðni & Hlutfall (\%) & Gilt hlutfall (\%) & Uppsafnað hlutfall (\%) \\
& Mjög mikið & 8 & 8.3 & 9.5 & 9.5 \\
& Frekar mikið & 15 & 15.6 & 17.9 & 27.4 \\
& Nokkuð & 29 & 30.2 & 34.5 & 61.9 \\
& Frekar lítið & 10 & 10.4 & 11.9 & 73.8 \\
& Mjög lítið & 9 & 9.4 & 10.7 & 84.5 \\
& Ekkert & 13 & 13.5 & 15.5 & 100.0 \\
& Samtals & 84 & 87.5 & 100.0 & \\
Vantar & & 12 & 12.5 & & \\
\hline \hline
\end{tabular}

Færri sögðust hafa kynnt sér innihald gæðastjórnunarstaðalsins ISO 9001, en rúmlega 42\% svarenda sögðust hafa kynnt sér staðalinn mjög vel, frekar vel eða nokkuð og 20\% höfðu ekkert kynnt sér hann.

Tafla 278 Hefur pú kynnt pér innihald gaððastjórnunarstaðalsins ISO 9001 ?

\begin{tabular}{llcccc}
\hline \hline \multirow{2}{*}{ Gilt } & Tíðni & Hlutfall (\%) & Gilt hlutfall (\%) & Uppsafnað hlutfall (\%) \\
& Mjög mikið & 6 & 6.3 & 7.1 & 7.1 \\
& Frekar mikið & 9 & 9.4 & 10.6 & 17.6 \\
& Nokkuð & 21 & 21.9 & 24.7 & 42.4 \\
& Frekar lítið & 16 & 16.7 & 18.8 & 61.2 \\
& Mjög lítið & 16 & 16.7 & 18.8 & 80.0 \\
& Ekkert & 17 & 17.7 & 20.0 & 100.0 \\
& Samtals & 85 & 88.5 & 100.0 & \\
Vantar & & 11 & 11.5 & & \\
Samtals & 96 & 100.0 & & \\
\hline \hline
\end{tabular}

Spurt var hvort pátttakendum pætti vöntun á stöðluðum og samræmdum útboðsgögnum og svöruðu rúmlega $61 \%$ pví að peim pætti mjög eða frekar mikil vöntun á slíkum útboðsgögnum. 


\begin{tabular}{llcccc}
\hline \hline & & Tíðni & Hlutfall (\%) & Gilt hlutfall (\%) & Uppsafnað hlutfall (\%) \\
\hline Gilt & Mjög mikil & 19 & 19.8 & 22.4 & 22.4 \\
& Frekar mikil & 33 & 34.4 & 38.8 & 61.2 \\
& Hvorki mikil né lítil & 22 & 22.9 & 25.9 & 87.1 \\
& Frekar lítil & 7 & 7.3 & 8.2 & 95.3 \\
& Mjög lítil & 3 & 3.1 & 3.5 & 98.8 \\
& Engin & 1 & 1.0 & 1.2 & 100.0 \\
& Samtals & 85 & 88.5 & 100.0 & \\
Vantar & & 11 & 11.5 & & \\
Samtals & & 96 & 100.0 & & \\
\hline \hline
\end{tabular}

\subsection{Verklag}

Verklag verktaka var kannað og gáfu niðurstöður til kynna að margt megi bæta par varðandi skipulag og utanumhald.

Rúmlega 51\% svarenda sögðu að tilboð og samningar væru alltaf eða oft geymd í tölusettri röð til ákveðins tíma en $24 \%$ svöruðu að slíkt kæmi sjaldan eða aldrei til.

Tafla 280 Eru samningar og tilboð geymd í tölusettri röð til ákveðins tíma?

\begin{tabular}{llcccc}
\hline \hline \multirow{2}{*}{ Gilt } & & Tíðni & Hlutfall (\%) & Gilt hlutfall (\%) & Uppsafnað hlutfall (\%) \\
& Alltaf & 24 & 25.0 & 30.0 & 30.0 \\
& Oft & 17 & 17.7 & 21.3 & 51.3 \\
& Stundum & 12 & 12.5 & 15.0 & 66.3 \\
& Sjaldan & 12 & 12.5 & 15.0 & 81.3 \\
& Aldrei & 11 & 11.5 & 13.8 & 95.0 \\
& Veit ekki & 4 & 4.2 & 5.0 & 100.0 \\
& Samtals & 80 & 83.3 & 100.0 & \\
Vantar & & 16 & 16.7 & & \\
Samtals & & 96 & 100.0 & & \\
\hline \hline
\end{tabular}

Pátttakendur voru spurðir hvort farið hefði verið eftir ákveðnu kerfi fyrir merkingu, geymslu, varðveislutíma og förgun skjala. Af pessum fjórum páttum voru flestir með ákveðið kerfi fyrir geymslu skjala eða tæplega $49 \%$ pátttakenda ${ }^{130}$ en mjög svipað hlutfall var fyrir merkingu og varðveislutíma skjala, eða $46 \%$ og $45 \%$ en færri, eða rúmlega $29 \%$ voru með sérstakt kerfi fyrir förgun skjala.

${ }^{130}$ Athuga að hlutföllin sem nefnd eru hér að ofan eru miðuð við heildarfjölda pátttakenda en ekki heildarfjölda svara við spurningunni. 


\begin{tabular}{llcccc}
\hline \hline & & Vantar & Já & Nei & Veit ekki \\
\hline Merkingu skjala & Tíoni & 22 & 44 & 27 & 3 \\
& Hlutfall (\%) & $22.9 \%$ & $45.8 \%$ & $28.1 \%$ & $3.1 \%$ \\
Geymslu skjala & Tíoni & 23 & 47 & 24 & 2 \\
& Hlutfall (\%) & $24.0 \%$ & $49.0 \%$ & $25.0 \%$ & $2.1 \%$ \\
Varðveislutíma skjala & Tíðni & 23 & 43 & 28 & 2 \\
& Hlutfall (\%) & $24.0 \%$ & $44.8 \%$ & $29.2 \%$ & $2.1 \%$ \\
Förgun skjala & Tíoni & 24 & 28 & 40 & 4 \\
& Hlutfall (\%) & $25.0 \%$ & $29.2 \%$ & $41.7 \%$ & $4.2 \%$ \\
\hline \hline
\end{tabular}

Ef ofangreindar niðurstöður eru settar upp í köngulóarrit má virða pær myndrænt fyrir sér.

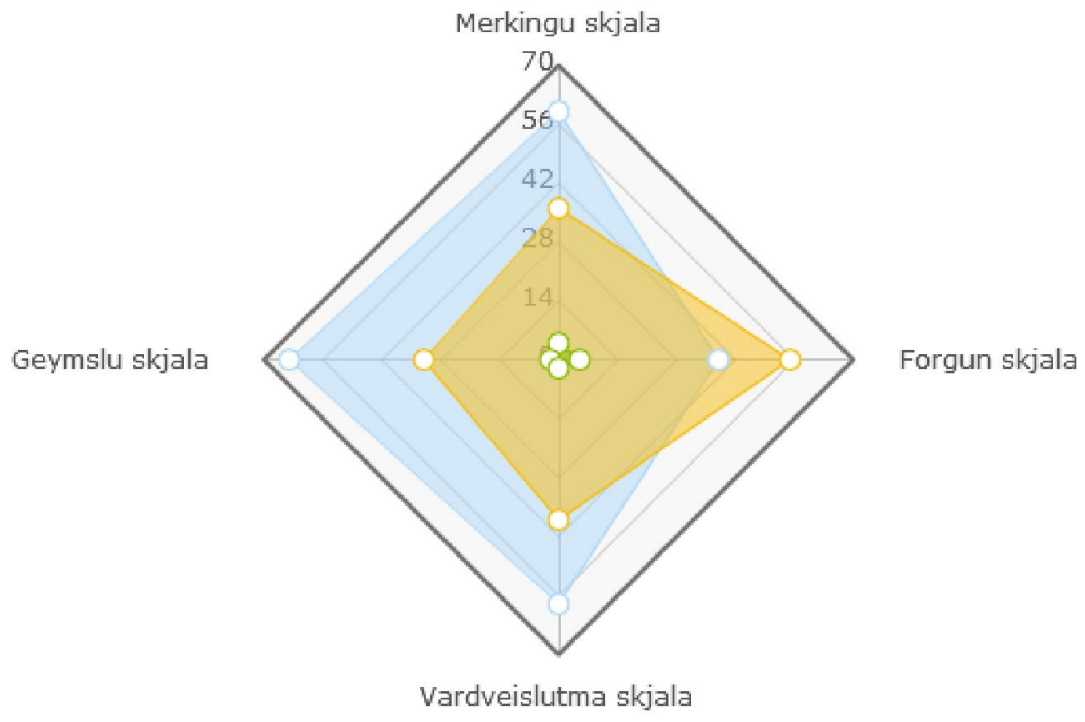

Mynd 66 Köngulóarit af svörum við spurningunni "er farið eftir ákveðnu kerfi fyrir eftirfarandi patti ?"

Pátttakendur voru spurðir hvort til væru starfslýsingar fyrir starfsmenn í fyrirtækinu og svöruðu 50\% að engar eða fáar starfslýsingar væru til en tæplega 19\% sögðu að til væru starfslýsingar fyrir alla starfsmenn. 


\begin{tabular}{llcccc}
\hline \hline & & Tíoni & Hlutfall (\%) & Gilt hlutfall (\%) & Uppsafnað hlutfall (\%) \\
\hline Gilt & Alla starfsmenn & 17 & 17.7 & 18.9 & 18.9 \\
& Flesta starfsmenn & 18 & 18.8 & 20.0 & 38.9 \\
& Fáa starfsmenn & 10 & 10.4 & 11.1 & 50.0 \\
& Enga starfsmenn & 35 & 36.5 & 38.9 & 88.9 \\
& Veit ekki & 10 & 10.4 & 11.1 & 100.0 \\
& Samtals & 90 & 93.8 & 100.0 & \\
Vantar & & 6 & 6.3 & & \\
Samtals & & 96 & 100.0 & & \\
\hline \hline
\end{tabular}

Peir starfsmenn sem svöruðu að til væru starfslýsingar fyrir starfsmenn voru jafnframt spurðir hvort innihald starfslýsinga væri kynnt fyrir starfsmönnum og voru rúmlega $62 \%$ starfsmanna sannfærðir um að innihald peirra væri kynnt mjög eða frekar vel fyrir starfsmönnum. Rúmlega 13\% töldu að innihald starfslýsinga væri ekkert eða frekar illa kynnt fyrir starfsmönnum.

Tafla 283 Er innihald viðkomandi starfslýsinga kynnt fyrir starfsmönnum?

\begin{tabular}{llcccc}
\hline \hline & & Tíðni & Hlutfall (\%) & Gilt hlutfall (\%) & Uppsafnað hlutfall (\%) \\
\hline Gilt & Mjög vel & 13 & 13.5 & 28.9 & 28.9 \\
& Frekar vel & 15 & 15.6 & 33.3 & 62.2 \\
& Hvorki vel né illa & 10 & 10.4 & 22.2 & 84.4 \\
& Frekar illa & 5 & 5.2 & 11.1 & 95.6 \\
& Ekkert & 1 & 1.0 & 2.2 & 97.8 \\
& Veit ekki & 1 & 1.0 & 2.2 & 100.0 \\
& Samtals & 45 & 46.9 & 100.0 & \\
Vantar & & 51 & 53.1 & & \\
Samtals & & 100.0 & & \\
\hline \hline
\end{tabular}

Tæplega 28\% svarenda sögðust aldrei eða sjaldan leggja fram skriflega verkáætlun. Flestir sögðust stundum leggja fram skriflega verkáætlun, eða $28 \%$ svarenda en rúmlega $46 \%$ sögðust alltaf eða oft leggja slíkt fram. 


\begin{tabular}{llcccc}
\hline \hline \multirow{2}{*}{ Gilt } & & Tíðni & Hlutfall (\%) & Gilt hlutfall (\%) & Uppsafnað hlutfall (\%) \\
& Alltaf & 16 & 16.7 & 19.5 & 19.5 \\
& Oft & 22 & 22.9 & 26.8 & 46.3 \\
& Stundum & 23 & 24.0 & 28.0 & 74.4 \\
& Sjaldan & 8 & 8.3 & 9.8 & 84.1 \\
& Aldrei & 13 & 13.5 & 15.9 & 100.0 \\
& Samtals & 82 & 85.4 & 100.0 & \\
Vantar & 14 & 14.6 & & \\
Samtals & 96 & 100.0 & & \\
\hline \hline
\end{tabular}

Peir pátttakendur sem svöruðu að peir leggðu, oft, stundum eða sjaldan fram verkáætlun voru spurðir í hvaða tilfellum peir gerðu pað. Svörin má sjá á bls. 446.

Rúmlega 19\% svarenda sögðust alltaf senda verkkaupa skriflega rökstudda tilkynningu um verktöf pegar svo bæri undir en tæplega 40\% svarenda sögðust sjaldan eða aldrei senda verkkaupa slíkt skjal.

Tafla 285 Sendið bið verkkaupa skriflega rökstudda tilkynningu um verktöf pegar svo ber undir ?

\begin{tabular}{llcccc}
\hline \hline \multirow{2}{*}{ Gilt } & & Tíðni & Hlutfall (\%) & Gilt hlutfall (\%) & Uppsafnað hlutfall (\%) \\
& Alltaf & 16 & 16.7 & 19.3 & 19.3 \\
& Oft & 16 & 16.7 & 19.3 & 38.6 \\
& Stundum & 18 & 18.8 & 21.7 & 60.2 \\
& Sjaldan & 13 & 13.5 & 15.7 & 75.9 \\
& Aldrei & 20 & 20.8 & 24.1 & 100.0 \\
& Samtals & 83 & 86.5 & 100.0 & \\
Vantar & & 13.5 & & \\
Samtals & & 100.0 & & \\
\hline \hline
\end{tabular}

beir pátttakendur sem svöruðu að peir sendu verkkaupa, oft, stundum eða sjaldan skriflega rökstudda tilkynningu um verktöf voru spurðir í hvaða tilfellum peir gerðu pað. Svörin má sjá á bls. 447.

$53 \%$ svarenda sögðust alltaf eða oft gera skriflega greiðsluáætlun en rúmlega 25\% svarenda sögðust aldrei eða sjaldan útbúa slíka áætlun. 


\begin{tabular}{llcccc}
\hline \hline \multirow{2}{*}{ Gilt } & & Tíðni & Hlutfall (\%) & Gilt hlutfall (\%) & Uppsafnað hlutfall (\%) \\
& Alltaf & 20 & 20.8 & 24.1 & 24.1 \\
& Oft & 24 & 25.0 & 28.9 & 53.0 \\
& Stundum & 18 & 18.8 & 21.7 & 74.7 \\
& Sjaldan & 8 & 8.3 & 9.6 & 84.3 \\
& Aldrei & 13 & 13.5 & 15.7 & 100.0 \\
& Samtals & 83 & 86.5 & 100.0 & \\
Vantar & 13 & 13.5 & & \\
Samtals & 96 & 100.0 & & \\
\hline \hline
\end{tabular}

Peir pátttakendur sem svöruðu að peir gerðu, oft, stundum eða sjaldan skriflega greiðsluáætlun við verkkaupa voru spurðir í hvaða tilfellum peir gerðu pað. Svörin má sjá á bls. 448.

Pátttakendur voru spurðir hvort venja væri að koma á samkomulagi um reglubundna verkfundi með verkkaupa. Tæplega 19\% sögðu að slíkt samkomulag væri alltaf gert, en tæplega 74\% svöruðu að slíkt samkomulag væri gert oft eða stundum ${ }^{131}$.

Tafla 287 Er venja að gert sé samkomulag um reglubundna verkfundi með verkkaupa?

\begin{tabular}{llcccc}
\hline \hline \multirow{6}{*}{ Gilt } & & Tíðni & Hlutfall (\%) & Gilt hlutfall (\%) & Uppsafnað hlutfall (\%) \\
& Alltaf & 15 & 15.6 & 18.8 & 18.8 \\
& Oft & 29 & 30.2 & 36.3 & 55.0 \\
& Stundum & 27 & 28.1 & 33.8 & 88.8 \\
& Sjaldan & 3 & 3.1 & 3.8 & 92.5 \\
& Aldrei & 6 & 6.3 & 7.5 & 100.0 \\
& Samtals & 80 & 83.3 & 100.0 & \\
Vantar & & 16 & 16.7 & & \\
Samtals & & 96 & 100.0 & & \\
\hline \hline
\end{tabular}

Peir pátttakendur sem svöruðu að samkomulag um reglubundna verkfundi væri, oft, stundum eða sjaldan gert voru spurðir í hvaða tilfellum pað væri. Svörin má sjá á bls. 448.

Tæplega 48\% svarenda sögðu pað væri alltaf rituð fundargerð á verkfundum, tæplega 28\% sögðu að oft eða stundum væri rituð fundargerð en ekki nema rúmlega $15 \%$ svöruðu að aldrei eða sjaldan væri fundargerð rituð á verkfundum.

${ }^{131}$ Sjá greiningu út frá stærð fyrirtækja og fleira á bls. 


\begin{tabular}{llcccc}
\hline \hline \multirow{2}{*}{ Gilt } & & Tíðni & Hlutfall (\%) & Gilt hlutfall (\%) & Uppsafnað hlutfall (\%) \\
& Alltaf & 38 & 39.6 & 47.5 & 47.5 \\
& Oft & 16 & 16.7 & 20.0 & 67.5 \\
& Stundum & 14 & 14.6 & 17.5 & 85.0 \\
& Sjaldan & 3 & 3.1 & 3.8 & 88.8 \\
& Aldrei & 9 & 9.4 & 11.3 & 100.0 \\
& Samtals & 80 & 83.3 & 100.0 & \\
Vantar & 16 & 16.7 & & \\
Samtals & 96 & 100.0 & & \\
\hline \hline
\end{tabular}

Peir pátttakendur sem svöruðu að fundargerð væri, oft, stundum eða sjaldan rituð á verkfundum voru spurðir í hvaða tilfellum pað væri. Svörin má sjá á bls. 449.

Tæplega 32\% svarenda sögðust alltaf halda verkdagbók og tæplega 28\% sögðust gera pað oft en tæplega $41 \%$ svarenda heldur aldrei, sjaldan eða stundum verkdagbók.

Tafla 289 Haldið pið verkdagbók?

\begin{tabular}{llcccc}
\hline \hline \multirow{6}{*}{ Gilt } & & Tíðni & Hlutfall (\%) & Gilt hlutfall (\%) & Uppsafnað hlutfall (\%) \\
& Alltaf & 25 & 26.0 & 31.6 & 31.6 \\
& Oft & 22 & 22.9 & 27.8 & 59.5 \\
& Stundum & 10 & 10.4 & 12.7 & 72.2 \\
& Sjaldan & 6 & 6.3 & 7.6 & 79.7 \\
& Aldrei & 16 & 16.7 & 20.3 & 100.0 \\
& Samtals & 79 & 82.3 & 100.0 & \\
Vantar & 17 & 17.7 & & \\
Samtals & & 100.0 & & \\
\hline \hline
\end{tabular}

Pátttakendur sem sögðust halda verkdagbók, alltaf, oft, stundum eða sjaldan voru spurðir hvað komi fram í verkdagbókinni. Svör má sjá á bls. 449.

Tæplega 30\% svarenda sagði að pað væri aldrei tekið fram í samningum hjá peim að pað beri að fara eftir kröfum samskiptastaðalsins IST 30 og tæplega 22\% sagði að pað væri sjaldan eða stundum tekið fram. Eftir standa rúmlega 47\% sem sögðu að slíkt kæmi oft eða alltaf fram í samningum. 
Tafla 290 Er venja að pað sé tekið fram í samningum að pað beri að fara eftir kröfum samskiptastaðalsins IST 30 ?

\begin{tabular}{llcccc}
\hline \hline \multirow{6}{*}{ Gilt } & Tíðni & Hlutfall (\%) & Gilt hlutfall (\%) & Uppsafnað hlutfall (\%) \\
& Alltaf & 12 & 12.5 & 15.4 & 15.4 \\
& Oft & 25 & 26.0 & 32.1 & 47.4 \\
& Stundum & 13 & 13.5 & 16.7 & 64.1 \\
& Sjaldan & 4 & 4.2 & 5.1 & 69.2 \\
& Aldrei & 23 & 24.0 & 29.5 & 98.7 \\
& Veit ekki & 1 & 1.0 & 1.3 & 100.0 \\
& Samtals & 78 & 81.3 & 100.0 & \\
Vantar & & 18 & 18.8 & & \\
Samtals & & 100.0 & & \\
\hline \hline
\end{tabular}

Peir pátttakendur sem svöruðu að pað væri oft, stundum eða sjaldan tekið fram í samningum að pað beri að fara eftir kröfum samskiptastaðalsins ÍST 30 voru spurðir í hvaða tilfellum pað væri. Svörin má sjá á bls. 450.

Flestir, eða tæplega 43\% svarenda sögðust tilkynna verkkaupa skriflega um frábrigði, en rúmlega 34\% sögðu að pað væri mismunandi hvernig verkkaupa væri tilkynnt um slíkt.

Tafla 291 Hvernig er verkkaupa tilkynnt um frábrigði?

\begin{tabular}{llcccc}
\hline \hline \multirow{2}{*}{ Gilt } & & Tíðni & Hlutfall (\%) & Gilt hlutfall (\%) & Uppsafnað hlutfall (\%) \\
& Skriflega & 34 & 35.4 & 43.0 & 43.0 \\
& Munnlega & 13 & 13.5 & 16.5 & 59.5 \\
& Mismunandi & 27 & 28.1 & 34.2 & 93.7 \\
& Veit ekki & 5 & 5.2 & 6.3 & 100.0 \\
& Samtals & 79 & 82.3 & 100.0 & \\
Vantar & & 17 & 17.7 & & \\
Samtals & & 100.0 & & \\
\hline \hline
\end{tabular}

Tæplega 70\% svarenda sögðust alltaf eða oft skrá óskir um aukaverk og breytingar en tæplega 31\% sögðust gera pað stundum, sjaldan eða aldrei. 


\begin{tabular}{llcccc}
\hline \hline \multirow{2}{*}{ Gilt } & & Tíðni & Hlutfall (\%) & Gilt hlutfall (\%) & Uppsafnað hlutfall (\%) \\
& Alltaf & 38 & 39.6 & 46.3 & 46.3 \\
& Oft & 19 & 19.8 & 23.2 & 69.5 \\
& Stundum & 11 & 11.5 & 13.4 & 82.9 \\
& Sjaldan & 3 & 3.1 & 3.7 & 86.6 \\
& Aldrei & 11 & 11.5 & 13.4 & 100.0 \\
& Samtals & 82 & 85.4 & 100.0 & \\
Vantar & & 14 & 14.6 & & \\
Samtals & & 96 & 100.0 & & \\
\hline \hline
\end{tabular}

Peir pátttakendur sem svöruðu að óskir um aukaverk og breytingar væru oft, stundum eða sjaldan skráð voru spurðir í hvaða tilfellum pað væri. Svörin má sjá á bls. 450.

Tæplega 62\% svarenda sagði að ef óskir um aukaverk og breytingar væru skráðar pá kæmi par jafnframt, alltaf eða oft, fram áhrif á verðlagningu heildarverks og framvindu.

Tafla 293 Ef óskir um aukaverk og breytingar eru skráðar, kemur pá fram í skráningu áhrif á verðlagningu heildarverks og framvindu?

\begin{tabular}{llcccc}
\hline \hline \multirow{3}{*}{ Gilt } & & Tíðni & Hlutfall (\%) & Gilt hlutfall (\%) & Uppsafnað hlutfall (\%) \\
& Alltaf & 21 & 21.9 & 30.9 & 30.9 \\
& Oft & 21 & 21.9 & 30.9 & 61.8 \\
& Stundum & 14 & 14.6 & 20.6 & 82.4 \\
& Sjaldan & 2 & 2.1 & 2.9 & 85.3 \\
& Aldrei & 9 & 9.4 & 13.2 & 98.5 \\
& Veit ekki & 1 & 1.0 & 1.5 & 100.0 \\
& Samtals & 68 & 70.8 & 100.0 & \\
Vantar & & 28 & 100.0 & & \\
Samtals & & 96 &
\end{tabular}

Deir pátttakendur sem svöruðu að fram kæmu áhrif á verðlagningu heildarverks eftir framvindu í skráningu óska um aukaverk eða breytingar, oft, stundum eða sjaldan voru spurðir í hvaða tilfellum pað væri. Svörin má sjá á bls. 451 .

Pegar pátttakendur voru spurðir hversu oft peir skiluðu skrá yfir hugsanlegar kröfur um greiðslur vegna aukaverka og breytinga svöruðu flestir að peir gerðu slíkt mánaðarlega, eða rúmlega 29\%. 
Tafla 294 Hversu oft skilið pið skrá yfir hugsanlegar kröfur um greiðslur vegna aukaverka og breytinga til verkkaupa?

\begin{tabular}{llcccc}
\hline \hline & & Tíðni & Hlutfall (\%) & Gilt hlutfall (\%) & Uppsafnað hlutfall (\%) \\
\hline Gilt & Vikulega & 15 & 15.6 & 19.0 & 19.0 \\
& Mánaðarlega & 23 & 24.0 & 29.1 & 48.1 \\
& Að verki loknu & 15 & 15.6 & 19.0 & 67.1 \\
& Aldrei & 10 & 10.4 & 12.7 & 79.7 \\
& Veit ekki / annað & 16 & 16.7 & 20.3 & 100.0 \\
& Samtals & 79 & 82.3 & 100.0 & \\
Vantar & & 17.7 & & \\
Samtals & & 100.0 & & \\
\hline \hline
\end{tabular}

Athuga að í töflunni hérna að ofan hefur flokkunum veit ekki og annað verið skeytt saman, en peir pátttakendur sem svöruðu annað voru spurðir hversu oft. Svör peirra má sjá á bls. 451.

Flestir sögðust aldrei gera hættumat og/eða áhættugreiningu á verkstað eða rúmlega 33\% en tæplega $62 \%$ sögðust stundum, sjaldan eða aldrei gera áhættumat. Ekki nema rúmlega 10\% pátttakenda sögðust alltaf gera slíkt.

Tafla 295 Gerið pið haettumat og/eða áhaettugreiningu á verkstað ?

\begin{tabular}{llcccc}
\hline \hline \multirow{6}{*}{ Gilt } & Tíðni & Hlutfall (\%) & Gilt hlutfall (\%) & Uppsafnað hlutfall (\%) \\
& Alltaf & 8 & 8.3 & 10.3 & 10.3 \\
& Oft & 21 & 21.9 & 26.9 & 37.2 \\
& Stundum & 15 & 15.6 & 19.2 & 56.4 \\
& Sjaldan & 7 & 7.3 & 9.0 & 65.4 \\
& Aldrei & 26 & 27.1 & 33.3 & 98.7 \\
& Veit ekki & 1 & 1.0 & 1.3 & 100.0 \\
& Samtals & 78 & 81.3 & 100.0 & \\
Vantar & & 18 & 18.8 & & \\
Samtals & & 100.0 & & \\
\hline \hline
\end{tabular}

Peir pátttakendur sem svöruðu að peir gerði oft, stundum eða sjaldan hættumat/áhættugreiningu á verkstað voru spurðir í hvaða tilfellum pað væri gert. Svörin má sjá á bls. 452.

Rúmlega 51\% pátttakenda sögðust aldrei styðjast við utanaðkomandi pjónustu við gæðaeftirlit eða úttektir, prátt fyrir pað var rúmlega $\mathbf{4 6 \%}$ pátttakenda sem sagðist ekki vera með skipulagt innra eftirlit á framkvæmdum. 


\begin{tabular}{llcccc}
\hline \hline \multirow{6}{*}{ Gilt } & & Tíðni & Hlutfall (\%) & Gilt hlutfall (\%) & Uppsafnað hlutfall (\%) \\
& Alltaf & 10 & 10.4 & 12.8 & 12.8 \\
& Oft & 7 & 7.3 & 9.0 & 21.8 \\
& Stundum & 17 & 17.7 & 21.8 & 43.6 \\
& Sjaldan & 4 & 4.2 & 5.1 & 48.7 \\
& Aldrei & 40 & 41.7 & 51.3 & 100.0 \\
& Veit ekki & 0 & 0.0 & 0.0 & \\
& Samtals & 78 & 81.3 & 100.0 & \\
Vantar & & 18 & 18.8 & & \\
Samtals & & 96 & 100.0 & & \\
\hline \hline
\end{tabular}

Tafla 297 Er skipulagt innra eftirlit á framkvaemdum hjá fyrirtakinu (gąðastýringarácetlun)?

\begin{tabular}{llcccc}
\hline \hline Gilt & & Tíðni & Hlutfall (\%) & Gilt hlutfall (\%) & Uppsafnað hlutfall (\%) \\
& Alltaf & 10 & 10.4 & 12.8 & 12.8 \\
& Oft & 11 & 11.5 & 14.1 & 26.9 \\
& Stundum & 15 & 15.6 & 19.2 & 46.2 \\
& Sjaldan & 4 & 4.2 & 5.1 & 51.3 \\
& Aldrei & 36 & 37.5 & 46.2 & 97.4 \\
& Veit ekki & 2 & 2.1 & 2.6 & \\
& Samtals & 78 & 81.3 & 100.0 & \\
Vantar & & 18 & 18.8 & & \\
Samtals & & 96 & 100.0 & & \\
\hline \hline
\end{tabular}




\subsection{Kröfur verkkaupa}

Pátttakendur voru spurðir hvernig peim pætti kröfur verkkaupa (einstaklinga, fyrirtækja og opinberra stofnanna) um skipulag og markvissa stjórnun í garð verktaka hafa verið annars vegar fyrir efnahagshrun og hins vegar eftir efnahagshrun. Pátttakendum fannst í öllum tilfellum, p.e. fyrir einstaklinga, fyrirtæki og opinberar stofnanir að kröfur um slíkt hefðu aukist eftir efnahagshrunið.

Hlutfall svarenda sem fannst kröfur einstaklings verkkaupa vera mjög eða frekar litlar lækkaði um 9\% eftir efnahagshrunið en hlutfall svarenda sem fannst kröfur einstaklings verkkaupa vera mjög eða frekar miklar hækkaði um rúmlega $17 \%$ eftir efnahagshrun.

Hlutfall svarenda sem fannst kröfur fyrirtækja verkkaupa vera mjög eða frekar litlar lækkaðu um tæplega $17 \%$ eftir efnahagshrunið og hlutfall svarenda sem fannst kröfur fyrirtækja verkkaupa vera mjög eða frekar miklar hækkaði um rúmlega $14 \%$ eftir efnahagshrun.

Að lokum lækkaði hlutfall svarenda sem fannst slíkar kröfur hjá opinberum stofnunum vera mjög eða frekar litlar um rúmlega 11\% eftir efnahagshrunið en hlutfall svarenda sem fannst pær vera mjög eða frekar miklar hækkaði um tæplega 9\% eftir efnahagshrun.

Tafla 298 Hvernig finnst pér kröfur verkkaupa um skipulag og markvissa stjórnun í garð verktaka?

\begin{tabular}{|c|c|c|c|c|c|c|}
\hline & & Mjög litlar & $\begin{array}{c}\text { Frekar } \\
\text { litlar }\end{array}$ & $\begin{array}{l}\text { Hvorki miklar } \\
\text { né litlar }\end{array}$ & $\begin{array}{l}\text { Frekar } \\
\text { miklar }\end{array}$ & $\begin{array}{l}\text { Mjög } \\
\text { miklar }\end{array}$ \\
\hline \multicolumn{7}{|l|}{ FYRIR efnahagshrun } \\
\hline \multirow{3}{*}{ Einstaklings verkkaupar } & Tíoni & 16 & 20 & 26 & 9 & 1 \\
\hline & Hlutfall (\%) & $22,2 \%$ & $27,8 \%$ & $36,1 \%$ & $12,5 \%$ & $1,4 \%$ \\
\hline & Tíoni & 5 & 12 & 33 & 20 & 1 \\
\hline Fyrirtækja verkkaupar & Hlutfall (\%) & $7,0 \%$ & $16,9 \%$ & $46,5 \%$ & $28,2 \%$ & $1,4 \%$ \\
\hline \multirow[t]{2}{*}{ Opinbera stofnanir } & Tíðni & 4 & 5 & 27 & 23 & 9 \\
\hline & Hlutfall (\%) & $5,9 \%$ & $7,4 \%$ & $39,7 \%$ & $33,8 \%$ & $13,2 \%$ \\
\hline \multicolumn{7}{|l|}{ EFTIR efnahagshrun } \\
\hline \multirow[b]{2}{*}{ Einstaklings verkkaupar } & Tíðni & 10 & 13 & 31 & 14 & 2 \\
\hline & Hlutfall (\%) & $14,3 \%$ & $18,6 \%$ & $44,3 \%$ & $20,0 \%$ & $2,9 \%$ \\
\hline & Tíðni & 3 & 4 & 31 & 27 & 6 \\
\hline Fyrirtækja verkkaupar & Hlutfall (\%) & $4,2 \%$ & $5,6 \%$ & $43,7 \%$ & $38,0 \%$ & $8,5 \%$ \\
\hline \multirow{2}{*}{ Opinbera stofnanir } & Tíoni & 1 & 2 & 25 & 22 & 17 \\
\hline & Hlutfall (\%) & $1,5 \%$ & $3,0 \%$ & $37,3 \%$ & $32,8 \%$ & $25,4 \%$ \\
\hline
\end{tabular}


Almennt virðist sem verktökum finnist kröfur einstaklings verkkaupa í garð verktaka um skipulag og markvissa stjórnun vera litlar hvort sem er fyrir eða eftir efnahagshrun prátt fyrir að greina megi auknar kröfur eftir efnahagshrunið. Hjá opinberum stofnunum virðast kröfurnar almennt vera miklar fyrir og eftir efnahagshrun en jafnframt má greina auknar kröfur eftir efnahagshrun.

Niðurstöðurnar voru settar upp í köngulóarit til að skoða pær myndrænt.

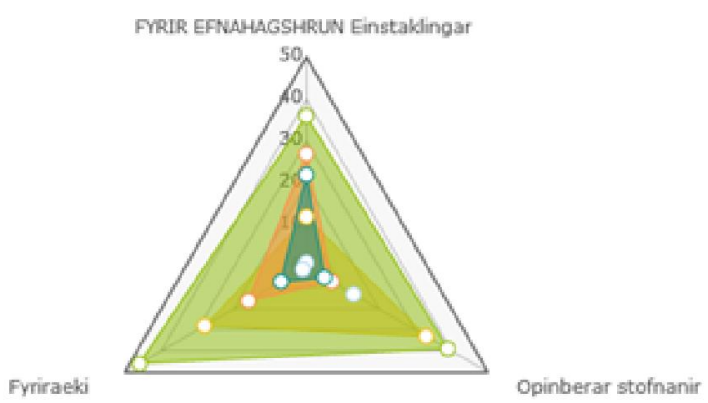

Mioo miklar Frekar miklar Mion litlar

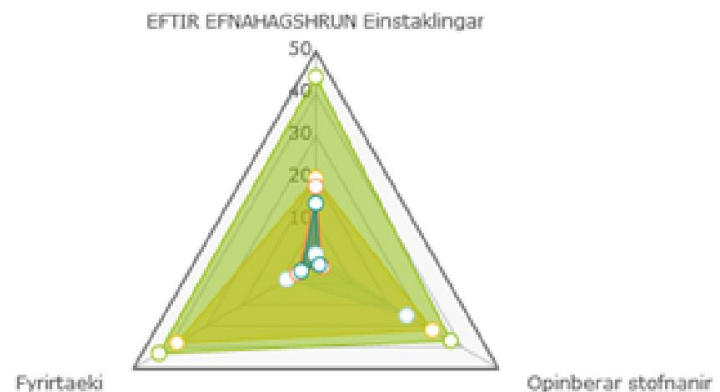

Mynd 67 Kóngulóarit af kröfum verkkaupa i garð verktaka - fyrir og eftir efnahagshrun 


\subsection{Annað}

Verktakar voru að lokum spurðir opinnar spurningar, hvort pað væri eitthvað að lokum sem peir vildu koma á framfæri. Svörin í heild sinni má sjá á bls. 453. En hér eru nokkur dæmi:

\section{Tafla 299 Er eitthvað að lokum sem pú vilt koma á framfaeri?}

- „Við höfum lítið verið að vinna eftir hrun. Gęðastjórnunarkerfi eru góð hugmynd fyrir bá sem eru að byrja með fyrirtceki núna en $i$ hans tilfelli pá byggja vinnubrögð hans á áralangri reynslu og telur hann sig pvi ekki burfa að vinna eftir ákveðnu gœðastjórnunarkerfi. Dau fyrirtceki sem gefa sig út fyrir að vera að vinna eftir ákveðnu kerfi eru ekki endilega með mannskapinn sem parf til að fylgja pví eftir. En kerfið er tilgangslaust ef eftirfylgnin er ekki noeg. "

- „Með nýjum mannvirkjalögum erum við neyddir til að innleiða goeðastjórnunarkerfi en hjá svona litlum fyrirtoekjum er pað allt of umfangsmikið. Dað vantar umfangsminna kerfi fyrir lítil fyrirtceki. Mér finnst vanta samramd útboðsgögn sem hoegt vari að nálgast á auðveldan hátt með helstu lykilatriðum. “

- ,starfshoettir verktaka vera i 'ruglinu' fyrir hrun. Fór alltaf fram á “ goeðatryggingu frá undirverktökum á beim tíma en núna er allt miklu rólegra..."

- „Ég hef trú á gæððastjórnun fyrir stcerri fyrirtceki. Óparfi fyrir minni fyrirtceki. “

- „Vöntun á geeðastjórnunarkerfi fyrir litil fyrirtceki. Dað er mikið um fúskara parna úti.. “
- „Vil hvetja alla sem að mannvirkjagerd koma, til að taka upp faglegri vinnubrögð. Hönnun parf að stórbceta, pvi allt of oft er kastað par til höndum, sem leiðir til mikils aukakostnaðar og tafa á verktíma. Verkferla og samskipti aðila parf að setja i fastari skorður, og meiri metnað vantar til að skila góðu verki er ábótavant. Dað er ekki nóg að finna upp gaðakerfi, pað purfa allir að sameinast um að fylgja pví."

- „Honum fannst kröfur $i$ garð verkkaupa varðandi lágt verð hafa aukist mikið $i$ kjölfar hrunsins auk pess sem honum fannst útboðsgögn vera 'harðari' núna en fyrir kreppu. Honum fannst vera pörf fyrir gœðastjórnunarkerfi fyrir lítil fyrirtceki og taldi slikt kerfi geta borið mikinn árangur ef pað vari ekki of flókið og pungt. Honum fannst mikill skortur i samrcminu á teikningum."

- „,... nei við höfum aldrei unnið eftir neinni geðastjórnun, aðeins eftir heiðarleika og gódri samvisku ... “

- „Eftir hrun! Er ekki marktcekt mun minna um stcerri verk. “

- „, „Pað er ekkert að marka útboðsgögn núna. Lagstu tilboðum alltaf bara tekið og svo er ekkert farið eftir útboðsgögnunum - alltaf farið fram hjá skilmálum. Kröfur verkkaupa um lágt verð hafa stóraukist eftir hrun. “" 



\section{Viðauki I - Tengslatöflur og fylgni milli breyta hjá verktökum}

Eins og áður hefur komið fram er samband milli tveggja eða fleiri breyta er gefið upp í tengslatöflu (e. contingency table) eða $\mathrm{RxC}$ töflum, par sem $\mathrm{R}$ stendur fyrir $R o w$ eða röð og $\mathrm{C}$ fyrir column eða dálk. Par er tíðni svara gefið í flokkum milli breyta auk pess sem fylgnistuðlar eru reiknaðir. Fyrir raðbreytur var notast við eftirfarandi fylgnistuðla; Spearman's fylgnistuðull, gamma Goodmans og Kruskal's, Sommers‘d, Kendall's Tau b eða Tau c eftir pví sem við á. Fyrir nafnabreytur (eða nafnabreytu og raðbreytu) var notast við tengsla stuðul (e.contingency coefficient), lambda og óvissu stuðul (e. uncertanity coefficient). En pessir stuðlar gefa til kynna hversu sterk tengsl eru milli breyta og hvort pau eru marktæk ${ }^{132}$.

Notast verður við breytuheiti sem eru skilgreind í par til gerðum viðauka á bls. 201 til að auðvelda uppsetningu á tengslatöflum.

Athuga að raðbreytum var gefin töluleg gildi fyrir svarflokka til að tryggja að fylgnistuðlar væru reiknaðir rétt. Sá svarflokkur sem talinn er vera bestur, eins og mjög áncegð/ur fékk hæstu töluna og sá sem talinn er vera verstur fékk lægstu töluna.

\subsection{Grunnupplýsingar}

\subsubsection{Tvívítt fylgnifylki: ánægja_umræddan, stærð, aldur_fyrirt}

Tafla 300 Tvívitt fylgnifylki: áncegja umrceddan, stcerð, aldur fyrirt

\begin{tabular}{lllccc}
\hline \hline & & & ánægja_umræddan & stærð & aldur_fyrirt \\
\hline \multirow{2}{*}{$\begin{array}{l}\text { Spearman's } \\
\text { rho }\end{array}$} & ánægja_umræddan & Fylgnistuðull & 1,000 & $.366^{* *}$ & $.333^{*}$ \\
& & Sig. (2-tailed) &. &, 003 &, 024 \\
& & $\mathrm{~N}$ & 116 & 65 & 46 \\
\cline { 2 - 6 } & \multirow{2}{*}{ stærð } & Fylgnistuðull & $.366^{* *}$ & 1,000 & $.778^{* *}$ \\
& &, 003 &. &, 000 \\
& & Sig. (2-tailed) & 65 & 65 & 44 \\
\cline { 2 - 6 } & aldur_fyrirt & Fylgnistuðull & $.333^{*}$ & $.778^{* *}$ & 1,000 \\
& &, 024 &, 000 &. \\
& & Sig. (2-tailed) & 46 & 44 & 46 \\
\hline \hline
\end{tabular}

**. Correlation is significant at the 0.01 level (2-tailed).

*. Correlation is significant at the 0.05 level (2-tailed).

${ }^{132}$ Sjá nánar um fylgnistuðla í kafla um greiningaraðferðir og grunnathuganir á bls. 81 


\subsubsection{Stærð, GSK}

Fylgni milli stcerð (hversu stórt fyrirtceki verktaka er) og GSK (hvort verkkaupi starfi eftir gæeðastjórnunarkerfi byggðu á viðurkenndum gæeðastjórnunarstaðli) var skoðuð. 93 tilfelli flokkast undir gild tilfelli.

Tafla 301 Yfirlit tilfella í greiningu milli stoerd og GSK

\begin{tabular}{lccccccc}
\hline \hline & \multicolumn{9}{c}{ Tilfelli } \\
\cline { 2 - 8 } & \multicolumn{2}{c}{ Gild } & \multicolumn{2}{c}{ Vantar } & \multicolumn{2}{c}{ Samtals } \\
\cline { 2 - 8 } & $\mathrm{N}$ & Hlutfall & $\mathrm{N}$ & Hlutfall & $\mathrm{N}$ & Hlutfall \\
\hline stærð * GSK & 93 & $96.9 \%$ & 3 & $3.1 \%$ & 96 & $100.0 \%$ \\
\hline \hline
\end{tabular}

Tafla 302 Tengslatafla (tïđni): staerd * GSK

\begin{tabular}{llccc}
\hline \hline & \multicolumn{3}{c}{ GSK } & \\
\cline { 3 - 4 } & & $\begin{array}{c}\text { Nei, veit ekki eða ekki } \\
\text { byggt á stöðlum }\end{array}$ & Já eða í innleiðingu & Samtals \\
\hline stærð & $<10$ & 59 & 8 & 67 \\
& $10-20$ & 6 & 4 & 10 \\
& $21-31$ & 1 & 5 & 6 \\
& $31-50$ & 0 & 3 & 3 \\
& $51<$ & 1 & 6 & 7 \\
Samtals & & 67 & 26 & 93 \\
\hline \hline
\end{tabular}

Fylgni milli stcerð og GSK reyndist vera mjög marktæk og sterk

Tafla 303 Ósamhverf fylgnimæligildi: staerd, GSK

\begin{tabular}{|c|c|c|c|c|c|c|}
\hline \multirow{4}{*}{$\begin{array}{l}\text { Raðbreyta } \\
\text { á móti } \\
\text { raðbreytu }\end{array}$} & & & Gildi & fervik $^{\mathrm{a}}$ & $\mathrm{T}^{\mathrm{b}}$ & Sig. \\
\hline & \multirow[t]{3}{*}{ Somers' d } & Samhverft & ,577 & ,085 & 5,194 & ,000 \\
\hline & & $\begin{array}{l}\text { stærð } \\
\text { svarbreyta }\end{array}$ & 617, & 101 & 5,194 & ,000 \\
\hline & & $\begin{array}{l}\text { GSK } \\
\text { svarbreyta }\end{array}$ & ,542 & , 081 & 5,194 & ,000 \\
\hline
\end{tabular}

a. Not assuming the null hypothesis.

b. Using the asymptotic standard error assuming the null hypothesis. 
Tafla 304 Samhverf fylgnimaligildi: stoerð, GSK

\begin{tabular}{llcccc}
\hline \hline & & Gildi & fervik $^{\mathrm{a}}$ & $\mathrm{T}^{\mathrm{b}}$ & Sig. \\
\hline Raðbreyta á & Kendall's tau-b &, 578 &, 085 & 5,194 &, 000 \\
móti & Kendall's tau-c &, 497 &, 096 & 5,194 &, 000 \\
raðbreytu & Gamma &, 870 &, 062 & 5,194 &, 000 \\
& Spearman fylgnistuðull &, 607 &, 091 & 7,290 & $.000^{\mathrm{c}}$ \\
& 93 & & & \\
\hline
\end{tabular}

a. Not assuming the null hypothesis.

b. Using the asymptotic standard error assuming the null hypothesis.

c. Based on normal approximation.

\subsubsection{Fylgni: úrtak, GSK}

Fylgni milli úrtak (bess i hvaða flokki, af flokkunum 4 sem úrtak verktaka samanstendur af) og GSK (hvort verkkaupi starfi eftir gaðastjórnunarkerfi byggðu á viðurkenndum gœðastjórnunarstaðli) var skoðuð.

Öll 96 tilfellin flokkast undir gild tilfelli.

Tafla 305 Yfirlit tilfella í greiningu milli úrtak og GSK

\begin{tabular}{lcccccc}
\hline \hline & \multicolumn{9}{c}{ Tilfelli } \\
\cline { 2 - 8 } & \multicolumn{2}{c}{ Gild } & \multicolumn{2}{c}{ Vantar } & \multicolumn{2}{c}{ Samtals } \\
\cline { 2 - 8 } & $\mathrm{N}$ & Hlutfall & $\mathrm{N}$ & Hlutfall & $\mathrm{N}$ & Hlutfall \\
\hline Úrtak * GSK & 96 & $100.0 \%$ & 0 & $.0 \%$ & 96 & $100.0 \%$ \\
\hline \hline
\end{tabular}

Tafla 306 Tengslatafla (tíðni): Úrtak * GSK

\begin{tabular}{llccc}
\hline \hline & & \multicolumn{2}{c}{ GSK } & \\
\cline { 3 - 4 } & & $\begin{array}{c}\text { Nei, veit ekki } \\
\text { eða ekki byggt á } \\
\text { stöðlum }\end{array}$ & Já eða í innleiðingu & Samtals \\
\hline Úrtak & Fundur & 25 & 3 & 28 \\
& Póstlisti & 22 & 11 & 33 \\
& Slembiúrtak & 2 & 1 & 3 \\
& Umræddir verktakar & 21 & 11 & 32 \\
Samtals & 70 & 26 & 96 \\
\hline \hline
\end{tabular}

Fylgni milli Úrtak og GSK reyndist ekki marktæk. 


\begin{tabular}{|c|c|c|c|c|c|c|}
\hline \multirow{4}{*}{\multicolumn{2}{|c|}{$\begin{array}{l}\text { Nafnabreyta á } \\
\text { móti } \\
\text { nafnabreytu }^{133}\end{array}$}} & & Gildi & fervik $^{\mathrm{a}}$ & $\mathrm{T}^{\mathrm{b}}$ & Sig. \\
\hline \multirow{8}{*}{$\begin{array}{l}\text { Nafnabreyta á } \\
\text { móti } \\
\text { nafnabreytu }\end{array}$} & & Samhverft & ,034 & ,076 & ,438 & ,661 \\
\hline & & $\begin{array}{l}\text { Úrtak } \\
\text { svarbreyta }\end{array}$ &, 048 & , 106 & ,438 & ,661 \\
\hline & & $\begin{array}{l}\text { GSK } \\
\text { svarbreyta }\end{array}$ &, 000 & ,000 &.$^{\mathrm{c}}$ &.${ }^{\mathrm{c}}$ \\
\hline & \multirow[t]{2}{*}{$\begin{array}{l}\text { Goodman and } \\
\text { Kruskal tau }\end{array}$} & $\begin{array}{l}\text { Úrtak } \\
\text { svarbreyta }\end{array}$ & ,025 & ,017 & & $.071^{\mathrm{d}}$ \\
\hline & & $\begin{array}{l}\text { GSK } \\
\text { svarbreyta }\end{array}$ & ,056 & ,038 & & $.150^{\mathrm{d}}$ \\
\hline & \multirow[t]{3}{*}{ Óvissu stuðull } & Samhverft & 035 & ,026 & 1,346 & $.109^{\mathrm{e}}$ \\
\hline & & $\begin{array}{l}\text { Úrtak } \\
\text { svarbreyta }\end{array}$ & ,026 & ,020 & 1,346 & $.109^{\mathrm{e}}$ \\
\hline & & $\begin{array}{l}\text { GSK } \\
\text { svarbreyta }\end{array}$ &, 054 & ,040 & 1,346 & $.109^{\mathrm{e}}$ \\
\hline
\end{tabular}

a. Not assuming the null hypothesis.

b. Using the asymptotic standard error assuming the null hypothesis.

c. Cannot be computed because the asymptotic standard error equals zero.

d. Based on chi-square approximation

e. Likelihood ratio chi-square probability.

Tafla 308 Samhverf fylgnimaligildi: Úrtak, GSK

\begin{tabular}{llcc}
\hline \hline & & Gildi & Sig. \\
\hline $\begin{array}{l}\text { Nafnabreyta á móti } \\
\text { nafnabreytu }\end{array}$ (134 & Tengsla stuðull &, 230 &, 146 \\
N af gildum tilfellum & & 96 & \\
\hline \hline
\end{tabular}

\subsection{Gæðastjórnun}

\subsubsection{Fylgni: öryggi_verkstað, GSK}

Fylgni milli öryggi verkstað (hversu oft/hvort verktaki framkvaemdi öryggisráðstafanir á verkstað) og GSK (hvort verkkaupi starfi eftir gaðastjórnunarkerfi byggðu á viðurkenndum gceðastjórnunarstaðli) var skoðuð. 82 tilfellin flokkast undir gild tilfelli.

${ }^{133}$ GSK er einnig meðhöndluð sem nafnabreyta í pessu tilfelli til að reikna fylgnistuðlana

${ }^{134}$ GSK er einnig meðhöndluð sem nafnabreyta í pessu tilfelli til að reikna fylgnistuðlana 


\begin{tabular}{lccccccc}
\hline \hline & \multicolumn{9}{c}{ Tilfelli } \\
\cline { 2 - 7 } & \multicolumn{2}{c}{ Gild } & \multicolumn{2}{c}{ Vantar } & \multicolumn{2}{c}{ Samtals } \\
\cline { 2 - 7 } & $\mathrm{N}$ & Hlutfall & $\mathrm{N}$ & Hlutfall & $\mathrm{N}$ & Hlutfall \\
\hline öryggi_verkstað* & 82 & $85.4 \%$ & 14 & $14.6 \%$ & 96 & $100.0 \%$ \\
GSK & & & & & & & \\
\hline \hline
\end{tabular}

Tafla 310 Tengslatafla (tíðni): öryggi_verkstað * GSK

\begin{tabular}{llccc}
\hline \hline & & \multicolumn{2}{c}{ GSK } & \\
\cline { 3 - 5 } & & $\begin{array}{c}\text { Nei, veit ekki eða ekki } \\
\text { byggt á stöðlum }\end{array}$ & $\begin{array}{c}\text { Já eða í } \\
\text { innleiðingu }\end{array}$ & Samtals \\
\hline öryggi_verkstað & Veit ekki & 1 & 0 & 1 \\
& Aldrei & 1 & 0 & 1 \\
& Sjaldan & 2 & 0 & 2 \\
& Stundum & 13 & 2 & 15 \\
& Oft & 21 & 10 & 31 \\
Samtals & Alltaf & 20 & 12 & 32 \\
\hline \hline
\end{tabular}

Fylgni milli öryggi $i_{\text {verksta }}$ og GSK reyndist marktæk í öllum tilfellum nema með Spearmans fylgnistuðli. Fylgnin er ekki sérlega sterk en hæsti Gamma gildi sem er 0,384 sýnir mestu fylgnina.

Tafla 311 Ósamhverf fylgnimæligildi: öryggi_verkstað, GSK

\begin{tabular}{|c|c|c|c|c|c|}
\hline & & Gildi & fervik ${ }^{\mathrm{a}}$ & $\mathrm{T}^{\mathrm{b}}$ & Sig. \\
\hline \multirow{3}{*}{$\begin{array}{l}\text { Raðbreyta } \\
\text { á móti } \\
\text { raðbreytu }\end{array}$} & Samhverft & , 193 & ,089 & 2,115 & 034 \\
\hline & $\begin{array}{l}\text { öryggi_verkstað } \\
\text { svarbreyta }\end{array}$ & 253 &, 117 & 2,115 & ,034 \\
\hline & GSK svarbreyta &, 156 & ,073 & 2,115 & 034 \\
\hline
\end{tabular}

a. Not assuming the null hypothesis.

b. Using the asymptotic standard error assuming the null hypothesis. 
Tafla 312 Samhverf fylgnimæligildi: öryggi_verkstað, GSK

\begin{tabular}{llcccc}
\hline \hline & & Gildi & fervik $^{\mathrm{a}}$ & $\mathrm{T}^{\mathrm{b}}$ & Sig. \\
\hline Raðbreyta á & Kendall's tau-b &, 199 &, 091 & 2,115 &, 034 \\
móti & Kendall's tau-c &, 209 &, 099 & 2,115 &, 034 \\
raðbreytu & Gamma &, 384 &, 171 & 2,115 &, 034 \\
& Spearman fylgnistuðull &, 212 &, 098 & 1,944 & $.055^{\mathrm{c}}$ \\
& 82 & & & \\
\hline \hline
\end{tabular}

a. Not assuming the null hypothesis.

b. Using the asymptotic standard error assuming the null hypothesis.

c. Based on normal approximation.

\subsection{Viðhorf við gæðastjórnun}

Tafla 313 Samantekt á marktokriri fylgni viðhorfs verktaka við GSK

\begin{tabular}{lcccccc}
\hline \hline & \multicolumn{4}{c}{ GSK } & \\
\cline { 2 - 3 } & Gylgnistuðull & Sig. & & Fylgnistuðull & Sig. & N \\
\cline { 2 - 3 } áhrif_á_frábrigði &, 706 &, 000 & &, 462 &, 000 & 77 \\
samkeppnishæfi &, 679 &, 000 & &, 411 &, 000 & 84 \\
rekstrarafkoma &, 654 &, 000 & &, 399 &, 000 & 86 \\
ávinningur/kostnaður &, 559 &, 002 & &, 347 &, 001 & 85 \\
trú &, 532 &, 005 & &, 309 &, 003 & 88 \\
ávinningur &, 466 &, 019 & &, 240 &, 025 & 87 \\
\hline \hline
\end{tabular}

\subsubsection{Fylgni: ávinningur, GSK}

Fylgni milli ávinningur (hvort verktaki teldi ávinning nást með innleiðingu gœðastjórnunarkerfis) og GSK (hvort verkkaupi starfi eftir gœðastjórnunarkerfi byggðu á viðurkenndum gœðastjórnunarstaðli) var skoðuð. 87 tilfellin flokkast undir gild tilfelli.

Tafla 314 Yfirlit tilfella í greiningu milli ávinningur og GSK

\begin{tabular}{lcccccc}
\hline \hline & \multicolumn{7}{c}{ Tilfelli } \\
\cline { 2 - 8 } & \multicolumn{2}{c}{ Gild } & \multicolumn{2}{c}{ Vantar } & \multicolumn{2}{c}{ Samtals } \\
\cline { 2 - 8 } & $\mathrm{N}$ & Hlutfall & $\mathrm{N}$ & Hlutfall & $\mathrm{N}$ & Hlutfall \\
\hline ávinningur * GSK & 87 & $90.6 \%$ & 9 & $9.4 \%$ & 96 & $100.0 \%$ \\
\hline \hline
\end{tabular}




\begin{tabular}{llccc}
\hline \hline & & \multicolumn{2}{c}{ GSK } & \\
\cline { 3 - 4 } & & $\begin{array}{c}\text { Nei, veit ekki } \\
\text { eða ekki byggt á } \\
\text { stöðlum }\end{array}$ & Já eða í innleiðingu & Samtals \\
\hline ávinningur & Frekar lítill & 1 & 0 & 1 \\
& Hvorki mikill né lítill & 5 & 1 & 6 \\
& Frekar mikill & 31 & 8 & 39 \\
& Mjög mikill & 24 & 17 & 41 \\
Samtals & & 61 & 26 & 87 \\
\hline \hline
\end{tabular}

Fylgni milli ávinningur og GSK mældist marktæk bæði með Sommers`d og samhverfu fylgnimæligildunum en ekki ýkja sterk.

Tafla 316 Ósamhverf fylgnimaligildi: ávinningur, GSK

\begin{tabular}{|c|c|c|c|c|c|c|}
\hline & & & Gildi & fervik $^{\mathrm{a}}$ & $\mathrm{T}^{\mathrm{b}}$ & Sig. \\
\hline \multirow{3}{*}{\multicolumn{2}{|c|}{$\begin{array}{l}\text { Raðbreyta } \\
\text { á móti } \\
\text { raðbreytu }\end{array}$}} & Samhverft & ,230 & ,096 & 2,340 & ,019 \\
\hline & & $\begin{array}{l}\text { ávinningur } \\
\text { svarbreyta }\end{array}$ & ,272 &, 113 & 2,340 & ,019 \\
\hline & & $\begin{array}{l}\text { GSK } \\
\text { svarbreyta }\end{array}$ & ,199 & ,085 & 2,340 & ,019 \\
\hline
\end{tabular}

a. Not assuming the null hypothesis.

b. Using the asymptotic standard error assuming the null hypothesis.

Tafla 317 Samhverf fylgnimæligildi: ávinningur, GSK

\begin{tabular}{llcccc}
\hline \hline & & Gildi & fervik $^{\mathrm{a}}$ & $\mathrm{T}^{\mathrm{b}}$ & Sig. \\
\hline Raðbreyta á & Kendall's tau-c &, 228 &, 097 & 2,340 &, 019 \\
móti & Gamma &, 466 &, 182 & 2,340 &, 019 \\
raðbreytu & Spearman fylgnistuðull &, 240 &, 101 & 2,281 & $.025^{\mathrm{c}}$ \\
N af gildum tilfellum & 87 & & & \\
\hline \hline
\end{tabular}

a. Not assuming the null hypothesis.

b. Using the asymptotic standard error assuming the null hypothesis.

c. Based on normal approximation.

\subsubsection{Fylgni: ávinningur/kostnaður, GSK}

Fylgni milli ávinningur/kostnaður (hvort verktaki teldi ávinning vera meiri eða minni en kostnað af innleiðingu gæeðastjórnunarkerfis) og GSK (hvort verkkaupi starfi eftir gœðastjórnunarkerfi byggðu á viðurkenndum gœðastjórnunarstaðli) var skoðuð. 85 tilfellin flokkast undir gild tilfelli. 


\begin{tabular}{lcccccc}
\hline \hline & \multicolumn{7}{c}{ Tilfelli } \\
\cline { 2 - 7 } & \multicolumn{3}{c}{ Gild } & \multicolumn{2}{c}{ Vantar } & \multicolumn{2}{c}{ Samtals } \\
\cline { 2 - 7 } & $\mathrm{N}$ & Hlutfall & $\mathrm{N}$ & Hlutfall & $\mathrm{N}$ & Hlutfall \\
\hline $\begin{array}{l}\text { ávinningur/kostnaður } \\
\text { * GSK }\end{array}$ & 85 & $88.5 \%$ & 11 & $11.5 \%$ & 96 & $100.0 \%$ \\
\hline \hline
\end{tabular}

\begin{tabular}{llccc}
\multicolumn{2}{c}{ Tafla 319 Tengslatafla (tíðni): ávinningur/kostnaður * GSK } \\
\cline { 3 - 5 } & & \multicolumn{3}{c}{ GSK } \\
\cline { 3 - 5 } & & $\begin{array}{c}\text { Nei, veit ekki eða ekki } \\
\text { byggt á stöðlum }\end{array}$ & $\begin{array}{c}\text { Já eða í } \\
\text { innleiðingu }\end{array}$ & Samtals \\
\hline ávinningur & Mun minni & 0 & 1 & 1 \\
/kostnaður & Aðeins minni & 1 & 1 & 2 \\
& Hvorki meiri né minni & 17 & 2 & 19 \\
& Aðeins meiri & 25 & 3 & 28 \\
& Mun meiri & 16 & 19 & 35 \\
Samtals & & 59 & 26 & 85 \\
\hline \hline
\end{tabular}

Fylgni milli ávinningur/kostnaður og GSK mældist marktæk bæði með Sommers`d og samhverfu fylgnimæligildunum en prátt fyrir að hún teljist ekki sterk pá er hún sterkari en á milli ávinningur og GSK.

Tafla 320 Ósamhverf fylgnimæligildi: ávinningur/kostnaður, GSK

\begin{tabular}{|c|c|c|c|c|c|}
\hline & & Gildi & fervik $^{\mathrm{a}}$ & $\mathrm{T}^{\mathrm{b}}$ & Sig. \\
\hline \multirow{3}{*}{$\begin{array}{l}\text { Raðbreyta } \text { Somers'd } \\
\text { á móti } \\
\text { raðbreytu }\end{array}$} & Samhverft & ,316 & , 100 & 3,111 &, 002 \\
\hline & $\begin{array}{l}\text { ávinningur/kostnaður } \\
\text { svarbreyta }\end{array}$ & ,408 &, 126 & 3,111 & ,002 \\
\hline & GSK svarbreyta & ,258 & ,086 & 3,111 &, 002 \\
\hline
\end{tabular}

a. Not assuming the null hypothesis.

b. Using the asymptotic standard error assuming the null hypothesis.

Tafla 321 Samhverf fylgnimaligildi: ávinningur/kostnaður, GSK

\begin{tabular}{llcccc}
\hline \hline & & Gildi & fervik $^{\mathrm{a}}$ & $\mathrm{T}^{\mathrm{b}}$ & Sig. \\
\hline Raðbreyta á & Kendall's tau-c &, 347 &, 111 & 3,111 &, 002 \\
móti & Gamma &, 559 &, 168 & 3,111 &, 002 \\
raðbreytu & Spearman fylgnistuðull &, 347 &, 109 & 3,366 & $.001^{\mathrm{c}}$ \\
N af gildum tilfellum & 85 & & & \\
\hline \hline
\end{tabular}

a. Not assuming the null hypothesis.

b. Using the asymptotic standard error assuming the null hypothesis.

c. Based on normal approximation. 


\subsubsection{Fylgni: rekstrarafkoma, GSK}

Fylgni milli rekstrarafkoma (hvort verktaki teldi að rekstrarafkoma fyrirtcekja breytist með innleiðingu gœðastjórnunarkerfis) og GSK (hvort verkkaupi starfi eftir gaeðastjórnunarkerfi byggðu á viðurkenndum gaðastjórnunarstaðli) var skoðuð. 86 tilfellin flokkast undir gild tilfelli.

Tafla 322 Yfirlit tilfella í greiningu milli rekstrarafkoma og GSK

\begin{tabular}{|c|c|c|c|c|c|c|}
\hline & \multicolumn{6}{|c|}{ Tilfelli } \\
\hline & \multicolumn{2}{|c|}{ Gild } & \multicolumn{2}{|c|}{ Vantar } & \multicolumn{2}{|c|}{ Samtals } \\
\hline & $\mathrm{N}$ & Hlutfall & $\mathrm{N}$ & Hlutfall & $\mathrm{N}$ & Hlutfall \\
\hline rekstrarafkoma * GSK & 86 & $89.6 \%$ & 10 & $10.4 \%$ & 96 & $100.0 \%$ \\
\hline
\end{tabular}

Tafla 323 Tengslatafla (tíðni): rekstrarafkoma * GSK

\begin{tabular}{llccc}
\hline \hline & & \multicolumn{2}{c}{ GSK } & \\
\cline { 3 - 4 } & & $\begin{array}{c}\text { Nei, veit ekki eða } \\
\text { ekki byggt á stöðlum }\end{array}$ & $\begin{array}{c}\text { Já eða í } \\
\text { innleiðingu }\end{array}$ & Samtals \\
\hline rekstrarafkoma & Hvorki batni né versni & 18 & 3 & 21 \\
& Batni & 35 & 9 & 44 \\
Samtals & Batni til muna & 7 & 14 & 21 \\
\hline \hline
\end{tabular}

Fylgni milli rekstrarafkoma og GSK reyndist mjög marktæk hvort sem notast var við Sommers‘d eða samhverfu fylgnistuðlana. Segja má að fylgnin sé tæplega miðlungs sterk.

Tafla 324 Ósamhverf fylgnimæligildi: rekstrarafkoma, GSK

\begin{tabular}{|c|c|c|c|c|c|}
\hline & & Gildi & fervik $^{a}$ & $\mathrm{~T}^{\mathrm{b}}$ & Sig. \\
\hline \multirow{3}{*}{$\begin{array}{l}\text { Raðbreyta } \\
\text { á móti } \\
\text { raðbreytu }\end{array}$} & Samhverft & ,372 & ,093 & 3,733 &, 000 \\
\hline & $\begin{array}{l}\text { rekstrarafkoma } \\
\text { svarbreyta }\end{array}$ & ,458 &, 115 & 3,733 &, 000 \\
\hline & GSK svarbreyta & ,312 & ,081 & 3,733 &, 000 \\
\hline
\end{tabular}

a. Not assuming the null hypothesis.

b. Using the asymptotic standard error assuming the null hypothesis.

Tafla 325 Samhverf fylgnimaligildi: rekstrarafkoma, GSK

\begin{tabular}{llcccc}
\hline \hline & & Gildi & fervik $^{\mathrm{a}}$ & $\mathrm{T}^{\mathrm{b}}$ & Sig. \\
\hline Raðbreyta á & Kendall's tau-c &, 387 &, 104 & 3,733 &, 000 \\
móti & Gamma &, 654 &, 140 & 3,733 &, 000 \\
raðbreytu & Spearman fylgnistuðull &, 399 &, 100 & 3,982 & $.000^{\mathrm{c}}$ \\
N af gildum tilfellum & 86 & & & \\
\hline \hline
\end{tabular}

a. Not assuming the null hypothesis.

b. Using the asymptotic standard error assuming the null hypothesis.

c. Based on normal approximation. 


\subsubsection{Fylgni: samkeppnishæfi, GSK}

Fylgni milli samkeppnishœefi (hvort verktaki teldi að samkeppnishœfi fyrirtoekja sé meiri/minni eftir innleiðingu gaðastjórnunarkerfis) og GSK (hvort verkkaupi starfi eftir gœðastjórnunarkerfi byggðu á viðurkenndum gœðastjórnunarstaðli) var skoðuð. 84 tilfellin flokkast undir gild tilfelli.

Tafla 326 Yfirlit tilfella í greiningu milli samkeppnishaefi og GSK

\begin{tabular}{lccccccc}
\hline \hline & \multicolumn{9}{c}{ Tilfelli } \\
\cline { 2 - 7 } & \multicolumn{2}{c}{ Gild } & \multicolumn{2}{c}{ Vantar } & \multicolumn{2}{c}{ Samtals } \\
\cline { 2 - 7 } & $\mathrm{N}$ & Hlutfall & $\mathrm{N}$ & Hlutfall & $\mathrm{N}$ & Hlutfall \\
\hline samkeppnishæfi $*$ & 84 & $87.5 \%$ & 12 & $12.5 \%$ & 96 & $100.0 \%$ \\
GSK & & & & & & & \\
\hline \hline
\end{tabular}

Tafla 327 Tengslatafla (tíðni): samkeppnishaefi * GSK

\begin{tabular}{llccc}
\hline \hline & \multicolumn{3}{c}{ GSK } \\
\cline { 3 - 4 } & $\begin{array}{c}\text { Nei, veit ekki eða } \\
\text { ekki byggt á stöðlum }\end{array}$ & $\begin{array}{c}\text { Já eða í } \\
\text { innleiðingu }\end{array}$ & Samtals \\
\hline samkeppnishæfi & Hvorki meiri né minni & 11 & 2 & 13 \\
& Aðeins meiri & 36 & 5 & 41 \\
& Mun meiri & 13 & 17 & 30 \\
Samtals & 60 & 24 & 84 \\
\hline \hline
\end{tabular}

Fylgni milli samkeppnishœefi og GSK reyndist mjög marktæk hvort sem notast var við Sommers'd eða samhverfu fylgnistuðlana. Segja má að fylgnin sé tæplega miðlungs sterk, en engu að síður ögn sterkari en milli rekstarafkoma og GSK.

Tafla 328 Ósamhverf fylgnimæligildi: samkeppnishaefi, GSK

\begin{tabular}{|c|c|c|c|c|c|}
\hline & & Gildi & fervik $^{\mathrm{a}}$ & $\mathrm{T}^{\mathrm{b}}$ & Sig. \\
\hline \multirow{3}{*}{$\begin{array}{l}\text { Raðbreyta } \\
\text { á móti } \\
\text { raðbreytu }\end{array}$} & Samhverft & ,385 &, 097 & 3,764 &, 000 \\
\hline & $\begin{array}{l}\text { samkeppnishæfi } \\
\text { svarbreyta }\end{array}$ & ,480 &, 117 & 3,764 & ,000 \\
\hline & GSK svarbreyta & ,321 &, 086 & 3,764 & ,000 \\
\hline
\end{tabular}

a. Not assuming the null hypothesis.

b. Using the asymptotic standard error assuming the null hypothesis. 
Tafla 329 Samhverf fylgnimaligildi: samkeppnishaefi, GSK

\begin{tabular}{|c|c|c|c|c|c|}
\hline & & Gildi & fervik $^{a}$ & $\mathrm{~T}^{\mathrm{b}}$ & Sig. \\
\hline Raðbreyta á & Kendall's tau-c & ,392 &, 104 & 3,764 & ,000 \\
\hline móti & Gamma & 679 & 144 & 3,764 &, 000 \\
\hline raðbreytu & Spearman fylgnistuðull & 411 &, 103 & 4,083 & $.000^{\mathrm{c}}$ \\
\hline \multicolumn{2}{|c|}{$\mathrm{N}$ af gildum tilfellum } & 84 & & & \\
\hline
\end{tabular}

a. Not assuming the null hypothesis.

b. Using the asymptotic standard error assuming the null hypothesis.

c. Based on normal approximation.

\subsubsection{Fylgni: áhrif_á_frábrigði, GSK}

Fylgni milli áhrif_á frábrigði (hvort verktaki teldi að frábrigðum myndi fjölga/fcekka með innleiðingu gœðastjórnunarkerfis) og GSK (hvort verkkaupi starfi eftir gaðastjórnunarkerfi byggðu á viðurkenndum gœðastjórnunarstaðli) var skoðuð. 77 tilfelli flokkast undir gild tilfelli.

Tafla 330 Yfirlit tilfella í greiningu milli áhrif_á_frábrigði og GSK

\begin{tabular}{lccccccc}
\hline \hline & \multicolumn{9}{c}{ Tilfelli } \\
\cline { 2 - 8 } & \multicolumn{2}{c}{ Gild } & \multicolumn{2}{c}{ Vantar } & \multicolumn{2}{c}{ Samtals } \\
\cline { 2 - 8 } & $\mathrm{N}$ & Hlutfall & $\mathrm{N}$ & Hlutfall & $\mathrm{N}$ & Hlutfall \\
\hline $\begin{array}{l}\text { áhrif_á_frábrigði* } \\
\text { GSK }\end{array}$ & 77 & $80.2 \%$ & 19 & $19.8 \%$ & 96 & $100.0 \%$ \\
\hline \hline
\end{tabular}

Tafla 331 Tengslatafla (tỉðni): áhrif_á_frábrigði, GSK

\begin{tabular}{llccc}
\hline \hline & & \multicolumn{2}{c}{ GSK } & \\
\cline { 3 - 4 } & & $\begin{array}{c}\text { Nei, veit ekki eða } \\
\text { ekki byggt á stöðlum }\end{array}$ & Já eða í innleiðingu & Samtals \\
\hline áhrif_á_frábrigði & Mun fleiri & 2 & 0 & 2 \\
& Aðeins fleiri & 7 & 2 & 9 \\
& Hvorki fleiri né & 22 & 1 & 23 \\
& færri & & 3 & 11 \\
& Aðeins færri & 13 & 19 & 32 \\
Samtals & Mun færri & 52 & 25 & 77 \\
\hline \hline
\end{tabular}

Fylgni milli áhrif_á_frábrigði og GSK reyndist mjög marktæk hvort sem notast var við Sommers'd eða samhverfu fylgnistuðlana. Fylgnin er rétt tæplega miðlungs sterk. 


\begin{tabular}{|c|c|c|c|c|c|}
\hline & & Gildi & fervik $^{\mathrm{a}}$ & $\mathrm{T}^{\mathrm{b}}$ & Sig. \\
\hline \multirow{3}{*}{$\begin{array}{l}\text { Raðbreyta } \\
\text { á móti } \\
\text { raðbreytu }\end{array}$} & Samhverft & ,414 & ,088 & 4,514 &, 000 \\
\hline & $\begin{array}{l}\text { áhrif_á_frábrigði } \\
\text { svarbreyta }\end{array}$ & ,539 &, 110 & 4,514 & ,000 \\
\hline & GSK svarbreyta & ,336 & ,078 & 4,514 &, 000 \\
\hline
\end{tabular}

a. Not assuming the null hypothesis.

b. Using the asymptotic standard error assuming the null hypothesis.

Tafla 333 Samhverf fylgnimæligildi: áhrif_á_frábrigði, GSK

\begin{tabular}{llcccc}
\hline \hline & & Gildi & fervik $^{\mathrm{a}}$ & $\mathrm{T}^{\mathrm{b}}$ & Sig. \\
\hline Raðbreyta á & Kendall's tau-c &, 473 &, 105 & 4,514 &, 000 \\
móti & Gamma &, 706 &, 130 & 4,514 &, 000 \\
raðbreytu & Spearman fylgnistuðull &, 462 &, 097 & 4,508 & $.000^{\mathrm{c}}$ \\
N af gildum tilfellum & 77 & & & \\
\hline \hline
\end{tabular}

a. Not assuming the null hypothesis.

b. Using the asymptotic standard error assuming the null hypothesis.

c. Based on normal approximation.

\subsubsection{Fylgni: mannafli, GSK}

Fylgni milli mannafli (hvort verktaki teldi að nýting mannafla myndi batna/versna með innleiðingu gœðastjórnunarkerfis) og GSK (hvort verkkaupi starfi eftir gaðastjórnunarkerfi byggðu á viðurkenndum gœðastjórnunarstaðli) var skoðuð. 85 tilfelli flokkast undir gild tilfelli.

Tafla 334 Yfirlit tilfella í greiningu milli mannafli og GSK

\begin{tabular}{lccccccc}
\hline \hline & \multicolumn{6}{c}{ Tilfelli } \\
\cline { 2 - 8 } & \multicolumn{2}{c}{ Gild } & \multicolumn{2}{c}{ Vantar } & \multicolumn{2}{c}{ Samtals } \\
\cline { 2 - 8 } & $\mathrm{N}$ & Hlutfall & $\mathrm{N}$ & Hlutfall & $\mathrm{N}$ & Hlutfall \\
\hline mannafli * GSK & 85 & $88.5 \%$ & 11 & $11.5 \%$ & 96 & $100.0 \%$ \\
\hline \hline
\end{tabular}

Tafla 335 Tengslatafla (tíðni): mannafli * GSK

\begin{tabular}{llccc}
\hline \hline & \multicolumn{2}{c}{ GSK } & \\
\cline { 3 - 4 } & & $\begin{array}{c}\text { Nei, veit ekki eða ekki } \\
\text { byggt á stöðlum }\end{array}$ & $\begin{array}{c}\text { Já eða í } \\
\text { innleiðingu }\end{array}$ & Samtals \\
\hline mannafli & Mun verri & 1 & 0 & 1 \\
& Aðeins verri & 0 & 2 & 2 \\
& Hvorki betri né verri & 15 & 4 & 19 \\
& Aðeins betri & 27 & 9 & 36 \\
& Mun betri & 18 & 9 & 27 \\
Samtals & 61 & 24 & 85 \\
\hline \hline
\end{tabular}


Fylgni milli mannafli og GSK reyndist ekki vera marktæk hvort sem notast var við Sommers ‘d eða samhverfu fylgnistuðlana.

Tafla 336 Ósamhverf fylgnimæligildi: mannafli, GSK

\begin{tabular}{|c|c|c|c|c|c|c|}
\hline & & & Gildi & fervik ${ }^{a}$ & $\mathrm{~T}^{\mathrm{b}}$ & Sig. \\
\hline \multirow{3}{*}{\multicolumn{2}{|c|}{$\begin{array}{l}\text { Raðbreyta } \\
\text { á móti } \\
\text { raðbreytu }\end{array}$}} & Samhverft & ,039 &, 103 & ,376 & ,707 \\
\hline & & $\begin{array}{l}\text { mannafli } \\
\text { svarbreyta }\end{array}$ & ,051 & , 136 & ,376 & ,707 \\
\hline & & $\begin{array}{l}\text { GSK } \\
\text { svarbreyta }\end{array}$ & ,031 & ,083 & ,376 & ,707 \\
\hline
\end{tabular}

a. Not assuming the null hypothesis.

b. Using the asymptotic standard error assuming the null hypothesis.

Tafla 337 Samhverf fylgnimæligildi: mannafli, GSK

\begin{tabular}{llcccc}
\hline \hline & & Gildi & fervik $^{\mathrm{a}}$ & $\mathrm{T}^{\mathrm{b}}$ & Sig. \\
\hline Raðbreyta á & Kendall's tau-c &, 042 &, 110 &, 376 &, 707 \\
móti & Gamma &, 075 &, 200 &, 376 &, 707 \\
raðbreytu & Spearman fylgnistuðull &, 043 &, 113 &, 388 & $.699^{\mathrm{c}}$ \\
N af gildum tilfellum & 85 & & & \\
\hline \hline
\end{tabular}

a. Not assuming the null hypothesis.

b. Using the asymptotic standard error assuming the null hypothesis.

c. Based on normal approximation.

\subsubsection{Fylgni: trú, GSK}

Fylgni milli trú (hvort verktaki hefði trú á gaeðastjórnun i byggingaiðnaði) og GSK (hvort verkkaupi starfi eftir gæðastjórnunarkerfi byggðu á viðurkenndum gœðastjórnunarstaðli) var skoðuð. 88 tilfelli flokkast undir gild tilfelli.

Tafla 338 Yfirlit tilfella í greiningu milli trú og GSK

\begin{tabular}{lcccccc}
\hline \hline & \multicolumn{7}{c}{ Tilfelli } \\
\cline { 2 - 7 } & \multicolumn{2}{c}{ Gild } & \multicolumn{2}{c}{ Vantar } & \multicolumn{2}{c}{ Samtals } \\
\cline { 2 - 7 } & $\mathrm{N}$ & Hlutfall & $\mathrm{N}$ & Hlutfall & $\mathrm{N}$ & Hlutfall \\
\hline trú* GSK & 88 & $91.7 \%$ & 8 & $8.3 \%$ & 96 & $100.0 \%$ \\
\hline \hline
\end{tabular}




\begin{tabular}{llccc}
\hline \hline & \multicolumn{2}{c}{ GSK } & \\
\cline { 3 - 4 } & $\begin{array}{c}\text { Nei, veit ekki eða ekki } \\
\text { byggt á stöðlum }\end{array}$ & $\begin{array}{c}\text { Já eða í } \\
\text { innleiðingu }\end{array}$ & Samtals \\
\hline trú & Frekar litla & 2 & 1 & 3 \\
& Hvorki mikla né & 10 & 2 & 12 \\
& & & \\
litla & 33 & 5 & 38 \\
& Frekar mikla & 18 & 17 & 35 \\
Mikla & 63 & 25 & 88 \\
Samtals & &
\end{tabular}

Fylgni milli trú og GSK reyndist vera marktæk hvort sem notast var við Sommers'd eða samhverfu fylgnistuðlana en ekki ýkja sterk.

Tafla 340 Ósamhverf fylgnimæligildi: trú, $\mathbf{G S K}$

\begin{tabular}{|c|c|c|c|c|c|c|}
\hline & & & Gildi & fervik $^{\mathrm{a}}$ & $\mathrm{T}^{\mathrm{b}}$ & Sig. \\
\hline \multirow{3}{*}{$\begin{array}{l}\text { Raðbreyta } \\
\text { á móti } \\
\text { raðbreytu }\end{array}$} & \multirow[t]{3}{*}{ Somers' d } & Samhverft & ,285 & ,098 & 2,837 &, 005 \\
\hline & & trú svarbreyta & ,366 & 123 & 2,837 &, 005 \\
\hline & & $\begin{array}{l}\text { GSK } \\
\text { svarbreyta }\end{array}$ & ,234 & ,084 & 2,837 & ,005 \\
\hline
\end{tabular}

a. Not assuming the null hypothesis.

b. Using the asymptotic standard error assuming the null hypothesis.

Tafla 341 Samhverf fylgnimæligildi: trú, GSK

\begin{tabular}{llcccc}
\hline \hline & & Gildi & fervik $^{\mathrm{a}}$ & $\mathrm{T}^{\mathrm{b}}$ & Sig. \\
\hline Raðbreyta á & Kendall's tau-c &, 298 &, 105 & 2,837 &, 005 \\
móti & Gamma &, 532 &, 172 & 2,837 &, 005 \\
raðbreytu & Spearman fylgnistuðull &, 309 &, 106 & 3,014 & $.003^{\mathrm{c}}$ \\
N af gildum tilfellum & 88 & & & \\
\hline \hline
\end{tabular}

a. Not assuming the null hypothesis.

b. Using the asymptotic standard error assuming the null hypothesis.

c. Based on normal approximation. 


\subsubsection{Fylgni: skráningarkerfi, GSK}

Fylgni milli skráningarkerfi (hvort verktaki upplifði goðastjórnunarkerfi einungis sem skráningarkerfi) og GSK (hvort verkkaupi starfi eftir gaeðastjórnunarkerfi byggðu á viðurkenndum gæeðastjórnunarstaðli) var skoðuð. 89 tilfelli flokkast undir gild tilfelli.

\section{Tafla 342 Yfirlit tilfella í greiningu milli skráningarkerfi og GSK}

\begin{tabular}{|c|c|c|c|c|c|c|}
\hline & \multicolumn{6}{|c|}{ Tilfelli } \\
\hline & \multicolumn{2}{|c|}{ Gild } & \multicolumn{2}{|c|}{ Vantar } & \multicolumn{2}{|c|}{ Samtals } \\
\hline & $\mathrm{N}$ & Hlutfall & $\mathrm{N}$ & Hlutfall & $\mathrm{N}$ & Hlutfall \\
\hline $\begin{array}{l}\text { skráningarkerfi * } \\
\text { GSK }\end{array}$ & 89 & $92.7 \%$ & 7 & $7.3 \%$ & 96 & $100.0 \%$ \\
\hline
\end{tabular}

Tafla 343 Tengslatafla (tíðni): skráningarkerfi * GSK

\begin{tabular}{|c|c|c|c|}
\hline & \multicolumn{2}{|c|}{ GSK } & \multirow[b]{2}{*}{ Total } \\
\hline & $\begin{array}{l}\text { Nei, veit ekki eða } \\
\text { ekki byggt á stöðlum }\end{array}$ & Já eða í innleiðingu & \\
\hline skráningarkerfi J & 20 & 6 & 26 \\
\hline & 43 & 20 & 63 \\
\hline Total & 63 & 26 & 89 \\
\hline
\end{tabular}

Fylgni milli skráningarkerfi og GSK reyndist ekki vera marktæk hvort sem notast var við Sommers'd eða samhverfu fylgnistuðlana.

\section{Tafla 344 Ósamhverf fylgnimæligildi: skráningarkerfi, GSK}

\begin{tabular}{|c|c|c|c|c|c|}
\hline & & Gildi & fervik $^{\mathrm{a}}$ & $\mathrm{T}^{\mathrm{b}}$ & Sig. \\
\hline \multirow{3}{*}{$\begin{array}{l}\text { Raðbreyta } \\
\text { á móti } \\
\text { raðbreytu }\end{array}$} & Samhverft & ,087 & ,101 & ,853 & ,394 \\
\hline & $\begin{array}{l}\text { skráningarkerfi } \\
\text { svarbreyta }\end{array}$ & ,087 & , 101 & 853 & ,394 \\
\hline & GSK svarbreyta & 087 & 101 & 853 & ,394 \\
\hline
\end{tabular}

a. Not assuming the null hypothesis.

b. Using the asymptotic standard error assuming the null hypothesis.

Tafla 345 Samhverf fylgnimæligildi: skráningarkerfi, GSK

\begin{tabular}{llcccc}
\hline \hline & & Gildi & fervik $^{\mathrm{a}}$ & $\mathrm{T}^{\mathrm{b}}$ & Sig. \\
\hline Raðbreyta á & Kendall's tau-c &, 072 &, 084 &, 853 &, 394 \\
móti & Gamma &, 216 &, 257 &, 853 &, 394 \\
raðbreytu & Spearman fylgnistuðull &, 087 &, 101 &, 812 & $.419^{\mathrm{c}}$ \\
N af gildum tilfellum & 89 & & & \\
\hline \hline
\end{tabular}

a. Not assuming the null hypothesis.

b. Using the asymptotic standard error assuming the null hypothesis.

c. Based on normal approximation. 


\subsection{Gæðatrygging}

\subsubsection{Fylgni: gæðatrygging_verktaki, GSK}

Fylgni milli gaððtrygging_verktaki og GSK var skoðuð. 89 tilfelli flokkast undir gild tilfelli.

Tafla 346 Yfirlit tilfella í greiningu milli gaeðatrygging_verktaki og GSK

\begin{tabular}{lccccccc} 
& \multicolumn{6}{c}{ Tilfelli } \\
\cline { 2 - 8 } & \multicolumn{2}{c}{ Gild } & \multicolumn{2}{c}{ Vantar } & \multicolumn{2}{c}{ Samtals } \\
\cline { 2 - 8 } & $\mathrm{N}$ & Hlutfall & $\mathrm{N}$ & Hlutfall & $\mathrm{N}$ & Hlutfall \\
\hline gæðatrygging_verktaki & 82 & $85.4 \%$ & 14 & $14.6 \%$ & 96 & $100.0 \%$ \\
* GSK & & & & & & & \\
\hline \hline
\end{tabular}

Tafla 347 Tengslatafla (tíðni): gaððatrygging_verktaki * GSK

\begin{tabular}{llccc}
\hline \hline \multirow{2}{*}{} & & \multicolumn{2}{c}{ GSK } & \\
\cline { 3 - 4 } & & $\begin{array}{c}\text { Nei, veit ekki eða } \\
\text { ekki byggt á stöðlum }\end{array}$ & $\begin{array}{c}\text { Já eða í } \\
\text { innleiðingu }\end{array}$ & Samtals \\
\hline gæðatrygging & Aldrei & 22 & 1 & 23 \\
-verktaki & Einungis pegar um er beðið & 10 & 5 & 15 \\
& Sjaldan & 5 & 0 & 5 \\
& Stundum & 8 & 3 & 11 \\
& Oft & 11 & 9 & 20 \\
& Alltaf & 3 & 5 & 8 \\
Samtals & 59 & 23 & 82 \\
\hline \hline
\end{tabular}

Fylgni milli gœðatrygging_verktaki og GSK reyndist vera mjög marktæk hvort sem notast var við Sommers'd eða samhverfu fylgnistuðlana, en ekki mjög sterk.

Tafla 348 Ósamhverf fylgnimæligildi: gaðatrygging_verktaki, GSK

\begin{tabular}{|c|c|c|c|c|c|}
\hline & & Gildi & fervik $^{\mathrm{a}}$ & $\mathrm{T}^{\mathrm{b}}$ & Sig. \\
\hline \multirow{3}{*}{$\begin{array}{l}\text { Raðbreyta Somers'd } \\
\text { á móti } \\
\text { raðbreytu }\end{array}$} & Samhverft & 329 & ,078 & 3,936 & ,000 \\
\hline & $\begin{array}{l}\text { gæðatrygging_verktaki } \\
\text { svarbreyta }\end{array}$ & ,490 & ,113 & 3,936 &, 000 \\
\hline & GSK svarbreyta & ,248 &, 063 & 3,936 &, 000 \\
\hline
\end{tabular}

a. Not assuming the null hypothesis.

b. Using the asymptotic standard error assuming the null hypothesis. 
Tafla 349 Samhverf fylgnimæligildi: gaðatrygging_verktaki, GSK

\begin{tabular}{|c|c|c|c|c|c|}
\hline & & Gildi & fervik $^{\mathrm{a}}$ & $\mathrm{T}^{\mathrm{b}}$ & Sig. \\
\hline \multirow{3}{*}{$\begin{array}{l}\text { Raðbreyta á } \\
\text { móti } \\
\text { raðbreytu }\end{array}$} & Kendall's tau-c & ,396 &, 100 & 3,936 & ,000 \\
\hline & Gamma & ,580 & 123 & 3,936 &, 000 \\
\hline & Spearman fylgnistuðull & ,390 & 092 & 3,793 & $.000^{\mathrm{c}}$ \\
\hline \multicolumn{2}{|c|}{$\mathrm{N}$ af gildum tilfellum } & 82 & & & \\
\hline
\end{tabular}

a. Not assuming the null hypothesis.

b. Using the asymptotic standard error assuming the null hypothesis.

c. Based on normal approximation.

\subsubsection{Fylgni: gæðatrygging_ósk, GSK}

Fylgni milli gaððatrygging_ósk (hversu oft verkkaupar foeru fram á gaððatryggingu frá verktaka) og GSK (hvort verkkaupi starfi eftir gœðastjórnunarkerfi byggðu á viðurkenndum gœðastjórnunarstaðli) var skoðuð. 74 tilfelli flokkast undir gild tilfelli.

Tafla 350 Yfirlit tilfella í greiningu milli gaeðatrygging_ósk og GSK

\begin{tabular}{lccccccc}
\hline \hline & \multicolumn{9}{c}{ Tilfelli } \\
\cline { 2 - 7 } & \multicolumn{2}{c}{ Gild } & \multicolumn{2}{c}{ Vantar } & \multicolumn{2}{c}{ Samtals } \\
\cline { 2 - 8 } & $\mathrm{N}$ & Hlutfall & $\mathrm{N}$ & Hlutfall & $\mathrm{N}$ & Hlutfall \\
\hline gæðatrygging_ósk * & 74 & $77.1 \%$ & 22 & $22.9 \%$ & 96 & $100.0 \%$ \\
GSK & & & & & & & \\
\hline \hline
\end{tabular}

Tafla 351 Tengslatafla (tíðni): gaeðatrygging_ósk * GSK

\begin{tabular}{llccc}
\hline \hline & & \multicolumn{2}{c}{ GSK } & \\
\cline { 3 - 4 } & & $\begin{array}{c}\text { Nei, veit ekki eða } \\
\text { ekki byggt á stöðlum }\end{array}$ & $\begin{array}{c}\text { Já eða í } \\
\text { innleiðingu }\end{array}$ & Samtals \\
\hline gæðatrygging_ósk & Aldrei & 24 & 4 & 28 \\
& Mjög sjaldan & 14 & 1 & 15 \\
& Frekar sjaldan & 5 & 4 & 9 \\
& Hvorki oft né sjaldan & 4 & 8 & 12 \\
& Frekar oft & 6 & 2 & 8 \\
Samtals & Mjög oft & 0 & 2 & 2 \\
\hline \hline
\end{tabular}

Fylgni milli gœeðatrygging_ósk og GSK reyndist vera marktæk hvort sem notast var við Sommers'd eða samhverfu fylgnistuðlana, en ekki mjög sterk. 
Tafla 352 Ósamhverf fylgnimæligildi: gaðatrygging_ósk, GSK

\begin{tabular}{|c|c|c|c|c|c|}
\hline & & Gildi & fervik $^{\mathrm{a}}$ & $\mathrm{T}^{\mathrm{b}}$ & Sig. \\
\hline \multirow{3}{*}{$\begin{array}{l}\text { Raðbreyta } \\
\text { á móti } \\
\text { raðbreytu }\end{array}$} & Samhverft & ,313 & ,093 & 3,191 &, 001 \\
\hline & $\begin{array}{l}\text { gæðatrygging_ósk } \\
\text { svarbreyta }\end{array}$ & ,450 & 132 & 3,191 &, 001 \\
\hline & GSK svarbreyta & ,240 &, 074 & 3,191 &, 001 \\
\hline
\end{tabular}

a. Not assuming the null hypothesis.

b. Using the asymptotic standard error assuming the null hypothesis.

Tafla 353 Samhverf fylgnimaligildi: gaeðatrygging_ósk, GSK

\begin{tabular}{llcccc}
\hline \hline & & Gildi & fervik $^{\mathrm{a}}$ & $\mathrm{T}^{\mathrm{b}}$ & Sig. \\
\hline Raðbreyta á & Kendall's tau-c &, 366 &, 115 & 3,191 &, 001 \\
móti & Gamma &, 534 &, 139 & 3,191 &, 001 \\
raðbreytu & Spearman fylgnistuðull &, 364 &, 108 & 3,321 & $.001^{\mathrm{c}}$ \\
N af gildum tilfellum & 74 & & & \\
\hline \hline
\end{tabular}

a. Not assuming the null hypothesis.

b. Using the asymptotic standard error assuming the null hypothesis.

c. Based on normal approximation.

\subsubsection{Fylgni: gæðatrygging_undirverkt, GSK}

Fylgni milli gaðatrygging_undirverkt (hvort verktakar faeru fram á goeðatryggingu frá undirverktökum) og GSK (hvort verkkaupi starfi eftir gœðastjórnunarkerfi byggðu á viðurkenndum gaðastjórnunarstaðli) var skoðuð. 74 tilfelli flokkast undir gild tilfelli.

\section{Tafla 354 Yfirlit tilfella í greiningu milli gaeðatrygging_undirverkt og GSK}

\begin{tabular}{lccccccr}
\hline \hline & \multicolumn{6}{c}{ Tilfelli } \\
\cline { 2 - 8 } & \multicolumn{4}{c}{ Gild } & \multicolumn{2}{c}{ Vantar } & \multicolumn{2}{c}{ Samtals } \\
\cline { 2 - 8 } & $\mathrm{N}$ & Hlutfall & $\mathrm{N}$ & Hlutfall & $\mathrm{N}$ & Hlutfall \\
\hline gæðatrygging_undirverkt * GSK & 80 & $83.3 \%$ & 16 & $16.7 \%$ & 96 & $100.0 \%$ \\
\hline \hline
\end{tabular}

Tafla 355 Tengslatafla (tíðni): gaeðatrygging_undirverkt * GSK

\begin{tabular}{llccc}
\hline \hline \multicolumn{1}{c}{} & \multicolumn{3}{c}{ GSK } & \\
\cline { 3 - 4 } & & $\begin{array}{c}\text { Nei, veit ekki eða } \\
\text { ekki byggt á } \\
\text { stöðlum }\end{array}$ & $\begin{array}{c}\text { Já eða í } \\
\text { innleiðingu }\end{array}$ & Samtals \\
\hline gæðatrygging_undirverkt & Aldrei & 35 & 4 & 39 \\
& Sjaldan & 11 & 7 & 18 \\
& Stundum & 5 & 9 & 14 \\
& Oft & 4 & 3 & 7 \\
Samtals & Alltaf & 1 & 1 & 2 \\
\hline \hline
\end{tabular}

Fylgni milli gaðatrygging_undirverktog GSK reyndist vera mjög marktæk hvort sem notast var við Sommers'd eða samhverfu fylgnistuðlana, og rétt tæplega miðlungs sterk. 
Tafla 356 Ósamhverf fylgnimaligildi: gaððatrygging_undirverkt, GSK

\begin{tabular}{|c|c|c|c|c|c|}
\hline & & Gildi & fervik $^{\mathrm{a}}$ & $\mathrm{T}^{\mathrm{b}}$ & Sig. \\
\hline \multirow{3}{*}{$\begin{array}{l}\text { Raðbreyta } \\
\text { á móti } \\
\text { raðbreytu }\end{array}$} & Samhverft &, 380 & ,089 & 4,063 &, 000 \\
\hline & $\begin{array}{l}\text { gæðatrygging_undirverkt } \\
\text { svarbreyta }\end{array}$ & ,495 &, 112 & 4,063 &, 000 \\
\hline & GSK svarbreyta & ,309 & ,077 & 4,063 &, 000 \\
\hline
\end{tabular}

a. Not assuming the null hypothesis.

b. Using the asymptotic standard error assuming the null hypothesis.

Tafla 357 Samhverf fylgnimaligildi: gaðdrygging_undirverkt, GSK

\begin{tabular}{llcccc}
\hline \hline & & Gildi & fervik $^{\mathrm{a}}$ & $\mathrm{T}^{\mathrm{b}}$ & Sig. \\
\hline Raðbreyta á & Kendall's tau-c &, 416 &, 102 & 4,063 &, 000 \\
móti & Gamma &, 622 &, 117 & 4,063 &, 000 \\
raðbreytu & Spearman fylgnistuðull &, 422 &, 098 & 4,109 & $.000^{\mathrm{c}}$ \\
N af gildum tilfellum & 80 & & & \\
\hline \hline
\end{tabular}

a. Not assuming the null hypothesis.

b. Using the asymptotic standard error assuming the null hypothesis.

c. Based on normal approximation.

\subsection{Pekking á gæðastjórnun}

Tafla 358 Samantekt á marktoekri fylgni pekkingar við GSK

\begin{tabular}{|c|c|c|c|c|c|}
\hline \multirow[b]{4}{*}{ ÍST30 } & \multicolumn{4}{|c|}{ GSK } & \multirow[b]{3}{*}{$\mathrm{N}$} \\
\hline & \multicolumn{2}{|c|}{ Gamma } & \multicolumn{2}{|c|}{ Spearman's rho } & \\
\hline & Fylgnistuðull & Sig. & Fylgnistuðull & Sig. & \\
\hline &, 742 &, 000 & 0,489 & ,000 & 84 \\
\hline almennt & ,719 &, 000 & 0,462 &, 000 & 85 \\
\hline ISO9001 & 680 &, 000 & 0,476 &, 000 & 85 \\
\hline
\end{tabular}

\subsubsection{Fylgni: almennt, GSK}

Fylgni milli almennt (hvort verktakar hefðu kynnt sér gæeðastjórnun almennt) og GSK (hvort verkkaupi starfi eftir gœðastjórnunarkerfi byggðu á viðurkenndum gœðastjórnunarstaðli) var skoðuð. 85 tilfelli flokkast undir gild tilfelli.

\section{Tafla 359 Yfirlit tilfella í greiningu milli almennt og GSK}

\begin{tabular}{lccccccc}
\hline \hline & \multicolumn{9}{c}{ Tilfelli } \\
\cline { 2 - 8 } & \multicolumn{3}{c}{ Gild } & \multicolumn{2}{c}{ Vantar } & \multicolumn{2}{c}{ Samtals } \\
\cline { 2 - 8 } & $\mathrm{N}$ & Hlutfall & $\mathrm{N}$ & Hlutfall & $\mathrm{N}$ & Hlutfall \\
\hline almennt * GSK & 85 & $88.5 \%$ & 11 & $11.5 \%$ & 96 & $100.0 \%$ \\
\hline \hline
\end{tabular}




\begin{tabular}{llccc}
\hline \hline & & \multicolumn{2}{c}{ GSK } & \\
\cline { 3 - 4 } & & $\begin{array}{c}\text { Nei, veit ekki eða ekki } \\
\text { byggt á stöðlum }\end{array}$ & $\begin{array}{c}\text { Já eða í } \\
\text { innleiðingu }\end{array}$ & Samtals \\
\hline almennt & Ekkert & 11 & 0 & 11 \\
& Mjög lítið & 9 & 1 & 10 \\
& Frekar lítið & 8 & 2 & 10 \\
& Nokkuð & 26 & 10 & 36 \\
& Frekar mikið & 6 & 8 & 14 \\
& Mjög mikið & 0 & 4 & 4 \\
Samtals & & 60 & 25 & 85 \\
\hline \hline
\end{tabular}

Fylgni milli gaeðatrygging undirverkt og GSK reyndist vera mjög marktæk hvort sem notast var við Sommers‘d eða samhverfu fylgnistuðlana, og rétt tæplega miðlungs sterk.

Tafla 361 Ósamhverf fylgnimæligildi: almennt, $\mathbf{G S K}$

\begin{tabular}{|c|c|c|c|c|c|c|}
\hline & & & Gildi & fervik $^{\mathrm{a}}$ & $\bar{T}^{b}$ & Sig. \\
\hline \multirow{3}{*}{\multicolumn{2}{|c|}{$\begin{array}{l}\text { Raðbreyta } \\
\text { á móti } \\
\text { raðbreytu }\end{array}$}} & Samhverft & 4,400 & ,070 & 4,948 & $\overline{, 000}$ \\
\hline & & $\begin{array}{l}\text { almennt } \\
\text { svarbreyta }\end{array}$ & ,559 & ,099 & 4,948 &, 000 \\
\hline & & $\begin{array}{l}\text { GSK } \\
\text { svarbreyta }\end{array}$ & ,311 & 059 & 4,948 & ,000 \\
\hline
\end{tabular}

a. Not assuming the null hypothesis.

b. Using the asymptotic standard error assuming the null hypothesis.

Tafla 362 Samhverf fylgnimaligildi: almennt, $\mathbf{G S K}$

\begin{tabular}{llcccc}
\hline \hline & Gildi & fervik $^{\mathrm{a}}$ & $\mathrm{T}^{\mathrm{b}}$ & Sig. \\
\hline Raðbreyta á & Kendall's tau-c &, 464 &, 094 & 4,948 &, 000 \\
móti & Gamma &, 719 &, 109 & 4,948 &, 000 \\
raðbreytu & Spearman fylgnistuðull &, 462 &, 082 & 4,742 & $.000^{\mathrm{c}}$ \\
N af gildum tilfellum & 85 & & & \\
\hline \hline
\end{tabular}

a. Not assuming the null hypothesis.

b. Using the asymptotic standard error assuming the null hypothesis.

c. Based on normal approximation.

\subsubsection{Fylgni: ÍST30, GSK}

Fylgni milli ÍST30 (hvort verktaki hefði kynnt sér innihald samskiptastaðalsins ÍST 30) og GSK (hvort verkkaupi starfi eftir goeðastjórnunarkerfi byggðu á viðurkenndum gœeðastjórnunarstaðli) var skoðuð. 84 tilfelli flokkast undir gild tilfelli. 


\begin{tabular}{|c|c|c|c|c|c|c|}
\hline & & & Tilt & & & \\
\hline & $\mathrm{Gi}$ & & Val & & Sam & als \\
\hline & $\mathrm{N}$ & Hlutfall & $\mathrm{N}$ & Hlutfall & $\mathrm{N}$ & Hlutfall \\
\hline ÍST30 * GSK & 84 & $87.5 \%$ & 12 & $12.5 \%$ & 96 & $100.0 \%$ \\
\hline
\end{tabular}

Tafla 364 Tengslatafla (tỉðni): ÍST30 * GSK

\begin{tabular}{clccc}
\hline \hline & & \multicolumn{2}{c}{ GSK } & \\
\cline { 3 - 4 } & & $\begin{array}{c}\text { Nei, veit ekki eða ekki } \\
\text { byggt á stöðlum }\end{array}$ & $\begin{array}{c}\text { Já eða í } \\
\text { innleiðingu }\end{array}$ & Samtals \\
\hline ÍST30 & Ekkert & 13 & 0 & 13 \\
& Mjög lítið & 8 & 1 & 9 \\
& Frekar lítið & 9 & 1 & 10 \\
& Nokkuð & 22 & 7 & 29 \\
& Frekar mikið & 7 & 8 & 15 \\
& Mjög mikið & 2 & 6 & 8 \\
Samtals & 61 & 23 & 84 \\
\hline \hline
\end{tabular}

Fylgni milli ÍST30 og GSK reyndist vera mjög marktæk hvort sem notast var við Sommers‘d eða samhverfu fylgnistuðlana, og rétt tæplega miðlungs sterk.

Tafla 365 Ósamhverf fylgnimaligildi: ÍST30, GSK

\begin{tabular}{|c|c|c|c|c|c|}
\hline & & Gildi & fervik $^{\mathrm{a}}$ & $\mathrm{T}^{\mathrm{b}}$ & Sig. \\
\hline \multirow{3}{*}{$\begin{array}{l}\text { Raðbreyta } \\
\text { á móti } \\
\text { raðbreytu }\end{array}$} & Samhverft & 4,412 & ,067 & 5,218 &, 000 \\
\hline & $\begin{array}{l}\text { ÍST30 } \\
\text { svarbreyta }\end{array}$ & ,616 & ,096 & 5,218 & ,000 \\
\hline & $\begin{array}{l}\text { GSK } \\
\text { svarbreyta }\end{array}$ & ,310 & ,058 & 5,218 & ,000 \\
\hline
\end{tabular}

a. Not assuming the null hypothesis.

b. Using the asymptotic standard error assuming the null hypothesis.

Tafla 366 Samhverf fylgnimaligildi: ÍST30, GSK

\begin{tabular}{llcccc}
\hline \hline & & Gildi & fervik $^{\mathrm{a}}$ & $\mathrm{T}^{\mathrm{b}}$ & Sig. \\
\hline Raðbreyta á & Kendall's tau-c &, 490 &, 094 & 5,218 &, 000 \\
móti & Gamma &, 742 &, 099 & 5,218 &, 000 \\
raðbreytu & Spearman fylgnistuðull &, 489 &, 080 & 5,078 & $.000^{\mathrm{c}}$ \\
N af gildum tilfellum & 84 & & & \\
\hline \hline
\end{tabular}

a. Not assuming the null hypothesis.

b. Using the asymptotic standard error assuming the null hypothesis.

c. Based on normal approximation. 


\subsubsection{Fylgni: ISO9001, GSK}

Fylgni milli ISO9001 (hvort verktaki hefði kynnt sér innihald geððastjórnunarstaðalsins ISO 9001) og GSK (hvort verkkaupi starfi eftir gaeðastjórnunarkerfi byggðu á viðurkenndum gaððastjórnunarstaðli) var skoðuð. 85 tilfelli flokkast undir gild tilfelli.

\section{Tafla 367 Yfirlit tilfella í greiningu milli ISO9001 og GSK}

\begin{tabular}{lcccccc}
\hline \hline & \multicolumn{6}{c}{ Tilfelli } \\
\cline { 2 - 8 } & \multicolumn{2}{c}{ Gild } & \multicolumn{2}{c}{ Vantar } & \multicolumn{2}{c}{ Samtals } \\
\cline { 2 - 8 } & $\mathrm{N}$ & Hlutfall & $\mathrm{N}$ & Hlutfall & $\mathrm{N}$ & Hlutfall \\
\hline ISO9001 * GSK & 85 & $88.5 \%$ & 11 & $11.5 \%$ & 96 & $100.0 \%$ \\
\hline \hline
\end{tabular}

Tafla 368 Tengslatafla (tíðni): ISO9001* GSK

\begin{tabular}{llccc}
\hline \hline & \multicolumn{2}{c}{ GSK } & \\
\cline { 3 - 4 } & & $\begin{array}{c}\text { Nei, veit ekki eða } \\
\text { ekki byggt á stöðlum }\end{array}$ & $\begin{array}{c}\text { Já eða í } \\
\text { innleiðingu }\end{array}$ & Samtals \\
\hline ISO9001 & Ekkert & 16 & 1 & 17 \\
& Mjög lítið & 13 & 3 & 16 \\
& Frekar lítið & 13 & 3 & 16 \\
& Nokkuð & 17 & 4 & 21 \\
& Frekar mikið & 2 & 7 & 9 \\
& Mjög mikið & 0 & 6 & 6 \\
Samtals & & 61 & 24 & 85 \\
\hline \hline
\end{tabular}

Fylgni milli ISO9001 og GSK reyndist vera mjög marktæk hvort sem notast var við Sommers`d eða samhverfu fylgnistuðlana, og rétt tæplega miðlungs sterk.

Tafla 369 Ósamhverf fylgnimæligildi: ISO9001, GSK

\begin{tabular}{|c|c|c|c|c|c|}
\hline & & Gildi & "fervik ${ }^{\mathrm{a}}$ & $\mathrm{T}^{\mathrm{b}}$ & Sig. \\
\hline \multirow{3}{*}{$\begin{array}{l}\text { Raðbreyta } \\
\text { á móti } \\
\text { raðbreytu }\end{array}$} & Samhverft & ,398 & ,077 & 4,611 & 000 \\
\hline & $\begin{array}{l}\text { ISO9001 } \\
\text { svarbreyta }\end{array}$ & ,598 &, 114 & 4,611 & ,000 \\
\hline & $\begin{array}{l}\text { GSK } \\
\text { svarbreyta }\end{array}$ & 299 & ,062 & 4,611 & ,000 \\
\hline
\end{tabular}

a. Not assuming the null hypothesis.

b. Using the asymptotic standard error assuming the null hypothesis. 
Tafla 370 Samhverf fylgnimaligildi: ISO9001, GSK

\begin{tabular}{|c|c|c|c|c|c|}
\hline & & Gildi & fervik $^{\mathrm{a}}$ & $\mathrm{T}^{\mathrm{b}}$ & Sig. \\
\hline Raðbreyta á & Kendall's tau-c &, 485 &, 105 & 4,611 & 000 \\
\hline móti & Gamma & 680 &, 116 & 4,611 &, 000 \\
\hline raðbreytu & Spearman fylgnistuðull & ,476 & ,093 & 4,926 & $.000^{\mathrm{c}}$ \\
\hline \multicolumn{2}{|c|}{$\mathrm{N}$ af gildum tilfellum } & 85 & & & \\
\hline
\end{tabular}

a. Not assuming the null hypothesis.

b. Using the asymptotic standard error assuming the null hypothesis.

c. Based on normal approximation.

\subsubsection{Fylgni: útboðsgögn, GSK}

Fylgni milli útboðsgögn (hvort verktaka poetti vöntun á stöðluðum útboðsgögnum) og GSK (hvort verkkaupi starfi eftir gceðastjórnunarkerfi byggðu á viðurkenndum geeðastjórnunarstaðli) var skoðuð. 85 tilfelli flokkast undir gild tilfelli.

Tafla 371 Yfirlit tilfella í greiningu milli útboðsgögn og GSK

\begin{tabular}{lcccccc}
\hline \hline & \multicolumn{7}{c}{ Tilfelli } \\
\cline { 2 - 8 } & \multicolumn{3}{c}{ Gild } & \multicolumn{2}{c}{ Vantar } & \multicolumn{2}{c}{ Samtals } \\
\cline { 2 - 8 } & $\mathrm{N}$ & Hlutfall & $\mathrm{N}$ & Hlutfall & $\mathrm{N}$ & Hlutfall \\
\hline útboðsgögn * GSK & 85 & $88.5 \%$ & 11 & $11.5 \%$ & 96 & $100.0 \%$ \\
\hline \hline
\end{tabular}

Tafla 372 Tengslatafla (tíðni): útboðsgögn * GSK

\begin{tabular}{llccc}
\hline \hline & & \multicolumn{2}{c}{ GSK } & \\
\cline { 3 - 5 } & & $\begin{array}{c}\text { Nei, veit ekki eða } \\
\text { ekki byggt á stöðlum }\end{array}$ & Já eða í innleiðingu & Samtals \\
\hline útboðsgögn & Engin & 1 & 0 & 1 \\
& Mjög lítil & 2 & 1 & 3 \\
& Frekar lítil & 5 & 2 & 7 \\
& Hvorki mikil né lítil & 17 & 5 & 22 \\
& Frekar mikil & 23 & 10 & 33 \\
& Mjög mikil & 13 & 6 & 19 \\
Samtals & 61 & 24 & 85 \\
\hline \hline
\end{tabular}

Fylgni milli útboðsgögn og GSK reyndist ekki vera mjög marktæk hvort sem notast var við Sommers'd eða samhverfu fylgnistuðlana. 


\begin{tabular}{|c|c|c|c|c|c|c|}
\hline & & & Gildi & fervik ${ }^{\mathrm{a}}$ & $\mathrm{T}^{\mathrm{b}}$ & Sig. \\
\hline \multirow{3}{*}{$\begin{array}{l}\text { Raðbreyta } \\
\text { á móti } \\
\text { raðbreytu }\end{array}$} & \multirow[t]{3}{*}{ Somers'd } & Samhverft & ,054 & ,095 & ,572 & ,567 \\
\hline & & $\begin{array}{l}\text { útboðsgögn } \\
\text { svarbreyta }\end{array}$ & ,076 &, 132 &, 572 & ,567 \\
\hline & & GSK svarbreyta & ,042 & ,074 &, 572 & ,567 \\
\hline
\end{tabular}

a. Not assuming the null hypothesis

b. Using the asymptotic standard error assuming the null hypothesis.

Tafla 374 Samhverf fylgnimæligildi: útboðsgögn, GSK

\begin{tabular}{llcccc}
\hline \hline & & Gildi & fervik $^{\mathrm{a}}$ & $\mathrm{T}^{\mathrm{b}}$ & Sig. \\
\hline Raðbreyta á & Kendall's tau-c &, 061 &, 107 &, 572 &, 567 \\
móti & Gamma &, 105 &, 183 &, 572 &, 567 \\
raðbreytu & Spearman fylgnistuðull &, 062 &, 108 &, 565 & $.574^{\mathrm{c}}$ \\
N af gildum tilfellum & 85 & & & \\
\hline \hline
\end{tabular}

a. Not assuming the null hypothesis.

b. Using the asymptotic standard error assuming the null hypothesis.

c. Based on normal approximation. 


\subsection{Verklag}

\subsubsection{Marktæk fylgni við GSK}

Tafla 375 Deir paettir úr könnun verktaka tengdir verklagi verktaka sem maeldust með marktceku fylgni við GSK ${ }^{135}$

\begin{tabular}{|c|c|c|c|c|c|}
\hline & \multicolumn{4}{|c|}{ GSK } & \multirow[b]{3}{*}{$\mathrm{N}$} \\
\hline & \multicolumn{2}{|l|}{ Gamma } & \multicolumn{2}{|c|}{ Spearman's rho } & \\
\hline & Fylgnistuðull & Sig. & Fylgnistuðull & Sig. & \\
\hline öryggisstrúnaðarm & 801 &, 000 & 495 &, 000 & 51 \\
\hline aukaverk_skráð & ,791 &, 000 & ,464 &, 000 & 82 \\
\hline gæðastýringaráætlun & ,764 & 000 &, 550 &, 000 & 78 \\
\hline verkdagbók & ,757 &, 000 &, 500 &, 000 & 79 \\
\hline verktöf_skrifleg & ,739 & 000 &, 520 &, 000 & 83 \\
\hline ÍST30_kröfur & ,738 &, 000 & ,479 &, 000 & 78 \\
\hline merking & ,717 &, 000 & ,362 & 002 & 74 \\
\hline verkáætlun_skrifleg & ,707 &, 000 & ,478 &, 000 & 82 \\
\hline starfslýsingar_skriflegar & ,706 &, 000 & ,505 &, 000 & 90 \\
\hline tölusett & 685 &, 000 & ,464 & 000 & 80 \\
\hline öryggisstjóri & ,666 &, 002 & ,406 & 002 & 54 \\
\hline geymslu & 638 & 003 & ,300 & 010 & 73 \\
\hline verkfundir_reglubundnir & ,633 &, 000 & ,393 &, 000 & 80 \\
\hline fundargerð & 628 & 000 & ,359 & 001 & 80 \\
\hline gæðatrygging_undirverkt & 622 &, 000 & ,422 &, 000 & 80 \\
\hline gæðatrygging_verktaki &, 580 & 000 &, 390 &, 000 & 82 \\
\hline hættumat &, 563 &, 000 & ,372 & 001 & 78 \\
\hline gæðatrygging_ósk &, 534 & 001 & ,364 & 001 & 74 \\
\hline frábrigði_tilkynnt & ,482 & 011 & ,279 & 013 & 79 \\
\hline greiðsluáætlun skrifleg & 356 & 024 & 230 &, 036 & 83 \\
\hline
\end{tabular}

\subsubsection{Fylgni: tölusett, GSK}

Fylgni milli tölusett (hvort verktaki geymi tilboð og samninga i tölusettri röð til ákveðins tíma ) og GSK (hvort verkkaupi starfi eftir gœðastjórnunarkerfi byggðu á viðurkenndum gaeðastjórnunarstaðli) var skoðuð. 80 tilfelli flokkast undir gild tilfelli.

Tafla 376 Yfirlit tilfella í greiningu milli útboðsgögn og GSK

\begin{tabular}{lccccccc}
\hline \hline & \multicolumn{9}{c}{ Tilfelli } \\
\cline { 2 - 8 } & \multicolumn{3}{c}{ Gild } & \multicolumn{2}{c}{ Vantar } & \multicolumn{2}{c}{ Samtals } \\
\cline { 2 - 8 } & $\mathrm{N}$ & Hlutfall & $\mathrm{N}$ & Hlutfall & $\mathrm{N}$ & Hlutfall \\
\hline tölusett * GSK & 80 & $83.3 \%$ & 16 & $16.7 \%$ & 96 & $100.0 \%$ \\
\hline \hline
\end{tabular}

${ }^{135}$ Skýringar á breytuheitum sem eru notuð í töfluna eru í viðauka um breytuheiti. 


\begin{tabular}{llccc}
\hline \hline & & \multicolumn{2}{c}{ GSK } & \\
\cline { 3 - 4 } & & $\begin{array}{c}\text { Nei, veit ekki eða ekki } \\
\text { byggt á stöðlum }\end{array}$ & $\begin{array}{c}\text { Já eða í } \\
\text { innleiðingu }\end{array}$ & Samtals \\
\hline \multirow{6}{*}{ tölusett } & Veit ekki & 3 & 1 & 4 \\
& Aldrei & 10 & 1 & 11 \\
& Sjaldan & 12 & 0 & 12 \\
& Stundum & 12 & 0 & 12 \\
& Oft & 9 & 8 & 17 \\
& Alltaf & 10 & 14 & 24 \\
Samtals & & 56 & 24 & 80 \\
\hline \hline
\end{tabular}

Fylgni milli útboðsgögn og GSK reyndist vera mjög marktæk hvort sem notast var við Sommers'd eða samhverfu fylgnistuðlana og segja má að hún sé rétt tæplega miðlungs sterk.

Tafla 378 Ósamhverf fylgnimæligildi: tölusett, GSK

\begin{tabular}{|c|c|c|c|c|c|}
\hline & & Gildi & fervik $^{a}$ & $\mathrm{~T}^{\mathrm{b}}$ & Sig. \\
\hline \multirow{3}{*}{$\begin{array}{l}\text { Raðbreyta } \\
\text { á móti } \\
\text { raðbreytu }\end{array}$} & Samhverft & ,393 & ,080 & 4,556 & ,000 \\
\hline & $\begin{array}{l}\text { tölusett } \\
\text { svarbreyta }\end{array}$ & ,571 & ,112 & 4,556 & ,000 \\
\hline & $\begin{array}{l}\text { GSK } \\
\text { svarbreyta }\end{array}$ & ,300 & ,067 & 4,556 & ,000 \\
\hline
\end{tabular}

a. Not assuming the null hypothesis.

b. Using the asymptotic standard error assuming the null hypothesis.

Tafla 379 Samhverf fylgnimaligildi: tölusett, GSK

\begin{tabular}{llcccc}
\hline \hline & & Gildi & fervik $^{\mathrm{a}}$ & $\mathrm{T}^{\mathrm{b}}$ & Sig. \\
\hline Raðbreyta á & Kendall's tau-c &, 479 &, 105 & 4,556 &, 000 \\
móti & Gamma &, 685 &, 126 & 4,556 &, 000 \\
raðbreytu & Spearman fylgnistuðull &, 464 &, 094 & 4,623 & $.000^{\mathrm{c}}$ \\
N af gildum tilfellum & 80 & & & \\
\hline \hline
\end{tabular}

a. Not assuming the null hypothesis.

b. Using the asymptotic standard error assuming the null hypothesis.

c. Based on normal approximation.

\subsubsection{Fylgni: merking, GSK}

Fylgni milli merking (hvort verktaki fari eftir ákveðnu kerfi við merkingu skjala) og GSK (hvort verkkaupi starfi eftir gœðastjórnunarkerfi byggðu á viðurkenndum gaðastjórnunarstaðli) var skoðuð. 74 tilfelli flokkast undir gild tilfelli. 


\begin{tabular}{lccccccc}
\hline \hline & \multicolumn{9}{c}{ Tilfelli } \\
\cline { 2 - 8 } & \multicolumn{3}{c}{ Gild } & \multicolumn{2}{c}{ Vantar } & \multicolumn{2}{c}{ Samtals } \\
\cline { 2 - 8 } & $\mathrm{N}$ & Hlutfall & $\mathrm{N}$ & Hlutfall & $\mathrm{N}$ & Hlutfall \\
\hline merking * GSK & 74 & $77.1 \%$ & 22 & $22.9 \%$ & 96 & $100.0 \%$ \\
\hline \hline
\end{tabular}

Tafla 381 Tengslatafla (tíðni): merking * GSK

\begin{tabular}{llccc}
\hline \hline & & \multicolumn{2}{c}{ GSK } & \\
\cline { 3 - 4 } & & $\begin{array}{c}\text { Nei, veit ekki eða } \\
\text { ekki byggt á stöðlum }\end{array}$ & $\begin{array}{c}\text { Já eða í } \\
\text { innleiðingu }\end{array}$ & Samtals \\
\hline \multirow{2}{*}{ merking } & Veit ekki & 3 & 0 & 3 \\
& Nei & 23 & 4 & 27 \\
& Já & 23 & 21 & 44 \\
Samtals & 49 & 25 & 74 \\
\hline \hline
\end{tabular}

Fylgni milli merking og GSK reyndist vera mjög marktæk hvort sem notast var við Sommers'd eða samhverfu fylgnistuðlana en hún mælist ekki mjög sterk.

Tafla 382 Ósamhverf fylgnimæligildi: merking, GSK

\begin{tabular}{|c|c|c|c|c|c|c|}
\hline & & & Gildi & fervik $^{\mathrm{a}}$ & $\mathrm{T}^{\mathrm{b}}$ & Sig. \\
\hline \multirow{3}{*}{\multicolumn{2}{|c|}{$\begin{array}{l}\text { Raðbreyta } \\
\text { á móti } \\
\text { raðbreytu }\end{array}$}} & Samhverft & ,355 & ,092 & 3,634 & ,000 \\
\hline & & $\begin{array}{l}\text { merking } \\
\text { svarbreyta }\end{array}$ & ,380 & , 100 & 3,634 & ,000 \\
\hline & & $\begin{array}{l}\text { GSK } \\
\text { svarbreyta }\end{array}$ & ,333 & ,089 & 3,634 & ,000 \\
\hline
\end{tabular}

a. Not assuming the null hypothesis.

b. Using the asymptotic standard error assuming the null hypothesis.

Tafla 383 Samhverf fylgnimaligildi: merking, GSK

\begin{tabular}{llcccc}
\hline \hline & & Gildi & fervik $^{\mathrm{a}}$ & $\mathrm{T}^{\mathrm{b}}$ & Sig. \\
\hline Raðbreyta á & Kendall's tau-c &, 340 &, 094 & 3,634 &, 000 \\
móti & Gamma &, 717 &, 147 & 3,634 &, 000 \\
raðbreytu & Spearman fylgnistuðull &, 362 &, 094 & 3,295 & $.002^{\mathrm{c}}$ \\
N af gildum tilfellum & 74 & & & \\
\hline \hline
\end{tabular}

a. Not assuming the null hypothesis.

b. Using the asymptotic standard error assuming the null hypothesis.

c. Based on normal approximation. 


\subsubsection{Fylgni: geymslu, GSK}

Fylgni milli geymslu (hvort verktaki fari eftir ákveðnu kerfi við geymslu skjala) og GSK (hvort verkkaupi starfi eftir gæðastjórnunarkerfi byggðu á viðurkenndum gœðastjórnunarstaðli) var skoðuð. 73 tilfelli flokkast undir gild tilfelli.

Tafla 384 Yfirlit tilfella í greiningu milli geymslu og GSK

\begin{tabular}{lcccccc}
\hline \hline & \multicolumn{6}{c}{ Tilfelli } \\
\cline { 2 - 8 } & \multicolumn{2}{c}{ Gild } & \multicolumn{2}{c}{ Vantar } & \multicolumn{2}{c}{ Samtals } \\
\cline { 2 - 8 } & $\mathrm{N}$ & Hlutfall & $\mathrm{N}$ & Hlutfall & $\mathrm{N}$ & Hlutfall \\
\hline geymslu * GSK & 73 & $76.0 \%$ & 23 & $24.0 \%$ & 96 & $100.0 \%$ \\
\hline \hline
\end{tabular}

Tafla 385 Tengslatafla (tíðni): geymslu * GSK

\begin{tabular}{llccc}
\hline \hline & \multicolumn{2}{c}{ GSK } & \\
\cline { 3 - 4 } & $\begin{array}{c}\text { Nei, veit ekki eða } \\
\text { ekki byggt á stöðlum }\end{array}$ & $\begin{array}{c}\text { Já eða í } \\
\text { innleiðingu }\end{array}$ & Samtals \\
\hline geymslu & Veit ekki & 2 & 0 & 2 \\
& Nei & 20 & 4 & 24 \\
& Já & 26 & 21 & 47 \\
Samtals & 48 & 25 & 73 \\
\hline \hline
\end{tabular}

Fylgni milli geymslu og GSK reyndist vera mjög marktæk hvort sem notast var við Sommers 'd eða samhverfu fylgnistuðlana en hún mælist ekki mjög sterk.

Tafla 386 Ósamhverf fylgnimæligildi: geymslu, GSK

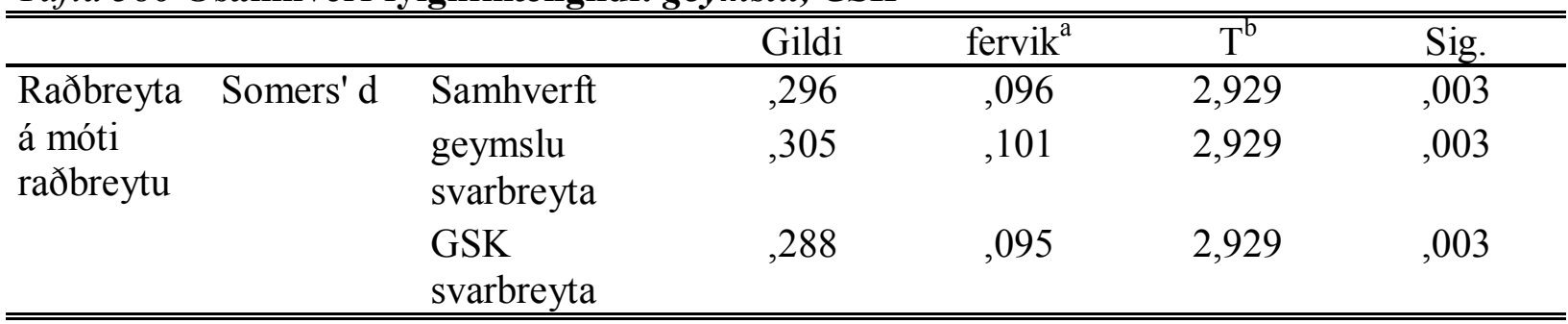

a. Not assuming the null hypothesis.

b. Using the asymptotic standard error assuming the null hypothesis.

\section{Tafla 387 Samhverf fylgnimæligildi: geymslu, $\mathbf{G S K}$}

\begin{tabular}{llcccc}
\hline \hline & & Gildi & fervik $^{\mathrm{a}}$ & $\mathrm{T}^{\mathrm{b}}$ & Sig. \\
\hline Raðbreyta á & Kendall's tau-c &, 275 &, 094 & 2,929 &, 003 \\
móti & Gamma &, 638 &, 181 & 2,929 &, 003 \\
raðbreytu & Spearman fylgnistuðull &, 300 &, 098 & 2,651 & $.010^{\mathrm{c}}$ \\
N af gildum tilfellum & 73 & & & \\
\hline \hline
\end{tabular}

a. Not assuming the null hypothesis.

b. Using the asymptotic standard error assuming the null hypothesis.

c. Based on normal approximation. 


\subsubsection{Fylgni: varðveislutími, GSK}

Fylgni milli varðveislutimi (hvort verktaki fari eftir ákveðnu kerfi við varðveislutíma skjala) og GSK (hvort verkkaupi starfi eftir gaeðastjórnunarkerfi byggðu á viðurkenndum gæeðastjórnunarstaðli) var skoðuð. 73 tilfelli flokkast undir gild tilfelli.

Tafla 388 Yfirlit tilfella í greiningu milli varðveislutíma og GSK

\begin{tabular}{|c|c|c|c|c|c|c|}
\hline & \multicolumn{6}{|c|}{ Tilfelli } \\
\hline & \multicolumn{2}{|c|}{ Gild } & \multicolumn{2}{|c|}{ Vantar } & \multicolumn{2}{|c|}{ Samtals } \\
\hline & $\mathrm{N}$ & Hlutfall & $\mathrm{N}$ & Hlutfall & $\mathrm{N}$ & Hlutfall \\
\hline varðveislutími * GSK & 73 & $76.0 \%$ & 23 & $24.0 \%$ & 96 & $100.0 \%$ \\
\hline
\end{tabular}

Tafla 389 Tengslatafla (tíðni): varðveislutími * GSK

\begin{tabular}{llccc}
\hline \hline & \multicolumn{2}{c}{ GSK } & \\
\cline { 3 - 4 } & & $\begin{array}{c}\text { Nei, veit ekki eða ekki } \\
\text { byggt á stöðlum }\end{array}$ & $\begin{array}{c}\text { Já eða í } \\
\text { innleiðingu }\end{array}$ & Samtals \\
\hline \multirow{2}{*}{ varðveislutími } & Veit ekki & 2 & 0 & 2 \\
& Nei & 21 & 7 & 28 \\
& Já & 25 & 18 & 43 \\
Samtals & 48 & 25 & 73 \\
\hline \hline
\end{tabular}

Fylgni milli varðveislutími og GSK reyndist ekki vera marktæk hvort sem notast var við Sommers'd eða samhverfu fylgnistuðlana.

Tafla 390 Ósamhverf fylgnimæligildi: varðveislutími, GSK

\begin{tabular}{|c|c|c|c|c|c|c|}
\hline & & & Gildi & fervik $^{\mathrm{a}}$ & $\overline{\mathrm{T}^{\mathrm{b}}}$ & Sig. \\
\hline \multirow{3}{*}{$\begin{array}{l}\text { Raðbreyta } \\
\text { á móti } \\
\text { raðbreytu }\end{array}$} & Somers' d & Samhverft & , 199 & 107 & 1,836 &, 066 \\
\hline & & $\begin{array}{l}\text { varðveislutími } \\
\text { svarbreyta }\end{array}$ & 211 & ,114 & 1,836 & 066 \\
\hline & & GSK svarbreyta & ,188 & ,101 & 1,836 & ,066 \\
\hline
\end{tabular}

a. Not assuming the null hypothesis.

b. Using the asymptotic standard error assuming the null hypothesis. 
Tafla 391 Samhverf fylgnimæligildi: varðveislutími, GSK

\begin{tabular}{|c|c|c|c|c|c|}
\hline & & Gildi & fervik $^{\mathrm{a}}$ & $T^{b}$ & Sig. \\
\hline Raðbreyta á & Kendall's tau-c & ,190 &, 103 & 1,836 & ,066 \\
\hline móti & Gamma & ,420 & ,214 & 1,836 &, 066 \\
\hline raðbreytu & Spearman fylgnistuðull & ,202 & ,108 & 1,734 & $.087^{\mathrm{c}}$ \\
\hline \multicolumn{2}{|c|}{$\mathrm{N}$ af gildum tilfellum } & 73 & & & \\
\hline
\end{tabular}

a. Not assuming the null hypothesis.

b. Using the asymptotic standard error assuming the null hypothesis.

c. Based on normal approximation.

\subsubsection{Fylgni: förgun, GSK}

Fylgni milli förgun (hvort verktaki fari eftir ákveðnu kerfi við förgun skjala) og GSK (hvort verkkaupi starfi eftir gœðastjórnunarkerfi byggðu á viðurkenndum gœðastjórnunarstaðli) var skoðuð. 72 tilfelli flokkast undir gild tilfelli.

Tafla 392 Yfirlit tilfella í greiningu milli förgun og GSK

\begin{tabular}{lcccccc}
\hline \hline & \multicolumn{7}{c}{ Tilfelli } \\
\cline { 2 - 8 } & \multicolumn{2}{c}{ Gild } & \multicolumn{2}{c}{ Vantar } & \multicolumn{2}{c}{ Samtals } \\
\cline { 2 - 8 } & $\mathrm{N}$ & Hlutfall & $\mathrm{N}$ & Hlutfall & $\mathrm{N}$ & Hlutfall \\
\hline förgun * GSK & 72 & $75.0 \%$ & 24 & $25.0 \%$ & 96 & $100.0 \%$ \\
\hline \hline
\end{tabular}

Tafla 393 Tengslatafla (tíðni): förgun * GSK

\begin{tabular}{llccc}
\hline \hline & & \multicolumn{2}{c}{ GSK } & \\
\cline { 3 - 4 } & & $\begin{array}{c}\text { Nei, veit ekki eða ekki } \\
\text { byggt á stöðlum }\end{array}$ & $\begin{array}{c}\text { Já eða í } \\
\text { innleiðingu }\end{array}$ & Samtals \\
\hline förgun & Veit ekki & 3 & 1 & 4 \\
& Nei & 29 & 11 & 40 \\
& Já & 15 & 13 & 28 \\
Samtals & 47 & 25 & 72 \\
\hline \hline
\end{tabular}

Fylgni milli förgun og GSK reyndist ekki vera marktæk hvort sem notast var við Sommers`d eða samhverfu fylgnistuðlana.

Tafla 394 Ósamhverf fylgnimæligildi: förgun GSK

\begin{tabular}{|c|c|c|c|c|c|}
\hline & & Gildi & fervik $^{a}$ & $\mathrm{~T}^{\mathrm{b}}$ & Sig. \\
\hline \multirow{3}{*}{$\begin{array}{l}\text { Raðbreyta } \\
\text { á móti } \\
\text { raðbreytu }\end{array}$} & Samhverft & , 187 &, 114 & 1,629 & ,103 \\
\hline & $\begin{array}{l}\text { förgun } \\
\text { svarbreyta }\end{array}$ & ,204 & , 124 & 1,629 & ,103 \\
\hline & $\begin{array}{l}\text { GSK } \\
\text { svarbreyta }\end{array}$ & ,172 & , 106 & 1,629 & 103 \\
\hline
\end{tabular}

a. Not assuming the null hypothesis.

b. Using the asymptotic standard error assuming the null hypothesis. 
Tafla 395 Samhverf fylgnimæligildi: förgun GSK

\begin{tabular}{llcccc}
\hline \hline & & Gildi & fervik $^{\mathrm{a}}$ & $\mathrm{T}^{\mathrm{b}}$ & Sig. \\
\hline Raðbreyta á & Kendall's tau-c &, 185 &, 114 & 1,629 &, 103 \\
móti & Gamma &, 365 &, 209 & 1,629 &, 103 \\
raðbreytu & Spearman fylgnistuðull &, 192 &, 117 & 1,637 & $.106^{\mathrm{c}}$ \\
N af gildum tilfellum & 72 & & & \\
\hline \hline
\end{tabular}

a. Not assuming the null hypothesis.

b. Using the asymptotic standard error assuming the null hypothesis.

c. Based on normal approximation.

\subsubsection{Fylgni: starfslýsingar_skriflegar, GSK}

Fylgni milli starfslýsingar_skriflegar (hvort til séu skriflegar starfslýsingar fyrir starfsmenn) og GSK (hvort verkkaupi starfi eftir gœðastjórnunarkerfi byggðu á viðurkenndum gaeðastjórnunarstaðli) var skoðuð. 90 tilfelli flokkast undir gild tilfelli.

Tafla 396 Yfirlit tilfella í greiningu milli starfslýsingar_skriflegar og GSK

\begin{tabular}{lccccccc}
\hline \hline & \multicolumn{9}{c}{ Tilfelli } \\
\cline { 2 - 7 } & \multicolumn{2}{c}{ Gild } & \multicolumn{2}{c}{ Vantar } & \multicolumn{2}{c}{ Samtals } \\
\cline { 2 - 7 } & $\mathrm{N}$ & Hlutfall & $\mathrm{N}$ & Hlutfall & $\mathrm{N}$ & Hlutfall \\
\hline $\begin{array}{l}\text { starfslýsingar_skriflegar } \\
* \text { GSK }\end{array}$ & 90 & $93.8 \%$ & 6 & & $6.3 \%$ & 96 & $100.0 \%$ \\
\hline \hline
\end{tabular}

Tafla 397 Tengslatafla (tiðni): starfslýsingar_skriflegar * GSK

\begin{tabular}{llccc}
\hline \hline & & \multicolumn{2}{c}{ GSK } & \\
\cline { 3 - 4 } & & $\begin{array}{c}\text { Nei, veit ekki eða ekki } \\
\text { byggt á stöðlum }\end{array}$ & $\begin{array}{c}\text { Já eða í } \\
\text { innleiðingu }\end{array}$ & Samtals \\
\hline starfslýsingar & Veit ekki & 9 & 1 & 10 \\
skriflegar & Enga starfsmenn & 34 & 1 & 35 \\
& Fáa starfsmenn & 7 & 3 & 10 \\
& Flesta starfsmenn & 6 & 12 & 18 \\
Samtals & Alla starfsmenn & 8 & 9 & 17 \\
\hline \hline
\end{tabular}

Fylgni milli starfslýsingar_skrifleg og GSK reyndist vera mjög marktæk hvort sem notast var við Sommers'd eða samhverfu fylgnistuðlana og segja má að hún sé miðlungs sterk. 
Tafla 398 Ósamhverf fylgnimæligildi: starfslýsingar_skriflegar GSK

\begin{tabular}{|c|c|c|c|c|c|}
\hline & & Gildi & fervik ${ }^{\mathrm{a}}$ & $\mathrm{T}^{\mathrm{b}}$ & Sig. \\
\hline \multirow{3}{*}{$\begin{array}{l}\text { Raðbreyta Somers'd } \\
\text { á móti } \\
\text { raðbreytu }\end{array}$} & Samhverft & 438 &, 074 & 5,369 &, 000 \\
\hline & $\begin{array}{l}\text { starfslýsingar_skriflegar } \\
\text { svarbreyta }\end{array}$ & ,618 & ,098 & 5,369 & 000 \\
\hline & GSK svarbreyta & ,339 & ,064 & 5,369 &, 000 \\
\hline
\end{tabular}

a. Not assuming the null hypothesis

b. Using the asymptotic standard error assuming the null hypothesis.

Tafla 399 Samhverf fylgnimæligildi: starfslýsingar_skriflegar GSK

\begin{tabular}{llcccc}
\hline \hline & & Gildi & fervik $^{\text {a }}$ & $\mathrm{T}^{\mathrm{b}}$ & Sig. \\
\hline Raðbreyta á & Kendall's tau-c &, 508 &, 095 & 5,369 &, 000 \\
móti & Gamma &, 706 &, 100 & 5,369 &, 000 \\
raðbreytu & Spearman fylgnistuðull &, 505 &, 084 & 5,483 & $.000^{\mathrm{c}}$ \\
N af gildum tilfellum & 90 & & & \\
\hline \hline
\end{tabular}

a. Not assuming the null hypothesis.

b. Using the asymptotic standard error assuming the null hypothesis.

c. Based on normal approximation.

\subsubsection{Fylgni: verkáætlun_skrifleg, GSK}

Fylgni milli verkácetlun_skrifleg (hvort verktaki leggi fram skriflega verkácetlun i upphafi framkvoemda) og GSK (hvort verkkaupi starfi eftir goðastjórnunarkerfi byggðu á viðurkenndum gœðastjórnunarstaðli) var skoðuð. 90 tilfelli flokkast undir gild tilfelli.

Tafla 400 Yfirlit tilfella í greiningu milli verkáaetlun_skrifleg og GSK

\begin{tabular}{lccccccc}
\hline \hline & \multicolumn{9}{c}{ Tilfelli } \\
\cline { 2 - 8 } & \multicolumn{2}{c}{ Gild } & \multicolumn{2}{c}{ Vantar } & \multicolumn{2}{c}{ Samtals } \\
\cline { 2 - 8 } & $\mathrm{N}$ & Hlutfall & $\mathrm{N}$ & Hlutfall & $\mathrm{N}$ & Hlutfall \\
\hline $\begin{array}{l}\text { verkáætlun_skrifleg* } \\
\text { GSK }\end{array}$ & 82 & $85.4 \%$ & 14 & $14.6 \%$ & 96 & $100.0 \%$ \\
\hline \hline
\end{tabular}

Tafla 401 Tengslatafla (tíðni): verkáaetlun_skrifleg * GSK

\begin{tabular}{llccc}
\hline \hline & & \multicolumn{2}{c}{ GSK } & \\
\cline { 3 - 4 } & & $\begin{array}{c}\text { Nei, veit ekki eða } \\
\text { ekki byggt á stöðlum }\end{array}$ & $\begin{array}{c}\text { Já eða í } \\
\text { innleiðingu }\end{array}$ & Samtals \\
\hline \multirow{2}{*}{ verkáætlun_skrifleg } & Aldrei & 13 & 0 & 13 \\
& Sjaldan & 7 & 1 & 8 \\
& Stundum & 20 & 3 & 23 \\
& Oft & 10 & 12 & 22 \\
Samtals & Alltaf & 7 & 9 & 16 \\
\hline \hline
\end{tabular}

Fylgni milli verkácetlun_skrifleg og GSK reyndist vera mjög marktæk hvort sem notast var við Sommers'd eða samhverfu fylgnistuðlana og segja má að hún sé rétt tæplega miðlungs sterk. 
Tafla 402 Ósamhverf fylgnimæligildi: verkáaetlun_skrifleg, GSK

\begin{tabular}{llcccc}
\hline \hline & & Gildi & fervik $^{\mathrm{a}}$ & $\mathrm{T}^{\mathrm{b}}$ & Sig. \\
\hline $\begin{array}{l}\text { Raðbreytá } \\
\text { á móti } \\
\text { raðbreytu }\end{array}$ &, 412 &, 070 & 5,289 &, 000 \\
& $\begin{array}{l}\text { Samhverft } \\
\text { verkáætlun_skrifleg } \\
\text { svarbreyta }\end{array}$ &, 583 &, 096 & 5,289 &, 000 \\
& GSK svarbreyta &, 318 &, 060 & 5,289 &, 000 \\
\hline \hline
\end{tabular}

a. Not assuming the null hypothesis.

b. Using the asymptotic standard error assuming the null hypothesis.

Tafla 403 Samhverf fylgnimæligildi: verkáaetlun_skrifleg, GSK

\begin{tabular}{llcccc}
\hline \hline & & Gildi & fervik $^{\text {a }}$ & $\mathrm{T}^{\mathrm{b}}$ & Sig. \\
\hline Raðbreyta á & Kendall's tau-c &, 494 &, 093 & 5,289 &, 000 \\
móti & Gamma &, 707 &, 100 & 5,289 &, 000 \\
raðbreytu & Spearman fylgnistuðull &, 478 &, 081 & 4,867 & $.000^{\mathrm{c}}$ \\
N af gildum tilfellum & 82 & & & \\
\hline \hline
\end{tabular}

a. Not assuming the null hypothesis.

b. Using the asymptotic standard error assuming the null hypothesis.

c. Based on normal approximation.

\subsubsection{Fylgni: verktöf_skrifleg, GSK}

Fylgni milli verktöf_skrifleg (hvort verktaki sendi verkkaupa skriflega rökstudda tilkynningu um verktöf pegar svo beri undir) og GSK (hvort verkkaupi starfi eftir gaðastjórnunarkerfi byggðu á viðurkenndum gæeðastjórnunarstaðli) var skoðuð. 90 tilfelli flokkast undir gild tilfelli.

Tafla 404 Yfirlit tilfella í greiningu milli verktöf_skrifleg og GSK

\begin{tabular}{lccccccc}
\hline \hline & \multicolumn{6}{c}{ Tilfelli } \\
\cline { 2 - 8 } & \multicolumn{2}{c}{ Gild } & \multicolumn{2}{c}{ Vantar } & \multicolumn{2}{c}{ Samtals } \\
\cline { 2 - 8 } & $\mathrm{N}$ & Hlutfall & $\mathrm{N}$ & Hlutfall & $\mathrm{N}$ & Hlutfall \\
\hline verktöf_skrifleg * GSK & 83 & $86.5 \%$ & 13 & $13.5 \%$ & 96 & $100.0 \%$ \\
\hline \hline
\end{tabular}

Tafla 405 Tengslatafla (tíðni): verktöf_skrifleg * GSK

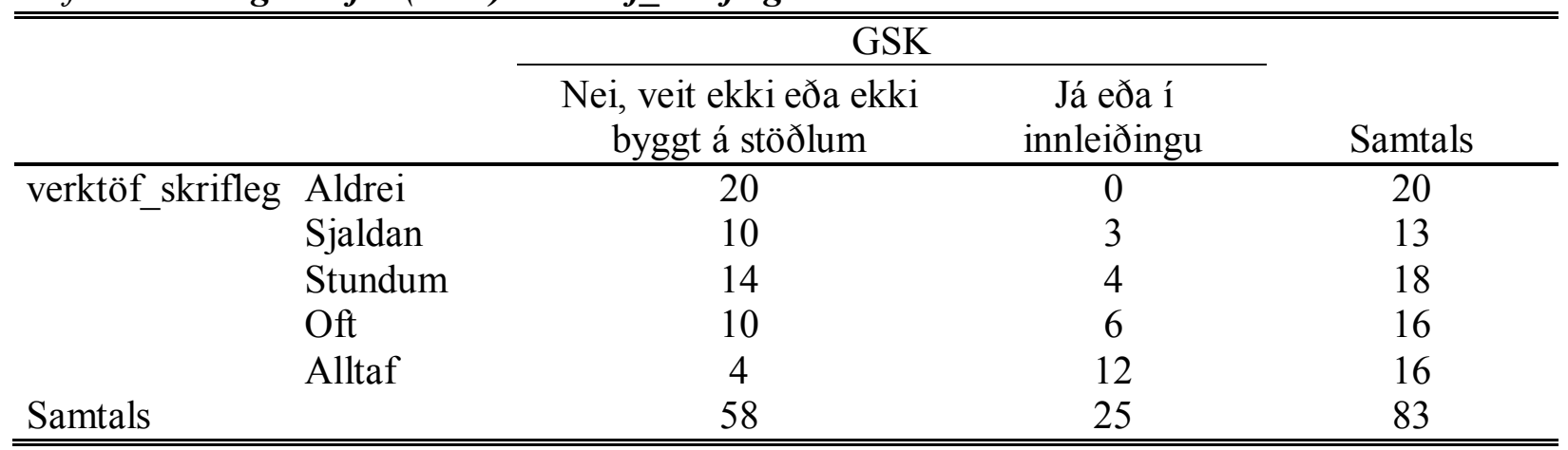


Fylgni milli verktöf_skrifleg og GSK reyndist vera mjög marktæk hvort sem notast var við Sommers'd eða samhverfu fylgnistuðlana og segja má að hún sé miðlungs sterk.

Tafla 406 Ósamhverf fylgnimæligildi: verktöf_skrifleg, GSK

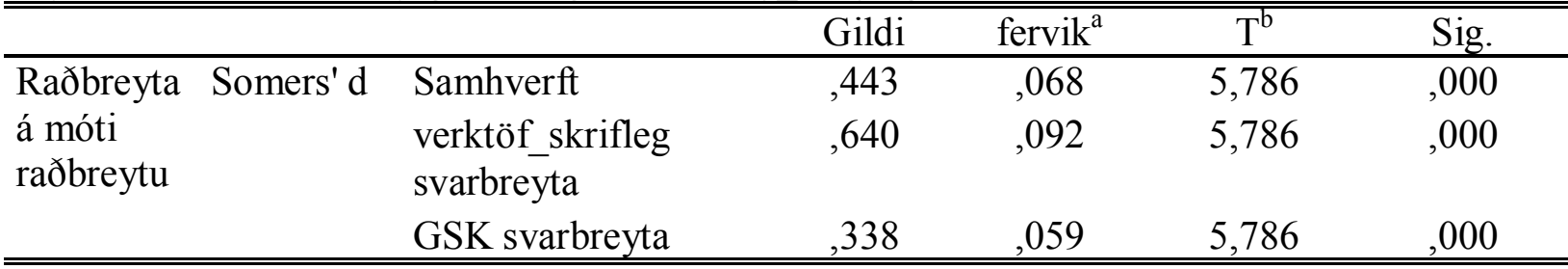

a. Not assuming the null hypothesis.

b. Using the asymptotic standard error assuming the null hypothesis.

\section{Tafla 407 Samhverf fylgnimæligildi: verktöf_skrifleg, GSK}

\begin{tabular}{llcccc}
\hline \hline & & Gildi & fervik $^{\mathrm{a}}$ & $\mathrm{T}^{\mathrm{b}}$ & Sig. \\
\hline Raðbreyta á & Kendall's tau-c &, 539 &, 093 & 5,786 &, 000 \\
móti & Gamma &, 739 &, 092 & 5,786 &, 000 \\
raðbreytu & Spearman fylgnistuðull &, 520 &, 079 & 5,475 & $.000^{\mathrm{c}}$ \\
N af gildum tilfellum & 83 & & & \\
\hline \hline
\end{tabular}

a. Not assuming the null hypothesis.

b. Using the asymptotic standard error assuming the null hypothesis.

c. Based on normal approximation.

\subsubsection{Fylgni: greiðsluáætlun_skrifleg, GSK}

Fylgni milli greiðsluácetlun_skrifleg (hvort verktaki leggi fram skriflega greiðsluácetlun i upphafi framkvomda) og GSK (hvort verkkaupi starfi eftir gœðastjórnunarkerfi byggðu á viðurkenndum gœðastjórnunarstaðli) var skoðuð. 83 tilfelli flokkast undir gild tilfelli.

Tafla 408 Yfirlit tilfella í greiningu milli greiðsluáaetlun_skrifleg og GSK

\begin{tabular}{lccccccc} 
& \multicolumn{6}{c}{ Tilfelli } \\
\cline { 2 - 8 } & \multicolumn{2}{c}{ Gild } & \multicolumn{2}{c}{ Vantar } & \multicolumn{2}{c}{ Samtals } \\
\cline { 2 - 8 } & $\mathrm{N}$ & Hlutfall & $\mathrm{N}$ & Hlutfall & $\mathrm{N}$ & Hlutfall \\
\hline $\begin{array}{l}\text { greiðsluáætlun_skrifleg * } \\
\text { GSK }\end{array}$ & 83 & $86.5 \%$ & 13 & $13.5 \%$ & 96 & $100.0 \%$ \\
\hline \hline
\end{tabular}




\begin{tabular}{llccc}
\hline \hline & & \multicolumn{2}{c}{ GSK } & \\
\cline { 3 - 4 } & & $\begin{array}{c}\text { Nei, veit ekki eða ekki } \\
\text { byggt á stöðlum }\end{array}$ & $\begin{array}{c}\text { Já eða í } \\
\text { innleiðingu }\end{array}$ & Samtals \\
\hline greiðsluáætlun_skrifleg & Aldrei & 12 & 1 & 13 \\
& Sjaldan & 6 & 2 & 8 \\
& Stundum & 12 & 6 & 18 \\
& Oft & 16 & 8 & 24 \\
Samtals & Alltaf & 11 & 9 & 20 \\
\hline \hline
\end{tabular}

Fylgni milli greiðsluácetlun_skrifleg og GSK reyndist vera marktæk hvort sem notast var við Sommers'd eða samhverfu fylgnistuðlana en ekki sterk.

Tafla 410 Ósamhverf fylgnimæligildi: greiðsluáaetlun_skrifleg, GSK

\begin{tabular}{|c|c|c|c|c|c|}
\hline & & Gildi & fervik $^{\mathrm{a}}$ & $\mathrm{T}^{\mathrm{b}}$ & Sig. \\
\hline \multirow{3}{*}{$\begin{array}{l}\text { Raðbreyta Somers' d } \\
\text { á móti } \\
\text { raðbreytu }\end{array}$} & Samhverft & , 199 & ,087 & 2,253 & ,024 \\
\hline & $\begin{array}{l}\text { greiðsluáætlun_skrifleg } \\
\text { svarbreyta }\end{array}$ & ,279 & ,121 & 2,253 & ,024 \\
\hline & GSK svarbreyta & ,154 & ,068 & 2,253 & ,024 \\
\hline
\end{tabular}

a. Not assuming the null hypothesis.

b. Using the asymptotic standard error assuming the null hypothesis.

Tafla 411 Samhverf fylgnimæligildi: greiðsluácetlun_skrifleg, GSK

\begin{tabular}{llcccc}
\hline \hline & & Gildi & fervik $^{\mathrm{a}}$ & $\mathrm{T}^{\mathrm{b}}$ & Sig. \\
\hline Raðbreyta á & Kendall's tau-c &, 240 &, 106 & 2,253 &, 024 \\
móti & Gamma &, 356 &, 152 & 2,253 &, 024 \\
raðbreytu & Spearman fylgnistuðull &, 230 &, 100 & 2,128 & $.036^{\mathrm{c}}$ \\
N af gildum tilfellum & 83 & & & \\
\hline \hline
\end{tabular}

a. Not assuming the null hypothesis.

b. Using the asymptotic standard error assuming the null hypothesis.

c. Based on normal approximation.

\subsubsection{Fylgni: verkfundir_reglubundnir, GSK}

Fylgni milli verkfundir_reglubundnir (hvort haldnir séu reglubundnir verkfundir með verkkaupa) og GSK (hvort verkkaupi starfi eftir gaðastjórnunarkerfi byggðu á viðurkenndum gœðastjórnunarstaðli) var skoðuð. 80 tilfelli flokkast undir gild tilfelli.

Tafla 412 Yfirlit tilfella í greiningu milli verkfundir_reglubundnir og GSK

\begin{tabular}{lccccccc}
\hline \hline & \multicolumn{9}{c}{ Gilfelli } \\
\cline { 2 - 8 } & \multicolumn{2}{c}{ Gild } & Hlutfall & $\mathrm{N}$ & Hlutfall & $\mathrm{N}$ & Hlutfall \\
\cline { 2 - 8 } & 80 & $83.3 \%$ & 16 & $16.7 \%$ & 96 & $100.0 \%$ \\
\hline $\begin{array}{l}\text { verkfundir_reglubundnir } \\
\text { * GSK }\end{array}$ & & & & & & & \\
\hline \hline
\end{tabular}




\begin{tabular}{llccc}
\hline \hline & & \multicolumn{2}{c}{ GSK } & \\
\cline { 3 - 4 } & & $\begin{array}{c}\text { Nei, veit ekki eða } \\
\text { ekki byggt á stöðlum }\end{array}$ & $\begin{array}{c}\text { Já eða í } \\
\text { innleiðingu }\end{array}$ & Samtals \\
\hline verkfundir_reglubundnir & Aldrei & 6 & 0 & 6 \\
& Sjaldan & 3 & 0 & 3 \\
& Stundum & 22 & 5 & 27 \\
& Oft & 18 & 11 & 29 \\
Samtals & Alltaf & 6 & 9 & 15 \\
\hline \hline
\end{tabular}

Fylgni milli verkfundir_reglubundnir og GSK reyndist vera mjög marktæk hvort sem notast var við Sommers'd eða samhverfu fylgnistuðlana en ekki sterk.

Tafla 414 Ósamhverf fylgnimæligildi: verkfundir_reglubundnir, GSK

\begin{tabular}{|c|c|c|c|c|c|}
\hline & & Gildi & fervik $^{\mathrm{a}}$ & $\mathrm{T}^{\mathrm{b}}$ & Sig. \\
\hline \multirow{3}{*}{$\begin{array}{l}\text { Raðbreyta } \\
\text { á móti } \\
\text { raðbreytu }\end{array}$} & Samhverft & ,351 & ,081 & 4,029 &, 000 \\
\hline & $\begin{array}{l}\text { verkfundir_reglubundnir } \\
\text { svarbreyta }\end{array}$ & ,466 & , 108 & 4,029 &, 000 \\
\hline & GSK svarbreyta & ,281 &, 068 & 4,029 &, 000 \\
\hline
\end{tabular}

a. Not assuming the null hypothesis.

b. Using the asymptotic standard error assuming the null hypothesis.

Tafla 415 Samhverf fylgnimæligildi: verkfundir_reglubundnir, GSK

\begin{tabular}{llcccc}
\hline \hline & & Gildi & fervik $^{\mathrm{a}}$ & $\mathrm{T}^{\mathrm{b}}$ & Sig. \\
\hline Raðbreyta á & Kendall's tau-c &, 401 &, 099 & 4,029 &, 000 \\
móti & Gamma &, 633 &, 124 & 4,029 &, 000 \\
raðbreytu & Spearman fylgnistuðull &, 393 &, 092 & 3,775 & $.000^{\mathrm{c}}$ \\
N af gildum tilfellum & 80 & & & \\
\hline \hline
\end{tabular}

a. Not assuming the null hypothesis.

b. Using the asymptotic standard error assuming the null hypothesis.

c. Based on normal approximation.

\subsubsection{Fylgni: fundargerð, GSK}

Fylgni milli fundargerð (hvort verktaki riti fundargerð á verkfundum) og GSK (hvort verkkaupi starfi eftir gœðastjórnunarkerfi byggðu á viðurkenndum gœðastjórnunarstaðli) var skoðuð. 80 tilfelli flokkast undir gild tilfelli.

Tafla 416 Yfirlit tilfella í greiningu milli fundargerð og GSK

\begin{tabular}{lccccccc}
\hline \hline & \multicolumn{9}{c}{ Tilfelli } \\
\cline { 2 - 8 } & \multicolumn{3}{c}{ Gild } & \multicolumn{2}{c}{ Vantar } & \multicolumn{2}{c}{ Samtals } \\
\cline { 2 - 8 } & $\mathrm{N}$ & Hlutfall & $\mathrm{N}$ & Hlutfall & $\mathrm{N}$ & Hlutfall \\
\hline fundargerd * GSK & 80 & $83.3 \%$ & 16 & $16.7 \%$ & 96 & $100.0 \%$ \\
\hline \hline
\end{tabular}




\begin{tabular}{llccc}
\hline \hline & & \multicolumn{2}{c}{ GSK } & \\
\cline { 3 - 4 } & & $\begin{array}{c}\text { Nei, veit ekki eða ekki } \\
\text { byggt á stöðlum }\end{array}$ & $\begin{array}{c}\text { Já eða í } \\
\text { innleiðingu }\end{array}$ & Samtals \\
\hline fundargerð & Aldrei & 9 & 0 & 9 \\
& Sjaldan & 3 & 0 & 3 \\
& Stundum & 12 & 2 & 14 \\
& Oft & 11 & 5 & 16 \\
& Alltaf & 21 & 17 & 38 \\
Samtals & & 56 & 24 & 80 \\
\hline \hline
\end{tabular}

Fylgni milli fundargerð og GSK reyndist vera mjög marktæk hvort sem notast var við Sommers'd eða samhverfu fylgnistuðlana en ekki sterk.

Tafla 418 Ósamhverf fylgnimæligildi: fundargerð, GSK

\begin{tabular}{|c|c|c|c|c|c|}
\hline & & Gildi & " fervik ${ }^{\mathrm{a}}$ & $\bar{T}^{b}$ & Sig. \\
\hline \multirow{3}{*}{$\begin{array}{l}\text { Raðbreyta } \\
\text { á móti } \\
\text { raðbreytu }\end{array}$} & Samhverft & 321 & ,077 & 3,874 & ,000 \\
\hline & $\begin{array}{l}\text { fundargerð } \\
\text { svarbreyta }\end{array}$ & ,424 & , 101 & 3,874 & ,000 \\
\hline & $\begin{array}{l}\text { GSK } \\
\text { svarbreyta }\end{array}$ & ,258 & ,066 & 3,874 &, 000 \\
\hline
\end{tabular}

a. Not assuming the null hypothesis.

b. Using the asymptotic standard error assuming the null hypothesis.

Tafla 419 Samhverf fylgnimaligildi: fundargerð, GSK

\begin{tabular}{llcccc}
\hline \hline & & Gildi & fervik $^{\mathrm{a}}$ & $\mathrm{T}^{\mathrm{b}}$ & Sig. \\
\hline Raðbreyta á & Kendall's tau-c &, 356 &, 092 & 3,874 &, 000 \\
móti & Gamma &, 628 &, 136 & 3,874 &, 000 \\
raðbreytu & Spearman fylgnistuðull &, 359 &, 086 & 3,400 & $.001^{\text {c }}$ \\
N af gildum tilfellum & 80 & & & \\
\hline \hline
\end{tabular}

a. Not assuming the null hypothesis.

b. Using the asymptotic standard error assuming the null hypothesis.

c. Based on normal approximation.

\subsubsection{Fylgni: verkdagbók, GSK}

Fylgni milli verkdagbók (hvort verktaki haldi verkdagbók) og GSK (hvort verkkaupi starfi eftir gœðastjórnunarkerfi byggðu á viðurkenndum gœðastjórnunarstaðli) var skoðuð. 80 tilfelli flokkast undir gild tilfelli. 


\begin{tabular}{lccccccc}
\hline \hline & \multicolumn{9}{c}{ Tilfelli } \\
\cline { 2 - 8 } & \multicolumn{3}{c}{ Gild } & \multicolumn{2}{c}{ Vantar } & \multicolumn{2}{c}{ Samtals } \\
\cline { 2 - 8 } & $\mathrm{N}$ & Hlutfall & $\mathrm{N}$ & Hlutfall & $\mathrm{N}$ & Hlutfall \\
\hline verkdagbók * GSK & 79 & $82.3 \%$ & 17 & $17.7 \%$ & 96 & $100.0 \%$ \\
\hline \hline
\end{tabular}

Tafla 421 Tengslatafla (tíðni): verkdagbók * GSK

\begin{tabular}{llccc}
\hline \hline & & \multicolumn{2}{c}{ GSK } & \\
\cline { 3 - 4 } & & $\begin{array}{c}\text { Nei, veit ekki eða } \\
\text { ekki byggt á stöðlum }\end{array}$ & $\begin{array}{c}\text { Já eða í } \\
\text { innleiðingu }\end{array}$ & Samtals \\
\hline \multirow{2}{*}{ verkdagbók } & Aldrei & 15 & 1 & 16 \\
& Sjaldan & 5 & 1 & 6 \\
& Stundum & 10 & 0 & 10 \\
& Oft & 16 & 6 & 22 \\
& Alltaf & 9 & 16 & 25 \\
Samtals & & 55 & 24 & 79 \\
\hline \hline
\end{tabular}

Fylgni milli verkdagbók og GSK reyndist vera mjög marktæk hvort sem notast var við Sommers`d eða samhverfu fylgnistuðlana og segja má að hún flokkist undir pað að vera miðlungs sterk.

Tafla 422 Ósamhverf fylgnimæligildi: verkdagbók, $\mathbf{G S K}$

\begin{tabular}{|c|c|c|c|c|c|c|}
\hline & & & Gildi & fervik $^{\mathrm{a}}$ & $\mathrm{T}^{\mathrm{b}}$ & Sig. \\
\hline \multirow{3}{*}{$\begin{array}{l}\text { Raðbreyta } \\
\text { á móti } \\
\text { raðbreytu }\end{array}$} & Somers' d & Samhverft & ,435 & ,076 & 5,200 & ,000 \\
\hline & & $\begin{array}{l}\text { verkdagbók } \\
\text { svarbreyta }\end{array}$ & ,608 & , 101 & 5,200 & ,000 \\
\hline & & GSK svarbreyta & ,338 &, 067 & 5,200 &, 000 \\
\hline
\end{tabular}

a. Not assuming the null hypothesis.

b. Using the asymptotic standard error assuming the null hypothesis.

Tafla 423 Samhverf fylgnimaligildi: verkdagbók, GSK

\begin{tabular}{llcccc}
\hline \hline & & Gildi & fervik $^{\mathrm{a}}$ & $\mathrm{T}^{\mathrm{b}}$ & Sig. \\
\hline Raðbreyta á & Kendall's tau-c &, 514 &, 099 & 5,200 &, 000 \\
móti & Gamma &, 757 &, 108 & 5,200 &, 000 \\
raðbreytu & Spearman &, 500 &, 087 & 5,070 & $.000^{\mathrm{c}}$ \\
& $\begin{array}{l}\text { fylgnistuðull } \\
\text { N af gildum tilfellum }\end{array}$ & 79 & & & \\
\hline \hline
\end{tabular}

a. Not assuming the null hypothesis.

b. Using the asymptotic standard error assuming the null hypothesis.

c. Based on normal approximation. 


\subsubsection{Fylgni: ÍST30_kröfur, GSK}

Fylgni milli ÍST30_kröfur (hvort pað kœemi fram i samningum að hann bceri að uppfylla kröfur ÍST30) og GSK (hvort verkkaupi starfi eftir geððastjórnunarkerfi byggðu á viðurkenndum gœeðastjórnunarstaðli) var skoðuð. 80 tilfelli flokkast undir gild tilfelli.

Tafla 424 Yfirlit tilfella í greiningu milli ÍST30_kröfur og GSK

\begin{tabular}{lccccccc}
\hline \hline & \multicolumn{9}{c}{ Tilfelli } \\
\cline { 2 - 8 } & \multicolumn{2}{c}{ Gild } & \multicolumn{2}{c}{ Vantar } & \multicolumn{2}{c}{ Samtals } \\
\cline { 2 - 9 } & $\mathrm{N}$ & Hlutfall & $\mathrm{N}$ & Hlutfall & $\mathrm{N}$ & Hlutfall \\
\hline ÍST30_kröfur * GSK & 78 & $81.3 \%$ & 18 & $18.8 \%$ & 96 & $100.0 \%$ \\
\hline \hline
\end{tabular}

Tafla 425 Tengslatafla (tíðni): ÍST30_kröfur * GSK

\begin{tabular}{llccc}
\hline \hline & & \multicolumn{2}{c}{ GSK } & \\
\cline { 3 - 4 } & & $\begin{array}{c}\text { Nei, veit ekki eða } \\
\text { ekki byggt á stöðlum }\end{array}$ & $\begin{array}{c}\text { Já eða í } \\
\text { innleiðingu }\end{array}$ & Samtals \\
\hline İST30_kröfur & Veit ekki & 1 & 0 & 1 \\
& Aldrei & 21 & 2 & 23 \\
& Sjaldan & 4 & 0 & 4 \\
& Stundum & 12 & 1 & 13 \\
& Oft & 14 & 11 & 25 \\
& Alltaf & 4 & 8 & 12 \\
Samtals & 56 & 22 & 78 \\
\hline \hline
\end{tabular}

Fylgni milli ÍST30_kröfur og GSK reyndist vera mjög marktæk hvort sem notast var við Sommers'd eða samhverfu fylgnistuðlana og segja má að hún sé rétt tæplega miðlungs sterk.

Tafla 426 Ósamhverf fylgnimæligildi: ÍST30_kröfur, GSK

\begin{tabular}{|c|c|c|c|c|c|}
\hline & & Gildi & fervik $^{\mathrm{a}}$ & $\mathrm{T}^{\mathrm{b}}$ & Sig. \\
\hline \multirow{3}{*}{$\begin{array}{l}\text { Raðbreyta } \\
\text { á móti } \\
\text { raðbreytu }\end{array}$} & Samhverft & ,414 &, 077 & 4,736 &, 000 \\
\hline & $\begin{array}{l}\text { ÍST30_kröfur } \\
\text { svarbreyta }\end{array}$ & ,594 & , 107 & 4,736 &, 000 \\
\hline & GSK svarbreyta & ,318 & ,067 & 4,736 & ,000 \\
\hline
\end{tabular}

a. Not assuming the null hypothesis.

b. Using the asymptotic standard error assuming the null hypothesis.

Tafla 427 Samhverf fylgnimæligildi: ÍST30_kröfur, GSK

\begin{tabular}{llcccc}
\hline \hline & & Gildi & fervik $^{\mathrm{a}}$ & $\mathrm{T}^{\mathrm{b}}$ & Sig. \\
\hline Raðbreyta á & Kendall's tau-c &, 481 &, 102 & 4,736 &, 000 \\
móti & Gamma &, 738 &, 112 & 4,736 &, 000 \\
raðbreytu & Spearman fylgnistuðull &, 479 &, 090 & 4,763 & $.000^{\mathrm{c}}$ \\
N af gildum tilfellum & 78 & & & \\
\hline \hline
\end{tabular}

a. Not assuming the null hypothesis.

b. Using the asymptotic standard error assuming the null hypothesis. 
c. Based on normal approximation.

\subsubsection{Fylgni: frábrigði, GSK}

Fylgni milli frábrigði_tilkynnt (hvernig verktaki tilkynnir verkkaupa um frábrigði) og GSK (hvort verkkaupi starfi eftir geeðastjórnunarkerfi byggðu á viðurkenndum gąastjórnunarstaðli) var skoðuð. 79 tilfelli flokkast undir gild tilfelli.

Tafla 428 Yfirlit tilfella í greiningu milli frábrigði_tilkynnt og GSK

\begin{tabular}{|c|c|c|c|c|c|c|c|}
\hline & \multicolumn{6}{|c|}{ Tilfelli } \\
\hline & & \multicolumn{2}{|c|}{ Gild } & \multicolumn{2}{|c|}{ Vantar } & \multicolumn{2}{|c|}{ Samtals } \\
\hline & & $\mathrm{N}$ & Hlutfall & $\mathrm{N}$ & Hlutfall & $\mathrm{N}$ & Hlutfall \\
\hline frábrigði_tilkynnt & GSK & 79 & $82.3 \%$ & 17 & $17.7 \%$ & 96 & $100.0 \%$ \\
\hline \multicolumn{8}{|c|}{ Tafla 429 Tengslatafla (tíðni): frábrigði_tilkynnt * GSK } \\
\hline & & & \multicolumn{4}{|c|}{ GSK } & \\
\hline & & & \multicolumn{3}{|c|}{$\begin{array}{c}\text { Nei, veit ekki eða ekki } \\
\text { byggt á stöðlum }\end{array}$} & $\begin{array}{c}\text { Já eða í } \\
\text { innleiðingu }\end{array}$ & Samtals \\
\hline \multirow[t]{4}{*}{ frábrigði_tilkynnt } & \multicolumn{2}{|c|}{ Veit ekki } & \multicolumn{3}{|c|}{4} & 1 & 5 \\
\hline & Mism & & \multicolumn{3}{|c|}{22} & 5 & 27 \\
\hline & Munr & & \multicolumn{3}{|c|}{11} & 2 & 13 \\
\hline & Skrif & & \multicolumn{3}{|c|}{18} & 16 & 34 \\
\hline \multicolumn{3}{|l|}{ Samtals } & \multicolumn{3}{|c|}{55} & 24 & 79 \\
\hline
\end{tabular}

Fylgni milli frábrigði_tilkynnt og GSK reyndist vera marktæk hvort sem notast var við Sommers'd eða samhverfu fylgnistuðlana en ekki mjög sterk.

Tafla 430 Ósamhverf fylgnimæligildi: frábrigði_tilkynnt, GSK

\begin{tabular}{|c|c|c|c|c|c|}
\hline & & Gildi & fervik $^{\mathrm{a}}$ & $\mathrm{T}^{\mathrm{b}}$ & Sig. \\
\hline \multirow{3}{*}{$\begin{array}{l}\text { Raðbreyta } \\
\text { á móti } \\
\text { raðbreytu }\end{array}$} & Samhverft & 254 & ,098 & 2,535 &, 011 \\
\hline & $\begin{array}{l}\text { frábrigði_tilkynnt } \\
\text { svarbreyta }\end{array}$ & ,327 &, 125 & 2,535 & 011 \\
\hline & GSK svarbreyta & 208 & ,083 & 2,535 &, 011 \\
\hline
\end{tabular}

a. Not assuming the null hypothesis.

b. Using the asymptotic standard error assuming the null hypothesis.

Tafla 431 Samhverf fylgnimaligildi: frábrigði_tilkynnt, GSK

\begin{tabular}{llcccc}
\hline \hline & & Gildi & fervik $^{\mathrm{a}}$ & $\mathrm{T}^{\mathrm{b}}$ & Sig. \\
\hline Raðbreyta á & Kendall's tau-c &, 277 &, 109 & 2,535 &, 011 \\
móti & Gamma &, 482 &, 176 & 2,535 &, 011 \\
raðbreytu & Spearman fylgnistuðull &, 279 &, 108 & 2,545 & $.013^{\mathrm{c}}$ \\
N af gildum tilfellum & 79 & & & \\
\hline \hline
\end{tabular}

a. Not assuming the null hypothesis.

b. Using the asymptotic standard error assuming the null hypothesis.

c. Based on normal approximation. 


\subsubsection{Fylgni: aukaverk_skrád, GSK}

Fylgni milli aukaverk_skráð (hvernig verktaki tilkynnir verkkaupa um frábrigði) og GSK (hvort verkkaupi starfi eftir gæeðastjórnunarkerfi byggðu á viðurkenndum gaðastjórnunarstaðli) var skoðuð. 82 tilfelli flokkast undir gild tilfelli.

Tafla 432 Yfirlit tilfella í greiningu milli aukaverk_skráð og GSK

\begin{tabular}{lccccccc}
\hline \hline & \multicolumn{9}{c}{ Tilfelli } \\
\cline { 2 - 8 } & \multicolumn{2}{c}{ Gild } & \multicolumn{2}{c}{ Vantar } & \multicolumn{2}{c}{ Samtals } \\
\cline { 2 - 8 } & $\mathrm{N}$ & Hlutfall & $\mathrm{N}$ & Hlutfall & $\mathrm{N}$ & Hlutfall \\
\hline aukaverk_skrád * GSK & 82 & $85.4 \%$ & 14 & $14.6 \%$ & 96 & $100.0 \%$ \\
\hline \hline
\end{tabular}

Tafla 433 Tengslatafla (tíðni): aukaverk_skrád * GSK

\begin{tabular}{llccc}
\hline \hline & & \multicolumn{2}{c}{ GSK } & \\
\cline { 2 - 4 } & & $\begin{array}{c}\text { Nei, veit ekki eða ekki } \\
\text { byggt á stöðlum }\end{array}$ & $\begin{array}{c}\text { Já eða í } \\
\text { innleiðingu }\end{array}$ & Samtals \\
\hline aukaverk_skráð & Aldrei & 10 & 1 & 11 \\
& Sjaldan & 3 & 0 & 3 \\
& Stundum & 11 & 0 & 11 \\
& Oft & 16 & 3 & 19 \\
Samtals & Alltaf & 18 & 20 & 38 \\
\hline \hline
\end{tabular}

Fylgni milli aukaverk_skrád og GSK reyndist vera mjög marktæk hvort sem notast var við Sommers'd eða samhverfu fylgnistuðlana og flokkast hún undir að vera rétt tæplega miðlungs sterk.

Tafla 434 Ósamhverf fylgnimaligildi: frábrigð__tilkynnt, GSK

\begin{tabular}{|c|c|c|c|c|c|}
\hline & & Gildi & fervik $^{\mathrm{a}}$ & $\mathrm{T}^{\mathrm{b}}$ & Sig. \\
\hline \multirow{3}{*}{$\begin{array}{l}\text { Raðbreyta } \\
\text { á móti } \\
\text { raðbreytu }\end{array}$} & Samhverft & ,413 &, 074 & 5,010 &, 000 \\
\hline & $\begin{array}{l}\text { aukaverk_skráð } \\
\text { svarbreyta }\end{array}$ & ,553 &, 095 & 5,010 &, 000 \\
\hline & GSK svarbreyta & ,330 & ,068 & 5,010 &, 000 \\
\hline
\end{tabular}

a. Not assuming the null hypothesis.

b. Using the asymptotic standard error assuming the null hypothesis. 
Tafla 435 Samhverf fylgnimæligildi: frábrigði_tilkynnt, GSK

\begin{tabular}{llcccc}
\hline \hline & & Gildi & fervik $^{\mathrm{a}}$ & $\mathrm{T}^{\mathrm{b}}$ & Sig. \\
\hline Raðbreyta á & Kendall's tau-c &, 458 &, 091 & 5,010 &, 000 \\
móti & Gamma &, 791 &, 114 & 5,010 &, 000 \\
raðbreytu & Spearman fylgnistuðull &, 464 &, 083 & 4,683 & $.000^{\mathrm{c}}$ \\
N af gildum tilfellum & 82 & & & \\
\hline \hline
\end{tabular}

a. Not assuming the null hypothesis.

b. Using the asymptotic standard error assuming the null hypothesis.

c. Based on normal approximation.

\subsubsection{Fylgni: aukaverk_skrá, GSK}

Fylgni milli aukaverk_skrá (hversu oft verktaki skilar verkkaupa skrá um hugsanlegar kröfur um greiðslur vegna aukaverka og breytinga) og GSK (hvort verkkaupi starfi eftir gaðastjórnunarkerfi byggðu á viðurkenndum gœðastjórnunarstaðli) var skoðuð. 79 tilfelli flokkast undir gild tilfelli.

Tafla 436 Yfirlit tilfella í greiningu milli aukaverk_skráðog GSK

\begin{tabular}{ccccccc}
\hline \hline & \multicolumn{9}{c}{ Tilfelli } \\
\cline { 2 - 8 } & \multicolumn{3}{c}{ Gild } & \multicolumn{2}{c}{ Vantar } & \multicolumn{2}{c}{ Samtals } \\
\cline { 2 - 8 } & $\mathrm{N}$ & Hlutfall & $\mathrm{N}$ & Hlutfall & $\mathrm{N}$ & Hlutfall \\
\hline aukaverk_skrá * GSK & 79 & $82.3 \%$ & 17 & $17.7 \%$ & 96 & $100.0 \%$ \\
\hline \hline
\end{tabular}

Tafla 437 Tengslatafla (tíðni): aukaverk_skrá * GSK

\begin{tabular}{llccc}
\hline \hline & \multicolumn{2}{c}{ GSK } & \\
\cline { 3 - 4 } & $\begin{array}{c}\text { Nei, veit ekki eða } \\
\text { ekki byggt á stöðlum }\end{array}$ & $\begin{array}{c}\text { Já eða í } \\
\text { innleiðingu }\end{array}$ & Samtals \\
\hline aukaverk_skrá & Veit ekki / annað & 9 & 7 & 16 \\
& Aldrei & 9 & 1 & 10 \\
& Að verki loknu & 12 & 3 & 15 \\
& Mánaðarlega & 15 & 8 & 23 \\
& Vikulega & 11 & 4 & 15 \\
Samtals & 56 & 23 & 79 \\
\hline \hline
\end{tabular}

Fylgni milli aukaverk_skrá og GSK reyndist ekki vera marktæk hvort sem notast var við Sommers 'd eða samhverfu fylgnistuðlana. 


\begin{tabular}{|c|c|c|c|c|c|}
\hline & & Gildi & fervik ${ }^{\mathrm{a}}$ & $\mathrm{T}^{\mathrm{b}}$ & Sig. \\
\hline \multirow{3}{*}{$\begin{array}{l}\text { Raðbreyta } \\
\text { á móti } \\
\text { raðbreytu }\end{array}$} & Samhverft &,- 027 &, 100 &,- 267 & ,790 \\
\hline & $\begin{array}{l}\text { aukaverk_skrá } \\
\text { svarbreyta }\end{array}$ &,- 039 & 145 &,- 267 & ,790 \\
\hline & GSK svarbreyta &,- 020 & ,076 & -267 &, 790 \\
\hline
\end{tabular}

a. Not assuming the null hypothesis.

b. Using the asymptotic standard error assuming the null hypothesis.

Tafla 439 Samhverf fylgnimæligildi: aukaverk_skrá, GSK

\begin{tabular}{llcccc}
\hline \hline & & Gildi & fervik $^{\mathrm{a}}$ & $\mathrm{T}^{\mathrm{b}}$ & Sig. \\
\hline Raðbreyta á & Kendall's tau-c &,- 032 &, 120 &,- 267 &, 790 \\
móti & Gamma &,- 049 &, 184 &,- 267 &, 790 \\
raðbreytu & Spearman fylgnistuðull &,- 031 &, 117 &,- 275 & $.784^{\mathrm{c}}$ \\
N af gildum tilfellum & 79 & & & \\
\hline \hline
\end{tabular}

a. Not assuming the null hypothesis.

b. Using the asymptotic standard error assuming the null hypothesis.

c. Based on normal approximation.

\subsubsection{Fylgni: hættumat, GSK}

Fylgni milli hoettumat (hvort verktaki útbúi hoettumat áður en framkvoemdir hefjast) og GSK (hvort verkkaupi starfi eftir gceðastjórnunarkerfi byggðu á viðurkenndum geeðastjórnunarstaðli) var skoðuð. 78 tilfelli flokkast undir gild tilfelli.

Tafla 440 Yfirlit tilfella í greiningu milli hattumat og GSK

\begin{tabular}{lcccccc}
\hline \hline & \multicolumn{7}{c}{ Tilfelli } \\
\cline { 2 - 8 } & \multicolumn{3}{c}{ Gild } & \multicolumn{2}{c}{ Vantar } & \multicolumn{2}{c}{ Samtals } \\
\cline { 2 - 8 } & $\mathrm{N}$ & Hlutfall & $\mathrm{N}$ & Hlutfall & $\mathrm{N}$ & Hlutfall \\
\hline hættumat * GSK & 78 & $81.3 \%$ & 18 & $18.8 \%$ & 96 & $100.0 \%$ \\
\hline \hline
\end{tabular}




\begin{tabular}{llccc}
\hline \hline & & \multicolumn{2}{c}{ GSK } & \\
\cline { 3 - 5 } & & $\begin{array}{c}\text { Nei, veit ekki eða } \\
\text { ekki byggt á stöðlum }\end{array}$ & $\begin{array}{c}\text { Já eða í } \\
\text { innleiðingu }\end{array}$ & Samtals \\
\hline \multirow{2}{*}{ hættumat } & Veit ekki & 1 & 0 & 1 \\
& Aldrei & 25 & 1 & 26 \\
& Sjaldan & 4 & 3 & 7 \\
& Stundum & 10 & 5 & 15 \\
& Oft & 14 & 7 & 21 \\
& Alltaf & 3 & 5 & 8 \\
Samtals & 57 & 21 & 78 \\
\hline \hline
\end{tabular}

Fylgni milli hoettumat og GSK reyndist vera mjög marktæk hvort sem notast var við Sommers'd eða samhverfu fylgnistuðlana en ekki mjög sterk.

Tafla 442 Ósamhverf fylgnimaligildi: haettumat, $\mathbf{G S K}$

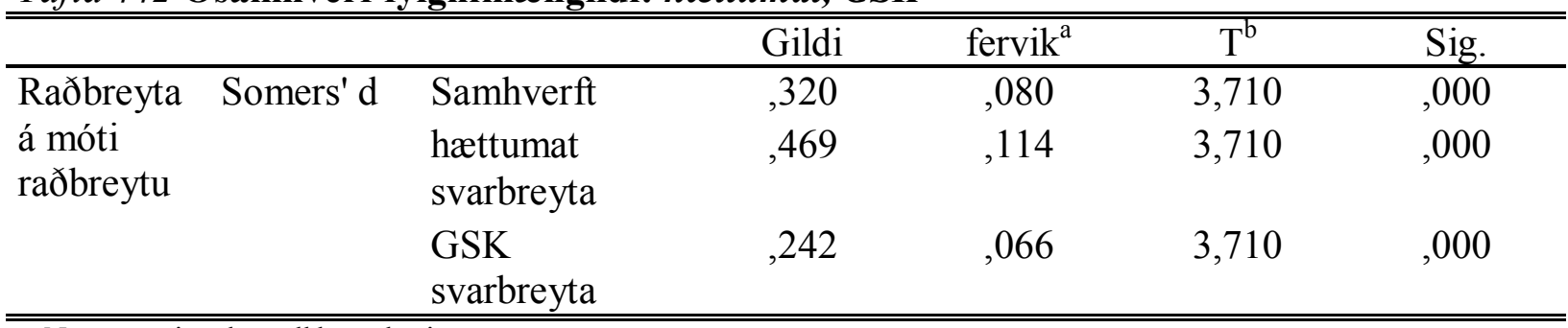

a. Not assuming the null hypothesis.

b. Using the asymptotic standard error assuming the null hypothesis.

Tafla 443 Samhverf fylgnimæligildi: haettumat, $\mathbf{G S K}$

\begin{tabular}{llcccc}
\hline \hline & & Gildi & fervik $^{\mathrm{a}}$ & $\mathrm{T}^{\mathrm{b}}$ & Sig. \\
\hline Raðbreyta á & Kendall's tau-c &, 369 &, 099 & 3,710 &, 000 \\
móti & Gamma &, 563 &, 127 & 3,710 &, 000 \\
raðbreytu & Spearman fylgnistuðull &, 372 &, 093 & 3,499 & $.001^{\mathrm{c}}$ \\
N af gildum tilfellum & 78 & & & \\
\hline \hline
\end{tabular}

a. Not assuming the null hypothesis.

b. Using the asymptotic standard error assuming the null hypothesis.

c. Based on normal approximation.

\subsubsection{Fylgni: gæðaeftirlit_utanaðkomandi, GSK}

Fylgni milli gaððaeftirlit_utanaðkomandi (hvort verktaki notist við utanaðkomandi pjónustu við gœðaeftirlit) og GSK (hvort verkkaupi starfi eftir gœðastjórnunarkerfi byggðu á viðurkenndum gœðastjórnunarstaðli) var skoðuð. 78 tilfelli flokkast undir gild tilfelli. 


\begin{tabular}{lccccccc}
\hline \hline & \multicolumn{6}{c}{ Tilfelli } \\
\cline { 2 - 8 } & \multicolumn{2}{c}{ Gild } & \multicolumn{2}{c}{ Vantar } & \multicolumn{2}{c}{ Samtals } \\
\cline { 2 - 7 } & $\mathrm{N}$ & Hlutfall & $\mathrm{N}$ & Hlutfall & $\mathrm{N}$ & Hlutfall \\
\hline gæðaeftirlit_utanaðkomandi & 78 & $81.3 \%$ & 18 & $18.8 \%$ & 96 & $100.0 \%$ \\
$*$ GSK & & & & & & & \\
\hline \hline
\end{tabular}

Tafla 445 Tengslatafla (tỉðni): gaeðaeftirlit_utanaðkomandi * GSK

\begin{tabular}{llccc}
\hline \hline & & \multicolumn{2}{c}{ GSK } & \\
\cline { 3 - 4 } & & $\begin{array}{c}\text { Nei, veit ekki eða ekki } \\
\text { byggt á stöðlum }\end{array}$ & $\begin{array}{c}\text { Já eða í } \\
\text { innleiðingu }\end{array}$ & Samtals \\
\hline gæðaeftirlit_utanaðkomandi & Aldrei & 27 & 13 & 40 \\
& Sjaldan & 4 & 0 & 4 \\
& Stundum & 13 & 4 & 17 \\
& Oft & 3 & 4 & 7 \\
Samtals & Alltaf & 9 & 1 & 10 \\
\hline \hline
\end{tabular}

Fylgni milli gœðaeftirlit_utanaðkomandi og GSK reyndist ekki vera marktæk hvort sem notast var við Sommers'd eða samhverfu fylgnistuðlana.

Tafla 446 Ósamhverf fylgnimæligildi: gąaeftirlit_utanaðkomandi, GSK

\begin{tabular}{|c|c|c|c|c|c|}
\hline & & Gildi & fervik $^{\mathrm{a}}$ & $\mathrm{T}^{\mathrm{b}}$ & Sig. \\
\hline \multirow{3}{*}{$\begin{array}{l}\text { Raðbreyta Somers' d } \\
\text { á móti } \\
\text { raðbreytu }\end{array}$} & Samhverft &,- 070 &, 100 &,- 698 &, 485 \\
\hline & $\begin{array}{l}\text { gæðaeftirlit_utanaðkomandi } \\
\text { svarbreyta }\end{array}$ &,- 093 & 132 &,- 698 & ,485 \\
\hline & GSK svarbreyta &,- 057 &, 081 &,- 698 & ,485 \\
\hline
\end{tabular}

a. Not assuming the null hypothesis.

b. Using the asymptotic standard error assuming the null hypothesis.

Tafla 447 Samhverf fylgnimæligildi: gaeðaeftirlit_utanaðkomandi, GSK

\begin{tabular}{llcccc}
\hline \hline & & Gildi & fervik $^{\mathrm{a}}$ & $\mathrm{T}^{\mathrm{b}}$ & Sig. \\
\hline Raðbreyta á & Kendall's tau-c &,- 075 &, 107 &,- 698 &, 485 \\
móti & Gamma &,- 141 &, 205 &,- 698 &, 485 \\
raðbreytu & Spearman fylgnistuðull &,- 078 &, 112 &,- 683 & $.496^{\mathrm{c}}$ \\
N af gildum tilfellum & 78 & & & \\
\hline \hline
\end{tabular}

a. Not assuming the null hypothesis.

b. Using the asymptotic standard error assuming the null hypothesis.

c. Based on normal approximation. 


\subsubsection{Fylgni: gæðastýringaráætlun, GSK}

Fylgni milli gæeðastýringarácetlun (hvort verktaki veeri með skipulagt innra eftirlit með framkvoemdum) og GSK (hvort verkkaupi starfi eftir gæeðastjórnunarkerfi byggðu á viðurkenndum gceðastjórnunarstaðli) var skoðuð. 78 tilfelli flokkast undir gild tilfelli.

\section{Tafla 448 Yfirlit tilfella í greiningu milli gaeðastýringaráaetlun og GSK}

\begin{tabular}{lccccccc}
\hline \hline & \multicolumn{9}{c}{ Tilfelli } \\
\cline { 2 - 8 } & \multicolumn{2}{c}{ Gild } & \multicolumn{2}{c}{ Vantar } & \multicolumn{2}{c}{ Samtals } \\
\cline { 2 - 8 } & $\mathrm{N}$ & Hlutfall & $\mathrm{N}$ & Hlutfall & $\mathrm{N}$ & Hlutfall \\
\hline $\begin{array}{l}\text { gæðastýringaráætlun * } \\
\text { GSK }\end{array}$ & 78 & $81.3 \%$ & 18 & $18.8 \%$ & 96 & $100.0 \%$ \\
\hline \hline
\end{tabular}

Tafla 449 Tengslatafla (tíðni): gaeðastýringaráaetlun * GSK

\begin{tabular}{llccc}
\hline \hline & & \multicolumn{2}{c}{ GSK } & \\
\cline { 3 - 4 } & & $\begin{array}{c}\text { Nei, veit ekki eða ekki } \\
\text { byggt á stöðlum }\end{array}$ & $\begin{array}{c}\text { Já eða í } \\
\text { innleiðingu }\end{array}$ & Samtals \\
\hline gæðastýringaráætlun & Veit ekki & 2 & 0 & 2 \\
& Aldrei & 34 & 2 & 36 \\
& Sjaldan & 3 & 1 & 4 \\
& Stundum & 8 & 7 & 15 \\
& Oft & 5 & 6 & 11 \\
Samtals & 3 & 7 & 10 \\
\hline \hline
\end{tabular}

Fylgni milli gæeðastýringarácetlun og GSK reyndist vera mjög marktæk hvort sem notast var við Sommers'd eða samhverfu fylgnistuðlana og flokkast hún til pess að vera miðlungs sterk.

\section{Tafla 450 Ósamhverf fylgnimæligildi: gaeðastýringarácetlun, $\mathbf{G S K}$}

\begin{tabular}{|c|c|c|c|c|c|}
\hline & & Gildi & fervik $^{\mathrm{a}}$ & $\mathrm{T}^{\mathrm{b}}$ & Sig. \\
\hline \multirow{3}{*}{$\begin{array}{l}\text { Raðbreyta Somers' d } \\
\text { á móti } \\
\text { raðbreytu }\end{array}$} & Samhverft & 485 & ,075 & 5,671 &, 000 \\
\hline & $\begin{array}{l}\text { gæðastýringaráætlun } \\
\text { svarbreyta }\end{array}$ & ,657 & ,095 & 5,671 &, 000 \\
\hline & GSK svarbreyta & ,385 & ,068 & 5,671 &, 000 \\
\hline
\end{tabular}

a. Not assuming the null hypothesis.

b. Using the asymptotic standard error assuming the null hypothesis. 


\begin{tabular}{llcccc}
\hline \hline & & Gildi & fervik $^{\mathrm{a}}$ & $\mathrm{T}^{\mathrm{b}}$ & Sig. \\
\hline Raðbreyta á & Kendall's tau-c &, 546 &, 096 & 5,671 &, 000 \\
móti & Gamma &, 764 &, 085 & 5,671 &, 000 \\
raðbreytu & Spearman fylgnistuðull &, 550 &, 085 & 5,743 & $.000^{\mathrm{c}}$ \\
N af gildum tilfellum & 78 & & & \\
\hline \hline
\end{tabular}

a. Not assuming the null hypothesis.

b. Using the asymptotic standard error assuming the null hypothesis.

c. Based on normal approximation.

\subsection{Kröfur verkkaupa}

Fylgni milli annars vegar kröfur_einst_EH, kröfur_einst_FH, kröfur_fyrirt_EH, kröfur fyrirt_FH, kröfur_opinb_EH, kröfur_opinb_FH, p.e. kröfum verkkaupa til verktaka fyrir og eftir efnahagshrun og hins vegar GSK sýndi í öllum tilfellum að ekki var marktæk fylgni par á milli. 


\section{Viðauki J - Athugasemdir um könnun fyrir verktaka}

\subsubsection{Grunnupplýsingar}

- Pátttakendur voru spurðir hvernig verktakar peir væru og ákveðnir flokkar voru lagðir fram. Ekki var gefinn kostur á pví að velja meira en einn valmöguleika, en pátttakendur gátu valið ,,annað“ og fengið pá upp glugga fyrir „opið“ svar. Færa má rök fyrir pví að betra hefði verið að gefa verktökum kost á að merkja við meira en eitt svar eða að betra hefði verið að hafa spurninguna alveg opna. Undirritaðri fannst fýsilegra að leggja fram flokka með spurningunni svo að verktakar myndu finna sig innan peirra.

- Spurt er um aldur og starfsmannafjölda fyrirtækis sem pátttakendar starfa hjá. Ákveðið var að skipta upp í flokka pegar spurningin var lögð fram en ekki eftir á. Rökin felast í pví að líklegra pótti að pátttakendur myndu svara spurningunni ef hún væri lögð fram með fyrirfram gefnum flokkum ef peir væru ekki alveg vissir á aldri eða starfsmannafjölda en ef spurt væri opinnar spurningar.

- Spurt var um aldur pátttakenda og eins og áđur var skipt upp í aldursflokka pegar spurningin var lögð fram til að gæta samræmis við aldurs spurningar vegna fyrirtækis.

- Pátttakendur voru spurðir í hvaða sveitarfélagi fyrirtækið starfi sem viðkomandi starfar hjá. Pátttakendur sem svöruðu á fundi með meistarafélagi Iðnaðarmanna í Hafnarfirði voru ekki spurðir að pessari spurningu en gert er ráð fyrir að pau fyrirtæki starfi í Hafnarfirði.

- Pegar pátttakendur voru spurðir hvaða stöðu peir gegndu innan fyrirtækisins var peim gefinn kostur á að merkja við fleiri en einn valmöguleika.

\subsubsection{Gæðastjórnun}

- Peir pátttakendur sem sögðu fyrirtæki sitt starfa eftir gæðastjórnunarkerfi byggðu á viðurkenndum gæðastaðli voru spurðir hvaða staðli kerfið byggði á og var pá gefin kostur á pví að velja fleiri en einn svarmöguleika. Svarmöguleikarnir eru eftirfarandi: „ISO“, „SI“, „ÍST 30“, „Veit ekki“ og ,annað“. Ekki pótti fýsilegt að tilgreina nánar hvaða ISO staðli sökum pess að pað gæti reynst pátttakendum ruglandi. Með „SI“ er átt við kerfi Samtaka Iðnaðarins sem byggir á ISO. Valmöguleikinn ,ÍST 30“ var hafður prátt fyrir að ÍST 30 sé samskiptastaðall og er pað á gráu svæði hvort fyrirtæki sem byggi kerfi sitt á peim staðli geti talist með í hópi fyrirtækja með virk gæðastjórnunarkerfi.

- beir pátttakendur sem sögðu fyrirtæki sitt vera með vottað gæðastjórnunarkerfi voru spurðir hvernig vottun fyrirtækið hefði hlotið og var pá gefin kostur á pví að velja fleiri en einn svarmöguleika.

- Pátttakendur voru spurðir hvort peir viðhefðu sérstakar öryggisráðstafanir á verkstað, og voru svarmöguleikarnir, „alltaf“, „oft“, „stundum“, „,sjaldan“ og ,aldrei“. Mögulega 
gefa svarmöguleikarnir „oft“, „stundum“, ,sjaldan“ of mikið eftir til túlkunar og leggur skýrsluhöfundur til að ef rannsóknin verði framkvæmd aftur að svarmöguleikarnir bjóði upp á minni túlkun. Ef til vill væri betra að hafa bara „alltaf“, „stundum“ og ,aldrei“.

\subsubsection{Gæðatrygging}

- Pátttakendur voru spurðir hvort peir sýndu verkkaupa fram á gæðatryggingu í verkbyrjun með svarmöguleikunum, ,alltaf“, „oft“, „stundum“, „sjaldan“, „einungis pegar um er beðið“, ,aldrei“ eða „veit ekki“. Svarmöguleikinn „einungis pegar um er beðið“ getur virka villandi innan um hina svarmöguleikana og gefur einn og sér litlar upplýsingar um fjölda tilvika sem verktaki sýnir fram á gæðatryggingu. Ákveðið var að hafa valmöguleikann inni vegna eðli spurningarinnar og með tilliti til pess að í næstu spurningu hvar spurt hversu oft verkkaupi óski eftir gæðatryggingu. Peir pátttakendur sem svöruðu pví að peir sýndu verkkaupa einungis fram á gæðatryggingu ef pess var óskað eru sérstaklega skoðaðir með tilliti til næstu spurningu og pannig hægt að greina hversu oft slíkt plagg er lagt fram.

\subsubsection{Verklag}

- Ekki var spurt beint hvort verktaki væri með nákvæma hráefnis og tíma-skráningu. En fram kemur í bókinni "Hvernig gera má betur - kennslubók SI", eftir Ferdinand Hansen, að nákvæm tíma- og hráefnisskráning er meðal máttarstólpa hvers fyrirtækis og með tímaskráningu safnast bæði upplýsingar og staðreyndir sem hægt er að nota t.d. til að reikna út gagnlegar upplýsingar svo sem eins og laun starfsmanna, afkomu verkefna og verðlagningu, við áætlunar gerð og daglega skipulagningu auk ýmissa umbóta- og hagræðingarverkefna (Ferdinand Hansen, Samtök iðnaðarins, 2007) 


\subsubsection{Kröfur verkkaupa}

- Verktakar voru spurðir sérstaklega um kröfur verkaupa um skipulag og markvissa stjórnun í garð verktaka. Í ljós kom pegar viðtöl voru tekin við verktaka að mörgum pótti pessar kröfur hafa breyst hverfandi lítið eftir efnahagshrunið miðað við kröfur verkkaupa um lægra verð. Dví hefơi verið ráðlagt að spyrja einnig um slíkar kröfur. 


\section{Viðauki K - Flokkunar aðhvarfsgreining (e. Categorical Regression - CATREG)}

\subsection{Líkanið í CATREG}

Öll stærðfræðitákn sem eru notuð í kafla um CATREG eru skilgreind í viðauka á bls. 399.

Markfallið (e. objective function) í CATREG finnur sett af $\mathbf{y}_{r}, \mathbf{b}$, and $\mathbf{y}_{j}, j \in J_{p}$, pannig að fallið Jafna 1: Markfall i CATREG

$$
\sigma\left(y_{r} ; \boldsymbol{b} ; y_{j}\right)=\boldsymbol{G}_{r} y_{\boldsymbol{r}}-\int_{j \in j_{p}} b_{j} \boldsymbol{G}_{j} \boldsymbol{y}_{j}^{\prime} \mathbf{W}\left(\boldsymbol{G}_{r} y_{\boldsymbol{r}}-\int_{j \in{ }_{p}} b_{j} \boldsymbol{G}_{j} \boldsymbol{y}_{j}\right)
$$

sé lágmarkandi undir normalskorðunum $\mathbf{y}^{\prime} r \mathbf{D} r \mathbf{y} r=n w$. Mælingargildi fyrir svarbreytuna eru einnig miðjuð, p.e. pau uppfylla $\mathbf{u}^{\prime} \mathbf{W} \mathbf{G} r \mathbf{y} r=0$ par sem $\mathbf{u}$ er einingavigur af stigi $\mathrm{n}$ (SPSS Statistics Inc., 2010).

Með pjálgun (e. regularization) er tapfallinu (e. loss function) varpað yfir í

Jafna 2 tapföll i CATREG:

$$
\begin{gathered}
\int_{j \in J p}^{P} \beta_{j}^{2} \leq t_{2} \text { fyrir Ridge og } \\
\int_{j \in J p}^{P}\left|\beta_{j}^{2}\right| \leq t_{1} \text { fyrir Lasso og að lokum } \\
\int_{j \in J p}^{P}\left|\beta_{j}\right| \leq t_{1} \text { og } \int_{j \in J p}^{P} \beta_{j}^{2} \leq t_{2} \quad \text { fyrir Elastic Net. }
\end{gathered}
$$

Einnig er hægt að skrifa skorðaða tapfallið sem refsi- tapfall (e. penalized loss functions)

Jafna 3 Refsi-tapföll i CATREG

$$
L^{\text {ridge }}=L+\lambda_{2} \int_{j \in J p}^{P} \beta_{j}^{2}
$$




$$
\begin{gathered}
L^{\text {lasso }}=L+\lambda_{1} \int_{j \in J p}^{P} \operatorname{sign}\left(\beta_{j}\right) \beta_{j} \quad o g \\
L^{\mathrm{e}-\mathrm{net}}=L+\lambda_{1} \int_{j \in J p}^{P} \operatorname{sign}\left(\beta_{j}\right) \beta_{j}+\lambda_{2} \int_{j \in J p}^{P} \beta_{j}^{2}
\end{gathered}
$$

(SPSS Statistics Inc., 2010).

\subsection{Reiknirit}

Markfallið í CATREG er bestað með eftirfarandi reikniriti (SPSS Statistics Inc., 2010) par sem að $\mathrm{n}_{\text {tot }}$ er heildarfjöldi tilfella, $\mathrm{w}_{\mathrm{i}}=$ vægi hlutar $\mathrm{i}, \mathbf{W}$ er hornlínufylki $\mathrm{n}_{\text {tot }} \times \mathrm{n}_{\text {tot }}$ með $\mathrm{w}_{\mathrm{i}}$ á hornalínunni, $\mathrm{k}_{\mathrm{j}}$ er fjöldi flokka af breytu $\mathrm{j}, \mathbf{G}_{\mathrm{j}}$ er vísa fylki fyrir breytu $\mathrm{j}$, af stigi $\mathrm{n}_{\mathrm{tot}} \times \mathrm{k}_{\mathrm{j}}, \mathrm{y}_{\mathrm{j}}$ er kvarði spábreytu $\mathrm{j}$ af stigi $\mathrm{k}_{\mathrm{j}}, \mathbf{D}_{\mathrm{j}}$ er hornalínufylki $\mathrm{k}_{\mathrm{j}} \times \mathrm{k}_{\mathrm{j}}$, sem inniheldur vegna dálka summu af $\boldsymbol{G}^{\prime}{ }_{j}\left(\mathbf{D}_{\mathbf{j}}=\mathbf{G}_{\mathbf{j}} \mathbf{W} \mathbf{G}_{\mathbf{j}}\right), \mathrm{n}_{\mathrm{w}}$ er veiginn fjöldi tilfella og $\mathrm{m}$ er fjöldi greiningar breyta. Öll stærðfræðitákn sem notuð eru í kaflanum eru tekin saman og útskírð nánar í viðauka á bls. 399.

Reiknirit bestunar felst í eftirfarandi ítrunar skrefum:

1. Upphafsstilling I eða II

2. Uppfæra kvarða fyrir flokka (e. quantification) á svarbreytu

3. Uppfæra kvarða fyrir flokka og vægi aðhvarfsgreiningarstuðla

4. Samleitni próf: endurtakaskref 2 og 3 eða halda áfram.

Nánari útskýring á skrefunum fjórum;

\subsubsection{Frumstilling}

\section{Tilviljunarkennt}

Upphafsstilling flokka mælinga, $\tilde{y}_{j}\left(\right.$ fyrir $\mathrm{j}=1, \ldots, \mathrm{m}$ ) er skilgreind sem $\mathrm{k}_{\mathrm{j}}$ flokka vísir af breytu j, stöðluð pannig að $u^{\prime} \boldsymbol{W} G_{j}{\widetilde{y_{j}}}=0$ og $\tilde{y}_{j} D_{j} \tilde{y}_{j}=n_{w^{\prime}}$ og upphaf aðhvarfsgreininga stuðlarnir eru fylgni við svarbreytu. 


\section{Tölulegt}

Ítrana skrefin eru framkvæmd tvisvar í pessari aðferð. Í fyrsta hring er upphafsstilling með aðferð I par sem allar breytur eru meðhöndlaðar eins og tölulegar breytur. Annar hringur hefst með flokka kvörðum og aðhvarfsgreiningar stuðlum frá fyrsta hringnum.

\section{Fjölstart (ALLT)}

Fjölstart felur í sér að allar mögulegar kerfisbundnar upphafsstillingar eru notaðar sem tryggir að besta víðfeðma (e. global) lausn fæst pegar ein eða fleiri svarbreyta er kvörðuð sem splæst raðbreyta eða sem raðbreyta (Anita J. van der Kooij, 2003, bls. 446-462). Með fjölstarti er ítrana hringurinn að ofan framkvæmdur $2^{\mathrm{s}}$, par sem $\mathrm{s}$ er fjöldi spábreyta sem eru kvarðaðar sem splæsingar raðbreytur eða sem raðbreytur og $2^{\mathrm{s}}$ er fjöldi allra mögulegra samsetninga á formerkjum fyrir aðhvarfsgreiningar stuðlana hjá spábreytunum sem eru (splcestar) raðbreytur. Hver ítrun hefst á sömu frumstillingum fyrir kvarða flokkabreyta og aðhvarfsgreiningarstuðla (upphafsstilling I), en með mismunandi samsetningu á formerkjum fyrir stuðlana. Í ítrunarferlinu er formerkjunum haldið föstum. Að lokum er ítrunarhringurinn endurtekinn einu sinni enn með bestu samsetningu á formerkjum stuðlanna með tilliti til hæsta gildis á $\mathrm{R}^{2}$, eða $\mathrm{RSQ}^{\text {regu }}$ ef strjálgun er beitt.

\section{Fjölstart (GILDI)}

pegar gildi pröskuldsfalls er skilgreint sem kerfisbundinn upphafspunktur, er ítrunar ferlið framkvæmt tvisvar fyrir ákveðinn hluta af formerkja samsetningum á aðhvarfsgreiningar stuðlunum hjá spábreytunum sem eru með (splcesta) raðbreytu kvarða. Formerkja samsetningin er valin út frá samsetningu af stefnu hlutfallslegrar lækkunar í ferviki og stigveldis stefnu (Anita J. van der Kooij, 2003). Fjöldi mögulegrar samsetninga á formerkjum er pá $1+\sum_{i=1}^{s} i$.

Í fyrsta ítrunarhring (upphafsstilling með upphafsstillingu I) eru allar breytur meðhöndlaðar eins og nafnbreytur. Annar ítrunarhringur hefst með flokka kvörðun og aðhvarfsgreiningarstuðlum frá fyrsta hring. Eftir eina ítrun í öðrum hring er lækkun ferviks frá síðustu ítrun í fyrsta ítrunarhring til fyrstu ítrunar í öðrum ítrunarhring ákvarðað út frá spábreytum með (splcestum) raðbreytu kvarða. Ef lækkun í ferviki fyrir spábreytu er hærri en gildi pröskuldsfallsins, fær spábreytan neikvætt formerki. Pessi itrunarhringur eru endurtekinn nokkrum sinnum; einu sinni með alla aðhvarfsgreiningarstuðla spábreyta sem eru kvarðaðar sem (splcestar) raðbreytur, jákvæða og q sinnum ${ }^{136}$ með alla aðhvarfsgreiningarstuðla spábreyta sem kvarðaðar eru sem (splesstar) raðbreytur, jákvæða nema einn sem er neikvæður. Ef lausn par sem allir aðhvarfsgreiningarstuðlar eru með jákvæðum formerkjum er betri en besta lausn með einu neikvæðu formerki er ítrunarhringurinn framkvæmdur einu sinni enn með öllum formerkjum á aðhvarfsgreiningarstuðlum jákvæðum og lokalausn er fundin. Ef lausn með einu neikvæðu formerki á aðhvarfsgreiningarstuðlum er betri en lausn með öllum formerkjum jákvæðum er ítrunum haldið áfram og prófað er fyrir tvö neikvæð formerki á aðhvarfsgreiningarstuðlum. Ef lausnin með einu neikvæðu formerki er betri en sú sem fékkst með tveimur neikvæðum formerkjum er fyrrgreind lausn notuð, annars er hringurinn endurtekinn fyrir prjú neikvæð formerki, o.s.frv.

\footnotetext{
${ }^{136}$ par sem q er fjöldi spábreyta sem eru kvarðaðar sem (splcestar) raðbreytur og hafa fengið neikvætt formerki
} 


\section{Föst formerki}

Ítrunarhringurinn er framkvæmdur tvisvar. Í fyrsta hring (upphafsstilling með upphafsstillingu I) eru allar breytur meðhöndlaðar eins og nafnbreytur. Í öðrum hring eru flokka kvörðun og aðhvarfsgreininga stuðlar frá fyrsta hring og föst fyrirfram tilgreind formerki fyrir aðhvarfsgreiningar stuðlana hjá (splcestu) raðbreytunum notuð.

\subsubsection{Uppfæra kvarða fyrir flokka á svarbreytu}

Áfram er notast við skilgreiningar á stærðfræðitáknum úr viðauka á bls. 399.

Með föstum gildum á $\mathrm{y}_{\mathrm{j}}, j \in J_{p}$ er óskorðuð uppfærsla á $\tilde{y}_{r}=\mathrm{D}_{\mathrm{r}}^{-1} \mathrm{G}_{\mathrm{r}}^{\prime} \mathrm{W}_{\mathrm{v}}$

1. Ef svarbreytan er nafnbreyta gildir: $y_{r}^{*}=\tilde{y}_{r}$.

Fyrir næstu fjögur bestunar kvörðunar stig, ef breyta j var innsett í viðbótar flokk, pá er $y_{r}^{*}$ innifalinn flokkur $\mathrm{k}_{\mathrm{r}}$ í upphafs fasanum og viðbótarflokkur $\mathrm{k}_{\mathrm{r}}$ í lokafasanum.

2. Ef svarbreyta er splæst nafn- eða raðbreyta gildir: $y_{r}^{*}=d_{r}+S_{r} a_{r}$

Splæsta aðhvarfsgreiningin er framkvæmd eins og veigin aðhvarfsgreining (hornalinustök $\boldsymbol{D}_{r}$ eru veegisstuðlar) af $\tilde{y}_{r}$ á I-splæsingar grunn $\mathbf{S}_{\mathbf{r}}$. Fyrir splæstu raðbreytu eru stök $\mathbf{a}_{\mathbf{r}}$ skorðuð til að vera neikvæð, sem gerir $\boldsymbol{y}_{\boldsymbol{r}}^{*}$, einhalla vaxandi.

3. Ef svarbreyta er raðbreyta: $y_{r}^{*} \leftarrow W M O N\left(\widetilde{y_{r}}\right)$

WMON stendur fyrir vegnu einhalla aðhvarfsgreiningar ferli, sem gerir $\boldsymbol{y}_{\boldsymbol{r}}^{*}$ einhalla vaxandi. Vægisstuðlar eru notaðir sem hornalínustök í $\mathbf{D}_{\mathbf{r}}$.

4. Ef svarbreyta er töluleg breyta gildir: $y_{r}^{*} \leftarrow W L I N\left(\widetilde{y_{r}}\right)$

WILIN stendur fyrir vegnu línulegu aðhvarfsgreiningar ferli. Vogarstuðlarnir sem eru notaðir eru hornalínustök $\mathbf{D}_{\mathbf{r}}$. Næsta $\boldsymbol{y}_{\boldsymbol{r}}^{*}$ er staðlað (ef svarbreytan var innsett með viðbótar flokki, pá er $\boldsymbol{y}_{\boldsymbol{r}}^{*}$ innifalinn í flokki $\mathrm{k}_{\mathrm{r}}$ héðan frá):

$$
y_{r}^{+}=n_{w}^{\frac{1}{2}} y_{r}^{*}\left(y_{r}^{\prime *} \boldsymbol{D}_{r} y_{r}^{*}\right)^{-\frac{1}{2}}
$$

\subsubsection{Uppfæra kvarða fyrir flokka og vægi aðhvarfsgreiningarstuðla}

Til pess að uppfæra spábreytu $j, j \in J_{p}$, er framlag breytu $\mathbf{j}$ fjarlægt frá $\mathbf{v}: \mathbf{v}_{\mathbf{j}}-b_{j} \mathbf{G}_{\mathbf{j}} \mathbf{y}_{\mathbf{j}}$. Pá er óskorðaða uppfærslan af $\mathbf{y}_{\mathbf{j}}: \tilde{y}_{j}=D_{\mathbf{j}}^{-1} \mathbf{G}_{\mathbf{j}}^{\prime} \mathbf{W}\left(\mathbf{G}_{\mathbf{r}} \mathbf{y}_{\mathbf{r}}-\mathbf{v}_{\mathbf{j}}\right)$

Næst er $\tilde{y}_{j}$ skorðað og staðlað eins og í skrefi (2) til pess að fá $y_{j}^{+}$

Að lokum eru aðhvarfsgreiningarstuðlar uppfærðir: $b_{j}^{+}=n_{w}^{-1} \tilde{y}_{j}^{\prime} \boldsymbol{D}_{j} y_{j}^{+}$ 
Staðlaðir aðhvarfsgreiningarstuðlar eru fengnir með eftirfarandi:

Jafna 4: Staðlaðir aðhvarfsgreiningastuðlar (Ridge, Lassa og Elastic Net)

$$
\begin{gathered}
\beta_{j}^{+}=\frac{\beta_{j}^{*}}{1+\lambda_{2}} \text { fyrir Ridge, } \\
\beta_{j}^{+}=\left(\beta_{j}^{*}-\frac{\lambda_{1}}{2} w_{j}\right)+=\beta_{j}^{*}-\frac{\lambda_{1}}{2} \text { ef } \beta_{j}^{*}>0 \text { og } \beta_{j}^{*}+\frac{\lambda_{1}}{2} \text { ef } \beta_{j}^{*}<0, \text { fyrir Lasso og } \\
\beta_{j}^{+}=\frac{\left(\beta_{j}^{*}-\frac{\lambda_{1}}{2} w_{j}\right)+}{1+\lambda_{2}}=\frac{\left(\beta_{j}^{*}-\frac{\lambda_{1}}{2}\right)+}{1+\lambda_{2}} \text { ef } \beta_{j}^{*}>0 \\
o \frac{\left(\beta_{j}^{*}+\frac{\lambda_{1}}{2}\right)+}{1+\lambda_{2}} \text { ef } \beta_{j}^{*}<0 \text { fyrir Elastic Net }
\end{gathered}
$$

\subsubsection{Samleitni próf}

Munurinn á samfelldu gildunum og spáskekkju er borin saman við fyrirfram ákveðna samleitnitölu $\varepsilon$ sem er lítil jákvæð tala.

Munurinn á samliggjandi gildum er:

Jafna 5 Greinileg spáskekkja, APE

$$
A P E=n_{w}^{-1}\left(\boldsymbol{G}_{\boldsymbol{r}} \boldsymbol{y}_{\boldsymbol{r}}-\int_{\boldsymbol{j} \in J_{\boldsymbol{p}}} \beta_{j} \boldsymbol{G}_{\boldsymbol{j}} \boldsymbol{y}_{\boldsymbol{j}}\right)^{\prime} \boldsymbol{W}\left(\boldsymbol{G}_{\boldsymbol{r}} \boldsymbol{y}_{\boldsymbol{r}}-\int_{\boldsymbol{j} \in \boldsymbol{J}_{\boldsymbol{p}}} \beta_{j} \boldsymbol{G}_{\boldsymbol{j}} \boldsymbol{y}_{\boldsymbol{j}}\right)
$$

Án pjálgunar er APE jafnt og 1 mínus margvíði aðhvarfsgreiningarstuðullinn í öðru veldi. Skref (2) og (3) eru framkvæmd aftur og aftur á meðan munurinn í APE er meiri en $\varepsilon$.

\subsection{Bestunar kvarð̃ (e. optimal scaling)}

CATREG notar bestunar kvarða (e. optimal scaling) en með pví fá gögnin tölulegt gildi ${ }^{137}$ fyrir svarflokka hverrar breytu pannig að hægt er að fá línulegt líkan fyrir umbreyttu gögnin (e. transformed variables). Áætlaðir stuðlar endurspegla hvernig breyting á spábreytunum hefur áhrif á svarbreytuna en með CATREG er svarbreytan aðhvarfsgreind með flokka spágildunum. Par af leiðandi er einn stuðull metinn fyrir hverja breytu. Рað má pví segja að CATREG framlengi hefðbundið notkunargildi aðhvarfsgreiningar með pví að setja vogargildi á breytur með nafna-, rað-, og jafnbilamælikvarða ${ }^{138}$. En með CATREG er hægt að beita sömu aðferðum

\footnotetext{
${ }^{137}$ Athuga að CATREC vinnur með vísa að flokka breytum en mikilvægt er að vísarnir séu jákvæðar heiltölur.

${ }^{138}$ Sjá skilgreiningu bls. 331
} 
á breyturnar eins og pær væru tölulegar. Með pví að nota ólínulega umbreytingu (e. nonlinear transformation) á breytur er hægt að greina samband á milli breyta með mörgum aðferðum til að finna besta líkanið(Jacqueline J. Meulman, Willem J. Heiser, SPSS Inc, 2004).

Fyrir bæði svarbreytu og spábreytur parf að ákveða kjör kvarða (e. optimal scaling level). CATREG býður upp ${ }^{139}$ á;

- Splcest raðbreyta ( e. spline ordinal). Röðun hjá flokkum breytunnar er varðveitt. Flokka punktar eru í beinni línu um upphafspunktinn og umbreytingin er mjúkur ferill margliðu af ákveðnu stigi sem er einhalla ${ }^{140}$ á köflum (e. piecewise monotonic).

- Splcest nafnbreyta (e. spline nominal). Einu upplýsingarnar sem eru geymdar eru í hvaða flokkum gildin falla hjá breytunni, en engin sérstök röð flokka varðveitist. Umbreytingin er mjúkur ferill margliðu af ákveðnu stigi, hugsanlega ekki einhalla á köflum. Мeð öðrum orðum par sem $\mathrm{y}_{\mathrm{j}}=\mathrm{d}_{\mathrm{j}}+\mathrm{S}_{\mathrm{j}} \mathrm{a}_{\mathrm{j}}$ (jafnaðar og splæstar skorður), með $\mathrm{a}_{\mathrm{j}}$ skorðum til að fá jákvæð gildi.

- Raðbreytu (e. ordinal). Röðun flokka breytunnar helst og flokka punktar eru í beinni línu um upphafspunkt. Umbreytingin er ekki jafn mjúk og fyrir splæsta raðbreytu en passar betur fyrir gögnin. Með öðrum orðum par sem $\mathrm{y}_{\mathrm{j}} \in \mathrm{C}_{\mathrm{j}}$ (jafnaðar og einhalla skorður). Einhalla skorður $\mathrm{y}_{\mathrm{j}} \in \mathrm{C}_{\mathrm{j}}$ pýðir að $\mathrm{y}_{\mathrm{j}}$, verður að vera staðsett í ávaldri keilu fyrir alla $\mathrm{k}_{\mathrm{j}}$ vigra með vaxandi gildum.

- Nafnbreytu (e. nominal). Einungis jafnaðarskorður. Ef nafnbreyta er valin eru einu upplýsingarnar sem varðveitast í hvaða flokkum gildin falla hjá breytunni og engin sérstök röð flokka varðveitt. Umbreytingin passar betur við gögnin en splæsta nafnbreytan en er ekki jafn mjúkur ferill.

- Tölulega breytur (e. numeric). Flokkar eru meðhöndlaðir eins og jafn mikið sé á milli peirra. Flokka punktar eru á beinni línu um upphafspunkt. Ef allar breytur væru tölulegar væri greiningin eins og hefðbundin páttagreining. Með öðrum orðum $\mathrm{y}_{\mathrm{j}} \in \mathrm{L}_{\mathrm{j}}$ (jafnaðar og línulegar skorður). Línulegu skorðurnar, $\mathrm{y}_{\mathrm{j}} \in \mathrm{L}_{\mathrm{j}}$ býða að $\mathrm{y}_{\mathrm{j}}$ verður að vera staðsett í undirrými af öllum $\mathrm{k}_{\mathrm{j}}$ vigrum sem eru línuleg umbreyting af vigrum sem innihalda $\mathrm{k}_{\mathrm{j}}$ heiltölur í röð.

(SPSS Statistics Inc., 2010)

\subsection{Strjálun (e. discretization) fyrir CATREG}

Í CATREG er Strjálun framkvæmd á peim gögnum sem hafa ekki fengið vogunartölu. En með strjálun er átt við pegar samfelldum eiginleikum er umbreytt yfir á strjálar breytur (Wikipedia,

\footnotetext{
139 Skilgreiningar á ákjósanlegum mælikvarðastigum eru fengnar frá IBM SPSS Statistics Help tutorial og frá SPSS Catagories (Jacqueline J. Meulman, Willem J. Heiser, SPSS Inc, 2004)

${ }^{140}$ Fall $\mathrm{f}$ er skilgreint á hlutmengi rauntalna með raun gildum er kallað einhalla, ef fyrir öll $\mathrm{x}$ og $\mathrm{y}$ pannig að $\mathrm{x} \leq \mathrm{y}$ og $\mathrm{f}(\mathrm{x}) \leq \mathrm{f}(\mathrm{y})$, svo f varðveitir röð gilda. (Wikipedia, 2011)
} 
2011). CATREG býður upp á nokkrar aðferðir til að umskrifa breytur. pegar nafnabreytur ${ }^{141}$ eru umskrifaðar er notast við jákvæðar heiltölur með pví að tengja flokka vísa í hækkandi staftöluorða ${ }^{142}$ röð og eru pessar tölur notaðar í strjálun. Aðferðirnar sem CATREG býður upp á eru;

- Flokkun (e. grouping). Umbreytt yfir í ákveðið marga flokka eða umbreytt í flokka með ákveðið stóru bili á milli.

- Röðun (e. ranking). Tilfellum er raðað eftir röð.

- Margföldun (e. multiplying). Gildi eru stöðluð, margfölduð með 10, rúnnuð niður og svo bætt við fasta svo að lægsta gildi sem búið er að vinna verði einn.

(IBM SPSS Statistics 19.0 Inc., 2010)

\subsection{Meðhöndlun týndra gagna í CATREG}

CATREG býður upp á tvær stefnur um pað hvernig meðhöndla eigi gildi sem vantar. Annars vegar að útiloka hluti sem eru með týnd gögn (e. listwise deletion) eða að beitt er virkri aðferð (e. active treatment) og gildi sett í staðin fyrir gögn sem vantar. Í síðarnefndri stefnu er hægt að velja hvernig innsetning á sér stað. Hægt er að velja milli pess að auka flokkur sé fyrir gögn sem vantar eða að algengasta gildi sé sett inn fyrir gögn sem vantar.

Pegar virkri aðferð er beitt á gildi sem vantar hjá breytum, p.e. annað hvort er viðbótarflokk bætt við fyrir gildi sem vantar eða að innsetning með ákveðnum hætti fyrir gildin á sér stað, er fyrst $\mathrm{k}_{\mathrm{j}}$ hjá pessum breytum reiknað áour en eyðing á sér stað. Næst er innsetning fyrir flokka vísa með hæstu vegnu tíðni (fyrir innsetningar hátt) eða $\mathrm{k}_{\mathrm{j}}+1$ (viðbótarflokkur). Par næst á eyðing sér stað ef slíkt er viðeigandi, og k $\mathrm{k}_{\mathrm{j}}$ er aðlagað(SPSS Statistics 19.0 Inc., 2010).

\subsection{Jöfnur fyrir útaksstærðir í CATREG}

Eftirfarandi jöfnur sýna hvernig R gildi eru reiknuð í CATREG:

Jafna 6: R gildi i CATREG

$$
\text { Margfalt } R=\left(\boldsymbol{G}_{r} y_{r}\right)^{\prime} \boldsymbol{W} \mathbf{v}\left(\mathrm{n}_{\mathrm{w}} \mathbf{v}^{\prime} \mathbf{W} \mathbf{v}\right)^{-1 / 2}
$$

Aðlagað $R^{2}=1-\left(1-R^{2}\right)\left(n_{w}-1\right)\left(n_{w}-1-\boldsymbol{u}^{\prime} \boldsymbol{f}\right)$, par sem u er einingavigur af stigi $p$

$$
R^{2}=1-A P E, \text { án pjálgunar }
$$

APE er reiknuð í samleitni prófi með jöfnu sem er sýnd á bls. 395.

\footnotetext{
${ }^{141}$ Allar breytur sem eru string

${ }^{142}$ sambland af tölustöfum og bókstöfum
} 
Fylgni og eigingildi í CATREG

Jafna 7 Fyrir umbreytingu

$\boldsymbol{R}=n_{w}^{-1} \boldsymbol{H}^{\prime}{ }_{c} \boldsymbol{W H}_{\boldsymbol{c}}$, par sem $\boldsymbol{H}_{\boldsymbol{c}}$ er veigið og staðlað $\boldsymbol{H}$ að fráskildri svarbreytu

Jafna 8 Eftir umbreytingu

$$
\boldsymbol{R}=n_{w}^{-1} \boldsymbol{Q}^{\prime}{ }_{c} \boldsymbol{W} \boldsymbol{Q}, \text { par sem dálkar } \boldsymbol{Q} \text { eru } \boldsymbol{q}_{j}=\boldsymbol{G}_{\boldsymbol{j}} \boldsymbol{y}_{j}, j \in J_{p}
$$




\section{Viðauki L - Tákn fyrir CATREG}

Eftirfarandi tákn eru notuð í lýsandi jöfnun fyrir CATREG nema annað sé tekið fram.

$\mathrm{n}=$ fjöldi tilfella

$\mathrm{n}_{\mathrm{w}}=$ veiginn fjöldi tilfella $\sum_{i=1}^{n} \mathrm{w}_{\mathrm{i}}$

$\mathrm{n}_{\text {tot }}=$ heildarfjöldi tilfella (frá rannsókn og viðbótar)

$\mathrm{w}_{\mathrm{i}}=$ vægi hlutar $\mathrm{i} ; \mathrm{w}_{\mathrm{i}}=0$ ef hlutur i er viðbótarhlutur

$\mathbf{W}=$ hornlínufylki $\mathrm{n}_{\text {tot }} \times \mathrm{n}_{\text {tot }}$ með $\mathrm{w}_{\mathrm{i}}$ á hornalínunni

$\mathrm{P}=$ fjöldi spábreyta (vídda)

$\mathrm{m}=$ fjöldi greiningar breyta

$\mathrm{r}=$ vísir svarbreytu

$\mathbf{H}=$ gagnafylki (flokka vísar), af stigi $\mathrm{n}_{\text {tot }} \times \mathrm{m}$, eftir strjálun, innsetningu af týndum gildum (e. missing), og eyðing ef slíkt er viðeigandi

$\mathrm{J}_{\mathrm{p}}=$ vísir að spábreytum

$\lambda_{1}=$ Lasso refsifall

$\lambda_{2}=$ Ridge refsifall

Fyrir breytur $j ; j=1, \ldots, m$ gildir;

$\mathrm{k}_{\mathrm{j}}=$ fjöldi flokka af breytu $\mathrm{j}$ (fjöldi ákveðna gilda $\mathbf{i} \mathbf{h}_{\mathbf{j}}$, að meðtöldum viðbótar hlutum)

$\mathbf{G}_{\mathrm{j}}=$ vísa fylki fyrir breytu $\mathrm{j}$, af stigi $\mathrm{n}_{\text {tot }} \times \mathrm{k}_{\mathrm{j}}$, stök $\mathbf{G}_{\mathrm{j}}$ eru skilgreind sem $\mathrm{i}=1, \ldots, \mathrm{n}_{\text {tot }}, \mathrm{r}=1, \ldots, \mathrm{k}_{\mathrm{j}}$

$g_{(j) i r}=\left\{\begin{array}{c}1 \text { pegar stak } i \text { er í flokki r af breytu } j \\ 0 \text { pegar stak } i \text { er ekki í flokki r af breytu } j\end{array}\right.$

$\mathbf{D}_{\mathbf{j}}=$ hornalínufylki $\mathrm{k}_{\mathrm{j}} \times \mathrm{k}_{\mathrm{j}}$, sem inniheldur veigin einvíðan jaðar, p.e. vegna dálka summu af $\mathbf{G}_{\mathrm{j}}\left(\mathbf{D}_{\mathrm{j}}=\mathbf{G}^{\prime}{ }_{\mathrm{j}} \mathbf{W} \mathbf{G}_{\mathrm{j}}\right)$

$\mathbf{f}=$ vigur með frelsisgráðum fyrir spábreyturnar af stigi p

$\mathrm{S}_{\mathrm{j}}=$ splæsingargrunnur fyrir breytu $\mathrm{j}$, af stigi $\mathrm{k}_{\mathrm{j}} *\left(\mathrm{~s}_{\mathrm{j}}+\mathrm{t}_{\mathrm{j}}\right)$ 
$\mathbf{b}_{\mathrm{j}}=$ splæsinga stuðla vigur af stigi $\mathrm{s}_{\mathrm{j}}+\mathrm{t}_{\mathrm{j}}$

$\mathrm{d}_{\mathrm{j}}=$ splæsingar ássnið (e. intercept),

$\mathrm{s}_{\mathrm{j}}=$ stig margliðu

$\mathrm{t}_{\mathrm{j}}=$ innri hnútar,

Malingar fylkin (e. quantification matrices) og stuðla vigrar eru:

$\mathrm{y}_{\mathrm{r}}=$ kvarði svarbreytu af stigi $\mathrm{k}_{\mathrm{r}}$,

$\mathrm{y}_{\mathrm{j}}=$ kvarði spábreytu $\mathrm{j}$ af stigi $\mathrm{k}_{\mathrm{j}}$,

$\mathbf{b}=$ aðhvarfsgreiningarstuðlar fyrir spábreytu af stigi $\mathrm{p}$

Uppsafnað framlag spábreyta:

$\mathbf{v}=\sum_{j \in J_{p}}^{n} \mathrm{~b}_{\mathbf{j}} \mathbf{G}_{\mathbf{j}} \mathbf{y}_{\mathrm{j}}$

Ath. Fylkin $\mathbf{W}, \mathbf{G}_{\mathbf{j}}$, og $\mathbf{D}_{\mathbf{j}}$ eru einungis framsetningar tæki, pau eru geymd í ruddu formi og nýtur forritið (SPSS Statistics) góðs af pví hversu punnskipuð fylkin eru með pví að skipta út margfeldum fylkisins með völdum péttleika (SPSS Statistics Inc., 2010). 


\section{Viðauki M - Hvernig besta flokka aðhvarfsgreiningar líkan er valið}

Með pví að beita flokka aðhvarfsgreiningu á gögnin var markmiðið að finna líkan sem skýrði samband ánægju verkkaupa og annarra pátta. Hér verður farið stuttlega í nokkur líkan en ítarlegri skíring á lokalíkani er svo útlistuð.

\subsection{Val á ákjósanlegu CATREG líkani}

Við val á ákjósanlegu líkani par af skoða marga pætti. Eftirfarandi gildi eru skoðuð fyrir hvert líkan; R gildin, aðhvarfsgreiningarstuðla, fylgni milli spábreyta, polmörk, F próf, og mikilvægistölu (SPSS Statistics Inc., 2010). Hér verða ofangreind atriðið útlistuð betur.

\subsection{3 .1 R gildi}

Fyrst er horft á R gildin ${ }^{143}$. Markmiðið er að finna líkan sem er með sem hæst R gildi en gildið á $\mathrm{R}^{2}$ segir til um hversu stóran hluta að ferviki fyrir gögnin líkanið skýrir.

\subsubsection{Aðhvarfsgreiningastuðlar}

Oft er talað um að staðlaðir aðhvarfsgreiningarstuðlar endurspegli á einhvern hátt mikilvægi hverrar spábreytu í líkaninu. Ekki er pó hægt að taka peirri túlkun of bókstaflega og nauðsynlegt er að horfa samhliða á aðrar tölfræðistærðir. Ágætis pumalputtaregla er að líklegt er að breyta með hátt gildi fyrir aðhvarfsgreiningarstuðul sé mikilvægari fyrir líkanið en breyta með lágt gildi fyrir aðhvarfsgreiningarstuðul. Til að túlka framlag spábreytu er nauðsynlegt að horfa samhliða á stuðlana, fylgni, hlutfylgni og hluta-fylgni.

\subsubsection{Fylgni spábreyta}

Mikil fylgni milli spábreyta gefur óstöðugt líkan með óstöðugu mati á stuðlum og er mikilvægt að breyturnar séu valdar með tilliti til pess að pær séu ekki of háðar hver annarri. Fylgnitölur sem CATREG býður upp á eru núllta-stigs fylgni (e. zero order), hlutfylgni (e. partial correlations) og hluta fylgni (e. part correlations).

- Núllta-stigs fylgni. Núllta-stigs fylgni er fylgni milli umbreyttu spábreytanna og umbreyttu svarbreytunnar.

- Hlutfylgni. Hlutfylgni jafngildir fylgni milli restliða með aðhvarfsgreiningu spábreytu á aðrar spábreytur og restliði frá aðhvarfsgreiningu svarbreytu á aðrar spábreytur. En hafa ber í huga að aðrar spábreytur í líkaninu geta ruglað frammistöðu ákveðinnar spábreytu í pví að spá fyrir um svarbreytu. Hlutfylgni spábreytu í öðru veldi samsvarar hlutfalli

${ }^{143}$ Sjá jöfnur í viðauka 325 
ferviks sem skýrist af viðkomandi restliðaferviki af svarbreytu eftir að áhrif frá öðrum spábreytum hafa verið fjarlægð.

- Hluta-fylgni. Með pví að skoða hluta-fylgni eru einungis áhrif frá spábreytu fjarlægð (en ekki bæði spá- og svarbreytu eins og í hlutfylgni). Hluta fylgni fæst milli svarbreytu og restliða frá aðhvarfsgreiningu spábreytu á aðrar spábreytur. Með pví að setja hluta fylgni í annað veldi fæst hlutfall ferviks sem skýrist af heildar ferviki svarbreytu.

\subsubsection{Polmörk}

Polmörk segja til um hversu mikið spábreytur eru línulega háðar hvor annarri. Gildið er hlutfall af ferviki breytu sem ekki skýrist með öðrum spábreytum. Polmarkar gildi sem er nálægt einum gefur til kynna að ekki er hægt að spá fervik spábreytunnar með öðrum spábreytum í líkaninu og er sú breyta pví talin mikilvæg fyrir líkanið.

\subsubsection{F próf}

Samhliða athugunum um fylgni spábreyta er F próf skoðuð. Ef breyta reynist ómarktæk með F prófi er hugsanlegt að pað megi sleppa henni úr líkaninu. En varast ber að taka út fleiri en eina breytu úr líkaninu í einu með tilliti til $\mathrm{F}$ tölfræði par sem peir reikningar byggjast á marktækni breyta út frá viðkomandi líkani.

\subsubsection{Mikilvægisstuðull Pratt's}

Til viðbótar við fylgni og aðhvarfsgreiningar stuðla, hjápar mælieining Pratt's (Pratt, 1987) til við að túlka framlag spábreytu til líkansins. Stórt gildi í mikilvœegi miðað við gildi mikilvaegis hjá öðrum spábreytum gefur til kynna að sú spábreyta sé mikilvæg fyrir líkanið. Einnig getur lágt gildi í mikilvoegi gefið til kynna að spábreyta sé bælandi ef hún hefur svipað háan aðhvarfsgreiningarstuðul og breytan sem hefur hæsta gildi mikilvægis. Ólíkt aðhvarfsgreiningarstuðlunum pá sýnir mikilvaegi samlagningarmikilvægi spábreytu. P.e. mikilvægi hóps af spábreytum er summa mikilvægis fyrir einstaka spábreytur. Mikilvægi stuðull Pratt's jafngildir gildi aðhvarfsgreiningarstuðuls og núllta-stigs fylgni spábreytu. bessi gildi bæta við $\mathrm{R}^{2}$. Stórt gildi í Pratt's mikilvægis tölu getur gefið til kynna fjölfylgni (e. multicollinearity).

\subsection{Fjöldi spábreyta}

раð eru engar almennar reglur um hvað pýði parf að vera stórt með tilliti til pess hvað hægt er að hafa margar óháðar breytur í línulegu líkani. Pumalputtaregla sem Good og Hardin settu fram (Good PI, Hardin JW, 2009) er að $N=m^{n}$, par sem $N$ er stærð úrtaks, $n$ er fjöldi óháðra breyta og $m$ er fjöldi athuga sem parf til að ná peirri nákvæmni sem sóst er eftir ef einungis ein óháð breyta væri í líkaninu. Svo ef við gefum okkur að nægjanleg nákvæmi til pess að 
skilgreina línu $m$ séu 4 athuganir og að í úrtakinu séu 100 pátttakendur pá getur líkanið haft 3 óháðar breytur par sem að $\frac{\ln (10 \emptyset}{\ln (4)}=3,32$. Ef nákvæmnin er lækkuð pannig að 3 athuganir nægi til að skilgreina línu $m$ getur líkanið haft 4 óháðar breytur.

\subsection{Líkan í CATREG}

\subsubsection{Líkan 1}

Fyrsta líkanið sem var prófað í CATREG samanstóð af peim 5 páttum sem mesta fylgni hafa

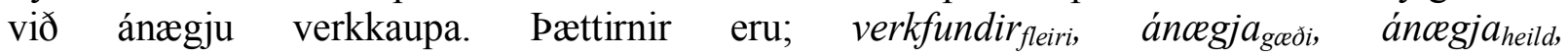

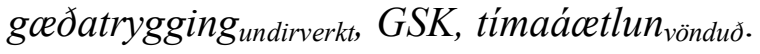

Allar breytur eru meðhöndlaðar sem raðbreytur, strjálun er sett sem röðun, gögn sem vantar eru meðhöndluð með lista-eyðingu, upphafsstilling er töluleg og pjálgun er engin.

Líkanið skýrir 92,2\% af ferviki fyrir gögnin. Fylgni, polmörk, marktekni, mikilvægisgildi ofl. má sjá í töflum hér að neðan:

Tafla 452 R gildi fyrir líkan 1

\begin{tabular}{cccc}
\hline \hline Margfalt $\mathrm{R}$ & $\mathrm{R}^{2}$ & ${\text { Aðlagað } \mathrm{R}^{2}}$ & APE \\
\hline .960 & .922 & .881 & .078 \\
\hline \hline
\end{tabular}

Dependent Variable: ánægja_umræddan

Predictors: verkfundir_fleiri ánægja_gæði ánægja_heild gæðatrygging_undirverkt GSK tímaáætlun_vönduð

Eins og sést í töflunni hér að neðan eru fylgnistuðlar ekki marktækir með pessu líkani, verður að skoða mikilvaegisstuðul Pratt's og út frá honum er breyta valin til að taka úr líkaninu.

Tafla 453 Fylgnistuðlar fyrir líkan 1

\begin{tabular}{|c|c|c|c|c|c|}
\hline & \multicolumn{2}{|c|}{ Staðlaðir stuðlar } & \multirow[b]{2}{*}{$\mathrm{df}$} & \multirow[b]{2}{*}{$\mathrm{F}$} & \multirow[b]{2}{*}{ Sig. } \\
\hline & Beta & $\begin{array}{l}\text { Bootstrap } \\
(1000) \text { mat á } \\
\text { Std. fráviki }\end{array}$ & & & \\
\hline verkfundir_fleiri & .136 & .253 & 1 & .287 & .600 \\
\hline ánægja_gæði & .038 & .204 & 1 & .035 & .855 \\
\hline ánægja_heild & .440 & .341 & 2 & 1.665 & .222 \\
\hline gæðatrygging_undirverkt & .320 & .296 & 1 & 1.169 & .297 \\
\hline GSK & .276 & .327 & 1 & .713 & .412 \\
\hline tímaáætlun_vönduð & -.249 & .248 & 2 & 1.004 & .390 \\
\hline
\end{tabular}

Dependent Variable: ánægja_umræddan 


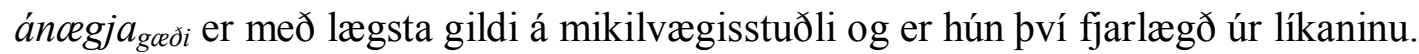

Tafla 454 Fylgni og polmörk fyrir líkan 1

\begin{tabular}{|c|c|c|c|c|c|c|}
\hline & \multicolumn{3}{|c|}{ Fylgni } & \multirow[b]{2}{*}{$\begin{array}{l}\text { Mikilvægis- } \\
\text { stuðull }\end{array}$} & \multicolumn{2}{|c|}{ Polmörk } \\
\hline & $\begin{array}{l}\text { Núllta- } \\
\text { stigs }\end{array}$ & Hluta & Hlut & & $\begin{array}{c}\text { Eftir } \\
\text { umbreytingu }\end{array}$ & $\begin{array}{c}\text { Fyrir } \\
\text { umbreytingu }\end{array}$ \\
\hline verkfundir_fleiri & ,285 &, 313 & ,092 &, 042 &, 459 &, 583 \\
\hline ánægja gæðði & 460 &, 117 & 033 & 019 & ,751 & ,569 \\
\hline ánægja heild & ,868 &, 735 & ,302 & 415 & ,471 & ,560 \\
\hline gæðatrygging undirverkt &, 723 & 622 & 221 & 251 & ,478 & ,498 \\
\hline GSK &, 755 & ,609 & ,214 & ,226 & ,601 & ,574 \\
\hline tímaáætlun_vönduð &,- 176 &,- 527 &,- 173 & 048 & 482 & ,580 \\
\hline
\end{tabular}

Dependent Variable: ánægja_umræddan

\subsection{5 .2 Líkan 2}

Næsta líkani sem var prófað samanstóð pví af sömu páttum og líkan 1 að utanskildu áncegja geðði. Líkanið samanstendur pví af eftirfarandi spábreytum; verkfundir $r_{f l e i r i}$ áncegja $a_{\text {heild }}$,

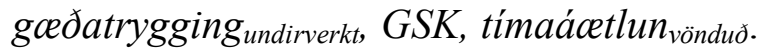

Allar breytur eru meðhöndlaðar sem raðbreytur, strjálun er sett sem röðun, gögn sem vantar eru meðhöndluð með lista-eyðingu, upphafsstilling er töluleg og pjálgun er engin.

Líkanið skýrir 92,1\% af ferviki fyrir gögnin. Fylgni, polmörk, marktekni, mikilvægisgildi ofl. má sjá í töflum hér að neðan:

Tafla 455 R gildi fyrir líkan 2

\begin{tabular}{cccc}
\hline \hline Margfalt $\mathrm{R}$ & $\mathrm{R}^{2}$ & Aðlagað $\mathrm{R}^{2}$ & APE \\
\hline .960 & .921 & .887 & .079 \\
\hline \hline
\end{tabular}

Dependent Variable: ánægja_umræddan

Predictors: verkfundir_fleiri ánægja_heild gæðatrygging_undirverkt GSK tímaáætlun_vönduð

Eins og áđur pá eru fylgnistuðlar ekki marktækir og pví verður aftur að skoða mikilvaegisstuðul Pratt's og meta hvaða breyta verður fjarlægð. 


\begin{tabular}{lccccc}
\hline \hline & \multicolumn{2}{c}{ Staðlaðir stuðlar } & & & \\
\cline { 2 - 5 } & \multicolumn{5}{c}{$\begin{array}{c}\text { Bootstrap } \\
(1000) \text { mat á }\end{array}$} \\
& Beta & Std. fráviki & df & F & Sig \\
\hline verkfundir_fleiri & .125 & .263 & 1 & .225 & .642 \\
ánægja_heild & .448 & .337 & 2 & 1.770 & .202 \\
gæðatrygging_undirverkt & .330 & .297 & 1 & 1.228 & .284 \\
GSK & .282 & .306 & 1 & .851 & .370 \\
tímaáætlun_vönduð & -.251 & .228 & 2 & 1.211 & .324 \\
\hline \hline
\end{tabular}

Dependent Variable: ánægja_umræddan

Tafla 457 Fylgni og bolmörk líkans 2

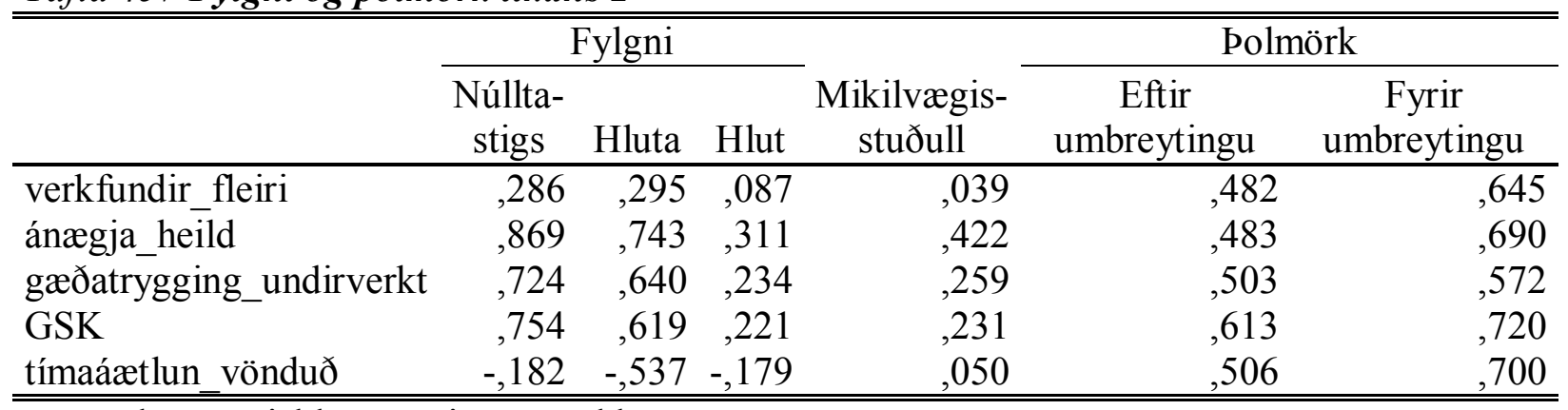

Dependent Variable: ánægja_umræddan

verkfundir ${ }_{f l e i r i}$ er með lægsta gildi á mikilvaegisstuðli og verður hún pví fjarlægð fyrir næsta líkan.

\subsubsection{Líkan 3}

Líkan 3 samanstendur af sömu páttum og líkan 2 að utanskildu verkfundir fleiri Líkanið

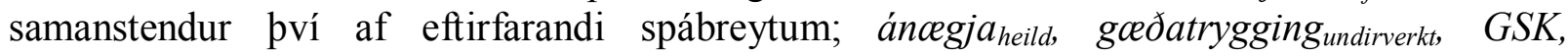
tímaácetlun $_{\text {vönduð. }}$

Allar breytur eru meðhöndlaðar sem raðbreytur, strjálun er sett sem röðun, gögn sem vantar eru meðhöndluð með lista-eyðingu, upphafsstilling er töluleg og pjálgun er engin.

Líkanið skýrir 91,6\% af ferviki fyrir gögnin. Fylgni, polmörk, marktekni, mikilvægisgildi ofl. má sjá í töflum hér að neðan: 


\begin{tabular}{cccc}
\hline \hline Margfalt $\mathrm{R}$ & $\mathrm{R}^{2}$ & ${\text { Aðlagað } \mathrm{R}^{2}}$ & APE \\
\hline .957 & .916 & .888 & .084 \\
\hline \hline
\end{tabular}

Dependent Variable: ánægja_umræddan

Predictors: ánægja_heild gæðatrygging_undirverkt GSK tímaáætlun_vönduð

Enn eru fylgnistuðlar ekki marktækir svo mikilvcegisstuðull Pratt's er skoðaður til að meta hvaða breyta verður fjarlægð.

Tafla 459 Fylgnistuðlar fyrir líkan 3

\begin{tabular}{lccccc}
\hline \hline & \multicolumn{5}{c}{ Staðlaðir stuðlar } \\
\cline { 2 - 5 } & \multicolumn{5}{c}{$\begin{array}{c}\text { Bootstrap } \\
\text { (1000) mat á }\end{array}$} \\
& Beta & Std. fráviki & df & F & Sig. \\
\hline ánægja_heild & .475 & .315 & 2 & 2.273 & .132 \\
gæðatrygging_undirverkt & .341 & .280 & 1 & 1.488 & .238 \\
GSK & .300 & .298 & 1 & 1.008 & .329 \\
tímaáætlun_vönduð & -.172 & .166 & 2 & 1.073 & .363 \\
\hline \hline
\end{tabular}

Dependent Variable: ánægja_umræddan

Tímaácetlun vönduð er með lægsta gildi á mikilvægisstuðli og er hún pví fjarlægð fyrr næsta líkan.

Tafla 460 Fylgni og polmörk fyrir likan 3

\begin{tabular}{|c|c|c|c|c|c|c|}
\hline & \multicolumn{3}{|c|}{ Correlations } & & \multicolumn{2}{|c|}{ Tolerance } \\
\hline & $\begin{array}{l}\text { Zero- } \\
\text { Order }\end{array}$ & Partial & Part & Importance & $\begin{array}{c}\text { After } \\
\text { Transformation }\end{array}$ & $\begin{array}{c}\text { Before } \\
\text { Transformation }\end{array}$ \\
\hline ánægja_heild &, 869 &, 758 & ,337 & ,451 & ,505 &, 725 \\
\hline gæðatrygging_undirverkt & ,728 & ,653 & ,250 & ,272 &, 537 & ,644 \\
\hline GSK &, 757 & 630 & ,236 & ,248 & ,619 & ,722 \\
\hline tímaáætlun_vönduð &,- 162 &,- 482 &,- 160 & 031 &, 859 & ,928 \\
\hline
\end{tabular}

Dependent Variable: ánægja_umræddan

\subsubsection{Líkan 4}

Líkan 4 samanstendur af sömu páttum og líkan 3 að utanskildu tímaácetlun vönduð. Líkanið samanstendur bví af eftirfarandi spábreytum; áncegja $a_{\text {heild }}$, GSK, gceðatrygging undirverkt $_{\text {. }}$

Allar breytur eru meðhöndlaðar sem raðbreytur, strjálun er sett sem röðun, gögn sem vantar eru meðhöndluð með lista-eyðingu, upphafsstilling er töluleg og pjálgun er engin.

Líkanið skýrir 77,0\% af ferviki fyrir gögnin. Fylgni, polmörk, marktekni, mikilvægisgildi ofl. má sjá í töflum hér að neðan: 
Tafla 461 R gildi fyrir líkan 4

\begin{tabular}{cccc}
\hline \hline Margfalt $\mathrm{R}$ & $\mathrm{R}^{2}$ & ${\text { Aðlagað } \mathrm{R}^{2}}^{2}$ & APE \\
\hline .878 & .770 & .740 & .230 \\
\hline \hline
\end{tabular}

Dependent Variable: ánægja_umræddan

Predictors: ánægja_heild gæðatrygging_undirverkt GSK

Enn eru ekki allir fylgnistuðlar marktækir og verður pví aftur horft á mikilvcegisstuðul Pratt's og önnur breyta fjarlægð samkvæmt pví.

Tafla 462 Fylgnistuðlar fyrir líkan 4

\begin{tabular}{lccccc}
\hline \hline \multicolumn{5}{c}{ Staðlaðir stuðlar } \\
\cline { 2 - 5 } & \multicolumn{5}{c}{ Bootstrap } \\
& Beta & Std. fráviki & df & F & Sig. \\
\hline ánægja_heild & .721 & .103 & 3 & 48.795 & .000 \\
gæðatrygging_undirverkt & .049 & .167 & 1 & .085 & .772 \\
GSK & .272 & .149 & 1 & 3.326 & .076 \\
\hline \hline
\end{tabular}

Dependent Variable: ánægja_umræddan

Tafla 463 Fylgni og polmörk fyrir líkan 4

\begin{tabular}{lccccccc}
\hline \hline & \multicolumn{3}{c}{ Fylgni } & & \multicolumn{2}{c}{ Dolmörk } \\
\cline { 2 - 3 } & $\begin{array}{c}\text { Núllta- } \\
\text { stigs }\end{array}$ & Hluta & Hlut & $\begin{array}{c}\text { Mikilvægis- } \\
\text { stuðull }\end{array}$ & $\begin{array}{c}\text { Eftir } \\
\text { umbreytingu }\end{array}$ & $\begin{array}{c}\text { Fyrir } \\
\text { umbreytingu }\end{array}$ \\
\hline ánægja_heild &, 830 &, 803 &, 647 &, 777 &, 803 &, 823 \\
gæðatrygging_undirverkt &, 540 &, 074 &, 036 &, 034 &, 531 &, 598 \\
GSK &, 533 &, 401 &, 210 &, 189 &, 593 &, 676 \\
\hline \hline
\end{tabular}

Dependent Variable: ánægja_umræddan

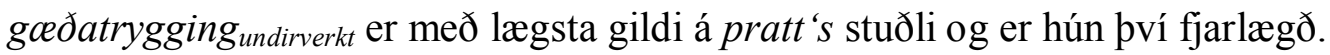

\subsubsection{Líkan 5}

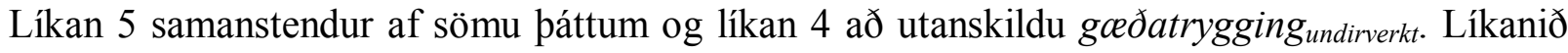
samanstendur pví af eftirfarandi spábreytum; áncegja $a_{h e i l d,}, G S K$.

Allar breytur eru meðhöndlaðar sem raðbreytur, strjálun er sett sem röðun, gögn sem vantar eru meðhöndluð með lista-eyðingu, upphafsstilling er töluleg og pjálgun er engin.

Líkanið skýrir 70,05\% af ferviki fyrir gögnin. Fylgni, polmörk, marktekni, mikilvægisgildi ofl. má sjá í töflum hér að neðan: 


\begin{tabular}{cccc}
\hline \hline Margfalt $\mathrm{R}$ & $\mathrm{R}^{2}$ & ${\text { Aðlagað } \mathrm{R}^{2}}$ & APE \\
\hline .840 & .705 & .677 & .295 \\
\hline \hline
\end{tabular}

Dependent Variable: ánægja_umræddan

Predictors: ánægja_heild GSK

Nú eru allir fylgnistuðlar marktækir.

Tafla 465 Fylgnistuðlar fyrir likan 5

\begin{tabular}{lccccc}
\hline \hline & \multicolumn{3}{c}{ Staðlaðir stuðlar } \\
\cline { 2 - 4 } & Beta & Bootstrap (1000) & & & \\
& mat á Std. fráviki & df & F & Sig. \\
\hline ánægja_heild & .670 & .116 & 3 & 33.330 & .000 \\
GSK & .329 & .122 & 1 & 7.241 & .010 \\
\hline \hline
\end{tabular}

Dependent Variable: ánægja_umræddan

Tafla 466 Fylgni og polmörk fyrir líkan 5

\begin{tabular}{lccccccc}
\hline \hline & \multicolumn{3}{c}{ Fylgni } & & \multicolumn{2}{c}{ Dolmörk } \\
\cline { 2 - 4 } \cline { 7 - 7 } & $\begin{array}{c}\text { Núllta- } \\
\text { stigs }\end{array}$ & Hluta & Hlut & Mikilvægis- & stuðull & Eftir umbreytingu & Fyrir umbreytingu \\
\hline ánægja_heild &, 780 &, 758 &, 631 &, 742 &, 887 &, 930 \\
GSK &, 553 &, 495 &, 310 &, 258 &, 887 &, 930 \\
\hline \hline
\end{tabular}

Dependent Variable: ánægja_umræddan

Líkanið lítur pví svona út:

$$
\text { ánægja } a_{u m r æ d d s}=0,553(G S K)+0,780\left(\text { ánægja } a_{\text {heild }}\right)
$$

\subsubsection{Líkan 6}

Ný nálgun var einnig reynd par sem að skýrsluhöfundi bótti ekki sérlega merkilegt að standa uppi með líkan fyrir ánægju verkkaupa með umræddan verktaka par sem önnur spábreytan var ánægja heild. Dví voru sömu skref endurtekin og hér að framan fyrir líkan 1-5, nema öllum breytum sem tengdust ánægju verkkaupa með aðra pætti var sleppt. Mörg líkan voru prófuð en er besta líkaninu lýst hér.

Allar breytur eru meðhöndlaðar sem raðbreytur, strjálun er sett sem röðun, gögn sem vantar eru meðhöndluð með lista-eyðingu, upphafsstilling er töluleg og pjálgun er engin.

Líkanið skýrir 45,3\% af ferviki fyrir gögnin. Fylgni, polmörk, marktekni, mikilvægisgildi ofl. má sjá í töflum hér að neðan: 
Tafla 467 R gildi fyrir líkan 6

\begin{tabular}{cccc}
\hline \hline Margfalt $\mathrm{R}$ & $\mathrm{R}^{2}$ & Aðlagað $\mathrm{R}^{2}$ & APE \\
\hline .673 & .453 & .425 & .547 \\
\hline \hline Dependent Variable: ánægja umræddan & &
\end{tabular}

Dependent Variable: ánægja_umræddan

Predictors: ánægja_heild GSK

\section{Tafla 468 Fylgnistuðlar fyrir líkan 6}

\begin{tabular}{lccccc}
\hline \hline & \multicolumn{3}{c}{ Staðlaðir stuðlar } \\
\cline { 2 - 5 } & Beta & $\begin{array}{c}\text { Bootstrap (1000) } \\
\text { mat á Std. } \\
\text { fráviki }\end{array}$ & df & F & Sig. \\
\hline GSK & .506 & .127 & 1 & 15.855 & .000 \\
verkfundir_fleiri & .367 & .154 & 1 & 5.723 & .022 \\
\hline \hline Dependent Variable: ánægja_umræddan
\end{tabular}

Tafla 469 Fylgni og polmörk fyrir líkan 6

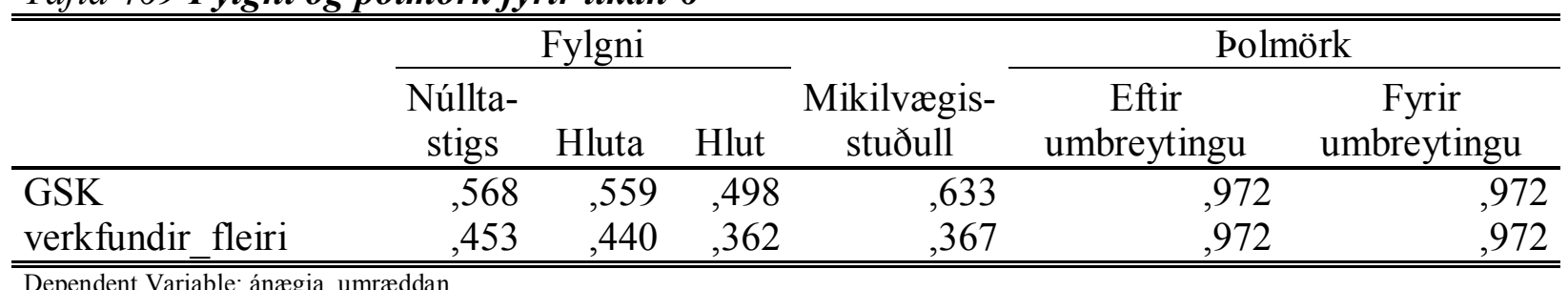

Til viðbótar er lýsandi tölfræði og mögnun fyrir breytur líkansins sýndar hér á eftir.

Tafla 470 Lýsandi tölfraeði fyrir ánaegja_umraeddan ${ }^{c}$ í líkani 6

\begin{tabular}{llccc}
\hline \hline & Flokkar eftir & \multicolumn{2}{c}{ Tíðni } \\
\cline { 3 - 5 } strjálun $^{\mathrm{a}}$ & & Upphafl. gögn & Greind gögn \\
\hline Gilt & Mjög óánægð/ur & 1 & 3 & 0 \\
& Frekar óánægð/ur & 2 & 15 & 2 \\
& Hvorki ánægð/ur né óánægð/ur & 3 & 21 & 7 \\
Frekar ánægð/ur & 4 & 45 & 18 \\
Mjög ánægð/ur & 5 & 32 & 14 \\
Samtals & & 116 & 41 \\
\hline \hline
\end{tabular}

a. Ranking

b. Mode.

c. Optimal Scaling Level: Ordinal. 


\begin{tabular}{|c|c|c|c|c|}
\hline & & \multirow{2}{*}{$\begin{array}{c}\text { Flokkar eftir } \\
\text { strjálun }^{\mathrm{b}}\end{array}$} & \multicolumn{2}{|c|}{ Tíoni } \\
\hline & & & Upphafl. gögn & Greind gögn \\
\hline \multirow[t]{3}{*}{ Gilt } & Nei eða ekki byggt á stöðlum ${ }^{a}$ & 1 & 24 & 19 \\
\hline & Já eða í innleiðingu & 2 & 23 & 22 \\
\hline & Samtals & & 47 & 41 \\
\hline $\operatorname{Vantar}^{\mathrm{c}}$ & & & 69 & \\
\hline & Samtals & & 69 & \\
\hline Samtals & & & 116 & 41 \\
\hline
\end{tabular}

a. Mode.

b. Ranking

c. Strategy for missing values: Exclude objects with missing values.

d. Optimal Scaling Level: Ordinal.

Tafla 472 Lýsandi tölfraeði fyrir verkfundir_fleirì í likani 6

\begin{tabular}{llcc}
\hline \hline & & \multicolumn{2}{c}{ Tíðni } \\
\cline { 3 - 4 } & & Upphafl. gögn & Greind gögn \\
\hline Gilt & Miklu oftar & 4 & 0 \\
& Oftar & 15 & 6 \\
& Hvorki oftar né sjaldnar & \\
& Samtals & 76 & 35 \\
& & 95 & 41 \\
Vantar $^{\mathrm{b}}$ & & 21 & \\
& Samtals & 21 & 41 \\
\hline \hline
\end{tabular}

a. Mode.

b. Strategy for missing values: Exclude objects with missing values.

c. Optimal Scaling Level: Ordinal.

Tafla 473 mögnun fyrir ánaegja_umraeddan ${ }^{a}$ i likani 6

\begin{tabular}{lcc}
\hline \hline Flokkar & Tíoni & Mögnun \\
\hline Frekar óánægð/ur & 2 & -2.011 \\
Hvorki ánægð/ur né óánægð/ur & 7 & -1.847 \\
Frekar ánægð/ur & 18 & .496 \\
Mjög ánægð/ur & 14 & .573 \\
\hline \hline
\end{tabular}

a. Optimal Scaling Level: Ordinal.

Tafla 474 mögnun fyrir GSK ${ }^{\text {a }}$ líkani 6

\begin{tabular}{lcc}
\hline \hline Flokkar & Tíðni & Mögnun \\
\hline Nei eða ekki byggt á stöðlum & 19 & -1.076 \\
Já eða í innleiðingu & 22 & .929 \\
\hline \hline
\end{tabular}


a. Optimal Scaling Level: Ordinal.

Tafla 475 mögnun fyrir verkfundir fleiri ${ }^{a}$ í likani 6

\begin{tabular}{lcc}
\hline \hline Flokkar & Tíðni & Mögnun \\
\hline Oftar & 6 & -2.415 \\
Hvorki oftar né sjaldnar & 35 & .414 \\
\hline \hline
\end{tabular}

a. Optimal Scaling Level: Ordinal. 


\section{Viðauki N- Ályktunartölfræði og marktektarpróf}

Til pess að geta yfirfært niðurstöður frá pátttakendum í rannsókninni yfir á stærri hóp parf að vanda til verka við samsetningu úrtaks. Úrtak er sá hópur sem valinn var í rannsóknina. býði er svo sá hópur sem við viljum álykta um.

Ýmsir pættir hafa áhrif á hversu nákvæma mynd af pýðinu úrtakið gefur. Í fyrsta lagi skiptir stærð úrtaksins máli. Spá verður betri eftir pví sem úrtakið er stærra. Eftir pví sem úrtakið er stærra, peim mun meiri líkur eru á pví að pað endurspegli pýðið. Aðrir áhrifapættir eru m.a. dreifing einkenna í úrtakinu, ef munur á einstaklingum í pýðinu er mikill parf stærra úrtak til að fá góða mynd af pýðinu en ef dreifing er lítil. Aldrei er hægt að vera fullkomlega viss um að hægt sé að yfirfæra niðurstöður frá úrtaki yfir á pýði. Sá möguleiki er alltaf fyrir hendi að úrtakið gefi fyrir tilviljun skakka mynd af pýðinu. Rannsóknir parf að endurtaka til að sýna fram á réttmæti niðurstaðna, m.a. vegna pess að úrtak getur gefið skakka mynd af pýðinu (Amalía Björnsdóttir, 2004).

\subsection{Marktektarpróf}

Marktektarpróf (e. significance tests) meta líkur á pví að fá einhverja ákveðna niðurstöðu í úrtaki miðað við að pað komi frá pýði með ákveðna eiginleika. Ef tveir hópar eru bornir saman og munur mælist á beim í úrtaki er marktektarprófi beitt til pess að skoða hversu líklegt er að munur sé einnig til staðar í býðinu. Tölfræðilega marktækur munur parf ekki endilega að vera munur sem er mikill eða skiptir máli, heldur að líklegt sé að pessi munur (jafnvel pó hann sé lítill) sé til staðar í pýðinu. Marktektarpróf hjálpa til við að meta hvort munur sem finnst í úrtaki hafi komið upp fyrir tilviljun eða hvort hann er raunverulega til staðar í pýðinu. Nokkrir pættir hafa áhrif á pað hvort munur telst marktækur, pað er m.a. stærð úrtaks og dreifing í úrtaki, en ef úrtak er nógu stórt verður smávægilegur munur marktækur. Pað er freistandi að álykta að marktækur munur sé alltaf munur sem skiptir máli en pað er fjarri pví að vera rétt. Einnig verður að skoða meðaltöl og gildi fylgnistuðuls til að meta pað hvort marktækur munur skipti máli. betta er annars vegar spurning um tölfræðilega marktækni og hins vegar hvort niðurstöður séu fræðilega markverðar eða hagnýtar (Amalía Björnsdóttir, 2004).

Pegar fylgnistuðlar eru skoðaðir verður að hafa í huga að upplýsingarnar um marktækni peirra byggjast á fjölda svara. Pumalputtaregla er að ef fjöldi svara er meira en 50 er ólíklegt að alvarleg skekkja sé til staðar, og ef fjöldi svara er yfir 100 er óparfi að hafa áhyggjur vegna normaldreifingar (StatSoft, Inc., 2011). 


\subsection{6 .1 p-gildi}

Tölfræðileg marktækni eru líkurnar á pví að fylgni milli breyta eða mismunur milli meðaltala í úrtaki sé einungis til staðar í úrtakinu af tilviljun en sé ekki til staðar í raunverulega býðinu. Með hækkandi p-gildi minnkar trúverðugleiki pess að sambandið sem er verið að skoða sé einnig til staðar í býðinu. Með 0,05 p-gildi eru 5\% líkur á pví að sambandið sem verið er að skoða sé ekki til staðar í býðinu (StatSoft, Inc., 2011). Í pessari rannsókn er alltaf notast við 0,05 p-gildi.

\subsection{Fylgnistuðlar í tengslatöflum}

Ef fylgni milli tveggja breyta er lítil í pýðinu pá er engin leið að finna marktæka fylgni á milli peirra nema að úrtakið sé stórt. Prátt fyrir að úrtakið lýsi pýðinu fullkomlega mælist fylgnin ekki marktæk ef úrtakið er lítið. Að sama skapi er má gera ráð fyrir að fylgni milli breyta sem er mjög sterk mælist marktæk jafnvel prátt fyrir að úrtakið sé lítið (StatSoft, Inc., 2011).

Eftirfarandi fylgnistuðlar eru gjarnan notaðir til að mæla fylgni með stikalausum aðferðum (StatSoft, Inc., 2011) og voru peir notaðir til að mæla marktækni fylgni milli raðbreyta í tengslatöflum.

Spearman's rank-order. Fyrir raðbreytu flokkagögn er algengast að notast sé við Spearman's rank-order fylgnistuðul. Aðferðin er samhverf en með samhverfum fylgnistuðli er átt við að hvor breyta um sig getur talist háð eða óháð. Aðferðin mælir tilhneigingu tveggja breyta til pess að breytast "saman" (gildi beggja breyta loekkar eða hoekkar) (SPSS Statistics Inc., 2010). Marktækni stig sem notast er við í pessari skýrslu er 0,05. Gildi Spearman's rank-order fylgnistuðuls er á milli 1 og -1, par sem 1 pýðir algjör jákvœe fylgni, -1 er algjör neikvœe fylgni og 0 pýðir engin fylgni. Rannsakendur leggja sjálfir mat á pað hvað peim pykir vera sterk eða veik tengsl, en almennar reglur um hvað flokkist undir sterk eða veik tengsl eru lítið eitt á reiki.

Samkvæmt höfunum bókarinnar Statistics in a Nutshell (Sarah Boslaugh \& Paul Andrew Watters, 2008), gilda eftirfarandi almennar reglur um pað hvernig túlka eigi gildi á fylgnistuðli Spearman's, par sem $r_{s}$ er fylgnistuðull Spearman's:

- $0,9 \leq r_{s} \leq 1$ gefa til kynna mjög sterk tengsl

- $0,7 \leq r_{s}<0,9$ gefa til kynna sterk tengsl

- $0,5 \leq r_{s}<0,7$ gefa til kynna miðlungs tengsl

Samkvæmt Dr. Maher Khelifa (Khelifa) má túlka gildi á Spearmans rank-order fylgnistuðli á sama hátt og Pearsons fylgnistuðli, eða samkvæmt eftirfarandi:

- $0,81 \leq r_{s} \leq 1$ gefa til kynna mjög sterk tengsl

- $0,61 \leq r_{s}<0,80$ gefa til kynna sterk tengsl

- $0,41 \leq r_{s}<0,60$ gefa til kynna miðlungs sterk tengs1

- $0,21 \leq r_{s}<0,40$ gefa til kynna frekar veik tengs1

- $0,0 \leq r_{s}<0,2$ gefa til kynna veik tengsl

En samkvæmt sömu heimild kemur einnig fram að í félagsfræðilegum rannsóknum eru gildin $0,1,0,3$, og 0,5 talin gefa til kynna lítil, miðlungs og sterk tengsl hver um sig. En samkvæmt eðli pessarar rannsóknar má færa rök fyrir pví að notast megi við sömu túlkunaraðferð. 
Goodman og Kruskal's gamma (oft bara nefnt gamma). Aðferðin er samhverf og er notuð fyrir raðbreytur og byggir á pví að reiknað er fjöldi samsvarandi og ósamsvarandi para á milli tveggja breyta. Aðferðin er stundum sögð einhalla par sem hún segir til pað hversu oft breytur hafa gildi í væntri röð. Til dæmis ef er tvær breytur í gagnasafni eru sagðar hafa jákvæða fylgni sín á milli, og tilfelli 2 hefur hærra gildi í fyrstu breytunni heldur en tilfelli 1, er eðlilegt að álykta að tilfelli 2 hafi einnig hærra gildi á seinni breytunni heldur en tilfelli 1. Slíkt par af breytum kallast samsvarandi. Ef tilfelli 2 hefði lægra gildi á seinni breytunni væri parið ósamsvarandi. Gamma leiðréttir ekki mæligildið fyrir jafntefli. P.e. pegar tilfelli 1 og tilfelli 2 taka sömu gildi í á breytum 1 og 2 (Sarah Boslaugh \& Paul Andrew Watters, 2008). Marktækni stig sem notast er við í rannsókninni er 0,05 (SPSS Statistics Inc., 2010). Pegar gögn flokkast undir pað að vera flokka-raðbreytur koma eðlilega mikið af jafnteflum sérstaklega pegar svarflokkarnir eru ekki mjög margir. Í slíkum aðstæðum er eðlilegt að notast við Gamma fylgnistuðul.

Kendall's tau-b. Mæligildi með tilliti til samsvarandi og ósamsvarandi para sem er aðlagað að fjölda jafntefla. Tau-b er með pekkta úrtaks dreifingu og tölfræðipakkar reikna yfirleitt marktækni og fervik fyrir gildið. Tau-b nálgast 1 eða -1, en bara fyrir töflur sem hafa jafn marga dálka og raðir (Sarah Boslaugh \& Paul Andrew Watters, 2008). Marktækni stig er 0,05 (SPSS Statistics Inc., 2010).

Kendall's tau-c. Mæligildið er notað fyrir töflur sem hafa ekki jafn margar raðir og dálka. Eins og tau-b pá er pekkt dreifing fyrir úrtaks tau-c og tölfræðipakkar gefa yfirleitt marktækni og fervik fyrir gildið (Sarah Boslaugh \& Paul Andrew Watters, 2008). Marktækni stig er 0,05 (SPSS Statistics Inc., 2010).

Sommer's d. Ósamhverft mæligildi svo pað skiptir máli hvor breytan er svarbreytan og hvor er spábreytan. Sommer's d er leiðrétt fyrir fjölda jafntefla í spábreytunni. Stundum er sagt að Sommers'd refsi gögnunum fyrir jafntefli, en með pví er átt við að fjöldi jafntefla er fjarlægður úr nefnaranum (Sarah Boslaugh \& Paul Andrew Watters, 2008). Marktækni stig er 0,05 (SPSS Statistics Inc., 2010).

Til að mæla fylgni milli nafnabreyta ${ }^{144}$ var notast við eftirfarandi fylgnistuðla:

Tengsla stuðull (e.contingency coefficient). Mæligildi byggt á kí-kvaðrat prófi. Fær gildi á milli 0 og 1, par sem 0 merkir engin tengsl milli breyta og 1 merkir mikla fylgni. Hæsta mögulega gildi á tengsla stuðlinum er breytilegt og fer eftir fjölda svarflokka hjá breytum sem fylgni er mæld á milli.

Lambda. Byggir á minnkun fráviks pegar gildi spábreytu eru notuð til að spá fyrir um gildi svarbreytu. Pegar lambda er 1 pýðir pað að spábreytan spáir fullkomlega til um gildi svarbreytu og pegar lambda er 0 pýðir pað að spábreytan gerir ekkert gagn í pví að spá til fyrir um svarbreytuna.

Óvissu stuðull (e. uncertanity coefficient). Segir til um hlutfallslega minnkun í fráviki pegar gildi einnar breytu eru notuð til að spá fyrir um gildi á annarri.

\footnotetext{
${ }^{144}$ Athuga að í pau skipti sem fylgni milli nafnbreytu og raðbreytu er könnuð er líka notast við pessa fylgnistuðla
} 


\section{Viðauki O - Svör við opnum spurningum}

Hér má sjá svör sem fengust annars vegar við opnum spurningum í könnun verkkaupa (bls. 415) og hins vegar við opnum spurningum við könnun verktaka.

Athuga að persónulegum upplýsingum um verkkaupa og verktaka sem voru í úrtaki, svo sem nafn, símanúmer og heiti lóðar, hvort sem viðkomandi svaraði könnun eða ekki, fylgja ekki með sökum nafnleyndar.

\subsection{Opnar spurningar úr könnun fyrir verkkaupa}

\subsection{1 Ástæða fyrir höfnun ?}

\begin{tabular}{|l|l|}
\hline 290789 & [annað] erlendis \\
\hline 290848 & [annað] erlendis \\
\hline 290854 & [annað] erlendis \\
\hline 290901 & [annað] erlendis \\
\hline 290918 & [annað] erlendis \\
\hline 315785 & [annað] samkomulag um að fá að viðtal um önnur verk \\
\hline 315792 & [annað] samkomulag um að fá viðtal um önnur verk \\
\hline 318496 & [annað] búið að loka símanr. \\
\hline 318516 & $\begin{array}{l}\text { [annað] Ekki lengur til - rann saman við Nathan \& Olsen hf. - ekki sömu starfsmenn } \\
\text { og með petta verkefni við störf lengur }\end{array}$ \\
\hline 318534 & [annað] enginn enn að vinna hjá stofnuninni sem sá um pessar framkvæmdir \\
\hline 318851 & [annað] samkomulag um að ég fengi frekar viðtal vegna annars verks \\
\hline 318864 & [annað] Samkomulag við Einar H. Jónssonr að ég fengi viðtöl fyrir 3 verk - ekki pessi \\
\hline 318935 & [annað] Samkomulag um að fá viðtal um Holtagarð frekar \\
\hline 349855 & [annað] Ágúst er látinn \\
\hline 360674 & [annað] gjaldprota \\
\hline 361286 & [annað] farnir á hausinn \\
\hline 386389 & [annað] í ljós kom að petta var bara gatnagerð \\
\hline
\end{tabular}

\subsubsection{Hvað starfa margir hjá fyrirtækinu ?}

\begin{tabular}{|l|l|}
\hline 292536 & 7 \\
\hline 292589 & 30 \\
\hline
\end{tabular}




\begin{tabular}{|c|c|}
\hline 293394 & 4 \\
\hline 295715 & 40 \\
\hline 295842 & 1740 \\
\hline 300249 & 60 \\
\hline 300470 & 24 \\
\hline 300689 & 11 \\
\hline 300958 & 10 \\
\hline 304046 & $150-200$ \\
\hline 304239 & 6 \\
\hline 304348 & 16 \\
\hline 304546 & voru 13 fyrir hrun, eru 10 núna \\
\hline 304831 & 50 \\
\hline 306985 & 64 \\
\hline 310271 & 110 \\
\hline 311083 & 530 \\
\hline 314216 & 6 \\
\hline 314467 & 14 \\
\hline 315235 & 75 \\
\hline 344214 & 9 \\
\hline 348008 & $30-40$ \\
\hline 348355 & 3 \\
\hline 348426 & 9 \\
\hline 361639 & 1 \\
\hline
\end{tabular}

\subsection{3 Í hvers konar starfsemi er fyrirtækið ?}

\begin{tabular}{|l|l|}
\hline 202036 & $\begin{array}{l}\text { Jarðvinnuverktaki - Traktorsgrafa-hjólagrafa-vörubíll-hálkuvörn - Önnur ótalin } \\
\text { sérhæfð byggingastarfsemi }\end{array}$ \\
\hline 292536 & $\begin{array}{l}\text { Fasteignapróunarfélagið Klasi var stofnað í maí 2004. Frá upphafi hefur félagið stefnt } \\
\text { að pví að vera leiðandi á sviði fasteignareksturs og fasteignapróunar á Íslandi. }\end{array}$ \\
\hline 292589 & útfarapjónusta og fleira tengt \\
\hline 293394 & ípróttastarfsemi fyrir fatlaða \\
\hline
\end{tabular}




\begin{tabular}{|c|c|}
\hline 295715 & $\begin{array}{l}\text { Hreinsitækni ehf., er leiðandi fyrirtæki á sviði sópunar og pvotta á gatnakerfum og } \\
\text { gönguleiðum }\end{array}$ \\
\hline 295735 & dvalarheimili fyrir aldraða \\
\hline 295842 & Háskóli \\
\hline 300249 & framleiðslufyrirtæki \\
\hline 300470 & leiga íbúðarhúsnæðis \\
\hline 300689 & leiga íbúðarhúsnæðis \\
\hline 300958 & framleiðsla og innflutningur á vörum fyrir matvælaiðnað \\
\hline 304046 & $\begin{array}{l}\text { framkvæmdum að smíða, byggja og reka húsnæði fyrir starfsemi borgarinnar og } \\
\text { götur }\end{array}$ \\
\hline 304163 & Vinnustaður fyrir proskaheft fólk \\
\hline 304239 & Bílapvotti \\
\hline 304348 & öryrkjabandalag \\
\hline 304546 & $\begin{array}{l}\text { Eigendur og rekstraraðilar Hörpunnar. (Borgin og ríkið eiga Portus, en Portus á } \\
\text { svæðið og fyrirtækið Totus og Ago. Totus á svo tónlistarhúsið og Ago kemur til með } \\
\text { að reka húsið en peir eiga Sítus sem á lóðina.) }\end{array}$ \\
\hline 304831 & Hjúkrunarheimili \\
\hline 306566 & Framkvæmdasvið borgarinnar \\
\hline 306985 & $\begin{array}{l}\text { Fyrirtækið á og rekur fjórar hafnir, Reykjavíkurhöfn, Grundartangahöfn, Akraneshöfn } \\
\text { og Borgarneshöfn }\end{array}$ \\
\hline 310271 & blönduð pjónustustarfsemi \\
\hline 310457 & Framkvæmdasvið borgarinnar \\
\hline 310822 & Framkvæmdasvið borgarinnar \\
\hline 311083 & Háskóli \\
\hline 314216 & Húsfélag \\
\hline 314467 & útleiga fasteigna \\
\hline 315235 & heildverslun \\
\hline 315498 & borgin \\
\hline 344123 & $\begin{array}{l}\text { Stálnaust sérhæfir sig í smíðum á færiböndum og ýmsum lausnum fyrir } \\
\text { matvælavinnslu innréttingar }\end{array}$ \\
\hline 344214 & vatnsskarðsnámur \\
\hline 348008 & $\begin{array}{l}\text { Héðinn er pekkingarfyrirtæki í málmiðnaði og véltækni. Gæðastjórnunarkerfi Héðins } \\
\text { hf. hafa verið vottuð samkvæmt ISO } 9001 \text { staðlinum }\end{array}$ \\
\hline
\end{tabular}




\begin{tabular}{|l|l|}
\hline 348355 & byggir geymslur sem hann ýmist leigir út eða selur \\
\hline 348426 & vatnsskarðsnámur \\
\hline 348584 & RST Net leggur megináherslu á sérhæfða pjónustu við raforkubúnað. \\
\hline 361504 & arkitektastofa \\
\hline 361639 & safn \\
\hline 361750 & heilsurækt \\
\hline
\end{tabular}

\subsection{4 Í hvaða tilgangi var farið út í verkframkvæmdir ?}

\begin{tabular}{|c|c|}
\hline 170493 & Endurselja \\
\hline 170568 & Íbúðarhúsnæði \\
\hline 172774 & Íbúðarhúsnæði \\
\hline 173014 & Íbúðarhúsnæði \\
\hline 173807 & Íbúðarhúsnæði \\
\hline 173897 & Íbúðarhúsnæði \\
\hline 183024 & Íbúðarhúsnæði \\
\hline 187277 & Íbúðarhúsnæði \\
\hline 187703 & Íbúðarhúsnæði \\
\hline 188514 & Íbúðarhúsnæði \\
\hline 188663 & Íbúðarhúsnæði \\
\hline 188733 & Íbúðarhúsnæði \\
\hline 188880 & Íbúðarhúsnæði \\
\hline 189016 & Íbúðarhúsnæði \\
\hline 201572 & Íbúðarhúsnæði \\
\hline 201606 & Íbúðarhúsnæði \\
\hline 201631 & Íbúðarhúsnæði \\
\hline 202036 & Húsnæði undir starfsemi fyrirtækis \\
\hline 202389 & Íbúðarhúsnæði \\
\hline 207391 & Íbúðarhúsnæði \\
\hline 207991 & Íbúðarhúsnæði \\
\hline 208122 & Íbúðarhúsnæði \\
\hline
\end{tabular}




\begin{tabular}{|c|c|}
\hline 208294 & Íbúðarhúsnæði \\
\hline 211566 & Íbúðarhúsnæði \\
\hline 211866 & Íbúðarhúsnæði \\
\hline 223924 & Íbúðarhúsnæði \\
\hline 225664 & Íbúðarhúsnæði \\
\hline 226544 & Íbúðarhúsnæði \\
\hline 227257 & Íbúðarhúsnæði \\
\hline 227392 & Íbúðarhúsnæði \\
\hline 230333 & Íbúðarhúsnæði \\
\hline 246443 & Íbúðarhúsnæði \\
\hline 250905 & Íbúðarhúsnæði \\
\hline 251062 & skóli \\
\hline 262014 & endursala \\
\hline 262501 & útbúa nýjan dýraspítala \\
\hline 279487 & Íbúðarhúsnæði \\
\hline 279570 & Íbúðarhúsnæði \\
\hline 285161 & bílskúrar og geymslur við íbúðarhús \\
\hline 285179 & Íbúðarhúsnæði \\
\hline 286136 & íbúðarhús \\
\hline 286219 & Íbúðarhúsnæði \\
\hline 286250 & endursala \\
\hline 287312 & Íbúðarhúsnæði \\
\hline 288339 & Endurselja \\
\hline 288382 & húsnæði undir starfsemi \\
\hline 292536 & verslunarmiðstöð \\
\hline 292589 & skrifstofuhús fyrir starfsemi \\
\hline 293394 & ípróttahús fyrir starfsemi \\
\hline 295735 & nýtt dvalarheimili \\
\hline 295842 & Háskólatorg \\
\hline 300249 & skrifstofan, vörugeymsla \\
\hline 300470 & útleiga \\
\hline
\end{tabular}




\begin{tabular}{|c|c|}
\hline 300689 & byggja leiguhúsnæði \\
\hline 300958 & Skrifstofuhúsnæði fyrir fyrirtækið \\
\hline 304046 & $\begin{array}{l}\text { borgin keypti brunarústir í peim tilgangi að endurbyggja í sem upprunalegustu mynd } \\
\text { og til að selja aftur. Óhefơbundið. Tryggja borgarmynd }\end{array}$ \\
\hline 304163 & Húsnæði undir starfsemi fyrirtækisins \\
\hline 304239 & húsnæði undir starfsemi \\
\hline 304546 & Bygging tónlistarhúss að fyrirmynd óperuhússins í köben \\
\hline 304831 & Byggja öryggisíbúðir fyrir aldraða \\
\hline 305140 & Búa til leikskóla \\
\hline 306566 & Byggja leikskóla \\
\hline 306985 & skrifstofuhús fyrir starfsemi \\
\hline 310271 & Bygging stúdentagarða \\
\hline 310457 & Reisa kirkju \\
\hline 310822 & Byggja skóla \\
\hline 311083 & Byggja skóla \\
\hline 314027 & Byggja hjúkrunarheimili \\
\hline 314216 & bílastæðahús við Glæsibæ \\
\hline 314467 & Byggja upp verslunarmoll og koma pví í leigu \\
\hline 315235 & til að hýsa starfsemi \\
\hline 315498 & stækkun á skóla \\
\hline 315650 & Byggja skóla \\
\hline 320862 & Íbúðarhúsnæði \\
\hline 320997 & Íbúðarhúsnæði \\
\hline 321276 & Íbúðarhúsnæði \\
\hline 324020 & íbúðarhús \\
\hline 324100 & Íbúðarhúsnæði \\
\hline 324318 & íbúðarhús \\
\hline 326926 & Íbúðarhúsnæði \\
\hline 329999 & íbúðarhús \\
\hline 331088 & Íbúðarhúsnæði \\
\hline 332246 & Íbúðarhúsnæði \\
\hline
\end{tabular}




\begin{tabular}{|l|l|}
\hline 335562 & íbúðarhús \\
\hline 335699 & Íbúðarhúsnæði \\
\hline 336061 & Íbúðarhúsnæði \\
\hline 336189 & Íbúðarhúsnæði \\
\hline 336443 & Íbúðarhúsnæði \\
\hline 341081 & Íbúðarhúsnæði \\
\hline 342241 & íbúðarhús \\
\hline 342417 & Íbúðarhúsnæði \\
\hline 343271 & sameina allt sviðið í einu húsi \\
\hline 344000 & bjónusta fyrirtækisins átti að vera parna - verkið er stopp \\
\hline 348355 & byggja geymslu \\
\hline 357981 & Íbúðarhúsnæði \\
\hline 358204 & Íbúðarhúsnæði \\
\hline 358305 & Íbúðarhúsnæði \\
\hline 361504 & skrifstofuhúsnæði fyrir starfsemi \\
\hline 361639 & húsnæði fyrir safn \\
\hline 361750 & heilsuræktarstöð \\
\hline
\end{tabular}

\subsubsection{Starfsgrein verktaka sem hafður er í huga?}

\begin{tabular}{|l|l|}
\hline 246751 & steypuvinna \\
\hline 262014 & múrari \\
\hline 279570 & uppsteypa \\
\hline 286250 & múrari \\
\hline 288339 & múrari \\
\hline 288382 & steypuvinna \\
\hline
\end{tabular}

\subsubsection{Hvers konar bygging ?}

\begin{tabular}{|l|l|}
\hline 187277 & Einingarhús \\
\hline 187703 & Einingarhús \\
\hline 188514 & kanadískt timburhús með steyptum grunn \\
\hline
\end{tabular}




\begin{tabular}{|c|c|}
\hline 188663 & Einingarhús \\
\hline 188733 & Steypt hús \\
\hline 188880 & Steypt hús \\
\hline 189016 & Einbýlishús \\
\hline 201572 & Einingarhús \\
\hline 201606 & Einingarhús \\
\hline 207391 & Einingarhús \\
\hline 207991 & Steypt hús \\
\hline 208122 & Steypt hús \\
\hline 208294 & Steypt hús \\
\hline 211566 & Einingarhús \\
\hline 211866 & Steypt hús \\
\hline 223924 & Steypt hús \\
\hline 225664 & Steypt hús \\
\hline 227257 & steypt- parhús \\
\hline 227392 & steypt- parhús \\
\hline 230333 & steypt einbýlishús \\
\hline 246443 & steypt og innflutt frá Kanada \\
\hline 246751 & steypt einbýlishús \\
\hline 250905 & steypt einbýlishús \\
\hline 251062 & skóli \\
\hline 259821 & landbúnaðarhús \\
\hline 259836 & landbúnaðarhús \\
\hline 262014 & steypt parhús \\
\hline 262501 & dýraspítali \\
\hline 263002 & parhús \\
\hline 285161 & bílskúrar og geymslur við íbúðarhús \\
\hline 285179 & einbýlishús \\
\hline 286136 & einbýlishús \\
\hline 286219 & parhús \\
\hline 286250 & fjölbýlishús \\
\hline
\end{tabular}




\begin{tabular}{|c|c|}
\hline 286281 & einbýlishús \\
\hline 287312 & einingarhús - parhús \\
\hline 288339 & einbýlishús \\
\hline 288382 & iðnaðarhús \\
\hline 292536 & verslunarmiðstöð \\
\hline 292589 & skrifstofuhús fyrir starfsemi \\
\hline 293394 & ípróttahús \\
\hline 295715 & iðnaðarhús \\
\hline 295735 & fjölbýlishús \\
\hline 295842 & Háskólatorg \\
\hline 300249 & skrifstofa, vörugeymsla \\
\hline 300470 & fjölbýlishús \\
\hline 300689 & Fjölbýlishús \\
\hline 300958 & skrifstofuhús fyrir starfsemi \\
\hline 304046 & $\begin{array}{l}\text { Húsið Austurstræti } 22 \text { er timburhús, ein hæð og rishæð. Pað er byggt í anda pess húss } \\
\text { sem stóð parna og upprunalega byggt árið } 180\end{array}$ \\
\hline 304163 & Fjölbýlishús \\
\hline 304239 & iðnaðarhús \\
\hline 304348 & raðhús \\
\hline 304546 & Tónlistar og ráostefnuhús \\
\hline 304831 & Fjölbýlishús \\
\hline 305140 & Leikskóli \\
\hline 306566 & Leikskóli \\
\hline 306985 & skrifstofuhús \\
\hline 310271 & Fjölbýlishús \\
\hline 310457 & Kirkja \\
\hline 310822 & skóli \\
\hline 311083 & Háskóli \\
\hline 314027 & Hjúkrunarheimili \\
\hline 314216 & bílastæðahús við Glæsibæ \\
\hline 314467 & Verslunarmoll \\
\hline
\end{tabular}




\begin{tabular}{|l|l|}
\hline 315235 & atvinnuhúsnæði \\
\hline 315498 & skóli \\
\hline 315650 & skóli \\
\hline 320997 & Einbýlishús \\
\hline 321276 & einbýlishús \\
\hline 324318 & Einingarhús \\
\hline 326926 & Einingarhús \\
\hline 329999 & Einingarhús \\
\hline 331088 & Einingarhús \\
\hline 336443 & Einingarhús \\
\hline 343271 & skrifstofuhús fyrir starfsemi \\
\hline 348355 & geymsla \\
\hline 357981 & Steypt hús \\
\hline 358204 & Einingarhús \\
\hline 358305 & Steypt hús \\
\hline 358601 & stálgrindarhús \\
\hline 361504 & skrifstofuhús fyrir starfsemi \\
\hline 361750 & líkamsræktarstöð \\
\hline
\end{tabular}

\subsubsection{Hvaða menntun hefur bú ?}

\begin{tabular}{|l|l|}
\hline 173807 & Skipstjóri \\
\hline 211566 & rafvirki \\
\hline 358305 & skipasmiður \\
\hline
\end{tabular}

\subsubsection{Hvaða páttur stóð upp úr sem pú varst mest ósátt/ur við ?}

\begin{tabular}{|l|l|}
\hline 170568 & vantaði upp á einangrun \\
\hline 172774 & ósáttur við framkvæmdarhraða og gallaðar einingar \\
\hline 173897 & dýrara en til stóð \\
\hline 187703 & $\begin{array}{l}\text { beir sem bjuggu til einingar og teiknuðu húsið gerðu mistök sem voru svo leiðrétt og } \\
\text { bætt }\end{array}$ \\
\hline 188514 & erfitt að ná í verktaka \\
\hline
\end{tabular}




\begin{tabular}{|c|c|}
\hline 188733 & Ósáttur við vinnu á gluggum \\
\hline 188880 & kostnaður og tími töluvert meiri \\
\hline 189016 & Seinagangur á verktaka. Hann var seinn til verka. \\
\hline 201572 & Frágangur ekki nógu góður hjá verktaka \\
\hline 201631 & kastað til höndunum \\
\hline 208294 & Umræddur verktaki var óvandvirkur og óreyndur \\
\hline 211566 & efniskaup \\
\hline 211866 & fúsk \\
\hline 246443 & vertaki gafst upp áður en hann kláraði \\
\hline 250905 & tími \\
\hline 259821 & ALLT \\
\hline 262014 & hönnunarpáttur - skipulag hverfis frá Reykjavíkurborg \\
\hline 262501 & Byggingastjóri ömurlegur - margt lélegt \\
\hline 279570 & $\begin{array}{l}\text { Ósáttur við píparana en pó ósáttastur við eftirlit frá borginni. Finnst súrt að borga fyrir } \\
\text { úttektir par sem úttektarmenn líta varla á pað sem verið er að taka út... }\end{array}$ \\
\hline 286219 & gluggaásetugerð \\
\hline 287312 & $\begin{array}{l}\text { Verktaki fór langt fram úr tímaáætlun og úttektir lélegar og gæði verks ekki góð. Sér } \\
\text { eftir pví að hafa haft byggingastjóra frá verktakafyrirtækinu, telur pað ekki hafa verið } \\
\text { faglegt pví hann sat pá báðum megin við borðið. }\end{array}$ \\
\hline 288339 & Múrarinn ekki að vanda sig nægilega mikið.. \\
\hline 288382 & Lélegir birgjar \\
\hline 292536 & $\begin{array}{l}\text { Verkið var unnið með marksamning par sem verktakinn hefur einnig hagsmuni af pví } \\
\text { að framgangur verksins gangi vel. Peir hefðu getað verið virkari í marksamningunum } \\
\text { á vissum sviðum með sínum undirverktökum }\end{array}$ \\
\hline 292589 & Tafir \\
\hline 295735 & undirverktakar hjá aðalverktaka \\
\hline 295842 & loftræstikerfið \\
\hline 300689 & lóðarfrágangur og milliveggjaefni \\
\hline 300958 & Málaferli og samskipti við borgina \\
\hline 304163 & Of margir undirverktakar \\
\hline 304239 & planið \\
\hline 304546 & $\begin{array}{l}\text { Hönnun og undirbúningur hönnunar. Hópurinn sem bauð í petta var portus, íav, nýsir } \\
\text { og fleiri, og áttu peir allir að koma að framkvæmdinni jafn ábyrgir. Íav óskaði svo }\end{array}$ \\
\hline
\end{tabular}




\begin{tabular}{|l|l|}
\hline & $\begin{array}{l}\text { eftir að ganga út úr samningum og varð par með gerður aðalverktaki og hinir } \\
\text { undirverktakar. Samningsgrundvellinum var pví breytt. Gæðaviðmiðun var sett að } \\
\text { húsið væri sambærilegt við óperuhúsið i köben. Pegar uppskipting var pá kom upp } \\
\text { ágreiningur og endalausnirnar voru ekki nógu góðar. }\end{array}$ \\
\hline 304831 & uppsteypa hjá undirverktaka \\
\hline 306985 & undirverktakar slæmir - gler og gluggar. Hnökrar við að klára hluti. \\
\hline 311083 & Hönnunaratriði \\
\hline 314216 & $\begin{array}{l}\text { Umsjón verksins. Eftirlit með framkvæmdum. Reikningahliðin, úttektir ofl. Hefði átt } \\
\text { að vera maður með bakgrunn í gæðaeftirliti. Ekki nógu gott eftirlit. }\end{array}$ \\
\hline 314467 & Nokkrir pættir. Núverandi staða á útkomu og framkvæmd \\
\hline 315498 & hönnunarundirbúning \\
\hline 320997 & pípulögn \\
\hline 324100 & uppsláttur fyrir pakinu hrundi og ferlið sem tók við eftir bað \\
\hline 326926 & sökkulvesen \\
\hline 332246 & tímaáætlun \\
\hline 335562 & veggur út í garði - lítilsháttar vesen \\
\hline 336189 & tímasetningar stóðust ekki \\
\hline 348355 & hönnunin \\
\hline 358204 & frágangur á gólfplötu \\
\hline 358601 & verkstjórn og skipulag verktaka \\
\hline 361750 & lokafrágangur \\
\hline
\end{tabular}




\subsubsection{Er verkið farið fram úr eða fór verkið fram úr tímaáætlun hjá umræddum verktaka - hvaða pátt telur bú að hafi haft mestu áhrif?}

Sjá bls. 215

\begin{tabular}{|c|c|}
\hline 170568 & [lítið ] Hrunið. Ekki að sakast við verktakann. \\
\hline 172774 & [mikið ] Allt of mikið að gera hjá verktaka \\
\hline 173897 & [lítið ] afhefting á efni dróst \\
\hline 183024 & [lítið ] Hrunið \\
\hline 187277 & [Mjög mikið ] Miklar annir hjá verktaka \\
\hline 188514 & [lítið ] annir hjá verktaka \\
\hline 188733 & [mikið ] upphaf verksins tafoist vegna anna hjá verktaka \\
\hline 188880 & [mikið ] Flóknara en var séð fyrir í byrjun - og rangar magntölur í byrjun \\
\hline 189016 & [Mjög mikið ] Lélegt utanumhald og stjórnleysi hjá verktaka \\
\hline 202389 & [Mjög mikið ] margir pættir spila inn í, t.d. hrunið og vöruvöntun \\
\hline 208122 & [lítið ] veður \\
\hline 208294 & [Mjög mikið ] Reynsluleysi verktaka \\
\hline 211866 & [Mjög mikið ] óvönduð og óraunhæf tímaáætlun \\
\hline 223924 & $\begin{array}{l}\text { [lítið ] ekki lofað neinum sérstökum dagsetningum en petta tók aðeins lengri tíma en } \\
\text { hann hafði hugsað sér }\end{array}$ \\
\hline 246443 & [Mjög mikið ] miklar annir hjá verktaka - byggt á útrásartíma \\
\hline 250905 & [mikið ] annir hjá verktaka - gert fyrir hrun \\
\hline 259821 & [Mjög mikið ] lélegur verktaki \\
\hline 259836 & [mikið ] breytingar í ferlinu - meiri framkvæmdir \\
\hline 262501 & [mikið ] ömurlegir verktakar \\
\hline 279570 & [lítið ] Aðallega vegna veðurs \\
\hline 285179 & [lítið ] óviðráðanlegar aðstæður eins og frost og annað \\
\hline 286136 & [mikið ] mannskortur \\
\hline 286219 & [mikið ] Ekki nægilega skipulagðir \\
\hline 287312 & [Mjög mikið ] allt of mikið að gera hjá verktaka \\
\hline 288382 & [Mjög mikið ] reykjavíkurborg tafoi teikningar mjög mikið \\
\hline 292589 & [Mjög mikið ] annir hjá verktaka \\
\hline
\end{tabular}




\begin{tabular}{|c|c|}
\hline 293394 & [mikið ] Aukaverk sem purfti að gera en ekki var séð fyrir í byrjun \\
\hline 295715 & [lítið ] breytingar \\
\hline 295842 & [lítið ] Hluti verksins, sem var aukaverk, tafðist vegna anna hjá verktaka \\
\hline 300249 & [Mjög mikið ] 2007 annir hjá verktaka \\
\hline 300958 & [mikið ] Breytt tæknilýsing og endurvinna vegna frábrigða \\
\hline 304163 & [Lítið ] ófyrirséðir pættir \\
\hline 304546 & [Lítið ] Hrunið \\
\hline 304831 & [Lítið ] Kreppan \\
\hline 306566 & [Mikið ] vanstjórn \\
\hline 306985 & $\begin{array}{l}\text { [Mjög mikið ] Undirverktaka mest að kenna - skaffaði gler og glugga allt of seint svo } \\
\text { afhending dróst }\end{array}$ \\
\hline 310271 & [Lítið ] skortur á aðföngum - kreppan \\
\hline 311083 & [Mikið ] hrunið, erfiðleikar að fá efni \\
\hline 314027 & [Mjög mikið ] Hrunið - lítil yfirvinna hjá verktaka \\
\hline 314216 & $\begin{array}{l}\text { [Mikið ] Seinkun vegna óvæntra atriða. Tafir á byggingatíma vegna færslu á ræsum, } \\
\text { broti á jarðvegi, veita frá vatni. Auk ýmissa atriða. Röng og óraunhæf tímaáætlun. }\end{array}$ \\
\hline 314467 & [Mikið] Stjórnleysi og breytingar. Ekki endilega við verktaka að sakast \\
\hline 315650 & [Mikið ] Magnbreytingar: verkið varð stærra og meira í ákveðum páttum \\
\hline 324020 & [Lítið ] mikið að gera árið 2007 \\
\hline 324100 & [Mikið ] hrunið á pakinu \\
\hline 326926 & [Mikið ] allt of mikið að gera hjá öllum \\
\hline 330942 & [Mikið] miklar annir og léleg tímastjórnun \\
\hline 331088 & [Mjög mikið ] Of mikið að gera hjá eskihúsi - byggt 2005 \\
\hline 332246 & [Mjög mikið ] margt. Illa skipulagt. Undirverktakar lélegir. \\
\hline 336061 & $\begin{array}{l}\text { [Lítið ] verktakinn kláraði sitt verk nánast á réttum tíma. ๖að sem eftir er, er vegna } \\
\text { fjármálaóstöðugleika. }\end{array}$ \\
\hline 336189 & $\begin{array}{l}\text { [Mjög mikið ] léleg verkefnastjórnun - verkinu er ekki enn lokið pví verktakinn er } \\
\text { farinn á hausinn. }\end{array}$ \\
\hline 343271 & [Lítið ] íkveikja \\
\hline 344000 & [Mjög mikið ] Verkið er stopp vegna vandamála við að fá lán frá banka. \\
\hline 348355 & [Mikið ] aðföng komu seint \\
\hline 348584 & [Lítið ] mönnuðu ekki verkin nógu vel yfir sumartímann \\
\hline
\end{tabular}




\begin{tabular}{|l|l|}
\hline 358204 & [Mikið ] ákvarðanafælni og efnisskortur hjá verktaka \\
\hline 358601 & [Mikið ] Skipulags- og stjórnleysi hjá verktaka \\
\hline 361750 & [Mikið ] margir pættir sem spiluðu saman \\
\hline
\end{tabular}

\subsubsection{Var greiðsluáætlunin endurskoðuð og uppfærð reglulega ?}

Sjá bls. $\underline{215}$

\begin{tabular}{|l|l|}
\hline 262014 & [Já] 3 mánaða fresti \\
\hline 292536 & [Já] verkkaupinn útbjó kostnaðaráætlun sem verktakar bjóða í \\
\hline 304831 & [Já] oftar en mánaðarlega \\
\hline 310271 & [Já] mánaðarlega \\
\hline
\end{tabular}

\subsubsection{Er verkið farið fram úr eða fór verkið fram úr greiðsluáætlun hjá umræddum verktaka?}

Sjá bls. 215

\begin{tabular}{|l|l|}
\hline 170568 & {$[$ Aðeins ] Hrunið } \\
\hline 172774 & {$[$ Mikið ] yfirborgaðir... } \\
\hline 173807 & {$[$ Aðeins ] vinna iðnaðarmanna } \\
\hline 173897 & {$[$ Mikið ] Hrunið } \\
\hline 183024 & {$[$ Mjög mikið ] Hrunið } \\
\hline 187703 & [Aðeins ] tafir \\
\hline 187991 & {$[$ Mjög mikið ] efnahagsástandið - auðvelt aðgengi að fé } \\
\hline 188733 & [Aðeins ] Tafir vegna veðurs og anna hjá verktaka \\
\hline 188880 & {$[$ Mikið ] Flóknara en í upphafi } \\
\hline 189016 & {$[$ Mikið ] Lélegar áætlanir og efnahagsástandið } \\
\hline 201631 & {$[$ Mikið ] Vanmat á tíma og vinnu } \\
\hline 202389 & {$[$ Mjög mikið ] Hrunið } \\
\hline 211866 & [Aðeins ] tímapáttur \\
\hline 246443 & [Mjög mikið ] margt sem vantaði inn í verklýsingu \\
\hline 246751 & [Aðeins ] aukaverk sem voru ekki séð fyrir í byrjun og voru ekki inn í samning \\
\hline 259821 & [Mjög mikið ] Öll stjórnun mjög slæm \\
\hline
\end{tabular}




\begin{tabular}{|c|c|}
\hline 259836 & $\begin{array}{l}\text { [Mikið ] efnahagsástandið - miklar hækkanir vegna pess. Purftu að bíða lengi eftir } \\
\text { byggingarleyfi og viðbótarkostnaður vegna yfirdráttavaxta }\end{array}$ \\
\hline 262014 & [Aðeins ] efniskostnaður og tímavinna of mikil \\
\hline 263002 & [Aðeins ] Hrunið \\
\hline 279487 & [Aðeins ] ekki viss \\
\hline 286219 & [Mikið] hrunið \\
\hline 287312 & [Mjög mikið ] Fall krónu og tafir \\
\hline 295735 & [Aðeins ] aukaverk \\
\hline 300249 & [Mikið] 2007 annir hjá verktaka \\
\hline 304239 & [Lítið ] Flækjustig verksins var mikið \\
\hline 305140 & [Lítið ] magnaukningar \\
\hline 306566 & [Lítið ] Magnaukning og vanstjórn \\
\hline 306985 & [Lítið ] Breytingar \\
\hline 310457 & [Lítið ] magnaukningar \\
\hline 311083 & [Mikið] hrunið, hækkaður efniskostn \\
\hline 314027 & [Mjög mikið ] Hrunið - verðbætur \\
\hline 314216 & $\begin{array}{l}\text { [Mikið ] Breytingar á byggingatíma. Varð flóknara mál. Ekki nægilega útlistað í } \\
\text { byrjun. Ekki farið í nákvæma útreikninga í byrjun. Bara slump út í loftið. }\end{array}$ \\
\hline 314467 & [Mikið] Stjórnleysi og breytingar. Ekki endilega við verktaka að sakast \\
\hline 324100 & [Mikið ] hrunið á pakinu \\
\hline 336061 & [Lítið ] ekki endilega að sakast við verktakann \\
\hline 343271 & [Lítið ] aukaverk \\
\hline 357981 & $\begin{array}{l}\text { [Lítið ] Verkið var á endanum dýrara en verkkaupinn lagði upp með en hann sagðist } \\
\text { ekki geta beint sakast við verktakann }\end{array}$ \\
\hline 361504 & $\begin{array}{l}\text { [Lítið ] ekki gefin upp nein tala í upphafi en verkið varð dýrara en verkkaupi hafði } \\
\text { gert sér í hugarlund }\end{array}$ \\
\hline 361750 & [Mjög mikið] mjög mikil \\
\hline
\end{tabular}

\subsubsection{Hafðir pú umsjónarmann sem sá um að umræddur verktaki framfylgdi ákvæðum samningsins ?}

\begin{tabular}{|l|l|}
\hline 170493 & [Já] Vélvirkjameistari \\
\hline 188663 & [Já] Ekki viss, stúlka í kanada \\
\hline
\end{tabular}




\begin{tabular}{|c|c|}
\hline 251062 & [Já] byggingameistari \\
\hline 262014 & [Já] Hönnuður \\
\hline 292536 & [Já] verkfræðingur \\
\hline 292589 & [Já] byggingaverkfræðing og arkitekt \\
\hline 293394 & [Já] verkfræðingur \\
\hline 295715 & [Já] hagfræði \\
\hline 295735 & [Já] arkitekt \\
\hline 295842 & [Já] Samningur við framkvæmdasýslu ríkisins - starfsmaður hans sá um eftirlit \\
\hline 300249 & [Já] Verkfræðingur - hnit með eftirlit \\
\hline 300689 & [Já] húsgagnasmiður \\
\hline 304046 & [Já] Verkmenntun í byggingaiðnaði \\
\hline 304163 & [Já] byggingameistari \\
\hline 304239 & [Já] verkfræðingur \\
\hline 304348 & [Já] Byggingameistari \\
\hline 304546 & $\begin{array}{l}\text { [Já] Eru } 5 \text { sem sinna pví að fara yfir einstaka pætti. } 3 \text { verkfræðingar og arkitekt og } \\
\text { hagfræðingur }\end{array}$ \\
\hline 304831 & [Já] Verkfræðingur frá teiknistofunni. Hafa verið mannabreytingar. \\
\hline 306985 & [Já] Byggingatæknifræðingur \\
\hline 310271 & [Já] tæknifræðingur \\
\hline 310822 & [Já] húsasmíðameistari \\
\hline 311083 & [Já] tveir. Arkitekt og viðskiptafræðingur \\
\hline 314216 & [Já] Endurskoðandi. Feillinn kannski hér. \\
\hline 314467 & [Já] B.Sc. Tæknifræði \\
\hline 315235 & [Já] Línuhönnun sá um slíkt. Verkfræðingur \\
\hline 315498 & [Já] byggingatæknifræðingur \\
\hline 315650 & [Já] húsasmíðameistari \\
\hline 343271 & [Já] tæknifræðingur \\
\hline 344000 & [Já] hann veit pað ekki ... \\
\hline 344214 & [Já] verkfræðingur \\
\hline 348426 & [Já] verkfræðingur \\
\hline 348584 & [Já] trésmiður \\
\hline
\end{tabular}


358601 [Já] Byggingaverkfræðingur og tæknifræðingur

361750 [Já] háskólamenntun

6.78.13 Hversu tídir voru verkfundir ?

\begin{tabular}{|c|c|}
\hline 187703 & 2 sinnum í viku \\
\hline 188514 & 4 fundir á verktíma \\
\hline 188733 & daglega \\
\hline 201606 & daglega \\
\hline 201631 & bara eftir hendinni \\
\hline 202389 & tvisvar í viku \\
\hline 208122 & vikulega \\
\hline 208294 & 1-2 í mán \\
\hline 211566 & vikulega \\
\hline 211866 & 4 vikna fresti \\
\hline 227257 & vikulega \\
\hline 227392 & daglega \\
\hline 246443 & daglega / vikulega \\
\hline 246751 & Verkkaupi mætti daglega á verkstað og fór yfir málin \\
\hline 250905 & Verkkaupi mætti reglulega á verkstað (vikulega) og fór yfir stöðu mála með verktaka \\
\hline 251062 & vikulega \\
\hline 259836 & daglega \\
\hline 262501 & Verkkaupi mætti nokkrum sinnum í viku á verkstað til að ræða við verktaka \\
\hline 263002 & vikulega \\
\hline 279570 & Bara kallað til verkfunda ef eitthvað var að sem purfti að skoða \\
\hline 285179 & vikulega \\
\hline 286136 & Verkkaupi mætti daglega á verkstað og ræddi við verktaka \\
\hline 286219 & vikulega \\
\hline 287312 & 4 fundir á verktíma \\
\hline 288339 & daglega \\
\hline 292536 & vikulega \\
\hline
\end{tabular}




\begin{tabular}{|l|l|}
\hline 292589 & vikulega \\
\hline 293394 & mánaðarlega \\
\hline 295715 & vikulega \\
\hline 295735 & vikulega \\
\hline 295842 & vikulega \\
\hline 300470 & hálfs mánaðarlega \\
\hline 300689 & 2 mán fresti \\
\hline 304163 & daglegir/annan hvern dag \\
\hline 304239 & mánaðarlega \\
\hline 304348 & hálfs mánaðarlega \\
\hline 305140 & vikulega \\
\hline 306566 & vikulega \\
\hline 306985 & vikulega \\
\hline 310457 & vikulega \\
\hline 314027 & hálfs mánaðarlega \\
\hline 341081 & daglega \\
\hline 357981 & daglega \\
\hline 358204 & hittust 3 á verktíma \\
\hline 358305 & daglega \\
\hline 358601 & vikulega \\
\hline 361504 & daglega \\
\hline 361639 & Eftir framvindu - c.a mánaðarlega \\
\hline
\end{tabular}

\subsubsection{Mattir bú á verkfundi ?}

\begin{tabular}{|l|l|}
\hline 314216 & [Aldrei] nei, sá sem var framkvæmdarstjóri á undan honum mætti alltaf \\
\hline 361750 & [Aldrei] nei \\
\hline
\end{tabular}

\subsubsection{Var rituð fundargerð á verkfundum ?}

\begin{tabular}{|l|l|}
\hline 251062 & [Alltaf ] eftirlitsmaður bæjarins \\
\hline 262014 & [Alltaf] Nokkurs konar fundargerð rituð núnabækur - verkkaupi sá sjálfur um pað \\
\hline 292536 & [Alltaf] verkkaupinn - eftirlitsmaðurinn \\
\hline
\end{tabular}




\begin{tabular}{|c|c|}
\hline 292589 & [Alltaf] eftirlitsmenn verkkaupa \\
\hline 293394 & [Alltaf] eftirlitsmaður \\
\hline 295715 & [Alltaf] verktaki \\
\hline 295735 & [Alltaf] verkkaupi \\
\hline 295842 & [Alltaf] eftirlitsmaður verkkaupa \\
\hline 300249 & [Alltaf] Eftirlitsmaður verkkaupa \\
\hline 300470 & [Alltaf] verkkaupi \\
\hline 304046 & [Alltaf] eftirlitsmaður verkkaupa sér um pað \\
\hline 304239 & [Stundum ] Maður frá verkkaupa \\
\hline 304348 & [Alltaf] umsjónarmaður verkkaupa \\
\hline 304546 & $\begin{array}{l}\text { [Oftast ] Sá sem boðar fundinn sér um fundargerð. Oftast er pað verktaki. Hefur ekki } \\
\text { alltaf verið gert á minni fundum, sem hefur gjarnan skapað vandamál par sem aðilar } \\
\text { eru ekki sammála um pað sem fram fór á fundinum. }\end{array}$ \\
\hline 304831 & [Alltaf] Ritari. Á vegum verkkaupa. \\
\hline 305140 & [Alltaf] verkkaupi \\
\hline 306566 & [Alltaf] Verkkaupi \\
\hline 306985 & [Alltaf] maður frá verkkaupa \\
\hline 310271 & [Alltaf] Starfsmaður verktakans - framkvæmdarstjóri verktakans \\
\hline 310457 & [Alltaf] verkkaupi \\
\hline 310822 & [Alltaf] Umsjónarmaðurinn \\
\hline 311083 & $\begin{array}{l}\text { [Alltaf ] starfsmaður bygginganefndar - verkfræðingur. Ráðgjafafyrirtæki sem var } \\
\text { ráðið að verkkaupa og verksala }\end{array}$ \\
\hline 314027 & [Alltaf] Verkkaupi - eftirlitsmaður \\
\hline 314216 & $\begin{array}{l}\text { [Alltaf ] Framkvæmdarstjóri húsfélagsins sem var umsjónarmaðurinn } \\
\text { (endurskoðandinn) (sá sem var framkvæmdarstjóri á undan svaranda) }\end{array}$ \\
\hline 314467 & [Alltaf] umsjónarmaður verkkaupa \\
\hline 315235 & [Alltaf] verktaki \\
\hline 315498 & [Alltaf] umsjónarmaður \\
\hline 315650 & [Alltaf] Umsjónarmaðurinn \\
\hline 342241 & [Stundum ] Aðili frá eskihús \\
\hline 343271 & [Alltaf] eftirlitsaðilinn, p.e. umsjónarmaðurinn \\
\hline 348008 & [Alltaf] Maður frá verkkaupa sá um að rita fundargerð \\
\hline
\end{tabular}




\subsubsection{Hvernig var bér tilkynnt um frábrigði ?}

\section{Bls.231}

\begin{tabular}{|l|l|}
\hline 288382 & ýmist munnlega eða ekki tilkynnt \\
\hline 305140 & allt í bland \\
\hline 314027 & allt í bland \\
\hline 329999 & ýmist munnlega eða ekki tilkynnt \\
\hline
\end{tabular}

\subsubsection{Hvað var pað sem pér pótti miður fara varðandi umgengni verktaka ef eitthvað var?}

\begin{tabular}{|l|l|}
\hline 172774 & slæm umgengni hjá undirverktökum \\
\hline 188663 & subbuskapur \\
\hline 188880 & Allt út um allt!! Verkkaupi stanslaust að taka til \\
\hline 189016 & Illa gengið frá verkfærum og byggingarefni \\
\hline 201572 & Sóðar \\
\hline 208122 & ekki nógu vel gengið um og farið með efni \\
\hline 208294 & sóði \\
\hline 246443 & sóði - gekk aldrei frá eftir sig \\
\hline 246751 & almennur sóðaskapur \\
\hline 259821 & allt \\
\hline 262014 & prifnaður og förgun á sorpi mætti vera betri \\
\hline 262501 & ekki klárað - skítaumgengni \\
\hline 286136 & $\begin{array}{l}\text { verkkaupi sá sjálfur um prif eftir verktakann pví umgengni verktakans var slakur og } \\
\text { verkkaupa var annt um að umgengni væri góð }\end{array}$ \\
\hline 287312 & Byggingarefni út um allt \\
\hline 288382 & Verkkaupi purfti að kalla aftur á verktaka og fá hann til að ganga betur frá eftir sig \\
\hline 292589 & Mætti vera betri \\
\hline 293394 & hefði mátt vera betri - óttalegir sóðar sem skapaði leiðindi við nágranna \\
\hline 304546 & Hreinlæti og snyrtimennska hefði mátt vera betri \\
\hline
\end{tabular}




\begin{tabular}{|l|l|}
\hline 330942 & létu kranann t.d. standa í 6 mán eftir verklok \\
\hline 331088 & Frágangur alveg til fyrirmyndar \\
\hline 335562 & Samt slæmur frágangur undirverktaka (múrara) \\
\hline 336189 & ekki gengið frá eftir sig :P \\
\hline 348008 & Umgengni undirverktaka ekki nægilega góður \\
\hline 358204 & slök utanhús \\
\hline
\end{tabular}

\subsubsection{Komu upp einhver vandamál í samskiptum bínum við verktaka? Hver pá ?}

\begin{tabular}{|l|l|}
\hline 173897 & nei, hefði mátt vera skýrari og meiri samskipti \\
\hline 187277 & $\begin{array}{l}\text { Ekki næg samskipti. Vantaði fundi. Hefði viljað hafa formlega verkfundi með } \\
\text { verktaka. }\end{array}$ \\
\hline 188514 & Verktaki ekki nógu aðgengilegur \\
\hline 188733 & Peir pekktust vel. Mjög góð samskipti \\
\hline 188880 & Ekki næg \\
\hline 189016 & Erfitt að ná í verktaka \\
\hline 201631 & Verktakinn er gamall kunningi Valgeirs og samskiptin voru eftir pví. \\
\hline 211866 & $\begin{array}{l}\text { Pegar verkkaupi fór eitthvað að setja út á gæði verks hjá verktaka pá var hann hinn } \\
\text { oliðlegasti í öllum samskiptum. }\end{array}$ \\
\hline 259821 & Hefði viljað hafa meiri samskipti \\
\hline 262501 & Allt of lítil samskipti - Verktaki lítið til staðar \\
\hline 286136 & $\begin{array}{l}\text { hefðu mátt vera fleiri frá verktaka á verkstað pví verkkaupi notaði bá leið að mæta á } \\
\text { verkstað sem samskiptaleið }\end{array}$ \\
\hline 286219 & verktaki ekki nægilega mikið til staðar \\
\hline 287312 & of lítil - verktaki erfiður í samskiptum \\
\hline 288382 & Verktakar hálf geðveikir :P \\
\hline 292589 & Seinagangur í samskiptum - og ekki næg \\
\hline 303394 & samskipti við nágranna ekki nógu góð \\
\hline 314216 & Einhver vandamál komu upp. \\
\hline 304546 & Einhver vandamál. Aðilum vantar upplýsingar \\
\hline 311083 & Einhver smávægileg \\
\hline $29 k i$ nægilega formleg - verktaki notaði ekki einu sinni tölvupóst - erfitt að ná í hann \\
\hline 1290
\end{tabular}




\begin{tabular}{|l|l|}
\hline 324020 & verkkaupi og verktaki pekkjast vel \\
\hline 324100 & of lítil samskipti \\
\hline 326926 & bara í tengslum við málarann \\
\hline 332246 & Erfitt að ná í verktaka - samskiptaleysi \\
\hline 336443 & $\begin{array}{l}\text { hefou mátt vera betri og meiri. Verkkaupi ekki spurður hvernig hann vildi láta hlutina } \\
\text { líta út }\end{array}$ \\
\hline 343271 & nei, ekkert sem ekki varð hægt að leysa \\
\hline
\end{tabular}

\subsubsection{Eru einhver atriði sem pér finnst hafa vantað upp á gæði ? Hvað pá ?}

Sjá bls. (242)

\begin{tabular}{|c|c|}
\hline 170568 & nei, bara hljóðeinangrunin sem hefði mátt vera betri. \\
\hline 173014 & nei \\
\hline 173897 & ákveðnir verkpættir sem hann er ekki sáttur með. \\
\hline 188514 & Vildi að hann hefði gengið frá umgjörð sléttari á uppsteypingu \\
\hline 188663 & Hefou mátt vera nákvæmari \\
\hline 188880 & Ýmislegt sem vantaði upp á. Illa steypt og margt fleira sem purfti að laga. \\
\hline 189016 & Hefur ekki tíma til að telja pað fram núna - ýmislegt sem vantaði upp á. \\
\hline 201572 & Hluti af pakinu lak \\
\hline 201631 & Ekki alveg réttir veggir og fleira \\
\hline 202036 & Sökklar ekki nógu vel gerðir. Purftu að rífa og færa pá. \\
\hline 211866 & $\begin{array}{l}\text { Margir pættir sem hann purfti að láta laga eftir verktakann. Hann hefði viljað hafa } \\
\text { samræmda verkfundi með öllum verktökum svo allir væru á sama blaði. }\end{array}$ \\
\hline 223924 & hann var ekki sáttur við rafvirkjameistarann - vantaði mikið upp á hjá honum \\
\hline 227257 & Nokkrir hlutir sem hefơ mátt vera betri - ekkert alvarlegt \\
\hline 227392 & ekkert stórvægilegt \\
\hline 230333 & $\begin{array}{l}\text { Verkkaupi er sjálfur iðnaðarmaður og gerir ekki kröfu til pess að verktakar geri engin } \\
\text { mistök (eins og hann sagði orðrétt " pað er ekki hægt að gera kröfu til pess að allt sé } \\
\text { fullkomið". }\end{array}$ \\
\hline 246443 & $\begin{array}{l}\text { Pað komu upp talsverð frávik en á endanum voru pau löguð og leiðrétt - en annir hjá } \\
\text { verktaka töfou allan framgang }\end{array}$ \\
\hline 246751 & Húsið heldur ;P \\
\hline 259821 & Frágangur og vinna öll mjög slæm \\
\hline
\end{tabular}




\begin{tabular}{|c|c|}
\hline 262014 & Í heildina frekar sáttur - pað má samt alltaf gera betur \\
\hline 262501 & margt sem var illa unnið og frágangur oft mjög slæmur \\
\hline 279570 & Verktaki mætti hafa nýrri mót \\
\hline 285179 & Skiluðu flottu verki :) \\
\hline 287312 & Húsið lekur og ýmislegt að gæðum. Gæði verks ekki góð. \\
\hline 288339 & $\begin{array}{l}\text { Hann flýtti sér allt of hratt í burtu - Verkkaupi purfti að ýta á verktaka til að hafa } \\
\text { gæðin í lagi }\end{array}$ \\
\hline 292589 & peir gerðu vel pað sem peir gerðu \\
\hline 295735 & Galli varðandi halógen lýsingu \\
\hline 300689 & $\begin{array}{l}\text { Ýmislegt smávægilegt varðandi gæði byggingaunnar sem vantaði upp á. Hann var } \\
\text { líka mjög ósáttur við samskipti verktaka }\end{array}$ \\
\hline 304546 & Fjárskortur sem fylgdi hruninu hafơi áhrif á gæði. \\
\hline 304831 & $\begin{array}{l}\text { Framkvæmd verktaka hefur verið fín. Ósátt við undirverktaka. Hefði viljað að } \\
\text { verktaki hefoi fylgst betur með undirverktaka. }\end{array}$ \\
\hline 306566 & Gæði hefðu mátt vera aðeins betri \\
\hline 306985 & Pað má alltaf gera betur :) \\
\hline 310271 & Smotteríshnökrar sem voru lagfærðir í snatri. Frágangur á gólfdúk var ábótavant \\
\hline 311083 & Sáttur við gæði aðalverktaka, en ekki alltaf undirverktaka. \\
\hline 314216 & Eftirfylgni með að ákveðin kerfi væru kláruð. Óljóst með ábyrgð. \\
\hline 315235 & Bara eitthvað smotterí, ekkert til að kvarta undan. \\
\hline 324100 & uppsláttur fyrir pakinu hrundi \\
\hline 326926 & $\begin{array}{l}\text { Verkkaupi sagði orðrétt pegar hann var spurður pessara spurningar: "gæði eru } \\
\text { hommaleg!" En sagði svo að líka að hann hefði verið óánægður með frágang múrara }\end{array}$ \\
\hline 330942 & mörg atriði \\
\hline 336443 & samskipti - verkkaupi ekki hafður með í ráðum varðandi útlit \\
\hline 343271 & 98\% í góðu lagi. Ekki svo sem við verktakann að sakast \\
\hline 344214 & ekkert alvarlegt \\
\hline 348008 & nei. \\
\hline 348355 & hefði viljað betri eftirlit - pað komu upp einhverjir gallar \\
\hline 358204 & mörg atriði sem voru illa unnin \\
\hline 358305 & $\begin{array}{l}\text { Hann valdi verktakann sérstaklega út frá góðu orðspori sem hann hafði heyrt um } \\
\text { verktakann. Hann telur ekki vera pörf fyrir "skrifræði" eins og hann orðar pað við } \\
\text { svona verk }\end{array}$ \\
\hline
\end{tabular}


361750 margir pættir sem hefðu mátt vera betri. Sérstaklega er við kemur lokafrágangi.

\subsubsection{Að lokum eitthvað sem pú vilt koma á framfæri ?}

Sjá bls. (242)

\begin{tabular}{|c|c|}
\hline 170568 & $\begin{array}{l}\text { Hrunið setti sannarlega svip sinn á framkvæmdirnar og áætlanir riðluðust ögn vegna } \\
\text { pess, svo ekki er við verktakann beint að sakast. }\end{array}$ \\
\hline 173014 & $\begin{array}{l}\text { Faðir minn á petta fyrirtæki og hann vann verkið fyrir mig. - of náin tengsl við } \\
\text { verktaka svo pað sé marktækt }\end{array}$ \\
\hline 173807 & Hefoi viljað sjá talsvert meira eftirlit að hálfu byggingarstjóra \\
\hline 173897 & Hrunið spilaði stóran pátt í pví sem illa fór \\
\hline 187277 & Umræddur verktaki er farinn á hausinn. \\
\hline 188663 & Hefôi viljað hafa formlega fundi með verktaka \\
\hline 188733 & Ath. verkkaupi og verktaki pekkjast vel. Ekki hlutleysi í svörum... \\
\hline 188880 & $\begin{array}{l}\text { Verkkaupi hefði viljað fá að fylgjast miklu betur með gangi mála, hafa allt skriflegt } \\
\text { og flott en andinn hjá verktakanum var alls ekki pannig. Hann hefði fengið annan } \\
\text { verktaka til að taka verkið af sér en pegar hann fór með útboðsgögnin til að reyna að } \\
\text { fá verktaka á sínum tíma } 2007 \text { vildi enginn taka við verkinu. Allt brjálað að gera hjá } \\
\text { öllum verktökum og ekki vilji til pess að taka við jafn flóknu verki sem var með } \\
\text { svona vel skilgreind útboðsgögn. Verktakinn sem varð fyrir valinu var síðan ekki } \\
\text { tilbúinn til að sampykkja að nota útboðsgögnin heldur var samningurinn mjög rýr } \\
\text { sem hann var tilbúinn að skrifa upp á. Eiginlega bara með c.a. verðtölum og c.a. } \\
\text { tímasetningu verkloka. }\end{array}$ \\
\hline 201572 & $\begin{array}{l}\text { Verkkaupi sá ekki ástæðu til að hafa formlega verkfundi par sem pað tók ekki nema } \\
\text { tvær vikur að reisa húsið. }\end{array}$ \\
\hline 201606 & Verktaki og verkkaupi pekkjast vel - ekki alveg hlutlaus svör. \\
\hline 201631 & Verkkaupi og verktaki eru kunningjar... \\
\hline 202389 & $\begin{array}{l}\text { Varðandi öryggismál: pá voru pau ekki rædd sérstaklega en peir fengu athugasemdir } \\
\text { frá öðrum verktökum stöku sinnum um að handriði pyrftu að vera betri... Verkkaupi } \\
\text { ráðleggur fólki sem er að fara í framkvæmdir að fá sér byggingastjóra sem ræður } \\
\text { undirverktaka -p.e. sem er pá aðalverktaki. Að hans mati er algengt að verkkaupi } \\
\text { lendi á milli tveggja verktaka í erjum og sem enda oft með pví að verkkaupinn parf } \\
\text { að borga mismun. Betra að hafa einn ábyrga aðila ábyrgan }\end{array}$ \\
\hline 207991 & $\begin{array}{l}\text { Verkkaupi hafði mikið út á að setja hvernig fyrirkomulag byggingastjóra er háttað } \\
\text { núna. Hann segir pað vera pannig að peir séu án undantekninga til skrauts! Hann } \\
\text { vann verkið í góðærinu, eða í öllu djamminu, eins og hann orðaði pað og sagði að pað } \\
\text { hefði ekki verið til siðs að hafa eitt né neitt formlegt. Hann hefði ekki kært sig um } \\
\text { pað og enn og síður verktakinn. }\end{array}$ \\
\hline 208122 & Verkkaupi er byggingaverkfræðingur og var alltaf með puttann á púlsinum. Hann \\
\hline
\end{tabular}




\begin{tabular}{|c|c|}
\hline & $\begin{array}{l}\text { sagði að hann hefði haft allt skriflegt og formlegt ef hann væri ekki svona vel að sér í } \\
\text { málunum, en hann sá ekki ástæðu til pess eins og hlutirnir voru. Hann sagði að á } \\
\text { peim tíma sem hann var að byggja hefði andrúmsloftið hjá verktökum verið pannig } \\
\text { að ekki var hægt að fara fram á að hafa forlega fundi með fundargerð í svona } \\
\text { smáverkum og erfitt hefði verið að fá eitthvað skriflegt m.a. vegna anna hjá } \\
\text { verktökum. Hann segið andrúmsloftið vera allt annað núna. Hann benti líka á að pað } \\
\text { sé mikil munur að byggja í Reykjavík eða kópavogi. Pað sé allt miklu liðlegra og } \\
\text { betra í kópavogi. Úttektamál séu par til fyrirmyndar samanborið við Reykjavík. }\end{array}$ \\
\hline 211566 & $\begin{array}{l}\text { Hann hefði eftir á kosið að hafa formlegri verkfundi til að styrkja stöðu sína ef } \\
\text { eitthvað hefði farið úrskeiðis }\end{array}$ \\
\hline 211866 & $\begin{array}{l}\text { Verkkaupi hefur margar athugasemdir við starfshætti iðnaðarmanna og hönnuða. } \\
\text { Hann segir pá hend til hendinni, vinna verk illa og ekki hugsa hluti til enda. Hans } \\
\text { upplifun er líka að peir mæti oft allt of seint bæði í kreppu og góðæri. Hann vill } \\
\text { meina að hægt sé að spara byggingakostnað um pað minnsta priðjung með bættum } \\
\text { vinnubrögðum. }\end{array}$ \\
\hline 223924 & $\begin{array}{l}\text { Verkkaupi taldi ekki purfa að hafa neitt formlegt eða varla skriflegt í svona litlu } \\
\text { verki. }\end{array}$ \\
\hline 226544 & $\begin{array}{l}\text { Verkkaupi telur verktaka vera að vinna eftir gæðakerfi sem sé ekki vottað, en ég hef } \\
\text { ekki sönnun pess... }\end{array}$ \\
\hline 246443 & $\begin{array}{l}\text { Pað var ekki til umræðu að fara fram á einhverja gæðatryggingu hjá verktökum á } \\
\text { pessum tíma. Peir hefðu bara helgið að manni. Maður spurði í mesta lagi bara "hefur } \\
\text { pú tíma til að taka petta verk að pér?" }\end{array}$ \\
\hline 246751 & $\begin{array}{l}\text { Hann telur pað vera ábyrgð byggingastjóra að athuga með gæðatryggingu - hann } \\
\text { hefði eftir á viljað hafa formlega verkfundi til að standa betur að vígi ef eitthvað } \\
\text { alverlegt hefði komið upp á }\end{array}$ \\
\hline 259821 & Verkaupi kveðst ætla að hafa allt formlegra ef hann fer aftur út í framkvæmdir seinna \\
\hline 262014 & $\begin{array}{l}\text { Verkkaupi segir verktaka vera að byggja upp gæðakerfi hjá sér pó pað komi ekki } \\
\text { fram á vefsíðu fyrirtækisins. }\end{array}$ \\
\hline 262501 & Hefði viljað hafa formlega verkfundi \\
\hline 263002 & $\begin{array}{l}\text { Grunur leikur á að verkkaupi eigi verktakafyrirtækið sem vann verkið prátt fyrir að } \\
\text { hann hafi ekki tekið pað fram. Sama heimilisfang á verktaka og verkkaupa }\end{array}$ \\
\hline 286250 & $\begin{array}{l}\text { Verktakinn sem hafður er í huga er góður félagi verkkaupa og hefur pað hugsanlega } \\
\text { áhrif á niðurstöður }\end{array}$ \\
\hline 287312 & $\begin{array}{l}\text { Sér eftir pví að hafa haft byggingastjóra frá verktakafyrirtækinu, telur pað ekki hafa } \\
\text { verið faglegt pví hann sat pá báðum megin við borðið. }\end{array}$ \\
\hline 292536 & $\begin{array}{l}\text { Verkkaupi og verktaki eru bundnir saman hagsmunum pegar peir skrifa undir } \\
\text { marksamning, eins og í pessu tilfelli. Pá parf mikið traust að gæta milli verktaka og } \\
\text { verkkaupa. Peir handvöldu } 5 \text { aðila sem uppfylltu peirra gæðakröfur sem peir fengu til } \\
\text { að bjóða í verkið. Pess ber að geta að verkið var undir kostnaðaráætlun. Með svona } \\
\text { marksamning pá græðir verktakinn á pví að vera undir kostnaðaráætlun. }\end{array}$ \\
\hline
\end{tabular}




\begin{tabular}{|c|c|}
\hline 292589 & $\begin{array}{l}\text { Peir týndu til alls kyns aukaverk í lokin sem verkkaupi var ekki á eitt um að ætti að } \\
\text { greiða aukalega fyrir - endaði í dómsmáli }\end{array}$ \\
\hline 295715 & verktaki sennilega farinn á hausinn \\
\hline 300958 & $\begin{array}{l}\text { Lentu í málaferlum og veseni en ekki svo sem ekki við umræddan verktaka að sakast } \\
\text { heldur undirverktaka og byggingastjóra }\end{array}$ \\
\hline 314216 & $\begin{array}{l}\text { Svarandi hóf störf hjá fyrirtækinu pegar verkið var langt á veg komið. Tók pví ekki } \\
\text { pátt að miklu leyti. }\end{array}$ \\
\hline 314467 & $\begin{array}{l}\text { Pað var of stuttur undirbúningstími fyrir verkið. Verkið fór illa undirbúið frá } \\
\text { verkkaupa til verktaka. Óraunhæft að vinna pað á pessum verktíma. Verktaki var } \\
\text { tilbúinn til að hjálpa en pað purfti að borga vel fyrir pað. Áætlunargerð og } \\
\text { undirbúningur verksins fór í algjört klúður. Verktakinn kunni vel að nota sér pað. Hjáa ár } \\
\text { p.G.Verktökum er starfandi gæðastjóri og gæðaráð. Gerðar eru reglulegar innri } \\
\text { úttektir á öllum verkpáttum og höfuðáhersla er lögð á vandaðar íbúðir, góða pjónustu } \\
\text { og skil íbúða á réttum tíma. }\end{array}$ \\
\hline 332246 & ath. verktaki er sennilega farinn á hausinn \\
\hline 335562 & ath. verkkaupi bekkti verktaka. \\
\hline 336061 & $\begin{array}{l}\text { Verkkaupi taldi verktaka hafa verið að fá einhverja vottun pegar peir voru að vinna } \\
\text { verkið fyrir hann. Skv. netsíðu eru peir með starfandi gæðastjóra en ekkert kemur } \\
\text { fram um kerfi. }\end{array}$ \\
\hline 336189 & verktaki er farinn á hausinn \\
\hline 336443 & verkkaupi telur að verktaki sé með gæðakerfi \\
\hline 342241 & verkkaupa minnir að verktaki sé með einhvern gæðastaðal \\
\hline 348584 & $\begin{array}{l}\text { * verkkaupi sá um að útbúa tíma og greiðsluáætlun sem verktaki sampykkti svo } \\
\text { verkkaupi taldi pá vera með gæðakerfi }\end{array}$ \\
\hline 358204 & verktaki er farinn á hausinn \\
\hline 358601 & petta var unnið sem fagverk - p.e. peir sömdu beint við verktaka í hverjum verkpætti \\
\hline 361504 & $\begin{array}{l}\text { Petta var lítið verk og verkkaupi taldi ekki nauðsynlegt að hafa hlutina formlegri en } \\
\text { peir voru. Hann valdi verktakann út frá eigin reynslu af peim. Hann fór ekki fram á að } \\
\text { verktakinn sýndi fram á hvernig hann ætlaði að vinna verkið par sem verkkaupi var } \\
\text { sjálfur með ákveðnar hugmyndir um pað og mætti daglega til að fylgjast með } \\
\text { verktaka á verkstað og segja til hvernig hann vildi að hlutum væri háttað }\end{array}$ \\
\hline 361639 & $\begin{array}{l}\text { Hann hefur góða reynslu af pessum verktökum. Verkið var allt unnið fyrir styrktarfé } \\
\text { og vinna verktakans var nánast styrkur - p.e. hann rukkaði lágmarksverð fyrir } \\
\text { vinnuna }\end{array}$ \\
\hline 227392 & $\begin{array}{l}\text { að sögn verkkaupa er umræddur verktaki farinn á hausinn og var hann ekki að vinna } \\
\text { eftir gæðastjórnunarkerfi }\end{array}$ \\
\hline 208294 & $\begin{array}{l}\text { Verkkaupi sagði að erfitt hefð̃i verið að klúðra svona verki, en pessum verktaka hefð̃i } \\
\text { tekist að gera pað ef verkkaupi hefði ekki verið með svona góðan 'óháðan' }\end{array}$ \\
\hline
\end{tabular}




\begin{tabular}{|l|l|}
\hline & $\begin{array}{l}\text { byggingastjóra til að fylgjast með framvindu mála. Hann sagði að verktaki væri ekki } \\
\text { með gæðastjórnunarkerfi. }\end{array}$ \\
\hline 324020 & $\begin{array}{l}\text { Verkkaupi og verktaki pekkjast vel - skekkir hugsanlega niðurstöður. Verkkaupi taldi } \\
\text { verktaka ekki vera að vinna eftir gæðakerfi }\end{array}$ \\
\hline
\end{tabular}

\subsection{Opnar spurningar úr könnun fyrir verktaka}

\subsubsection{Hvers konar verktaki ert pú ?}

Sjá bls. 308

\begin{tabular}{|l|l|}
\hline 632986 & Múrverktaki \\
\hline 661883 & Byggingar og jarðvinnuverktaki \\
\hline 677407 & Dúkari \\
\hline 679674 & Framleiðandi \\
\hline 680038 & Húshluta og almenn trésmíðabjón. \\
\hline 682612 & Allt að ofan nema húsgagnafr. \\
\hline 694876 & Pjónustuaðili í Gluggaviðgerðum \\
\hline 1367004 & Málaraverkt. \\
\hline 1375502 & Málaraverktaki \\
\hline 1418679 & Málun \\
\hline 1423050 & bygginga og jarðvinnu \\
\hline 1424067 & Framleiðsla malbiks og bikbindiefna auk útlagnar malbiks \\
\hline 1434864 & Járnabindingar \\
\hline 1463539 & Málari \\
\hline
\end{tabular}

\subsection{2 Í hvaða sveitarfélagi/um starfar fyrirtækið sem pú starfar hjá ?}

Sjá bls. 308

\begin{tabular}{|l|l|}
\hline 698967 & Njarðvík, en verkefni víða um landið \\
\hline 707176 & grindavík \\
\hline 710932 & Ísafjarðarbær/Akranes \\
\hline 719216 & Reykjavík \\
\hline 730587 & Reykjavíkursvæðið \\
\hline 734680 & Reykjavík og nágreni \\
\hline 746294 & Reykjavík \\
\hline 746433 & Akureyri \\
\hline
\end{tabular}




\begin{tabular}{|c|c|}
\hline 746458 & 2200 \\
\hline 746572 & Reykjavík \\
\hline 751324 & Reykjavíkursvæðinu \\
\hline 753321 & Reykjavíkursvæðinu \\
\hline 785046 & Reykjavíkursvæðinu \\
\hline 785753 & Reykjavíkursvæðinu \\
\hline 789858 & Akureyri \\
\hline 789996 & Hafnafjörður \\
\hline 838996 & Akranes og nærsveitir \\
\hline 847789 & Reykjavík, Mosfellsbæ, Hafnarfirði, Hrunamannaafrétt \\
\hline 848075 & Aðallega Kópvogi, en einnig Reykjavíkursvæðinu \\
\hline 848320 & Reykjavíkursvæðinu \\
\hline 662398 & Reykjanesbæ \\
\hline 685010 & Reykjavíkursvæðinu \\
\hline 659750 & Ísland \\
\hline 632986 & Reykjavíkursvæðinu \\
\hline 627251 & Reykjavíkursvæðinu \\
\hline 602834 & Skrifstofur á Selfossi og í Reykjavík \\
\hline 680257 & Skrifstofa á Akureyri \\
\hline 684138 & Hafnafjörður \\
\hline 1366875 & Fljótsdalshéraði \\
\hline 1367004 & Ak \\
\hline 1367026 & \\
\hline 1369175 & \\
\hline 1369433 & staðsett í Garðabæ, aðallega unnið á höfuðborgarsvæðinu, en nú um allt land \\
\hline 1369881 & Reykjavík \\
\hline 1371773 & \\
\hline 1375502 & Aðallega Kópavogi og Reykjavík. \\
\hline 1377031 & Reykjavík og nágreni \\
\hline 1386631 & Árborg \\
\hline 1386545 & Fljótsdalshéraði \\
\hline 1386612 & Ísafjarðarbæ \\
\hline 1414662 & Reykjavík \\
\hline 1415290 & Öllum á Suðurlandi Reykjavík og víðar \\
\hline 1415580 & Reykjavík \\
\hline 1418679 & Höfuðborgarsvæðið \\
\hline
\end{tabular}




\begin{tabular}{|l|l|}
\hline 1419605 & Höfuðborgarsvæðið \\
\hline 1423050 & Eyjafirði \\
\hline 1424067 & Hafnarfirði \\
\hline 1434864 & Reykjavík/Reykjanes \\
\hline 1435994 & Árborg \\
\hline 1457060 & Akureyri \\
\hline 1463539 & Akureyri \\
\hline
\end{tabular}

\subsubsection{Hvaða menntun hefur pú ?}

Sjá bls. 308

\begin{tabular}{|l|l|}
\hline 680038 & Byggingaiðnfræðingur \\
\hline 681223 & Húsgagnasmíði \\
\hline 682623 & ýmis námskeið \\
\hline 697648 & nám í vélskóla \\
\hline 698967 & Starfsnám viðurk. bókari \\
\hline 785753 & Sérmenntun í stálgrindarhúsum \\
\hline 1386545 & iðnnám \\
\hline 1415290 & Vélstjóra \\
\hline 1424067 & Diploma í Gæðastjórnun \\
\hline
\end{tabular}

\subsubsection{Hver er staða pín innan fyrirtækisins ?}

Sjá bls. 308

\begin{tabular}{|l|l|}
\hline 680845 & Smiður \\
\hline 681408 & Byggingastjóri \\
\hline 682623 & smiður \\
\hline 693435 & Allt \\
\hline 698967 & Bókari \\
\hline 751324 & eigandi \\
\hline 789858 & Stjórnarformaður \\
\hline 1369433 & vélamaður \\
\hline 1386612 & bókari \\
\hline 1415580 & Fjármál \\
\hline
\end{tabular}




\subsubsection{Hvernig vottun hefur fyrirtækið hlotið ?}

\begin{tabular}{|l|l|}
\hline 680038 & B-vottun si \\
\hline 691428 & \\
\hline 746433 & \\
\hline
\end{tabular}

\subsubsection{Veitið pið verkkaupa upplýsingar um gæðastjórnunarkerfið sem pið notið í verkbyrjun - Í hvaða tilfellum ?}

\begin{tabular}{|l|l|}
\hline 1377031 & {$[$ Oft ] Við tilboðsgerð } \\
\hline 1386631 & {$[$ Oft ] Pegar beðið er um upplýsingarnar } \\
\hline 1386545 & {$[$ Oft ] ef farið er fram á pað } \\
\hline 1414662 & {$[$ Stundum ] Ef hann fer fram á pað } \\
\hline 1424067 & {$[$ Oft ] I l stærri útboðsverkefnum og par sem pess er krafist } \\
\hline
\end{tabular}

\subsubsection{Viðhafið pið sérstakar öryggisráðstafanir á verkstað - Hvaða öryggisráðstafanir viðhafið pið ?}

\begin{tabular}{|c|c|}
\hline 1369433 & [Alltaf] ef slys eiga sér stað á vinnusvæði, hvort sem á fólki, eignum eða umhverfi \\
\hline 1386545 & [Alltaf ] eftir verkefnum \\
\hline 1386612 & [Alltaf ] Öryggishandbók á hvern stað. \\
\hline 1415290 & [Alltaf ] Vinnupallar fallvarnir öryggislínur Hlífðarbúnaður \\
\hline 1418679 & [Stundum] Í vinnu við fjölbýlishús \\
\hline 1419605 & $\begin{array}{l}\text { [Oft ] Notum rykgrímur, grímur með kolafylletrum, gleraugu, heyrnahlífar, hnélífar, öryggislínu á pökum, } \\
\text { opnum glugga og hleypum nýju lofti inn. Allat er petta í sambandi við málningarvinnu og spörtlun. } \\
\text { Spörtlun aðeins að innan en málun bæði að innan og utan húss. }\end{array}$ \\
\hline 1423050 & [Oft ] alltaf með hjálma, öryggislínur ef unnið er á paki og ph. \\
\hline 1424067 & $\begin{array}{l}\text { [Alltaf ] Alltaf er unnið samkvæmt Heilbrigðis- og öryggisáætlun fyrirtækisins. Í sérstaklega } \\
\text { umfangsmiklum verkefnum eða par sem sérstakar aðstæður krefjast gerum við sérstaka öryggisáætlun } \\
\text { fyrir verkið }\end{array}$ \\
\hline 1434864 & [Alltaf] Samræmt öryggiskerfi aðalverktaka \\
\hline
\end{tabular}

\subsubsection{Ef pið sýnið verkkaupa fram á gæðatryggingu hvað kemur pá fram í henni ?}

\begin{tabular}{|l|l|}
\hline 602834 & verkhandbók - stílææðr í hvert skipti \\
\hline 632986 & Reynsla af fyrri verkum \\
\hline 661883 & Allt pað úr gæðakerfinu sem við á um verklegar framkvæmdir og samskipti við verkkaupann \\
\hline 679539 & Skipulagt verklag Öryggismál Reikningar og greiðslur Uppgjör verka \\
\hline 679674 & Ábyrgðarskipting og verklag \\
\hline
\end{tabular}




\begin{tabular}{|c|c|}
\hline 680257 & Allir verkferlar og viðbrögð ef eitthvað fer úrseiðis, eða breyting verður á verki. \\
\hline 681541 & Unnin verk Umsögn viðskiptavina \\
\hline 682580 & Gæða kerfi pað sem ég hef skrifað og starfa eftir \\
\hline 682623 & Oftast jákvæðir \\
\hline 682728 & Ábyrgðarsjóður MSI \\
\hline 685010 & fyrri verk \\
\hline 693632 & upplýsingar um fyrri störf og verkefni \\
\hline 697648 & Áhvað hátt við reynum að tryggja gæði verksins. \\
\hline 698967 & $\begin{array}{l}\text { Pað hefur spurst út að hjá Sparra starfar gott fólk sem vandar til verka og pað hefur verið okkar } \\
\text { gæðamerki }\end{array}$ \\
\hline 710932 & Efnislisti. Vottanir(bruna/hljóð). \\
\hline 746294 & Efnisval, faglærðir starfsmenn, gátlistar, verkáætlun. \\
\hline 746433 & $\begin{array}{l}\text { td. veggjaklæðning. pá útskýrum við hvernig við ætlum að vinna verkið og hvaða efni við ætlum að nota. } \\
\text { tökum fram gildistíma á efni og sýnum hvernig okkar frágangur hjálpar efninu til pess að ná sem } \\
\text { lengstum líftíma. }\end{array}$ \\
\hline 751324 & Bara gott orðspor verktaka \\
\hline 753321 & $\begin{array}{l}\text { pað er stundum ákvæði í samningum að ef peir standi sig ekki pá geti verið gerð krafa um að peir hætti } \\
\text { með verkið... }\end{array}$ \\
\hline 785753 & Erum oft undirverktakar og eru pá alltaf beðnir um gæðatryggingu með verklýsingu í samning. \\
\hline 838996 & $\begin{array}{l}\text { Leggjum fram verktryggingu og bankatryggingu og par kemur fram hvernig peir hyggjast framkvæma } \\
\text { verkið. Petta er alltaf gert fyrir hið opinbera en aldrei fyrir einstaklinga. }\end{array}$ \\
\hline 847789 & Umfang og tíðni eftirlits og prófana \\
\hline 848075 & Ég byggi á góðu orðspori \\
\hline 1369433 & að efni (rör, steypa, jarðefni) eða vinnuaðferðir séu samkvæmt staðli eða verklýsingu. \\
\hline 1386631 & Раð sem um er beðið. \\
\hline 1386612 & Tillaga að verkmöppu \\
\hline 1415290 & Verkið sé unnið af pekkingu \\
\hline 1418679 & Fagleg ábyrgð með tryggingasjóð að baki \\
\hline 1419605 & $\begin{array}{l}\text { Meistaraskírteini og stundum trygging frá banka - framkvæmdartrygging um að verktaki komi til með að } \\
\text { ljúka verkinu á tilteknum tíma. }\end{array}$ \\
\hline 1424067 & Við leggjum fram gæðastjórnunarkerfið okkar. \\
\hline
\end{tabular}

\subsubsection{Leggið bið fram skriflega verkáætlun fyrir hvert verk - Í hvaða tilfellum ?}

\begin{tabular}{|l|l|}
\hline 632986 & {$[$ Stundum] Fer eftir umfangi verka } \\
\hline 659750 & $\begin{array}{l}\text { [Oftast] Í öllum stærri verkum eru gerðar verkáætlanir, pað er eingöngu í smæstu verkum sem ekki eru } \\
\text { gerðar verkáætlanir. }\end{array}$ \\
\hline 679539 & {$[$ Oftast] Par sem farið er fram á pað eða að verkið krefst pess. } \\
\hline 680257 & [Oftast] Td. Alltaf pegar verið er að vinna fyrir opinbera aðila og við öll stærri verk. \\
\hline
\end{tabular}




\begin{tabular}{|c|c|}
\hline 685010 & [Oftast] par sem beðið er um verkáætlun \\
\hline 693231 & [Oftast] Stærri verk \\
\hline 693632 & [Stundum] Pegar um er að ræða útboðsverk \\
\hline 694876 & $\begin{array}{l}\text { [Stundum] Verkáætlun er lögð fram pegar óskað er eftir pví en hún er alltaf til par sem verið er að } \\
\text { pjónusta marga aðila. }\end{array}$ \\
\hline 697554 & [Stundum] Fyrir stærri verk, en ekki endilega fyrir mjög lítil verk. \\
\hline 697648 & [Stundum] Pegar pess er óskað. \\
\hline 698967 & $\begin{array}{l}\text { [Oftast] Pegar við teljum pörf á að gera verksamning pá er hann gerður en nánast alltaf gerum við tilboð } \\
\text { i verkin }\end{array}$ \\
\hline 710932 & [Stundum] Flókin sérsmíđi. \\
\hline 746294 & [Oftast] Flestum útboðsverkum og stærri verkefnum. \\
\hline 746572 & [Stundum] í útboðsverkum par sem farið er fram á pað. \\
\hline 746433 & $\begin{array}{l}\text { [Oftast] fer eftir stærð verksins og pegar pað er ákveðinn dagur í verklok. erum með 2stk lítil verk núna } \\
\text { sem ekki var gerð verkáætlun. }\end{array}$ \\
\hline 789858 & [Stundum] pegar verkkaupi fer fram á pað - yfirleitt bara í stærri verkum \\
\hline 838996 & [Stundum] Ekki gert fyrir einstaklinga - bara fyrir opinbera aðila og fyrirtæki \\
\hline 1366875 & [Oft] pegar pað er farið fram á pað \\
\hline 1414662 & [Oft] ef um er beðið \\
\hline 1415290 & [Stundum] Útboðsverkum / samningaverkum \\
\hline 1418679 & [Oft] Útboðsverkum \\
\hline
\end{tabular}

\subsubsection{Sendið pið verkkaupa skriflega rökstudda tilkynningu um verktöf pegar svo ber undir - Í hvaða tilfellum?}

\begin{tabular}{|l|l|}
\hline 632986 & [Oftast] Pegar pað hefur áhrif á afhendingu verks með ákvörðuðum dagsektum \\
\hline 659750 & $\begin{array}{l}\text { [Oftast] Ættum alltaf að gera pað, en of oft kemur pað fyrir að stjórnendur verka gera pað einungis } \\
\text { munnlega. }\end{array}$ \\
\hline 680257 & [Oftast] Td. Alltaf pegar verið er að vinna fyrir opinbera aðila og við öll stærri verk. \\
\hline 685010 & [Stundum] pað sem pess er krafist \\
\hline 693632 & [Stundum] Pegar í ljós hefur komið að verkinu seinkar eða annað kemur upp \\
\hline 694876 & $\begin{array}{l}\text { [Stundum] Pað liggur alltaf fyrir hverjar eru orsakir tafa og vita menn pað fyriffram. Pað eru hins vegar } \\
\text { með tilkynningum í tölvupósti. }\end{array}$ \\
\hline 697554 & [Oftast] Oft er slíkt tekið upp á verkfundi og pá bókað í fundargerð í staðinn. \\
\hline 697648 & [Oftast] pegar pað er tilgreint í útboðsgögnum gert \\
\hline 698967 & $\begin{array}{l}\text { [Stundum] Ef pað er verktöf pá er hringt í viðkomandi, en pað er bara nánast aldrei sem að verk hafa } \\
\text { tafist hjá okkur }\end{array}$ \\
\hline 710932 & [Stundum] Pegar verksamningar eru skriflegir. \\
\hline 730587 & [Stundum] Ef verk tefst af einhverjum orsökum \\
\hline 746294 & [Stundum] Yfirleitt í útboðsverkum er kallað eftir útskýringum á verktöfum ef svo ber undir. \\
\hline
\end{tabular}




\begin{tabular}{|l|l|}
\hline 746572 & {$[$ Stundum] ef ástæða er til. } \\
\hline 838996 & [Stundum] Ekki gert fyrir einstaklinga - bara fyrir opinbera aðila og fyrirtæki \\
\hline 1386631 & {$[$ Oft] Pegar töfin hefur áhrif á krítíska línu verksins } \\
\hline 1414662 & {$[$ Sjaldan] Ef pað pjónar hagsmunum okkar } \\
\hline 1415290 & {$[$ Stundum] Útboðsverkum } \\
\hline 1418679 & {$[$ Sjaldan] Á verkfundum } \\
\hline
\end{tabular}

\subsubsection{Gerið pið skriflega greiðsluáætlun við verkkaupa fyrir hvert verk - í hvaða tilfellum?}

\begin{tabular}{|c|c|}
\hline 632986 & [Oftast] Allir stærri verksamningar en ekki í minni verkum \\
\hline 659750 & [Oftast] Verkkaupi óskar ekki alltaf eftir pví. \\
\hline 679539 & [Oftast] Par sem farið er fram á pað eða að verkið krefst pess. \\
\hline 680257 & [Stundum] Td. Alltaf pegar verið er að vinna fyrir opinbera aðila og við öll stærri verk. \\
\hline 682612 & [Oftast] Stærri verkum \\
\hline 685010 & [Stundum] Oftast í samningum \\
\hline 693231 & [Oftast] Stærri verk \\
\hline 693632 & [Stundum] í útboðsverkum \\
\hline 697554 & [Stundum] Ekki endilega fyrir smærri verk, nema verkkaupi óski eftir pví. \\
\hline 697648 & [Oftast] Í samræmi við útboðsgögn og eftir stærð verka. \\
\hline 730587 & [Stundum] Ef beðið er um tilboð \\
\hline 746294 & $\begin{array}{l}\text { [Oftast] pegar um tilboðsverk er að ræða og verkið pað stórt að upphæðin er kominn yfir eina milljón. } \\
\text { Og stundum um lægri upphæðir ef verkkaupi er nýr kúnni. }\end{array}$ \\
\hline 746433 & [Oftast] sama og fyrir ofan. \\
\hline 751324 & [Stundum] ef beðið er um pað \\
\hline 785046 & [Stundum] Pegar um er beðið \\
\hline 838996 & [Stundum] Ekki gert fyrir einstaklinga - bara fyrir opinbera aðila og fyrirtæki \\
\hline 847789 & [Stundum] Pegar samningur krefst pess \\
\hline 1414662 & [Sjaldan] ef um er beðið \\
\hline 1415290 & [Stundum] Útboðsverkum / samningsverkum \\
\hline 1418679 & [Sjaldan] Fylgir verkáætlun \\
\hline 1419605 & [Oft] Geri verk og greiðslusamning við viðskiptavini um verkið. Ég er málningarverktaki. \\
\hline
\end{tabular}

\subsubsection{Er venja að gert sé samkomulag um reglubundna verkfundi með verkkaupa - Í hvaða tilfellum?}

\begin{tabular}{|l|l|}
\hline 632986 & [Oftast] Í öllum stærri verkum en ekki í minni verkum \\
\hline 680257 & [Oftast] Td. Alltaf pegar verið er að vinna fyrir opinbera aðila og við öll stærri verk. \\
\hline
\end{tabular}




\begin{tabular}{|c|c|}
\hline 682612 & [Stundum] Stærri verkum \\
\hline 684138 & [Stundum] Í ákveðnum verkum \\
\hline 685010 & [Oftast] Flestum stærri verkefnum \\
\hline 691428 & $\begin{array}{l}\text { [Oftast] Pegar um stæri útboðsverk er að ræða er nánast alltaf reglulegir fundir, en í minni } \\
\text { viðhaldsverkum eru peir óreglulegir }\end{array}$ \\
\hline 693231 & [Oftast] Stór verk \\
\hline 693632 & [Stundum] pegar um útboð er að ræða ekki í tímavinnu verkum \\
\hline 697554 & [Oftast] Í stærri verkum \\
\hline 697648 & [Stundum] Í samræmi við útboðsg. Annars eftir verkum. \\
\hline 710932 & [Stundum] Pegar pað er tilgreint í verksamningi. \\
\hline 746294 & [Oftast] Í Stærri verkum og útboðsverkum. \\
\hline 746433 & $\begin{array}{l}\text { [Stundum] verkkaupi óskar oftast eftir slíku, pað er í öllum stærri verkum en eins og núna erum við að } \\
\text { smíða hesthús ofl. smá verk pá er enginn reglubundinn verkfundur. }\end{array}$ \\
\hline 751324 & [Stundum] ef beðið er um pað \\
\hline 785046 & $\begin{array}{l}\text { [Oftast] Pegar verkkaupi biður um pað. Mjög mismunandi hversu involveraðir verkkaupar vilja vera í } \\
\text { málunum. Sumir eru mjög nákvæmir á međan öđrum er alveg sama. }\end{array}$ \\
\hline 1414662 & [Oft] Samkvæmt útboðsgögnum \\
\hline 1415290 & [Oft] Útboðs og samningsvekum \\
\hline 1418679 & [Oft] Útboðsverkum \\
\hline 1419605 & [Sjaldan] Í stærri verkum svo sem að mála 30 íbúđa blokk. Verkeftirlit er pá á hendi verkfræðistofu. \\
\hline 1424067 & [Oft] Í stærri verkefnum. \\
\hline
\end{tabular}

\subsubsection{Er venja að rituð sé fundargerð á verkfundum - Í hvaða tilfellum?}

\begin{tabular}{|l|l|}
\hline 680257 & [Oftast] Td. Alltaf pegar verið er að vinna fyrir opinbera aðila og við öll stærri verk. \\
\hline 685010 & [Oftast] Flestum stærri verkefnum \\
\hline 693231 & [Oftast] Stór verk \\
\hline 693632 & $\begin{array}{l}\text { [Stundum] pegar um útboðsverk er að ræða, væri æskilegt að gera pað einnig pegar um annarskonar } \\
\text { tilhögun á vinnunni er að ræða tímavinna eða tilboð á gagna. }\end{array}$ \\
\hline 751324 & [Stundum] ef beðið er um pað \\
\hline 785046 & [Stundum] Pegar verkkaupi fer fram á pað \\
\hline 1419605 & [Oft] HJá verkeftirlistmanni sem vinnur hjá verkfræðistofu sem hefur eftirlit með verki sem ég vinn að. \\
\hline
\end{tabular}

\subsubsection{Haldið bið verkdagbók - Hvað kemur fram í henni ?}

\begin{tabular}{|l|l|}
\hline 632986 & $\begin{array}{l}\text { [Oftast] Við skráum og höldum utanum allan mannskap, efni og tæki í hverju verki fyrir sig en ekki } \\
\text { endilega uppl. um veðurfar nema pegar pað skiptir máli }\end{array}$ \\
\hline 682612 & [Stundum] Stæri verkum \\
\hline
\end{tabular}




\begin{tabular}{|l|l|}
\hline 685010 & [Stundum] Lýsing á verkefnum dagsins, veðurfar og fl \\
\hline 693632 & [Stundum] í útboðsverkum væri líka æskilegt að gera pað i öðrum verkum \\
\hline 698967 & {$[$ Oftast] Við skráum öll innkaup á ákveðin verk í tölvukerfi okkar. } \\
\hline 707176 & {$[$ Stundum] Í útboðsverkum } \\
\hline 730587 & [Oftast] Öll verk eru skráð í tímaröð og númeri og geymd pannig. \\
\hline 746294 & $\begin{array}{l}\text { [Stundum] Skráð fjöldi starfsmanna, veðurfar ef við á, aukaverk, við hvað er unnið pann daginn, örsakir } \\
\text { tafa ef einhverjar eru. }\end{array}$ \\
\hline 746572 & [Stundum] ef farið er fram á pað. \\
\hline 1415290 & {$[$ Oft] Útboðs og samningsverkum } \\
\hline 1419605 & [Sjaldan] Hef einstakasinnum skrifað í verkdagbók sem eftirlistaðili lætur mig hafa. \\
\hline
\end{tabular}

\subsubsection{Er venja að pað sé tekið fram í samningum að pað beri að fara eftir kröfum samskiptastaðalsins IST 30 - Í hvaða tilfellum ?}

\begin{tabular}{|c|c|}
\hline 602834 & $\begin{array}{l}\text { [Oftast] gallinn er sá og einkum og sér í lagi við opinbera verkkaupa, pá byrjar opinberi aðilinn að segja } \\
\text { að IST } 30 \text { gildi með eftirfarandi undantekningum og allar kröfur til verkkaupa teknar út. }\end{array}$ \\
\hline 682612 & [Oftast] Flestu útboðum \\
\hline 685010 & [Oftast] Öllum nema minniháttar verkum \\
\hline 693231 & [Stundum] Stór verk \\
\hline 693632 & [Oftast] í útboðum \\
\hline 697554 & $\begin{array}{l}\text { [Oftast] Verkkaupi ræður pví yfirleitt hvort tekið er fram að farið sé eftir IST } 30 \text { eða ekki. Stundum óskar } \\
\text { verkkaupi eftir að farið sé eftir öðrum (pá yfirleitt erlendum) stöðlum. Við reynum yfirleitt að koma pví á } \\
\text { framfæri í samningum að við viljum fara eftir IST-30 og í raun er sá staðall oftast hafður til hliðsjónar } \\
\text { hvort sem pað er skjalfest í samningi eða ekki. }\end{array}$ \\
\hline 707176 & [Stundum] Í opinberum útboðum \\
\hline 730587 & [Stundum] Ríkiskaupatilfellum \\
\hline 746294 & [Stundum] Fer eftir útboðsgögnum og verklýsingu. \\
\hline 847789 & [Oftast] Pegar aðrir samskiptastaðlar eru ekki notaðir s.s. Fidic \\
\hline 1415290 & $\begin{array}{l}\text { [Oft] Útboðs og samningsverkum Verkaupi undanskilur einstaka greinar mjög oft úr staðli sér til } \\
\text { hagsbóta }\end{array}$ \\
\hline 1419605 & [Stundum] Í stærri verkum hjá verkfræðistofum \\
\hline 1424067 & [Oft] Engin regla. Oft eru útboð mismunandi. Í smærri verkum \\
\hline
\end{tabular}

\subsubsection{Eru óskir verkkaupa um aukaverk og breytingar skráðar - Í hvaða tilfellum?}

\begin{tabular}{|l|l|}
\hline 682612 & [Oftast] Útboðum \\
\hline 684138 & [Oftast] Ef um verkfundi er að ræða. \\
\hline 685010 & [Oftast] Öllum stærri verkum \\
\hline 693632 & [Oftast] Í tilboðsverkum ætti að skrá pau sérstaklega í öllum verkum pegar umviðbót frá upphaflegu \\
\hline
\end{tabular}




\begin{tabular}{|l|l|}
\hline & plani er breytt \\
\hline 694876 & [Stundum] pessar spurningar eiga við stærri aðila í byggingaiðnaði par sem útboð hafa farið fram. \\
\hline 697554 & $\begin{array}{l}\text { [Oftast] Stundum er um munnlegar óskir að ræða, sem er mjög slæmt, bví pá er líka yfirleitt erfitt að } \\
\text { rukka inn kostnað vegna aukaverksins. }\end{array}$ \\
\hline 697648 & {$[$ Oftast] Fer eftir hvað er verið að biðja um, hvort pað hefur áhrif á kostnað. } \\
\hline 698967 & $\begin{array}{l}\text { [Stundum] Oftast er munnlegur samningur um aukaverk en pegar óskað er eftir skriflegum pá er pað } \\
\text { gert }\end{array}$ \\
\hline 1415290 & {$[$ [Stundum] Útboðs og samningsverkum } \\
\hline 1419605 & $\begin{array}{l}\text { [Oft] Pegar einhver verkpáttur er fyrir utan tilboðspætti. Pá er venja að taka mynd af verkinu og skrifa } \\
\text { skíringu og rukka sem fyrst fyrir verkið til að fá viðbrögð sem fyrst. }\end{array}$ \\
\hline 1457060 & {$[$ [Stundum] Fer eftir verktaka } \\
\hline
\end{tabular}

\subsubsection{Ef óskir um aukaverk og breytingar eru skráðar, kemur bá fram í skráningu áhrif á verðlagningu heildarverks og framvindu - Í hvaða tilfellum?}

\begin{tabular}{|c|c|}
\hline 659750 & $\begin{array}{l}\text { [Oftast] Ef hægt er á sama tíma og ósk kemur fram en annars pegar verktaki er búinn að fara yfir ósk } \\
\text { verkkaupa og meta hana. }\end{array}$ \\
\hline 691428 & $\begin{array}{l}\text { [Stundum] Ef breyting er vel skilgreind af hendi verkkaupa, er hægt að gefa upp verð, en allt of oft er } \\
\text { verkið illa undirbúið og illa skilgreint af hendi verkkaupa, og pví vonlaust að verðleggja breytinguna } \\
\text { fyrirfram. }\end{array}$ \\
\hline 693231 & [Oftast] stór verk \\
\hline 694876 & [Stundum] Pegar óskað er eftir sértilboði í pau verk. Alltaf er unnið eftir verðskrá. \\
\hline 697554 & [Oftast] Ef pað er ljóst \\
\hline 698967 & [Oftast] Ef að gerður er skriflegur samningur um aukaverk \\
\hline 746294 & [Stundum] Stundum er sampykkt tímavinna ef aukaverið er lítið, annars oftast tilboð. \\
\hline 847789 & $\begin{array}{l}\text { [Stundum] Pegar um meiriháttar breytingar er að ræða er farið í áhrif á verðlagningu og framvindu. } \\
\text { Annars bara kostaður við sjálft aukaverkið. }\end{array}$ \\
\hline 1369433 & $\begin{array}{l}\text { [Oft] í fyrstu skráningu er talað um verðlagningu og hvaða hugsanlega áhrif breytingarnar og aukaverkin } \\
\text { hafa á kostnað og svo kemur pað ákveðið fram í aukaverkasamningum og breytingarsamningum }\end{array}$ \\
\hline 1415290 & [Stundum] Útboðs og samningsverkum \\
\hline 1419605 & [Sjaldan] Ef um meiriháttar breytingu er um að ræða. \\
\hline
\end{tabular}

\subsubsection{Hversu oft skilið pið skrá yfir hugsanlegar kröfur um greiðslur vegna aukaverka og breytinga til verkkaupa - Hversu oft?}

\begin{tabular}{|l|l|}
\hline 602834 & reglulega \\
\hline 632986 & [Að verki loknu] Aukaverkareikningar eru gerðir fyrir hvert tilfelli sérstaklega \\
\hline 661883 & [Mánaðalega] Eða pegar pær koma upp og er pað pá lagt fram á verkfundum \\
\hline 679539 & [Mánaðalega] Misjafnt milli verka, stundum vikulega, stundum mánaðarlega \\
\hline 680257 & $\begin{array}{l}\text { [Mánaðalega] Á öllum verkfundum pegar ákveðið er að láta vinna aukaverk / viðbótarverk og búið er að } \\
\text { reikna út kostnað til hækkunar / lækkunar. }\end{array}$ \\
\hline
\end{tabular}




\begin{tabular}{|l|l|}
\hline 681541 & Næsta verkfundi \\
\hline 684214 & Um leið og pær verða til \\
\hline 685010 & [Mánaðalega] Eins fljótt og kostur er \\
\hline 691428 & $\begin{array}{l}\text { [Mánaðalega] Reynum að senda kröfur reglulega, bæði til að verkkaupi átti sig betur á viðbótarkostnaði } \\
\text { í verkinu, og einnig er dýrt að fjármagna lengi pann kostnað sem búið er að leggja út fyrir. }\end{array}$ \\
\hline 694876 & $\begin{array}{l}\text { [Að verki loknu] Mín verk taka yfir stuttan tíma og pví sjaldnast farið fram á greiðslur á meðan á verki } \\
\text { stendur. }\end{array}$ \\
\hline 697648 & [Mánaðalega] Fer eftir samningum \\
\hline 746572 & eftir pörfum. \\
\hline 746433 & $\begin{array}{l}\text { [Mánaðalega] við reynum alltaf að gera grein fyrir kostnaði á aukaverki áður en verkið hefst. kemur alltaf } \\
\text { reikningur mánaðalega pó svo að verkið sé ekki lokið. }\end{array}$ \\
\hline 1366875 & 14 daga fresti \\
\hline 1367004 & 1 \\
\hline 1369433 & um leið og pau verk koma upp eru pau send á verkkaupa og aukaverka- og breytingalistinn uppfærður \\
\hline 1415290 & eftir framvindu verks \\
\hline 1424067 & Mismunandi \\
\hline
\end{tabular}

\subsubsection{Gerið pið hættumat og/eða áhættugreiningu á verkstað ?}

\begin{tabular}{|c|c|}
\hline 661883 & [Alltaf] Öryggis og heilbrigðiskerfi fyrirtækisins krefst pess að pað sé gert í upphafi hvers verks \\
\hline 680257 & [Stundum] Ef um er að ræða pannig verk og pegar parf að vera í samráði við Vinnueftirlitið. \\
\hline 694876 & [Alltaf] Pað er alltaf farið yfir hvernig haga skuli verki með öryggi í huga. \\
\hline 697554 & $\begin{array}{l}\text { [Alltaf] Einu sinni í viku er farið yfir verkefni vikunnar (oftar ef ástæða er til) og skoðað hvers eðlis verkin } \\
\text { eru og hvort pau fela í sér mögulegar hættur, t.d. vegna fallhættu o.fl. Gert er nákvæmt hættumat fyrir } \\
\text { alla verkpætti sem teljast fela í sér hættur, með verkkaupa og öllum starfsmönnum sem tengjast } \\
\text { viðkomandi verkpætti. }\end{array}$ \\
\hline 697648 & [Stundum] Fer eftir umfangi verka. \\
\hline 746572 & [Stundum] ef við teljum vinnustað hættulegan. \\
\hline 746433 & [Oftast] ekki við smærri verk, annars gerum við öryggis- og heilbrigðisáætlun. \\
\hline 751324 & [Stundum] Fer eftir stærð verks \\
\hline 847789 & [Oftast] Fyrir alla áhættumikla eða óvenjulega verkliði. \\
\hline 1369433 & $\begin{array}{l}\text { [Stundum] í byrjun verks, byrjun hvers verkhluta, á meðan verkinu/verkhlutanum stendur og við lok } \\
\text { verks/verkhlutar eru hættumat gerð. En farið er yfir verkstað reglulega ef ekki á hverjum degi og skoðað } \\
\text { hvort eitthvað hafi breyst í matinu. }\end{array}$ \\
\hline 1386631 & [Oft] Pegar pess er krafist \\
\hline 1386545 & [Oft] eftir viðfangi verksins \\
\hline 1415290 & [Oft] Höldum rýnifund og förum yfir verkið \\
\hline 1419605 & $\begin{array}{l}\text { [Sjaldan] Innbyggt í verkreynslu. Parf að fá framkvæmdarleyfi frá lögreglu útaf umferð ? - Parf að vinna } \\
\text { á sérstökum tíma vegna hávaða eđa óprifnaðar eða annað? o.sf. }\end{array}$ \\
\hline 1424067 & $\begin{array}{l}\text { [Stundum] Í smærri og hefðbundnum verkefnum vinnum við eftir Heilbrigðis- og Öryggisáætlun } \\
\text { fyrirtækisins en í stærri og sérhæfðari verkum framkvæmum við áhættugreiningu. }\end{array}$ \\
\hline
\end{tabular}




\subsubsection{Eitthvað að lokum sem pú vilt koma á framfæri ?}

\begin{tabular}{|c|c|}
\hline 632986 & Flotgólf ehf er með í vinnslu að koma á virku gæðastjórnunarkerfi í náinni framtíð \\
\hline 661883 & Mér lýst vel á petta verkefni pitt og hefði gaman af að fá að sjá niðurstöðurnar pegar pær liggja fyrir \\
\hline 682612 & Eftir hrun! Er ekki marktækt mun minna um stærri verk. \\
\hline 694876 & $\begin{array}{l}\text { Pessi póstur hefur ekki verið sendur á fyrirtæki með verktakastarfssemi en ég er samt með } \\
\text { verktakastarfsemi og með póstfagnið smidi@smidi.is. Petta er lítið fyrirtæki sem starfar lítið á pessum } \\
\text { nótum sem verið er að spyrja um. Er samt í annarri starfssemi par sem ísT30 er mikið notaður og } \\
\text { verkfundir og fundargerðir p.e. í útboðum og eftirliti með framkvæmdum. }\end{array}$ \\
\hline 697554 & Áhugaverð og veluppsett könnun, gangi pér vel með verkefnið :) \\
\hline 697648 & Pað vantar nauðsynlega gæðastjórnunar kerfi fyrir lítil og meðalstór fyrirtæki. Kv. P K \\
\hline 719216 & $\begin{array}{l}\text { sæl Anna hulda nei við höfum aldrei unnið eftir neinni gæðastjórnun, aðeins eftir heiðarleika og góðri } \\
\text { samvisku. Reynt að borga öllum góð laun, haft mjög litla yfirbyggingu og haft pað að leiðarljósi að sem } \\
\text { flestar flestir sem að verkinu komi njóti sín launalega séð, sem og höfum við ávallt reynt að vinna sem } \\
\text { hagkvæmast, við bendum td. viðskiptavinum á hagkvæmari lausnir ef við sjáum slíkt í upphafi, við } \\
\text { skiljum að hver sem leggur út í slíkar fjárfestingar leggur mikið undir og öllum er pað hjartans mál. Að } \\
\text { hafa í huga framgreind atriði tel ég common sense gæðastjórnun. Prátt fyrir ánægða viðskiptavini bæði } \\
\text { hjá einstaklingum og ekki síst hinu opinbera, pá stundar hið opinbera nú viðskipti við kennitöluflakkara. } \\
\text { Engin meðmæli, útkoma gæðastjórnunar, góður árangur eða nokkuð annað sem vel hefur verið gert } \\
\text { kemur par við sögu. Ekkert er metið að verðleikum, við sitjum bara við sama borð og hver annar. } \\
\text { Lægsta tilboð er pað eina sem horft er á og viðundandi verktrygging sem oftar en ekki er veð í húsi } \\
\text { verktakans. Pví miður hef ég ekki hug á pátttöku í könnun pinni pví ekkert passar lengur og öll svör væri } \\
\text { pví í raun fölsk. Pað er bara gagnstætt heiðarleika mínum að svara. Pað myndi bara skekkja pína mynd, } \\
\text { fyrirtæki mitt er svo til komið í prot og án breyttra viðhorfa stjórnar til pessara iðngreinar en dæmið dautt. } \\
\text { Svo ég geta bara óskað pér velfarnaðar í pínu námi og framtíð og veit pú tekur pví ekki illa pó ég taki } \\
\text { ekki pátt. }\end{array}$ \\
\hline 746294 & Nei \\
\hline 751324 & $\begin{array}{l}\text { Ég tók viðtal við hann í gegnum síma. Hann sagði að fyrir hrun hefðu starfshættir verktaka vera í } \\
\text { "ruglinu" og fór hann pví alltaf fram á gæðatryggingu frá undirverktökum á peim tíma en núna sé allt } \\
\text { miklu rólegra. Hann hefur ekki neina pekkingu á gæðastjórnun en hann telur fyrirtækið sitt vinna eftir } \\
\text { eigin gæðastjórnunarkerfi pó pað sé ekki byggt á neinum staðli. }\end{array}$ \\
\hline 753321 & $\begin{array}{l}\text { Honum fannst kröfur í garð verkkaupa varðandi lágt verð hafa aukist mikið í kjölfar hrunsins auk pess } \\
\text { sem honum fannst útboðsgögn vera 'harðari' núna en fyrir kreppu. Honum fannst vera pörf fyrir } \\
\text { gæðastjórnunarkerfi fyrir lítil fyrirtæki og taldi slíkt kerfi geta borið mikinn árangur ef pað væri ekki of } \\
\text { flókið og pungt. Honum fannst mikill skortur í samræminu á teikningum. }\end{array}$ \\
\hline 785046 & $\begin{array}{l}\text { Finnst kröfur verkkaupa til lægri kostnaðar við framkvæmdir hafa stóraukist eftir hrun. Ekki eins mikil } \\
\text { aukning á kröfum um markvissa stjórnun. Kröfur verkkaupa eru auk pess mjög mismunandi. Hef trú á } \\
\text { gæðastjórnun í byggingaiðnaði að pví marki að farið sé eftir henni. Óttast að peir sem segjast vera með } \\
\text { ákveðið gæðastjórnunarkerfi séu ekki alltaf að vinna eftir pví. İ einu skiptin sem hann heyrir minnst á } \\
\text { gæðastjórnunarstaðla eins og IST } 30 \text { eða ISO er hjá verkfræðistofum og stundum hjá hönnuðum með } \\
\text { teikningar. }\end{array}$ \\
\hline 785753 & $\begin{array}{l}\text { Pað er ekkert að marka útboðsgögn núna. Lægstu tilboðum alltaf bara tekið og svo er ekkert farið eftir } \\
\text { útboðsgögnunum - alltaf farið fram hjá skilmálum. Kröfur verkkaupa um lágt verð hafa stóraukist eftir } \\
\text { hrun. }\end{array}$ \\
\hline 789858 & $\begin{array}{l}\text { Kröfur á verkkaupa um minni kostnað hafa stóraukist með hruninu. Рað væri magnað að hafa } \\
\text { gæðastjórnunarkerfi sem væri stílað inn á minni fyrirtæki. pað vantar kerfi með minna umfang sem } \\
\text { hentar fyrirtækjum með } 1-10 \text { starfsmenn. Ég hef unnið i fyrirtæki par sem unnið var eftir } \\
\text { gæðastjórnunarkerfi og pað fór allt of mikill tími í skriffinnsku og vesen. }\end{array}$ \\
\hline 789996 & Vöntun á gæðastjórnunarkerfi fyrir lítil fyrirtæki. ১að er mikið um fúskara parna úti... \\
\hline 83899 & $\begin{array}{l}\text { Finnst vanta gæðastjórnunarkerfi sem er umfangsminna en pað sem er í gagni núna, sem gæti nýst } \\
\text { litlum fyrirtækjum. Er sannærður um að gæðastjórnun er framtíðin en pað parf að vera miklu }\end{array}$ \\
\hline
\end{tabular}




\begin{tabular}{|c|c|}
\hline & $\begin{array}{l}\text { umfangsminna kerfi fyrir lítil fyrirtæki. Varðandi útboðsgögn pá fara menn frjálslega með pau núna. } \\
\text { Menn taka út og setja inn liði og eru sífellt að breyta. }\end{array}$ \\
\hline 847789 & $\begin{array}{l}\text { Ástæða breytinga á kröfum um skipulag og stjórnun er meira breyting á samsetningu verkkaupa (mun } \\
\text { færri) frekar en stefnubreyting verkkaupanna sjálfra. Einstaklingar hafa ekki verið verkkaupar hjá İstak } \\
\text { eftir hrun. }\end{array}$ \\
\hline 848075 & $\begin{array}{l}\text { Með nýjum mannvirkjalögum erum við neyddir til að innleiða gæðastjórnunarkerfi en hjá svona litlum } \\
\text { fyrirtækjum er pað allt of umfangsmikið. •að vantar umfangsminna kerfi fyrir lítil fyrirtæki. Mér finnst } \\
\text { vanta samræmd útboðsgögn sem hægt væri að nálgast á auðveldan hátt með helstu lykilatriðum. }\end{array}$ \\
\hline 627251 & $\begin{array}{l}\text { Við höfum lítið verið að vinna eftir hrun. Gæðastjórnunarkerfi eru góð hugmynd fyrir pá sem eru að byrja } \\
\text { með fyrirtæki núna en í hans tilfelli pá byggja vinnubrögð hans á áralangri reynslu og telur hann sig pví } \\
\text { ekki purfa að vinna eftir ákveðnu gæðastjórnunarkerfi. Pau fyrirtæki sem gefa sig út fyrir að vera að } \\
\text { vinna eftir ákveðnu kerfi eru ekki endilega með mannskapinn sem parf til að fylgja pví eftir. En kerfið er } \\
\text { tilgangslaust ef eftirfylgnin er ekki næg. }\end{array}$ \\
\hline 630915 & Ég hef trú á gæðastjórnun fyrir stærri fyrirtæki. Óparfi fyrir minni fyrirtæki. \\
\hline 691428 & $\begin{array}{l}\text { Vil hvetja alla sem að mannvirkjagerð koma, til að taka upp faglegri vinnubrögð. Hönnun parf að } \\
\text { stórbæta, pví allt of oft er kastað par til höndum, sem leiðir til mikils aukakostnaðar og tafa á verktíma. } \\
\text { Verkferla og samskipti aðila parf að setja í fastari skorður, og meir metnað vantar hjá til að skila góðu } \\
\text { verki er ábótavant. Pað er ekki nóg að finna upp gæðakerfi, pað purfa allir að sameinast um að fylgja } \\
\text { pví. Bætt við eftir símtal frá svaranda: 'Jón hjá spöng sagði: Peir keyptu kerfi } 2008 \text { en voru í raun bara } \\
\text { að byrja að vinna eftir pví núna. Pegar hrunið var pá voru peir bara í pví að slökkva elda. Honum finnst } \\
\text { ekki spurning að verktakar eigi að vera með gæðakerfi en honum finnst mikið vanta upp á ferlið eins og } \\
\text { pað er núna. Hann lýsti pessu við að petta væri eins og að eiga bíl með bens merki en vita ekki hvað } \\
\text { merkið stæði fyrir og geta pví eins verið með volvo með bens merki. Hann sagði að pað væri ekki nóg } \\
\text { að verktakar væru með gæðakerfi ef hönnuðir og aðrir sem koma að ferlinu eru ekki með pað. par er } \\
\text { potturinn brotinn. Einnig eru kröfur verkkaupa mjög misjafnar.' ath. peir sögðust vera með vottað SI } \\
\text { kerfi- ég breytti niðurst. skv. upplýsingum frá SI par sem segir að peir séu í innleiðingarferlinu. }\end{array}$ \\
\hline 679539 & $\begin{array}{l}\text { Óska eftir að sjá niðurstöður úr pessari könnun sem og fróðlegt væri að fá afrit eða úrdrátt úr } \\
\text { meistarareitgerð. (ath - ég breytti í svari frá pví að vera með gæðakerfi og vera í innleiðingu skv. } \\
\text { gögnum frá SI) }\end{array}$ \\
\hline 1367004 & nei \\
\hline 1369433 & $\begin{array}{l}\text { Kröfur frá verkkaupum til verktaka um gæðastjórnun og gæðahandbækur hafa alltaf verið og eru enn } \\
\text { meiri núna eftir efnahagshrunið. En eftirlit verkkaupa við pví hvort kerfið er notað er mjög uppábótavant! } \\
\text { peir hafa áhuga á pessu en ganga ekkert eftir pví. Glaumur hefur ávallt notast við innra gæðaeftirlit en } \\
\text { frá pví árið } 2006 \text { hefur pað stækkað og verið notast út á verkstað við úttektir fyrir fyrirtækið sjálft. Eftir að } \\
\text { pað kerfi byrjaði í notkun, hafa verkin verið betur unnin og hlutfall kostnaðar og nýtingu orðið betra og } \\
\text { yfirsjón yfir verkið batnað. (fékk auka athugasemd í pósti frá svarenda: "Ég er búin með könnunina pína } \\
\text { og bað væri hægt að segja svo mikið um gæðakerfi, viðhorf og notkun peirra í jarðvinnu- og } \\
\text { byggingabransanum. Hvað íslendingar purfa að bæta sig í pessu bæði verkkaupa megin og verktaka } \\
\text { megin og hvað petta gætur bætt nýtingu í hvaða iðnaði sem er og svo framvegis. En vonandi gengur } \\
\text { petta vel hjá pér." }\end{array}$ \\
\hline 1415290 & $\begin{array}{l}\text { Gæðastjórnun og gæði verks eru ekki pað sama.Opinberir aðilar eru með miklar kröfur um } \\
\text { gæðastjórnun í útboði en semja alltaf við lægstbjóðanda og pá falla gæði verks og kaupandi sættir sig } \\
\text { við }\end{array}$ \\
\hline 1419605 & $\begin{array}{l}\text { Er jákvæður gangvart gæðastjórnun. Hef reynt að koma henni á hjá mér við spörtlun innan dyra. Held } \\
\text { að verkferlið hafi batnað en pað er innbyggt í mér að reyna að gera betur næst - alltaf }\end{array}$ \\
\hline 1457060 & Með gæðastjórnun yrðu verk skilvirkari \\
\hline
\end{tabular}




\section{Viðauki P - Hönnun spurningalista fyrir verkkaupa og verktaka}

Eins og nefnt var í kafla um aðferðafræði, bls. 44, var farið í gegnum 11 pætti Alvin C. Burns og Ronald F. Bush (Alvin C. Burns and Ronald F. Bush, 2009) við hönnun og útfærslu spurningalistanna.

\section{Skilgreina pörfina.}

Skilgreina pörfina. Skilgreina hvað pað er sem raunverulega parf að fá út úr rannsókninni.

Fyrir verkkaupa

- Mikilvægt er fyrir verkkaupa að geta tekið upplýsta ákvörðun við val á verktökum með tilliti til pess hvort verktaki notist við gæðastjórnunarkerfi eða ekki. Einnig er mikilvægt að vitneskja liggi fyrir um pað hvort verktakar séu raunverulega að notast við gæðastjórnunarkerfi eins og peir gefa hugsanlega upplýsingar um.

Fyrir verktaka

- Erfitt er að gera sér grein fyrir stöðu gæðastjórnunar í mannvirkjagerð og peim áhrifum sem gæðastjórnun hefur í slíku umhverfi. Pörfin fyrir slíkar upplýsingar liggur hjá fyrirtækjunum í slíkum iðnaði til að brýna á gagnsemi og ávinning af notkun slíks kerfis

Ytri aðilar

- Dörfin fyrir upplýsingar um ávinning af notkun gæðastjórnunarkerfis liggur einnig hjá löggjafarvaldinu en með mannvirkjalögunum koma fram áætlanir um aukna áherslu á gæðastjórnun í mannvirkjagerð(Alpingi, 2010). Vitneskja um áhrif gæðastjórnunar í mannvirkjagerð hefði pví styrkjandi áhrif á lögin.

\section{Vandamálið}

Vandamálið. Mikilvægt er að vanda skilgreiningu vandamálsins. •að getur dregið verulega úr árangri sé skilgreiningin röng eða ónákvæm.

- Grunsemdir eru um að gæðastjórnun hjá fyrirtækjum í byggingaiðnaði sé misjafnlega beitt og með misgóðum afleiðingum. Vandamálið felst í beitingu gæðastjórnunar innan fyrirtækja í mannvirkjagerð og augljós gagnsemi hennar fyrir fyrirtækin.

\section{Skilgreina markmið}

Skilgreina markmið. Í skilgreiningu markmiðs purfa pær upplýsingar að koma fram sem parf til að leysa vandamálið

- Eitt aðal markmiðið með tilkomu spurningalistanna er að rannsóknin gefi góða mynd af áhrifum gæðastjórnunar í mannvirkjagerð á Íslandi auk pess sem að upplýsingar fáist um gæðatryggingu og samskipti verkkaupa og verktaka. 


\section{Aðferðir/gerð}

Aðferðir/gerð. Í pessu skrefi er rannsóknaraðferð valin. T.d. eigindleg eða megindleg aðferð (Boris Blumberg, Donald R. Cooper and Pamela S. Schindler, 2008, bls. 191-222). Í markaðsrannsóknum núna er algengt að nota eigindlegar aðferðir við undirbúning, megindlegar við framkvæmd og í nánari skoðun sé notast við eigindlegar aðferðir aftur.

- Við rannsóknina voru helst notaðar megindlegar aðferðir ${ }^{145}$. En auk pess voru eiginlegar aðferðir notaðar með hugaflugs fundum, viðtölum, ráðstefnum og lestri fræðigreina.

\section{Tegund upplýsinga}

Tegund upplýsinga. Ákveðið er hvaða upplýsingar á að nota. Annars vegar kannað hvaða gögn eru fyrirliggjandi og hins vegar kannað hvort safna purfi frumgögnum

- Við hönnun spurningalistanna var bæði notast við frumgögn sem og önnur fyrirliggjandi gögn. Til fyrirliggjandi gagna teljast aðrir spurningalistar sem hægt var að styðjast við, gæðastaðlar, bækur, ritgerðir og greinar. Frumgögn eru pær upplýsingar sem fengust frá svarendum, verkkaupa og leiðbeinanda sem nýttust við gerð spurningalistans.

\section{6. Öflun gagna}

Í pessu skrefi er gögnum aflað ásamt pví að ákveðið er hvaða aðferð er beitt við söfnun peirra, svo sem, símhringingar, póstsendingar, söfnun gagna í gegnum netið, með heimasíðu eða með fundum

Fyrir verkkaupa

- Við öflun gagna voru haldnir fundir eftir pörfum með verkkaupa og leiðbeinanda. Auk pess var haft samband við byggingafulltrúa á Akranesi, Akureyri, Garðabæ, Hafnarfirði, Hveragerði, Kópavogsbæ, Mosfellsbæ, Reykjanesbæ og Reykjavík og voru peir beðnir um að gefa upp gögn um pað hvaða einstaklingar og fyrirtæki í sínu umdæmi hefou fengið úthlutaða lóð á síðustu 5 árum og nú pegar tekið bygginguna í notkun. Tekið var fram að ekki var sett skilyrði að lokaúttekt hafi farið fram.

- Tekin var ákvörðun um að skilvirkast væri að safna gögnum með símaviðtölum við verkkaupa

Fyrir verktaka

- Við öflun gagna fyrir könnun verktaka var notast við veraldarvefinn, upplýsingar sem fengust úr könnun fyrir verkkaupa og fyrirliggjandi gagna frá Samtökum Iðnaðarins.

- Tekin var sú ákvörðun að safna gögnum með símaviðtölum, netkönnun og á fundi.

\footnotetext{
${ }^{145}$ Til megindlegra aðferða teljast spurningalistakannanir (Vísindavefurinn, 2005).
} 


\section{Spurningalisti/form}

Spurningalisti/form. Spurningalistinn er hannaður í pessu skrefi. Mikilvæg atriði sem hafa parf í huga við gerð spurningalista eru listuð hér að neðan:

a. Málefnið parf að vera afmarkað.

b. Hafa spurningar stuttar og hnitmiðaðar.

c. Tryggja parf að allir túlki spurninguna á sama hátt.

d. Spurningar eiga ekki að vera á sérfræðimáli, heldur pannig að allir skilji hver meiningin er.

e. Nota einfalda setningu eftir fremsta megni.

f. Ekki skal spyrja um pað sem viðkomandi hefur ekki vit á.

g. Varast að hafa spurningar sértækar pegar leitað er eftir almennu svari.

h. Leitast eftir peirri nákvæmni sem parf, ekki meiri.

i. Spurningar eiga ekki að innihalda orð sem ýkja aðstæður. Eins og sterk lýsingarorð.

j. Spurningar mega ekki vera tvíræðar.

Fyrir verkkaupa \& verktaka

- Spurningalistinn inniheldur bæði lokaðar og opnar spurningar pó fleiri spurningar séu lokaðar, p.e. með fyrirfram skilgreindum svarmöguleikum. Við lokuðu spurningarnar var notast við Likert skala sem var próaður af Rensis Likert árið 1932 (Sarah Boslaugh \& Paul Andrew Watters, 2008). Svarendur hafa pá kost á að vera mjög sammála, sammála, hlutlaus, ósammála eða mjög ósammála framsettri staðhæfingu. Pessi skali getur gefið góða hugmynd um skoðanir svarenda á málefnum (Boris Blumberg, Donald R. Cooper and Pamela S. Schindler, 2008, bls. 466). Einnig var notast við einfaldar já og nei spurningar.

- Stig mælikvarða fyrir hverja spurningu voru skilgreind en pað skiptir miklu máli fyrir val á tölfræðiaðferð að gera sér grein fyrir á hvaða kvarða breytan er mæld. Pessir kvarðar eru kallaðir nafnkvarðar (e. nominal scale), raðkvarðar (e. ordinal scale), jafnbilakvarðar (e. interval scale) og hlutfallskvarðar (e. ratio scale) (Amalía Björnsdóttir, 2004).

Fyrir verkkaupa

- Ferdinand Hansen verkefnastjóri gæðastjórnunar hjá Samtökum Iðnaðarins fór yfir spurningalistann ásamt Eyjólfi Bjarnasyni gæðastjóra hjá ÍAV og Dr. Helga Pór Ingasyni leiðbeinanda verkefnisins.

Fyrir verktaka

- Unnur Guðnadóttir, annars árs nemi í meistaranámi í félagssálfræði, sem hefur auk pess tekið námskeið í gerð spurningalista fór yfir og leiðrétti spurningalistann fyrir verktaka. Ferdinand Hansen, gæðastjórnunar hjá Samtökum Iðnaðarins og Friðrik Á. Ólafsson, forstöðumaður Samtaka Iðnaðarins fóru auk pess yfir spurningalistann. 


\section{8. Úrtakið}

Í pessu skrefi er úrtakið og úrtaksstærð valin.

Pegar valið er í úrtak er mikilvægt að hafa í huga hversu stórt úrtakið parf að vera til að raunhæft sé að draga ályktanir fyrir býðið út frá niðurstöðum sem úrtakið gefur. Einnig er krafa um að í úrtaki sé fullkomlega tilviljunarkenndur hópur af pýðinu er gerð til rannsókna sem teljast trúverðuglegar(Sarah Boslaugh \& Paul Andrew Watters, 2008).

Fyrir verkkaupa

- Byggingafulltrúar á Akranesi, Akureyri, Garðabæ, Hafnarfirði, Hveragerði, Kópavogsbæ, Mosfellsbæ, Reykjanesbæ og Reykjavík voru allir beðnir um að senda gögn um pað hvaða einstaklingar og fyrirtæki í sínu umdæmi hefou fengið úthlutaða lóð á árunum 2005-2010 og nú pegar tekið bygginguna í notkun pó að ekki sé sett skilyrði að lokaúttekt hafi farið fram.Valið var í úrtakið frá ofangreindum gögnum, með handahófskenndu val, en stærðin afmarkaðist við fjölda viðtala sem náðist að taka á tilteknu tímabili.

- Við val á úrtakinu fyrir verkkaupana var notast við upplýsingar sem fengust frá byggingafulltrúum á ofantöldum svæðum og valið í handahófskennt úrtak frá peim upplýsingum sem fengust frá hverjum byggingafulltrúa fyrir sig. Ekki var leitast eftir upplýsingum um verkkaupa á öllu Íslandi sökum tímaramma verkefnis, en í fullkomnum heimi hefði úrtakið samanstaðið af handahófskenndu úrtaki allra verkkaupa á Íslandi á árunum 2005-2010.

Fyrir verktaka

- Allir verkkaupar sem voru í úrtakinu í fyrri hluta rannsóknarinnar voru spurðir hvaða verktakar hefðu komið að verkinu og voru peir beðnir um að hafa einn verktaka í huga pegar spurningalistanum var svarað. Ef ráðinn hafði verið aðalverktaki yfir verkinu voru spurningarnar miðaðar út frá honum. Allir peir verktakar sem unnið höfðu verk fyrir verkaupa í fyrri hluta rannsóknar voru í úrtakshópi verktaka og var spurningalistinn lagður fyrir pá símleiðis og í gegnum veraldarvefinn. Til viðbótar var spurningalistinn sendur á slembiúrtak verktaka sem upplýsingar um netfang lágu fyrir auk pess sem listinn var lagður fyrir á fundi hjá meistarafélagi iðnaðarmanna í Hafnarfirði.

- Hugsanlegt er að í úrtaki verktaka megi finna ákveðna hneigð eða skekkju (e. bias) vegna samsetningar úrtaks. Til að mynda var ekki haft samband við verktaka sem ekki fundust nægilegar upplýsingar um (símanúmer eða netfang). En hafa verður í huga að rannsóknin var framkvæmd á tíma par sem mörg fyrirtæki í iðnaðinum voru vængbrotin, annaðhvort alfarið hætt starfsemi sinni eða nánast alveg hætt starfsemi sinni og voru upplýsingar um slík fyrirtæki gjarnan á reiki.

Áður en farið var í næsta skref gagnasöfnun var farið í gegnum eftirfarandi 5 skref sem mikilvægt að hugað sé að áður en gagnasöfnun hefst skv. Söruh Boslaugh and Paul Andrew Watters (Sarah Boslaugh \& Paul Andrew Watters, 2008):

1. Kennsl borin á rannsóknareiningar (e. experimental units) sem meiningin er að mæla eitthvað út frá. 
- Varast að draga ályktanir fyrir býði frá úrtaki sem er ekki valið af handahófi út frá pýðinu. Gera verður ráð fyrir að ákveðinn skekkja (e. bias) sé annars í úrtakinu.

2. Kennsl borin á meðferð sem rannsakandi vill stjórna.

- Meðferðin sem úrtakshópurinn hjá verkkaupunum gekkst undir voru framkvæmdir á árunum 2005-2010. Margir pættir gætu haft áhrif á svör pátttakenda sem rannsakandi gat ekki stjórnað. Hugsanlega hefur árferði haft áhrif, en rannsóknin var framkvæmd pegar mikill ólgusjór var í efnahagslífi pjóðarinnar. Meðferð fyrir úrtak verktakanna má segja að sé gæðastjórnunarkerfi.

3. Kennsl borin á meðferðarstig.

- Deir pættir sem rannsakandi telur að gætu haft áhrif á niðurstöður eru skilgreindir sem pættir.

4. Kennsl borin á svarbreytur sem verða notaðar til að mæla rannsóknareiningar.

- Ánægja verkkaupa verður notuð sem mælikvarði á að tilteknum gæðum hafi verið náð og kannað hvort munur sé milli fyrirtækja sem starfa eftir gæðastjórnunarkerfi og peirra sem starfa ekki eftir gæðastjórnunarkerfi.

5. Útbúa kenningu sem spáir fyrir um áhrif meðferðar á svarbreytu.

- Kenningin er að fyrirtæki sem starfa eftir gæðastjórnunarkerfi hafi ánægðari viðskiptavini, vinni samkvæmt markvissari vinnubrögðum.

\section{Gagnasöfnun}

Söfnun gagna er ýmist gerð með póstkönnunum, símakönnunum, persónulegum viðtölum, hópviðtölum, rýnihópum eða könnunum á netinu. Í spurningum í töluðu máli er mikilvægt að spyrlar séu vel pjálfaðir, par sem viðhorf spyrils kemur ekki fram beint né óbeint (t.d. pegar spurning er borin fram). Hafa parfí huga hvað skal gera ef viðmælandi er ekki við, hann neitar að svara eða gefur ranga svörun.

Mikilvægt er að hafa í huga að gæði tölfræðigreininga felast í gæði gagna. Eins og máltakið sem á uppruna í heim tölvuforritara kemur inn á; "Garbage in, garbage out", eða GIGO (Sarah Boslaugh \& Paul Andrew Watters, 2008). Pví var lagt mikið upp úr pví að safna sem bestu gögnum bæði í könnun fyrir verktaka og í könnun fyrir verkkaupa. Til að tryggja að ekki hafi verið um innsláttarvillur að ræða voru niðurstöður úr hverri spurningu fyrir sig bornar saman við pað sem fékkst úr QuestionPro og pað sem fékkst úr IBM SPSS Statistics.

Fyrir verkkaupa

- Tekin voru símaviðtöl við verkkaupa.

Fyrir verktaka

- Verktakar tóku könnunina ýmist í formi símaviðtala, í gegnum internetið eða á blaði á sérstökum fundi. Öll pessi form voru notuð til að ná sem flestum svörum. 


\section{Greining gagna}

Í pessu skrefi eru gögnin úr rannsókninni greind.

Fyrir verkkaupa \& verktaka

- Svör verkkaupa og verktaka voru fyrst sett inn í vefviðhorf sem kallast QuestionPro Survey Software (QuestionPro Survey Software, 2010) og var viðmótið notað til fá tíðnitöflur við öllum spurningum. Svo voru gögnin sett inn í forritið $I B M$ SPSS Statistics 19 og var pá flestum gögnum komið yfir á tölulegt form par sem hverjum svarflokki fyrir sig var gefið ákveðið gildi. petta var gert til að auðvelda gagnaúrvinnslu. Tíðnitöflur fyrir allar spurningar voru prentaðar í IBM SPSS Statistics 19 og bornar saman við niðurstöður í QuestionPro Survey Software til að sannreyna að innsláttarvillur vegna umbreytingu gagna í tölulegt form hafi ekki átt sér stað.

\section{Skýrsla}

Í pessu skrefi eru pær niðurstöður sem komu fram í rannsókninni settar fram á skilmerkilegan hátt. 


\section{Viðauki Q - Tilgátupróf}

Eftirfarandi núlltilgáta var sett fram í upphafi;

$\mathrm{H}_{0}=$ enginn munur er á áncegju verkkaupa eftir pví hvort umrceddur verktaki starfar eftir gœðastjórnunarkerfi byggðu á viðurkenndum gœðastjórnunarstöðlum eða ekki.

Núlltilgáta er ávallt hrakin eða studd, en ekki sönnuð eða afsönnuð. Tvenns konar mistök eða villur geta átt sér stað í tölfræðilegri ályktun annars vegar höfnunarvilla og hins vegar sampykktarvilla (Sarah Boslaugh \& Paul Andrew Watters, 2008)

Höfnunarvilla (e. Type I error), er pað nefnt pegar núlltilgátan er ranglega hrakin. Líkurnar á pessu eru $\alpha$ í venjulegu tilgátuprófi par sem vikmörkin eru $\alpha$ (Sarah Boslaugh \& Paul Andrew Watters, 2008).

Sampykktarvilla (e. Type II error), er pað nefnt pegar núlltilgátan er ranglega studd. Venja er að tákna líkurnar á pessari villu með $\beta$ (Sarah Boslaugh \& Paul Andrew Watters, 2008).

Notast var við Mann-Whitney $U$ test (einnig kallað Mann-Whitney-Wilcoxon (MWW) eða Wilcoxon rank-sum test) sem er stikalaust próf notað til að sannreyna hvort tvö óháð úrtök af athugunum hafi jafn há gildi. Prófið er eitt pekktasta sinnar tegundar (Wikipedia, 2011). Valin vikmörk eru 0,05, og öryggisbil er 95\%. Samkvæmt útreikningum með SPSS Statistics er núlltilgátunni hafnað sem pýðir að pað er marktækur munur á ánægju verkkaupa með framkvæmd verksins hjá umræddum verktaka með tilliti til pess hvort umræddur verktaki starfar eftir gæðastjórnunarkerfi byggðu á viðurkenndum gæðastjórnunarstöðlum eða ekki.

Hypothesis Test Summary

\begin{tabular}{|c|c|c|c|c|}
\hline & Null Hypothesis & Test & Sig. & Decision \\
\hline 1 & $\begin{array}{l}\text { The distribution of } \\
\text { anaegia umraddan sum is the } \\
\text { same across categories of } 6 S \mathrm{~K}\end{array}$ & $\begin{array}{l}\text { Independent- } \\
\text { Samples } \\
\text { Mann- } \\
\text { Whitney U } \\
\text { Test }\end{array}$ & .004 & $\begin{array}{l}\text { Reject the } \\
\text { null } \\
\text { hypothesis. }\end{array}$ \\
\hline
\end{tabular}

Asymptotic significances are displayed. The significance level is .05. 
Independent-Samples Mann-Whitney U Test

GSK

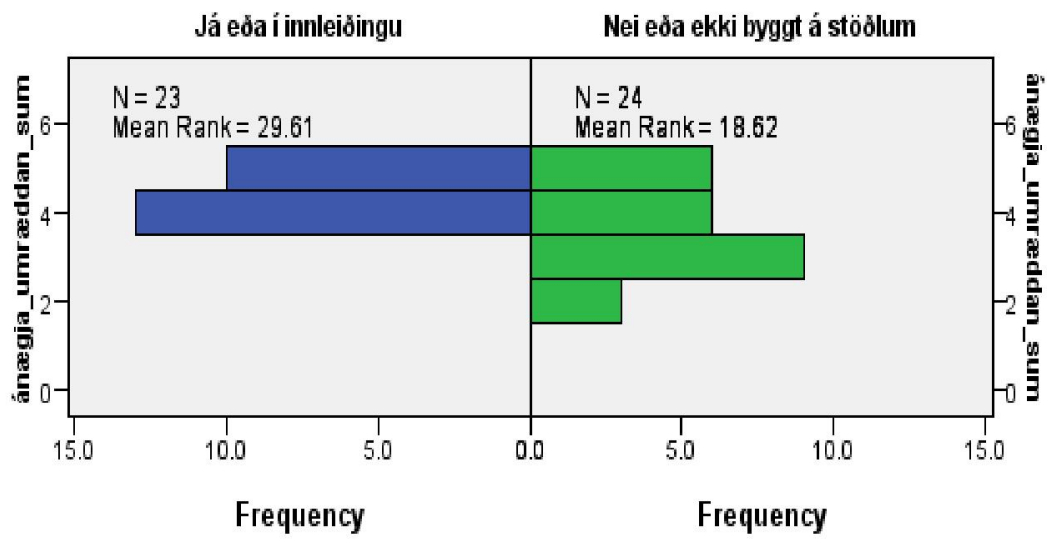

\begin{tabular}{|lr|}
\hline Total N & 47 \\
\hline Mann-Whitney U & 405.000 \\
\hline Wilcoxon W & 681.000 \\
\hline Test Statistic & 405.000 \\
\hline Standard Error & 44.270 \\
\hline Standardized Test Statistic & 2.914 \\
\hline Asymptotic Sig. (2-sided test) & .004 \\
\hline
\end{tabular}

Mynd 69 Upplýsingar sem notast var við í Mann-Whitney U prófi 